
709 


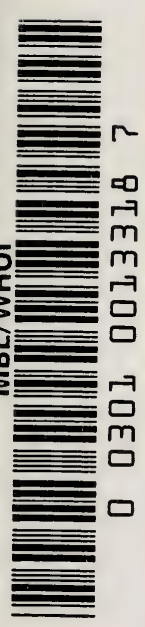





\section{HISTORY OF BOTANY}

$S A C H S$ 


\section{andon}

HENRY FROWDE

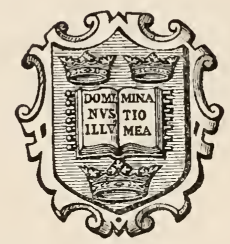

OXFord UNIVERSity Press WARehouse

Amen Corner, E.C. 


\section{HISTORY OF BOTANY}

(I $530-\mathrm{I} 860)$

\section{JULIUS VON SACHS}

PROFESSOR OF BOTANY IN THE UNIVERSITY OF WÜRZBURG

AUTHORISED TRANSLATION

BY

HENRY E. F. GARNSEY, M.A.

Fellow of Magdalen College, Oxford

REVISED BY

ISAAC BAYLEY BALFOUR, M.A., M.D., F.R.S.

Professor of Botany in the University

And Keeper of the Royal Botanic Garden, Edinburgh

\section{Oxford}

AT THE CLARENDON PRESS

1890

[All rights reserved] 


\section{Oxford \\ PRINTED AT THE CLARENDON PRESS}

BY HORACE HART, PRINTER TO THE UNIVERSITY

10563 


\section{PREFACE.}

Botanical Science is made up of three distinct branches of knowledge, Classification founded on Morphology, Phytotomy, and Vegetable Physiology. All these strive towards a common end, a perfect understanding of the vegetable kingdom; but they differ entirely from one another in their methods of research, and therefore presuppose essentially different intellectual endowments. That this is the case is abundantly shown by the history of the science, from which we learn that up to quite recent times morphology and classification have developed in almost entire independence of the other two branches. Phytotomy has indeed always maintained a certain connection with physiology, but where principles peculiar to each of them, fundamental questions, had to be dealt with, there they also went their way in almost entire independence of one another. It is only in the present day that a deeper conception of the problems of vegetable life has led to a closer union between the three. I have sought to do justice to this historical fact by treating the parts of my subject separately; but in this case, if the present work was to be kept within suitable limits, it became necessary to devote a strictly limited space only to each of the three historical delineations. It is obvious that the weightiest and most important matter only could find a place in so narrow a frame, but this I do 
not exactly regard as a misfortune, and in the interests of the reader it is rather an advantage; for, in accordance with the objects of the 'General History of the Sciences,' this History of Botany is not intended for professional persons only, but for a wider circle of readers, and to these perhaps even the details presented in it may here and there seem wearisome.

The style of the narrative might have been freer, and greater space might have been allotted to reflections on the inner connection of the whole subject, if I had had before me better preliminary studies in the history of botany; but as things are, I have found myself especially occupied in ascertaining questions of historical fact, in distinguishing true merit from undeserved reputation, in searching out the first beginnings of fruitful thoughts and observing their development, and in more than one case in producing lengthy refutations of wide-spread errors. These things could not be done within the allotted space without a certain dryness of style and manner, and I have often been obliged to content myself with passing allusions where detailed explanation might have been desired.

As regards the choice of topics, I have given prominence to discoveries of facts only when they could be shown to have promoted the development of the science; on the other hand, I have made it my chief object to discover the first dawning of scientific ideas and to follow them as they developed into comprehensive theories, for in this lies, to my mind, the true history of a science. But the task of the historian of Botany, as thus conceived, is a very difficult one, for it is only with great labour that he succeeds in picking the real thread of scientific thought out of an incredible chaos of empirical material. 
It has always been the chief hindrance to a more rapid advance in botany, that the majority of writers simply collected facts, or if they attempted to apply them to theoretical purposes, did so very imperfectly. I have therefore singled out those men as the true heroes of our story who not only established new facts, but gave birth to fruitful thoughts and made a speculative use of empirical material. From this point of view I have taken ideas only incidentally thrown out for nothing more than they were originally; for scientific merit belongs only to the man who clearly recognises the theoretical importance of an idea, and endeavours to make use of it for the promotion of his science. For this reason I ascribe little value, for instance, to certain utterances of earlier writers, whom it is the fashion at present to put forward as the first founders of the theory of descent; for it is an indubitable fact that the theory of descent had no scientific value before the appearance of Darwin's book in 1859 , and that it was Darwin who gave it that value. Here, as in other cases, it appears to me only true and just to abstain from assigning to earlier writers merits to which probably, if they were alive, they would themselves lay no claim.

\section{J. SACHS.}

WüRZBURG, July 22, 1875 . 


\section{THE AUTHOR'S PREFACE}

\section{To the English translation of the History of Botany of Julius von Sachs.}

I AM gratefully sensible of the honourable distinction implied in the determination of the Delegates of the Clarendon Press to have my History of Botany translated into the world-wide language of the British Empire. Fourteen years have elapsed since the first appearance of the work in Germany, from fifteen to eighteen years since it was composed,- a period of time usually long enough in our age of rapid progress for a scientific work to become obsolete. But if the preparation of an English translation shows that competent judges do not regard the book as obsolete, I should be inclined to refer this to two causes. First of all, no other work of a similar kind has appeared, as far as I know, since 1875 , so that mine may still be considered to be, in spite of its age, the latest history of Botany; secondly, it has been my endeavour to ascertain the historical facts by careful and critical study of the older botanical literature in the original works, at the cost indeed of some years of working-power and of considerable detriment to my health, and facts never lose their value,-a truth which England especially has always recognised.

But the present work is not a simple enumeration of the 
names of botanists and of their writings, no mere list of the dates of botanical discoveries and theories; such was not at all my plan when I designed it. On the contrary I purposed to present to the reader a picture of the way in which the first beginnings of scientific study of the vegetable world in the sixteenth century made their appearance in alliance with the culture prevailing at the time, and how gradually by the intellectual efforts of gifted men, who at first did not even bear the name of botanists, an ever deepening insight was obtained into the relationship of all plants one to another, into their outer form and inner organisation, and into the vital phenomena or physiological processes dependent on these conditions.

For the attainment of this end it was above all things necessary for me to form a clear judgment respecting the influence of the views and principles enunciated by the different authors on the further development of botanical science. This is to the historian of science the central point round which all beside should be disposed, and without which the entire work breaks up into a collection of unmeaning details, and it is one which demands knowledge of the subject, and capacity and impartiality of judgment. On questions connected with times long gone by the decision of the experts has in most cases been already given, though I myself found to my surprise that older authors had for centuries been regarded as the founders of views which they had distinctly repudiated as absurd, showing how necessary it is that the works of our predecessors should from time to time be carefully read and compared together. But in the majority of cases there is no dispute at the present day respecting the historical value, that is the operative 
influence on posterity, of works written three hundred or even one hundred years ago.

But it is a very different matter when the author of a book like mine ventures, as I have done for sufficient reasons but at the same time with regret, to sit in judgment on the works of men of research and experts, who belong to our own time and who exert a lively influence on their generation. In this case the author can no longer appeal to the consentient opinion of his contemporaries ; he finds them divided into parties, and involuntarily belongs to a party himself. But it is a still more weighty consideration that he may subsequently change his own point of view, and may arrive at a more profound insight into the value of the works which he has criticised; continued study and maturer years may teach him that he overestimated some things fifteen or twenty years ago and perhaps undervalued others, and facts, once assumed to be well established, may now be acknowledged to be incorrect.

Thus it has happened in my own case also in some but not in many instances, in which I have had to express an opinion respecting the character of works which appeared after I860, and which to some extent influenced my judgment on the years immediately preceding them. But this was from fifteen to eighteen years ago when I was working at my History. It might perhaps be expected that I should remove all such expressions of opinion from the work before it is translated. In some few cases, in which this could be effected by simply drawing the pen through a few lines, I have so done; but it appeared to me that to alter with anxious care every sentence which I should put into a different form at the present day would serve no good 
purpose, for I came to the conclusion that my book itself may be regarded as a historical fact, and that the kindly and indulgent reader may even be glad to know what one, who has lived wholly in the science and taken an interest in everything in it old and new, thought from fifteen to eighteen years ago of the then reigning theories, representing as he did the view of the majority of his fellowbotanists.

However, these remarks relate only to two famous writers on the subjects with which this History is concerned. If the work had been brought to a close with the year $185^{\circ}$ instead of I860, I should hardly have found it necessary to give them so prominent a position in it. Their names are Charles Darwin and Karl Nägeli. I would desire that whoever reads what I have written on Charles Darwin in the present work should consider that it contains a large infusion of youthful enthusiasm still remaining from the year 1859 , when the 'Origin of Species' delivered us from the unlucky dogma of constancy. Darwin's later writings have not inspired me with the like feeling. So it has been with regard to Nägeli. He, like Hugo von Mohl, was one of the first among German botanists who introduced into the study that strict method of thought which had long prevailed in physics, chemistry, and astronomy; but the researches of the last ten or twelve years have unfortunately shown that Nägeli's method has been applied to facts which, as facts, were inaccurately observed. Darwin collected innumerable facts from the literature in support of an idea, Nägeli applied his strict logic to observations which were in part untrustworthy. The services which each of these men rendered to the science are still 
acknowledged; but my estimate of their importance for its advance would differ materially at the present moment from that contained in my History of Botany. At the same time I rejoice in being able to say that I may sometimes have overrated the merits of distinguished men, but have never knowingly underestimated them.

$$
\text { DR. J. von SACHS, }
$$

WÜrzburg, March 24, I889.

Foreign Fellow of the Royal Society.

\section{NOTE BY THE TRANSLATOR.}

No History of Botany in English has ever been published, and it is to supply in some measure this want, long felt by English-speaking students, that this translation of Professor Sachs' masterly sketch has been prepared.

H. E. F. G. 


\section{CONTENTS.}

FIRST BOOK.

History of Morphology and Classification.

$$
\text { I 530-1 } 860 \text {. }
$$

Introduction

\section{CHAPTER I.}

The Botanists of Germany and the Netherlands from Brunfels to Caspar Bauhin, I530-1623 . . . . . . .

\section{CHAPTER II.}

Artificial Systems and Terminology of Organs from Cesalpino to Linnaeus, $\mathrm{I}_{5}^{8} 3^{-1} 760$. $\quad . \quad . \quad . \quad . \quad$.

CHAPTER III.

Development of the Natural System under the Influence of the Dogma of the Constancy of Species, I 759-1850. . . . IOS

\section{CHAPTER IV.}

Morphology under the Influence of the Doctrine of Metamorphosis and of the Spiral Theory, I790-1850 . . . .

\section{CHAPTER V.}

Morphology and Systematic Botany under the Influence of the History of Development and the knowledge of the Cryptogams, I $840-1860$ 


\section{SECOND BOOK.}

History of Vegetable Anatomy.

$$
\text { x } 67 x-x 860 .
$$

Introduction

CHAPTER I.

Phytotomy founded by Malpighi and Grew, 1671-1682 . .

CHAPTER II.

Phytotomy in the Eighteenth Century . . . . . $24^{6}$

CHAPTER III.

Examination of the Matured Framework of Cell-Membrane in Plants, I $800-1840$

\section{CHAPTER IV.}

History of Development of the Cell, Formation of Tissues, Molecular Structure of Organised Forms, I840-1860

\section{THIRD BOOK.}

History of Vegetable Physiology.

$$
\text { I } 583-1860 \text {. }
$$

Introduction

\section{CHAPTER I.}

History of the Sexual Theory

I. From Aristotle to R. J. Camerarius . . . . . 376

2. Establishment of the Doctrine of Sexuality in Plants by R. J.

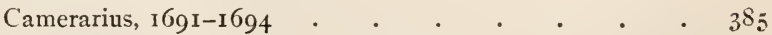

3. Dissemination of the New Doctrine; its Adherents and

Opponents, 1700-1760 • . . . . . . 390

4. The Theory of Evolution and Epigenesis . . . 402 
5. Further Development of the Sexual Theory by J. G. Koelreuter and Konrad Sprengel, 1761-1793 . . . . 406

6. New opponents of Sexuality and their refutation by Ex-

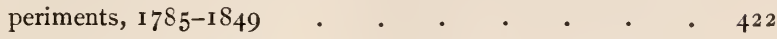

7. Microscopic Investigation into the Processes of Fertilisation in the Phanerogams, the Pollen-Tube and Eggs, I830-I850 43I

8. Discovery of Sexuality in the Cryptogams, $1837-1860$. $43^{6}$

\section{CHAPTER II.}

History of the Theory of Nutrition of Plants, ${ }_{5} 5^{8} 3^{-1} 860$ 445

I. Cesalpino, I583

2. First Inductive Experiments and Opening of New Points of View in the History of the Theory of the Nutrition of

3. Fruitless Attempts to Explain the Movement of the Sap in Plants, 1730-1780. • . • .

4. The Modern Theory of Nutrition Founded by Ingen-Houss and Theodore de Saussure, 1779-1804 . . . . 491

5. Vital Force. Respiration and Heat of Plants. Endosmose,

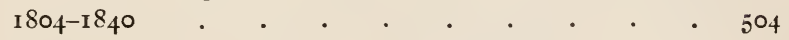

6. Settlement of the Question of Food-Material of Plants, I $840-1860$

\section{CHAPTER III.}

History of Phytodynamics

From end of $17^{\text {th }}$ century to about $1860 \quad \cdot \quad \cdot \quad \cdot \quad 335$

$\operatorname{INDEX} \cdot \quad \cdot \quad \cdot \quad \cdot \quad \cdot \quad \cdot \quad \cdot \quad \cdot \quad \cdot \quad \cdot \quad \cdot 5^{6} 5$ 
$$
-
$$ 


\section{NTRODUCTION.}

THE authors of the oldest herbals of the I6th century, Brunfels, Fuchs, Bock, Mattioli and others, regarded plants mainly as the vehicles of medicinal virtues; to them plants were the ingredients in compound medicines, and were therefore by preference termed 'simplicia,' simple constituents of medicaments. Their chief object was to discover the plants employed by the physicians of antiquity, the knowledge of which had been lost in later times. The corrupt texts of Theophrastus, Dioscorides, Pliny and Galen had been in many respects improved and illustrated by the critical labours of the Italian commentators of the $15^{\text {th }}$ and of the early part of the I6th century; but there was one imperfection which no criticism could remove,--the highly unsatisfactory descriptions of the old authors or the entire absence of descriptions. It was moreover at first assumed that the plants described by the Greek physicians must grow wild in Germany also, and generally in the rest of Europe; each author identified a different native plant with some one mentioned by Dioscorides or Theophrastus or others, and thus there arose as early as the r6th century a confusion of nomenclature which it was scarcely possible to clear away. As compared with the efforts of the philological commentators, who knew little of plants from their own observation, a great advance was made by the first German composers of herbals, who went straight to nature, described the wild plants growing around them and had figures of them carefully executed in wood. Thus was made the first beginning of a really scientific examination of plants, though the aims pursued were not yet truly scientific, for no questions 
were proposed as to the nature of plants, their organisation or mutual relations; the only point of interest was the knowledge of individual forms and of their medicinal virtues.

The descriptions were at first extremely inartistic and unmethodical; but the effort to make them as exact and clear as was possible led from time to time to perceptions of truth, that came unsought and lay far removed from the object originally in view. It was remarked that many of the plants which Dioscorides had described in his Materia Medica do not grow wild in Germany, France, Spain, and England, and that conversely very many plants grow in these countries, which were evidently unknown to the ancient writers; it became apparent at the same time that many plants have points of resemblance to one another, which have nothing to do with their medicinal powers or with their importance to agriculture and the arts. In the effort to promote the knowledge of plants for practical purposes by careful description of individual forms, the impression forced itself on the mind of the observer, that there are various natural groups of plants which have a distinct resemblance to one another in form and in other characteristics. It was seen that there were other natural alliances in the vegetable world, beside the three great divisions of trees, shrubs, and herbs adopted by Aristotle and Theophrastus. The first perception of natural groups is to be found in Bock, and later herbals show that the natural connection between such plants as occur together in the groups of Fungi, Mosses, Ferns, Coniferae, Umbelliferae, Compositae, Labiatae, Papilionaceae was distinctly felt, though it was by no means clearly understood how this connection was actually expressed; the fact of natural affinity presented itself unsought as an incidental and indefinite impression, to which no great value was at first attached. The recognition of these groups required no antecedent philosophic reflection or conscious attempt to classify the objects in the vegetable world; they present themselves to the unprejudiced eye as naturally as do the groups of mammals, birds, reptiles, 
fishes and worms in the animal kingdom. The real resemblance of the organisms in such groups is unconsciously accepted by the mind through the association of ideas, and it is not till this involuntary mental act, which in itself requires no effort of the understanding, is accomplished, that any necessity is felt for obtaining a clearer idea of the phenomenon, and the sense of this necessity is the first step to intentional systematic enquiry. The series of botanical works published in Germany and the Netherlands from 1530 to 1623 , from Brunfels to Kaspar Bauhin, shows very plainly how this perception of a grouping by affinity in the vegetable kingdom grew more and more distinct; but it also shows how these men merely followed an instinctive feeling in the matter, and made no enquiry into the cause of the relationship which they perceived.

Nevertheless a great step in advance was thus taken; all the foreign matter introduced into the description of plants by medical superstition and practical considerations was seen to be of secondary importance, and was indeed altogether thrown aside by Kaspar Bauhin; the fact of natural affinity, the vivifying principle of all botanical research, came to the front in its place, and awakened the desire to distinguish more exactly whatever was different, and to bring together more carefully all that was like in kind. Thus the idea of natural affinity in plants is not a discovery of any single botanist, but is a product, and to some extent an incidental product, of the practice of describing plants.

But before the exhibition of the natural affinity gave birth to the first efforts at classification on the part of de l'Obel (Lobelius) and afterwards of Kaspar Bauhin, the Italian botanist Cesalpino $\left(\mathrm{r}_{5} 83\right)$ had already attempted a system of the vegetable kingdom on a very different plan. He was led to distribute all vegetable forms into definite groups not by the fact of natural affinity, which impressed itself on the minds of the botanists of Germany and the Netherlands through involuntary association 
of ideas, but by philosophical reflection. Trained in the philosophy which flourished in Italy in the I6th century, deeply imbued with the doctrines of Aristotle, and practised in all subtleties of the schools, Cesalpino was not the man to surrender himself quietly to the influence of nature on the unconscious powers of the mind; on the contrary, he sought from the first to bring all that he learnt from the writings of others and from his own acute observation of the forms of plants into subjection to his own understanding. Hence he approached the task of the scientific botanist in an entirely different way from that of de l'Obel and Kaspar Bauhin. It was by philosophical reflections on the nature of the plant and on the substantial and accidental value of its parts, according to Aristotelian conceptions, that he was led to distribute the vegetable kingdom into groups and sub-groups founded on definite marks.

This difference in the origin of the systematic efforts of Cesalpino on the one hand and of de l'Obel and Bauhin on the other is unmistakably apparent; the Germans were instinctively led by the resemblances to the conception of natural groups, Cesalpino on the contrary framed his groups on the sharp distinctions which resulted from the application of predetermined marks; all the faults in Bauhin's system are due to incorrect judgment of resemblances, those of Cesalpino to incorrectness in distinguishing.

But the main point of difference lies in the fact, that the system is presented by de l'Obel and Bauhin without any statement of the principles on which it rests ; in their account of it the association of ideas is left to perfect itself in the mind of the reader, as it grew up before in the authors themselves. De l'Obel and Bauhin are like artists, who convey their own impressions to others not by words and descriptions, but by pictorial representations; Cesalpino, on the other hand, addresses himself at once to the understanding of his reader and shows him on philosophic grounds that there must be a classification, and states the principles of this classifi- 
cation; it was on philosophic grounds also that he made the characters of the seed and the fruit the basis of his arrangement, while the German botanists, paying little attention to the organs of fructification, were chiefly influenced by the general impression produced by the plant, by its habit as the phrase now is.

The historians of botany have overlooked the real state of the case as here presented, or have not described it with sufficient emphasis; due attention has not been paid to the fact, that systematic botany, as it began to develope in the I 7 th century, contained within itself from the first two opposing elements; on the one hand the fact of a natural affinity indistinctly felt, which was brought out by the botanists of Germany and the Netherlands, and on the other the desire, to which Cesalpino first gave expression, of arriving by the path of clear perception at a classification of the vegetable kingdom which should satisfy the understanding. These two elements of systematic investigation were entirely incommensurable; it was not possible by the use of arbitrary principles of classification which satisfied the understanding to do justice at the same time to the instinctive feeling for natural affinity which would not be argued away. This incommensurability between natural affinity and a priori grounds of classification is everywhere expressed in the systems embracing the whole vegetable kingdom, which were proposed up to $173^{6}$, and which including those of Cesalpino and Linnaeus were not less in number than fifteen. It is the custom to describe these systems, of which those of Cesalpino, Morison, Ray, Bachmann (Rivinus), and Tournefort are the most important, by the one word 'artificial' ; but it was by no means the intention of those men to propose classifications of the vegetable kingdom which should be merely artificial, and do no more than offer an

1 It will be shown in a later chapter that Linnaeus' sextlal system was intended to be artificial. 
arrangement adapted for ready reference. It is true that the botanists of the $I 7$ th century and Linnaeus himself often spoke of facility of use as a great object to be kept in view in constructing a system; but every one who brought out a new system did so really because he believed that his own was a better expression of natural affinities than those of his predecessors. If some like Ray and Morison were more influenced by the wish to exhibit natural affinities by means of a system, and others as Tournefort and Magnol thought more of framing a perspicuous and handy arrangement of plants, yet it is plain from the objections which every succeeding systematist makes to his predecessors, that the exhibition of natural affinities was more or less clearly in the minds of all as the main object of the system; only they all employed the same wrong means for securing this end, for they fancied that natural affinities could be brought out by the use of a few easily recognised marks, whose value for systematic purposes had been arbitrarily determined. This opposition between means and end runs through all systematic botany from Cesalpino in 1583 to Linnaeus in 1736 .

But a new departure dates from Linnaeus himself, since he was the first who clearly perceived the existence of this discord. $\mathrm{He}$ was the first who said distinctly, that there is a natural system of plants, which could not be established by the use of predetermined marks, as had been previously attempted, and that even the rules for framing it were still undiscovered. In his Fragments of the date of 1738 , he gave a list of sixty-five groups or orders, which he regarded provisionally as cycles of natural affinity, but he did not venture to give their characteristic marks. These groups, though better separated and more naturally arranged than those of Kaspar Bauhin, were like his founded solely on a refined feeling for the relative resemblances and graduated differences that were observed in comparing plants with one another, and this is no less true of the enumeration of natural families attempted by Bernard de Jussieu in 
I 759. To such of these small groups of related forms as had not been already named both Linnaeus and Jussieu gave names, which they took not from certain marks, but from the name of a genus in each group. But this mode of naming plainly expresses the idea which from that time forward prevailed in systematic botany, that there is a common type lying at the foundation of each natural group, from which all its forms though specifically distinct can be derived, as the forms of a crystal may all be derived from one fundamental form, - an idea which was also expressed by Pyrame de Candolle in 18 ig.

But botanists could not rest content with merely naming natural groups; it was necessary to translate the indistinct feeling, which had suggested the groups of Linnaeus and Bernard de Jussieu, into the language of science by assigning clearly recognised marks; and this was from this time forward the task of systematists from Antoine Laurent de Jussieu and de Candolle to Endlicher and Lindley. But it cannot be denied, that later systematists repeatedly committed the fault of splitting up natural groups of affinity by artificial divisions and of bringing together the unlike, as Cesalpino and the botanists of the I 7 th century had done before them, though continued practice was always leading to a more perfect exhibition of natural affinities.

But while natural relationship was thus becoming more and more the guiding idea in the minds of 'systematists, and the experience of centuries was enforcing the lesson, that predetermined grounds of classification could not do justice to natural affinities, the fact of affinity became itself more unintelligible and mysterious. It seemed impossible to give a clear and precise definition of the conception, the exhibition of which was felt to be the proper. object of all efforts to discover the natural system, and which continued to be known by the name of affinity. A sense of this mystery is expressed in the sentence of Linnaeus: 'It is not the character (the marks used to characterise the genus) which makes the genus, but the genus 
which makes the character;' but the very man, who first distinctly recognised this difficulty in the natural system, helped to increase it by his doctrine of the constancy of species. This doctrine appears in Linnaeus in an unobtrusive form, rather as resulting from daily experience and liable to be modified by further investigation; but it became with his successors an article of faith, a dogma, which no botanist could even doubt without losing his scientific reputation; and thus during more than a hundred years the belief, that every organic form owes its existence to a separate act of creation and is therefore absolutely distinct from all other forms, subsisted side by side with the fact of experience, that there is an intimate tie of relationship between these forms, which can only be imperfectly indicated by definite marks. Every systematist knew that this relationship was something more than mere resemblance perceivable by the senses, while thinking men saw the contradiction between the assumption of an absolute difference of origin in species (for that is what is meant by their constancy) and the fact of their affinity. Linnaeus in his later years made some strange attempts to explain away this contradiction; his successors adopted a way of their own; various scholastic notions from the 16 th century still survived among the systematists, especially after Linnaeus had assumed the lead among them, and it was thought that the dogma of the constancy of species might find especially in Plato's misinterpreted doctrine of ideas a philosophical justification, which was the more acceptable because it harmonised well with the tenets of the Church. If, as Elias Fries said in 1835 , there is ' quoddam supranaturale' in the natural system, namely the affinity of organisms, so much the better for the system; in the opinion of the same writer each division of the system expresses an idea ('singula sphaera (sectio) ideam quandam exponit'), and all these ideas might easily be explained in their ideal connection as representing the plan of creation. If observation and theoretical considerations occasionally 
suggested objections to such views, these objections were usually little regarded, and in fact reflections of this kind on the real meaning of the natural system did not often make their appearance; the most intelligent men turned away with an uncomfortable feeling from these doubts and difficulties, and preferred to devote their time and powers to the discovery of affinities in individual forms. At the same time it was well understood that the question was one which lay at the foundation of the science. At a later period the researches of Nägeli and others in morphology resulted in discoveries of the greatest importance to systematic botany, and disclosed facts which were necessarily fatal to the hypothesis, that every group in the system represents an idea in the Platonic sense; such for instance were the remarkable embryological relations, which Hofmeister discovered in I $85 \mathrm{I}$, between Angiosperms, Gymnosperms, Vascular Cryptogams and Muscineae; nor was it easy to reconcile the fact, that the physiologico-biological peculiarities on the one hand and the morphological and systematic characters on the other are commonly quite independent of one another, with the plan of creation as conceived by the systematists. Thus an opposition between true scientific research and the theoretical views of the systematists became more and more apparent, and no one who paid attention to both could avoid a painful feeling of uncertainty with respect to this portion of the science. This feeling was due to the dogma of the constancy of species, and to the consequent impossibility of giving a scientific definition of the idea of affinity.

This state of things finally ceased with the appearance of Darwin's first and best book on the origin of species in 1859 ; from a multitude of facts, some new, but most of them long well-known, he showed that the constancy of species was no longer an open question; that the doctrine was no result of exact observation, but an article of faith opposed to observation. The establishment of this truth was followed almost as a 
matter of course by the true conception of that which had been hitherto figuratively called affinity; the degrees of affinity expressed in the natural system indicated the different degrees of derivation of the varying progeny of common parents; out of affinity taken in a figurative sense arose a real blood-relationship, and the natural system became a table of the pedigree of the vegetable kingdom. Here was the solution of the ancient problem.

Darwin's theory has this special interest in the history of the science, that it established clearness in the place of obscurity, a scientific principle in place of a scholastic mode of thought, in the domain of systematic botany and morphology. Yet Darwin did not effect this change in opposition to the historical development of our science or independently of it; on the contrary his great merit is that he has correctly appreciated the problems long existing in systematic botany and morphology from the point of view of modern research, and has solved them.

That the constancy of species is incompatible with the idea of affinity, that the morphological (genetic) nature of organs does not proceed on parallel lines with their physiological and functional significance, are facts which were known in botany and zoology before the time of Darwin ; but he was the first to show, that variation and natural selection in the struggle for existence solve these problems, and enable us to conceive of these facts as the necessary effects of known causes; it is at the same time explained, why the natural affinity first recognised by de l'Obel and Kaspar Bauhin cannot be exhibited by the use of predetermined principles of classification, as was attempted by Cesalpino. 


\section{CHAPTER I.}

The Botanists of Germany and the Netherlands from Brunfels to Kaspar Bauhin ${ }^{1}$.

I $530-1623$.

WHEN those who are accustomed to modern botanical literature take up for the first time the works of Otto Brunfels ( 1530 ), Leonhard Fuchs (1542), Hieronymus Bock (Tragus), or of the later authors Rembert Dodoens (Dodonäus), Charles de l'Écluse (Carolus Clusius), Matthias de l'Obel (Lobelius, I576), or even those of Kaspar Bauhin from the beginning of the 17 th century, they are surprised not only by the strange form, the curious and unfamiliar accessories from which what is really useful must be laboriously extracted, but still more by the extraordinary poverty of thought which characterises these composers of usually very thick folios. If however instead of travelling backwards from the present time they pursue the opposite direction ; if they have previously occupied themselves with the botanical views of Aristotle and the comprehensive botanical works of his disciple Theophrastus of Eresus, with Pliny's Natural History and the medical science of Dioscorides;

1 Kurt Sprengel in his 'Geschichte der Botanik,' i. I8I7, and Ernst Meyer in his ' Geschichte der Botanik,' iv. I 857 have described the connection between the first beginnings of modern botany and the general state of learning in the $\mathbf{1}_{5}$ th and 16 th centuries; a particularly interesting notice of Valerius Cordus from the pen of Thilo Irmisch will be found in the 'Prüfungsprogramm' of the Schwarzburg gymnasium of Sondershausen for I 862 . Here, as throughout, the present work will be confined to the investigation and description of the development of strictly botanical ideas. 
I 4 Botanists of Germany and the Netherlands [Boor I.

if they have made themselves acquainted with the botanical literature of the middle ages and noted how it continually grows less and less valuable, and have proceeded through the works of Albertus Magnus, as prolix as they are deficient in ideas, to the 'Hortus Sanitatis' (Garden of Health), the popular work on natural history before and after 1500 , and similar productions, then certainly they receive a very different and almost imposing impression even from the first herbals, those of Brunfels, Bock, and Fuchs. These books will appear to them almost modern in comparison with the last-named productions of medieval superstition, nor will they fail to perceive that a new epoch of natural science commenced with these men, and above all that they laid the foundations of modern botany. They give us, it is true, nothing but separate descriptions of the wild and cultivated plants of Germany, and these for the most part of common occurrence, arranged by Fuchs alphabetically, by Bock grouped under the heads of herbs, shrubs, and trees, and following one another under each head in the most motley order ; it is true that these descriptions are so naive and inartistic as hardly to offer points of comparison with modern scientifically correct diagnoses; but the great point is, that they are taken from the plants as they lay before the writers, who had often seen and carefully examined them. Woodcuts are added to supply any defects in the description, and to give a clear idea of the plant intended by the name; and these figures, which always give the whole plant and were drawn immediately from nature by the hands of practised artists, are so true to nature that a botanist's eye at once recognises in every case the object meant to be represented. These figures and descriptions (the latter are wanting in Brunfels ${ }^{1}$, 1530) would have rendered a great service to the

1 Otto Brunfels, born at Mainz before the year I500, was at first a student of theology and a monk; becoming a convert to Protestantism he was actively engaged at Strassburg first as a teacher and afterwards as a physician; he died in 1534 . 
science, even if they had not been as good as they are; for botanical literature had sunk so low, that not only were the figures embellished with fabulous additions, as in the 'Hortus Sanitatis,' and sometimes drawn purely from fancy, but the meagre descriptions of quite common plants were not taken from nature, but borrowed from earlier authorities and eked out with superstitious fictions. The powers of independent judgment were oppressed and stunted in the middle ages, till at last the very activity of the senses, resting as it does to a great extent on unconscious operations of the understanding, became weak and sickly; natural objects presented themselves to the eye even of those who made them their study in grotesquely distorted forms; every sensuous impression was corrupted and deformed by the influence of a superstitious fancy. In comparison with these perversions the artless descriptions of Bock appear suitable and true, and are refreshing from their immediate contact with nature; while in the more learned Fuchs criticism of other writers is already seen united with actual examination of natural objects. Great was the gain when men began once more to look at plants with open eyes, to take pleasure in their variety and beauty. It was not necessary for a while that they should speculate on the nature of plants, or the cause of plant-life; time enough for that when sufficient practice had been gained in the perception of their resemblances and differences.

The German fathers of botany connected their labours with the botanical literature of classical antiquity only so far as they sought to recognise in the plants of their own country those named by Theophrastus, Dioscorides, Pliny and Galen. The attempt to do this indeed led to many mistakes, for the descriptions of the ancient botanists were very imperfect and often quite unserviceable for the recognition of the plants described. In this point therefore the compilers of herbals found no models worthy of imitation in the old writers. But in seeking to recover a knowledge of the medicinal plants of the Greek 
physicians $^{1}$, they were compelled to compare together a great variety of native plants, and thus to exercise and perfect the faculty of apprehending differences of form. This mode of proceeding, arising out of medical requirements, directed the attention entirely to the individual form, which was also the chief thing required in the interest of pure science, and much more was thus gained than if these men had only followed the philosophical writings of Aristotle ${ }^{2}$ and Theophrastus ${ }^{3}$. The Greek authors built their views on the philosophy of botany on very weak foundations; scarcely a plant was known to them exactly in all its parts; they derived much of their knowledge from the accounts of others, often from dealers in herbs. From this scanty material and from various popular superstitions had Aristotle formed his views on the nature of plants, and if Theophrastus possessed more experimental knowledge, he still saw facts in the light of his master's philosophical doctrines. If we succeed in the present day in extracting much that is accurate from the writings of Aristotle and Theophrastus, it was nevertheless well that the first compilers of herbals ceased to pay attention to them, and occupied themselves with accumulating descriptions of individual plants worked out by them-

1 Beside the herbals mentioned in the text, which may be regarded as scientific works on botany, a considerable number of books on the signature of plants were written in the 16 th and 17 th centuries in the interests of medicine or medical superstition. It was believed that certain external marks and resemblances between parts of plants and the organs of the human body indicated the plants and the parts of them which possessed healing virtues. Pritzel mentions by name twenty-four works of the kind, which appeared between $\mathrm{I}_{55} \mathrm{O}$ and $\mathrm{I} 697$. The herbals also noticed the signatures, and even Ray has an enquiry into the subject.

2 The fragments of Aristotelian botany which have come down to us are to be found translated from Wimmer's edition in Ernst Meyer's 'Geschichte der Botanik,' i. p. 94 .

${ }^{3}$ Ernst Meyer (Geschichte der Botanik) gives a full account of Theophrastus, who was born at Lesbos A.C. 371 and died A.C. 286. An edition of his work 'De historia et de causis plantarum' was published by Theodor Gaza in $\mathrm{I}_{4}{ }^{8} 3$. See also Pritzel's 'Thesaurus literarum botanicarum.' 
Chap. I.] from Brunfels to Kaspar Bauhin.

selves with all possible exactness. History shows that in this way a new science arose in the course of a few years, while the philosophical botany of Aristotle and Theophrastus has led to no important result. Moreover we shall see how even in the hands of a philosophically gifted and scholarly man like Cesalpino the teaching of Aristotle had only a mischievous effect on the study of plants.

If the compilers of herbals did not aim at deducing general conclusions from their observations, yet the continually accumulating descriptions of individual forms gradually gave rise of themselves to perceptions of an abstract and more comprehensive character. The feeling for resemblance and difference of form especially was developed, and finally the idea of natural relationship; and though this idea was as yet by no means worked out with scientific precision, it was nevertheless, even in the indistinct form in which it appears in de l'Obel in 1576 and more clearly in Kaspar Bauhin in 1623 , a result of the highest value, and one of which neither learned antiquity nor the middle ages had ever caught a glimpse. The perception of a natural affinity among plants could only be obtained from exact description a thousand times repeated, never from the abstractions of the Aristotelian school, which rested essentially on superficial observation. It appears then that the scientific value of the herbals of the $\mathrm{I}$ 6th century lay mostly in the description of such plants as every botanist found in a somewhat limited portion of his native land, and considered worth his notice; at the same time the later compilers endeavoured to give a universal character to each herbal by admitting plants which had not been actually seen by the writer; each as far as possible gathered from his predecessors all that they had seen, and added what he had himself seen that was new ; but in contrast with the previous centuries the peculiar merit of each new herbal was held to depend not on what the compiler had borrowed from his predecessors, but on what he had added from his own observation. Hence every one was anxious to 
introduce into his work as many plants unknown till that time or unnoticed as he possibly could, and the number of descriptions of individual forms mounted rapidly up; in Fuchs in I 542 we find about five hundred species described and figured, but in 1623 the number of species as enumerated by Kaspar Bauhin had risen to six thousand. As the botanists were spread over a large part of Germany, Fuchs in Bavaria and afterwards at Tübingen, Bock on the middle Rhine, Konrad Gesner at Zürich, Dodoens and de l'Obel in the Netherlands, a territory of considerable extent was thus examined ; it was enlarged by the contributions which travellers brought or transmitted to the botanists, and de l'Écluse especially traversed a large part of Germany and Hungary and even of Spain, and eagerly collected and described the plants of those countries. During this period also the number of known plants was increased from Italy, partly by the exertions of Italian botanists, such as Mattioli, and partly by travelling Germans. The first flora of the Thüringer-Wald was written by Thal, but not published till after his death in ${ }^{5} 58$. Botanical gardens even, though in more modest form than in our day, were already helping in the I 6 th century to add to the knowledge of plants ; the first were formed in Italy, as at Padua in 1545 , at Pisa in 1547 , at Bologna in 1567 under Aldrovandi, afterwards under Cesalpino. Soon similar collections of living plants were made in the north; in 1577 a botanic garden was founded at Leyden, over which de l'Écluse long presided, in 1593 at Heidelberg and at Montpellier; in the course of the next century the number of these gardens was considerably increased.

The preserving of dried plants, the formation of the collections which we now call herbaria, dates from the 16 th century; at that time however the word herbarium meant a book of plants. In this matter also the Italians led the way. According to Ernst Meyer, Luca Chini seems to have been the first who made use of dried plants for scientific purposes, and his two pupils Aldrovandi and Cesalpino are said to have formed 
the first herbaria in our sense of the word; one of the first collections of the kind, perhaps of the date of r559, was the herbarium formed by Ratzenberger, which was discovered in the museum at Cassel a few years since and described by Kessler.

These are matters somewhat external to our immediate subject, but they show how lively an interest was taken in botany in the latter half of the sixteenth century; this is still more shown by the great number of books of plants, published with numerous and expensive plates and in some cases going through several editions. But the artistic and scientific value of the drawings, which were appended to the descriptions and in later herbals were reckoned by thousands, did not keep equal pace with their number; Fuchs' splendid figures remained unapproached, and gradually, as the distance from Dürer's time increased, the woodcuts grew smaller and poorer ${ }^{1}$, and sometimes even quite indistinct. The art of describing on the contrary continually improved; the descriptions became fuller, and gradually a certain method appeared in assigning marks and in estimating their value; critical remarks on the identity or non-identity of species, the separation of forms previously considered to be alike, and similar matters occur morefrequently. The descriptions in de l'Écluse may in fact claim to be called scientific; in Kaspar Bauhin they appear in the form of terse and methodical diagnoses.

The most remarkable thing to us in these descriptions from Fuchs and Bock to Bauhin is the striking neglect of the flowers and fruit. The earliest descriptions, especially those of Bock, endeavour to depict the form of the plant in words, to render directly the impression on the senses; special attention was paid to the shape of the leaves, the nature of the ramification, the character of the roots, the size and colour of the flowers.

1 See L. C. Treviranus in his work, 'Die Anwendung des Holzschnitts zur bildlichen Darstellung der Pflanzen,' Leipzig, 1855, and Choulant ' Graphische Incunabeln,' Leipzig, I 858 . 
KonRAD GESNER ${ }^{1}$ was the only one who bestowed a closer attention on the flowers and parts of the fruits; he figured them repeatedly, and recognised their great value for the determination of affinity, as we learn from his expressions in his letters ; but the much occupied and much harassed man died before he could complete the work on plants which he had long been preparing, and when in the $\mathrm{I} 8$ th century Schmiedel published Gesner's figures, which meanwhile had passed through various hands, the work too long delayed remained useless to a science which had already outstripped it.

It will be gathered from the above remarks, that we find in these authors no approach to a system of morphology founded on a comparative examination of the parts of plants, and therefore no regular technical language. Still the more learned among them felt the necessity of connecting the words they used in describing a plant with a fixed sense, of defining their conceptions; and though their first efforts in this direction were weak, they deserve notice, because they show more than anything else how great has been the advance in the study of nature from the I6th century to the present day.

The first attempt to establish a botanical terminology is to be found as early as I542 in the 'Historia Stirpium' of LEONHARD FUCHS ${ }^{2}$. Four pages at the beginning of the work are thus occupied. A considerable number of words are explained in alphabetical order-the mode of arrangement which he followed also in describing his plants. It is difficult

1 Konrad Gesner, born in Zürich in ${ }_{5} \mathrm{I} 6$, became after many vicissitudes of fortune Professor of Natural History in his native town, and died there of the plague in ${ }^{5} 5_{5}$. See Ernst Meyer, 'Geschichte der Botanik,' iv.

- Leonhard Fuchs, born at Membdingen in Bavaria in I 501 , was a student of the classics under Reuchlin in Ingolstadt in 1519 , and became Doctor of Medicine in $\mathbf{5} 5 \mathbf{2 4}$. Owing to his conversion to Protestantism he led an unsettled life for some years, but was finally made Professor of Medicine in Tübingen in ${ }^{1} 535$, and died there in ${ }_{5} 566$. See Meyer, ' Geschichte der Botanik,' iv. 
to give a clear idea of this the first botanic terminology by selected examples; yet the attempt must be made, because it is in this way only that we learn to see from what feeble beginnings the later scientific terminology and morphology has been developed. Thus we read: 'Acinus' denotes not merely, as many believe, the grains inside the grape, but the whole fruit, which consists of juice, of a fleshy portion with the stones ('vinaceis'), and of the outer skin. Galen is quoted as authority for the following explanation: 'Alae' are said to be the hollows (angles) between the stem and its branches (the leaves), from which new sprouts (' proles') proceed. 'Asparragi,' the germs of herbs which appear before the leaves and the first edible shoots are developed. 'Baccae' are smaller 'foetus' of herbs, shrubs, and trees, which appear separate and isolated on the plant, as for example laurel-berries ('partus lauri '), and differ from acini, inasmuch as these are more crowded together. 'Internodium' is that which lies between the articulations or knees. 'Racemus' is used for the bunch of grapes, but does not belong to the vine only, but also to the ivy and other herbs and shrubs which bear clusters of any kind. The majority of such explanations of names concern the forms of the stem and the branches, but the most remarkable thing about the whole list is, that it does not include the words flower and root; yet under the word 'julus' occurs the statement, that it is that which in the hazel 'compactili callo racematim cohaeret,' and may be described as a long worm borne on a special pendent stalk and coming before the fruit. Though the word flower is not explained, yet some parts of the flower are mentioned; thus it is said, 'stamina sunt, qui in medio calycis erumpunt apices, sic dicta quod veluti filamenta intimo floris sinu prosiliant.' The explanation of the word fruit may be added: 'Fructus, quod carne et semine compactum est ; frequenter tamen pro eo, quod involucro perinde quasi carne et semine coactum est, accipi solet.'

Progress in this direction was slow but still recognisable. In 
the last edition of the 'Pemptades' of Dodoens' of the year. I6I6, a folio volume of 872 pages, only one page and a third are devoted to the explanation of the parts of plants; but the selection of the words explained and the substance of the explanations hit the essential points better than in Fuchs. We find for instance: Root ('radix, $\dot{p} i \xi a$ ') is the name given in the tree and in every other plant to the lower part, by which it penetrates into the earth and cleaves to it, and by which it draws its nourishment. This part, unlike the leaves which are usually deciduous, is common to all plants, a few only excepted which live and grow without roots, such as Cassytha, Viscum, and the plant called 'Hyphear,' Fungi, Mosses, and Fuci, all which are however usually reckoned among фĩ a. 'Caudex' is in trees and shrubs that which springs from the root and rises above the ground, and by which the nourishment is carried upwards; the same part is called in herbs caulis or cauliculus. Leaf ('folium') is in every plant that which clothes and adorns it, and without which trees and other plants appear naked. The definition of a flower would lose in a translation: ' flos, äv $\theta_{o s}$, arborem et herbarum gaudium dicitur, futurique fructus spes est ; unaquaeque etenim stirps pro natura sua post florem partus ac fructus gignit.' The parts of the flower are with him the calyx ('calyx'), in which the blossom is at first enclosed and with which the 'foetus' is soon surrounded, stamens ('stamina') which arise like threads from the depth of the blossom and from the calyx, and 'apices' (anthers), certain thickish appendages on the summit of the stamens. 'Julus' (catkin) is that which hangs down round and long in place of the flower, as in the walnut, hazel, mulberry, beech, and other

1 Rembert Dodoens (Dodonaeus), born at Malines in $15^{\mathrm{I}} 7$, was a physician, and a man of varied culture; he published a number of botanical wcrks, some of them in Flemish, after $155^{2}$, and finally in 1583 his 'Stirpium Historiae Pemptades vi' (Antwerp). From 1574 to 1579 he was physician to the Emperor Maximilian II. In $\mathbf{I}_{5} 82$ he became Professor in Leyden and died in ${ }^{5} 5^{8}$. See Ernst Meyer, 'Geschichte der Botanik,' iv. p. $34^{\circ}$. 
trees. 'Fructus' is that in which the seed is formed, but frequently it is itself the seed, as where the latter is not enclosed in anything else and is formed naked. We must not be led by these words to think of our Gymnosperms, but must understand that here, as with all botanists till the time of A. L. de Jussieu and Joseph Gärtner ( 1788 ), naked seeds mean dry indehiscent fruits.

De l'Obel, from whom especially we might have looked for similar explanations, has given none.

The absence of more profound comparative examination of the parts of plants, as shown in the examples of terminology here adduced, may serve as an additional support of the assertion, that natural affinity was not inferred from exact comparison of the form of organs, but was the result of a feeling arising from the likeness of habit directly apprehended by the senses, that is by the collective impression produced by the whole plant.

Passing to the consideration of the attempts in systematic botany made by the Germans in this period, the chief thing to notice is, that the division into the main groups of trees, shrubs, undershrubs, and herbs was the one generally adopted; these groups were borrowed from antiquity and were maintained even by the special systematists, from Cesalpino to the beginning of the 18 th century; nor was any change made in principle when these four groups were reduced to three or two (trees and herbs). It was moreover considered to be self-evident that trees were the most perfect plants. Hence when relationship is spoken of in subsequent remarks, it must be understood that this holds good only within the groups just mentioned. The classifications of the German and Dutch botanists not only sprang from the describing of individual plants, but they were originally in a certain sense identical with it. In undertaking to describe individual forms, the first task was to separate those which closely resembled one another, for the resemblance of syste- 
matically-allied plants is often so great, that to distinguish them specifically requires consideration and careful comparison. The resemblance is more obvious than the difference. There are moreover many plants which are entirely distinct from one another in their inner nature, but which appear strikingly alike if we regard the impression produced immediately on the senses, and the converse of this statement is equally true. Hence the attempt to circumscribe and fix individual forms in the act of describing was at once found to involve difficulties, the solution of which leads directly to the conception of some kind of arrangement. A comparison of the herbals of Fuchs and Bock up to Kaspar Bauhin shows very plainly how these difficulties were gradually overcome, how the describing of single species led necessarily, and without the intention of the describer, to considerations of a distinctly systematic character. Where the species in a group of forms, which we now designate as a genus or family, closely resemble each other in habit, there arose of itself the instinctive feeling that such forms belong to one another. This feeling asserted itself in words when, as was done from the first, a number of such forms were without conscious reflection designated by the same name; thus, to mention one of many examples, we find Bock applying the name Wolfsmilk, Euphorbia, not to one species of the genus, but to several, which he then distinguishes by epithets (common, least, cypress, sweet). The customary mode of expression in the herbals is very instructive on this point; there are, they say, two or more of this or that plant which have not been hitherto distinguished. But this feeling of connection and similarity of kind was produced not only by forms that were closely allied, but also by such as belong to extensive groups of the system; thus the words moss, lichen, fungus, alga, fern, had long served to include a great number of distinct forms, though the separation of these groups had nowhere in truth been carried out with logical precision.

These remarks are important as serving to show in the most 
decisive manner the incorrectness of the assertion, that the study of organisms sprang from the recognition of individual species ; that it is this which is directly given, and that without it no advance in the science is possible. 'The historical fact rather is, that descriptive botany began often, perhaps most often, not with species but with genera and families, that very often at first whole groups of forms were conceived of as unities, which had to be divided later and of set purpose into separate forms ; and up to the present day one part of the task of the systematist is to undertake the splitting up of forms previously regarded as identical. The notion that the species is the object originally presented to the observer, and that certain species were afterwards united into genera, is one that was invented in post-Linnaean times under the dominion of the dogma of the constancy of species ; it happened so sometimes, but just as often the genus was the object first presented, and the task of the describer was to resolve it into a number of species. In the 16 th century the conception neither of genus or species had yet been defined; for the botanists of that period genera and species had the same objective reality. But, in the process of continually making the descriptions of individual plants more exact, forms once separated were united, and those before assumed to be identical were separated, till it gradually became apparent that both operations must be pursued with system and method. It cannot therefore be exactly said that somebody first established the species, another the genus, and a third person again the larger groups. It is more correct to say that the botanists of the I6th century carried out this process of separation up to a certain point without intending it, and in the effort to give the greatest possible preciseness to their descriptions of individual forms. It lay therefore in the nature of the case, that those groups which we call genera and species should first be cleared up, and we find in fact at the end of this period in Kaspar Bauhin the genera already distinguished by names, if not by characters; the species by names 
and characters. Together with these smaller groups, many more comprehensive ones, which we now designate families, were also marked off and supplied with names, which are still in use. The r6th century established the groups and names of Coniferae, Umbelliferae, Verticillatae (Labiatae), Capillares (Ferns), and others. It is true that the determination of the limits of these groups by distinct marks was not yet attempted, but the plants belonging to these groups were again and again treated of in special chapters or ranged in due succession one after another. But as long as this was done to some extent without design, and the real meaning of this relationship was not yet recognised, other considerations of very various kinds influenced the composition of the books and disturbed the natural arrangement. The feeling for natural affinity supplants all other considerations in de l'Obel first, and after him much more completely in Kaspar Bauhin.

Enough perhaps has now been said to render the main result of the botanical efforts of the period, which we are considering, intelligible to the reader; but a clear view of the method of describing plants at that time, and of the way in which systematic botany came into being, can only be shown by examples; and if we proceed to give some here, it is with the purpose with which figures copied as exactly as possible from nature are added to treatises on natural history, because a real understanding is only to be gained in this way. The botanical literature of the I6th century is so different from that of the 19 th, that a very indistinct idea of it could be obtained from a statement of results expressed in modern terms.

Fuchs, Historia Stirpium, I 542.

The common plant now known as Convolvulus arvensis is there called Helxine cissampelos, and is described in the following manner:

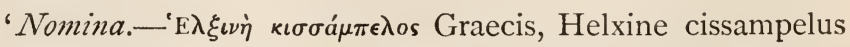
et Convolvulus Latinis nominatur. Vulgus herbariorum et 
officinae Volubilem mediam et vitealem appellant, Germani Mittelwinden oder Weingartenwinden. Recte autem Cissampelos dicitur, in vineis enim potissimum nascitur et folio hederaceo. Convolvulus vero quod crebra revolutione vicinos frutices et herbas implicet.

Forma.-Folia habet hederae similia, minora tamen, ramulos exiguos circumplectentes quodcumque contigerint. Folia denique ejus scansili ordine alterna subeunt. Flores primum candidos lilii effigie, dein in puniceum vergentes, profert. Semen angulosum in folliculis acinorum specie.

Locus.-In vineis nascitur, unde etiam ei appellatio cissampeli, ut diximus, indita est.

Tempus.-Aestate, potissimum autem Julio et Augusto mensibus, floret.'

Hieronymus Bock', at page 299 of his 'Herbal,' published at Strassburg in 1560 , describes the same plant and Convolvulus sepium as follows:

' Of the white wind-bell.

'Two common wind-plants grow everywhere in our land with white bell-flowers. The larger prefers to dwell by hedges, and creeps over itself, twists and twines, etc. The little windor bell-flower (Convolvulus arvensis) is like the large one with its roots, round stems, leaves and bell-flowers, in all things smaller, thinner, and shorter. Some flowers on this plant are quite white, some of a beautiful flesh colour, painted with red dish brown streaks. It grows in dry meadows, in herb- and onion-gardens, and does harm therein, because with its creeping and twining it oppresses other garden herbs, and is also bad to exstirpate, because the thin white rootlets make their way deep

1 Hieronymus Bock (Tragus) was born at Heiderbach in the Zweibrücken in 1498 ; he was destined to the cloister, but embraced Protestantism and became a schoolmaster in Zweibrïcken and superintendent of the Prince's garden; he was afterwards preacher in Hornbach, where he practised also as a physician and pursued his botanical studies; he died in I 554. See Erust Meyer, 'Geschichte der Botanik,' iv. p. 303. 
downwards, spread very widely, and are continually putting forth new and young clusters like hops.'

Then follows a long paragraph on the names, that is, a critical review of the opinions of different writers on the question, which of Dioscorides' or Pliny's names should be applied to the plant described. 'I must think,' says Bock, 'that this flower is a wild sort, Scammonia Dioscoridis (but harmless), which herb Dioscorides also calls colophonia, dactylion, apopleumenon, sanilum, and colophonium,' and so on. Then follows a chapter on its virtue and effect externally and internally.

As regards the arrangement of the 567 species described by Bock, he divides his book into three parts, the first and second containing the smaller herbs, the third the shrubs and trees. In each part closely allied plants are generally described in larger or smaller numbers one immediately after another, though the compiler is all the time under the influence of very various considerations, and follows no general principle. For instance, our Convolvulus stands in the midst of a number of other very different. plants, which either climb as the ivy, or twine with tendrils as Smilax; then follows Lysimachia Nummularia, which simply runs along the ground, then the hop, Solanum Dulcamara, Clematis, Bryonia, Lonicera, and different Cucurbitaceae; immediately after come the Burdocks, Teasels, and Thistles, and these are followed by some Umbelliferae. The whole work is conceived in a similar spirit; the feeling for relationship is clearly to be traced within very narrow circles, but it finds imperfect expression and is frequently disturbed by reference to biological habit; this appears especially in the beginning of the third part, which treats of shrubs generally, shrubs which form hedges, and trees, 'as they grow in our German land'; the first chapter is on the fungi which grow on trees, the second on some mosses, and these are followed immediately by the mistletoe. Then come the heather and some smaller shrubs, 
and finally larger and the largest trees. The chapter on Fungi under the section 'Of names' contains a statement of views on the nature of fungi, such as are often repeated even into the I 7 th century: 'Mushrooms are neither herbs nor roots, neither flowers nor seeds, but merely the superfluous moisture of the earth and trees, of rotten wood and other rotten things. From such moisture grow all tubera and fungi. This is plain from the fact that all the above-mentioned mushrooms, those especially which are used for eating, grow most when it will thunder or rain, as Aquinas Ponta says. For this reason the ancients paid peculiar regard to them, and were of opinion that tubera, since they come up from no seed, have some connection with the sky; Porphyrius speaks also in this manner, and says that fungi and tubera are called children of the gods, because they are born without seeds and not as other kinds.'

We pass over Valerius Cordus, Conrad Gesner, Mattioli ${ }^{1}$, and some other unimportant writers, and turn to Dodoens, de l'Écluse, and Dalechamps, in whom a marked tendency to orderly arrangement appears, though the principle of arrangement in all three lies essentially in points external and accidental, and above all in the relations of the plant-world to mankind. Within the divisions thus artificially formed a constantly increasing attention is paid to natural affinities, but at the same time allied forms are separated without scruple in deference to the artificial principle of classification. It can also be plainly seen, that these writers think more of giving some order to their matter than of discovering the arrangement that will be in conformity with nature. It is impossible to give the reader a good idea of these classifications in our scientific language;

1 Pierandrea Mattioli, who was born at Siena in I 501 and died there in $\mathbf{1 5 7 7}$, was for many years physician at the court of Ferdinand I. He wrote rather in the interests of medicine than of botany; his herbal, originally a commentary on Dioscorides, was gradually enlarged and went through more than sixty editions and issues in different languages. See Meyer, ' Geschichte der Botanik,' vi. 
it would be necessary to transcribe them. For brevity's sake we will here quote DE L'ÉCLUSE only ${ }^{1}$, the best of the three writers named above. In his 'Rariorum plantarum historia,' which appeared as early as 1576 , but which lies before the writer of these pages in the edition of r6or, the first book treats of trees, shrubs, and undershrubs; the second of bulbous plants; the third of sweet-smelling flowers; the fourth of those without smell; the fifth of poisonous, narcotic, and acrid plants ; the sixth of those that have a milky juice, and of Umbelliferae, Ferns, Grasses, Leguminosae, and some Cryptogams.

A similar arrangement is found in Dalechamps ${ }^{2}$; that of Dodoens in his 'Pemptades' is more perplexed and unnatural ; but the design in both of them is evidently much the same as that of de l'Écluse. This design is best seen from the introductory observations to each book; de l'Écluse, for instance, says at page 127 , 'Having treated of the history of trees, shrubs, and under-shrubs, and put these together in the preceding book, we will now in this second book describe such plants as have a bulbous or tuberous root, many of which attract and delight the eyes of all persons in an extraordinary degree by the elegance and variety of their flowers, and which therefore ought not to have the lowest place assigned to them among garland-plants ('inter coronarias'). We will begin with the plants of the lily kind, on account of their size and the beauty of their flowers, etc. etc.' The introductions to the several books of the 'Pemptades' of Dodoens are more learned and more diffuse. It is plain that the composers of these works had no thought of arranging

${ }^{1}$ Charles de l'Écluse (Carolus Clusius) was born in Arras in $\mathbf{1 5}_{526 .}$ His family suffered from religious persecution in France, and he spent the greater part of his life in Germany and the Netherlands ; in 1573 he removed to Vienna by the invitation of Maximilian II ; in $\mathbf{I} 593$ he became professor in Leyden and died there in 1609 . See Meyer, 'Geschichte der Botanik,' iv, who gives full information respecting the eventful life of this distinguished man.

${ }^{2}$ Jacques Dalechamps, a native of Caen, who died in ${ }_{1} 588$, was a philologist rather than an original investigator of nature, as is remarked by Meyer in his 'Geschichte der Botanik,' vi. p. 395. 
their matter on the principles of a true natural system, but were only anxious to give some kind of order to their descriptions of individual plants. Hence their divisions do not appear under the names of classes and subdivisions ('genera majora et minora,' as they would have been called at that time), but they are sections of the whole work kept as symmetrical as was possible. If we would discover in these works whatever may really lay claim to systematic value, we must not rely on the sections as they are typographically distinguished, but must observe within each of them the order in which the plants are given, and then it becomes apparent that within the frame once established forms naturally allied are, as far as may be, grouped together. For instance, we find in the second book of de l'Écluse's work first of all a long list of true Liliaceae and Asphodeleae, Melanthaceae, and Irideae described in unbroken succession; then comes Calamus, and then without any explanation a number of the Ranunculaceae, among which the genera Ranunculus and Anemone are very well distinguished; but then follows the genus Cyclamen with several species, and next a number of Orchideae, in the middle of which appear Orobanche and Corydalis, followed by Helleborus niger, Veratrum album, Polygonatum, and others. So it is in the other sections, though in general the species of a genus stand together, and even the genera of a family are not unfrequently united; but with all this there are no proper breaks, because other considerations are perpetually disturbing the feeling for natural relationship. 'The descriptions of de l'Écluse are generally commended, and they deserve to be commended for their fulness of detail and their attention to the structure of the flowers, though he, like de l'Obel and Dodoens, describes the leaves more minutely than any other part of the plant.

With DE L'OBEL ${ }^{1}$, as has been already observed, the feeling

${ }^{1}$ Mathias de l'Obel (Lobelius); the friend and fellow-countryman of 
for natural affinity declares itself for the first time so decidedly as to outweigh if not entirely to set aside all other considerations. The fact is disclosed to us in the preface to his 'Stirpium adversaria nova' of $5_{576}$, where these words occur : 'proinde adversariorum voce novas veteribus additas plantas et novum ordinem quadantenus innuimus. Qui ordo utique sibi similis et unus progreditur ducitque a sensui propinquioribus et magis familiaribus ad ignotiora et compositiora, modumque sive progressum similitudinis sequitur et familiaritatis, quo et universim et particulatim, quantum licuit per rerum varietatem et vastitatem, sibi responderet. Sic enim ordine, quo nihil pulchrius in coelo aut in sapientis animo, quae longe lateque disparata sunt unum quasi fiunt, magno verborum memoriae et cognitionis compendio, ut Aristoteli et Theophrasto placet.'

We must not indeed expect to find that de l'Obel really produced a natural system of plants ; but his 'Observationes' still more than his 'Adversaria' attest his efforts to arrange plants according to their resemblances in form; and in these efforts he is guided not by instinct merely and the general habit, but mainly and with evident purpose by the form of the leaves ; thus beginning with Grasses, which have narrow, long, and simple leaves, he proceeds to the broader-leaved Liliaceae and Orchideae; then passing on to the Dicotyledons he exhibits the main groups in fairly well limited masses. Still the Ferns appear in the middle of the Dicotyledons on account of the form of their leaves, while on the other hand, the Cruciferae, Umbelliferae, Papilionaceae and Labiatae remain but little disturbed in their continuity by secondary considerations.

The progress of botanical science in the period which we have been considering reaches its highest point in the labours of

Dodoens and de l'Écluse, was born at Lille in $\mathrm{r}_{53} 8$ and died in England in 16I6. A full account of this botanist will be found in Meyer. 
Kaspar Bauhin ${ }^{1}$, as regards both the naming and describing of individual plants and their classification according to likeness of habit. In Bauhin all secondary considerations have disappeared; his works may be called botanical in the strict scientific meaning of the word, and they show how far it is possible to advance in a descriptive science without the aid of a general system of comparative morphology, and how far the mere perception of likeness of habit is a sufficient foundation for a natural classification of plants; it was scarcely possible to make greater advances on the path pursued by the botanists of Germany and the Netherlands.

The descriptions of species in the 'Prodromus Theatri Botanici' of KASPAR BAUHin ( 1620 ) notice all obvious parts of the plant with all possible brevity and in a fixed order; the form of the root, height and form of the stem, characters of the leaves, flowers, fruit, and seed are given in concise sentences seldom occupying more than twenty short lines; the description of a single species is here in fact developed into an art and becomes a diagnosis.

A still higher value must be set on the fact, that in Kaspar Bauhin the distinction between species and genus is fully and consciously carried out; every plant has with him a generic and a specific name, and this binary nomenclature, which Linnaeus is usually thought to have founded, is almost perfectly maintained by Bauhin, especially in the 'Pinax'; it is true that a third and fourth word is not unfrequently appended to the second, the specific name, but this additional word is evidently only an auxiliary. It is remarkable on the other hand, that he has added no characters to the names of the

1 Kaspar Bauhin was born at Basle in $\mathbf{I} 55^{\circ}$, and like his elder brother John studied under Fuchs; he collected plants in Switzerland, Italy, and France, and became professor in Basle; he died in 1624. Some account is given of him and of his brother by Haller in the preface to his 'Historia Stirpium Helvetiae' ( $\mathrm{I} 768$ ), and by Sprengel in his 'Geschichte der Botanik,' i. p. $36_{4}$ (1818). 


\section{Botanists of Germany and the Netherlands [Bоо I.}

genera; it is only from the name that we know that several species belong to one genus; we might almost believe that the characters of the genus are intended to be supplied by the strange etymological explanation appended in italics to the generic name. These fanciful etymologies maintained themselves to the end of the 17 th century, when Tournefort did battle with them; they were an evil which sprang in a great measure from Aristotelian and scholastic modes of thought, and from the belief that it was possible to conceive of the nature of a thing from the original meaning of its name.

Nothing shows better the earnestness of Bauhin's research than the fact, that he devoted the labour of forty years to his ' Pinax,' in order to show how each one of the species given by him was named by earlier botanists. The example already given from Fuchs shows how many names a plant had received by the middle of the 16 th century; even in Dioscorides and Pliny we find a whole row of names given for a single plant, and the botanists of Fuchs' time used their utmost endeavours to attach the names in Dioscorides and other ancient writers to particular plants found in central Europe. Dioscorides, Theophrastus, and Pliny either add no descriptions to the names of their plants, or they describe them in so unsatisfactory a manner, that it was a very difficult task for the science of that day, as it is still for us, to recognise the plants of the ancient writers ; hence arose such a confusion of names that the reader of a botanical work can never be sure whether the plant of one author is the same as that of another with the same name. A description of a plant is therefore usually accompanied in the r 6 th century by a critical enquiry how far the name used agrees with that of other authors. Kaspar Bauhin sought to put an end to this condition of uncertainty by his 'Pinax,' in which he showed in the case of all species known to him what were the names given to them by the earlier writers, and he has thus enabled us to see our way through the nomenclature of the period of which we are speaking; the 'Pinax' is in a word the 
first and for that time a completely exhaustive book of synonyms, and is still indispensable for the history of individual species-no small praise to be given to a work that is more than 250 years old.

It would not have been unsuitable to the purpose of the author of the 'Pinax,' if he had allowed himself to give the plants in alphabetical order, but instead of this we find a careful arrangement according to natural affinities. This directly proves what is also confirmed by the 'Prodromus,' that Bauhin regarded such an arrangement as of the greatest importance. In this point, as in others, he goes far beyond his predecessors; he pursues the same method as de l'Obel had pursued forty years before, but he carries it out more thoroughly. At the same time he shares with his predecessors the peculiarity of not distinguishing the larger groups, which with some exceptions answer to our present families, by special names or by descriptions; it is only from the order in which the species follow one another that we can gather his views on natural relationship. It follows therefore that the natural families, so far as they are distinguishable in Bauhin's works, have no sharp bounding lines; we might almost conclude that he purposely avoided assigning such limits, that he might be able to pass without interruption from one chain of relationship to another.

Like de l'Obel, Bauhin proceeds in his enumeration from the supposed most imperfect to the more perfect forms, beginning with the Grasses and the majority of Liliaceae and Zingiberaceae, passing on to dicotyledonous herbs, and ending with shrubs and trees.

The Cryptogams that were known to him stand in the middle of the series of dicotyledonous herbs, between the Papilionaceae and the Thistles, the Equisetaceae being reckoned among the Grasses. On the great distinction between Cryptogams and Phanerogams the views of Bauhin were evidently less clear than those of many of his predecessors ; but it will not seem strange that he should place some Phanerogams, as for 


\section{$3^{6}$ Botansts of Germany and the Netherlands.}

instance the Duckweeds, among the Cryptogams and the Salviniaceae among the Mosses, and unite the Corals, Alcionieae, and Sponges with the Seaweeds, when we consider that it was not till the middle of the $\mathrm{I} 8$ th century that more correct views arose in respect to these forms, and that Linnaeus himself could not decide whether the Zoophytes should be excluded from the vegetable kingdom and ranked with animals. The knowledge of plants in the scientific sense of the word was till the beginning of the $19^{\text {th }}$ century limited to the Phanerogams; and in speaking of principles and methods in descriptive botany before that time we must think only of the Phanerogams, or at most of the Phanerogams and the Ferns. The methodical examination of the Cryptogams belongs to quite recent botanical research. The matter is here alluded to only in connection with the fact, that it is from the works of Kaspar Bauhin, a writer of ability, in whom the first period of scientific botany culminates, that we most clearly see how great the advance has been since his time. 


\section{CHAPTER II.}

Artificial Systems and Terminology of Organs from Cesalpino to Linnaeus.

$$
\text { I } 583-1760 .
$$

WhiLe botany was being developed in Germany and the Netherlands in the manner described in the previous chapter, and long before this process of development reached its furthest point in Kaspar Bauhin, Andrea Cesalpino in Italy was laying down the general plan, on which the further advance of descriptive botany was to proceed in the $\mathrm{I} 7$ th and till far into the I8th century; all that was done in the I 7 th century in Germany, England, and France towards furthering morphology and systematic botany was done with a reference to Cesalpino's principles, whether these were accepted and made use of, or whether it was sought to refute them. This connection with Cesalpino became gradually less close and less obvious, being concealed by new points of view and by the increase of material for observation; but Cesalpino's ideas on the theoretical principles of systematic botany and the nature of plants appear so plainly, even in the views of Linnaeus, that no one can read both authors without lighting not unfrequently upon passages in Linnaeus' 'Fundamenta' or in his 'Philosophia Botanica,' which remind him of Cesalpino, and even upon sentences borrowed from him. As we saw in Kaspar Bauhin the close of the course of development commenced by Fuchs and Bock, so we may regard Linnaeus as having built up and completed the edifice of doctrine founded by Cesalpino. 


\section{$3^{8}$ Artificial Systems and Terminology of Organs [Воок I.}

Cesalpino comes before us, in strong contrast with the simple-minded empiricism of the German fathers of botany, as the thinker in presence of the vegetable world. Their main task was the amassing descriptions of individual plants. Cesalpino made the material gathered by experience the subject of earnest reflection; he sought especially to obtain universals from particulars, important principles from sensuous perceptions; but as his forms of thought were entirely Aristotelian, it was inevitable that his interpretation of the facts should introduce into them much that would have to be got rid of subsequently by the inductive method. Cesalpino differs also from the German botanists in another respect; he did not rest satisfied with the general impression produced by the plants, but carefully examined the separate parts and paid attention to the small and concealed organs; he was the first who converted observation into real scientific research; and thus we find in him a remarkable union of inductive natural science and Aristotelian philosophy, a mixture which gives a peculiar character to the theoretical efforts of his successors down to Linnaeus.

Cesalpino was moreover much before his time in his mode of contemplating the vegetable kingdom, seeking always for philosophical combinations and comprehensive points of view. His work which appeared in $1_{5} 8_{3}$ exercised no perceptible influence on his contemporaries; a trace of such influence only may be seen in Kaspar Bauhin thirty or forty years later, while the work of the botanists who followed Bauhin down to 1670 was confined everywhere to increasing the knowledge of individual plants. With this object travels were undertaken after 1600 to all parts of the world; many new botanic gardens were added to the few which had been founded in the 16 th century-as at Giessen in 1617 , at Paris in 1620 , at Jena in 1629 , at Oxford in 1632 , at Amsterdam in 1646 , at Utrecht in 1650 . Instead of endeavouring to embrace with their labours the whole vegetable kingdom, botanists preferred to devote themselves to the examination of 
single districts. This gave rise to the first local floras (the word flora, however, was first introduced by Linnaeus in the next century), and of these Germany especially soon produced a considerable number; a flora of Altorf was published by Ludwig Jungermann in r6 5 , of Ingolstadt by Albert Menzel in 1618 , of Giessen by Jungermann in 1623 , of Dantzic by Nicolaus Oelhafen in r643, of Halle by Carl Scheffer in r662, of the Palatinate by Frank von Frankenau in r68o, of Leipsic by Paul Ammann in 1675, of Nuremberg by J. Z. Volkamer in I 700 .

But though travel, catalogues in local floras, and the cultivation of plants in botanic gardens promote knowledge of very varied kind, yet this remains scattered about among descriptions of plants, until at last a writer with powers of combination and wider and deeper glance endeavours to gain some general conclusions from them. Such attempts we first meet with late in the second half of the $\mathbf{r} 7$ th century in Morison, Ray, Bachmann (Rivinus), Tournefort, and others, who took up Cesalpino's principles after they had lain neglected for almost a hundred years, and indeed were almost forgotten by botanists.

In the dearth of higher scientific efforts during this period, the describing of plants and cataloguing of species prolonged a somewhat pitiful existence. This describing, a work of great usefulness in the fathers of German botany, was now become by perpetual repetition a mechanical labour; all that was to be gained in this way had already been gained by de l'Obel and Bauhin. This sterility which followed upon the fruitful beginnings of the I6th century was general; neither in Germany nor Italy, neither in France nor England, did the botanists produce anything of importance. The representatives of the science did not count among the more highly gifted or among the thinkers of their time; and so content with the minor work of collecting and cataloguing plants, and with endeavouring to know all plants as far as possible by name, they lost whatever capacity they may have possessed for 
40 Artificial Systems and Termmology of Organs [Воок I.

more difficult operations of the mind simply by not attempting them.

There was one man indeed in Germany who studied the vegetable kingdom in the first half of the $\mathrm{r} 7$ th century in the spirit of Cesalpino before him, but who, like Cesalpino, found no honour among contemporary botanists. This man was the well-known philosopher Joachim Jung, who invented a comparative terminology for the parts of plants, and occupied himself with critical enquiries into the theory of the system, the naming of species and other subjects, embodying their results in a long array of aphorisms. Free from the geniusstifling burden which the knowledge of individual species had become, a man possessed of varied accomplishments and a well-trained mind, Jung was better qualified than the professed botanists to see what was wanted in botany and would advance it - a phenomenon more than once repeated in the history of the science. But his results remained unknown to all except his immediate pupils, till Ray admitted them into his great work on plants in 1693 , and made them the foundation of his own theoretical botany. Enriched by Ray's good morphological remarks, Jung's terminology passed to Linnaeus, who adopted it as he adopted every thing useful that literature offered him, improving it here and there, but impairing its spirit by his dry systematising manner.

The labours of the botanists of Germany and the Netherlands during the $\mathrm{r} 7$ th century, which culminated in Kaspar Bauhin, were not without important influence upon the development of systematic botany which began with Cesalpino. When Cesalpino wrote the work which forms an epoch in the science, he was perhaps unacquainted with the natural classification of de l'Obel ( 1576$)$; at least there is nothing in his book which shows that he had seen it; it appears even as though he had made the discovery independently, that there is an actual connection of relationship among plants expressed in their organisation as a whole; it is at any rate certain that this fact 
assumed from the first an entirely different expression in his system from that which it received at the hands of de l'Obel and Bauhin, inasmuch as he was not guided by an indistinct feeling for resemblances, but believed that he could establish on predetermined grounds a system of marks, by which the objective relationship must be recognised. If Cesalpino was thus in advance of the German botanists, since he endeavoured to express with clearness and on principle that which they only felt indistinctly, he was at the same time treading a dangerous path, and one which led succeeding botanists astray till the time of Linnaeus, - the path which must always lead to artificial classifications, since the natural system can never be laid down upon a priori principles of division. Through this labyrinth, in which botanists down to Linnaeus wandered fruitlessly hither and thither, there remained one guide consistently pointing to the goal to be attained, namely, the feeling for natural affinity first vividly apprehended by the German botanists, and expressed by them to some extent in their classifications. And when at last Linnaeus and Bernard de Jussieu made the first feeble attempts at a natural arrangement, it was the same indistinct perception which asserted itself in them as in de l'Obel and Bauhin, and enabled them to see that the path hitherto trodden could only lead astray.

The period in the development of descriptive botany which begins with Cesalpino and reaches to Linnaeus may accordingly be perhaps best characterised by saying, that botanists sought to do justice to natural affinities by means of artificial classifications, till at length Linnaeus clearly perceived the contradiction involved in this method of proceeding. But inasmuch as Linnaeus left it to the future to work out the natural system, and arranged the plants which he described in a confessedly artificial manner, he so far marks rather the close of a previous condition of the science than the beginning of modern botany.

These introductory observations will have supplied the reader with the thread which will guide him through the 
following account of the more prominent points in the history of botanical science from Cesalpino to Linnaeus.

The often-quoted work of Andrea Cesalpino', 'De plantis libri XVI,' appeared in Florence in the year $\mathrm{I}_{5} 8_{3}$. If the value of the contemporary German botanists lies pre-eminently in the accumulation of descriptions of individual plants, and these, it is true, occupy fifteen books of Cesalpino's work, it is on the contrary the introduction in the first book, a discussion of the general theory of the subject, which in his case is of much the higher importance for the history of botany. This contains in thirty pages a full and connected exposition of the whole of theoretical botany, and though based on broad and general views is at the same time extremely rich in matter conveyed in a very concise form. The different branches into which the subject has since been divided are here united into an inseparable whole; morphology, anatomy, biology, physiology, systematic botany, terminology are so closely combined, that it is difficult to explain Cesalpino's views on any one more general question without at the same time touching on a variety of other matters. Three things more especially characterise this introductory book; first, a great number of new and delicate observations; secondly, the great importance which Cesalpino assigns to the organs of fructification as objects of morphological investigation; lastly, the way in which he philosophises in strictly Aristotelian fashion on the material thus gained from experience. If this treatment has produced a work beautiful in style and fascinating to the reader, if the whole subject is vivified by it while each separate fact gains a more general value, it is on the other hand apparent that the writer is often led astray by the well-known elements of the Aristotelian philosophy, which are opposed to the interests of scientific investigation. Mere creations of thought, the abstractions of

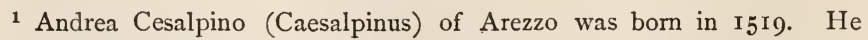
was a pupil of Ghini and professor at Pisa, and afterwards physician to Pope Clement VIII. He died in 1603 . 
the understanding, are treated as really existent substances, as active forces, under the name of principles; final causes appear side by side with efficient; the organs and functions of the organism exist either alicujus gratiâ or merely ob necessitatem; the whole account is controlled by a teleology, the influence of which is the more pernicious because the purposes assumed are supposed to be acknowledged and self-evident, plants and vegetation being conceived of as in every respect an imperfect imitation of the animal kingdom. It was moreover a necessary consequence of the treatment of his material adopted by Cesalpino, that his ignorance of the sexuality of plants and of the use of leaves as organs of nutrition led him to false and mischievous conclusions; this defect of knowledge would have been of less importance in a purely morphological consideration of plants, as we shall see presently in Jung; but with Cesalpino morphological and physiological considerations are so mixed up together, that a mistake in the one direction necessarily involved mistakes in the other.

These remarks on Cesalpino's method may be illustrated by some examples tending to show how closely he attaches himself to Aristotle, and how certain Aristotelian conceptions, the origin of which has not been sufficiently regarded, passed through him into later botanical speculation. We shall recur in the History of Physiology to Cesalpino's views on nutrition, and to his rejection of the doctrine of sexuality in plants.

'As the nature of plants,' so begins Cesalpino's book, 'possesses only that kind of soul by which they are nourished, grow, and produce their like, and they are therefore without sensation and motion in which the nature of animals consists, plants have accordingly need of a much smaller apparatus of organs than animals.' This idea reappears again and again in the history of botany, and the anatomists and physiologists of the 18 th century were never weary of dilating on the simplicity of the structure of plants and of the functions of their organs. 'But since,' continues Cesalpino, 'the function of the nutritive 
soul consists in producing something like itself, and this like has its origin in the food for maintaining the life of the individual, or in the seed for continuing the species, perfect plants have at most two parts, which are however of the highest necessity; one part called the root by which they procure food; the other by which they bear the fruit, a kind of foetus for the continuation of the species; and this part is named the stem ('caulis') in smaller plants, the trunk ('caudex') in trees.'

This in the main correct conception of the upright stem as the seed-bearer of the plant was also long maintained in botany. We should observe also that the production of the seed is spoken of as merely another kind of nutrition, a notion which afterwards prevented Malpighi from correctly explaining the flower and fruit, and in a modified form led Kaspar Friedrich Wolff in I 759 to a very wrong conception of the nature of the sexual function. The next sentence in Cesalpino takes us into the heart of the Aristotelian misinterpretation of the plant, according to which the root answers to the mouth or stomach, and must therefore be regarded in idea as the upper part although it is the lower in position, and the plant would have to be compared with an animal set on its head, and the upper and lower parts determined accordingly: 'this part (the root) is the nobler ('superior') because it is prior in origin and sunk in the ground; for many plants live by the roots only after the stem with the ripe seeds has disappeared; the stem is of less importance ('inferior') although it rises above the ground; for the excreta, if there are any, are given off by means of this part; it is, therefore, with plants as with animals as regards the expressions ' pars superior' and 'inferior.' When indeed we take into consideration the mode of nourishment, we must define the upper and the lower in another way ; since in plants and animals the food mounts upward (for that which nourishes is light because it is carried upwards by the heat), it was necessary to place the roots below and to make the stem go straight upwards, for in animals also the veins are rooted in the lower part of the 
stomach, while their main trunk ascends to the heart and the head.' Here, in genuine Aristotelian fashion, the facts are forced into a previously constructed scheme.

Cesalpino's discussion of the seat of the soul in plants is of special interest in connection with certain views of later botanists. 'Whether any one part in plants can be assigned as the seat of the soul, such as the heart in animals, is a matter for consideration-for since the soul is the active principle ('actus') of the organic body, it can neither be 'tota in toto' nor ' tota in singulis partibus,' but entirely in some one and chief part, from which life is distributed to the other dependent parts. If the function of the root is to draw food from the earth, and of the stem to bear the seeds, and the two cannot exchange functions, so that the root should bear seeds and the shoot penetrate into the earth, there must either be two souls different in kind and separate in place, the one residing in the root, the other in the shoot, or there must be only one, which supplies both with their peculiar capabilities. But that there are not two souls of different kinds and in a different part in each plant may be argued thus; we often see a root cut off from a plant send forth a shoot, and in like manner a branch cut off send a root into the ground, as though there were a soul indivisible in its kind present in both parts. But this would seem to show that the whole soul is present in both parts, and that it is wholly in the whole plant, if there were not this objection that, as we find in many cases, the capabilities are distributed between the two parts in such a way that the shoot, though buried in the ground, never sends out roots, for example in Pinus and Abies, in which plants also the roots that are cut off perish.' This, he thinks, proves that there is only one soul residing in root and stem, but that it is not present in all the parts; in a further discussion he seeks to discover the true seat of the soul. He points out an anatomical distinction between the shoot and the root; the root consists of the rind and an inner substance which in some cases is hard and woody, in 


\section{Artificial Systems and Terminology of Organs [Boor I.}

others soft and fleshy. In the stem on the other hand there are three constituent parts; outside the rind, inside the pith, between the two a body which in trees is called the wood. This, on the whole, correct distinction between stem and root is followed by a thoroughly Aristotelian deduction.

'Since then in all creatures' (we must remark, that this is assuming a point which has yet to be proved in the case of the half of living creatures) ' nature conceals the principle of life in the innermost parts, as the entrails in animals, it is reasonable to conclude that the principle of life in plants is not in the rind, but is more deeply hidden in the inner parts, that is, in the pith, which is found in the stem and not in the root. That this was the opinion of the ancients we may gather from the name, for they called this part in plants the heart ('cor'), or brain ('cerebrum' or 'matrix'), because from this part in some degree the principle of foetification (the formation of the seed) is derived.' Here we see why the seed must, according to Cesalpino, have its origin in the pith; the idea was loyally repeated after him by Linnaeus, as we shall see hereafter. The argument, which is a long one, ends with the sentence: 'There are then two chief parts in plants, the root and the ascending part; therefore the most suitable spot for the heart of plants seems to be in the central part, namely, where the shoot joins on to the root. There appears also at this spot a certain substance differing both from the shoot and from the root, softer and more fleshy than either, for which reason it is usually called the cerebrum; it is edible in many plants while they are young.' We shall see below how important a part this seat of the soul of the plant, brought to light with such difficulty and with all appliances of scholasticism, is intended to play in Cesalpino's system, and how by this a priori path he was led to the use of the position of the embryo in the seed as his principle of division. It may be remarked here that the point of union between the root and the stem, in which Cesalpino placed the seat of the plant-soul, afterwards received the name of root- 
neck (collet); and though the Linnaean botanists of the igth century were unaware of what Cesalpino had proved in the I6th, and did not even believe in a soul of plants, they still entertained a superstitious respect for this part of the plant, which is really no part at all ; and this, it would seem, explains the fact, that an importance scarcely intelligible without reference to history was once attributed to it, especially by some French botanists. To return once more to Cesalpino's 'cor,' he is not much troubled by the circumstance that plants can be reproduced from severed portions; in true Aristotelian manner he says that although the principle of life is actually only one, yet potentially it is manifold. Ultimately a 'cor' is found in the axil of every leaf, by which the axillary shoot is united with the pith of the mother-shoot, and finally, in direct contradiction to the previous proof that the crown of the root is the seat of the plant-soul, it is distinctly affirmed in Chapter $\mathrm{V}$ that the soul of plants is in some sense diffused through all their parts.

The theoretical introduction to his excellent and copious remarks on the parts of fructification may supply another example of Cesalpino's peripatetic method: 'As the final cause ('finis') of plants consists in that propagation which is effected by the seed, while propagation from a shoot is of a more imperfect nature, in so far as plants do exist in a divided state, so the beauty of plants is best shown in the production of seed; for in the number of the parts, and the forms and varieties of the seed-vessels, the fructification shows a much greater amount of adornment than the unfolding of a shoot; this wonderful beauty proves the delight ('delitias') of generating nature in the bringing forth of seeds. Consequently as in animals the seed is an excretion of the most highly refined food-substance in the heart, by the vital warmth and spirit of which it is made fruitful, so also in plants it is necessary that the substance of the seeds should be secreted from the part in which the principle of the natural heat lies, and this part is the pith. For this reason, 
therefore, the pith of the seed (that is, the substance of the cotyledons and of the endosperm) springs from the moister and purer part of the food, while the husk which surrounds the seed for protection springs from the coarser part. It was unnecessary to separate a special fertilising substance from the rest of the matter in plants, as it is separated in animals which are thus distinguished as male and female.'

This last remark and some lengthy deductions which follow are intended to prove, after the example of Aristotle, the absence and indeed the impossibility of sexuality in plants, and accordingly Cesalpino goes on to compare the parts of the flower, which he knew better than his contemporaries, with the envelopes of the ova in the foetus of animals, which he regards as organs of protection. Calyx, corolla, stamens, and carpels are in his view only protecting envelopes of the young seed, as the leaves are only a means of protecting the young shoots. Moreover by the word flower ('flos') Cesalpino understands only those parts of the flower which do not directly belong to the rudiment of the fruit, namely, the calyx, the corolla, and the stamens. This must be borne in mind if we would understand his theory of fructification, and especially his doctrine of metamorphosis. We must also note, that by the expression pericarp he understands exclusively juicy edible fruit-envelopes, though at the same time pulpy seed-envelopes inside the fruit pass with him for pericarps. 'The parts of his flower are the 'folium,' which evidently means the corolla, but in certain cases includes also the calyx ; the 'stamen,' which is our style ; and the 'flocci,' our stamens. We see that Cesalpino uses the same word 'folium' without distinction for calyx, corolla, and ordinary leaves ; just as he, and Malpighi a hundred years later, unhesitatingly regarded the cotyledons as metamorphosed leaves. In fact the envelopes of the flower and the cotyledons approach so nearly to the character of leaves, that every unprejudiced eye must instinctively perceive the resemblance; and if doubts arose on this point in post-Linnaean times, it was only a conse- 
quence of the Linnaean terminology, which neglected all comparative examination.

Moreover the doctrine of metamorphosis appears in a more consistent and necessary form in Cesalpino than in the botanists of the Igth century before Darwin; it flows more immediately from his philosophical views on the nature of plants, and appears therefore up to a certain point thoroughly intelligible. We may also consider as part of this doctrine in Cesalpino the view that the substance of the seed (embryo and endosperm) arises from the pith, because the pith contains the vital principle $^{1}$, and as the pith in the shoot is surrounded for protection by the wood and the bark, so the substance of the seed is surrounded by the woody shell, and by the bark-like pericarp or by a fruit-envelope answering to a pericarp. According to Cesalpino therefore the substance of the seed with its capability of development springs from the pith, the woody shell from the wood, the pericarp from the rind of the shoot. The difficulty which arises from this interpretation, namely, that in accordance with his theory the parts of the flower also, the calyx, the corolla, and the stamens ought to spring from the outer tissues of the shoot, he puts aside with the remark (p. I9) that these parts of the flower are formed when the pericarp is still in a rudimentary state; that the pericarp is only fully developed after these parts have fallen off, and that they are so thin that there is nothing surprising in this view of the matter. We see in Cesalpino's doctrine of metamorphosis without doubt the theory of the flower afterwards adopted by Linnaeus, though in a somewhat different form. That Linnaeus himself regarded the theory ascribed to him on the nature of the flower

1 We find it stated in Theophrastus that if the pith of the vine is destroyed the grapes contain no stones; this evidently points to a still higher antiquity for the view that the seeds are formed from the pith; see the De causis plantarum, v. ch. 5 , in the 'Theophrasti quae supersunt opera' of Schneider, Leipzig, I8I 8. 
as the opinion of Cesalpino also, is shown in his 'Classes Plantarum,' where in describing Cesalpino's system he says: 'He regarded the flower as the interior portions of the plant, which emerge from the bursting rind; the calyx as a thicker portion of the rind of the shoot; the corolla as an inner and thinner rind; the stamens as the interior fibres of the wood, and the pistil as the pith of the plant.' It may be observed however that this was not exactly what Cesalpino says; but it is nevertheless certain that Linnaeus' own view as given in these words was intended to reproduce that of Cesalpino; and if it does not do this exactly, there is no essential difference in principle between the two, Linnaeus' conception being perhaps a more logical statement of Cesalpino's meaning. Cesalpino's doctrine of metamorphosis appears plainly on another occasion also; he says, that we do not find envelopes, stamens, and styles in all flowers; the flowers change in some cases into another substance, as in the hazel, the edible chestnut, and all plants that bear catkins; the catkin is in place of a flower, and is a longish body arising from the seat of the fruit, and in this way fruits appear without flowers, for the styles ('stamina') form the longer axis of the catkin ('in amenti longitudinem transeunt'), while the leafy parts and the stamens are changed into its scales. All this shows that the notion of a metamorphosis, of which we find intimations as early as Theophrastus, was a familiar one to Cesalpino, and it fitted in perfectly with his Aristotelian philosophy, while Goethe's doctrine on the same subject is equally scholastic in its character, and therefore looks strange and foreign in modern science. It has already been observed that Cesalpino includes only the envelopes and stamens under the word flower, and distinguishes the rudiments of the fruit from them; therefore he says that there are plants which produce something in the shape of a catkin, without any hope of fruit, for they are entirely unfruitful ; but those which bear fruit have no flowers, as Oxycedrus, Taxus, and among herbs Mercurialis, Urtica, Cannabis, in which 
the sterile plants are termed male, the fruitful female. Thus he distinguished the cases which we now call dioecious from the previously mentioned monoecious plants, among which he reckons the maize.

All this may serve to give the reader some idea, though a very incomplete one, of Cesalpino's theory ; to do him justice, it would be necessary to give a full account of his very numerous, accurate, and often acute observations on the position of leaves, the formation of fruit, the distribution of seeds and their position in the fruit, of his comparative observations on the parts of the fruit in different plants, and above all of his very excellent description of plants with tendrils and climbing plants, of those that are armed with thorns and the like. Though there is naturally much that is erroneous and inexact in his accounts, yet we have before us in the chapters on these subjects the first beginning of a comparative morphology, which quite casts into the shade all that Aristotle and Theophrastus have said on the subject. But the most brilliant portions of his general botany are contained in the 12 th, I $3^{\text {th, and }} \mathrm{I} 4^{\text {th }}$ chapters, in which he gives the outlines of his views on the systematic arrangement of plants; to prepare the way for what is to follow, he shows first that it is better to give up the four old divisions of the vegetable kingdom, and to unite the shrubs with the trees and the undershrubs with the herbs. But how these genera are to be distinguished into species is, he says, hard to conceive, for the multitude of plants is almost innumerable; there must be many intermediate genera containing the 'ultimae species,' but few are as yet known. He then turns to the divisions founded on the relations of plants to men. Such groups, he says, as vegetables and kinds of grain, which are put together under the name of 'fruges' and kitchen-herbs ('olera '), are formed more from the use made of them than from the resemblance of form, which we require; and he shows this by good examples. The discerning of plants, he continues, is very difficult, for so long as the genera (larger groups) are undetermined, the species must 
necessarily be mixed up together ${ }^{1}$; the difficulty arises from our uncertainty as to the rules by which we should determine the resemblances of the genera. While there are two chief parts in plants, the root and the shoot, we cannot, as it seems, determine the genera and species from the likeness or unlikeness either of the one or of the other; for if we make a genus of those plants which have a round root, as the turnip, Aristolochia, Cyclamen, Arum, we separate generically things which agree together in a high degree, as rape and radish which agree with the turnip, and the long Aristolochia which agrees with the round, while at the same time we unite things most dissimilar, for the Cyclamen and the turnip are in every other respect of a quite different nature; the same is the case with divisions which rest merely on differences in the leaves and flowers.

In pursuing these reflections, which have the conception of species chiefly in view, he arrives at the following proposition : That according to the law of nature like always produces like, and that which is of the same species with itself.

All that Cesalpino says on systematic arrangement shows that he was perfectly clear in his own mind with regard to the distinction between a division on subjective grounds, and one that respects the inner nature of plants themselves, and that he accepted the latter as the only true one. He says, for instance, in the next chapter: "We seek out similarities and dissimilarities of form, in which the essence ('substantia') of plants consists, but not of things which are merely accidents of them ('quae accidunt ipsis ').' Medicinal virtues and other useful qualities are, he says, just such accidents. Here we see the path opened, along which all scientific arrangement must proceed, if it is to exhibit real natural affinities; but at the same time there is a warning already of the error which beset systematic botany up

1 These words are quoted by Linnaeus in the 'Philosophia Botanica,' par. I59. 
to Darwin's time; if in the above sentence we substitute the word idea for that of substance, and the two expressions have much the same meaning in the Aristotelian and Platonic view of nature, we recognise the modern predarwinian doctrine, that species, genera, and families represent 'ideam quandam ' and 'quoddam supranaturale.'

Pursuing his deductions, Cesalpino next shows, that the most important divisions, those of woody plants and herbs, must be maintained in accordance with the most important function of vegetation, that of drawing up the food through root and shoot; this division passed from the first and later on up to the time of Jung for an unassailable dogma, to which science simply had to conform. The second great function of plants is the producing their like, and this is effected by the parts of fructification. Though these parts are only found in the more perfect forms, yet the subdivisions ('posteriora genera') must be derived in both trees and herbs from likeness and unlikeness in the fructification. And thus Cesalpino was led, not by induction but by the deductive path of pure Aristotelian philosophy, to the conclusion, that the principles of a natural classification are to be drawn from the organs of fructification; for which conclusion Linnaeus declared him to be the first of systematists, while he thought de l'Obel and Kaspar Bauhin, who founded their arrangements on the habit only, scarcely deserving of notice.

It appears, then, that Cesalpino obtained the subdivisions which he founded on the organs of fructification from a priori views of the comparative value of organs, such as run through all Aristotelian philosophy. Of much interesting matter in the remainder of his introduction we must mention only that he makes the highest product of plants to be the fructification, of animals sense and movement, of man the intellect ; and because the latter stands in need of no special bodily instruments, there is no specific difference in men, and therefore only one species of man.

In his 14 th chapter he gives in broad outline a view of the 


\section{Artificial Systems and Terminology of Organs [Boor I.}

system of plants which he founded on the fructification, beginning with the least perfect; no one who knows the botanical writers of the $\mathrm{I} 7$ th and $\mathrm{I} 8$ th centuries will be surprised to find that Cesalpino admits the doctrine of ' generatio spontanea' in the case of the lower plants, and in a somewhat crude form; this came from the teaching of Aristotle, and even a hundred years later Mariotte endeavoured to set up a plausible defence of spontaneous generation on physical grounds even in highly developed plants.

'Some plants,' says Cesalpino, ' have no seed; these are the most imperfect, and spring from decaying substances; they have only therefore to feed themselves and grow, and are unable to produce their like; they are a sort of intermediate existences between plants and inanimate nature. In this respect Fungi resemble Zoophytes, which are intermediate between plants and animals, and of the same nature are the Lemnae, Lichenes, and many plants which grow in the sea.'

Some on the other hand produce seed, which they form after their peculiar nature in an imperfect condition, as the mule among animals; these are of the same nature as mere monstrosities or diseased growths of other plants, and many occur in the class of grain and bear empty ears. Cesalpino is evidently speaking of the Ustilagineae, but he includes also the Orobancheae and Hypocystis, which instead of seed contain only a powder; and he adds that some of the more perfect plants are sterile, but they do not belong to this division, because the peculiarity is confined in their case to individuals.

Some plants bear a substance, a kind of wool, on the leaves, which to some extent answers to seed, because it serves to propagate the plant; such plants have neither stem, flower, nor true seed, and the Ferns are of this kind. We should notice this conclusion from Cesalpino's morphology, that plants without true seeds have also no stem; the view that ferns have no stems continued to be held by later botanists, though the original reason for it was gradually lost; and those who in the 


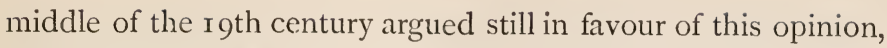
little suspected that they were endeavouring to establish a dogma of the Aristotelian philosophy. It is a similar case to that of the crown of the root mentioned above. But other plants, continues Cesalpino, produce true seeds; and he proceeds to treat of this division first, on account of its great extent as comprising all perfect plants. Three things, he says, contribute especially to the constitution of organs, the number, position, and shape of the parts; the play of nature in the composition of fruits varies according to their differences, and hence arise the different divisions of plants. He then shows how he proposes to apply these relations to the framing of his system, but his various points of view may be omitted here, as they can be better and more shortly gathered from the table below.

Other marks to be derived from roots, stems, and leaves, may be used, he says, for forming the smaller divisions. Lastly, some marks which contribute to the constitution neither of the whole plant nor of the fruit, such as colour, smell, taste, are mere accidents and are due to cultivation, place of growth, climate, and other causes.

The first of Cesalpino's sixteen books ends with this general view of his system. The remaining fifteen books contain about 600 pages of descriptions of individual plants arranged in fifteen classes; some of the descriptions are exceedingly minute; the trees come first, and are followed by the shrubs on account of their affinity ('ob affinitatem'). Two things have interfered with the recognition and acceptance of this system; the omission of a general view to precede the text, and its appearance in the traditional form of books and chapters, such as we find in de l'Écluse, Dodoens, and Bauhin, instead of in classes and orders, though it is true that the headings and introductions to the several books contain the designations and general characteristics of the classes described in them. Linnaeus has done good service by giving in his 'Classes Plantarum' a general view of all the systems proposed before his time, 
among which he gives the first rank to that of Cesalpino; he has also pointed out the peculiar characteristics of each system, and has appended to the old names of the genera those with which he has himself made us familiar. This invaluable work, which is a key to the understanding of the efforts that were made in systematic botany from Cesalpino to Linnaeus himself, will often be referred to in later pages of this history; it will supply us here with a tabular view of Cesalpino's main divisions as precisely formulated by Linnaeus, which is well worth the space it will occupy, as presenting the first plan proposed for a systematic arrangement of the vegetable kingdom, with characters for each division. For the better understanding of these diagnoses it should be remembered that the 'cor' (heart) is the important point in the seed with Cesalpino, and that it is the place in the embryo where the radicle and the plumule unite, as has been said in a former page; Cesalpino himself says somewhat inexactly, the place from which the cotyledons spring.

The characters of the classes are given, for brevity's sake, in Latin.

\section{Arboreae}

\section{(Arbores et frutices).}

I. Corde ex apice seminis. Seminibus saepius solitariis (e.g. Quercus, Fagus, Ulmus, Tilia, Laurus, Prunus).

II. Corde e basi seminis, seminibus pluribus (e.g. Ficus, Cactus, Morus, Rosa, Vitis, Salix, Coniferae, etc.).

\section{Herbaceae}

(Suffrutices et herbae).

III. Solitariis seminibus. Semine in fructibus unico (e.g. Valeriana, Daphne, Urtica, Cyperus, Gramineae).

IV. Solitariis pericarpiis. Seminibus in fructu pluribus, quibus est conceptaculum carnosum, bacca aut pomum (e.g. Cucurbitaceae, Solaneae, Asparagus, Ruscus, Arum).

V. Solitariis vasculis. Seminibus in fructu pluribus quibus 
est conceptaculum e siccâ materiâ (e.g. various Leguminosae, Caryophylleae, Gentianeae, etc.).

VI. Binis seminibus. Semina sub singulo flosculo invicem conjuncta, ut unicum videantur ante maturitatem ; cor in parte superiore, quâ flos insidet. Flores in umbellâ (Umbelliferae).

VII. Binis conceptaculis (e.g. Mercurialis, Poterium, Galium, Orobanche, Hyoscyanuus, Nicotiana, Cruciferae).

VIII. Triplici principio (ovary) non bulbosae. Semina trifariam distributa; corde infra sito, radix non bulbosa (e.g. Thalictrum, Euphorbia, Convolvulus, Viola).

IX. Triplici principio bulbosae. Semina trifariam distributa; corde infra sito, radix bulbosa (Large-flowered Monocotyledons).

$\mathrm{X}$. Quaternis seminibus. Semina quatuor nuda in communi sede (Boragineae and Labiatae).

XI. Pluribus seminibus, anthemides. Semina nuda plurima, cor seminis interius vergens; flos communis distributus per partes in apicibus singuli seminis (Compositae only).

XII. Pluribus seminibus, cichoraceae aut acanaceae. Semina nuda plurima, cor seminis inferius vergens, flos communis distributus per partes in apicibus singuli seminis (Compositae, Eryngium, and Scabiosa).

XIII. Pluribus seminibus, flore communi. Semina solitaria plurima, corde interius ; flos communis, non distributus, inferius circa fructum (e.g. Ranunculus, Alisma, Sanicula, Geranium, Linum).

XIV. Pluribus folliculis. Semina plura in singulo folliculo (e.g. Oxalis, Gossypium, Aristolochia, Capparis, Nymphaea, Veratrum, etc.).

XV. Flore fructuque carentes (Filices, Equiseta, Musci including Corals, Fungi).

The examples appended by me to the diagnoses show that with the exception of the sixth, tenth, and fifteenth classes, no one perfectly represents a natural group of the vegetable kingdom. Most of them are a collection of heterogeneous objects, and the distinction of Dicotyledons and Monocotyledons, almost 


\section{Artificial Systems and Terminology of Organs [Воок I.}

perfectly carried out by de l'Obel and Bauhin, is to a great extent effaced; the ninth class certainly contains only Monocotyledons, but not all of them. This result of great efforts on the part of a mind so well trained as Cesalpino's is highly unsatisfactory. Not a single new group founded on natural affinities is established, which does not appear already in the herbals of Germany and the Netherlands. It is characteristic of the natural system to reveal itself to a certain extent more readily to instinctive perception than to the critical understanding. We have seen that Cesalpino intended as far as possible to give expression in his system to natural affinities, and the final result was a series of highly unnatural groups, almost every one of which is a collection of the most heterogeneous forms. The cause of this apparently so remarkable fact is this, that he believed that he could establish on predetermined grounds the marks which indicate natural affinities. The uninterrupted labour of nearly 300 years, starting again and again from the same principle or practically under its influence, has given us inductive proof that the path taken by Cesalpino is the wrong one. And if, while this path was pursued even into the middle of the $\mathrm{I} 8$ th century, we see natural groups emerge with increasing distinctness, it is because the botanist, though on the wrong track, was still continually gaining better acquaintance with the ground over which he was wandering, and attained at length to an anticipation of the truer way.

JOACHIM JUNG ${ }^{1}$ was born in Lübeck in the year ${ }^{8} 5^{8} 7$, and died after an eventful life in $\mathbf{6}_{57}$. He was a contemporary of Kepler, Galileo, Vesal, Bacon, Gassendi, and Descartes. After having been already a professor in Giessen, he applied himself to the study of medicine in Rostock, was in Padua in 1618 and

${ }^{1}$ See his biography by Guhraner, 'Joachim Jungius und sein Zeitalter,' Tuibingen, 1850 ; on his place in philosophy consult Ueberweg ('Geschichte der Philosophie,' iii. p. 119), who regards him as a forerunner of Leibnitz. 
I619, and there, as we may confidently believe, became acquainted with the botanical doctrines of Cesalpino, who had died fifteen years before. Returning to Germany, he held various professorships during the succeeding ten years in Lübeck and Helmstädt, and became Rector of the Johanneum in Hamburg in r629. He occupied himself with the philosophy of the day, in which he appeared as an opponent of scholasticism and of Aristotle, and also with various branches of science, mathematics, physics, mineralogy, zoology, and botany. In all these subjects he displayed high powers as a student and a teacher, and especially as a critical observer ; in botany at least he was a successful investigator. He was the first in Germany, as Cesalpino had been in Italy, who combined a philosophically educated intellect with exact observation of plants.

His pupils were at first the only persons who profited by his botanical studies, for with his many occupations and a perpetual desire to make his investigations more and more complete he himself published nothing. In 1662 his pupil Martin Fogel printed the 'Doxoscopiae Physicae Minores,' a work of enormous compass left in manuscript at the master's death, and another pupil, Johann Vagetius, the 'Isagoge Phytoscopica,' in I678. Ray however tells us that a copy of notes on botanical subjects had already reached England in r66o. The 'Doxoscopiae' contains a great number of detached remarks on single plants and on their distinguishing marks, and propositions concerning the methods and principles of botanical research,--all in the form of aphorisms which he had from time to time committed to paper. The number and contents of these aphorisms show the earnest attention which he bestowed on the determination of species; he is displeased that so many botanists devote more time and labour to the discovery of new plants, than to referring them carefully and logically to their true genera by means of their specific differences. He was the first who objected to the traditional division of plants into trees and herbs, as not founded on their true nature. But 
how firmly this old dogma was established is well shown by the fact, that Ray at the end of the century still retained this division, though he founded his botanical theories on the 'Isagoge' of Jung. Jung was in advance of Cesalpino and his own contemporaries in repeatedly expressing his doubt of the existence of spontaneous generation.

The 'Isagoge Phytoscopica,' a system of theoretical botany, very concisely written and in the form of propositions arranged in strict logical sequence, was a more important work and had more lasting effects upon the history of botany. We must look more closely into the contents of this volume, because it contains the foundation of the terminology of the parts of plants subsequently established by Linnaeus. Since the matter of the 'Isagoge' is produced in Ray's 'Historia Plantarum ' in italics, with special mention of the source from which it is derived, it cannot be doubted that Linnaeus had made acquaintance with the teaching of Jung as a young man, in any case before I738. It is as important as a matter of history to know that Linnaeus' terminology is founded on Jung, as it is to learn that his most general philosophical propositions on botanical subjects are to be traced to Cesalpino. It will moreover be fully shown in the account of the doctrine of sexuality that his knowledge of that subject was derived from Rudolf Jacob Camerarius.

The first chapter of the 'Isagoge' discusses the distinction between plants and animals. A plant is, according to Jung, a living but not a sentient body; or it is a body attached to a fixed spot or a fixed substratum, from which it can obtain immediate nourishment, grow and propagate itself. A plant feeds when it transforms the nourishment which it takes up into the substance of its parts, in order to replace what has been dissipated by its natural heat and interior fire. A plant grows when it adds more substance than has been dissipated, and thus becomes larger and forms new parts. The growth of plants is distinguished from that of animals by the circumstance 
that their parts are not all growing at the same time, for leaves and shoots cease to grow as soon as they arrive at maturity; but then new leaves, shoots, and flowers are produced. A plant is said to propagate itself when it produces another specifically like itself; this is the idea in its broader acceptation. We see that here, as in Cesalpino, the idea of the species is connected with that of propagation. The second chapter, headed 'Plantae Partitio,' treats of the most important morphological relations in the external differentiation of plants; here Jung adheres essentially to Cesalpino's view, that the whole body in all plants, except the lowest forms, is composed of two chief parts, the root as the organ which takes up the food, and the stem above the ground which bears the fructification. Jung, too, draws attention to the meeting-point of the two parts, Cesalpino's 'cor,' but under the name of 'fundus plantae.'

The upper part, or a portion of the plant, is either a stem, a leaf, a flower, a fruit, or a structure of secondary importance, such as hairs and thorns. His definition of the stalk and the leaf is noteworthy; the stalk, he says, is that upper part which stretches upwards in such a manner, that a back and front, a right and left side, are not distinguished in it. A leaf is that which is extended from its point of origin in height, or in length and breadth, in such a manner, that the bounding surfaces of the third dimension are different from one another, and therefore the outer and inner surfaces of the leaf are differently organised. The inner side of the leaf, which is also called the upper, is that which looks towards the stem, and is therefore concave or less convex than the other side. One conclusion he draws, which is a striking one for that time, that the compound leaf is taken for a branch by inexperienced or negligent observers, but that it may easily be determined by having an inner and an outer surface, like the simple leaf, and by falling off as a whole in autumn. He calls a plant 'difformiter foliata,' whose lower leaves are strikingly different from 
the upper, an idea which Goethe, in the fragment in Guhrauer, seems to have altogether misunderstood.

In connection with these general definitions, the different forms of the stem and of the ramification, and the varieties of leaves are pointed out and supplied with distinctive names, which are for the most part still in use. The fourth chapter treats of the division of the stem into internodes; if the stem or branch, says Jung, is regarded as a prismatic body, the articulations, that is, the spots where a branch or a leaf-stalk arises, are to be conceived of as cross-sections parallel to the base of the prism. These spots when they are protuberant are called knees or nodes, and that which lies between such spots is an internode.

It is not possible to quote all the many excellent details which follow these definitions; but some notice must be taken of Jung's theory of the flower, which he gives at some length from the 13 th to the 27 th chapters. It suffers, as in Cesalpino, from his entire ignorance of the difference of sexes in plants, which is sufficient to render any satisfactory definition of the idea of a flower impossible. Like Cesalpino too he distinguishes the pistil from the flower, instead of making it a part of the flower. He regards the flower as a more delicate part of the plant, distinguished by colour or form, or by both, and connected with the young pistil. Like all botanists up to the end of the i 8th century, he follows Cesalpino in including under the term fruit both the dry indehiscent fruits which were supposed to be naked seeds, and any seed-vessel. He differs from him in calling the stamens 'stamina,' and the style 'stilus,' but like Cesalpino he uses the word 'folium' for the corolla. He calls a flower perfect only when it has all these three parts. $\mathrm{He}$ afterwards describes the relations of form and number in the parts of the flower, and among other things he enunciates the first correct view of the nature of the capitulum in the Compositae, which Cesalpino quite misunderstood; and he examined inflorescences and superior and inferior flowers, which Cesalpino 
CHAP. II.]

had already distinguished, with more care than they had previously received. In his theory of the seed he follows Cesalpino, and adds nothing to him.

There is nothing which more essentially distinguishes the theoretical botany of Jung, and marks the advance which he made upon Cesalpino's views, than the way in which he discusses morphology in as entire independence as was possible of all physiological questions, and therefore abstains from teleological explanations. His eye is fixed on relations of form only, while his mode of treating them is essentially comparative, and embraces the whole of the vegetable kingdom that was known to him. Jung certainly learnt much from Cesalpino; but in rejecting at least the grosser aberrations of the Aristotelian philosophy and of scholasticism, he freed himself from the prepossessions of his master, and succeeded in arriving at more correct conceptions. of the morphology of plants. That his mathematical gifts assisted him in this respect is easy to be gathered from his definitions as given above, which bring into relief the symmetry apparent in the forms of stems and leaves. No more profound or apt definitions were supplied till Schleiden and Nägeli introduced the history of development into the study of morphology.

While Cesalpino, Kaspar Bauhin, and Jung stand as solitary forms each in his own generation, the last thirty years of the $\mathrm{I}$ th century are marked by the stirring activity of a number of contemporary botanists. While during this period physics were making rapid advances in the hands of Newton, philosophy in those of Locke and Leibnitz, and the anatomy and physiology of plants by the labours of Malpighi and Grew, systematic botany was also being developed, though by no means to the same extent or with equally profound results, by Morison, Ray, Bachmann (Rivinus), and Tournefort. The works of these men and of their less gifted adherents, following rapidly upon or partly synchronous with each other, led to an exchange of opinions and sometimes to polemical discussion, such as had 
not before arisen on botanical subjects; this abundance of literature, with the increased animation of its style, excited a more permanent interest, which spread beyond the narrow circle of the professional adepts. The systematists abovenamed endeavoured to perfect the morphology and the terminology of the parts of plants, and they found ready to their hands in the works of their predecessors a considerable store of observations and ideas, upon which they set themselves to work. A very great number of descriptions of individual plants had been accumulated since the time of Fuchs and Bock, and the fact of natural affinity had been recognised in the 'Pinax' of Kaspar Bauhin as the foundation of a natural system ; Cesalpino had pointed to the organs of fructification as the most important for such a system, and Jung had supplied the first steps to a comparative morphology in place of a mere explanation of names. The botanists of the last thirty years of the $I 7$ th century could not fail to perceive that the series of affinities as arranged by de l'Obel and Bauhin could not be defined by predetermined marks in the way pursued by Cesalpino, nor fashioned in this way into a wellarticulated system. Nevertheless they held fast in principle to Cesalpino's mode of proceeding, though they endeavoured to amend it by obtaining their grounds of division, not as he had done, chiefly from the organisation of the seed and fruit, but from other parts of the flower; variations in the corolla, the calyx, and the general habit were employed to found systems, which were intended to exhibit natural affinities. And while the true means were thus missed, the end itself was not clearly and decidedly adhered to; a system was desired for the purpose of facilitating the acquisition of a knowledge of the greatest possible number of individual forms; the weight of the burden caused by the foolish demand that every botanist should know all described plants, was continually increasing, and naturally led to seeking some alleviation in systematic arrangement. Excessive devotion to the describing of plants 
stood in the way of such a profound study of the principles of systematic botany as might have led to enduring results, and even destroyed the very capacity for those difficult intellectual operations, which were absolutely necessary to build up a truly natural system on scientific foundations; the wood could not be seen for the trees. Above all the morphology founded by Jung, though acknowledged and employed, was not sufficiently developed by the labours of others to form the foundation of the system in its grander features, - a reproach which must be made against the systematists of the succeeding hundred years with few exceptions. How could the botanists of the 17 th century succeed in acquiring a true conception of the larger groups indicated by natural affinity, when they still held to the old division into trees and herbs, which Jung had already set aside and which is opposed to all consistent morphology, and when they paid so little attention to the structure of the seed and the fruit, that they commonly treated dry indehiscent fruits as naked seeds, and were guilty of other and similar mistakes? But if nothing new and good in principle found its way into systematic botany, much service was rendered to it in matters of detail. The working out of various systems helped to show what marks are not admissible in fixing the limits of the natural groups; the contradiction between the method and aim of the systematists became in this empirical way continually more apparent, till at length Linnaeus was able to recognise it distinctly; and this. was beyond doubt a great gain.

To attempt to give an account of all the systematists of England, France, Italy, Germany, and the Netherlands during this period would serve only to obscure the subject; all that is historically important will be brought out more clearly by mentioning those only who have really enriched systematic botany. Whoever wishes for a more complete knowledge of all the systems which made their appearance before Linnaeus will find a masterly account of them in his 'Classes Plantarum,' 
66 Artificial Systems and Terminology of Organs [Booк I.

and another worth consulting in Michel Adanson's ' Histoire de la Botanique' (Paris, I864). It is sufficient for our present purpose to consider more particularly the labours of the four men whose names have recently been mentioned.

ROBERT MORISON ${ }^{1}$, who was born in Aberdeen in 1620 and died in London in $\mathrm{I}_{68}$, was the first after Cesalpino and Bauhin who devoted himself to systematic botany, that is, to founding and perfecting the classification of plants. He was reproached by his contemporaries and successors with having borrowed without acknowledgment from Cesalpino; this was an exaggeration. Morison commenced his efforts as a systematist with a careful examination of Kaspar Bauhin's 'Pinax'; there he obtained his conceptions of natural relationship in plants; and if he afterwards founded his own system more peculiarly on the forms of the fruit, it was in a very different way from that adopted by Cesalpino. Linnaeus answers the reproach above-mentioned by the pertinent remark, that Morison departs as far from Cesalpino in this point as he is inferior to him in the purity of his method. In the year 1669 appeared a work with the characteristic title, 'Hallucinationes Kaspari Bauhini in Pinace tum in digerendis quam denominandis plantis,' which Haller justly calls an 'invidiosum opus'; for as there are writers at all times who ungratefully accept all that is good and weighty in their predecessors as self-evident, while they point with malicious pleasure to every little mistake which the originator of a great idea may commit, so Morison has no word of recognition for the great and obvious merits of the 'Pinax,' though such a recognition was specially due from one whose design was to point out the numerous mistakes in that work on the subject of affinities. Kurt Sprengel in his

1 Morison served in the royal army against Cromwell, and after the defeat of his party retired to Paris, where he studied botany under Robin. He was made physician to Charles II and Professor of Botany in I660, and Professor of the same faculty in Oxford ten years later. See Sprengel, 'Geschichte der Botanik,' ii. p. 30 . 
'Geschichte,' ii. p. 30, also suspects with reason that Jung's manuscript, which was communicated by Hartlieb to Ray in I66I, was not unknown to Morison, and in this paper he might certainly have found much that suited his purposes. Sprengel says well, that the 'Hallucinationes' are a wellgrounded criticism of the arrangement of plants, which the Bauhins had chosen; that the writer goes through the 'Pinax' page by page, and shows what plants occupy a false position, and that it is certain that Morison laid the first foundation of a better arrangement and a more correct discrimination of genera and species.

His 'Plantarum umbelliferarum distributio nova,' Oxford, I672, shows considerable advance; it is the first monograph which was intended to carry out systematic principles strictly within the limits of a single large family. The very complex arrangement is founded exclusively on the external form of the fruit, which he naturally terms the seed. It is the first work in which the system is no longer veiled by the old arrangement in books and chapters, perspicuity being provided for by typographical management,- an improvement which de l'Obel, it is true, made a feeble attempt to introduce a hundred years before. Morison also endeavours to give a clear idea of the systematic relations within the family by the aid of linear arrangement, to some extent the first hint of what we now call a genealogical tree, and a proof at any rate of the lively conception which he had formed of affinity, not drawn indeed only ' $\mathrm{ex}$ libro naturae,' as the title of his book states, but in principle from Bauhin. Morison's inability to appreciate the merits of his predecessors, and to believe that when he made a step in advance the way had ever been trodden before, may be seen in this work also. One of its merits is, that it contains for the first time careful representations of separate parts of plants, executed in copper plate ${ }^{1}$. In 1680 appeared the first volumes

${ }^{1}$ The wood-engraving of the 16 th century had fallen into decay, and 
of his 'Historia plantarum universalis Oxoniensis,' the third portion of which was published after his death by Bobart in 1699 , - a collection of most of the plants then known and a large number of new ones with descriptions ; the systematic arrangement in this work is to be seen in Linnaeus' 'Classes Plantarum.' If Morison in his criticism of Bauhin displayed considerable acuteness within narrow circles of affinity, his universal system on the contrary shows extremely small feeling for affinities on the large scale; the most different forms are brought together even in the smaller divisions; the last class of his Bacciferae, for example, contains genera like Solanum, Paris, Podophyllum, Sambucus, Convallaria, Cyclamen, a result which is the more surprising as Morison does not, like Cesalpino, confine himself to single fixed marks, but has regard also to the habit. On the whole his arrangement as an expression of natural affinities must be ranked after those of de l'Obel and Bauhin.

Morison's merit lay in truth less in the quality of what he did, than in the fact that he was the first to renew the cultivation of systematic botany on a comprehensive scale. The number of his adherents was always small; in Germany Paul Ammann, Professor in Leipsic, adopted Morison's views in his 'Character Plantarum Naturalis' (1685), and Paul Hermann, Professor in Leyden from 1679 to 1695 , after collecting plants in Ceylon for eight years, proposed a system founded on that of Morison, but which can scarcely be called an improvement upon it.

In contrast to Morison, JoHn RAY ${ }^{1}$ ( 1628 to I 705 ) not only

engraving on copper-plate had taken its place. A thick volume of figures of plants in the largest folio size engraved on copper, the 'Hortus Eistädtensis,' appeared in the beginning of the $I 7$ th century.

1 John Ray, born at Black Notley in Essex, was also a zoologist of eminence. He studied theology and travelled in England and on the continent, and afterwards devoted himself entirely to science, being supported by a pension from Willoughby. See Carus, 'Geschichte der Zoologie,' p. 428. 
knew how to adopt all that was good and true in the works of his predecessors, and to criticise and complete them from his own observations, but could also joyfully acknowledge the services of others, and combine their results and his own into a harmonious whole. He wrote many botanical works; but none display his character as a man and a naturalist better than his comprehensive 'Historia Plantarum,' published in three large folio volumes without plates in the period from I 686 to 1704 . This work contains a series of descriptions of all plants then known; but the first volume commences with a general account of the science in fifty-eight pages, which, printed in ordinary size, would itself make a small volume, and which treats of the whole of theoretic botany in the style of a modern text-book. If morphology, anatomy, and physiology, in which latter subject he relies on the authority of Malpighi and Grew, are not kept strictly apart in his exposition, yet it is easy to separate the morphological part, and his theory of systematic botany is in fact given separately. Jung's definitions of the subject-matter of each of the chapters on morphology are first given, and Ray then adds his own remarks, in which he criticises, expands, and supplements those of his predecessor. Omitting all that is not his own, and the anatomical and physiological portions, we will describe some of the more important results of his studies on system. First and foremost Ray adopted the idea which Grew had conceived, but in a very clumsy form, that difference of sex prevails in the vegetable kingdom, and hence the flower had a different meaning and importance for him from what it had had for his predecessors, though his views on the subject were still indistinct. Ray perceived more clearly than Cesalpino that many seeds contain not only an embryo but also a substance, which he calls 'pulpa' or 'medulla,' and which is now known as the endosperm, and that the embryo has not always two cotyledons, but sometimes only one or none ; and though he was not quite clear as regards the distinction, which we now express by the words dicotyle- 


\section{Artificial Systems and Terminology of Organs [Boox I.}

donous and monocotyledonous embryo, yet he may claim the great merit of having founded the natural system in part upon this difference in the formation of the embryo. He displays more conspicuously than any systematist before Jussieu the power of perceiving the larger groups of relationship in the vegetable kingdom, and of defining them by certain marks; these marks moreover he determines not on a priori grounds, but from acknowledged affinities; but it is only in the great divisions of his system that he is thus true to the right course; in the details he commits many and grievous offences against his own method, as we shall see below when we come to an enumeration of his classes. Modern writers have often attributed to Ray the merit of having first taught the transmutation of species, and of being thus one of the founders of the theory of descent. Let us see how much truth there is in this assertion. Though plants, says Ray, which spring from the same seed and produce their species again through seed, belong to the same species, yet cases may occur in which the specific character is not perpetual and infallible. Seeds may sometimes degenerate and produce plants specifically distinct from the mother-plant, though this may not often happen, and so there would be a transmutation of species, as experience teaches. It is true that he considered the statements of various writers, that Triticum may change into Lolium, Sisymbrium into Mentha, Zea into Triticum, etc., to be very doubtful, yet there were, he thought, other cases which were well ascertained; it was in evidence in a court of law that a gardener in London had sold cauliflower seed which had produced only common cabbage. It is to be observed, he says, that such transmutations only occur between nearly allied species and such as belong to the same genus, and some perhaps would not allow that such plants are specifically distinct. These words, especially when judged by Ray's general views, appear only to express the opinion that certain inconsiderable variations are possible within a narrow circle of affinity, especially in 
cultivated plants. Ray does not speak of the appearance of new forms, but says that a known form changes into another already existing and known form, which is the reverse of that which the theory of descent requires.

In his development of the principles of his system, among other errors we encounter one that leads to very important consequences in his application of the dictum, 'natura non facit saltus,' which he interprets as though all affinities must present themselves in a series that would be represented by a straight line, -an error which has misled systematists even in recent times, and was first recognised as an error by Pyrame de Candolle. Ray overlooked the fact that the dictum holds good even when the affinities arrange themselves in the form of branching series, that is, after the manner of a genealogical tree. Much more sound is his remark, that the framing of the true system had previously been impossible, because the differences and agreements of forms were not sufficiently known; and another saying of his, that nature refuses to be forced into the fetters of a precise system, shows the dawn of the knowledge which afterwards led in Linnaeus to a strict separation of the natural and artificial systems.

It excites no small astonishment after all Ray's judicious and clear-sighted utterances on the nature and method of the natural system to find him adopting the division into woody plants and herbs; nor is the matter improved by his making the distinctive mark of trees and shrubs to be the forming of buds, that is, distinct winter buds, which is a mistake into the bargain. Yet we feel ourselves in some degree compensated for this serious error by his dividing trees and herbs into those with a two-leaved and those with a one-leaved or leafless embryo, in modern language into Dicotyledons and Monocotyledons. Ray's system is undoubtedly the one which in the time preceding Linnaeus does most justice to natural affinities. The following synopsis of his Classes will serve to show the progress made since Cesalpino. The names in brackets are 
72 Artificial Systems and Terminology of Organs [Воок I. the Linnaean names for some of the genera in particular classes.

A. Plantae gemmis carentes (herbae).

(a) Imperfectae.

I. Plantae submarinae (chiefly Polypes, Fucus).

II. Fungi.

III. Musci (Confervae, Mosses, Lycopods).

IV. Capillares (Ferns, Lemna, Equisetum).

(b) Perfectae.

V. Apetalae.

Dicotyledones (binis cotyledonibus).

VI. Planipetalae lactescentes.

VII. Discoideae semine papposo.

VIII. Corymbiferae.

IX. Capitalae (vi-ix are Compositae).

$\mathrm{X}$. Semine nudo solitario (Valerianeae, Mirabilis, Thesium, etc.).

XI. Umbelliferae.

XII. Stellatae.

XIII. Asperifoliae.

XIV. Verticillatae (Labiatae).

XV. Semine nudo polyspermo (Ranunculus, Rosa, Alisma!). XVI. Pomiferae (Cucurbitaceae).

XVII. Bacciferae (Rubus, Smilax, Bryonia, Solanum, Menyanthes).

XVIII. Multisiliquae (Sedum, Helleboreae, Butomus, Asclepias).

XIX. Vasculiferae monopetalae (various).

XX. Vasculiferae dipetalae (various).

XXI. Tetrapetalae siliquosae (Cruciferae, Ruta, Monotropa).

XXII. Leguminosae.

XXIII. Pentapetalae vasculiferae enangiospermae (various). 
Monocotyledones (singulis aut nullis cotyledonibus).

XXIV. Graminifoliae floriferae vasculo tricapsulari (Liliaceae, Orchideae, Zingiberaceae).

XXV. Stamineae (Grasses).

XXVI. Anomalae incertae sedis.

B. Plantae gemmiferae (arbores).

(a) Monocotyledones.

XXVII. Arbores arundinaceae (Palms, Dracaena).

(b) Dicotyledones.

XXVIII. Arbores fructu a flore remoto seu apetalae (Coniferae and various others).

XXIX. Arbores fructu umbilicato (various).

XXX. Arbores fructu non umbilicato (various).

XXXI. Arbores fructu sicco (various).

XXXII. Arbores siliquosae (woody Papilionaceae).

XXXIII. Arbores anomalae (Ficus).

Of these classes only the Fungi, Capillares, Stellatae, Labiatae, Pomiferae, Tetrapetalae, Siliquosae, Leguminosae, Floriferae, and Stamineae can pass as wholly or approximately natural groups, and there are mistakes even in these; moreover the majority of them had long been recognised. The examples annexed in brackets show how open the others are to objection. If it must be allowed on the one side that Ray, like Jung, doubts whether the Cryptogams are propagated without seeds, it is on the other side obvious that he makes as little objection as his predecessors, contemporaries, and immediate successors to the idea that Polypes and Sponges are vegetables. But worse than this is the extremely faulty subordination and coordination in his system; while the class of Mosses contains the Confervae, Lichens, Liverworts, Mosses, and Clubmosses, and therefore objects as distinct from one another as Infusoria, Worms, Crabs, and Mollusks, we find on the contrary the one family of Compositae split up into 
74 Artificial Systems and Terminology of Organs [Boox I.

four classes founded on quite petty and unimportant differences. Finally, if Ray recognised the general importance to the system of the leaf-formation in the embryo, he was still far fronı strictly separating all Monocotyledons and Dicotyledons.

Ray's chief merit is that he to some extent recognised natural affinities in their broader features; the systematic separation of the smaller groups was but little advanced by him. He too, like Morison, found two adherents in Germany in the persons of Christopher Knaut (1638-1694), who published a flora of Halle in $\mathrm{I} 687$ arranged after Ray's method, and Christian Schellhammer (1649-17 16), professor at Helmstädt and afterwards at Jena.

Augustus Quirinus Bachmann (Rivinus) ${ }^{1}$ (1652-1725) was for Germany what Morison and Ray were for England, and Tournefort for France. From the year I69r he was Professor of botany, physiology, materia medica, and chemistry in Leipsic; he applied himself with such ardour to astronomy that he injured his eyesight by observing spots in the sun. With such a variety of occupations it is not surprising that his special knowledge of plants was inconsiderable when compared with that of the three just named; but he was better able than they to appreciate the principles of morphology laid down by Jung, and to use them for deciding questions of systematic botany. He did most service by his severe strictures on the more prominent errors which botanists up to his time had persisted in, his own positivecontributions, at least as far as the recognition of affinities is concerned, being inconsiderable. His 'Introductio universalis in rem herbariam,' which appeared in 1690 , and contains 39 pages of the largest size, is the most interesting for us; in

1 A. Q. Bachmann (Rivinus) was the third son of Andreas Bachmann, a physician and philologist of Halle. He is said to have spent 80,000 florins on the publication of his works and the providing them with the 500 copper-plates with which they were illustrated. A life of him and just estimate of his work, by Du Petit-Thouars, is to be found in the 'Biographie universelle ancienne et moderne.' 
it he declines the great quantity of unnecessary work with which botanists occupied themselves, and declares the scientific study of plants to be the only end and aim of botany. He first treats of naming, and lays down with respect, to generic and specific names the principles which Linnaeus afterwards consistently applied, whereas Bachmann himself did not follow his own precepts, but injured his reputation as a botanist by a tasteless nomenclature. Nevertheless he declared distinctly that the best plan is to designate each plant by two words, one of which should be the name of the genus, the other that of the species, and he ingeniously pointed out the great convenience of this binary nomenclature in dealing with medicinal plants, and in the writing of prescriptions. He refused to regard cultivated varieties as species, though Tournefort and others continued to do so.

In his system he rejected the division into trees, shrubs, and herbs, showing by good examples that there is no real distinction of the kind in nature. From many of his remarks in his critical dissertations we might infer that he possessed a very fine feeling for natural relationship, but at the same time expressions occur which seem to show that he did not at all appreciate its importance in the system; we notice this in Tournefort also. Because flowers come before the fruit he jumps with curious logic to the conclusion that the main divisions in the system should be derived from the flower, and in following this rule he makes use of exactly that mark in the corolla which has the least value for classification, namely, regularity or irregularity of form. It is strange, moreover, that Bachmann, who spent a considerable fortune on the production of copper-plate figures of plants without any special object, though he founded his system on the form of the flower, should yet have devoted only a superficial study to its construction; his account of it is very inferior to that of any one before or since his time. His classification thus founded cannot be said to be an advance in systematic botany; never- 
theless, he had no lack of adherents, and among them in Germany, Heucher, Knaut, Ruppius, Hebenstreit, and Ludwig; in England, Hill and others, who made alterations here and there in his system, but any real development of it was from its nature an impossibility; he endeavoured to defend it against the assaults of Ray and Dillen; Rudbeck also declared against him.

Joseph Pitton de Tournefort ${ }^{1}$ (1656-1708) founded his system also on the form of the corolla, but his views are to some extent opposed to those of Bachmann. While the latter was pre-eminently critical and deficient in knowledge of species, Tournefort was more inclined to dogmatise, and atoned in the eyes of his contemporaries for want of morphological insight by his extensive acquaintance with individual plants. $\mathrm{He}$ is commonly regarded as the founder of genera in the vegetable kingdom; but it has been already shown that the conceptions of genera and species had been framed as early as the r6th century from the describing of plants, and that Kaspar Bauhin also, in naming his plants, consistently distinguished genera and species; moreover Bachmann in 1690 had supported the claims of the binary nomenclature as the most suitable for the designation of plants, though he did not himself adopt it; Tournefort did adopt it, but in an entirely different way from that of Bauhin. Bauhin gave only the name of the genus, and supplied the species with characters; Tournefort, on the other hand, provided his genera with names and characters, and added the species and varieties without special description. Tournefort therefore was not the first who established genera;

1 Tournefort was born at Aix in Provence, and received his early education in a Jesuit college. He was intended for the Church, but after his father's death, in 5677 , he was able to devote himself entirely to botany. After travelling in France and Spain, he became Professor at the Jardin des Plantes in 1683 ; but while thus engaged he made various journeys in Europe, and in I 700 visited Greece, Asia, and Africa-everywhere diligently collecting the plants which he afterwards described. 
he merely transferred the centre of gravity, so to speak, in descriptive botany to the definition of the genera; but in doing so he committed the great fault of treating specific differences within the genus as a matter of secondary importance. How little depth there was in his botanical ideas may be seen not only from his very poor theory of the flower, the imperfections in which, as in the case of Bachmann, are the more remarkable, since he founded his system on the outward form of the flower, but still more from the expression which he uses at the end of his history of botany, a work otherwise of considerable merit; he says there that the science of botany has been so far advanced since the age of Hippocrates, that hardly anything is still wanting except an exact establishing of genera. His general propositions on the subject of systematic botany, together with much that is good, but which is generally not new and is better expressed in the works of Morison, Ray, and Bachmann, contain strange misconceptions; for instance, he classes plants which have no flower and fruit with those in which these parts are to be seen only with the microscope, that is, the smallness of the organs is equivalent to their absence. It may seem strange that his theory of the flower should be so imperfect, when the excellent investigations of Malpighi and Grew into the structure of flowers, fruit, and seed were already before the world (I 700), and Rudolph Jacob Camerarius had made known his discovery of sexuality in the vegetable kingdom. This doctrine, however, Tournefort expressly refused to admit. But the reproach of neglecting the labours of Malpighi and Grew is equally applicable to Bachmann and the systematists up to A. L. de Jussieu; we have here only the first example of the fact since so often confirmed, that professed systematists shrank with a certain timidity from the results of more delicate morphological research, and rested their classifications as far as possible on obvious external features in plants,-a proceeding which more than anything else delayed the construction of the natural system. 
78 Artificial Systems and Terminology of Organs [Воок I.

Tournefort's system is thoroughly artificial, if possible, more artificial than that of Bachmann, and certainly inferior to Ray's. If we meet with single groups that are really natural, it is simply because in some families the genera so agree together in all their marks, that they necessarily remain united, whatever mark we select for the systematic purpose. We do not find in Tournefort the distinction between Phanerogams and Cryptogams already established by Ray, nor the division of woody plants and herbs into Monocotyledons and Dicotyledons; if his chief work, to which we confine ourselves here, the 'Institutiones rei herbariae,' did not bear the date of $\mathrm{r} 700$, we might conclude that it was written before the 'Historia Plantarum' of Ray, and the chief work of Bachmann. Yet it has one merit of a purely formal kind; it is pervaded by a rigorous spirit of system; every class is divided into sections, these into genera, and these again into species; figures of the leaves and of the parts of the flower, very beautifully engraved on copper-plate and filling a whole volume, are perspicuously arranged; the whole work therefore is easy to consult and understand. But to form an idea of the confusion as regards natural affinities that reigns in his system, we need only examine the first three sections of his first class, when we shall find Atropa and Mandragora together in the first section, Polygonatum and Ruscus in the second, Cerinthe, Gentiana, Soldanella, Euphorbia, and Oxalis in the third. The handiness of the book, the little interest taken by most of the botanists of the time in the question of natural relationship, and the continually increasing eagerness for a knowledge of individual plants, are evidently the reasons why Tournefort gained over to his side most of the botanists not only of France, but also of England, Italy, and Germany ; and why later attempts in systematic botany during the first thirty or forty years of the $\mathbf{I} 8$ th century were almost exclusively founded on his system, as they were afterwards on the sexual system of Linnaeus. Boerhaave, among others, proposed a system in $\mathrm{I} 7 \mathrm{IO}$, which may be regarded as a combination of 
those of Ray, Hermann, and Tournefort, but it met with no support on any other grounds.

We here take our leave of the systematists of the 17 th century, and, passing over the mere plant-collectors of the first thirty years of the $\mathrm{I} 8 \mathrm{th}$, turn at once to Linnaeus.

Carl Linnaeus ${ }^{1}$, called Carl von Linné after 1757 , was born in $\mathbf{I} 707$ at Rashult in Sweden, where his father was preacher. He began the study of theology, but was soon drawn away from it by his preference for botany, and in this pursuit he was encouraged by Dr. Rothmann, who sent him to the works of Tournefort. In Lund, where he now studied medicine, he became acquainted with Vaillant's treatise, 'De sexu plantarum,' and had his attention drawn by it to the sexual organs. In I730, when he was only twenty-three years old, the aged Professor Rudbeck gave up to him his botanical lectures and the management of the botanic gardens, and here Linnaeus began the composition of the 'Bibliotheca Botanica,' the 'Classes Plantarum,' and the 'Genera Plantarum.' In the year I $73^{2}$ he made a botanical journey to Lapland, and in 1734 to Dalecarlia; in $\mathbf{I} 735$ he went to Holland, where he obtained a degree ; in that country he remained three years, and printed the works above-named, together with the 'Systema Naturae,' the 'Fundamenta Botanica,' and other treatises. From Holland he visited England and France. In the year $173^{8}$ he returned to Stockholm and was compelled to gain a livelihood as a physician, till in I 74I he became Professor of Botany in Upsala, where he died in the year 1778 .

Linnaeus is commonly regarded as the reformer of the

1 In addition to the Autobiography of Linnaeus, various accounts of his life have been written, some of which are mentioned in Pritzel's 'Thesaurus Lit. Bot.' A strange revelation of his character and sentiments is to be found in his treatise on the 'Nemesis divina,' which he bequeathed to his son. Of this work Professor Fries has unfortunately published an epitome only, which is noticed in the Regensburg Flora, No. 44 (1851). On Linnaeus' services to zoology, see Carus, 'Geschichte der Zoologie,' München, $\mathbf{1 8 7 2 .}$ 
natural sciences which are distinguished by the term descriptive, and it is usual to say that a new epoch in the history of our science begins with him, as a new astronomy began with Copernicus, and new physics with Galileo. This conception of Linnaeus' historical position, as far at least as his chief subject, botany, is concerned, can only be entertained by one who is not acquainted with the works of Cesalpino, Jung, Ray, and Bachmann, or who disregards the numerous quotations from them in Linnaeus' theoretical writings. On the contrary, Linnaeus is pre-eminently the last link in the chain of development represented by the above-named writers; the field of view and the ideas of Linnaeus are substantially the same as theirs; he shares with them in the fundamental errors of the time, and indeed essentially contributed to transmit them to the I $9^{\text {th }}$ century. But to maintain that Linnaeus marks not the beginning of a new epoch, but the conclusion of an old one, does not at all imply that his labours had no influence upon the time that followed him. Linnaeus stands in the same relation to the systematists of the period we are considering that Kaspar Bauhin does to the botanists of the I6th century; as Bauhin gathered up all that was serviceable in his predecessors, Cesalpino only excepted, while the botanists of our second period drew again from him, though they set out from other points of view than his; so Linnaeus adopted all that the systematists of the $I 7$ th century had built upon the foundation of Cesalpino's ideas, gave it unity and fashioned it into a system without introducing into it anything that was fundamentally and essentially new ; all that had been developed in systematic botany from Cesalpino to Tournefort culminated in him, and the results, which he put together in a very original form and with the power of a master, were no more unfruitful for the further development of botany than the contents of Kaspar Bauhin's works for the successors of Cesalpino.

Whoever carefully compares the works of Cesalpino, Jung, Morison, Ray, Bachmann, and Tournefort with Linnaeus, 
'Fundamenta Botanica' ( $173^{6}$ ), his 'Classes Plantarum '( $\left.173^{8}\right)$, and his 'Philosophia Botanica' (I75I), must be thoroughly convinced that the ideas on which his theories are based are to be found scattered up and down in the works of his predecessors ; further, whoever has traced the history of the sexual theory from the time of Camerarius (I694), must allow that Linnaeus added nothing new to it, though he contributed essentially to its recognition, and that even after Koelreuter's labours he continued to entertain some highly obscure and even mystical notions on the subject.

But that which gave Linnaeus so overwhelming an importance for his own time was the skilful way in which he gathered up all that had been done before him; this fusing together of the scattered acquisitions of the past is the great and characteristic merit of Linnaeus.

Cesalpino was the first who introduced Aristotelian modes of thought into botany; his system was intended to be a natural one, but it was in reality extremely unnatural; Linnaeus, in whose works the profound impression which he had received from Cesalpino is everywhere to be traced, retained all that was important in his predecessor's views, but perceived at the same time what no one before him had perceived, that the method pursued by Cesalpino, Morison, Ray, Tournefort, and Bachmann could never do justice to those natural affinities which it was their object to discover, and that in this way only an artificial though very serviceable arrangement could be attained, while the exhibition of natural affinities must be sought by other means.

As regards the terminology of the parts of plants, which was all that the morphology of the day attempted, Linnaeus simply adopted all that was contained in the Isagoge of Jung, but gave it a more perspicuous form, and advanced the theory of the flower by accepting without hesitation the sexual importance of the stamens, which was still but little attended to; he thus arrived at a better general conception of the flower, and this 
bore fruit again in a terminology which is as clear as it is convenient; the terms monoecious, dioecious, triandrous, monogynous, etc., still used in the science, and the later-invented expressions dichogamous, protandrous, protogynous, etc., owe their origin to this correct conception of the sexual relations in plants. But there was one great misconception in the matter, which has not a little contributed to increase Linnaeus' reputation. He called his artificial system, founded on the number, union, and grouping of the stamens and carpels, the sexual system of plants, because he rested its supposed superiority on the fact, that it was founded upon organs the function of which lays claim to the very highest importance. But it is obvious that the sexual system of Linnaeus would have the same value for the purposes of classification, if the stamens had nothing whatever to do with propagation, or if their sexual significance were quite unknown. For it is exactly those characters of the stamens which Linnaeus employs for purposes of classification, their number and mode of union, which are matter of entire indifference as regards the sexual function.

But though the notion that this artificial system has any important connection with the doctrine of the sexuality of plants is evidently due to a confusion of ideas, yet the progress of the science has shown, that Linnaeus' sexual system did often and necessarily lead to the establishing of natural groups for the very reason, that the characters of the stamens which he employed are entirely independent of their function; for we must regard it as an important result of the labours of systematists, that those characters of organisms are shown to be of the greatest value for classification, which are entirely or in a very great measure independent of the functions of the organs. The error, which led Cesalpino to make the functional importance of the parts of fructification the principle of his division, reappears therefore in Linnaeus in another form; to find a principle of division, he turns to those organs, whose function appears to him the most important, but he takes his characters 
not from differences of function, but from the number and mode of union, which are of no importance for the sexual function. We meet with this error in Leibnitz and Burckhard, who are mentioned here merely to defend Linnaeus from the charge repeatedly brought against him by his contemporaries that he was indebted to these two writers for the idea of his sexual system. They erroneously found in the great physiological importance of the sexual organs a reason for deriving from their differences the principles of division that were to found a system; this error in theory Linnaeus shared with them, but they did not correct it in practice, as Linnaeus did, by confining himself to purely morphological features in working out his system. What the renowned philosopher ${ }^{1}$ incidentally uttered in the year I 701 on the matter in question is moreover so unimportant and so indistinct, that Linnaeus could not gain much from it; what Burckhard ${ }^{2}$ says on the subject in his oftenquoted letter to Leibnitz (I 702) is indeed much better, and comes near to Linnaeus' idea; but it is a very long way from the hints there given to the completion of the well-articulated and highly practical system which Linnaeus constructed.

The botanists of the I6th century, and in the main even Morison and Ray, had in one-sided fashion devoted their chief attention to distinguishing species, Bachmann and Tournefort to the establishment of generic characters, while they neglected species; Linnaeus, on the contrary, applied equal care and much greater skill to describing both genera and species. He reduced to practical shape the suggestion which Bachmann had left to his successors, and so must be regarded, if not as the inventor, at least as the real founder of the binary nomenclature of organisms.

It is only fulfilling the duty of a historian to state the sources

1 Printed in Jessen's ' Botanik der Gegenwart and Vorzeit,' p. 287.

2 'Epistola ad Godofredum Gulielmum Leibnitzium etc. cum Laurentii Heisteri praefatione,' Helmstadii, I 750. 
from which Linnaeus drew, but it would be a misapprehension to see in this any depreciation of a great man; it were to be desired that all naturalists would, like Linnaeus, adopt all that is good in the contributions of their predecessors, and improve or adapt it as he did. Linnaeus himself has repeatedly quoted the sources of his knowledge as far as they were known to him, and has in many cases estimated the services of his predecessors with a candour which never betrays a trace of jealousy, but often displays a warm respect, as may be seen especially in the short introductions to the several systems given in the 'Classes Plantarum.' Linnaeus could not only recognise what was good in his predecessors and occasionally make use of it, but he imparted life and fruitfulness to the thoughts of others by applying them as he applied his own thoughts, and bringing out whatever theoretical value they possessed. It was evidently this freshness of life that often misled his successors into believing that Linnaeus thought out and discovered everything for himself. We learn to appreciate the contributions of Cesalpino and his successors in the 17 th century, and even of Kaspar Bauhin for the first time in the works of Linnaeus; we are astonished to see the long-known thoughts of these writers, which in their own place look unimportant and incomplete, fashioned by Linnaeus into a living whole; thus he was at once and in the best sense both receptive and productive, and he might perhaps have done more for the theory of the science if he had not been entangled in one grave error, which was more sharply pronounced in him than in his predecessors and contemporaries, that, namely, of supposing that the highest and only worthy task of a botanist is to know all species of the vegetable kingdom exactly by name. Linnaeus distinctly declared that this was his view, and his school in Germany and England adhered to it so firmly that it established itself with the general public, who to the present day consider it as a self-evident proposition that a botanist exists essentially for the purpose of at once designating any 
and every plant by a name. Like his predecessors, Linnaeus regarded morphology and general theoretical botany only as means to be used for discovering the principles of terminology and definition, with a view to the improvement of the art of describing plants.

We have hitherto spoken chiefly of the manner in which Linnaeus dealt with his subject in matters of detail; in his inner nature he was a schoolman, and that in a higher degree than even Cesalpino himself, who should rather be called an Aristotelian in the strict sense of the word. But to say that Linnaeus' mode of thought is thoroughly scholastic is virtually saying that he was not an investigator of nature in the modern meaning of the word ; we might point to the fact that Linnaeus never made a single important discovery throwing light on the nature of the vegetable world; but that would still not prove that he was a schoolman.

True investigation of nature consists not only in deducing rules from exact and comparative observation of the phenomena of nature, but in discovering the genetic forces from which the causal connexion, cause and effect may be derived. In the pursuit of these objects, it is compelled to be constantly correcting existing conceptions and theories, producing new conceptions and new theories, and thus adjusting our own ideas more and more to the nature of things. The understanding does not prescribe to the objects, but the objects to the understanding. The Aristotelian philosophy and its medieval form, scholasticism, proceeds in exactly the contrary way; it is not properly concerned with acquiring new conceptions and new theories by means of investigation, for conceptions and theories have been once for all established; experience must conform itself to the ready-made system of thought; whatever does not so conform must be dialectically twisted and explained till it apparently fits in with the whole. From this point of view the intellectual task consists essentially in this twisting and turning of facts, for the general 
idea of the whole is already made and needs not to be altered. Experience in the higher sense of investigation of nature is rendered impossible by the fact, that we are supposed to know all the ultimate principles of things; but these ultimate principles of scholasticism are at bottom only words with extremely indefinite meaning, abstractions obtained by a series of jumps from every-day experience, which has not been tried and refined in the crucible of science, and is therefore worthless; and the higher the abstraction is raised, the farther it withdraws from the guiding hand of experience, the more venerable and more important do these 'abstracta' appear, and we can finally come to a mutual understanding about them, though again only through figures and metaphors ${ }^{1}$. Science, according to the scholastic method, is a playing with abstract conceptions; the best player is he who can so combine them together, that the real contradictions are skilfully concealed. On the contrary, the object of true investigation, whether in philosophy or in natural science, is to make unsparing discovery of existing contradictions and to question the facts until our conceptions are cleared up, and if necessary the whole theory and general view is replaced by a better. In the Aristotelian philosophy and in scholasticism facts are merely examples for the illustration of fixed abstract conceptions, but in the real investigation of nature they are the fruitful soil from which new conceptions, new combinations of thought, new theories, and general views spring and grow. The most pernicious feature in scholasticism and the Aristotelian philosophy is the confounding of mere conceptions and words with the objective reality of the things denoted by them; men took a special pleasure in deducing the nature of things from the original meaning of the words, and even the question of the existence or non-existence of a thing

1 See the excellent account of the Platonic and Aristotelian philosophies and of scholasticism in Albert Lange's 'Geschichte des Materialismus,' second edition, $18_{74}$. 
Cнар. II.] Organs from Cesalpino to Linnaeus.

was answered from the idea of it. This way of thinking is found everywhere in Linnaeus, not only where he is busy as systematist and describer, but where he wishes to give information on the nature of plants and the phenomena of their life, as in his 'Fundamenta,' his 'Philosophia Botanica,' and especially in his 'Amoenitates Academicae.' From among many instances we may select his mode of proving sexuality in plants. Linnaeus knew and lauded the services rendered to botany by Rudolph Jacob Camerarius, who as a genuine investigator of nature had demonstrated the sexuality of plants in the only possible way, namely, that of experiment. But Linnaeus cares little for this experimental proof ; he just notices it in passing, and expends all his art on a genuine scholastic demonstration intended to prove the existence of sexuality as arising necessarily from the nature of the plant. He connects his demonstration with the dictum 'omne vivum ex ovo,' which Harvey had founded on an imperfect induction, and which he evidently takes for an a priori principle, and concludes from it that plants also must proceed from an 'ovum,' overlooking the fact that in 'omne vivum ex ovo' plants already form a half of the 'omne vivum'; then he continues, 'reason and experience teach us that plants proceed from an 'ovum,' and the cotyledons confirm it'; reason, experience, and cotyledons! Surely a remarkable assemblage of proofs. In the next sentence he confines himself at first to the cotyledons, which according to him spring in animals from the yolk of the egg, in which the life-point is found; consequently, he says, the seed-leaves of plants, which envelope the 'corculum,' are the same thing; but that the progeny is formed not simply from the 'ovum,' nor from the fertilising matter in the male organs, but from the two combined, is shown by animals, hybrids, reason, and anatomy. By reason in this and the previous sentence he understands the necessity, concluded from the nature, that is, the conception of the thing, that it must be so ; animals supply him with the analogy, and anatomy can prove nothing, as long as it is not known what is 
the design of the anatomical arrangements. But the weakest side of this proof lies in the hybrids, for Linnaeus, when he wrote the 'Fundamenta,' knew of none except the mule; hybrids in plants were first described by Koelreuter in $176 \mathrm{r}$, and these Linnaeus nowhere mentions; and what amount of proof can be drawn from the vegetable hybrids, which Linnaeus afterwards supposed himself to have observed, but which were no hybrids, we shall see in the history of the sexual theory; here we need only remark that he arrives at the existence of these hybrids from the idea of sexuality exactly as he arrived at that of sexuality from the idea of hybridisation. Then he goes on with his demonstration; 'that an egg germinates without fecundation is denied by experience, and this must hold good therefore of the eggs ${ }^{1}$ of plants-every plant is provided with flower and fruit, even where these are not visible to the eye'; with Linnaeus, of course, this is logically concluded from the conception of the plant or of the 'ovum'; he alleges indeed certain observations as well, but they are incorrect. He continues, "The fructification consists of the sexual organs of the flowers; that the anthers are the male organs, the pollen the fertilising matter, is proved by their nature, further by the fact that the flower precedes the fruit, as also by their position, the time, the loculaments (anthers), by castration, and by the structure of the pollen.' Here too the main point with Linnaeus is the nature of the male organs, and that we may know what this nature is he refers to a former paragraph, where we learn that the essence of the flower is in the anthers and stigma. Almost all his denıonstrations consist of such reasonings in a circle and in arguing from the thing to be proved. And while the passages quoted show how much he did for the

1 The comparison of the vegetable seed with the egg in animals, which is in itself incorrect, comes, as Aristotle tells us, from Empedocles, and was a favourite one with the systematists. 
doctrine of sexuality, we find this sophistical style of reasoning still more copiously displayed in the essay entitled 'Sponsalia Plantarum' in the 'Amoenitates' (i. p. 77), and in a worse form still in the essay, 'Plantae Hybridae' (Amoen. iii. p. 29). That Linnaeus had not the remotest conception of the way in which the truth of a hypothetical fact is proved on the principles of strict inductive investigation is shown by these and many other examples, and by his enquiry into the seeds of mosses (Amoen. ii. p. 266), upon which he prided himself not a little, but which is really inconceivably bad even for that time (1750). It was not Linnaeus' habit to occupy himself with what we should call an enquiry; whatever escaped the first critical glance he left quietly alone; it did not occur to him to examine into the causes of the phenomena that interested him; he classified them and had done with them; as for instance in his 'Somnus Plantarum,' as he called the periodical movements of plants. We cannot read much of the 'Philosophia Botanica' or the 'Amoenitates' without feeling that we are transported into the literature of the middle ages by the kind of scholastic sophistry which is all that his argumentation amounts to; and yet these works of Linnaeus date from the middle of the last century, from a time when Malpighi, Grew, Camerarius, and Hales had already carried out their model investigations, and his contemporaries Duhamel, Koelreuter, and others were experimenting in true scientific manner. This peculiarity in Linnaeus explains why men like Buffon, Albert Haller, and Koelreuter treated him with a certain contempt; and also why his strict adherents in Germany, who lived on his writings and were unable to separate what was really good in him from his mode of reasoning, came to make their own botany like anything rather than a science of nature. Linnaeus was in fact a dangerous guide for weak minds, for his curious logic, among the worst to be met with in the scholastic writers, was combined with the most brilliant powers of description; the enormous extent of his knowledge of par- 
ticulars, and above all the pre-eminent firmness and certainty which distinguished his mode of dealing with systematic botany, could not fail to make the profoundest impression on those who judged of the powers of an investigator of nature by these qualities alone. One of his greatest gifts was without doubt the power which he possessed of framing precise and striking descriptions of species and genera in the animal and vegetable kingdoms by means of a few marks contained in the smallest possible number of words ; in this point he was a model of unrivalled excellence to all succeeding botanists.

On the whole the superiority of Linnaeus lay in his natural gift for discriminating and classifying the objects which engaged his attention; he might almost be said to have been a classifying, co-ordinating, and subordinating machine. He dealt with everything about which he wrote in the way in which he dealt with objects of natural history. The systematic botanists whom he mentions in the 'Classes Plantarum' are classified then and there as fructists, corollists, and calycists. All who occupy themselves in any way with botany are divided into two great classes, the true botanists and mere botanophils, and it is very characteristic of his way of thinking that he places anatomists, gardeners, and physicians in the latter class. True botanists again are either mere collectors or systematists. To the collectors belong all who add to the number of known plants, also authors of monographs and floras, and the. botanical explorers of foreign countries, whom we should now more courteously call systematists. By systematists Linnaeus understands those who occupy themselves with the classification and naming of plants, and he divides them into philosophers, systematists proper, and nomenclators; the philosophers are those who study the theory of the science on principles founded on reason and observation, and are subdivided into orators, institutors, erystics, and physiologists ; the latter are those who discovered the mystery of sexuality in plants, and hence Malpighi, Hales, and such men are not 
physiologists in Linnaeus' sense. The second class of systematists, the systematists proper, he distinguishes into orthodox and heterodox, the former taking the grounds of division exclusively from the organs of fructification, while the latter use other marks as well. In this manner Linnaeus treats every subject of which he has to speak, and wherever he can in short, numbered sentences, which look like descriptions of genera and species. His mind and character were fully formed in 1736 when he wrote his 'Fundamenta,' and he preserved his peculiarities of style from that time forward; we find the same modes of expression in the 'Nemesis Divina,' a treatise on religion and morals addressed as a legacy to his son. Where these peculiarities of manner and expression are suitable they make a favourable impression on the reader, as for instance in the short accounts he gives of the various systems in the 'Classes Plantarum,' a work in which Linnaeus was quite in his element; there he traces with a fine instinct the guiding principles of each system, pronounces upon its merits and defects, and sets it before the reader in numbered sentences of epigrammatic brevity. This manner is strictly adhered to in the 'Philosophia' also, and it has certainly helped not a little to withdraw the attention of his reader from his many fallacies in argument, especially his oft-recurring reasonings in a circle.

This remarkable combination of an unscientific philosophy with mastery over the classification of things and conceptions, this mixture of consistency in carrying out his scholastic principles with gross inaccuracies of thought, impart to his style an originality, which is rendered still more striking by the native freshness and directness, and not unfrequently by the poetic feeling, which animate his periods.

In any attempt to estimate the advance which the science owes to the labours of Linnaeus, the chief prominence must be assigned to two points; first to his success in carrying out the binary nomenclature in connection with the careful and 
methodical study which he bestowed on the distinguishing of genera and species; this system of nomenclature he endeavoured to extend to the whole of the then known vegetable world, and thus descriptive botany in its narrower sense assumed through his instrumentality an entirely new form, which, serving as a model for the naming and defining of the larger groups, could be applied without modification to the founding and completing the natural system. When at a later time Jussieu and De Candolle marked out their families and groups of families, their mode of proceeding was in the main that of Linnaeus when distinguishing his genera by abstraction of specific differences. This merit has been always assigned to Linnaeus without reserve. The second merit has been less recognised, and yet it is at least of equal importance ; it is that of having first perceived that the attempt made by Cesalpino and his successors to found a system, that shall do justice to natural affinities, on predetermined marks can never succeed. Linnaeus framed his artificial sexual system, but he exhibited a fragment of a natural system by its side, while he repeatedly declared that the chief task of botanists is to discover the natural system. Thus he cleared the ground for systematic botany. He made use of his own system, because it was extremely convenient for describing individual plants, but he ascribed all true scientific value exclusively to the natural system; and with what success he laboured to advance it may be gathered from the fact, that Bernard de Jussieu founded his improved series of families on the fragment of Linnaeus, and that his nephew, A. L. de Jussieu, by simply adopting Linnaeus' conception of the principle which lies at the foundation of the natural system, succeeded in carrying it on to a further stage of development.

The main features of Linnaeus' theoretical botany can best be learned from the 'Philosophia Botanica,' which may be regarded as a text-book of that which Linnaeus called botany, and which far surpasses all earlier compositions of the kind in 
perspicuity and precision, and in copiousness of material ; and indeed it would be difficult to find in the ninety years after I 78r a text-book of botany which treats what was known on the subject at each period with equal clearness and completeness. In giving the reader some idea of the way in which Iinnaeus deals with his subject, it will be well to pass over the first two chapters, which discuss the literature and the various systems which had been proposed, and turn to the third, which under the heading 'Plantae' treats of the general nature of plants, and specially of the organs of vegetation. The vegetable world, says Linnaeus, comprises seven families, Fungi, Algae, Mosses, Ferns, Grasses, Palms, and Plants. All are composed of three kinds of vessels, sap-vessels which convey the fluids, tubes which store up the sap in their cavities, and tracheae which take in air; these statements Linnaeus adopts from Malpighi and Grew. He gives no characteristic marks for the Fungi; of the Algae he says that in them root, leaf, and stem are all fused together; to the Mosses he ascribes an anther without a filament, and separate from the female flower which has no pistil; the seeds of the Mosses have no integument or cotyledons; this characteristic of the Mosses is explained in his paper entitled 'Semina Muscorum ' in the 'Amoenitates Academicae,' ii. The Ferns are marked by the fructification on the under side of the fronds, which are therefore not conceived of as leaves. The very simple leaves, the jointed stalk, the 'calyx glumosus,' and the single seed mark the Grasses. 'The simple stem, the rosette of leaves at the summit, and the spathe of the inflorescence are characteristic of the Palms. All vegetable forms which do not belong to any of the previous families he names Plants. $\mathrm{He}$ rejects the customary division into herbs, shrubs, and trees as unscientific. This arrangement of the vegetable kingdom must not be confounded with Linnaeus' fragment of a natural system, in which he adopts sixty-seven families (orders), the Fungi, Algae, Mosses, and Ferns forming each a family. $\mathrm{He}$ 
evidently introduces the divisions in the 'Philosophia,' in order that it may be seen how far the statements that follow are applicable to all the Vegetabilia or only to certain sections of them. The parts in the individual plant which the beginner must distinguish are three ; the root, the herb ${ }^{1}$, and the parts of fructification, in which enumeration Linnaeus departs from his predecessors, by whom the fructification and the herb together are opposed to the root. In the central part of the plant is the pith, enclosed by the wood which is formed from the bast; the bast is distinct from the rind, which again is covered by the epidermis; these anatomical facts are from Malpighi; the statement that the pith grows by extending itself and its envelopes is borrowed from Mariotte. Cesalpino's view on the formation of the bud is expressed by Linnaeus in the statement, that the end of a thread of the pith passing through the rind is resolved into a bud, etc. The bud is a compressed stem, capable of unlimited extension till fructification puts a term to vegetation. The fructification is formed by the leaves uniting into a calyx, from which the apex of a branch issues as a flower about one year in advance, while the fruit arising from the substance of the pith cannot begin a new life till the woody substance of the stamens has been absorbed by the fluids of the pistil. In this way Linnaeus corrected Cesalpino's theory of the flower, that he might take into account the sexual importance of the stamens discovered by Camerarius. He concludes by saying that there is no new creation but only a continuous generation, for which he gives the remarkable and thoroughly Cesalpinian reason, 'cum corculum seminis constat parte radicis medullari.'

The root, which takes up the food, and produces the stem and the fructification, consists of pith, wood, bast, and rind, and is divided into the two parts, 'caudex' and 'radicula.'

1 Linnaens uses the word 'herba' for the older word ' germen,' which with him means the ovary. 
Chap. II.] Organs from Cesalpino to Limnaens.

The 'caudex' answers pretty nearly to our primary root and rhizomes, the 'radicula' to what we now call secondary roots.

The herb springs from the root, and is terminated by the fructification; it consists of the stem, leaves, leaf-supports ('fulcrum'), and the organs of hibernation ('hibernaculum'). Then follow the further distinctions of stem and leaves; the terminology, still partly in use and resting essentially on the definitions of Jung, is here set forth in great detail. Linnaeus however does not mention the remarkable distinction between stem and leaf which Jung founded on relations of symmetry, and in general he shows less depth of conception than Jung, confining himself more to the direct impression on the senses, and so distinguishing sometimes where there is no real difference. Examples of this are furnished by the paragraph devoted to 'fulcra.' By this term he designates the subsidiary organs of plants, among which he reckons stipules, bracts, spines, thorns, tendrils, glands, and hairs. It appears from this, that Linnaeus did not extend the idea of the leaf ('folium') to stipules and bracts, and the examples he gives of tendrils show at the same time that he was ignorant of the different morphological character of the organ in Vitis and Pisum. The putting the seven organs above-named together under the idea of 'fulcrum' shows plainly enough that Linnaeus, in framing his terminology, aimed only at distinguishing what was different to the sense by fixed words, in order to obtain means for short diagnoses of species and genera. He had no thought of arriving at more general propositions from a comparison of forms in plants, in order to attain to a deeper insight into their nature. The same thing appears from his notion of 'hibernaculum,' by which he understands a part of the plant which envelopes the stem in its embryonal state and protects it from harm from without; he here distinguishes bulbs from the winter buds of woody plants. In this course of mixing up morphological and biological 
96 Artificial Systems and Terminology of [Book I.

relations of organs he was followed by botanists till late into our own century.

Linnaeus goes far beyond his predecessors in distinguishing and naming the organs of fructification, the subject of the fourth chapter of the 'Philosophia Botanica.' The fructification, he says, is a temporary part in plants devoted to propagation, terminating the old and beginning the new. He distinguishes the following seven parts: (I) the calyx, which represents the rind, including in this term the involucre of the Umbelliferae, the spathe, the calyptra of Mosses, and even the volva of certain Fungi,-another instance of the way in which Linnaeus was guided by external appearance in his terminology of the parts of plants; (2) the corolla, which represents the inner rind (bast) of the plant; (3) the stamen, which produces the pollen; (4) the pistil, which is attached to the fruit and receives the pollen; here for the first time the ovary, style, and stigma are clearly distinguished. But next comes as a special organ (5) the pericarp, the ovary which contains the seed. As bulbs and buds were treated not simply as young shoots, but as separate organs, so here too the ripe fruit is regarded not merely as the developed ovary, but as a special organ. Nevertheless, Linnaeus distinguishes the different forms of fruit much better than his predecessors had done. (6) The seed is a part of the plant that falls off from it, the rudiment of a new plant, and it is excited to active life by the pollen. The treatment of the seed and its parts is the feeblest of all Linnaeus' efforts; he follows Cesalpino, but his account of the parts of the seed is much more imperfect than that of Cesalpino and his successors. The embryo is called the 'corculum,' and two parts are distinguished in it, the 'plumula' and the 'rostellum' (radicle). The cotyledon is co-ordinated with the 'corculum,' and is regarded therefore not as part of the embryo but as a distinct organ of the seed; it is defined as 'corpus laterale seminis bibulum caducum.' Nothing could be worse, and it seems almost incredible that so bad a defini- 
tion and distinction could be given in $175 \mathrm{I}$, and again in $\mathrm{I} 770$, by the first botanist of his time, when Malpighi and Grew, nearly a hundred years earlier, had illustrated the parts of the seed and even the history of its development and its germination by numerous figures. He does not mention the endosperm, evidently confounding it with the cotyledon, though Ray had already distinguished it clearly from the other parts of the seed. Linnaeus' terminology of the seed supplies more than sufficient corroboration of our previous remark, that he shows incapacity for the careful investigation of any object at all difficult to observe, and it will now seem a small matter that he, like most of the earlier botanists, treats one-seeded indehiscent fruits as seeds, and hence makes the pappus a part of the seed. (7) By the word 'receptaculum' he understands everything by which the parts of the fructification are connected together, both the 'receptaculum proprium,' which unites the parts of the single flower, and the 'receptaculum commune,' under which term he comprises the most diverse forms of inflorescence (umbel, cyme, spadix).

He concludes with the remark that the essence of the flower consists in the anther and the stigma, that of the fruit in the seed, that of the fructification in the flower and the fruit, and that of all vegetable forms in the fructification, and he adds a long list of distinctions between the organs of fructification with their names; among these organs appear the nectaries, which he was the first to distinguish.

In the fifth chapter he discusses the question of difference of sex in plants. His views on this subject have been already mentioned in order to show that they were entirely founded on worthless scholastic deductions; here we may quote a few of the propositions which were famous in after times. We assume, he says, that two individuals of different sexes were created in the beginning of things in every kind of living creatures. Plants, though they are without sensation, yet live as do animals, for they have a beginning and an advance in age (aetas), and are 
98 Artificial Systems and Terminology of [Bоoк I.

liable to disease and death ; they have also a power of movement, a natural appetency (propulsio), an anatomy, and an organic structure (organismus). Simple explanations are given of these words, but they prove nothing about the matter. $\mathrm{He}$ then expounds the whole theory of sexuality, which is made to rest entirely on scholastic arguments, and in doing this he spins out to excessive length the parallel which he draws between the conditions of sexuality in animals and plants. It is manifestly this chapter of the 'Philosophia Botanica,' together with the treatise 'Sponsalia Plantarum,' which led the adherents of Linnaeus, who were ignorant of the older literature of the subject and were much impressed by his scholastic dexterity, to celebrate him as the founder of the sexual theory of plants; whereas a more careful study of history shows incontrovertibly that Linnaeus helped in this way to disseminate the doctrine, but did absolutely nothing to establish it.

The writings of Linnaeus which we have hitherto examined are occupied with the nature of plants, and of this he knew nothing more than he gathered from the investigations and reflections of his predecessors; and it is here especially that his peculiar scholasticism is exhibited in contrast with the facts obtained by induction which he communicated to his readers. But the strong side of his intellect appears with splendid effect in the succeeding chapters of the 'Philosophia,' which treat of the principles of systematic botany; here, where he has no longer to establish facts, but to arrange ideas, to dispose and summarise, we find Linnaeus thoroughly in his element.

The groundwork of botanical science, he begins, is twofold, classification and naming. The constituting of classes, orders, and genera he calls theoretical classification; the constituting of species and varieties is practical classification. The work of classification carried out by Cesalpino, Morison, Tournefort, and others leads to the establishing of a system; the mere practice of describing species may be carried on by those who know nothing of systematic botany. These expressions of 
Linnaeus are interesting, because like other remarks of his they show that he placed the establishment and arrangement of the larger groups above the mere distinguishing of individual forms ; his disciples to a great extent forgot their master's teaching, and fancied that the collecting and distinguishing of species was systematic botany. He opposes the system itself, which deals with the relative conceptions of classes, orders, genera, species, and varieties, to a mere synoptical view, serving with its dichotomy only to practical ends. Then comes the oftenquoted sentence, "We reckon so many species as there were distinct forms created "in principio." ' In a former place he had said 'ab initio' instead of 'in principio'; instead therefore of a beginning in time he here posits an ideal, theoretical beginning, which is more in accordance with his philosophical views. That new species can arise is, he continues, disproved by continuous generation and propagation, and by daily observation, and by the cotyledons. It is hard to understand how the Linnaean school till far into our own century could have remained firm in a doctrine resting on such arguments as these. Linnaeus' definition of varieties shows that he understood by the word species fundamentally distinct forms; there are, he says, as many varieties as there are different plants growing from the seed of the same species; and he adds that a variety owes its origin to an accidental cause, such as climate, soil, warmth, the wind ; but this is evidently mere arbitrary assumption. Judging by all he says, his view is that species differ in their inner nature, varieties only in outward form. Here, where we find the dogma of the constancy of species for the first time expressed in precise terms, - a dogma generally accepted till the appearance of the theory of descent, we should be justified in demanding proof; but since dogmas as a rule do not admit of proof, Linnaeus simply states his view $^{1}$, unless we are to take the sentence, 'negat generatio

${ }^{1}$ It would not be difficult to prove that the doctrine of the constancy of 
100 Artificial Systems and Terminology of [Book I.

continuata, propagatio, observationes quotidianae, cotyledones,' as proving the assertion that new species never appear. We shall see further on to what surprising conclusions Linnaeus was himself led by his dogma, when he had to take into account the relations of affinity in genera and larger groups. The species and the genus, he continues, are always the work of nature, the variety is often that of cultivation; the class and the order depend both on nature and on art, which must mean that the larger groups of the vegetable kingdom have not the same objective reality as the species and the genus, but rest partly on opinion. That Linnaeus estimated the labours of the systematists after Cesalpino and the contributions of the German fathers of botany up to Bauhin, as they have been judged of in the present work, is shown by paragraph $16_{3}$, where he explains the word habit, and adds that Kaspar Bauhin and the older writers had excellently divined (divinarunt) the affinities of plants from their habit, and even real systematists had often erred, where the habit pointed out to them the right way. But he says that the natural arrangement, which is the ultimate aim of botany, is founded, as the moderns have discovered, on the fructification, though even this will not determine all the classes. It is interesting therefore to observe how Linnaeus further on (paragraph I68) directs, that in forming genera, though they must rest on the fructification, yet it is needful to attend to the habit also, lest an incorrect genus should be established on some insignificant mark (levi de causâ): but this attention to the habit must be managed with reserve, so as not to disturb the scientific diagnosis.

species is properly a conclusion from scholasticism, and ultimately from the Platonic doctrine of ideas, and was therefore assumed as self-evident before the time of Linnaeus, who only gave it a more distinet and conscious expression; his arguments from experience are without force. The strength of the dogma lies in its relation to the platonico-scholastic philosophy, which the systematists followed, more or less consciously, up to quite recent times. 
Linnaeus next lays down with great detail each several rule, which must be observed in establishing species, genera, orders, and classes, and it is here that he displays his unrivalled skill as a systematist. These rules were strictly observed by himself in his numerous descriptive works, and thus a spirit of order and clearness was introduced into the art of describing plants, which gave it at once a different appearance from that which it had received at the hands of his predecessors. Whoever therefore compares the 'Genera Plantarum,' the 'Systema Naturae,' and other descriptive works of Linnaeus with those of Morison, Ray, Bachmann, or Tournefort, finds so great a revolution effected by them, that he is impressed with the persuasion that botany first became a science in the hands of Linnaeus ; all former efforts seem to be so unskilful and without order in comparison with his method. Without doubt the greatest and most lasting service which Linnaeus rendered both to botany and to zoology lies in the certainty and precision which he introduced into the art of describing. But if a reformation was thus effected in botany, as Linnaeus himself took pleasure in saying, it must not be overlooked that the knowledge of the nature of plants was rather hindered than advanced by him. Ray, Bachmann, and in part also Morison and Tournefort, had already liberated themselves to a great extent from the influence of scholasticism, and they still give us the impression of having been genuine investigators of nature; but Linnaeus fell back again into the scholastic modes of thought, and these were so intimately combined with his brilliant performances in systematic botany, that his successors were unable to separate the one from the other.

The feeling for order and perspicuity, which made Linnaeus a reformer of the art of describing, combined with his scholasticism, was evidently the cause of his not bestowing more energetic labour on the natural system. It has been repeatedly mentioned that it was he who first established sixty-five truly natural groups in his fragment of the early date of $173^{8}$; and 
a certain feeling for natural affinity is shown in the establishment of his seven families, Fungi, Algae, Mosses, Ferns, Grasses, Palms, and Plants properly so-called. Moreover in paragraph ${ }^{6} 63$ of the 'Philosophia Botanica,' he carries out the division of the whole vegetable kingdom into Acotyledons, Monocotyledons, and Polycotyledons with their subdivisions very admirably; and thus we see him continually impelled towards a natural arrangement, but never bestowing upon it the necessary labour and thought.

And so two different conceptions of a system of plants continued to subsist side by side with each other in the mind of Linnaeus; one more superficial, and adapted for practical use, expressed in his artificial sexual system, and one more profound and scientifically valuable, embodied in his fragment and in the natural groups above-mentioned.

The same may be said also of Linnaeus' morphological views; here, too, a more superficial pursued its way along with a more profound conception. He formed his terminology of the parts of plants for practical use in describing them, and convenient as it is, it seems nevertheless shallow or superficial, because its foundations are not more deeply laid in the comparative study of forms. But we discover from very various passages in his writings that he felt the need of a more profound conception of plant-form, and what he was able to say on the subject he put together under the head of 'metamorphosis plantarum.' His doctrine of metamorphosis is entirely based on the views of Cesalpino, with which we have already become acquainted, though he did not adopt them in their original form, but endeavoured to develop them in true Cesalpinian fashion; for on the one hand he derived leaves and parts of flowers from the tissues of the stem, and on the other conceived of the parts of the flower as only altered leaves. This doctrine of metamorphosis appears in somewhat confused form in the last page of his 'Philosophia Botanica.' There he says that the whole of the 
herb is a continuation of the medullary substance of the root; the principle of the flowers and leaves is the same, because both spring from the tissue-layers surrounding the pith, as Cesalpino had taught. The statement which follows, that the principle of the bud and the leaves is identical, would be a departure from Cesalpino, and in any case inconsistent, without the explanation that the bud consists of rudimentary leaves; but this again puts the axial portion of the bud out of sight. The perianth, he says, comes from concrescent rudiments of leaves. How closely Linnaeus adhered to Cesalpino in his later years appears in his explanation of the catkin, which comes next and which is taken entirely from Cesalpino's theory. That a more superficial and a more profound conception pursue their way together unadjusted in Linnaeus' speculations on form is specially shown by the fact, that in the text of the 'Philosophia Botanica,' paragraph 84 , he places the 'stipulae' under the idea of 'fulcra' and not under that of 'folia,' while on the contrary at the end of the same work, where he brings together the different paragraphs respecting metamorphosis, he speaks of the 'stipulae' as appendages of the leaves.

The idea of Cesalpino, that the parts of the flower which surround the fruit arise like the ordinary leaves from the tissues that enclose the pith, is further developed by Linnaeus in his 'Metamorphosis Plantarum,' in the fourth volume of the 'Amoenitates Academicae' (I 759), in a very strange manner. He compares the formation of the flower with the metamorphosis of animals, and especially of insects, and after describing the changes that take place in animals, he says at page 370 that plants are subject to similar change. The metamorphosis of insects consists in the putting off different skins, so that they finally come forth naked in their true and perfect form. This metamorphosis we also find in most plants, for they consist, at least in the truly living part of the root, of rind, bast, wood, and pith. The rind is to the plant what the skin is to the larva of an insect, and after putting this skin off there 
104 Artificial Systems and Terminology of [Boox I.

remains a naked insect. When the flower is produced in the plant the rind opens and forms the calyx (exactly Cesalpino's view), and from out of this the inner parts of the plant issue to form the flower, so that the bast, the wood, and the pith issue forth naked in the form of corolla, stamens, and stigma. So long as the plant lies concealed within the rind and clothed only with leaves, it appears to us as unrecognisable and obscure as a butterfly, which in its larva-condition is covered with skin and spines.

In this doctrine of metamorphosis, which Linnaeus founded on Cesalpino, the chief point to observe is, that the ordinary leaves are identical with the exterior parts of the flower, because both originate in the outer tissues of the stem. The pertinent fact, which may easily be observed without a microscope, that the concentric arrangement of outer and inner rind, wood, and pith occurs only in some flowering plants, that the case is quite different with Monocotyledons, and that Cesalpino's theory of the flower cannot properly be applied to them,- - these are things which we must not expect to find Linnaeus with his peculiar modes of thought taking into consideration.

The want of firm standing-ground in experience is shown also by the fact, that with his own and Cesalpino's theory of the flower he combined another view of its nature, which under the name of 'prolepsis plantarum ' was set forth in two dissertations in 1760 and 1763 , but the two theories are scarcely compatible with one another. While the last paragraph in the 'Philosophia Botanica' says, 'Flos ex gemmâ annuo spatio foliis praecocior est,' the dissertations contain the doctrine ${ }^{1}$, that the flower is nothing but the synchronous appearance of leaves, which properly belong to the bud-formations of six consecutive years, in such a way that the leaves of the bud destined to be unfolded in the second year of the plants become bracts, the

1 The authority for the contents of these dissertations is Wigand's ' Kritik und Geschichte der Metamorphose' (I 846 ). 
leaves of the third year the calyx, those of the fourth the corolla, those of the fifth the stamens, those of the sixth the pistil. Here we see once more how Linnaeus moves in the sphere of arbitrary assumptions with no thought of exact observation, for this whole theory of prolepsis rests on nothing that can be called a well-ascertained fact.

Yet a third time we find in Linnaeus the juxtaposition of a superficial view resting on every-day perception, and a more profound and to some extent a philosophical view; this is the case where he is concerned on the one hand with the dogma of the constancy of species, and on the other hand has to explain the fact of natural relationship and its gradations. Apart from some insignificant verbal explanations, Linnaeus adduced nothing in support of the dogma but the every-day perception of the unchangeableness of species, and to this he held fast to the end of his life ; but it was important to find an explanation of the fact, to which he himself repeatedly drew attention, that genera, orders, and classes do not merely rest on opinion but indicate really existing affinities. His mode of solving the difficulty was a very remarkable one ; not only does the scholastic manner of thought appear here again quite unalloyed by modern science, but he grounds his explanation once more on the old a priori notion that the pith is the vital principle in the plant, and also on his own assumption, that in the sexual act the woody substance of the anthers combines with the pithsubstance of the pistil. Hugo Mohl has given a clear account of the matter in No. 46 of the 'Botanische Zeitung' for 1870 , although neither he nor Wigand nor most of Linnaeus' biographers seem to know, that his theories are all to be traced to Cesalpino. Linnaeus' theory of natural affinities, as he gave it in 1762 in the 'Fundamentum Fructificationis,' and in 1764 in the sixth edition of the 'Genera Plantarum,' is as follows: At the creation of plants (in ipsa creatione) one species was made as the representative of each natural order, and these plants so corresponding to the natural orders were distinct from one 
106 Artificial Systems and Terminology of [Bоок I.

another in habit and fructification, that is, absolutely distinct. In the communication of 1764 the following words occur :-

I. Creator T.O. in primordio vestiit vegetabile medullare principiis constitutivis diversi corticalis, unde tot difformia individua, quot ordines naturales, prognata.

2. Classicas has plantas Omnipotens miscuit inter se, unde tot genera ordinum, quot inde plantae.

3. Genericas has miscuit natura, unde tot species congeneres, quot hodie existunt.

4. Species has miscuit casus, unde totidem quot passim occurrunt varietates.

Hugo Mohl was right in rejecting Heufler's assumption that a view resembling the modern theory of descent was contained in these paragraphs. It must be plain to any one who knows the ideas of Aristotle, Theophrastus, and Cesalpino, within the sphere of which Linnaeus is here moving, what he understands by his 'vegetabile medullare' and 'corticale'; that he does not for a moment mean a plant of simplest organisation, but that both expressions indicate only the original elements of vegetation which the Creator, according to Linnaeus, united to one another at the first. He assumed that plants of the highest and of the lowest grades of organisation were originally created at the same time and alongside of one another; no new class-plants were afterwards created, but from the mingling together of the existing ones by the act of the Creator generically distinct forms were produced, and the natural mingling of these gave birth to species, while varieties were mere chance deviations from species. But it is to be noticed that in these minglings or hybridisations the woody substance of the one form which supplies the pollen is united with the pith-substance of the other form, whose pistil is thus fertilised; and so in these supposed crossings it is always the two original elements of the plant, the medullary and the cortical, which are mingled together. 
Chap. II.] Organs from Cesalpino to Limnaeus. 107

No further proof is wanting that this theory of Linnaeus is no precursor of our theory of descent, but is most distinctly opposed to it ; it is utterly and entirely the fruit of scholasticism, while the essential feature in Darwin's theory of descent is that scholasticism finds no place in it. 


\section{CHAPTER III.}

Development of the Natural System under the Influence of the Dogma of the Constancy of Species.

$$
\text { I 759-1 } 850 \text {. }
$$

From the year I $75^{\circ}$ Linnaeus' terminology of the organs of plants and his binary method of naming species came into general use; the opposition which his doctrines had till then encountered by degrees died away, and if all that he taught was not universally accepted, his treatment of the art of describing plants soon became the common property of all botanists.

But in course of time two very different tendencies were developed; most of the German, English, and Swedish botanists adhered strictly to Linnaeus' dictum, that the merit of a botanist was to be judged by the number of species with which he was acquainted; they accepted Linnaeus' sexual system as one that completed the science in every respect; they thought that botany had reached its culminating point in Linnaeus, and that any improvement or addition could only be made in details, by continuing to smooth over some unevennesses in the system, to collect new species and describe them. The inevitable result was that botany ceased to be a science; even the describing of plants which Linnaeus had raised to an art became once more loose and negligent in the hands of such successors; in place of the morphological examination of the parts of plants there was an endless accumulating of technical terms devoid of depth of scientific meaning, till at length a 
text-book of botany came to look more like a Latin dictionary than a scientific treatise. In proof of this we may appeal to Bernhardi's 'Handbuch der Botanik,' published at Erfurt in I 804 , and Bernhardi was one of the best representatives of German botany of the time. How botany, especially in Germany, gradually degenerated under the influence of Linnaeus' authority into an easy-going insipid dilettantism may very well be seen from the botanical periodical, entitled 'Flora,' the first volumes of which cover the greater part of the first fifty years of the I 9 th century; it is scarcely conceivable how men of some cultivation could occupy themselves with such worthless matter. It would be quite lost labour to give any detailed account of this kind of scientific life, if it can be so called, this dull occupation of plant-collectors, who called themselves systematists, in entire contravention of the meaning of the word. It is true indeed that these adherents of Linnaeus did some service to botany by searching the floras of Europe and of other quarters of the globe, but they left it to others to turn to scientific account the material which they collected.

But before this evil had spread very widely, a new direction to the study of systematic botany and morphology was given in France, where the sexual system had never met with great acceptance. Bernard de Jussieu and his nephew, Antoine Laurent de Jussieu, taking up Linnaeus' profounder and properly scientific efforts, made the working out of the natural system, in Linnaeus' own opinion the highest aim of botany, the task of their lives. Here more was needed than a perpetual repetition of descriptions of single plants after a fixed pattern; more exact inquiries into the organisation of plants, and especially of the parts of the fructification, must supply the foundation of larger natural groups. It was a question therefore of new inductive investigation, of real physical science, of penetrating into the secrets of organic form, whereas the botanists who confined themselves to Linnaeus' art of description made no new discoveries respecting the nature of plants. And if these men 


\section{I10 Development of the Natural System under [Bоoк I.}

held to the dictum just quoted from Linnaeus, and therefore regarded themselves as his genuine disciples, the founders of the natural system had as good a right to the title, not because they followed his nomenclature and method of diagnosis, but because they strove after exactly that object which he had placed first in the science, the construction of the natural system; they were really the men whom he had meant when he spoke of 'methodici' and 'systematici.' The German, English, and Swedish collectors of plants adhered to the less profound, every-day, practical precepts of their master; the founders of the natural system followed the deeper traces of his knowledge. This direction proved to be the only one endowed with living power, the true possessor of the future.

The efforts of Jussieu, Joseph Gärtner, De Candolle, Robert Brown, and their successors up to Endlicher and Lindley, are not marked only by the fact that they did truly seek to exhibit the gradations of natural affinities by means of the natural system ; equally characteristic of these men is their firm belief in the dogma of the constancy of species as defined by Linnaeus. Here at once was a hindrance to their efforts; the idea of natural relationship, on which the natural system exclusively rests, necessarily remained a mystery to all who believed in the constancy of species; no scientific meaning could be connected with this mysterious conception; and yet the farther the inquiry into affinities proceeded, the more clearly were all the relations brought out, which connect together species, genera, and families. Pyrame de Candolle developed with great clearness a long series of such affinities as revealed to us by comparative morphology, but how were these to be understood, so long as the dogma of the constancy of species severed every real objective connection between two related organisms? Little indeed could be made of these acknowledged affinities; still, in order to be able to speak of them and describe them, recourse was had to indefinite expressions, to which arbitrary and figurative meanings could 
be assigned. Where Linnaeus had spoken of a class-plant or generic plant, the expression 'plan of symmetry' or 'type' was used, meaning an ideal original form, from which numerous related forms might be derived. It was left undecided, whether this ideal form ever really existed, or whether it was merely the result of intellectual abstraction; and thus the forms of thought of the old philosophy soon began to reappear. The Platonic ideas, though mere abstractions and therefore only products of the understanding, had been regarded not only by the school of Plato, but also by the so-called Realists among the schoolmen, as really existing things. The systematists obtained the idea of a type by abstraction, and the next step was easy, to ascribe with the Platonists an objective existence to this creature of thought, and to conceive of the type in the sense of a Platonic idea. This was the only view that was possible in combination with the dogma of the constancy of species, and so Elias Fries, in his 'Corpus Florarum,' I 835 , in speaking of the natural system, could consistently say, 'est quoddam supranaturale,' and maintain that each division of it 'ideam quandam exponit.' So long as the constancy of species is maintained, there is no escaping from the conclusion drawn by Fries, but it is equally certain that systematic botany at the same time ceases to be a scientific account of nature. Systematists, adopting this conclusion as necessarily following from the dogma, might consider themselves as seeking to express in the natural system the plan of creation, the thought of the Creator himself; but in this way systematic botany became mixed up with theological notions, and it is easy to understand why the first feeble attempts at a theory of descent encountered such obstinate, nay, fanatical opposition from professed systematists, who looked upon the system as something above nature, a component part of their religion. And if we look back we find that these views are based on the dogma of the constancy of species, while Linnaeus' 'Philosophia Botanica' teaches us on what grounds this dogma rests, where it says, 'Novas species 
I 2 Development of the Natural System under [Воок I.

dari in vegetabilibus negat generatio continuata, propagatio, observationes quotidianae, cotyledones.'

In spite of all this one important advance was made by the successors of Jussieu; the larger groups of genera, the families, were defined with the certainty and precision, with which Linnaeus had fixed the boundaries of species and genera, and were supplied with characteristic marks. They succeeded also in clearly distinguishing various still larger groups founded on natural affinity, such as the Monocotyledons and Dicotyledons ; the distinction between Cryptogams and Phanerogams was by degrees better appreciated, though this point could not be finally settled, so long as it was attempted to reduce the Cryptogams entirely to the scheme of the Phanerogams. The chief hindrance however to the advance of systematic botany, at least at the beginning of this period, lay in the defective morphology enshrined in Linnaeus' terminology and in his doctrine of metamorphosis. A great improvement certainly was effected in the early part of the i 9 th century by De Candolle's doctrine of the symmetry of plants, - a doctrine which has been much undervalued, and that merely on account of its name; it is really a comparative morphology, and the first serious attempt of the kind since the time of Jung that has produced any great results; a series of the most important morphological truths, with which every botanist is now conversant, were taught for the first time in De Candolle's doctrine of symmetry in 1813 . But one thing was wanting not only in Jussieu and De Candolle, but in all the systematists of this period, with the single exception of Robert Brown, and this was the history of development. The history of the morphology and systematic botany of this period shows indeed, that the comparison of mature forms leads to the recognition of many and highly important morphological facts; but as long as matured organisms only are compared, the morphological consideration of them is always disturbed by the circumstance that the organs to be compared are already adapted to definite physiological functions, and 
thus their true morphological character is often entirely obscured; on the other hand, the younger the organs are, the less is this difficulty experienced, and this is the real reason why the history of development is of so great service to morphology. It was then one of the characteristic features of the period we are describing, that its morphology was formed upon the study of matured forms ; the history of development, or at all events of very early stages of development, could not be turned to account till after 1840 , for skill in the use of the microscope, here indispensable, was not sufficiently advanced before that time to make it possible to follow the growth of organs from their first beginnings.

The establishment of natural affinities combined with the assumption of the constancy of species, the growth of comparative morphology without the history of development, lastly, the very subordinate attention still paid to the Cryptogams, - these are the special characteristics of the period which has now to be described at greater length.

Here we must once more call attention to the fact, that Linnaeus was the first to perceive that a system which was to be the expression of natural affinities could not be attained in the way pursued by Cesalpino and his immediate successors. All who have attentively studied the writings of Linnaeus which appeared after the 'Classes Plantarum' ( $173^{8}$ ) must have seen the difference between that way and the one recommended by him - a difference which is the more obvious because Linnaeus himself, like his predecessors, constructed an artificial system on predetermined principles of classification, and always employed it for practical purposes, while he published at the same time in the above-named work his fragment of a natural system, and in the preface set forth the peculiar features of the natural and artificial systems in striking contrast with one another. The first thing and the last, he says in his prefatory remarks to his 
I 4 Development of the Natural System under [Boox I.

fragment, which is demanded in systematic botany, is the natural method, which slighted by less learned botanists has always been highly regarded by the more sagacious, and has not yet been discovered. If, he continues, we collect the natural orders from all existing systems (up to 1738 ), we shall get but a small list of really allied plants, though so many systems have claimed to be natural. He had himself long laboured to discover the natural method and had found out some things that were new ; but though he had not succeeded in carrying it through to a perfect work, he would continue his efforts as long as his life lasted. He makes the very important remark, that a key, that is, a priori principles of classification, cannot be given for the natural method, till all plants have been reduced to orders; that for this no a priori rule is of value, neither this nor that part of the fructification, but the simple symmetry alone (simplex symmetria) of all the parts, which is often indicated by special marks. He suggests to those who are bent on trying to find a key to the natural system, that nothing has more general value than relative position, especially in the seed, and in the seed especially the 'punctum vegetans, --a distinct reference to Cesalpino. He says that he establishes no classes himself, but only orders; if these are once obtained, it will be easy to discover the classes. The essence of the natural system could not have been more clearly expounded in Linnaeus' time, than it is in these sentences. $\mathrm{He}$ established as early as 1738 sixty-five natural orders, which he at first simply numbered; but in the first edition of the 'Philosophia Botanica' in $\mathrm{r} 75 \mathrm{I}$, where the list is increased to sixty-seven, he gave a special name to each group; and he showed his judgment by either taking his names from really characteristic marks, or what was still better, by selecting a genus and so modifying its name as to make it serve as a general term for a whole group. Many of these designations are still in use, though the extent and content of the groups have been greatly changed. This mode of naming is an import- 
ant point, because it expresses the idea, that the different genera of such a group are to some extent regarded as forms derived from the one selected to supply the name. Many of Linnaeus' orders do in fact indicate cycles of natural affinity, though single genera are not unfrequently found to occupy a false position; at all events, Linnaeus' fragment is much the most natural system proposed up to 1738 , or even to $175 \mathrm{I}$. It is distinguished from Kaspar Bauhin's enumeration in this, that its groups do not run into one another, but are defined by strict boundaries and fixed by names.

The Linnaean list is distinctly marked by the endeavour to make first the Monocotyledons, then the Dicotyledons, and finally the Cryptogams follow one another; that the old division into trees and herbs already rejected by Jung and Bachmann, but still maintained by Tournefort and Ray, disappears in Linnaeus' natural system will be taken for granted after what has been already said of it, and from this time forward this ancient mistake is banished for ever.

In BERNARD DE JUSSIEU's ${ }^{1}$ arrangement of I 759 we find some improvements in the naming, the grouping, and the succession, but at the same time some striking offences against natural affinity. He published no theoretical remarks on the system, but gave expression to his views on relations of affinity in the vegetable kingdom in laying out the plants in the royal garden of Trianon, and in the garden-catalogue. His nephew published his uncle's enumeration in the year 1789 in his 'Genera Plantarun,' affixing the date of I 759 given above. The difference between it and the Linnaean fragment does not seem

1 Bernard de Jussieu, born at Lyons in 1699 , and at first a practising physician there, was by Vaillant's intervention called to Paris, and after Vaillant's death became Professor and Demonstrator at the Royal Garden. He and Peissonel were among the first who declared against the vegetable nature of the Corals. It is expressly stated in his Éloge ("Histoire de l'Académie Royale des Sciences,' Paris, 1777 ) that he founded his natural families on the Linnaean fragment. He died in 1777 . 
I 6 Development of the Natural System under [Boox I.

sufficiently marked to make it necessary to reproduce it here. It should be noticed however that Jussieu begins with the Cryptogams, passes through the Monocotyledons to the Dicotyledons, and ends with the Conifers. Adanson's claims of priority over Bernard de Jussieu (see the 'Histoire de la Botanique' de Michel Adanson, Paris, i 864, p. 36) may be passed over as unimportant. The natural system was not advanced by Adanson to any noticeable extent; how little he saw into its real nature and into the true method of research in this department of botany is sufficiently shown by the fact, that he framed no less than sixty-five different artificial systems founded on single marks, supposing that natural affinities would come out of themselves as an ultimate product,- -an effort all the more superfluous, because a consideration of the systems proposed since Cesalpino's time would have been enough to show the uselessness of such a proceeding.

The first great advance in the natural system is due to Antoine Laurent de Jussieu ${ }^{1}$ ( $1748-1836$ ). After all that has been said no further proof is needed that he was no more the discoverer or founder of the natural system than his uncle before him. His real merit consists in this, that he was the first who assigned characters to the smaller groups, which we should now call families, but which he called orders. It is not uninteresting to note here how Bauhin first provided the species with characters, and named the genera but did not characterise them, how Tournefort next defined the limits of the genera, how Linnaeus grouped the genera together, and simply named these groups without assigning to them characteristic marks, and how finally Antoine Laurent de Jussieu supplied characters

1 A. L. de Jussieu, born at Lyons, came to Paris to his uncle Bernard in 1 765. In 1790 he was a member of the Municipality, and till $179^{2}$ Superintendent of Hospitals. When the Annales du Museum were founded in 1802, he resumed his botanical pursuits. In 1826 his son Adrien took his place at the Museum. See his life by Brougniart in the 'Annales des Sciences Naturelles,' vii (1837). 
to the families which were now fairly recognised. Thus botanists learnt by degrees to abstract the common marks from like forms ; the groups thus constituted were being constantly enlarged, and an inductive process was thus completed which proceeded from the individual to the more general.

It might appear that the merit of Antoine de Jussieu is rated too low, when we praise him chiefly and simply for providing the families with characters; but this praise will not seem small to those who know the difficulty of such a task; very careful and long-continued researches were necessary to discover what marks are the common property of a natural group. Jussieu's numerous monographs show with what earnestness he addressed himself to the task; and it must be added, that he was not content simply to adopt the families established by Linnaeus and by his uncle and the limits which they had assigned to them, but that he corrected their boundaries and in so doing established many new families, and was the first who attempted to distribute these into larger groups, which he named classes. But in this he was not successful. His attempt to exhibit the whole vegetable kingdom in all its main divisions, to unite the classes themselves into higher groups, was also unsuccessful, for these larger divisions remained evidently artificial. The three largest groups on the contrary, into which he first divides the world of plants, the Acotyledons, Monocotyledons, and Dicotyledons are natural; but they had been already partly marked out by Ray, afterwards by Linnaeus, and finally in Bernard de Jussieu's enumerations. Still it is the younger Jussieu's great and abiding merit, to have first attempted to substitute a real division of the whole vegetable kingdom into larger and gradually subordinate groups for mere enumerations of smaller co-ordinated groups,- - an undertaking which Linnaeus expressly declared to be beyond his powers. If then Jussieu's system was far from giving a satisfactory insight into the affinities of the great divisions of the vegetable kingdom, yet it opened out 
I 8 Dovelopment of the Natural Sy'stem under [Bоoк I.

many important points of view, from which they could afterwards be discovered, and it certainly became the foundation for all further advance in the natural method of classification ; for this reason it is necessary to give a view of it in the following table:-

\section{A. L. de Jussieu's System of 1789.}

\section{Acotyledones}

Monocotyledones

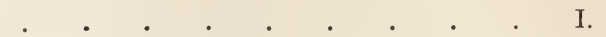

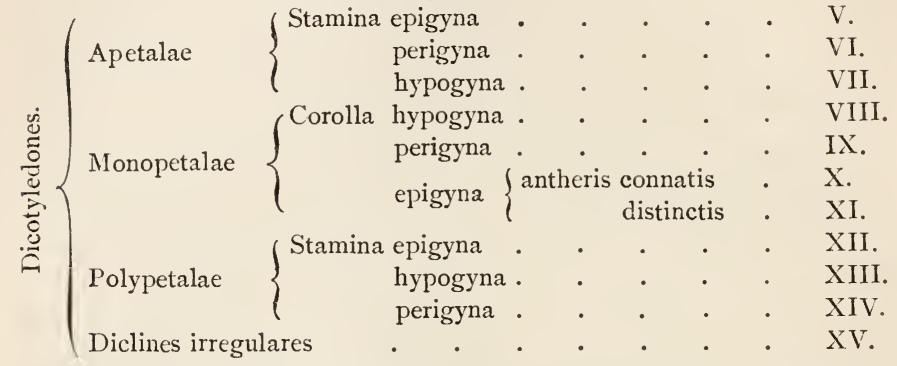

This table shows that Jussieu did not oppose the Cryptogams, which he calls Acotyledones, to the whole body of Phanerogams, as Ray did under the name of Imperfectae; he rather regards the Acotyledones as a class co-ordinate with the Monocotyledones and Dicotyledones; but this mistake or similar mistaken views run through all systematic botany up to 1840; the morphology founded by Nägeli and by Hofmeister's embryological investigations first showed that the Cryptogams separate into several divisions, which co-ordinate with the Monocotyledons and Dicotyledons. At the same time the use of the word Acotyledones for Linnaeus' Cryptogams shows that Jussieu overrated the systematic value of the cotyledons, because, as is seen from the introduction to his 'Genera Plantarum,' he was quite in the dark on the subject of the great difference between the spores of Cryptogamic plants and the seeds of Phanerogams. His conception of the organs of 
generation was essentially that of Linnaeus; hence he judged of the Cryptogams according to the scheme of the Phanerogams, and, not perceiving their peculiarities, he virtually characterised them by negative marks.

If we notice in the above table how the Phanerogams are separated into classes, it strikes us that the triple division into hypogynous, perigynous, and epigynous is repeated no less than four times; this shows that Jussieu had mistaken ideas of the value of these marks for classification, whereas the recurrence of them so often should of itself have suggested a doubt on this point. To judge of his system more exactly we must here give his series of the families, which he had already raised to the number of a hundred.

Class I.

I. Fungi.

2. Algae.

3. Hepaticae.

4. Musci.

5. Filices.

6. Naiades.

Class II.

7. Aroideae.

8. Typhae.

9. Cyperoideae.

ı. Gramineae.

Ir. Palmae.

I2. Asparagi.

13. Junci.

I4. Lilia.

I5. Bromeliae.

16. Asphodeli.

17. Narcissi.

I8. Irides.

Class IV.

19. Musae.

20. Cannae.

2 I. Orchides.

22. Hydrocharides.
Class V.

23. Aristolochiae.

Class VI.

24. Elaeagni.

25. Thymeleae.

26. Proteae.

27. Lauri.

28. Polygoneae.

29. Atriplices.

Class VII.

30. Amaranthi.

31. Plantagines.

32. Nyctagines.

33. Plumbagines.

Class VIII.

34. Lysimachiae.

35. Pediculares.

36. Acanthi.

37. Jasmineae.

38 . Vitices.

39. Labiatae.

40. Scrophulariae.

41. Solaneae.

42. Borragineae.

43. Convolvuli.
44. Polemonia.

45. Bignoniae.

46. Gentianeae.

47. Apocyneae.

4. Sapotae.

Class IX.

49. Guajacanae.

5c. Rhododendra.

51. Ericae.

52. Campanulaceae.

Class X.

53. Cichoraceae.

54. Cinarocephalae.

55. Corymbiferae.

Class XI.

56. Dipsaceae.

57. Rubiaceae.

58. Caprifolia.

Class XII.

59. Araliae.

6o. Umbelliferae.

Class XIII.

6I. Ranunculaceae.

62. Papaveraceae. 
I20 Development of the Natural System under [Book I.

63. Cruciferae.

64. Capparides.

65. Sapindi.

66. Acera.

67. Malpighiae.

68. Hyperica.

69. Guttiferae.

7o. Aurantia.

7I. Meliae.

72. Vites.

73. Gerania.

74. Malvaceae.

75. Magnoliae.

76. Anonae.
77. Menisperma.

78. Berberides.

7y. Tiliaceae.

8o. Cisti.

81. Rutaceae.

82. Caryophylleae.

$$
\text { Class XIV. }
$$

83. Sempervivae.

84. Saxifragae.

85. Cacti.

86. Portulaceae.

87. Ficoideae.

88. Onagrae.
89. Myrti.

90. Melastomae.

91. Salicariae.

92. Rosaceae.

93. Leguminosae.

94. Terebinthaceae.

95. Rhamni.

Class XV.

96. Euphorbiae.

97. Cucurbitaceae.

98. Urticae.

99. Amentaceae.

roo. Coniferae.

Jussieu's division of the Cryptogams and Monocotyledons offers much that is satisfactory, if we put the position of the Naiades out of sight. The grouping of the Dicotyledons on the contrary is to a great extent unsuccessful, chiefly owing to the too great importance which he attached to the insertion of the parts of the flowers, that is, to the hypogynous, perigynous, and epigynous arrangement. It is in this grouping of families into classes that the weak side of the system lies; it is utterly artificial, and the task of his successors has been to arrange the families of the Phanerogams, which were most of them wellestablished, and especially those of the Dicotyledons, in larger natural groups. But this could not be effected, till morphology opened new points of view for systematic botany; Jussieu, as has been already remarked, accepted Linnaeus' views of the morphology of the organs of fructification in Phanerogams, though he introduced many improvements in details. He laid greater stress on the number and relative positions of the different parts of the flower; attention to their insertion on the flowering axis, which he designated as hypogynous, perigynous, and epigynous, would have been a great step in advance, if he had not overrated its systematic value. The morphology of the fruit is very superficial in Jussieu ; even the designation of dry indehiscent fruits as naked seeds recurs in his definitions, 
though as it happens this misconception does not cause any great disturbance. How inexact was his investigation of the organs of fructification, when they were somewhat small and obscure, is best shown by the fact that the Naiades, which are made to include Hippuris, Chara, and Callitriche, appear among the Acotyledons, and that Lemna and the Cycads are placed with the Ferns.

Jussieu explained the dictum, 'Natura non facit saltus,' to mean that the whole body of plants in its natural arrangement must exhibit a lineal series ascending from the most imperfect to the highest forms ; but he does not say whether Linnaeus' comparison of the natural system to a geographical map, the countries in which answer to orders and classes, is also admissible.

His theoretical observations on the value to be given to certain marks in a systematic point of view are not attractive, and for the most part not very correct; he speaks as though some marks must have a more extensive, others a less extensive value ; the perception of the fact, so far as it is true, rests entirely upon induction; that is, after the natural affinities have been already recognised to a certain extent, it becomes apparent that certain marks remain constant in larger or smaller groups; the systematist can now go on to try whether such constant marks occur in other plants also, which he had hitherto assigned to other groups, and thus put it to the test whether those marks may not be accompanied by others, which would serve to establish the affinities; that Jussieu did so proceed in defining his families admits of no doubt, but he was not himself thoroughly conscious of the fact; at all events, he did not extend this mode of proceeding, the seeking after leading marks, to the establishing of larger groups or classes, for these he founded on predetermined principles.

Jussieu's labours as a systematist were not confined to the publication of his 'Genera Plantarum'; on the contrary, his most fruitful researches began after 1802 , and were continued 
122 Development of the Natural System under [Book I.

to the year 1820 , and their results appeared in a long series of monographs on different families in the Mémoires du Museum. He felt with De Candolle, Robert Brown, and later systematists, that the perfecting of the natural system depended mainly on the careful establishing and defining of families. His efforts received a new impulse from the work of a German writer, whose first volume had appeared in $\mathrm{r} 788$, a year therefore before the 'Genera Plantarum,' a second following it in I 79r, and a supplementary volume in 1805 .

This work was JosePH GÄrTnER's 'De fructibus et seminibus plantarum,' in which the fruits and seeds of more than a thousand species are described and carefully figured. But almost more important than these numerous descriptions, though they offered rich material to the professed systematists, were the introductions to the first two volumes, and especially to those of $\mathrm{I} 788$. They contain valuable reflections on sexuality in plants, - a subject which had remained in the condition in which it was left by Camerarius (1694) till it was greatly developed by Koelreuter after $176 \mathrm{r}$, and had since then been little studied,- - and an account of the morphology of fruits and seeds, the knowledge of which had gone back rather than advanced since the days of Malpighi and Grew. Gärtner was well qualified for this work by his unparalleled knowledge of the forms of fruits, and still more by the character of his mind. Free from

${ }^{1}$ Joseph Gärtner was born at Calw in Würtemberg in $\mathrm{I} 73^{2}$, and died in I 79I. He commenced his studies in Göttingen in $\mathrm{I} 75 \mathrm{I}$, where he was a pupil of Haller. He travelled into Italy, France, Holland, and England in order to make the acquaintance of famous naturalists, and worked also at physics and zoology. In 1760 he was Professor of Anatomy in Tübingen, and in $\mathrm{I} 768$ became Professor of Botany at St. Petersburg; but finding himself unable to bear the climate, he returned to Calw in 1770 , and gave himself up entirely to his book, 'De fructibus et seminibus plantarum,' which he had already commenced. Banks and Thunberg, one of whom had returned from a voyage round the world, the other from Japan, handed over to him the collections of fruits which they had made. His persistent study, partly with the microscope, brought him near to blindness. There is an interesting life of Gärtner by Chaumeton in the 'Biographie Universelle.' 
Linnaeus' scholastic bias, he addressed himself to the examination of the most difficult organs of plants with as great freedom from prepossessions as exact acquaintance with the writings of others; he gives us the impression of a modern man of science more than any other botanist of the I Sth century, with the exception of Koelreuter. He knew how to communicate with clearness of language and perspicuity of arrangement whatever he gathered of general importance from each investigation. Though it is easy to see that the founding of the natural system was ever before his mind as the final object of his protracted labours, he was in no eager haste to reach it; he contented himself with arranging his fruits, saying expressly that the natural system would never be founded by these means alone, though the exact knowledge of fruits and seeds supplied the most important means for decision. Thus his great work was at once an inexhaustible mine of single well-ascertained facts, and a guide to the morphology of the organs of fructification and to its application to systematic botany. The imperfections, which are to be found even in this work, are due to the circumstances of the time; in spite of Schmiedel's and Hedwig's researches into the Mosses there was still the old obscurity with regard to the organs of propagation in the Cryptogams, and this rendered a right definition of the ideas, seed and fruit, extremely difficult. But Gärtner made one great step in advance on this very point when he showed that the spores of the Cryptogams were essentially different from the seeds of Phanerogams, with which they had been hitherto compared, because they contain no embryo; he called them therefore not seeds, but gemmae. The second great hindrance to a true conception of certain characters in fruits and seeds on the part of Gärtner was the entire ignorance of the history of development which then reigned; yet even here we see an advance, if only a small one, made by him in his repeatedly going back to the young state for a more correct idea of the organs. 
124 Development of the Natural System under [Bоoк I.

Above all, Gärtner put an end to the blunder of regarding dry indehiscent fruits as naked seeds, by rightly defining the pericarp as in all cases the ripened wall of the ovary, and by considering its strong or weak construction, its dry or pulpy condition, as a secondary matter. It is obvious that the whole theory of the flower was thus placed upon a better basis, since dry indehiscent fruits may come from inferior or superior ovaries. But Gärtner's theory of the seed is one of his most valuable contributions to the science. After careful consideration of the seed-envelopes, he submitted the inner portion (nucleus) enclosed by them to a searching comparative examination; he correctly distinguished the endosperm from the cotyledons, and described the variations in its form and position. This was the more needful, since Linnaeus had denied the existence of an 'albumen' in plants, which Grew had already recognised and so named; to Linnaeus it appeared to be of no use to the seed. Though Gärtner speaks of the cotyledons as uniting with the embryo to form the nucleus of the seed, yet his account shows that he regarded them as outgrowths of the embryo itself. The uncertainty which still existed in the interpretation of the parts of the seed is shown even in Gärtner by his curious notion of a 'vitellus,' which in fact takes in everything that he was unable to explain aright inside the seed; for instance, he makes the scutellum in grasses, and even the cotyledonary bodies of Zamia a vitellus, and applies the same name to the whole contents of the spores of Seaweeds, Mosses, and Ferns. In spite of the striking defects connected with this mistaken notion in his theory of the seed, his views far surpass in clearness and consistency all that had hitherto been taught on the subject. His giving the term embryo to that part of the seed which is capable of development was also an advance in respect of logic and morphology, in spite of his mistake in not admitting the cotyledons which are attached to the embryo into the conception; this, however, could easily be corrected at a later time. What Gärtner now named the 
embryo, had been up to his time called the 'corculum seminis,' especially by Linnaeus and Jussieu; it was evidently thought that Cesalpino's phraseology was thus retained; but he, as we have seen, understood by the words 'cor seminis' the spot where the cotyledons spring from the germ, which spot he wrongly took for the meeting-point of root and stem and the seat of the soul of the plant. And so at last after two hundred years the word disappeared from use, which might have reminded the botanist of Cesalpino's views respecting the soul of plants.

A work such as Gärtner's could scarcely find a fruitful soil in Germany, where some thirty years before even Koelreuter's brilliant investigations had met with little sympathy, and Conrad Sprengel's remarkable enquiries into the relations of the structure of the flower to the insect-world in I 793 failed to be understood; Gärtner complains in the second part, published in I 79I, that not two hundred copies of the first volume were sold in three years. But the work, which forms an epoch in the history of botany, was better received in France, where the Academy placed it as second in the list of the productions which in later times had been most profitable to science; there lived the man who was able to measure the whole value of such a work-Antoine Laurent de Jussieu. But even in Germany, where plant-describing was comfortably flourishing, there were not altogether wanting men who knew how to estimate both the services of Gärtner and the importance of the natural system. First among these was August Johann Georg Karl Batsch, Professor in Jena from $\mathrm{I} 76 \mathrm{I}$ to $\mathrm{I} 802$, who published in the latter year a 'Tabula affinitatum regni vegetabilis,' with characters of the groups and families. Kurt Sprengel, who was born in I 766, and died as Professor of Botany in Halle in I833, contributed still more to the spread of clearer views respecting the real character of the natural system and the task of scientific botany generally by numerous works, and especially by his 'Geschichte der Botanik,' which appeared in 18 I 7 and 18 I8. But even this highly gifted and accomplished man agreed with 
the Linnaean botanists in attributing an excessive value to the describing of plants, as is shown in his history, where to exalt the merits of the old botanists he gives figures of the plants first described by them.

Meanwhile the meritorious efforts of these men were not in themselves capable of directly advancing the natural system, or of greatly increasing the number of its adherents in Germany, nor did it find general acceptance in that country till it had made considerable progress in the hands of the two foremost botanists of the time, De Candolle and Robert Brown.

Augustin Pyrame de Candolle ${ }^{1}$ (I 778-i 84I) belongs to the number of those distinguished investigators of nature, who at the end of the last and the beginning of our own century made their native city Geneva a brilliant centre of natural science. De Candolle was the contemporary and fellow-countryman of Vaucher, Theodore de Saussure, and Senebier. Physics and physiology especially were being successfully cultivated at that

${ }^{1}$ Augustin Pyrame de Candolle sprang from a Provençal family, which had fled from religious persecution to Geneva, where it was and is still held in great estimation. He associated as a boy with Vaucher, and on his first visit to Paris in $\mathbf{I} 796$ with Desfontaines and Dolomieu, and after his return to Geneva was a friend of Senebier. The elder Saussure, and afterwards Biot, whom he assisted in an investigation in physics, endeavoured to attach him to that study. He spent the years from 1798 to 1808 in Paris, where he lived in close intercourse with the naturalists of that city. Numerous smaller monographs, and the publication of his work on succulent plants and of a new edition of De Lamarck's ' Flore Française,' occupied this earlier period of his life. From I 808 to 18 I 6 he was Professor of Botany at Montpellier. During this time he made many botanical journeys in all parts of France and the neighbouring countries, and wrote many monographs, his essays on the geography of plants, and his most important work, the 'Théorie élémentaire.' From I8I6 till his death in I84I he resided once more in Geneva, which had freed itself in $\mathbf{I} 8 \mathbf{I} 3$ from the enforced connection with France established in $179^{8}$. Here De Candolle found time to take part in political and social questions, in addition to an almost incredible amount of botanical labour. (Notice sur la vie et les ouvrages de A. P. De Candolle par De la Rive, Genève, I845.) 
time in Geneva, and Pyrame de Candolle was attracted to these studies; among his youthful efforts are some important investigations into the effect of light on vegetation, and the contributions which he made to vegetable physiology in his great work on that subject will be noticed in a later portion of this history. De Candolle turned his attention to all parts of theoretical and applied botany, but his importance for the history of the science lies chiefly in the direction of morphology and systematic botany, and it is this which we will now proceed to describe.

The amount and compass of De Candolle's labours as a systematic and descriptive botanist exceed those of any writer before or after him. He wrote a series of comprehensive monographs of large families of plants, and published a new edition of De Lamarck's large 'Flore Française' substantially altered and enlarged; and in addition to these and many similar works and treatises on the geographical distribution of plants, he set on foot the grandest work of descriptive botany that is as yet in existence, the 'Prodromus Systematis Naturalis,' in which all known plants were to be arranged according to his natural system and described at length,a work not yet fully completed, and in which many other descriptive botanists of the last century participated, but none to so large an extent as De Candolle, who alone completed more than a hundred families. It is not possible to give an account in few words of the service rendered to botany by such labours as these; they form the real empirical basis of general botany, and the better and more carefully this is laid, the greater the security obtained for the foundations of the whole science.

But a still higher merit perhaps can be claimed for De Candolle, inasmuch as he not only like Jussieu elaborated the system and its fundamental principles in his descriptive works, but developed the theory, the laws of natural classification, with a clearness and depth such as no one before him had 


\section{I28 Development of the Natural System under [Boor I.}

displayed. To this purpose he applied morphological researches, which in profundity and wealth of thought and in the fruitfulness of their results for the whole domain of systematic botany far surpassed all that Linnaeus and Jussieu had accomplished, and show us that while engaged in his splendid labours in descriptive botany he had caught during his ten years' residence in Paris the true spirit of modern investigation of nature, as it had been developed by the French naturalists of the end of the previous century. Scarcely a trace is to be found in De Candolle of the scholasticism of Cesalpino and Linnaeus, which occasionally makes its appearance even in Jussieu. For instance, he dealt with morphology as essentially the doctrine of the symmetry of form in plants, that is, he found the basis of morphological examination in the relative position and numbers of the organs, disregarding their physico-physiological properties as of no account from the morphological point of view. He was therefore the first who recognised the remarkable discordance between the morphological characters of organs, which are of value for systematic purposes, and their physiological adaptations to the conditions of life, though it must at the same time be acknowledged, that he did not consistently carry out this principle, but committed grave offences against it in laying down his own system. It is a point of the highest interest in De Candolle's morphological speculations, that he was the first who endeavoured to refer certain relations of number and form to definite causes, and thus to distinguish what is primary and important in the symmetry of plants from merely secondary variations, as is seen in his doctrine of the abortion and adherence of organs. In these distinctions De Candolle laid the foundation of morphological views, which, though now modified to some extent, do still contain the chief elements of morphology and the natural system; but his morphological speculations were confined to the domain of the Phanerogams, and chiefly advanced the theory 
of the flower; a morphology of the Cryptogams was as little to be thought of in the condition of microscopy before 1820 , as the application of the history of development to the establishment of morphological theories.

De Candolle published his morphology or doctrine of symmetry and his theory of classification together in a book which appeared first in I 8 I 3 , with the title, 'Théorie Élémentaire de la botanique ou exposition des principes de la classification naturelle et de l'art de décrire et d'étudier les végétaux,' and again in $\mathbf{1} 8 \mathrm{rg}$ in an improved and enlarged edition. The second edition will be the one referred to in the further account of his views. The second chapter of the second book concerns us most at present. After alluding to the fact, that anatomy and physiology are concerned with the structure of the individual organ only so far as the power to fulfil its proper function depends on the structure, he points out that the physiological point of view is no longer sufficient when we are engaged in comparing the organs of different plants. Though it is true that the function of the organs is the most important for the life and permanence of the individual, yet we find these functions modified in the case of homologous organs in different plants; for the natural classification we must take into consideration only the entire system of organisation, that is, the symmetry of the organs. All organisms of a kingdom, he continues, have the same functions with slight modifications; the immense amount of variation in systematically different species depends therefore only on the way in which the general symmetry of structure varies. This symmetry of the parts, the discovery of which is the great object in the investigation of nature, is nothing more than the sum total (l'ensemble) of the positional relations of the parts. Whenever these relations (disposition) are regulated according to the same plan, the organisms exhibit a certain general resemblance to one another, independently of the form of the organs in detail; when this general resemblance 
I30 Development of the Natural System under. [Book I.

is perceived, without any attempt to give any account of it in the detail, we have what has been called habitual relationship; but it is the task of the doctrine of symmetry to resolve this likeness of habit into its elements, and to explain its causes. Without this study of symmetry it may easily happen that two different kinds of symmetry may be supposed to be alike, because they seem outwardly alike to our senses, just as forms of crystals of different systems may be confounded together for want of careful examination; the chief thing is to know the plan of symmetry in every class of plants, and the study of this is the foundation of every theory of natural affinities. But success in this study depends on the certainty with which organs are distinguished, and the distinguishing them must be independent of changes of form, size, and function. He then shows that the difficulties in the morphological comparison of organs, or, as we should now say, in the establishing the homology, are due to three causes; abortion, degeneration, and adherence (adhérence). These three causes, by which the original symmetry of a class is changed and may even be utterly obscured, are then fully illustrated by examples.

In respect to abortion he distinguishes that which is produced by internal causes from that which is due to accidental and external ones; he refers especially to the abortion of two loculaments in the fruit of the horse-chestnut and the oak, to the suppression of the terminal bud in some shrubs by the adjoining axillary buds, and to the fact that all organs of plants may become abortive in a similar manner ; for instance, the sexual organs disappear entirely in the disk-flowers of Viburnum Opulus, and one of the two sexes in the flower of Lychnis dioica. He goes on to answer the question, how it is possible to discover the symmetry in such cases; one method he finds supplied by monstrosities, among which there are even some that may be regarded as a return to the original symmetry, the cases known as peloria. Analogy 
or 'induction' is, he says, less certain, but of much more extensive application; this is founded exclusively on the knowledge of the relative position of organs. Armed with this, we find that the flower of Albuca, which corresponds to a flower of Liliaceae in everything except in having only three stamens, is to be considered one of the Liliaceae, because it has three filaments placed between the three stamens exactly in the position of the three other stamens in the Liliaceae ; it must be concluded therefore that they are abortive stamens. Similar conclusions from analogy must be carried from species to species, from organ to organ, and the great systematists have in fact done so. In certain cases abortion is produced by defect, in others by excess of nourishment, of which he gives examples. An important sentence occurs in this place; everything in nature, he says, leads us to believe that all organisms in their inner nature are regular, and that different forms of abortion differently combined are the cause of all irregularity; from this point of view the smallest irregularities are important, because they lead us to expect greater ones in nearly allied plants; and wherever in a given system of organisation there are inequalities between organs of the same name, the inequality will possibly reach a maximum, that is, end by annihilating the smallest part. Thus in the Labiatae with two stamens, it is the two which in other cases also are the smaller, which are here completely aborted. When in Crassulaceae there are twice as many stamens as petals, those that alternate with the petals are larger and earlier developed, and we may therefore expect that those which are opposite the petals may become abortive; and therefore we may place a genus like Sedum, in which the latter are sometimes wanting, with Crassulaceae; but we could not do so, if we found only the stamens that are superposed upon the petals. It occurs sometimes, he continues, that an organ is prevented from fulfilling its function by partial abortion. In this case it may assume another function, as 


\section{Development of the Natural System under [Bоoк I.}

the abortive leaves of the vetch and the abortive inflorescences of the vine are employed as tendrils. In other cases the abortive organ appears to be quite useless, as for instance many rudimentary leaves. All such useless organs, says De Candolle, exist only in consequence of the primitive symmetry of all organs. Finally the abortion may be so complete that no trace of the organ remains, of which case there are however two kinds, one where the organ is at first perceptible and afterwards quite disappears, as in the abortive loculaments in the fruit of the oak; in other instances no trace is to be seen from the first of the abortive organs, as happens with the fifth stamen of Antirrhinum.

All that has here been said might be alleged word for word in proof of the theory of descent, but our author is an adherent of the dogma of the constancy of species ; what from his point of view he really means by abortion is difficult to say, for the object which is aborted is wanting. If species are constant, and therefore of absolutely distinct origin, we must not speak of abortion; we can only say that an organ which is present or large in one species is small or wanting in another. In introducing the idea of abortion De Candolle at once goes beyond the dogma of the constancy of species, without being clear in his own mind with regard to this important step. His proceeding shows that facts lead even a defender of constancy against his will to theories which run counter to that dogma. This is confirmed by his perception of the correlation of growth, which is connected with abortion; he points to the fact that owing to the disappearance of sexual organs in the disk-flowers of Viburnum Opulus the corollas become larger, as do the bracts of the abortive flowers of Salvia Horminum; similarly he regards the disappearance of the seeds in Ananas, Banana, and the Bread-fruit tree as the cause of the enlargement of the pericarps ; it does not escape him, that the fertile flowerstalks in Rhus Cotinus remain naked, while an elegant pubescence forms on the barren ones; the leaf-like expansion 
of the leaf-stalks of Acacia heterophylla, which do not develop their laminae, he refers also to this correlation of growth. He finds the most remarkable example of the kind in the doubling of flowers, where according to his view the disappearance of the anthers is a condition of the corolline expansion of the filaments; in the same way sometimes the carpel is changed into a petal through the disappearance of the stigma. Though in many of these cases it is quite possible to conceive of the relations of cause and effect in the reverse way, yet De Candolle's principle of correlation will be equally applicable.

The second cause by which the symmetry may be obliterated, namely degeneration, asserts itself in the formation of thorns, of threadlike prolongations of membranous expansions, and in the production of fleshy parts, or of parts with dry membranes.

The third kind of departure from the symmetrical plan is the adherence of parts, the theory of which he grounds first and chiefly on the phenomena of grafting, and then passes to more difficult cases. The close packing of the ovaries in some species of honeysuckle, is, he says, the primary cause of their adherence. This therefore does not depend on the plan of symmetry, but upon an accident, which however is constant in its appearance, owing to the specific constitution of such plants. In connection with the phenomena of adherence he next considers the question whether a structure composed of several parts, as for instance a compound ovary, should be considered as originally simple and afterwards divided into parts, or whether the converse is the true account, and he says that we must examine each particular case and decide which is the correct conception. Thus it may be shown that the perfoliate leaves of honeysuckles, as well as the involucres of many Umbelliferae, and monosepalous calyces and monopetalous corollas are due to adherence, and he proceeds to prove that ovaries with several loculaments and several parts 


\section{Development of the Natural System under [Boor I.}

have in like manner been formed by adherence of two or more carpellary leaves, and concludes by pointing out the systematic importance of such considerations. Further on he takes occasion to speak of the significance of the relative number of the parts of the flower, on which head he says much that is good, but does not thoroughly investigate the matter; it was not till a later time that Schimper's doctrine of phyllotaxis made it possible to express these relations of number and position more precisely.

He concludes his rules for the application of his morphology to the determination of relations of affinity with the declaration, that the whole art of natural classification consists in discerning the plan of symmetry, and in making abstraction of all the deviations from it which he has described,-much in the same way as the mineralogist seeks to discover the fundamental forms of crystals from the many derivative forms. It is obvious that all this teaching was a great step in advance upon the right path, that De Candolle has here given utterance for the first time to an important principle of morphology and systematic botany; nevertheless he did not succeed in always consistently carrying out his own principle; he was true to himself only in the determination of small groups of relationship; in framing the largest divisions of the vegetable kingdom he entirely lost sight of the rule which he had himself laid down, that the morphological character of organs and the extent to which it can be turned to account for systematic purposes is entirely independent of their physiological character, and that the most important physiological characters are just those which are of quite subordinate importance in the determination of affinities. In spite of this strange inconsistency, to De Candolle belongs the merit of being the first to point emphatically to the distinction between morphological and physiological marks, and to bring clearly to light the discordance between morphological affinity and physiological habit; but in this discordance lurks a problem, which could 
only be solved forty years later by Darwin's theory of selection. A genuine inductive process alone could reveal these remarkable relations between the morphological and physiological characters of organs. But it is at the same time true that De Candolle could not have made this discovery, if his predecessors had not already established a large number of affinities. It was while he was engaged in an exact comparison of forms already recognised as undoubtedly related to one another, that that which he called the plan of symmetry, and which was afterwards named a type, revealed itself to him; and as he examined it more closely, and compared it with peculiarities of habit in different plants formed on the same plan, he discovered certain causes, by means of which the deviations were to be explained; these were abortion, degeneration, and adherence. By attending to these he succeeded in discovering affinities that had been hitherto doubtful or unknown; this was at all events the true inductive way of advancing the system, and whatever the earlier systematists had effected that was really valuable had been effected virtually in the same way, only they never arrived at a clear understanding of their own mode of proceeding; they had followed unconsciously the method which De Candolle clearly understood and consciously pursued.

The majority of De Candolle's successors were far from fully appreciating the entire significance of his theory, its importance as a matter of method and principle; on the contrary in the search for affinities they continued to surrender themselves to a blind feeling rather than to a clearly recognised method, and the same must be said unhappily of De Candolle himself, when he was dealing with the establishment of the large divisions of the vegetable kingdom. With equal surprise we find him in the book before us, in which he has developed the true method in systematic botany, expressing the opinion that the most important physiological characters must be employed for the primary divisions of the system, and this 
I36 Development of the Natural System under [Воок I.

idea is not improved by the fact that he ascribes to the organs physiological characters which they do not really possess; thus he regards the vessels as the most important organs of nutrition, which they are not in fact, and upon this double error he builds his primary division of the whole vegetable kingdom into vascular and cellular plants, and then by a third mistake believes that this division coincides with the division of plants into those which have and those which have not cotyledons. The already established division into Monocotyledons and Dicotyledons, which rests upon a leading and purely morphological mark, is spoilt by De Candolle through his following Desfontaines in ascribing to the Dicotyledons a different mode of growth in thickness from that of the Monocotyledons, and characterising the one as exogenous, the other as endogenous. But this notion is utterly incorrect, as von Mohl showed twelve years later; and if it were correct, it would still be unimportant in a systematic point of view, because it appeals to a mark which is morphologically of quite subordinate importance. The worst consequence of these mistakes was, that the Vascular Cryptogams were introduced into the same class with the Monocotyledons, - a decided step backwards, if we compare De Candolle's system with that of Jussieu. In spite of these grave defects in the primary divisions of the whole vegetable kingdom De Candolle's system deserved the fame which it acquired and long maintained; it had this advantage over Jussieu's system that in the class of Dicotyledons, the largest division of the whole kingdom, larger sub-divisions appeared, and these served to unite families that were in many points essentially related; the Dicotyledons were in fact divided first of all into two artificial groups according to the presence of two floral envelopes or one; the first and much the larger of these was again broken up into a series of subordinate groups, which pointed in many ways to natural affinities. That these groups, which have only quite recently been materially altered, did to a very considerable extent take 
account of natural affinities, is due to the fact that De Candolle in framing them really followed his own rules, whereas the superior divisions, which are artificial, owe their existence to his disregard of them.

De Candolle declared emphatically against the old notion, that the vegetable system answers to a linear series, - a notion which sprang from a misunderstanding of the saying, 'Natura non facit saltus,'-and demonstrated its impossibility by examples; but he allowed himself to be too much influenced by the idea which had been thrown out by Linnaeus, and taken up by Giseke, Batsch, Bernardin de St. Pierre, L'Heritier, Du Petit-Thouars and others, that the vegetable kingdom might be compared as respects its grouping to a geographical map, in which the quarters of the globe answer to the classes, the kingdoms to the families, and so on. If the theory of descent is to a certain degree compatible with the idea of a linear sequence from the most imperfect to the highest forms of plants, it is quite incompatible with the above comparison; and systematic investigation, led astray from the right path, is in danger of ascribing the importance of real affinities to mere resemblances of habit, incidental analogies, by which a group of plants appears to be connected with five or six others. In exhibiting his system on paper De Candolle allowed the use of the linear sequence as a convenience, for here it was not, he said, a matter of any importance, since the true task of the science is to study the relations of symmetry in each family and the mutual relations of families to one another; yet in a linear presentation of the system for didactic purposes the sequence ought not to begin with the most simple plants, for these are the least known, but with the most highly developed. Thus De Candolle was the means of removing from the system the last trace of anything which harmonised with an ascending and uninterrupted development of forms. Resting on the doctrine of the constancy of species, and assuming that every group of relationship is founded on a plan of symmetry 
round which individual forms are grouped as crystals round their parent form, De Candolle was quite consistent in his views. The mode of representation came to prevail in the vegetable kingdom which De Candolle's contemporary, Cuvier, an equally sturdy defender of the dogma of constancy, had introduced in the animal kingdom as the type-theory. Thus the most splendid results obtained by induction were united in the case of De Candolle with the barren dogma of the constancy of species, which, as Lange wittily remarks, comes direct from Noah's ark, to form an intimate mixture of truth and error; nor did De Candolle's many adherents succeed in unravelling the coil, though they removed the chief errors from his system and introduced many improvements.

To these remarks may be appended a table of the main divisions of De Candolle's system of I8I9, which so far as it is presented in linear arrangement he calls expressly an artificial system.

I. Vascular plants or plants with cotyledons.

I. Exogens or Dicotyledons.

A. With calyx and corolla :

Thalamiflorals (polypetalous hypogynous),

Calyciflorals (polypetalous perigynous),

Corolliflorals (gamopetalous).

B. Monochlamydeous plants (with a single floral envelope).

2. Endogens or Monocotyledons.

A. Phanerogams (true Monocotyledons),

B. Cryptogams (vascular Cryptogams including Naiadeae).

II. Cellular plants or Acotyledons.

A. With leaves (Muscineae),

B. Without leaves (Thallophytes).

The number of families, with Linnaeus 67 , with A. L. de Jussieu Io0, was increased by De Candolle to I6r. 
If the principles of comparative morphology laid down by De Candolle were at first prevented from being rapidly disseminated in Germany by the philosophical tendencies then reigning among its botanists, and especially by the obscurities of Goethe's doctrine of metamorphosis, yet these principles and his views also on the natural system won their way by degrees to acknowledgment and acceptance; and after the year i 830 the study of the system was prosecuted by the botanists of Germany, as well as by those of England and France, as the proper object of the science. We may even say that the impulse given by De Candolle worked more powerfully from that time forward in Germany than in France. It may be said too of De Candolle's contemporary, the Englishman RoBERT Brown ${ }^{1}$ (I773-I858), whose chief labours fall in the period between $\mathrm{I} 820$ and I 840 , that he, like De Candolle, was better

1 Robert Brown was the son of a Protestant minister of Montrose, and studied medicine first at Aberdeen and afterwards in Edinburgh; he then became a surgeon in the army, and was at first stationed in the north of Ireland. When the Admiralty despatched a scientific expedition to Australia under Captain Flinders in ISOI, he was appointed naturalist to the expedition on the recommendation of Sir Joseph Banks, F. Bauer being associated with him as botanical draughtsman, Good as gardener, Westall as landscape-painter; one of the midshipmen of the vessel was John Franklin. In consequence of the unseaworthiness of the ship Flinders left Australia, intending to return with a better one, but was shipwrecked on the voyage and detained by the French at Port Louis as a prisoner of war till 1810. The naturalists of the expedition remained in Australia till 1805 , when Brown returned to England with 4000 for the most part new species of plants. Sir J. Banks appointed him his librarian and keeper of his collections in 1810 ; he was also Librarian to the Linnaean Society of London. In 1823 he received the bequest of Banks' library and collections, which were to be transferred after his death to the British Museum; but by his own wish they were deposited there at once, and he himself received the appointment of Custodian of the Museum and remained in that position till his death. At Humboldt's suggestion Sir Robert Peel's Ministry granted him a yearly pension of $£ 200$. His merits were universally acknowledged, and Humboldt even named him 'botanicorum facile princeps.' 
appreciated during that time in Germany than in any other country. Robert Brown, who spent the five years from I 80 I to 1805 in Australia, studied the flora of that quarter of the world, and discussed in numerous essays the botanical results of various journeys made by other naturalists in polar regions and in the tropics. In this way he found opportunity to leaven the ideas, which through Humboldt's influence had become predominant respecting the geography of plants, with the spirit of the natural system; he also made the morphology and systematic position of a number of families the subject of critical investigation.

Robert Brown's literary efforts were limited to these monographs; he nowhere attempted to give a connected account of the principles which he follows in them, an exposition of his morphology or a theory of classification, nor did he frame a new system. The results of his studies which were really fruitful and served to advance the science are to be found in the more general remarks, which he managed to insert quite incidentally in his monographs. In this way he succeeded in clearing up the morphology of the flower and with it the systematic position of some difficult families of plants, such as the Grasses, Orchids, Asclepiads, the newly-discovered Rafflesiaceae and others, and to throw new light at the same time on wider portions of the system; in his considerations on the structure and affinities of the most remarkable plants, which had been collected in Africa by different travellers in the years immediately following I 820 , he discussed difficult and remarkable morphological relations in the structure of the flower. He referred especially in this essay (I826) to the relations between the numbers of the stamens and carpels, and those of the floral envelopes in the Monocotyledons and Dicotyledons, and showed how these typical, or as he calls them in De Candolle's phraseology, symmetrical relations were changed by abortion, while he entered at the same time into a more exact determination of the position of the aborted and of the perfect organs, in order to discover new relations of affinity. 
His most valuable work in this direction is a paper on a genus Kingia, discovered in New Holland in 1825 ; the structure of the seeds in this genus led him to seek more accurate knowledge of the unfertilised ovule in the Phanerogams generally, and especially in the Cycads and Conifers. In spite of the labours of Gärtner and the later researches of Treviranus, there was still considerable obscurity attaching to the theory of the seed, for no one had yet succeeded in referring the position of the embryo in the ripe seed to a general law. For this it was necessary to submit the ovule before fertilisation to careful examination, and Robert Brown carried out this first step to a history of development with great success; he was the first to distinguish the integuments and the nucleus in the ovule, and the embryo-sac in the nucleus, parts which Malpighi and Grew had indeed observed but had not brought out with perfect clearness. The micropyle and the hilum of the seed had not yet been properly distinguished, but had been to some extent even confounded with one another. Robert Brown showed that the hilum answers to the point of attachment of the ovule, while the micropyle is a canal formed by the integuments of the ovule and leading to the summit of the nucleus; that in anatropous ovules the micropyle lies beside the hilum, in orthotropous ovules opposite to it; that the embryo in the embryo-sac (amnion) is always formed at the spot which lies nearest the micropyle, and that the radicle of the embryo is always turned towards the micropyle,- - facts which at once established the general rule by which to determine the position of the embryo in the seed and in the fruit. $\mathrm{He}$ also gave the first correct explanation of the endosperm as a nourishing substance formed inside the embryo-sac after fertilisation, and more than this, he was the first to distinguish the perisperm as a substance formed outside the embryo-sac in the tissue of the nucleus.

In this way Robert Brown established morphological relations in the organisation of the seed of the Monocotyledons and Dicotyledons, which count among the most important 
142 Development of the Natural System under [Воок I.

principles of classification in these classes; he was still more happy in being the first to detect the peculiar structure of the flower of Conifers and Cycads, as compared with that of other flowering plants ; it was he who perceived that what had been hitherto called a female flower in these plants was really a naked ovule, a view which Trew of Nüremberg had, it is true, suggested in the year 1767 . He also called attention to the agreement in structure of the male and female organs in these families. Thus one of the most remarkable facts in vegetation, the gymnospermy of the Conifers and Cycads, was for the first time established, and this led afterwards through Hofmeister's investigations to the important result, that the Gymnosperms, which had been up to that time classed with Dicotyledons, are to be regarded as co-ordinate with Dicotyledons and Monocotyledons, forming a third class through which remarkable homologies were brought to light in the propagation of the higher Cryptogams and the formation of seeds in Phanerogams. No more important discovery was ever made in the domain of comparative morphology and systematic botany. The first steps towards this result, which was clearly brought out by Hofmeister twenty-five years later, were secured by Robert Brown's researches, and he was incidentally led to these researches by some difficulties in the construction of the seed of an Australian genus. He discussed in a similar manner, if not always with such important results, a great variety of questions in morphology and systematic botany ; even purely physiological problems were raised by him in this peculiar way, and especially the question how the fertilising matter of the pollengrains is conveyed to the ovule; he had already concluded from the position of the embryo that it is conveyed through the micropyle and not through the raphe and the hilum, as was then supposed, and he was the first also to follow the passage of the pollen-tubes in the ovary of Orchids up to the ovules; but this is a point which will be more properly considered in the history of the sexual theory. 
The peculiar character of the natural system as compared with every artificial arrangement is brought out into higher relief by Robert Brown than by Jussieu and De Candolle, and he succeeded better than any of his predecessors in separating purely morphological and systematically valuable relations of organisation from the physiological adaptations of organs. While the majority of systematists surrendered themselves to the guidance of a blind feeling in the discovery of affinities, their correct determinations being the accidental result of instinct and unconscious operations of the understanding, Brown endeavoured to give an account to himself in every case of the reasons why he took this or that view of the relationships which he determined; from what was already established and indubitable he gathered the value of certain marks, in order to obtain rules for the determination of unknown relationships. In this way he discovered also, that marks, which are of great value for classification within the limits of certain groups of affinity, may possibly prove to be valueless in other divisions. Thus Robert Brown in his numerous monographs supplied the model, by which others might be guided in further applying and completing the method of the natural system ; and in this respect he was met by the botanists of Germany in the spirit of the best good-will and most profound appreciation, as is shown by the fact that a collection of his botanical works, translated by different German botanists, was edited in five volumes by Nees von Esenbeck as early as the period between I825 and 1834. The natural system established itself in Germany through the labours of Brown and De Candolle; and the more correct appreciation of it as compared with the sexual system of Linnaeus was promoted by a work of Carl Fuhlrott which appeared in 1829 , in which the systems of Jussieu and De Candolle are compared with those of Agardh, Batsch, and Linnaeus, and the superiority of the natural system is clearly set forth. A still greater effect in this direction was produced by the appearance in 1830 of the 'Ordines naturales 
I44 Development of the Natural System under [Boox I.

plantarum' of Bartling, an independent contribution to this department of botany, and a distinct advance upon what had hitherto been effected. The contemporary monographs of Roeper on the Euphorbiaceae and Balsamineae and his treatise 'De organis plantarum' (I828), are an able, independent, and logical application of the principles of the morphology of the flower laid down by De Candolle and Brown to the elucidation of morphological and systematic conceptions. But the new methods of investigation introduced by De Candolle and Robert Brown had to encounter in Germany, and to some extent in France also, not only the antiquated views of Linnaeus, but, what was still worse, the erroneous notions of the nature-philosophy founded by Schelling. The misty tenets of this philosophy could scarcely find a more fruitful soil than the natural system with its mysterious affinities, and Goethe's doctrine of metamorphosis contributed not a little to increase the confusion. These historical phenomena will be further considered in the following chapter; at present we are more concerned to show how the professed systematists pursued the path opened by De Candolle and Brown. And here it must be noticed that from about the year 1830 , in Germany especially, morphological enquiry became separated as a special subject from systematic botany; it became more and more the fashion to treat the latter as independent of morphology, and thus to forsake the source of deeper insight which comparative and genetic morphology alone can open to the systematist; morphology on the other hand took a new flight, and as it thus developed itself apart from pure systematic botany, its progress must be described by itself in a later portion of this history.

If advance in systematic botany depended on the number of systems that were proposed from I 825 to 1845 , that period must be looked upon as its golden age; no less than twentyfour systems made their appearance during these twenty years, without counting those which were inspired by the views of the 
nature-philosophy. There was great and spreading growth, but no corresponding depth; no really new points of view were opened for classification, and as regards the true principles of the natural system there were symptoms of evident decline rather than of advance, as will be shown below. Improvements were effected certainly in the details of the system, since botanists generally adhered to the principles laid down by De Candolle, Jussieu, and Brown. Families were cleared up and better defined, and groups of families were proposed which assumed more and more the appearance of natural cycles of relationship. The class more especially treated was the extensive one of the Dicotyledons, in which the families, continually growing more and more numerous, were in Jussieu's arrangement a chaos, but had been united into larger groups in a somewhat artificial manner by De Candolle. Here we see once more how the formation of the system rises step by step from the particular to the more general; at an earlier period genera were constructed out of species, and families out of genera, and during the years from $\mathrm{x} 820$ to $\mathrm{I} 845$ the families were united into more comprehensive groups ; but these orders or classes were not yet grouped together in such a manner as to ensure the separation of the largest divisions of the vegetable kingdom in a natural manner. The great class of Dicotyledons is not even yet so arranged that the smaller aggregates of families connect satisfactorily one with another. Nevertheless a considerable advance was made by the establishment of a large number of smaller groups of families, and Bartling and Endlicher were especially successful in founding such groups and supplying them with names and characters.

If on the other hand we turn to the primary divisions of the vegetable kingdom, we find that certain large and natural groups came to be most generally recognised and placed in the front rank in every scheme; such were the groups of the Thallophytes, Muscineae, Vascular Cryptogams, Gymnosperms, Dicotyledons and Monocotyledons. But the co-ordination of 
I46 Development of the Natural System under [Воок I.

these great divisions of the whole vegetable kingdom was far from being rightly understood. It was usage rather than anything else, which gradually put them forward as primary types; in the systems themselves some received too great, others too little prominence, or other groups of doubtful character were admitted alongside of them. Bartling, for instance, whose system up to $185^{\circ}$ or even longer may rank as one of the most natural, adheres to De Candolle's division of the vegetable kingdom into cellular and vascular plants, and rightly divides the former into two main groups, Thallophytes and Muscineae (Homonemeae and Heteronemeae), while he separates the latter into Vascular Cryptogams and Phanerogams ; but the Phanerogams are divided into Monocotyledons and Dicotyledons, which again are distributed into four groups, one of these being characterised by the presence of a vitellus, that is, of an endosperm surrounded by a perisperm, - a thoroughly artificial division. The three other divisions are named apetalous, monopetalous, and polypetalous, but the Coniferae and Cycadeae are placed in the apetalous division. Less satisfactory is the primary division into Thallophytes and Cormophytes proposed by ENDLicher ${ }^{1}$, the latter separating into the divisions Acrobrya (Muscineae, Vascular Cryptogams,

1 Stephen Ladislaus Endlicher was born at Pressburg in 1805, and abandoning the study of theology became Scriptor in the Imperial Library at Vienna in $18_{2} 8$, and in 1836 Custos of the botanical department of the Imperial Collection of Natural History. Having graduated at the University in 1840 , he became Professor of Botany and Director of the Botanic Garden. His library and herbarium, valued at 24,000 thalers, he presented to the State, and with his private means founded the Annalen des Wiener-Museums, purchased botanical collections and expensive botanical books, and published his own works and works of other writers. His official salary was small, and having exhausted his resources in these various expenses, he put an end to his own life in March I849. Endlicher was not only one of the most eminent systematists of his day, but a philologist also, and a good linguist. He wrote among other things a Chinese grammar. See 'Linnaea,' vol. xxxiii (1864 and 1865 ), p. $5^{8} 3$. 
and Cycads), Amphibrya (Monocotyledons), and Acramphibrya (Dicotyledons and Conifers); the names of the three latter groups, the first of which is utterly unnatural, are founded on erroneous assumptions respecting growth in length and thickness, which Endlicher borrowed from Unger. While Endlicher's great work has continued down to our own time to be indispensable to the botanist as a book of reference on account of the fulness of its descriptions of families and genera, the system projected by Brongniart in $\mathrm{I} 843$ has acquired a sort of official authority in France. The whole vegetable kingdom is here distributed into two divisions, Cryptogams and Phanerogams, and the former are incorrectly characterised as asexual, the latter as having distinction of sex. The Phanerogams, divided into Monocotyledons and Dicotyledons, are distributed into groups in a manner that is not satisfactory; but the system has one merit, that it keeps the Gymnosperms together in one body; and if they are incorrectly classed with the Dicotyledons, it was still a sign of progress, that Robert Brown's discovery of gymnospermy was to some extent practically recognised. The system devised by John $\operatorname{LindLEY}^{1}$ attained to about the same importance in England as attached to those of Bartling and Endlicher in Germany, and that of Brongniart in France. After various earlier attempts he proposed a system in 1845 , in which, as in Brongniart's arrangement, the Cryptogams are characterised as asexual or flowerless plants, the Phanerogams as sexual or flowering plants; the former are divided into Thallogens and Acrogens, the Phanerogams into five classes; (I) Rhizogens (Rafflesiaceae, Cytineae, Balanophorae); (2) Endogens (parallel-nerved Monocotyledons); (3) Dictyogens (net-veined Monocotyledons); (4) Gymnogens (Gymnosperms) ; (5) Exogens (Dicotyledons). This classification is one of the most unfortunate that were ever attempted; the systematic value of the

1 John Lindley, Professor of Botany in the University of London, was born at Chatton near Norwich in 1799 , and died in London in 1865 . 
Rhizogens is much overrated on account of their striking habit; the Monocotyledons are separated into two classes on the strength of an unimportant mark. The characters assigned to all these groups are on the whole thoroughly faulty.

These systems have been selected for notice from among many others, because they attained an extended notoriety and importance from the circumstance that their authors, Brongniart excepted, made them the occasions of comprehensive descriptions of the whole vegetable kingdon, and again because it would be superfluous for our present purpose to bestow a closer consideration on the systems of less eminent men. Whoever desires further information on the matter will find it in the introduction to Lindley's 'Vegetable Kingdom' of 1853 .

If we consider the principles and points of view adopted in these systems, one thing especially strikes us, that, except in the case of Bartling, physiologico-anatomical marks were employed along with morphological ones to characterise the primary divisions; their authors fell into the mistake committed by De Candolle, and unfortunately these very marks rested in part or wholly on misapprehensions, as in Endlicher's division into Acrobrya, etc., and Lindley's classes of Rhizogens and Dictyogens. It was still more unfortunate that individual systematists obstinately refused to accept well authenticated facts, which it is true had not been discovered by systematists, but were nevertheless of the highest value for the system. It is scarcely credible that Lindley in 1845 , and again in 1853 , maintained the distinction between endogenous and exogenous growth in stems, though Hugo von Mohl had in I8 31 produced decisive proof that this distinction laid down by Desfontaines and adopted by De Candolle had no real existence. The same was the case with the characters of the Cryptogams, in which the mark of having no sexual organs was repeatedly adopted as running through the whole class, although various instances of sexuality in Cryptogams were known before I845; 
Schmidel had described the sexual organs of the Liverworts about the middle of the previous century, Hedwig those of the Mosses in 1782 , and Vaucher in 1803 had suggested that the conjugation of Spirogyra among the Algae should be regarded as a sexual act; the systematists in fact did not know what to make of these intimations.

It was again a misfortune that the systematists in their labours often neglected to distinguish between the search for marks and the use to be made of them; the examination of all possible marks should lead to the establishing the systematic importance of certain fixed marks or their value for classification. When research has done its work, then it is sufficient in exhibiting the system to put forward only the prominent marks; and frequently a single one suffices to unite a natural group. Such a leading mark is like the standard of a regiment; its significance is not great in itself, but it serves the great practical purpose of indicating a whole group of marks which are connected with it. It was a still greater misfortune that scarcely any systematist after De Candolle endeavoured to form a clear conception in his own mind of the principles on which the natural system must be elaborated, and to set them forth in a connected form as the theory of the system. The student had to accept the arrangement offered him as a fact simply without understanding it, and the systematists themselves usually followed only a blind feeling in the framing of their groups, and never unfolded the grounds of their proceeding with logical distinctness. In this respect John Lindley forms an honourable exception, inasmuch as he did, on several occasions after 1830 , give full expositions of his views on the principles of natural classification, and like De Candolle endeavoured to develop a theory of the system ${ }^{1}$. But he deserves credit only for the

1 Auguste de Saint Hilaire was born at Orleans in I779, and died there in 1853 ; he was Professor at Paris, and in $184^{\circ}$ published his 'Leçons de Botanique comprenant principalement la Morphologie Végétale,' etc. This 
endeavour, for the principles themselves which he laid down are not only to a great extent incorrect, but they are opposed to his own and to every other natural system. We find this opposition between theory and practice much more strongly marked in Lindley than in De Candolle; the cases only are so far different, that De Candolle laid down correct principles for the determination of affinities, but in some cases did not follow them, whereas Lindley deduced quite incorrect rules of system from existing and long-established natural affinities. The consideration of all the systems framed up to the year 1853 shows clearly that the characters of truly natural groups are to be found only in morphological marks; yet Lindley enunciates the principle that a mark, or, as he incorrectly says, an organ, is more important for classification in proportion as it possesses a higher physiological value for the preservation and propagation of the individual. If this were true, nothing would be easier than to frame a natural system of plants; it would suffice to divide plants first of all into those without and those with chlorophyll, for the presence of chlorophyll is more essential than that of any other substance to the nourishment of plants, and its physiological importance is therefore preeminent; in that case of course such Orchideae as have no chlorophyll, the Orobancheae, Cuscuta, Rafflesia, etc., would form one class with the Fungi, and all other plants the other. It is very important for the existence of a plant whether its organisation is adapted to its growing in water, or on dry land, or underground, and if we took Lindley at his word, he

work contains a somewhat diffuse account of P. de Candolle's doctrine of symmetry, together with Goethe's theory of metamorphosis and Schimper's doctrine of phyllotaxis, and his own views also on classification founded on the comparative morphology of the day. It is marked by fewer errors than will be found in Lindley's theoretical writings, but it is less profound, and touches only incidentally on fundamental questions; at the same time it possesses historical interest as giving a lucid description of the state of morphology before $\Omega_{4}$ o. 
would be obliged to bring the Algae, Rhizocarps, Vallisnerias, water Ranunculuses, Lemna, etc., into one group. It is very important for the existence of a plant whether it grows upright of itself, or climbs upwards by the aid of tendrils or of a twining stem or otherwise, and accordingly we might on Lindley's principle collect certain ferns, the vine, the passion-flower, many of the pea kind, etc., into one order. It is obvious that Lindley's main axiom of systematic botany appears in this way utterly unreasonable; yet by this principle he judges of the systematic value of anatomical characters, those of the embryo and endosperm, of the corolla and the stamens, everywhere laying stress on their physiological importance, which in these parts has really little systematic value. This mode of proceeding on the part of Lindley, compared with his own system, which with all its grave faults is still always a morphologically natural system, proves that like many other systematists, he did not literally and habitually follow the rules he himself laid down, for if he had, something very different from a natural system must have been the result. The success which was really obtained in the determination of affinities was due chiefly to a correctness of feeling, formed and continually being perfected by constant consideration of the forms of plants. It was still therefore virtually the same association of ideas as in de l'Obel and Bauhin, operating to a great extent unconsciously, by which natural affinities were by degrees brought to light; and men like Lindley, of pre-eminent importance as systematists, were, as the above examples show, never clear about the very rules by which they worked. And yet in this way the natural system was greatly advanced in the space of fifty years. The number of affinities actually recognised increased with wonderful rapidity, as appears from a comparison of the systems of Bartling, Endlicher, Brongniart, and Lindley, with those of De Candolle and Jussieu. Nothing shows the value of the systems thus produced before $185^{\circ}$ as classifications of the vegetable kingdom more forcibly than the fact that a clear 
152 Development of the Natural System under [Воок i.

and methodical thinker like Darwin was able to draw from them the chief supports of the theory of descent. For it is quite certain that Darwin has not framed his theory in opposition to morphology and system, and drawn it from any hitherto unknown principles; on the contrary, he has deduced his most important and most incontestable propositions directly from the facts of morphology and of the natural system, as it had been developed up to his time. $\mathrm{He}$ is always pointing expressly to the fact that the natural system in the form in which it has come to him, which he accepts in the main as the true one, is not built upon the physiological, but upon the morphological value of organs; it may, he says, be laid down as a rule, that the less any portion of the organisation is bound up with special habits of life, the more important it is for classification. Like Robert Brown and De Candolle, he insists upon the high importance for purposes of classification of aborted and physiologically useless organs; he points to cases in which very distant affinities are brought to light by numerous transition-forms or intermediate stages, of which the class of the Crustaceae offers a specially striking example in the animal kingdom, while certain series of forms of Thallophytes, the Muscineae, the Aroideae and others, may be adduced as instances of the same kind in the vegetable world; in such cases the most distant members of a series of affinities have sometimes no one common mark, which they do not share with all other plants of a much larger division. From these and other similar statements of Darwin we see plainly, that he actually did gather from existing natural systems of plants and animals the rules by which systematists had worked, but which they themselves observed only more or less unconsciously, and never with a full and clear recognition of them. He says quite rightly, when the investigators of nature are practically engaged with their task, they do not trouble themselves about the physiological value of the characters which they employ for the limiting a group or the establishment of a single species. 
Darwin clearly perceived and consistently kept in view the discordance between the systematic affinity of organisms and their adaptation to the conditions of life, which De Candolle had already but imperfectly recognised. The clear perception of this discordance was in fact the one thing needed to mark the true character of the natural system, and to make the theory of descent appear as the only possible explanation of it. The fact which morphologists and systematists had painfully brought to light, but had not sufficiently recognised in its full importance, that two entirely different principles are united in the nature of every individual organism, that on the one hand the number, the arrangement, and the history of the development of the organs of a species point to corresponding relations in many other species, while on the other hand the manner of life and the consequent adaptation of the same organs may be quite different in these allied species. This fact admits of no explanation but the one given by the theory of descent ; it is therefore the historical cause and the strongest logical support of that theory, and the theory itself is directly deduced from the results which the efforts of the systematists have established. That the majority of systematists did at first distinctly declare against the theory of descent can surprise no one who observes that they were so little able to give an account of their own mode of procedure, as appears in so striking a manner from Lindley's theoretical speculations.

One consequence of this want of clearness in combination with the dogma of the constancy of species has been already mentioned in the introduction; namely, the notion professedly adopted by Lindley, Elias Fries, and others, that an idea lies at the foundation of every group of affinities, that the natural system is a representation of the plan of creation. But the question, how such a plan of creation could explain the strange fact that the physiological adaptations of organs to the conditions of life have nothing at all to do with their systematic connection, was quietly disregarded; and in fact the notion, 


\section{I54 Development of the Natural System.}

founded on Platonic and Aristotelian philosophy, of a plan of creation and of ideal forms underlying systematic groups, could not explain this discordance between morphological and physiological characters. It would be easy to maintain the view of the systematists, that the natural system represents a plan of creation, if physiological and morphological characters went always truly hand in hand, if the adaptation of the organs to the conditions of life in the species were perfect; but facts show that the adaptation is in the best of cases comparatively imperfect, and that it is in all cases brought about by the accommodation to new requirements of organs which originally served to other functions. 


\section{CHAPTER IV.}

Morphology under the Influence of the Doctrine of Metamorphosis and of the Spiral Theory.

$$
\text { I } 790-1850 .
$$

THE efforts of Jussieu, De Candolle, and Robert Brown were directed to the discovery of the relationship between different species of plants by comparing them together; the doctrine of metamorphosis founded by Goethe set itself from the first to bring to light the hidden relationship between the different organs of one and the same plant. As De Candolle's doctrine of symmetry derived the different species of plants from an ideal plan of symmetry or type, so the doctrine of metamorphosis assumed an ideal fundamental organ, from which the different leaf-forms in a plant could be derived. The stem came into consideration only as carrying the leaves, the root was almost entirely disregarded. As the resemblance of nearly allied species of plants suggests itself naturally and unsought to the mind of the unbiassed observer, so also does the connection between different organs of a leafy nature in one and the same plant. Cesalpino called the corolla simply a 'folium' (leaf); he and Malpighi regarded the cotyledons also as leaves; Jung called attention to the variety of the leafforms, which are found in many plants at different heights on the same stem ; Caspar Friedrich Wolff, the first who bestowed systematic consideration on the subject, declared in 1766 , that 
he saw nothing ultimately in the plant but leaves and stem, including the root in the stem ${ }^{1}$.

Long before Goethe's time speculation had busied itself with attempts to explain these observations; we saw how Cesalpino and Linnaeus, starting from the old view that the pith is the seat of the soul in plants, regarded the seeds as metamorphosed pith, the floral envelopes with the stamens and the true leaves as metamorphosed layers of the rind and wood of the stem. The word metamorphosis from their point of view had a very plain meaning; it was really the cylindrical pith whose upper end changed into seeds, it was the actual substance of the cortex which produced both the ordinary leaves and the parts of the flower. Wolff on the other hand from a point of view of his own gave an apparently intelligible physical explanation of the proposition, that all appendages of the stem are leaves, but the explanation had the fault of not being true; he attributed the metamorphosis of leaves to altered nourishment, the flowers especially to his 'vegetatio languescens.'

Goethe's conception of the matter was from the first much less clear, and chiefly because he was never able to bring the abnormal into its true connection with the normal or ascending metamorphosis. In the first sentence of his 'Doctrine of metamorphosis' (I 790) he says, 'that it is open to observation that certain exterior parts of plants sometimes change and pass into the form of adjacent parts, either wholly or in a greater or less degree.' In the cases of which Goethe is here thinking a distinct meaning can be affixed to the word metamorphosis; if, for example, the seeds of a plant with normal flowers produce a plant which has petals in place of stamens, or in which the ovaries are resolved into green expanded leaves, it is actually the case that a plant of a known form has given rise to another plant of a different form, in other words, a change or metamorphosis has

${ }^{1}$ See Wigand, 'Geschichte und Kritik der Metamorphose,' Leipzig, I846, p. 38 . 


\section{Cнар. IV.] Metamorphosis and of the Spiral Theory. I57}

really taken place. But we cannot reason in this way in the case of that which Goethe calls normal or ascending metamorphosis. When in a given species, which has remained constant with all its marks for countless generations, the cotyledons, the leaves, the bracts, and the parts of the flower are called leaves, this must be merely the result of abstraction, which has led to the generalising of the idea of a leaf; if we make abstraction of the physiological characters of the carpels, stamens, floral envelopes, and cotyledons, and regard only the way in which they originate on the stem, we are justified in including them in one general idea with ordinary leaves, and to this idea we quite arbitrarily give the name leaf. But this does not justify us in speaking of a change of these organs, so long as we consider the whole plant in question as a hereditary and constant form. For the plant therefore taken as constant the idea of metamorphosis has only a figurative meaning; the abstraction performed by the mind is transferred to the object itself, if we ascribe to it a metamorphosis which has really taken place only in our conception. The case would be different, if here as well as in the abnormal instances above-mentioned we could assume that the stamens and other organs of the plants lying before us were ordinary leaves in their progenitors. So long as this assumption of an actual change is not even hypothetically made, the expression change or metamorphosis is purely figurative, the metamorphosis is a mere 'idea.' This distinction Goethe has not made; he did not clearly see that his normal ascending metamorphosis can only have the meaning of a scientific fact, if a real change is assumed to take place in the course of propagation in this case, as in that of abnormal metamorphosis or misformation. A comparison of his various expressions shows that he took the word metamorphosis sometimes in its literal, sometimes in its ideal and figurative sense; for instance, he says expressly, 'We may say that a stamen is a folded petal, just as we may say that a petal is a stamen in a state of expansion.' This sentence shows that Goethe did not 
regard a particular leaf-form as first in time, and that others proceeded from it by change; he uses the word metamorphosis in a purely ideal sense. At other times his remarks may be interpreted as though he really considered the normal ascending metamorphosis to be a real change in the organs, arising from a transmutation of the species. With this confusion of notion and thing, idea and reality, subjective conception and objective existence, Goethe took up exactly the position of the so-called nature-philosophy.

Goethe's doctrine could only make its way to logical consistency and clearness of thought by deciding for the one or the other way; he must either assume that the different leafforms, which were regarded as alike only in the idea, were really produced by change of a previous form,- - conception that at once presupposes a change of species in time; or he must entirely adopt the position of the idealistic philosophy, in which idea and reality coincide. In this case the assumption of a change in time was not necessary; the metamorphosis remained an ideal one, a mere mode of view; the word leaf then signifies only an ideal fundamental form from which the different forms of leaves actually observed may be derived, as De Candolle's constant species from an ideal type.

If now we read Goethe's further remarks on the doctrine of metamorphosis attentively ${ }^{1}$, we perceive that he really arrived at neither of these conclusions, but perpetually vacillated between the two; a number of his sayings might be collected, which might be taken for precursors of a theory of descent, as they have been taken by some modern writers; but it is quite as easy to make a selection which would carry us back to the position of the ideal philosophy and the constancy of species. In the later years of his life the idea of a physical metamorphosis accomplished in time, and involving a change of species, does appear more distinctly in Goethe's writings. This

1 See Goethe's collected works in forty volumes, Cotta, 1858 , vol. xxxvi. 
Chap. IV.] Metamorphosis and of the Spiral Theory. $\quad$ I59

explains the lively, nay passionate, interest which he took in the dispute between Cuvier and Geoffrey de St. Hilaire in I $830^{1}$. We gather from it that Goethe, in spite of all his wanderings in the mists of the nature-philosophy of the time, felt a growing need for some clearer insight into the nature of metamorphosis, both in plants and animals, without ever being able to make his way into the clear light.

But these better motions remained without importance for the history of botany; the adherents of his doctrine of metamorphosis all apprehended it in the sense of the naturephilosophy, and Goethe himself did not remonstrate against the frightful way in which it was distorted by them. Its further development therefore was in accordance with the principles of that philosophy, which was accustomed to apply the results of purely idealistic views in an uncritical way to imperfectly observed facts. Above all the difficulty remained unsolved, how the dogma of the constancy of species was to be brought into logical connection with the idea of the metamorphosis of organs. The supranatural, which Elias Fries found in the natural system, subsisted still in the doctrine of metamorphosis in comparing the organs of a plant.

Still more obscure and entirely the product of the nature-philosophy is Goethe's view of the spiral tendency in vegetation. At p. I94 of his essay entitled 'Spiraltendenz der Vegetation' ( $183 \mathrm{I}$ ) he says : 'Having fully grasped the idea of metamorphosis we next turn our attention to the vertical tendency, in order to gain a nearer acquaintance with the development of the plant. This tendency must be looked upon as an immaterial staff, which supports the existence . . . This principle of life (!) manifests itself in the longitudinal fibres which we use as flexible threads for many purposes; it is this which forms the wood in trees, which keeps annual and biennial plants erect, and even produces the extension from node to node

${ }^{1}$ See Haeckel, 'Natürliche Schöpfungsgeschichte,' ed. 4, I873, p. So. 
in climbing and creeping plants. Next we have to observe the spiral direction which winds round the other.' This spiral direction which passes at once with Goethe into a 'spiral tendency,' is seen in various phenomena of vegetation, as in spiral vessels, in twining stems, and sometimes in the position of leaves. The closing remarks of this short essay, in which he explains the vertical tendency as the male, the spiral as the female principle in the plant, show how far Goethe lost himself in the profundities of the nature-philosophy. Thus he introduced his readers into the deepest depths of mysticism.

It would be as useless as it would be wearisome to follow out in detail to its extremest point of absurdity the progressive transformation which the doctrine of metamorphosis underwent in the hands of the botanists of the nature-philosophy school, and to see how its catchwords, polarity, contraction and expansion, the stem-like and the fistular, anaphytosis and life-nodes, and others, were compounded with the results of the most every-day observation into meaningless conglomerates; rough obscure impressions of the sense, as well as incidental fancies, were regarded as ideas and principles. A full account of these inconceivable aberrations is to be found in Wigand's 'Geschichte und Kritik der Metamorphose.' Our own countrymen certainly, Voigt, Kieser, Nees von Esenbeck, C. H. Schulz, and Ernst Meyer (the historian of botany) bear off the palm of absurdity, but there were others also, among them the Swedish botanist Agardh, and many Frenchmen, Turpin, for instance, and Du Petit-Thouars ', who were not altogether free from this weak-

1 Robert du Petit-Thouars was born in Anjou in $175^{8}$ and collected plants during many years in the Mauritius, Madagascar, and Bourbon. $\mathrm{He}$ was afterwards Director of the Botanic Garden at Roule, and became Member of the Academy in 1820 . He died in 1831 . His articles in the 'Biographie Universelle' prove him to have been a writer of ability. Preconceived opinions interfered with the success of his own investigations, especially into the increase in thickness of woody stems, and obstinate 
Chap. IV.] Metamorphosis and of the Spiral Theory. I6I

ness. Even the best German botanists of the time, such as Ludolph Treviranus, Link, G. W. Bischoff, and others, managed to escape the influence of this philosophy of nature, only where they confined themselves to the most barren empiricism. Strange phenomenon! that as soon as gifted and understanding men began to talk of the metamorphosis of plants, they fell into senseless phrase-mongering; Ernst Meyer, for instance, was it is true no great botanist, but he shows in his 'Geschichte der Botanik' that he possessed a clever and cultivated intellect. The painful impression, which the treatment of the doctrine of metamorphosis by these writers makes upon us, is due partly to the fact that the deeper meaning of the idealistic philosophy never attained to logical expression in their hands, and still more to their indulgence in an unmeaning play of phrases, combining the highest abstractions with the most negligent and rudest empiricism, and sometimes with utterly incorrect observations. Oken can claim the merit of more correct observation and greater philosophical consistency, and if we reject his views, yet his mode of presenting them has at least the pleasing appearance of more consequential reasoning. We perceive for the first time the full greatness of the debt which modern botany owes to men like Pyrame de Candolle, Robert Brown, von Mohl, Schleiden, Nägeli, and Unger, the latter of whom only slowly worked his way out of the trammels of the nature-philosophy, when we compare the literature of the doctrine of metamorphosis before the year $\mathrm{r} 840$ with the present condition of our science, for which they paved the way.

In spite of the real and apparent differences between Goethe's doctrine of metamorphosis and De Candolle's doctrine of a plan of symmetry, these writers agreed in this, that they set out alike from the doctrine of the constancy of species, and led up equally to the result, that alongside of

adherence to such notions prevented an unbiassed interpretation of what he saw. See Flora, $18+5$, p. 439 . 
manifold physiological differences in the organs of plants certain points of formal agreement can be discovered, which are expressed chiefly in the order of their succession and in their relative positions. In this distinction lay the good kernel of the doctrine of metamorphosis in Goethe, and Wolff, and even in Linnaeus and Cesalpino : it was only necessary to set this free from the dross with which the nature-philosophy had surrounded it, and to make the relations of position in organs the subject of earnest investigation, in order to secure important results in this branch of morphology. The first step in this direction was taken by Carl Friedrich Schimper, who was followed by Alexander Braun; both adopted the main idea of the doctrine of metamorphosis in the form in which it can be reconciled with the doctrine of constancy, that is, in a purely idealistic sense. Both liberated themselves from the gross errors of the nature-philosophers, and thus gave a more logical expression to the purely idealistic morphological consideration of form in plants.

KARL Friedrich Schimper ${ }^{1}$ founded before the year i 830 the theory of the arrangement of leaves which is named after him, and which he expounded to the naturalists assembled at Stuttgart in $\mathrm{I}_{34}$ as a complete and perfected system. Alexander Braun, in a review of Schimper's exposition in 'Flora' of 1835 , gave a clear and simple account of the theory, having already himself published an excellent and comprehensive treatise on the same subject. The doctrine of phyllotaxis

1 K. F. Schimper, born in Mannheim in 1803 , was at first a student of theology in Heidelberg, but having afterwards travelled as a paid collector of plants in the south of France, he applied himself to the study of medicine. From $\mathbf{I}_{2} 8 \mathrm{~S}$ to $\mathbf{I}_{4} \mathbf{4}_{2}$ he was employed as a teacher in the University of Munich, though occasionally engaged in exploring the Alps, Pyrenees, and other districts, in the service of the King of Bavaria. It was during this period of his life that he composed his most important works on phyllotaxis, and essays on the former extension of glaciers, and on the glacial period. He returned to the Palatinate in $184^{2}$, and died at Schwetzingen in 1867 in the enjoyment of a pension from the Grand duke of Baden. 
Снар. IV.] Metamorphosis and of the Spiral Theory. ${ }_{16} 63$

appeared in these publications with a formal completeness which could not fail to attract the attention of the botanical world and indeed of a larger audience; and justly so, for, as unfortunately so very seldom happens in botanical subjects, a scientific idea was in this case not merely incidentally suggested, but was worked out in all its consequences as a complete structure, and this structure gained in external splendour from the circumstance that its propositions, dealing with geometrical constructions, could be expressed in numbers and formulae,a thing hitherto unknown in botanical science.

That the leaves are arranged on the stems that produce them according to fixed geometrical rules had been noticed by Cesalpino and by Bonnet in the middle of the eighteenth century; but nothing more resulted than weak attempts at mere description of different cases. Schimper's theory is marked by that which is at once its greatest merit and its fundamental error, the referring of all relations of position to a single principle. This principle lies in the idea that growth in a stem has an upward direction in a spiral line, and that the formation of leaves is a local exaggeration of this spiral growth. The direction of the spiral line may change in the same species, or in the same axis, and may even change from leaf to leaf. The important variations in the arrangement of leaves are not shown in their longitudinal distances, but in the measure of their lateral deviations on the stem. The characteristic point in this theory is the mode of considering these lateral deviations or divergences of the leaves as they follow one another on an axis, the referring them to a more general law of position. Means were at the same time skilfully supplied for discovering the true conditions of arrangement, the genetic spiral, in cases where the genetic succession of the leaves, and consequently their divergence, could not be immediately recognised. After innumerable observations, it appeared that there is a wonderful variety in the disposition of leaves, but that at the same time a comparatively small number of these variations 
commonly occur, and that these ordinary divergences $\frac{1}{2}, \frac{2}{3}, \frac{3}{8}$, $\frac{4}{13}, \frac{1}{2} \frac{3}{1}$, etc. have this remarkable relation to one another, that both the numerator and denominator of each successive fraction are obtained by adding together the numerators and denominators of the two preceding fractions, or the individual fractions named are the successive convergents of a continuous fraction :-

$$
\frac{I}{I+\frac{I}{I+\frac{I}{I \ldots .}}}
$$

By change of single cyphers in this, the simplest of all continuous fractions, the expressions were also obtained for all measures of position that deviate from the usual main series. The common occurrence of so-called leaf-whorls seemed at once to be opposed to the principle of special growth and to the doctrine of position founded upon it, especially in the cases in which it was supposed that all the leaves of a whorl arise simultaneously. But the founders of the doctrine, relying on their geometrical constructions, declared that every theory is incorrect, which sets out from the whorl as a simultaneous formation. But the way in which the different leaf-whorls of a stem are arranged among themselves, and are connected with continuous spiral positions, required new geometrical constructions; it was necessary to assume a supplementary relation (prosenthesis), which the measure of the phyllotaxis adopts in the transition from the last leaf of one cycle to the first of the next. Artificial as this construction appears, it has the advantage of saving the spiral principle, and the prosenthetic relation itself admits of being again expressed in highly simple fractions, - - great advantage for the formal consideration of the relative positions of the parts of the flower, and their relation to the preceding positions of the leaves. The great skill shown by the founders of the doctrine in the morphological consideration of the whole plant-form appears equally in the establishment of the rules, according to which the 
Cнар. IV.] Metamorphosis and of the Spiral Theory. ${ }_{1} 65$

relations of position of the leaves of a side-shoot connect with those of the mother-axis, and which made it possible to represent the nature of inflorescences especially with extreme clearness by means of geometrical figures. An expressive and elegant terminology not only made the whole theory attractive, but fitted it in a high degree to supply a suitable, plain, and precise phraseology for describing the most varied forms of plants. That the theory possesses such advantages as these may be gathered from the fact, that since 1835 the morphological examination and comparison not only of flowers and inflorescences, but also of vegetative shoots and their ramification, has reached great formal completeness. A thorough acquaintance with the principle of this doctrine has made it possible to explain to reader or hearer the most intricate forms of plants so clearly, that they may be said to reveal the law of their formation themselves, and to grow before the eye of the observer, while at the same time the most recondite relations of the organs of the same or of different plants were brought out distinctly and in elegant phraseology. When this mode of description was combined with De Candolle's views on abortion, degeneration, and adherence, and at the same time took into consideration the chief physiological forms of leaf-structures, according as these were developed as scales, foliage-leaves, bracts, floral envelopes, staminal and carpellary leaves, it was possible to give such an artistic account of every form of plant, as made it visible to sense in its entirety, and at the same time brought out the morphological law of its construction. Whoever reads the writings of Alexander Braun and Wydler, and especially of Thilo Irmisch (after 1873), who knew how to combine his descriptions in a variety of ways with remarks on the biological relations of plants, cannot fail to admire the extraordinary skill displayed by these men in describing plants. Compared with the dry diagnoses of the systematists, their descriptions attain to the dignity of an art, and present the commonest forms to the reader in a new 
and attractive light. But the theory had a further advantage ; it seemed not only to present the form of the plant in its matured state, but to treat it genetically; and in fact it did possess an element of historical development, inasmuch as it made the genetic succession of the leaves and of their axillary shoots, which is at the same time the succession from the base to the summit, the foundation of all consideration of the plantform. But it is also true that in this lay one of the weak sides of the theory; as long as it was a question only of continuous spirals, the succession of matured leaves does also represent the succession of their formation in time; but this was not actually proved in the case of leaf-whorls, and here, to save the theory, genetic relations had to be pre-supposed for which no further proof was forthcoming, while fresh researches have repeatedly shown that a strict application of Schimper's theory is found frequently to contradict the facts of development as directly observed $^{1}$. Moreover, regard was had only to those measurements of divergence on the continuous genetic spiral which were taken on the matured stem, while there was always the possibility that the divergences might have been different at the first, and been afterwards modified, as Nägeli subsequently suggested ${ }^{2}$. And again, the theory had a dangerous adversary to encounter in the frequent occurrence of leaves that are strictly alternate or crossed in pairs, and to conceive of this as a spiral arrangement must at once appear to be an arbitrary proceeding both from the mathematical point of view and from that of historical development; the assumption of a return of the genetic spiral from leaf to leaf, as for instance in the Grasses, like the prosenthesis in the change of divergence, afforded, it is true, a construction which was geometrically correct, but which could hardly be made to agree with the

1 See Hofmeister, 'Allgemeine Morphologie' (IS68), pp. 47I, 479, and Sachs, 'Lehrbuch der Botanik,' ed. 4 (I874), p. 195.

2 See Nägeli, 'Beiträge zur Wissenschaftlichen Botanik' (I85S), I, pp. 40, 49. 
history of development and the mechanical forces concerned. Again, it was a great and essential defect in the theory, that in assuming the spiral arrangement it entirely neglected the relations of symmetry of the plant-form, which are in many cases clearly expressed, and their connection with the outer world, on which Hugo von Mohl had already published some excellent remarks in 1836 ,- - a defect, which unhappily is not yet sufficiently appreciated. A due consideration of these objections, and of the cases in which the history of development is opposed to the constructions of the theory, must have led to the conviction that the idea of a spiral tendency in the growth of plants is at least not borne out in all cases, and more profound reflexion would show, that a scientific principle, really explaining the phenomena, is no more to be found in the assumption of such a general tendency, than in a like assumption with regard to the heavenly bodies, that they have a tendency to elliptic movement because they commonly move in ellipses. Hence Hofmeister, the latest investigator of the doctrine of phyllotaxis on the basis of the history of development, comes to the conclusion that the notion of a screw-shaped or spiral course of evolution of lateral members of plants is not merely an unsuitable hypothesis, but an error. Its unreserved abandonment is, he considers, the first condition for attaining an insight into the proximate causes of the varieties of relative position in the vegetable kingdom. But this judgment, correct as it is, was pronounced thirty years after the appearance of Schimper's theory; history, which speaks from another point of view, and not only enquires into the correctness of a theory but has to appraise its historical importance, speaks in a less unfavourable manner. The chief point here is not whether the theory was right, but how far it contributed to the advance of the science. It was distinctly fruitful in results, for it brought the important question of the relative positions of organs for the first time into the front rank in the study of morphology; we may even say that a 
large part of the results of the study of the history of development were first brought into the true light by the consistent application of the theory, or in the effort to disprove it. With all its fundamental errors, Schimper's theory remains one of the most interesting phenomena in the history of morphology, because it was carried out with thorough logical consistency. We should as little wish to omit it from our literature, as modern astronomy would wish to see the old theory of epicycles disappear from its history. Both theories served to connect together the facts that were known in their time.

The fundamental error of the theory lies much deeper than appears at first sight. Here too we have the idealistic conception of nature, which refuses to know anything of the causal nexus, because it takes organic forms for the everrecurring copies of eternal ideas, and in accordance with this platonic sphere of thought confounds the abstractions of the mind with the objective existence of things. This confusion shows itself in Schimper's doctrine, inasmuch as he takes the geometrical constructions, which he transfers to his plants and which, though they may be highly suitable from his point of view, are nevertheless purely arbitrary, for actual characters of the plants themselves, in other words, takes the subjective connection of the leaves by a spiral line for a tendency inherent in the nature of the plant. Schimper in making his constructions overlooked the fact that, because a circle can be described by turning a radius round one of its extremities, it does not follow that circular surfaces in nature must really have been formed in this way; in other words, he did not see that the geometrical consideration of arrangements in space, useful as it may otherwise be, gives no account of the causes to which they are due. But this was not properly an oversight in Schimper's case, for he would have scarcely admitted efficient causes in the true scientific sense into his explanations of the form of plants. How far Schimper was from regarding plants as some- 
thing coming into being in time and according to natural laws, how profoundly he despised the principles of modern natural science is shown in his judgment of Darwin's theory of descent and of the modern atomic theory, the coarseness of which is the more surprising, because Schimper was a man of refined and even poetic feeling. 'Darwin's doctrine of breeding,' he says, 'is, as I discovered at once and could not help perceiving more and more after repeated and careful perusal, the most shortsighted possible, most stupidly mean and brutal, much more paltry even than that of the tesselated atoms with which a modern buffoon and hired forger has tried to entertain us.' Here is the old platonic view of nature flying at modern science; the sternest 'opposites' that culture has ever produced.

The theory of Schimper, which should rather be called the theory of Schimper and Braun, considering the active part which Braun took from the first in framing and applying it, was capable of further development only in the mathematical and formal direction, as was shown especially in Naumann's essay, 'Ueber den Quincunx als Grundgesetz der Blattstellung vieler Pflanzen' (1845). The defects above described, but not the merits of the theory were shared by the doctrine of phyllotaxis laid down about ten years later by the brothers Louis and Auguste Bravais. Their theory makes use of mathematical formulae to even a greater extent than that of Schimper without paying any attention to genetic conditions, and yet it is less consistent with itself, for it assumes two thoroughly different kinds of phyllotaxis, the positions in which are arranged in a straight and in a curved line; for the latter without any apparent reason a purely ideal original divergence is assumed which stands in irrational relation to the circumference of the stem, and from it all other divergences should be derivable; and this ultimately degenerates into mere playing with figures which in this form afford no deeper insight into the causes of the relations of position. As regards serviceableness in the 
methodic description of plants the theory of the brothers Bravais is much inferior to that of Schimper ${ }^{1}$.

The genetic morphology founded about the year 1840 had to make the best terms it could with the doctrine of phyllotaxis, which was constructed on a totally different principle; the two went their way on the whole side by side without disturbance from one another till the year 1868, when Hofmeister in his general morphology attacked the principle of Schimper's theory, and endeavoured to substitute a genetic and mechanical explanation of the relative positions for the purely formal account of them; this attempt however, which from the nature of the case has not yet led to a finished theory but nevertheless contains the germ of a further development of this important doctrine, does not come within the scope of this history.

The doctrine of phyllotaxis of Schimper and Braun, as it appeared after 1830 , had clearly presented only one side of the theory of metamorphosis; what other elements there were in it capable of being turned to speculative account were further cultivated by Alexander Braun between the years I 840 and I 860 . In this period fresh points of view were asserting themselves in botanical research; the founding of the doctrine of cells, the study of the more delicate anatomy of plants and of the history of development, and increased methodical knowledge of the Cryptogams were enlarging the repertory of botanical facts, while the physico-mechanical method of investigation was being more and more adopted. Braun, who took an active part by his own researches in this revolution in morphological botany, remained true nevertheless to idealistic views; and in his frequent and comprehensive discussions of the general results of the new investigations in accordance with these views he has shown how far the idealistic platonising con-

I A comparison of the two theories and a refutation of Schleiden's assertion, that that of the brothers Bravais expresses better 'the simplicity of the law,' will be found in 'Flora,' 1847 , No. I3, from the pen of Sendtner, and in Braun's 'Verjünung,' p. 126. 
templation of nature is in a condition to do justice to the results of exact inductive enquiry. The opposition between his point of view and that of the most eminent representatives of the inductive method became more and more pronounced as years went on, and must be treated here as a historical fact. But if the new tendency in botany pursued especially by von Mohl, Schleiden, Nägeli, Unger, and Hofmeister may be called inductive in the absence of a better term, and be contrasted with the idealistic tendency represented by Braun and his school, it must not be supposed that the latter did not equally contribute in matters of detail to the enriching of the science by the method of induction; on the contrary, Braun himself was the author of a series of important works conceived in this spirit. When the new method is here called inductive, it should be understood that the word is used in a higher than the usual sense, and some explanation of this point will not be superfluous in this place. Idealistic views of nature of all times, whether they present themselves as Platonism, Aristotelian logic, Scholasticism or modern Idealism, have all of them this in common, that they regard the highest knowledge attainable by man as something already won and established; the highest axioms, the most comprehensive truths are supposed to be already known, and the task of inductive enquiry is essentially that of verifying them; the results of observation serve to elucidate already received views, to illustrate already known truths; inductive enquiry has only to establish individual facts. But in the sense in which inductive enquiry was understood by Bacon, Locke, Hume, Kant, and Lange, its task is one that goes essentially farther than this; it must not be content with establishing individual facts, but it must employ them in the critical examination of the most general notions that have come down to us, and do its best to deduce new and comprehensive theories from them, even where these may be entirely opposed to traditional views. But it is part of the very nature of this method of investigation, that its general results 
are subject to constant modification and improvement; each more general truth has only a temporary value, and endures as long as no new facts militate against it. The distinction therefore between idealism and the inductive method in the domain of natural science comes to this, that the former fits new facts into a scheme of old conceptions, the latter deduces new conceptions from new facts; the one is in its nature dogmatic and intolerant, the other eminently critical; the one is conservative, the other always pressing forwards; the one inclines to philosophic contemplation, the other to vigorous and productive investigation. To this must be added one point of great importance; the idealistic view of nature, rejecting causality, explains nature from notions of design, and is teleological; ethical and even theological elements are thus introduced into natural science.

It is in this form that the distinction between the idealistic view represented by Braun and the modern inductive morphology presents itself to us. If it were the task of this history only to record the discovery of new facts, it would be superfluous to allude to these differences here; but then it would also be impossible to estimate rightly that portion of Braun's long scientific labours which is at once the most original and the most interesting from the historical point of view, and which is to be found not so much in his many descriptive and monographic works, as in his philosophic efforts in the domain of morphology; these moreover deserve our consideration, because they carry out Goethe's half-explained conceptions to their remotest consequences, and express in purer form the idealism which lies at the foundation of the older nature-philosophy. No botanist since Cesalpino has so thoroughly endeavoured to leaven the entire results of inductive investigation with the principles of an idealistic philosophy, and to explain them in its light.

Braun's philosophical views not only accompany his knowledge of facts, but everywhere permeate and colour it ; in his writings, contributions, and monographs on the most various 
Снар. IV.] Metamorphosis and of the Spiral Theory. 173

subjects, facts are regarded from the point of view of his philosophy. He has given a general view of his philosophical principles and illustrated them by a vast variety of facts in his famous book, 'Betrachtungen über die Erscheinung der Verjüngung in der Natur, insbesondere in der Lebens- und Bildungsgeschichte der Pflanze' (1849-50). He himself directs attention to the opposition between his own stand-point and the modern induction in the tenth page of the preface, where he replies to the obvious objection, that his ideas may be regarded as antiquated, in the words, 'A more living contemplation of nature, such as is here attempted, which seeks in natural bodies not merely the operation of dead forces, but the expression of a living fact, does not lead, as is supposed, to airy structures of fancy, for it does not pretend to gain a knowledge of life in nature in any other way than as it is revealed in phenomena,' etc. This thought is still more distinctly uttered in page 13 of the text; 'As external nature without mankind presents to us only the spectacle of a labyrinth without a guide, so too scientific contemplation, which denies the inner spiritual principle in nature and the intimate connection of nature with the informing spirit ${ }^{1}$, leads to a chaos of substances and forces, which are unknown because divorced from spirit, or, to speak more precisely, to a chaos of nothing but unknown causes, which work together in an inexplicable manner.' In a note to this passage he points expressly to 'the comfortless character of such an unreal mode of viewing nature, which must necessarily endeavour to root out everything in the conceptions and language of science which appears from its own point of view to be anthropopathic,' and he requires a tender, ethical element as essential to botanical investigation. The chief object of the volume is to prove that everything in organic life may be resolved into rejuvenescence, of

1 This is not at all true of modern inductive science, which merely forms a different idea of the connection, and has regard to the relation between the percipient subject and the phenomena. 
which idea no definition is actually given, though the whole contents of the book are a search after a definition. We may regard the idea of rejuvenescence, as presented by Braun, as an extension of the idea of metamorphosis, in which extended form it is adapted to take in even the results of the cell-theory, of the history of development, and of the modern knowledge of the Cryptogams from the idealistic point of view. One peculiarity of his mode of expounding his views is observed here, as on other occasions, namely, that he gives no precise and arbitrary definition to a word, for instance, like rejurenescence in the present place, and in a later work to the word individual, but looks behind the word for a profound or even mysterious meaning, which is to be perceived and brought to light by contemplation of the phenomena. In page 5 he says, "Thus we see youth and age appear alternately in one and the same history of development; we see youth burst through age, and by growth or transformation step into the middle of the development. This is the phenomenon of rejuvenescence, which is repeated in endless multiplicity in every province of life, but nowhere appears more clearly expressed or more accessible to investigation than in the vegetable kingdom. Without rejuvenescence there is no history of development.'- 'If then we ask for the causes of the phenomena of rejuvenescence (page 7), we shall indeed allow that nature, into which special life enters in its various manifestations, excites, awakes, and works by the influences which the years and even the days bring with them; but the true and inner cause can only be found in the desire after perfection which belongs to every being in its kind, and urges it to bring the outer world, which is strange to it, more and more into complete subjection to itself, and to fashion itself in it as independently as its specific nature admits.' Further on he says (page 1 7), 'The impulse or tendency to development in each creature is likewise no direction of activity impressed from without, but one given from within and 
Cнар. IV.] Metamorphosis and of the Spiral Theory. 175

working as an inner deternimation and force from the depth of the inner nature.' A passage also from page i I of his treatise on polyembryony, published in 1860 , may be quoted here; 'Though the organism, in the process of realising itself, is subject to physical conditions, yet the proper causes of its morphological and biological characteristics do not lie in these conditions; its laws belong to a higher stage of development of its being, to a sphere in which the faculty of self-determination is distinctly manifested. If this is so, the laws of an organic being appear as tasks imposed, the fulfilling of which is not absolutely necessary but only in relation to the attainment of a definite end, as precepts, to which strict obedience may possibly not be paid.' To return once more to the idea of rejuvenescence, we find at page 18 the words, 'As regards the idea of rejuvenescence, from the foregoing considerations we draw the conclusion, that the surrender of growths already accomplished and the going back to new beginnings, the commencement of rejuvenescence, indicate only the outer side of the proceeding, while the essential part of it is an inner gathering up of forces, a new creating, as it were, out of the individual principle of life, a fresh reflecting upon the specific task or the gaining renewed hold upon the type which is to be presented in the outer organism. By this means rejuvenescence maintains its fixed relation to development, which can and ought to present in gradually attained perfection that only which lies in the nature of the creature, and is most intimately its own.' And at the conclusion of the work (page 347) he says, "The way in which the inner spiritual nature of life is specially manifested in the phenomenon of rejuvenescence may be defined as reminiscence in the true sense of the word, as the power of grasping anew in the phenomenon the inner destination of life as contrasted with its daily alienation and decay, and applying it with renewed strength towards that which is without,' etc.

This conception of rejuvenescence is, then, applied to all the phenomena of life in plants; not only the metamorphosis of 
leaves, the formation of shoots and their ramification, and the different modes of cell-formation, but even palaeontological facts are manifestations of rejuvenescence, which in the sequel puts off the form of an abstract idea, and becomes personified into an active personality, as is seen in page 8 in the expression, 'activity of rejuvenescence.'

The relation of Braun's views to the question of the constancy of species may to some extent appear doubtful; some utterances of his may be interpreted to admit a transmutation of species accomplished in the course of ages, while others are opposed to this, and it is the latter which appear to be consistent with the idealistic position. We read, for instance, at page 9, 'The appearance, as though the like was always repeating itself in nature, is suggested when we glance back from our station in time upon the succession of former epochs. Here we find the real first beginnings of species and genera, and even of orders and classes in the vegetable and animal kingdoms; we see at the same time that more or less thorough transformations are connected with the appearance of the higher grades in the organic kingdom, so that genera and species of the old world disappear, and new ones step into their place. All this change expresses not the mere accident of convulsions, which, while they destroy, at the same time prepare new ground for the prosperity of organic nature, but rather definite laws whose action pervades all the individual detail of the development of organic life.' On the other hand we find at the conclusion of the treatise on polyembryony, written a short time before the appearance of Darwin's memorable work, a sentence which makes the assumption of a transmutation of species appear very doubtful; it says (page 257), 'If we are justified in assuming a general organic connection in the history of development in plant-forms, can we imagine that the type of the Mosses and of the Ferns has come from the Algae, or vice versa, that the Alga-form owes its origin to the Mosses and Ferns?' 
Chap. IV.] Metamorphosis and of the Spiral Theory. 177

The sentences here quoted to show Braun's philosophical position still give no idea of the way in which the principles embodied in them influence the whole manner of presenting the facts in the arrangement of his empirical material, but to give a clear idea of this is impossible in so brief a notice as the present. His conception of his subject is shown still more distinctly in a treatise which appeared three years later, entitled 'Das Individuum der Pflanze in seinem Verhältniss zur Species, Generationsfolge, Generationswechsel und Generationstheilung der Pflanze' (1852-3). 'The definition of the word individual is here sought, as that of rejuvenescence was in the previous work, - a really difficult task, if we consider how many meanings have been assigned to this word in the course of time; in the individuals or atoms of Epicurus, the individuals or monads of Leibnitz, the atoms of modern chemistry, the speculations of the schoolmen on the 'principium individuationis' as opposed to the reality which they assigned to universal conceptions, and in the customary application of the word in every-day language, in which a man or a single tree is called an individual, we have the general views of various centuries, showing how the sense and meaning of old words become changed, not unfrequently into their exact opposites. From the nominalist position of modern natural science this is of little importance, because this treats words and ideas as mere instruments for mutual understanding, and seeks no meaning in either which has not been previously and purposely assigned to them. Braun's mode of proceeding is quite different; by comparison of very various phenomena of vegetation, and by examining former views on the subject of the individual plant, he seeks to demonstrate a deeper meaning which must be connected with the word.

Moreover, he makes the enquiry into the individual only a thread on which to string his own reflections, in the course of which he once more explains the principles of the teleological nature-philosophy, and points out its opposition to modern 
science, the latter being grievously misrepresented as materialistic, its atoms qualified as dead, its forces as blind. It would scarcely be guessed from Braun's account that the history of philosophy could point to Bacon, Locke, and Kant, as well as to Aristotle, that even the question of the individual had been already handled by the schoolmen. A consideration of the other point of view would have been all the more profitable, since the author in the beginning of his treatise expresses the opinion that the doctrine of the individual belongs to the elements of botany; it might certainly be maintained that it is altogether superfluous.

His train of thought in search of that which must be called an individual in the vegetable kingdom is briefly as follows : In forming a conception of the plant-individual as the unity of a cycle of formation or a morphological whole, our chief difficulty lies in the division into parts and the divisibility (Getheiltheit und Theilbarkeit) which are present in the very different stages of the organic structure of plants. It is requisite therefore to find the middle way between the morphological consideration of the individual plant which breaks up the whole from above downwards, and the physiological which extends it in the upward direction beyond all limits. Neither the leaf-bearing shoots, though they are capable of developing into independent plants, nor the parts of them, which have the same power, neither the single cells, nor the granules they contain, and least of all the atoms of dead matter which are the sport of blind forces, would answer to the idea of the individual in plants. We have therefore to decide which member of this many-graded series of potences in the cycle of development subordinated to the species deserves by preference the name of individual (p. 48). A compromise is then made; it is sufficient to find a part of the plant which answers above all others to the idea of the individual, for in this idea there must be two genetic forces, multiplicity and unity. He then decides for the shoot or bud. 'In contemplating the plant-stem which 
is usually branched, especially a tree with its many branches, mere instinctive feeling awakens the suspicion that it is not a single being, a single life, to be classed with the individual animal or individual man, but that it is a world of united individuals which spring from one another in a succession of generations,' etc. He proceeds to show that this conception, arising as it does from a sound, natural feeling, is also confirmed by scientific examination. It appears, however, that many phenomena in the growth of plants will not fall in well with this instinctive feeling, and so he says at page 69 , "We cut the Gordian knot in this way, that if we have other and sufficient grounds for regarding branches as individuals, we come to the determination to let every branch pass for an individual, however strongly the appearance may be against it.' The shoot is therefore the morphological individual in the plant, and is analogous to the individual animal. It may certainly be objected, that we may cut the knot in another way and maintain with Schleiden that the cells are the individuals in the regetable kingdom, if we do not actually arrive by the same path at calling each atom, or at the other end of the scale the whole self-nourishing plant, an individual, for about equally strong reasons might be adduced for both one and the other of these views. It all depends on the point of view we adopt in such speculations, and on the weight we allow to instinctive feeling in establishing scientific ideas. Braun declares very decidedly in page 39 against the notion that the invisible 'individua' or atoms of dead matter can be introduced into the consideration of the plant-individual, as though the plant were a mere concrete of mutually attracting and repelling atoms. If, he says, we will understand by the term individual something absolutely indivisible, this is certainly the last resort, but then we shall have no plant-individual. Moreover, no eye has ever seen these atoms ; their assumption is a mere hypothesis, which we may confront with the other hypothesis of the continuity and permeability of matter. The question therefore, 
he says, at page 39 , is whether we can speak of individuals in plants at all, and this coincides with the other question, whether the plant is a mere product of the activity of matter, and so an unsubstantial appearance in the general circulation of nature, the offspring of blind agencies, or whether it possesses a peculiar and independent existence. The views of the physiologists, who reject the vital force and explain the phenomena of life by physical and chemical laws, have robbed life of its mysterious and most directly operative principle, and pulled down the strong wall of separation between organic and inorganic nature. 'Because physical forces appear to be everywhere confined to matter and show in their operation a strict subjection to law, men have ventured to regard the sum total of natural phenomena as the result of original matter working in conjunction with definite powers according to the laws of blind necessity, as a natural mechanism moving in endless circulation.' But he objects that the eternally necessary can only be conceived of as accomplished from all eternity, and thus this physical view would make all eventuality inconceivable. Further, the purpose of the movement of nature must remain an insoluble enigma in this scheme of blind necessity. 'The inadequateness of the so-called physical view of nature as compared with the teleological is therefore most felt in the domain of organic nature, where special purpose in the phenomena of life appears everywhere in greatest distinctness.' The last remark is indisputable so long as we maintain either the constancy of species or a merely internal law of development; the solution of the enigma was discovered a few years later in Darwin's hypothesis, that all adaptations of organisms are to be explained by the maintenance or suppression of varieties, according as they are well or ill provided with the means of sustaining the struggle for existence. No other refutation or rather explanation of teleology in the science of organic life has hitherto been attempted. It has been already pointed out that systematic botany, by establishing the fact of 
Снар. IV.] Metamorphosis and of the Spiral Theory. 181 affinity, saw itself compelled at last to give up the constancy of specific forms in order to make this fact intelligible, and here we see how the idea of the adaptation of organisms is found to conflict with causality, unless we assume that the forms which arise through variation only maintain themselves, if they are sufficiently adapted to the surrounding conditions.

The movement which began with Goethe and the naturephilosophy assumed a clearer form, found its purest expression, and revealed its most hidden treasures in the writings of Schimper and Alexander Braun; it would be superfluous to submit to a detailed review the numerous works of less important representatives of these views.

We turn from this realm of idealistic philosophy and imagination, from rejuvenescence, the wave-pulse of metamorphosis, the spiral tendency of growth, and the individuality of plants, to the last chapter of our history of systematic botany and morphology, where there is less dogmatism and less poetry, but a firmer ground on which will spring an unexpected wealth of new discoveries and of deeper insight into the nature of the vegetable world. 


\section{CHAPTER V.}

Morphology and Systematic Botany under the Influence of the History of Development and the KNowledge of THE CRyptogans.

$$
\text { I } 840-\text { I } 860 \text {. }
$$

In the years immediately before and after 1840 a new life began to stir in all parts of botanical research, in anatomy, physiology, and morphology. Morphology was now specially connected with renewed investigations into the sexuality of plants and into embryology, and attention was no longer confined to the Phanerogams but was extended to the higher and later on to the lower Cryptogams. These researches into the history of development first became possible, when von Mohl had restored the study of anatomy, and Nägeli had founded and elaborated the theory of cell-formation about the year 1845 . The success of both these enquirers was due to the previous development of the art of microscopy; it was the microscope which revealed the facts on which the foundations of the new research were laid, while its promoters at the same time started from other philosophical principles than those which had hitherto prevailed among botanists. Investigation by means of the microscope enforces on the observer the very highest strain of attention and its concentration on a definite object, while at the same time a definite question to be decided by the observation has always to be kept before the mind; there are sources of error on all sides to be avoided, and possible deceptions to be taken into consideration; the 


\section{Morphology and Systematic Botany.}

securing of the facts demands all the powers which specially display the individual character of the observer. Thus serious attention to microscopy was one of the causes which introduced the best observers to the practice of inductive enquiry, and gave them an insight into its nature; and in a few years' time when the actual results of these investigations began to appear, and when a wholly new world disclosed itself to botanists, especially in the Cryptogams, then questions arose on which the dogmatic philosophy had not essayed its ancient strength; the facts and the questions were new and untouched, and presented themselves to unprejudiced observation in a purer form than those, which during the first three centuries had been so mixed up with the old philosophy and with the principles of scholasticism. Von Mohl, who only occasionally occupied himself with morphological subjects, was a firm adherent of the inductive method, and was bent on the establishment of individual facts rather than of general principles; but the founders also of the new morphology, Schleiden and Nägeli, started from philosophical points of view, which, different as they were in the two men, had yet two things in common, a demand for severely inductive investigation as the foundation of all science, and the rejection of all teleological modes of explaining phenomena, in which latter point their opposition to the idealistic nature-philosophy school was most distinctly manifested. They had indeed one very important point of contact with this school, the belief in the constancy of organic forms; but this belief, not being connected with the Platonic doctrine of ideas, was with them only a recognition of every-day observations, and was therefore of less fundamental importance, being felt merely as an inconvenient element in the science. Treating the question in this way, and influenced by the results of the new researches, they either inclined to entertain the idea of descent before the appearance of Darwin's great work, or gave a ready assent to the principle of the new doctrine, though they expressed some 
doubts respecting matters of detail. Hofmeister's researches in morphology and embryology ('Vergleichende Untersuchungen,' I 85I) threw an entirely new light on the relations of affinity between the great groups in the vegetable kingdom, and were leading more and more to the view, that there must be some special peculiarity in the question of the constancy of organic forms. But the idea of evolution in the vegetable kingdom was brought more distinctly home to men's minds by palaeontological researches; Sternberg (1820-1838), Brongniart (1828-1837), Goeppert (1837-1845), and Corda (1845) made the flora of former ages the subject of careful study, and compared fossil plants with living allied forms. Unger especially, while advancing the knowledge of the structure of cells and of vegetable anatomy and physiology, and generally taking a prominent part in the development of the new botany, applied the results of its investigations to the examination of primeval vegetation, and showed the morphological and systematic relations between past and existing floras. After twenty years of preliminary study he declared distinctly in 1852 , that the inmmutability of species is an illusion, that the new species which have made their appearance in geological periods are organically connected, the younger having arisen from the elder ${ }^{1}$. It was shown in the former chapter, how about the same time the leading representative of idealistic views, Alexander Braun, was driven to the hypothesis, though in a more indefinite form, of an evolution of the vegetable kingdom: and in the year that Darwin's book on the origin of species appeared, Nägeli ('Beiträge,' ii. p. 34) wrote :'External reasons, supplied by the comparison of the floras of successive geological periods, and internal reasons given in physiological and morphological laws of development and in the variability of the species, leave scarcely a doubt that species have proceeded one from another.'

${ }^{1}$ See A. Bayer, 'Leben und Wirken F. Unger's,' Gratz (1872), p. 52. 
Though these words might not contain a theory of descent capable at once of scientific application, yet they show that the latest researches and candid appreciation of facts were compelling the most eminent representatives of the botany of the day to give up the constancy of forms. At the same time in the genetic morphology which had developed itself mainly under Nägeli's guidance since 1844 , and still more in embryology, which in Hofmeister's hands was leading to results of the greatest systematic importance, there lay a fruitful element destined to correct and enrich Darwin's doctrine of descent in one essential point. That doctrine in its original form sought to show that selection, the result of the struggle for existence, combined with perpetual variation was the sole cause of progressive improvement in organic forms ${ }^{1}$; but Nägeli, relying on the results of German morphology, was able as early as 1865 to point out that this explanation was not satisfactory, because it leaves unnoticed certain morphological relations, especially between the large divisions of the vegetable kingdom, which scarcely seem explainable by mere selection in breeding. While Nägeli allowed that Darwin's principle of selection was well adapted to explain fully the adaptation of organisms to their environment and the suitableness and physiological peculiarities of their structure, he pointed out that in the nature of plants themselves there are intimations of laws of variation, which lead to a perfecting of organic forms and to their progressive differentiation, independently of the struggle for existence and of natural selection; the importance of this result of morphological research has since been recognised by Darwin. Thus Nägeli supplied what was wanting in the theory of descent and gave it the form, in which it is adequate to explain the problem already recognised by the systematists of the old persuasion,

1 See Darwin's repudiation of this statement on p. 42 I of Ed. 6 of the 'Origin of Species.' 
I86 Morphology and Systematic Botany under [Book I.

namely, how it is possible for the morphological affinity of species in the system to be in so high a degree independent of their physiological adaptation to their environment.

The modern teaching on vegetable cells, modern anatomy, and morphology, and the improved form of the theory of selection are the product of inductive enquiry since $\mathrm{r} 840$, a product, the full importance of which will be described in the following portions of our history. At present we have to deal only with morphological and systematic results, and therefore with a part only of the abundant labours of the botanists who will be noticed in this chapter; the remainder will be reserved for succeeding books, which contain the history of the anatomy and physiology of plants.

It is one of the characteristic features of this period of botany, that morphology enters into the closest connection with the doctrine of the cell, with anatomy and embryology, and that researches, especially into the process of fecundation and the formation of the embryo, form to some extent the central point of morphological and systematic investigations. A strict separation of these various enquiries, which are all ultimately applicable to the purposes of systematic botany, can therefore scarcely be maintained, and least of all in dealing with the lower Cryptogams.

The condition of botanical literature about the year I 840 was highly unsatisfactory; it is true that eminent service was rendered in the several domains of systematic botany, morphology, anatomy, and physiology, and a number of von Mohl's best works were produced in this period; Meyen also, Dutrochet, Ludolph Treviranus and others were cultivating vegetable anatomy and physiology, and it has been already stated that good and noticeable work was done in the previous years in morphology and systematic botany. But there was no one to put together, to criticise and apply the knowledge 
which had been accumulated in all parts of the science; no one really knew what a wealth there was at that time of important facts; least of ali was it possible to form a judgment on the matter from the text-books of the period, which were deficient in ideas and facts, and crammed with a superfluous terminology; their mode of treating their subject was trivial and tasteless, and whatever was specially worth knowing and important to the student they did not contain. Those who undertook really scientific enquiries separated themselves from those who dealt with botany after the old schematism of the Linnaean school; but botanical instruction, the propagation of knowledge, was almost everywhere in the hands of this school, though it was the one least fitted for the task; and thus a mass of lifeless phrases was the instruction offered to the majority of students under the name of botany, with the inevitable effect of repelling the more gifted natures from the study. This was the evil result of the old and foolish notion, that the sole or chief business of every botanist is to trifle away time in plant-collecting in wood and meadow and in rummaging in herbaria,-proceedings which could do no good to systematic botany even as understood by the linnaean school. Even the better sort lost the sense for higher knowledge while occupying themselves in this way with the vegetable world; the powers of the mind could not fail after a time to deteriorate, and every text-book of the period on every page supplies proof of this deterioration.

But such a condition of things is dangerous for every science; of what profit is it, that single men of superior merit advance this or that part of the science when a connected view of the whole is wanting, and the beginner has no opportunity of studying the best things in their mutual relations. However, the right man was found at the right moment to rouse easy indolence from its torpor, and to show his contemporaries, not in Germany only but in all countries where botany was studied, that no progress was possible in this 


\section{88 Morphology and Systematic Botany under [Boor I.}

way. This man was Matthias Jacob Schleiden, born at Hamburg in 1804 , and for many years Professor in Jena. Endowed with somewhat too great love of combat, and armed with a pen regardless of the wounds it inflicted, ready to strike at any moment, and very prone to exaggeration, Schleiden was just the man needed in the state in which botany then was. His first appearance on the scene was greeted with joy by the most eminent among those who afterwards contributed to the real advance of the science, though their paths it is true diverged considerably at a later period, when the time of reconstruction was come. If we were to estimate Schleiden's merit only by the facts which he discovered, we should scarcely place him above the level of ordinarily good botanists ; we should have to reckon up a list of good monographs, numerous refutations of ancient errors and the like; the most important of the theories which he proposed, and over which vigorous war was waged among botanists during many years, have long since been set aside. His true historical importance has been already intimated; his great merit as a botanist is due not to what he did as an original investigator, but to the impulse he gave to investigation, to the aim and object which he set up for himself and others, and opposed in its greatness to the petty character of the text-books. He smoothed the way for those who could and would do really great service; he created, so to speak, for the first time an audience for scientific botany capable of distinguishing scientific work from frivolous dilettanteism. Whoever wished from this time forward to take part in the discussion of botanical subjects must address all his powers to the task, for he would be judged by another standard than had hitherto prevailed.

Schleiden, who had commenced his botanical labours with some important researches in anatomy and the history of development, the most valuable of which in matter and form was an enquiry into the development of the ovule before fertilisation (1837), composed also a comprehensive text-book 
Cнар. V.] the Influence of the History of Development. I 89

of general botany, which appeared first in $1842-3$, and in much improved editions in 1845 and 1846 , and in two subsequent years. The difference between this and all previous text-books is the difference between day and night; in the one, an indolent carelessness and an absence of ideas; in the other, a fulness of life and thought, calculated to influence young minds all the more, because it was in many respects incomplete and still in a state of fermentation. On every page of this remarkable work, by the side of facts really worth knowing, the student found interesting reflections, a lively and generally coarse polemic, and praise and blame of others. It was not a book to be studied quietly and comfortably, but one that excited the reader everywhere to take a side for or against, and to seek for further instruction.

The work is generally quoted as 'Grundzüge der wissenschaftlichen Botanik,' but its chief title is 'Die Botanik als inductive Wissenschaft,' which indicates the point on which Schleiden laid most stress. His great object was to place the study, which had been so disfigured in the text-books as scarcely to wear the semblance of a natural science, on the same footing with physics and chemistry, in which the spirit of genuine inductive enquiry into nature had already asserted itself in opposition to the nature-philosophy of the immediately preceding years. It may seem strange to us now to see a text-book of botany introduced by a formal essay, I 3 I pages long, on the inductive method of investigation as opposed to dogmatic philosophy, and to find the principles of induction set forth again and again in connection with a great variety of subjects in the book itself. Many objections may be raised to the contents of this introduction; it may be said that many philosophical dicta are misunderstood in it; that Schleiden himself has frequently offended against the rules there laid down, for instance, when he substitutes a formative impulse (nisus formativus) for the vital force which he rejects, which is only introducing vital force again under 
Igo Morphology and Systematic Botany under [Bоoк I.

another name; that it is superfluous to present the history of development as a 'maxim' in Kant's use of the word, instead of showing that the history of development enters naturally and of itself into inductive investigation, and so on. All this will not lessen the historical importance of this philosophic introduction; the traditional way in which descriptive botany was at that time presented to the student was so thoroughly dogmatic and scholastic, trivial and uncritical, that it was necessary to impress upon him in many words, that this is not the method of true investigation of nature.

Passing on to the more special problems of botanical enquiry, Schleiden next dwells on the history of development as the foundation of all insight into morphology, though he overshot the mark when he rejected as unfruitful the simple comparative method, which had produced considerable results in the hands of De Candolle, and was virtually the fruitful element in the doctrine of phyllotaxis of Schimper and Braun. Still he took an active part himself in the study of development in plants, and gave special prominence to embryology; he also discussed the doctrine of metamorphosis from the point of view of the history of development, and pointed to Caspar Friedrich Wolff's treatment of that subject as much clearer than that which had been introduced by Goethe. Finally, Schleiden's mode of dealing with the natural system must be reckoned among the good services which he rendered to method; not because his classification of the vegetable kingdom presents any specially interesting features or brought to light any new affinities, but because we see an attempt made for the first time to give detailed characters drawn from morphology and the history of development to the primary divisions, and because by this means the positive and distinct nature of the Cryptogams was from the first clearly brought out. The old way of treating morphology, as though there were only Phanerogams in the world, and then having recourse to unmeaning negatives in dealing with the Cryptogams, was 
Chap. v.] the Influence of the History of Development. I I I

thus set aside, much to the profit of the immediate future, which directed its attention specially to the Cryptogams.

Schleiden however did not succeed in securing firm ground for the morphology of the Cryptogams as founded on the history of their development. His investigations into the morphology of the Phanerogams were more successful. His theory of the flower and fruit is an admirable performance for the time, even though we abandon his view of the stalk nature of placentas and some other notions, as we obviously must. As Robert Brown founded the history of the development of the ovule, so Schleiden founded that of the flower, and his example influenced other botanists. Soon investigations into the genesis of the flower was one of the chief occupations of morphologists, and the results of enquiry into development proved to be of great value for the systematic arrangement of the Phanerogams, especially when more exact attention was paid to the sequence of development in the organs of an inflorescence, to abortion, doubling and branching of the stamens, and to the like matters. Duchartre, Wigand, Gelesnoff and many others, were soon working in the same direction with great success. PAYER deserves special mention for his enormous perseverance in examining the development of the flower in all the more important families in his 'Organogénie de la fleur,' I 857, and thus producing a standard work, distinguished alike for the certainty of the observations, the simple unbiassed interpretation of the things observed, and the beauty and abundance of the figures-a work which became more important every year for the morphology of the flower.

Schleiden's text-book was the first of its kind that supplied the student with really good figures based on careful observations. With all its many and obvious defects it had one merit which cannot be rated too highly; its appearance at once put botany on the footing of a natural science in the modern sense of the word, and placed it upon a higher platform, extending its horizon by raising its point of view. 
I92 Morphology and Systematic Botany under [Bоок I.

Botany appeared all at once as a science rich in subjectmatter; Schleiden had not only himself made many investigations and broached new theories, but he everywhere drew attention to what was already before the world and was important; for it is not sufficient as regards the literature of a science that there should be good investigators; it is as necessary that the scientific public, and especially the rising generation of professed students, should be well and sufficiently instructed in the art of distinguishing important from unimportant contributions. It must be distinctly affirmed in this place, that if Schleiden's theory of cell-formation, his strange notion about the embryology of Phanerogams and the like were very quickly shown to be untenable, this does not in the least affect the great historical importance which his writings possess in the sense here indicated.

That others besides Schleiden in the period following I 840 felt strongly, that botany must thenceforward give up its complacent resting in the old ideas, was shown among other things by the addition at this time of new periodicals to the old journal 'Flora.' The 'Botanische Zeitung' was founded by von Mohl and Schlechtendal in I 843 , and the 'Zeitschrift für wissenschaftliche Botanik' by Schleiden and Nägeli. The latter, however, only lived three years, from I 844 to I 846 , and was filled almost entirely with Nägeli's contributions. Both publications expressly set themselves the task of representing the new aims in the science. The immediate consequence was that 'Flora' braced up its energies, and endeavoured to do more justice to the modern spirit ; excellent notices of botanical works now appeared in it under the exclusive management of Fürnrohr.

Schleiden's productivity in the higher sense of the word expended itself in his labours on the elements of scientific botany. His later somewhat discursive writings exerted no great influence on the further development of the science. The ideal which he had set up for scientific botany and had sketched in its larger outlines, could only be realised by the 
Снар.V.] the Influence of the Knowledge of Cryptogams. I93

most persevering labour not of one man only, but of whole generations of observers and thinkers, nor did he apply himself with painful unremitting industry to the attainment of this exalted aim.

Soon after Schleiden's 'Grundzüge' first stirred the scientific world, a man of a very different character of mind began to address himself to the great task. This was CARL NäGELI, whose researches from this time onwards laid the foundations of knowledge in every department of botany. He showed what points were the most immediately attainable, and aided in perfecting the inductive method of enquiry and in advancing the study of the history of development. He did not make discoveries here and there by desultory efforts, but worked with earnest endurance at every question which he took up till he had arrived at a positive result; and this was almost always an enlargement of previous knowledge, and a new foundation on which others might build, and a copious literature be developed.

Nägeli like others felt the necessity of first determining his position with respect to the philosophical principles of the investigation of nature, but he did not proceed to give a general exposition of the inductive method as opposed to the dogmatism of the idealistic school. He went straight to the application of the laws of induction to the most general problems of organic nature, and specially of vegetation. It is easy to say that the task of natural science is simply to deduce conceptions and laws from the facts of experience by aid of exact observation. Many considerations present themselves as soon as the attempt is made to satisfy this demand; for it is not enough merely to accumulate individual facts, the point to which the inductive enquiry is to lead must be kept constantly and clearly before the mind. Nägeli insisted that it is only in this way that facts and observations have any scientific value; that the one important thing is to make every single conception obtained by induction find its place in the scheme of all the rest of our knowledge. With greater con- 
sistency of reasoning than Schleiden, and in entire accordance with the nominalist view of genuine investigation of nature in its sternest opposition to the idealistic school, Nägeli's first principle is not only to deduce conceptions from the observation of phenomena, to classify them and establish their subordination, but to treat these conceptions as mere subjective products of the understanding and employ them as instruments of thought and communication, and to be always ready to modify them as soon as inductive enquiry renders such modification necessary. Till this happens, the conception once laid down and connected with a word is to be strictly adhered to, and every arbitrary change or confusion with another conception is strictly forbidden. Since in nature everything is in movement, and every phenomenon is transitory, presenting itself to us in organic life especially as the history of development, all due regard must be paid to this condition of constant motility in forming scientific conceptions. The history of development is not merely to be treated generally as one of various means of investigation, but as identical with investigation into organic nature. These views are expressed in Nägeli's detailed observations on method in the first and second volume of the journal which he brought out in conjunction with Schleiden in 1844 and 1855 , where the chief hindrance to his carrying them out fully and consistently is also to be found; for, like all his contemporaries, Nägeli believed at that time in the constancy of species, and consistently with this view he looked upon the natural system as a framework of conceptions, though these do not take the form of Platonic ideas with him as with the systematists of the idealistic school. It is equally consistent with his philosophical position, which refused to regard a change in our conceptions as a change in things themselves, that 'the idea of metamorphosis' in the sense of Goethe and Alexander Braun disappears in Nägeli from the field of scientific observation. It has been shown in the previous chapter that what Goethe called 
CHap.V.] the Influence of the Knowledge of Cryptogams. I 95

the normal or ascending metamorphosis has no scientific meaning unless species are supposed to be variable. It appeared moreover that if the Cryptogams are made the chief subjects of investigation, as Nägeli made them, the so-called metamorphosis of the leaves is a phenomenon of secondary importance, and only attains to its full importance in the Phanerogams. If Schleiden, illogically from his point of view, conceived of metamorphosis as the principle of development, Nägeli on the contrary scarcely employed the word. $\mathrm{He}$ regarded the history of development as the law of growth of the organs, and, in accordance with the theory of the constancy of species, the law of growth of every species and every organ was invariable in the same sense in which we apply the term to natural laws in physics and chemistry. In a word, Nägeli's considerations on the 'present task of natural history' in the work above cited, are not only logically and entirely consistent on the principles of the inductive method, but they are also consistent where others have been misled by the theory of the constancy of species into illogical conclusions.

Nägeli set himself in earnest to meet the demands of inductive enquiry, such as he had himself described them. It will be shown more in detail in the history of phytotomy, how he satisfied these demands in his refutation of Schleiden's doctrine of the cell, and in the establishment of his own, and at a later time in the framing of his theory of molecular structure and of the growth of organised bodies, and how he made these investigations true models of genuine inductive enquiry. Here we are concerned only with what he effected in this way for morphology and systematic botany. In this field of research he introduced two innovations of the profoundest importance, which affected both the aim and method of enquiry for some years. He connected his own morphological investigations, as far as possible, with the lower Cryptogams, extending them afterwards to the higher Cryptogams and to the Phanerogams; that is, he proceeded from simple and plain facts to the more 
I96 Morphology and Systematic Botany under [Воок I.

difficult, thus not only introducing the Cryptogams into the field of systematic investigation, but making them its startingpoint. In this way morphology not only secured a foundation in exact historical development, but it assumed a different aspect, inasmuch as the morphological ideas hitherto drawn from the Phanerogams were now examined by the light of the history of development in the Cryptogams. This was one innovation; the second, closely connected with it, was the way in which Nägeli made the new doctrine of the cell the starting-point of morphology. Both the first commencement of organs and their further growth were carried back to the formation of the separate cells; and the remarkable result was to show, that in the Cryptogams especially, whose growth is intimately connected with cell-division, precise conformity to law obtains in the succession and direction of the dividing walls, and that the origin and further growth of every organ is effected by cells of an absolutely fixed derivation. The most remarkable thing was, that every stem and branch, every leaf or other organ has a single cell at its apex, and that all succeeding cells are formed by division of this one cell according to fixed laws, so that the origin of all cell-tissue can be traced back to an apical cell; and as early as the years 1845 and 1846 Nägeli described in the 'Zeitschrift für wissenschaftliche Botanik' the three main forms, according to which the segmentation of an apical cell proceeds, namely, in one, two, and three rows (Delesseria, Echinomitrium, Phascum, Jungermannia, Moss-leaves). In this way the separate points in the history of growth in the Cryptogams were brought out with unusual clearness and decision; but on the other hand, Nägeli showed in 1844 in the case of a genus of Algae (Caulerpa) that the growth of a plant may show the usual morphological differentiation into axis, leaf, and root, when the propagative cell undergoes no celldivisions in the process of development and further growth, and similar conditions were for the first time demonstrated in I 847 in Valonia, Udotea, and Acetabularia. Beside other 
results it was established by these facts, that morphological differentiation during growth must not be regarded as an effect of cell-divisions, and from such cases as these the conception of the cell experienced a notable expansion.

Moreover, Nägeli was not satisfied with seeking instructive examples for general morphological axioms in the lower Cryptogams; he devoted special study to the Algae for systematic and descriptive purposes; and his 'Neuen Algensysteme,' which appeared in 1847 , and 'Gattungen einzelliger Algen,' of I 849 , were the first successful attempts to substitute serious investigation for the mere zeal of the collector in this part of the vegetable kingdom, which had not indeed been hitherto neglected, but had not been systematically worked since the time of Vaucher. In the same spirit Alexander Braun also in his 'Verjüngung' contributed a rich material of new observations on the mode of life of the Algae and the morphological conditions connected with it, and his labours were followed in the succeeding years by the important researches of Thuret, Pringsheim, De Bary, and others, to which we shall recur in a later portion of this history.

But before the examination of the Algae, and soon after of the Fungi also, led to such great results, the systematic botany of the higher plants underwent important changes through the methodical study of the embryology of the Muscineae and Vascular Cryptogams. These groups had been frequently and carefully examined by good observers since the last century, and the systematists, without penetrating deeply into the peculiarities of their organisation, had brought the species and genera, the families and even the higher divisions into tolerable order. Comprehensive and methodically arranged catalogues of these plants had been formed, and attempts had been made to explain their morphology by that of the Phanerogams; Schmidel ${ }^{1}$ published valuable observations on the Liverworts

${ }^{1}$ Casimir Christoph Schmidel was born in 1718 and died in $179^{2}$; he was 
in the year $175^{\circ}$, Hedwig especially on the Mosses in 1782 ; these works were followed by Mirbel's thorough examination of Marchantia in 1835 , by Bischoff's of Marchantieae and Riccieae, by Schimper's study of the Mosses in $185^{\circ}$, and by Lantzius Beninga's ${ }^{t}$ contributions to the knowledge of the structure of the moss-capsule in 1847 . The organisation, and to some extent the germination, of the Vascular Cryptogams had become better known since 1828 through Bischoff's ${ }^{2}$ researches; Unger had as early as I 837 described the spermatozoids in the antheridia of various Mosses, Nägeli had discovered them on an organ of the Ferns which had up to that time been taken for the cotyledonary leaf of these plants, and on the same part of the plant Suminski in 1848 observed the female sexual organs and the entrance of the spermatozoids into them. The history of the germination of the Rhizocarps, from which Schleiden thought that he had proved his erroneous theory of fertilisation with more than usual certainty, had been examined some years before by Nägeli, and also by Mettenius, in great detail; here too Nägeli detected the spermatozoids. Thus important fragments of the life and organisation of these plants had been described up to the year I 848 , but until they were more fully understood and connected together they had but little scientific value, the one fact perhaps excepted, that fertilisation in the Cryptogams

Professor of Medicine in Erlangen, and was the first who described the sexual organs in various Liverworts.

1 Lantzius Beninga, born in East Friesland in $\mathbf{~} 815_{\mathbf{5}}$, was a professor in Göttingen, and died in $187 \mathrm{I}$.

${ }^{2}$ Gottlieb Wilhelm Bischoff was born at Dürkheim on the Hardt in 1797 , and died as Professor of Botany at Heidelberg in 1854 . He wrote various manuals and text-books which are careful and industrious compilations, but being entirely conceived in the spirit of the times preceding Schleiden they are now obsolete; his investigations however into the Hepaticae, Characeae, and Vascular Cryptogams, illustrated by very beautiful drawings from his own hand, are still of value; and the same may be said of his 'Handbuch der botanischen Terminologie und Systemkunde' on account of its numerous figures. 
as in animals was effected by spermatozoids. A perfect insight into the embryological conditions in question could only be obtained when the embryology of the Phanerogams especially had been cleared up, for according to Schleiden's theory, which made the pollen-tube enter the embryo-sac in the ovule and develop into the embryo, the ovule was no longer to be regarded as a female sexual organ, but only as a place of incubation for the embryo, which was thus really produced asexually. This important question was set at rest by Wilhelm HofmeisTER'S work, 'Die Entstehung des Embryos der Phanerogamen,' which appeared in I849. In this work, and in a series of subsequent treatises, he showed that the egg-cell is formed in the embryo-sac before fertilisation, and that it is this which is excited to further development by the appearance of the pollen-tube, and produces the embryo. Hofmeister had observed the organisation of the ovule, the nature of the embryo-sac, and of the pollen-grain, and the formation of the embryo from the fertilised egg-cell step by step and cell by cell, and his account of these processes was aided by the light which Nägeli's theory of the cell, and his reference of all processes of development to the processes of cell-formation, had thrown upon the history of development. He went on to apply the same method to the study of the embryology of the Muscineae and the Vascular Cryptogams, and followed the development of the sexual organs cell by cell in a large number of species; he observed the origination of the egg-cell which was to be subsequently fertilised, and the formation of spermatozoids, and above all he showed the divisions which take place in the fertilised egg-cell, and the relation of its segments to the further growth of the sexual product in course of formation. The whole course of development in the Muscineae and Vascular Cryptogams displayed a return twice repeated to the single cell as the starting-point in each case of a new phase of development ; the true relation between the asexually produced spore and its germ-product on the one side, and the sexually generated 
embryo on the other, and their significance in the history of development, were brought out clearly by Hofmeister's investigation, while the exactness of his method rendered lengthy discussions on the subject unnecessary. With these embryological processes, especially those of the Rhizocarps and Selaginellae, in which the presence of two kinds of spores was now for the first time correctly interpreted, Hofmeister compared the embryology of the Conifers, and by their aid that of the Angiosperms also.

The results of the investigations published in the "Vergleichende Untersuchungen' in 1849 and $185 \mathrm{I}$ were magnificent beyond all that has been achieved before or since in the domain of descriptive botany; the merit of the many valuable particulars, shedding new light on the most diverse problems of the cell-theory and of morphology, was lost in the splendour of the total result, which the perspicuity of each separate description revealed to the reader before he came to the conclusion of the work, and there a few words in plain and simple style gave a summary of the whole. Briefly to describe this result in all its importance for botanical science is a difficult task; the idea of what is meant by the development of a plant was suddenly and completely changed; the intimate connection between such different organisms as the Liverworts, the Mosses, the Ferns, the Equisetaceae, the Rhizocarps, the Selaginellae, the Conifers, the Monocotyledons, and Dicotyledons could now be surveyed in all its relations with a distinctness never before attained. Alternation of generations, lately shown to exist though in quite different forms in the animal kingdom, was proved to be the highest law of development, and to reign according to a simple scheme throughout the whole long series of these extremely different plants. It appeared most clearly in the Ferns and Mosses, though at the same time with a certain difference in each; in the Ferns and allied Cryptogams a small inconspicuous body grows out of the asexually produced spore, and immediately produces the sexual organs; from the 
fertilisation of these organs proceeds the root-bearing and leafy stem of the Fern, which in its turn again produces only asexual spores. In the Muscineae, on the other hand, a much differentiated and usually long-lived plant is developed from the spore, and this plant proceeds again after some time to form sexual organs, the product of which is the so-called Moss-plant. The first generation that arose from the spore, the sexual, is in the Muscineae the vegetative plant, while in the Ferns and their allies the whole fulness of vital activity and of morphological differentiation is unfolded in the second generation which is asexually produced. Here all was at once clear and obvious ; but Hofmeister's researches also showed that the same scheme of development holds good in the Rhizocarps and Selaginellae where two kinds of spores are formed; and it appeared plainly from their case that the recognition of the true relation between the production of spores and sexual organs is the guide to the morphological interpretation. When the processes in the large female spore of the most perfect of the Cryptogams was known, the formation of the seeds in the Conifers was at once understood; the embryo-sac in these answered to this large spore, while the endosperm represented the prothallium, and the pollengrain the microspore; the last trace of alternation of generations, so obvious in the Ferns and Mosses, was seen in the formation of the seed in the Phanerogams. The changes, which the alternation of generations passes through from the Muscineae upwards to the Phanerogams, were, if possible, still more surprising than the alternation of generations itself.

The reader of Hofmeister's 'Vergleichende Untersuchungen' was presented with a picture of genetic affinity between Cryptogams and Phanerogams, which could not be reconciled with the then reigning belief in the constancy of species. He was invited to recognise a connection of development which made the most different things appear to be closely united together, the simplest Moss with Palms, Conifers, and angiospermous trees, and which was incompatible with the 
202 Morphology and Systematic Botany under [Воок I.

theory of original types. The assumption that every natural group represents an idea was here quite out of place; the notion entertained up to that time of what was really meant by the natural system had to be entirely altered; it could as little pass for a body of Platonic ideas as for a mere framework of conceptions. But the effect of the work was great in respect to the system also; the Cryptogams were now the most important objects in the study of morphology; the Muscineae were the standard by which the lower Cryptogams must be tried, the Ferns were the measure for the Phanerogams. Embryology was the thread which guided the observer through the labyrinth of comparative and genetic morphology; metamorphosis now received its true meaning, when every organ could be referred back to its parent-form, the staminal and carpellary leaves of the Phanerogams, for example, to the spore-bearing leaves of the Vascular Cryptogams. That which Häckel, after the appearance of Darwin's book, called the phylogenetic method, Hofmeister had long before actually carried out, and with magnificent success. When Darwin's theory was given to the world eight years after Hofmeister's investigations, the relations of affinity between the great divisions of the vegetable kingdom were so well established and so patent, that the theory of descent had only to accept what genetic morphology had actually brought to view.

So gorgeous a picture as Hofmeister had designed of the genetic connection of the vegetable kingdom, except the Thallophytes, could not possibly be completely perfect and correct in all its separate features; there were still many gaps to fill up and particular observations to correct. Hofmeister himself continued his labours; the remarkable genera Isoetes and Botrychium were in the following years more carefully studied by himself, the fertilisation and embryology of the Equisetaceae by himself and Milde, and those of Ophioglossum by Mettenius, and all were fitted into their place in the system. To the present day it is always a profitable 
CHAр.V.] the Influence of the Knowledge of Cryptogams. 203

task to submit the different forms of the Muscineae, the Vascular Cryptogams, and the Gymnosperms to exact investigation in order to ascertain all the details in the process of development in these plants, the formation of the embryo, the succession of cells at the apex, the first appearance and further growth of the lateral organs; and the more careful the observation, the more clearly even to its farthest results does the correctness of the alternation of generations asserted by Hofmeister everywhere appear. It does not fall within the limit of this history to pursue the subject further, and to show how the doctrine of alternation of generations and the knowledge of the morphology of the Cryptogams were further advanced by later and distinguished researches, such as those of Cramer on the Equisetaceae, of Pringsheim on Salvinia (1862), of Nägeli and Leitgeb on the formation of roots in the Cryptogams, of Hanstein on the germination of the Rhizocarps, and of others.

\section{THALLOPHYTES.}

The method of investigation which starts from the first steps towards the formation of the embryo before and after fertilisation, and follows the advancing segmentation and growth through all the stages of development up to the final completion of the embryo-plant, has led since I $85^{\circ}$ in the case of the Muscineae, Vascular Cryptogams, and Phanerogams to great certainty in the morphological explanation of the organs, while the determination of affinities has ceased to be arbitrary and insecure ; the way was now known which would lead to the desired end, whenever it was sought to establish the affinities of a genus of Cryptogams or of the larger groups of Phanerogams; the day of ingenious guessing and trying was over; the only plan was patient investigation, and this always yielded a result of lasting value.

The case was quite different with the Thallophytes still in 
204 Morphology and Systematic Botany under [Book I.

I850; what was certainly known about them only showed how uncertain the rest was; the Algae, Fungi, and Lichens presented a chaotic mass of obscure forms in contrast with the well-ordered knowledge of the Muscineae and Vascular plants. In the Mosses and Ferns the series of developments within the limits of the species was so set forth in its several stages, that all the important points in the advancing growth were clearly ascertained, while the alternation of generations at once sharply distinguished and connected together the chief sections in the development; on the other hand the development of the Algae and Fungi seemed to break up into a disorderly and motley throng of forms that appeared and disappeared, and it seemed scarcely possible to discover their regular genetic connection. Here the important point was to determine which of the known forms belonged to one and the same cycle of development, for these plants go back at the most various stages of development to the segregation of single cells, which are the beginning of a new development either repeating or carrying on the old one. The beginnings of the most different species of Algae lay mixed up together in the same drop of water, those of quite different Fungi grew together and even upon one another on the same substratum; in the Lichens, Fungus and Alga were united together. Such was the case with the small and microscopic species; the large Seaweeds, the Mushrooms, and the large Lichens were easier to distinguish specifically, but less if possible was known of their development than of that of the microscopic Thallophytes.

Nevertheless the knowledge of individual forms in these organisms had been considerably extended before $185^{\circ}$. Collectors and amateurs, intent only on determining what is immediately presented to the eye and making little enquiry into origin and affinities, were indefatigable in adding to their collections, and made catalogues and proposed various systems founded on external marks taken at pleasure. The names of species were counted by thousands, their characters filled thick 
Cнар.V.] the Influence of the Knowledge of Cryptogams. 205

volumes and the figures large folios; the abundance of forms in the Thallophytes proved to be so great that many botanists devoted their whole attention to them, many collected and described only the Algae, others only the Fungi and Lichens. It is true that a deeper insight into the connection of these forms of life with one another and with other plants was not to be obtained in this way; still an empirical basis was formed for a knowledge of the Cryptogams, such as had been established for the Phanerogams by the herbals of the $\mathrm{I} 7$ th century. All forms open to observation were named and arranged in one way or another; and there was no difficulty in understanding what form was meant, when names, or tables and figures, were cited from the various books. Of such works, those of Agardh $^{1}$, Harvey, and Kützing on the Algae, those of Nees von Esenbeck ${ }^{2}$, Elias Fries, Léveillé, and Berkeley on the Fungi, and especially Corda's elaborate work on the latter plants are the most valuable.

1 Karl Adolf Agardh (I $75^{-1859}$ ) was until I835 Professor in Lund, afterwards Bishop of Wermland and Dalsland. Jacob Georg Agardh, born in I 8I3, was Professor in Lund. William Henry Harvey (I8I I-I866) was Professor of Botany in Dublin. Friedrich Traugott Kützing, born in I80\%, was Professor in the Polytechnic School of Nordhausen.

${ }^{2}$ C. G. Nees von Esenbeck published his 'System der Pilze und Schwämme' in I8I6; Th. F. L. Nees von Esenbeck, in conjunction with A. Henty, a 'System der Pilze' in 1837 . The first $\left(177^{6-1858)}\right.$ was for a long time President of the Leopoldina, Professor of Botany in Breslau, and one of the chief representatives of the nature-philosophy. Elias Fries, born in 1794 , became Professor of Botany in Upsala in 1835 ; he died in 1878 . Léveillé (1796-1870) was a physician in Paris. Angust Joseph Corda was born at Reichenberg in Bohemia in 1809 , and became custodian of the National Museum in Prague in 1835 ; he undertook a journey to Texas in I 848 , from which he never returned, having probably perished by shipwreck in I 849. Weitenweber, in the 'Abhandlungen der Böhmischen Gesellschaft der Wissenschaft,' Bd. 7, Prag, 1852, gives a full account of this eminent mycologist. Corda was the first who thoroughly applied the microscope to copying and describing every form of Fungus that was known to him, and especially the minuter ones. His 'Icones Fungorum hucusque cognitorum' $(1837-1854)$ are still an indispensable manual in the study of the subject. 
206 Morphology and Systematic Botany under [Bоок I.

The views entertained on the subject of the development and propagation of the lower Cryptogams down to the year $185^{\circ}$ were very uncertain and fluctuating. In some Algae, Fungi, and Lichens certain organs of multiplication and propagation were known, in others they were quite unknown; some forms appeared in places and under circumstances which seemed to necessitate the assumption of spontaneous generation; in 1827 Meyen declared that the small Algae, known as 'Priestley's matter,' which are formed in stagnant water and even in closed vessels, are produced by free generation, and Kützing endeavoured to show this by experiment in 1833 ; some Fungi were regarded as diseased growths from other organisms, many were supposed to spring up spontaneously, though they might be capable at the same time of propagating themselves by spores; this view was shared by even the best botanists with regard to the most simple Fungi up to 1850 . But the systematic investigation of the Algae and Fungi was as little hindered by the notion of spontaneous generation after $185^{\circ}$ as that of Phanerogams had been in the 17 th century by the same notion; it was however at first affected by the view put forth by Hornschuch in 1821 and by Kützing in 1833 , that the simplest of all Alga-cells (Protococcus and Palmella), once produced spontaneously, could develop according to circumstances into a variety of Algae, and even of Lichens and Mosses; as some observers even now consider Penicillium and Micrococcus to be the starting-points of very different Fungi. There was a difficulty also in drawing the boundaryline between the lower animals and plants; the difficulty was solved by classing all objects capable of independent movement with animals; thus whole families of Algae (the Volvocineae, Bacillariaceae, and others) were claimed by the zoologists, and when the swarmspores of a genuine Alga were seen for the first time in the act of escaping, the phenomenon was described as the changing of the plant into an animal. Trentepohl in 1807 , and Unger in 1830 , explained in this way 
Cнар. ${ }^{\text {v.] }}$ the Influence of the Knowledge of Cryptogams. 207

the escape of the zoospores of Vaucheria. The remarkable thing is, not that such views were entertained, but that the majority of botanists combined with them a belief in the constancy of species. But this dogma rendered good service to the science in this instance, for the botanists, who at a later time applied themselves to the systematic examination of the Algae and Fungi, confided in the constancy of the processes of development in each species, which they expected would assert itself in these forms as in the Mosses and higher plants.

With much that was obscure and doubtful, the result of occasional observation accompanied by uncritical interpretation, the literature of the subject had contained for some time a certain number of single well-established facts of real importance, which were well adapted to serve as starting-points for earnest and exact investigation. Among the Algae the genera Spirogyra and Vaucheria especially had supplied remarkable phenomena; Joseph Gärtner observed the formation of zygospores in Spirogyra in 1788 , Hedwig saw in the mode of their production at least a suggestion of sexuality ( $\left.179^{8}\right)$, and Vaucher', in his 'Histoire de Conferves d'eau douce,' which appeared in 1803 and was far in advance of its time, called conjugation distinctly a sexual process; the optical means at his disposal did not enable him to observe the fertilisation in Vaucheria (Ectosperma), which was named after him, though he described the sexual organs accurately; the movement also of the zoospores in this genus escaped him, and Trentepohl first observed their escape and swarming in $1807^{2}$. Vaucher had also observed the formation of new nets in the old cells of Hydrodictyon, and Areschoug repeated the observation in $\mathbf{I} 84_{2}$, when he saw the swarming of young cells in the old ones. Bischoff, as early as 1828 , saw the spermatozoids of

1 Jean Pierre Étienne Vaucher, the instructor and friend of P. de Candolle, was a minister and professor in Geneva.

${ }^{2}$ Trentepohl's communication is to be found in the 'Botanische Bermerkangen und Berichtigungen' of A. W. Roth, Leipsic, 1807 . 
Chara, though without understanding them. Observations on conjugating Algae were multiplied; Ehrenberg in I834 saw corresponding phenomena in Closterium, and Morren described them more exactly in 1836 . The formation of swarmspores in fresh-water and salt-water Algae was frequently observed between 1820 and I 830 , and in his 'Neues System,' iii, which appeared in 1839 , Meyen gave a summary of all that was known up to that time of the propagation of the Algae. But a new aspect was given to the knowledge of the Algae by those researches of Nägeli between the years 1844 and 1849 , which have been already mentioned, and which are the first since Vaucher's time that can be regarded as systematic. Nägeli studied especially the laws of cell-division in sexual multiplication and growth, but he considered the Florideae to be the only Algae that were sexually differentiated, and distinguished the rest as being without sexuality. Braun in his 'Verjüngung' (I850) made numerous contributions to the biology of the fresh-water Algae, affording many and most interesting glimpses into a connection still little understood between these forms; and in $185^{2}$ he gave an account of the history of growth in the Characeae, a work conceived in Nägeli's spirit and a model of scientific research, in which the mode of derivation of every cell from the apical cell of the stem was shown, the sexual organs were minutely examined, and the relation established between the direction of the 'streaming' of the cell-contents and the morphology of the organs. Gustav Thuret had already made the zoospores of the Algae the subject of detailed examination.

Such was the condition of affairs with respect to the Algae about the year I 850 , when Hofmeister made the formation of the embryo in the Phanerogams, the Vascular Cryptogams, and the Muscineae the central point of investigation in morphology and systematic botany. He made it clear that a perfect insight into the whole cycle of development in the plant and into its affinities can only be obtained, if we succeed 
Снар. v.] the Influence of the Knowledge of Cryptogams. 209

in making its sexual propagation, the first commencement of the embryo, the starting-point of the investigation. It was natural to expect as happy results from the embryology of the Algae, as had been obtained in the case of the higher plants; it was important therefore, that the observer should no longer rest satisfied with a knowledge of the sexual multiplication of the Algae ; he must enquire into their asexual propagation, and by its aid discover the complete history of their development. Former observations suggested the probability that here too sexual propagation is the prevailing rule; but it was easy to foresee that it would be a task of great labour to make out a connected history of development, a task of which the collectors who liked to call themselves systematists had never formed a conception; but Nägeli's and Hofmeister's researches had made botanists familiar with the highest demands of this kind, and the men who were to gain new conquests for genuine science were already engaged in the work in $185^{\circ}$. A splendid result appeared in 1853 , in Thuret's account of the fertilisation of the genus Fucus; this was a simple process as a matter of embryology ; but the sexual act was so clear, and even open to experimental treatment, that it threw light at once upon other cases more difficult to observe. Then followed discoveries of sexual processes in rapid succession; Pringsheim solved the old enigma in Vaucheria in 1855 , and between 1856 and 1858 in the Oedogonieae, Saprolegnieae and Coleochaetae; in 1855 Cohn observed the sexual formation of spores in Sphaeroplea. Pringsheim however was not content with carefully observing the sexual act; he gave detailed descriptions of growth in the same families in its progress cell by cell, of the formation of the sexual organs, and the development of the sexual product. The asexual propagations which are intercalated into the vegetation and embryology were shown in their true connection. Processes were recognised which often recalled the alternation of generations in the Mus- 
2 IO Morphology and Systematic Botany under [Bоoк I.

cineae ; it was shown that very different forms of sexuality and of general development occur in the Algae, and these led to the formation of systematic groups, quite different from those founded on the superficial observation of collectors. It soon appeared in the Algae, and later in the Fungi and Lichens, that special investigation must lay new foundations for the system. From the confused mass of forms not before understood, Pringsheim brought out a series of characteristic groups, which, thoroughly examined and skilfully described in words and by figures, stood out as islands in the chaotic sea of still unexamined forms, and threw light in many ways on all around them. In like manner the morphology of the Conjugatae was thoroughly examined by De Bary before I860; fragments of the history of development in the Algae were added by Thuret, and he and Bornet cleared up the remarkable embryology of the Florideae in 1867 , while Pringsheim established the pairing of the swarm-spores in the Volvocineae in 1869. The Algae offer at present a greater variety in the processes of development than any other class of plants; sexual and asexual propagation and growth work one into the other in a way which opens entirely new glimpses into the nature of the vegetable world.

The old conceptions of the nature of plants had been greatly modified by Hofmeister's discovery of the alternation of generations, and the reduction to it of the formation of the seed in Phanerogams; in like manner the first beginnings of plant-life, the simplest forms of Algae, exhibit phenomena, which compel us to revise our fundamental conceptions of morphology, if we are ever to be able to give a systematic view of the whole vegetable kingdom.

The methodical examination of the Fungi after 1850 led to similar but still more comprehensive results. From earliest times the Fungi had been objects of wonder and superstition; what Hieronymus Bock said of them has been told in the first chapter ; this was repeated by Kaspar Bauhin, and similar 
Cнар. V.] the Influence of the Knowledge of Cryptogams. 2 I I

notions existed till late into our own century; about the middle of the 17 th century Otto Von Münchausen thought that mushrooms were the habitations of Polypes, and Linnaeus assented to that view. What the nature-philosophers, as Nees von Esenbeck for instance, had to say on the nature of Fungi, need not be reproduced here.

Still some useful observations had been accumulating for some time on this subject; as early as 1729 Micheli ${ }^{1}$ had collected the spores of numerous Fungi, had sown them and obtained not only mycelia but also sporophores (fructifications), and Gleditsch confirmed these observations in 1753 ; Jacob Christian Schaeffer ${ }^{2}$ about the year 1762 published very good figures of all the Fungi of Bavaria and the Palatinate, and collected the spores of many species. Yet Rudolphi and Link at the beginning of the present century ventured to deny the germination of the spores of Fungi; Persoon in 18 I 8 thought that some Fungi grow from spores, others from spontaneous generation. A decided improvement appears after 1820 in the views of botanists with respect to Fungi, and to this Ehrenberg's elaborate essay, 'De Mycetogenesi,' published in that year in the Leopoldina, contributed greatly. In that work he collected together all that was then known on the nature and propagation of the Fungi, and communicated observations of his own on spores and their germination; he gave figures also of the course of the hyphae in large sporophores and in other parts, but his most important service was a description of the first observed case of

1 Pier' Antonio Micheli, born at Florence in 1679 , was Director of the Botanic Garden there, and died in I 737. Johann Jacob Dillen (Dillenius), born in Darmstadt in 1687 , was Professor of Botany in Oxford, and died in I 747. These two botanists were the first who submitted the Mosses and the lower Cryptogams to scientific examination, and endeavoured to prove the presence of sexual organs in these plants.

2 Jacob Christian Schaeffer, born in 17 I8, was Superintendent in Regensburg; he died in 1790 . 
2 I 2 Morphology and Systematic Botany under [Boox I.

sexuality in a Mould, namely, the conjugation of the branches of Syzygites. In the same year Nees von Esenbeck sowed Mucor stolonifer on bread, and obtained ripe sporangia in three days (Flora, I820, p. 528); Dutrochet proved in 1834 (Mém. ii. p. I73) that the larger Fungi are only the sporophores of a filiform branching plant, which spreads usually under ground or in the interstices of organic substances, and had been till that time regarded as a peculiar form of Fungus under the name of Byssus. Soon after, Trog (Flora, I837, p. 609) carried these observations further; he distinguished the mycelium from the sporophore, and pointed out that the former is often perennial and is the first product of the germinating spores. He made an attempt to examine the morphology of the larger sporophores, and showed that it was possible to collect the spores of mushrooms on paper, and that those of Peziza and Helvella are forcibly ejected in little clouds of dust; he also produced new proofs of Gleditsch's statement, that the spores of Fungi are disseminated everywhere by the air. Schmitz published in 'Linnaea,' between the years 1842 and 1845 excellent observations on the growth and mode of life of several of the larger Fungi. It was not unnecessary at that time to make it clearly understood that the spores of Fungi reproduce their species exactly.

But the lower, the small and simple Fungi, those especially which are parasitic on plants and animals, were the most attractive objects in the whole field of mycology. Here were difficulties in abundance, here were the darkest enigmas with which botany has ever had to deal, here was new ground to be slowly won by extreme scientific circumspection and foresight. In these forms, as in the Algae, the first thing to be done was to make out the complete history of development in a few species; but it was much more difficult in the Fungi than in the Algae to discover what properly belonged to one cycle of development, and to separate it from casual phases of develop- 
Снар. v.] the Influence of the Knowledge of Cryptogams. 213

ment of other associated Fungi. The merit of first breaking ground in this direction belongs to the brothers Tulasne, who published before $185^{\circ}$ the first more exact researches into the Smuts and Rusts; these were followed by a long series of excellent works on different forms of Fungi, especially the subterranean, whose mode of life and anatomy were described and illustrated by splendid figures; but their account of the development of Ergot of rye (1853), their further investigations into the formation of the spores and the germination of Cystopus, Puccinia, Tilletia, and Ustilago, and their discovery of the sexual organs in Peronospora before I86I, were of greater theoretical importance. The 'Selecta Fungorum Carpologia,' which appeared in three volumes from I 86 I to I 865 with fine figures, some of which represented the process of development, contributed greatly to the reformation of mycology. Meanwhile, Cessati had published investigations into the Muscardinefungus of the silkworm-caterpillar, and Cohn into a remarkable Mould, the Pilobolus.

But mycology owes its present form to none more than to AnTON DE BARY, whose writings, the fruit of twenty years' labour, it would take too much space to enumerate one by one. With a correct understanding of the only means which can lead to sure results in this difficult branch of study, De Bary made it his first endeavour to perfect the methods of observation, and not only sought for the stages of development of the lower Fungi in their natural places of growth, but cultivated them himself with all possible precautions, and thus obtained complete and uninterrupted series of developments. By these means he succeeded in proving that parasitic Fungi make their way into the inside of healthy plants and animals, and that this is the explanation of the remarkable fact, that Fungi live in the apparently uninjured tissue of other organisms, a fact which formerly had led to the supposition that such Fungi owe their origin to spontaneous generation, or to the living contents of the cells of their entertainers. Pringsheim had already 
observed these occurrences in $185^{8}$ in the case of an unusually simple water-fungus (Pythium). De Bary showed that the intrusive parasite vegetates inside the plant or animal which is its host, and afterwards sends out its organs of propagation into the open air, and that at a given time the organism attacked by the fungus sickens or dies. These investigations were not only of high scientific interest to the biologist, but they produced a series of results of the greatest importance to agriculture and forestry, and even to medicine.

With the Fungi, even more than with the Algae, the chief difficulty in making out a complete series of developments in the history of each species arose from the frequent intercalation of the asexual mode of multiplication into the course of its development, and in the further peculiarity, that the several stages of development in some cases could only be completed on different substrata. One of the most important tasks was to find the sexual organs, the existence of which was rendered probable by various analogies, and after De Bary had observed the sexual organs in the Peronosporeae in I86I, he succeeded in 1863 in proving for the first time that the whole fruit-body of an Ascomycete is itself the product of a sexual act, which takes place on the threads of the mycelium.

The literature of mycology based on De Bary's methods of observation and its actual results has been enriched by others also in various directions since r 860 ; in the case of the Fungi, as in that of the Algae, it is not possible yet to see to what results investigation will ultimately lead; but it is one of the fairest fruits of strictly inductive method, that it has succeeded in smoothing this thorny and indeed perilous route, where the enquirer is constantly in danger of being misled, and in satisfying the severest demands of science. Conclusions have been already reached that are important for morphology and systematic botany, and among these the establishment of the nature of the large sporophores, and of processes similar to the alternation of generations in the higher Cryptogams should be 
especially mentioned. But the most important result remains to be told; it is, that the two classes of Algae and Fungi, hitherto kept strictly separate, must obviously be now united, and an entirely new classification adopted, in which Algae and Fungi recur as forms differing only in habit in various divisions founded on their morphology ${ }^{1}$.

A few words must be given here to the Lichens. They are the division of the Thallophytes, whose true nature was last recognised, and that only in modern times; till after 1850 scarcely more was known of their organisation than Wallroth had discovered in $1825^{2}$, namely, that green cells, known as gonidia are scattered through the fungus-like hyphal tissue of the thallus. After Mohl's investigations in 1833 , it was known that free spores were formed in the tubes of the fructifications (apothecia), and that a dust collected from the thallus and consisting of a mixture of gonidia and hyphae was in a condition to propagate the species. The genetic relation between the chlorophyll-containing gonidia and the fungus-like hyphae long continued to be obscure, till at last, after I868, it was shown that the gonidia are true Algae, and the hyphal tissue a genuine Fungus, and that therefore the Lichens are not a class co-ordinating with the Algae and Fungi, but a division of Ascomycetes, which have this peculiarity, that they spin their threads round the plants on which they feed, and take them up into their tissue. De Bary suggested this explanation, but it was Schwendener who adopted it without reserve and openly declared it, as much to the surprise as the annoyance of Lichenologists. It may be foreseen that their opposition will yield to the weight of facts, which already leave no doubt in the minds of the unprejudiced.

Thus researches in the domain of the Thallophytes have led

1 See Sachs, 'Lehrbuch der Botanik,' ed. 4 (I874), p. 245.

${ }^{2}$ Fr. Wilh. Wallroth, born in the Harz in $179^{2}$, was district physician at Nordhausen. He died in 1857 . See 'Flora' for 1857 , p. 336 . 


\section{Morphology and Systematic Botany.}

during the last twenty years to a complete revolution in the views entertained with respect to the nature of these organisms, and enriched botany with a series of surprising achievements ; and the movement there is still far from having come to an end. But we must regard it as one of the great results for the whole science that through the examination of the lower and higher Cryptogams, morphology and systematic botany have been rescued from many ancient prejudices, that the survey has become freer, the methods of investigation surer, the questions more clearly seen and put in more definite form. 


\section{SECOND BOOK}

HISTORY OF VEGETABLE ANATOMY

$$
\text { (1671-1860) }
$$





\section{N T R O D U C T I O N.}

That the substance of the more perfect plants consists of layers of different constitution was a fact that could not escape the most untutored observation in primitive times; ancient languages had still words to designate the most obvious anatomical components of plants, rind, wood and pith. It was also easy to perceive that the pith consists of an apparently homogeneous succulent mass, the wood of a fibrous substance, while the rind of woody plants is composed partly of membranous layers, partly of fibrous and pith-like tissue. The obtaining of threads for spinning from the rind of the flaxplant, for instance, must have suggested some idea, if only a vague one, in the earliest ages of the way, in which the fibrous could be separated from the pulpy part of the bark by decay and mechanical treatment. Neither Aristotle nor Theophrastus failed to compare these components of vegetable substance with corresponding ones in animal bodies, and it has been already shown in the first book how Cesalpino, following his masters, took the pith for the truly living part of the plant and the seat of the vegetable soul, and applied this idea in his morphology and physiology. He remarked that the root generally has no pith, and that the part of the root which answers to the wood of the stem is often soft and fleshy; the composition of the leaves from a green and succulent substance and strands of fibres at once suggested a certain resemblance to the green rind of the stem; and it was evidently this which led him to consider that not only the leaves, but also the leafforms of the flower-envelopes had their origin in the rind of the 
stem, while the soft, pulpy, succulent condition of the unripe seeds and seed-vessels seemed to point to their identity with the pith. That not only are juices contained in plants, but that they must move in them, could not escape the simplest reflection; and further, the bleeding of the vine, the flow of gum from resiniferous trees, the gushing of a milky juice from the wounds of certain plants, exhibited so striking a resemblance to the bleeding of a wound in the body of an animal, that the idea of canals inside the plant, which, like the veins in animals, contain those juices and set them in motion, appeared quite natural, as we see plainly from Cesalpino's reflections on these structural conditions. If we add that it was known that the seeds are enclosed in the fruits, and that the embryo, together with a pulpy mass (cotyledons and endosperm), are in their turn enclosed in the seed, we have pretty well the whole inventory of phytotomic knowledge up to about the middle of the seventeenth century.

With careful preparation and skilful dissection of suitable parts of plants, and attentive consideration of the changes produced by decay and corruption, anatomical knowledge might have been considerably enlarged at an earlier time; but seeing is an art that must be learnt and cultivated; a definite aim and end must stimulate the observer into willingness to see exactly, and to distinguish and connect together correctly what he sees. But this art of seeing was not far advanced in the middle of the $x 7_{\text {th }}$ century. All that was achieved in this direction did not go beyond the distinguishing the outer organs of leaf-forms and stem-forms, and we have seen in the first book how unsuccessful was the attempt to distinguish the minuter parts of the flower and fruit.

The invention of the microscope made small things seem large, and revealed to sight what was too small to be seen without it; but the use of magnifying glasses brought an advantage with it of a different kind-it taught those who used them to see scientifically and exactly. In arming the eye with 
these increased powers the attention was concentrated on definite points in the object; what was seen was to some extent indistinct, and always only a small part of the whole object; perception by means of the optic nerve had to be accompanied by conscious and intense reflection, in order to make the object, which is observed in part only with the magnifying glass, clear to the mental eye in all the relations of the parts to one another and to the whole. Thus the eye armed with the microscope became itself a scientific instrument, which no longer hurried lightly over the object, but was subjected to severe discipline by the mind of the observer and kept to methodical work. The philosopher Christian Wolff observed very truly in $172 \mathrm{I}$, that an object once seen with the microscope can often be distinguished afterwards with the naked eye ; and this, which is the experience of every microscopist, is sufficient evidence of the effect of the instrument in educating and training the eye. This remarkable fact appears also in another way. We saw in the history of morphology and systematic botany that botanists for a hundred years scarcely attempted to make themselves masters in a scientific sense of the external and obvious relations of form in plants, and to consider them from more general points of view. Jung was the first who applied systematic reflection to the morphological relations of plants which lay open before his eyes, and it was not till late in our own century that this part of botany was again handled in a scientific and methodical manner. This extremely slow progress in obtaining a mental mastery over external form in plants on the part of those who are continually occupied with them appears to be due chiefly to the fact, that the unassisted eye glances too impatiently over the form of the object, and the attention of the observer is disturbed by its hasty movements. In direct contrast to this customary want of thoughtfulness in contemplating the external form of plants, we find the first observers with the microscope, Robert Hooke, Malpighi, Grew, and Leeuwenhoek in the latter half of the 
seventeenth century, endeavouring by earnest reflection to apply the powers of the mind to the objects seen with the assisted eye, to clear up the true nature of microscopic objects, and to explain the secrets of their constitution. If we compare the works of these men with the utterances of the systematists of the same period on the relations of form in plants, we cannot fail to see how superior the matter of the former is in intellectual value. This appears most strikingly when we put what Malpighi and Grew tell us of the construction of the flower and fruit side by side with the knowledge of Tournefort, Bachmann, and Linnaeus on the same subject.

This enhancement of the mental capacity of the observer by the microscope is however the result of long practice; the best microscope in unpractised hands is apt soon to become a tiresome toy. It would be a great mistake to suppose that progress in the study of the anatomy of plants has simply depended on the perfecting of the microscope. It is obvious that the perception of anatomical objects must grow more distinct as the magnifying power of the instrument is increased, and the field of sight is made brighter and clearer, but these things by themselves would not add much to real knowledge. In examining the structure of plants, as in every science, it is necessary to work with the mind upon the object seen with the eye of sense, to separate the important from the unimportant, to discover the logical connection between the several perceptions, and to have a special aim in the examination; but the aim of the phytotomist can only be to obtain so clear an idea of the whole inner structure of the plant in all its connections, that it can be reproduced by the imagination at any moment in full detail with the perfect distinctness of sense-perception. It is not easy to attain this end because the more the microscope magnifies, the smaller is the part of the whole object which it shows; skilful and well-considered preparation is required, careful combination of different objects and long practice. The history of phytotomy shows how difficult a task 
it is to combine the separate observations and to fashion what has been seen bit by bit into a clear and connected representation.

It appears then that progressive improvement of the microscope was not in itself sufficient to ensure the advance of phytotomy. It would not indeed be too much to say, that the progress which microscopic anatomy made step by step with the aid of imperfect instruments repeatedly gave the impulse to energetic efforts to improve them. Only practical microscopists could tell where the real defects of existing instruments lay; it was their anxiety to make them more manageable, their constant complaints of the poor performance of the optical part-complaints loudly expressed, especially at the end of the previous and the beginning of the present century, which urged the opticians to turn their attention to the microscope and to endeavour to make it more perfect. Moreover, essential improvements in the instrument were made by microscopists themselves. Thus Robert Hooke was the first who in 1760 gave the compound microscope a form convenient for scientific observation, and Leeuwenhoek developed the powers of the simple microscope to their highest point. The modern microscope is greatly indebted for its perfectness to Amici; nor ought the name of von Mohl to be omitted here, who invented improved methods for microscopic measurement, and in his work 'Mikrographie' ( 1846 ) on the construction of the microscope gave many practical hints to the opticians.

We shall not then make the most important advances in the anatomy of plants depend as a matter of course and quite passively on the history of the microscope ; they were determined here as in other parts of botany by a logical necessity of their own; here as elsewhere we have to fix our eye on the objects pursued by successive enquirers. If for this purpose we cast a glance over the history of the subject, it will appear that its founders in the latter half of the seventeenth century, Malpighi and Grew, were chiefly bent on determining the con- 
nection between the cellular and fibrous elements in the structure of plants. Two fundamental forms of tissue were assumed from the first, the succulent cellular tissue composed of chambers or tubes, and, in contrast to this, the elongated usually fibrous or tubular elementary organs, the distinction of which into open canals or vessels and fibres with closed ends continued to be doubtful. The characteristic feature of this period is, that the investigation of the more delicate structure is everywhere closely interwoven with reflections on the function of the elementary organs, and that thus anatomy and physiology support each other, but not without mutual injury through the imperfections of both. But the physiological interest far outweighed the anatomical with the first phytotomists, who used anatomical research for the purposes of physiology.

The imperfectness of the microscope during the whole of the eighteenth century produced a certain disinclination to anatomical studies, which were after all only regarded as auxiliary to physiology. The latter had made very important progress without the help of anatomy in the hands of Hales, and later on towards the end of the 18 th century in those of IngenHouss and Senebier, and thus the interest in phytotomy was almost extinguished. Not only was very little addition made to the contributions of Malpighi and Grew during the I8th century, but they had to some extent ceased to be understood.

However towards the end of that time the microscope came again into fashion; in the compound form it had become somewhat more convenient and manageable; Hedwig showed how it revealed the organisation of the smallest plants, and especially of the Mosses, and he examined also the construction of cell-tissue and vascular bundles in the higher plants. But with the beginning of the present century the interest in phytotomy suddenly rose high again; Mirbel in France, Kurt Sprengel in Germany made the microscopic structure of plants once more the subject of serious investi- 
gation. The performances of both men were at first extremely weak and contradicted one another; a lively dispute on the nature of cells, fibres, and vessels grew up during the succeeding years, and many German botanists soon took part in it; life was once more infused into the whole subject, especially when the academy of Göttingen in I 804 offered a prize for the best essay on the disputed points, for which Link, Rudolphi and Treviranus contended, while Bernhardi occupied himself with private researches into the nature of vessels in plants. It was not much that was attained in this way; men began once more from the beginning, and after 130 years Malpighi and Grew were still the authorities to whom everybody appealed. Yet the questions now discussed were in the main different from the old ones; Malpighi, Grew and Leeuwenhoek had chiefly set themselves the task of studying the different tissues in their mutual connection; the moderns were chiefly concerned to get a clearer understanding of the more delicate construction of the various tissues themselves, to know what was the true account of cell-structure in parenchymatous tissue, and the real nature of vessels and fibres. That very slow progress was made at first in this direction was due partly to the imperfectness of the microscope, and still more to very unskilful preparations, to the influence of various prejudices, and to too slight exertion of the mind. But a comprehensive work by the younger Moldenhawer in 1812 was a considerable step in advance. It is marked by careful and suitable preparation of the objects, and by critical examination of what was observed by the writer himself and of what had been written by others; in fact it is a fresh commencement of a strict scientific treatment of phytotomy. Hugo von Mohl continued Moldenhawer's work after I 828, and Meyen was a contemporary and a zealous student of phytotomy; but the period in the study of vegetable anatomy which reaches to 1840 may be said to have been brought to a conclusion chiefly by von Mohl's contributions. Weak as the beginnings were at the 
commencement of this period (I800-I840), and important as was the advance made by von Mohl towards the end of it, yet we may include all that was done during that time in one view, since the questions examined were essentially the same; like Mirbel and Treviranus, Moldenhawer and Meyen, von Mohl was chiefly occupied up to the year I 840 in deciding the questions, what is the nature of the solid framework of cellulose in the plant in its matured state, whether a single or double wall of membrane lies between two cellspaces, what is the true account of pits and pores, and of the various forms of fibres and vessels; one great result of these efforts must be mentioned, namely, the establishment of the fact that all the elementary organs of plants may be referred to one fundamental form, the closed cell; that the fibres are only elongated cells, but that true vessels are formed by cells which are arranged in rows, and have entered into free communication with one another.

Phytotomists before 1840 , and von Mohl especially, had occasionally paid attention among other things to circumstances connected with the history of development, and single cases of the formation of various cells had been described by von Mohl and Mirbel between 1830 and 1840 , but greater interest was taken in the right understanding of the structure of mature tissues; physiological questions also, though no longer of the first importance in anatomical investigations, were still of weight, so far as the enquiry was influenced by the relation of anatomical structure to the functions of elementary organs. But with Schleiden and Nägeli the question of historical development and the purely morplıological examination of interior structure assumed an exclusive prominence in phytotomy. The first commencement of vegetable cells especially and their growth were the subjects now discussed. Schleiden had proposed a theory of cell-formation before 1840 , which, resting on too few and inexact observations, referred all processes of cell-formation in the vegetable kingdom to a 
single form ; it attracted great attention in the botanical world, but could not easily be reconciled with what was already known; and in I846 it was completely refuted by Nägeli, who substituted for it the history of the formation of the various kinds of vegetable cells in their main features, based on profound and extensive investigations. It was natural that these researches into the formation of cells should turn the attention of observers, which had hitherto been almost exclusively devoted to the solid framework of cell-tissue, to the juicy contents of cells. Robert Brown had already discovered the cell-nucleus; Schleiden recognised its more constant presence, but misunderstood its relation to cell-formation; Nägeli and von Mohl next demonstrated the peculiar nature of protoplasm, the most important component of vegetable cells, and especially the weighty part which it plays in their origination. Unger in 1855 called attention to the great resemblance which exists between the protoplasm of the vegetable cell and the sarkode of the more simple animals, - a discovery which was subsequently brought into prominence by observations on the behaviour of the Myxomycetes, and after $\mathrm{x} 860$ finally led zootomists as well as phytotomists to the conclusion, that protoplasm is the foundation of all organic development, vegetable and animal. But there is yet another direction in which the study of the history of development by the phytotomist led to new points of view and to new results; we have already pointed in the end of the first book to the way in which Nägeli after 1844 made the sequences of cell-division in the growth of organs the basis for his morphology, and how in this way the Cryptogams especially revealed their inner structure; we also noticed the splendid results which Hofmeister achieved by his study of the development of the embryo; here we have further to show, how after 1850 the various forms of tissue, especially the vascular bundles, were examined by observation of the history of their development, and how in this way botanical science has succeeded in explaining the 
inner histological connection between leaves and axes, shoots and parent-shoots, primary and secondary roots, and above all in gaining a correct insight into subsequent growth in thickness and so learning to understand the true mode of formation of a woody body and of the secondary rind.

It is then the task of the following chapter to give a more detailed account of the history of phytotomy, the salient points in which have now been indicated. 


\section{CHAPTER I.}

Phytotomy founded by Malpighi and GRew.

$$
\text { I } 67 \text { I-I } 682 .
$$

THE foundation of vegetable anatomy, indeed of all insight into the structure of the substance of plants, is the knowledge of their cellular structure. We find the first perception of this truth in a comprehensive work of ROBERT HoOkE ${ }^{1}$, which appeared in London in $\mathrm{I} 667$ under the title of 'Micrographia or some physiological descriptions of minute bodies made by magnifying glasses.' 'The author of this remarkable book was not a botanist, but an investigator of nature of the kind more especially to be found in the seventeenth century; he was mathematician, chemist, physicist, a great mechanician, and later an architect, and moreover a philosopher of the new school then rising. Beside many discoveries in various subjects he succeeded in 1660 in so far improving the compound microscope, that with considerable increase in magnifying power it had tolerably clear definition. With this instrument Henshaw in $166_{I}$ is stated to have discovered the vessels in walnutwood, a fact not of importance for our history. Hooke himself was anxious to show the world how much could be seen with his

1 Robert Hooke, born in 1635 at Freshwater in the Isle of Wight, was a man of marvellous industry and varied acquirement in spite of a delicate constitution. He became a Fellow of the Royal Society in 1662 , and was afterwards its Secretary and Professor of Geometry in Gresham College. He died in I 703. There is a good account of him by de l'Aulnaye in the 'Biographie Universelle.' 
improved instrument; as an adherent of the inductive method he desired to aid in perfecting the perceptions of sense which are the foundation of all human knowledge; with this feeling he submitted all sorts of objects to his glass, that it might be known how much the unassisted eye fails to perceive. He made what he saw texts for discussions on a multiplicity of questions of the day. The book therefore was not devoted to phytotomy; the structure of the substance of plants is noticed in the same incidental manner, as the discovery of parasitic fungi on leaves, or other similar matters. And what Hooke saw of the structure of plants was not much, but it was new, and on the whole fairly judged. It appears that he discovered the cellular structure in plants by examining charcoal with his glass, and that he then tried cork and other tissues. He says that a thin section of cork on a black ground (by direct light therefore) looks like honey-comb; he distinguishes between the hollow spaces (pores) and the dividing walls, and to the former he gives the name which they yet bear; he calls them cells. The arrangement of the cork-cells in rows misleads him into taking them for divisions of elongated hollow spaces, separated by diaphragms. These, he says, are the first microscopic pores, which he or any one else had ever seen, and he regards the cell-spaces of plants as examples of the porousness of matter, as do the text books of physics up to modern times. Hooke employed his discovery especially to explain the physical qualities of cork; he estimates the number of pores in a cubic inch at about twelve hundred millions. He draws another botanical conclusion; he gathers from the structure of the cork that it must be an outgrowth from the bark of a tree, and appeals to the statements of one Johnston in proof of this hypothesis. The fact, that cork is the bark of a tree, was therefore not yet known to all educated people in England. Hooke afterwards says that this kind of texture is not confined to cork; for as he examined the pith of elder and other trees with his microscope and the pulp of hollow stems, such as 
those of fennel, teasel and reed, he found a similar kind of structure with the difference only, that in the latter the pores (cells) are arranged lengthwise, in cork in transverse rows. He says that he has never seen any passages for communication between the cells, but that they must exist, because the nourishing juice passes from one to another; for he has seen how in fresh plants the cells are filled with sap, as are the long pores in the wood; but these he found empty of sap in the carbonised wood, and filled with air.

It is plain that it was not much that Hooke saw with his improved microscope; thin cross-sections of the stem of balsam or gourd, two plants that grew at that time in every garden, would have shown the naked eye as much or even more of vegetable structure. At the same time there is proof here of what was said above on the influence of the microscope on the use of the eye; the pleasure in the performance of the new instrument must first direct attention to things which can be seen without it, but were never seen.

About the time of the appearance of Hooke's ' Micrographia' Malpighi and Grew had already made the structure of the plant the subject of detailed and systematic investigations, the results of which they laid before the Royal Society in London almost at the same time in $167 x$. The question to which of the two the priority belongs has been repeatedly discussed, though the facts to be considered are undoubted. The first part of Malpighi's large work, the 'Anatomes plantarum idea,' which appeared at a later time, is dated Bologna, November I, I67I; and Grew, who from I677 was Secretary to the Royal Society, informs us in the preface to his anatomical work of 1682, that Malpighi laid his work before the Society on December $7,167 \mathrm{r}$, the same day on which Grew presented his treatise, 'The Anatomy of plantes begun,' in print, having already tendered it in manuscript on the eleventh of May in the same year. But it must be observed that these are not the dates of the larger works of the two men, but only of the 
preliminary communications, in which they gave a brief summary of the researches they had then made; the fuller and more complete treatises appeared afterwards; the preliminary communications formed the first part of the later works and to some extent the introduction to them. Malpighi's longer account was laid before the Society in 1674 , while Grew produced a series of essays on different parts of vegetable anatomy between 1672 and 1682 ; and these appeared together with his first communication in a large folio volume under the title, 'The anatomie of plantes,' in r682. Thus Grew had opportunity to use Malpighi's ideas in his later compositions; he actually did so, and the important point as regards the question of priority is, that where he makes use of Malpighi he distinctly quotes from him. No more is necessary to remove the serious imputation which Schleiden has made against Grew in the 'Grundzüge' (1845), i. p. 207.

Whoever has not himself read the elaborate works of Malpighi and Grew, but knows them only from the quotations in later phytotomists, may easily imagine that these fathers of phytotomy had found their way to a theory of the cell, such as we now possess. But it is not so ; their works have very little resemblance to modern descriptions of vegetable anatomy; the difference lies chiefly in this, that modern writers in their accounts of the structure of plants start with the idea of the cell, and afterwards treat of the connection of cells into masses of tissue. The founders of phytotomy on the contrary, as might naturally be expected, consider first and foremost the coarser anatomical circumstances; they describe the rind, bast, wood, and pith chiefly of woody dicotyledons, and the histological distinctions between root, stem, leaf, and fruit in their broader relations, and examine the detail of the structure of buds, flowers, fruits, and seeds for the most part only so far as it can be seen with the naked eye. The more delicate structural conditions are afterwards discussed as a supplement to this less minute anatomy and always in close connection with 
it. The chief emphasis is laid on the consideration of the way in which the fibrous tissue connects with the succulent parenchyma, while such questions as the nature of the cell, the fibre, and the vessel are only incidentally touched upon or discussed at greater length in the course of the exposition. The mode of investigation and exposition is therefore chiefly analytic, while in modern compendiums of phytotomy it is essentially synthetic. It need scarcely be said that with this mode of treatment the questions which are now regarded as fundamentally important are either treated as of secondary moment, or are disregarded; we must not therefore, in judging of the merit of these men, approach their works with the demands upon them which our more advanced science would lead us to make. It would be quite wrong even to think of measuring the value of their books by the extent to which their contents agree with the modern cell-theory. Both of them had enough to do to find their way at all in the new world which the microscope had revealed; many questions which have becone trivial for us had then to be solved for the first time, and the chief merit of both lies in this very effort to understand first of all the coarser relations of the anatomical structure of plants; in this respect the study of their works may yet be recommended to beginners, because modern phytotomical books are generally very imperfect on these points. And yet we must not undervalue what Malpighi and Grew had to say on the more delicate anatomy, and especially on the nature of the solid framework of cell-membrane in the plant; imperfect and crude as their views on such points may be, yet they continued for more than a hundred years to be the foundation of all that was known about cellular structure; and when phytotomy took a new flight at the beginning of the present century, Malpighi's and Grew's scattered remarks on the union of cells with one another, and on the structure of fibres and vessels, were adopted by the later phytotomists and connected with their own investigations. 
If the views of Malpighi and Grew agreed in the main on the points here mentioned, yet the style and manner of the two were very different. Malpighi kept more closely to that which could be directly seen; Grew delighted in tacking on a variety of theoretical discussions to his observations, and especially endeavoured to follow the path of speculation beyond the limits of what was visible with the microscope. Malpighi's account reads like a masterly sketch, Grew's like an elaborate production of great and almost pedantic carefulness; Malpighi displays a greater formal cultivation, and deals with the questions with light touches, allusively, and almost in the tone of conversation. Grew on the other hand is at pains to reduce the new science to a learned and well-studied system, and to bring it into connection with chemistry, physics, and above all with the Cartesian philosophy. Malpighi was one of the most famous physicians and zootomists of his time, and treated phytotomy from the points of view already opened in zootomy; Grew too occupied himself occasionally with zootomy, but he was a vegetable anatomist by profession, and gave himself up, especially after 1688 , almost exclusively to the study of the structure of plants with a devotion hardly to be paralleled till we come down to Mirbel and von Mohl.

As in medicine in the $\mathrm{I} 7$ th century human anatomy was intimately connected with physiology, and the latter was not yet treated as a distinct study, so the founders of phytotomy naturally combined the physiological consideration of the functions of organs with the examination of their structure. Considerations on the movement of sap and on food appear in the front of every anatomical enquiry; relations of structure, which the microscope could not reach, were assumed hypothetically on physiological grounds, although little positive was known at the time about the functions of the organs of plants; hence recourse was had to analogies between vegetable and animal life, and it is true that vegetable physiology received its first great impulse by this means, but occasion was given at 
the same time to many errors, which in their turn often misled the anatomist. At present, when vegetable anatomy has separated itself more than is desirable from physiology, that is, from the investigation of the functions of organs, it is difficult, nay impossible, to give the reader a brief account of the contents of these two books which form an epoch in the science. I must confine myself to noticing a few chief points, which are historically connected with the further development of phytotomy, though some of these are just the questions to which Malpighi and Grew only gave occasional attention, and which it is therefore a little unjust to them to bring into prominent notice. I shall recur to the physiological portion of their writings in the third book of this history, confining myself here to that which concerns the structural relations of plants.

The phytotomical work of MARCELlo MALPIGHI ${ }^{1}$ appeared under the title 'Anatome Plantarum,' and to it was added a treatise on hens' eggs during the process of incubation (1675). The phytotomical portion of the book separates into two main divisions, the first of which, the 'Anatomes Plantarum idea,' was, as was stated above, completed in $\mathrm{I} 67 \mathrm{I}$, and contains a general abstract and survey of Malpighi's views on the structure and functions of vegetable organs in fourteen-anda-half folio pages; the second and much larger portion illustrates in detail by numerous examples and with the help of many copper-plates the views expressed in the first part; it will answer our purpose best to turn principally to the connected expression of the author's views in the first part.

He begins his remarks with the anatomy of the stem, and as the rind first attracts the eye, he takes it first. The outer

1 Marcello Malpighi, born at Crevalcuore near Bologna in 1628 , became Doctor of Medicine in 1653 , and after 1656 was Professor in Bologna, Pisa, Messina, and a second time in Bologna; in 1691 he was named Physician to Innocent XII. He died in 1694 . On his services to comparative anatomy, and the anatomy of the human body, see the 'Diographie Universelle' and Carus, 'Geschichte der Zoologie,' p. 395. 
part of it, he says, the cuticle, consists of utricles or little sacs arranged in horizontal rows; these die in time and decay, sometimes forming a dry epidermis. On the removal of the epidermis, layer after layer of woody fibre is disclosed, and these layers, usually forming reticulations and lying one on another, follow the longitudinal direction of the stem. These fibrous bundles are composed of numerous fibres, and each single fibre of tubes which open into one another (' quaelibet fibra insignis fistulis invicem hiantibus constat') and so on. The interspaces of the network are filled with roundish tubes, which usually have a horizontal direction towards the wood. If the rind is removed the wood appears, chiefly composed of elongated fibres and tubes, and consisting of rings or vesicles open towards one another and arranged in longitudinal rows. The fibres also of the wood do not run parallel to one another, but allow a network of angular anastomosing spaces to be formed between them, the larger of which are filled with bundles of tubes, which run from the rind through these interspaces to the pith, etc., etc. Between the fibrous and fistulose bundles of the wood lie the spiral tubes ('spirales fistulae'), smaller in number but of larger size, so that in cross sections of the stem they appear with open orifices. They lie in different positions, but the majority in concentric circles. He says that in the course of ten years' examination (from i66 I therefore) he found these spiral tubes in all plants, and it may be added here that Grew in the introduction to his book expressly concedes the priority in this discovery to Malpighi; but Malpighi's ideas on the subject of these tubes are extremely indistinct ${ }^{1}$, and this gave occasion to

1 We read at p. 3: 'Componuntur expositae fistulae (spirales) zona tenui et pellucida, velut argentei coloris, lamina parum lata, quae spiraliter locata et extremis lateribus unita tubum interius et exterius aliquantulum asperum efficit; quin et avulsa zona capites seu extremo trachearum tum plantarum tum insectorum non in tot disparatos annulos resolvitur, ut in perfectorum trachea accidit; sed unica zona in longum soluta et extensa extrahitur.' 
much misinterpretation and to gross errors on the part of later writers. Malpighi thought he observed a peristaltic movement in these vessels, a delusion to which many of the naturephilosophers were particularly fond of surrendering themselves at the beginning of the present century.

In addition to the bundles of fibres and the tracheae, Malpighi observed a number of tubes in Ficus, Cupressus, and other plants, which allowed the escape of a milky juice, and he concludes that similar special tubes might be present also in the wood of stems from which milk, turpentine, gum, and the like exude.

Such are the elementary organs of plants, as far as they were known to Malpighi; in the subsequent part of his book we find them applied to a histology of the stem, and here a mistake at once makes its appearance, which, resting on his authority, was reproduced by the phytotomists of the i 8 th and even of the early part of the Igth century, - the theory, namely, that the young layers of wood in the stem originate in the periodic transformation of the innermost layers of bark (secondary bast-layers); Malpighi was led into this mistake, as it appears, partly by the softness and light colour of the alburnum, partly by its fibrous character. In this substance the spiral tubes are gradually formed, and as the mass becomes more solid and compact, it subsequently forms the true wood.

The pith lies in the centre of the stem, and, according to Malpighi, consists of numerous rows of spheres ('multiplici globulorum ordine') arranged longitudinally one after another, and composed of membranous tubes, as may be clearly seen in walnut, elder, and other trees. In this place also he mentions the milk-vessels in the pith of the elder. Passing over many and various matters, it may be mentioned next that Malpighi recognises the connection of the layers of tissue in young shoots with those of the parent-stem, and very expressly notices the same continuity of structure between the leaf and the axis of the shoot. He then briefly touches on the anato- 
mical relations of the fruit and the seed, the existence of the embryo in the seed and its structure, and then goes on to the roots. "The roots of trees are a part of the stem, which divides into branches and ultimately ends in capillary threads ('capillamenta'); so that, in fact, trees are simply fine tubes, which run separate from one another underground but gradually collect into bundles; these bundles unite further on with other and larger bundles, and all together ultimately join to form a single cylinder, the stem, which then by separation of the tubes at the opposite extremity stretches out its branches, and by continued gradual separation of the larger into smaller finally expands into leaves, and so reaches its furthest limits.' The conclusion of the whole account is chiefly concerned with the part played by the various kinds of tissue in the nourishment of the plant.

In the second part published in 1674 , the different kinds of tissue in the stem are discussed at greater length; here there is much that is really good, but at the same time much that is imperfect to an extent which cannot be attributed solely to the inferiority of his microscope. Very excellent is the way in which he endeavours to make out the more obvious anatomical relations of the rind, the wood, and the pith, and in the texture of the rind and the wood connects the longitudinal course of the vessels and woody fibre with the horizontal course of the medullary rays and the 'silver-grain.' The magnifying powers which he used must, to judge from his figures, have been very considerable; how much of what is imperfect in them is due to the indistinctness of the field of view, and how much to inaccurate observation, we cannot say. For instance, he sees the bordered pits in the wood of Conifers without perceiving the central pore, and represents them as coarse grains lying on the outside of the wood-cells; it was unfortunate for Malpighi, as for his successors, that the large vessels in the wood of dicotyledons, to which they gave most of their attention, are often filled with secondary tissue (thy- 
losis), which Malpighi figures Tab. vi, fig. 2 I, but the true nature of which was not understood till $\mathrm{r} 50$ years later. Malpighi, like succeeding phytotomists till as late as $\mathrm{I} 830$, lays great stress on the structure of the spiral vessels or tracheae, and mentions particularly that they are surrounded by a sheath of woody fibre; but he did not fall into the strange notions which Grew and other phytotomists entertained with regard to the nature of these vessels.

We may at present omit the numerous remarks on assimilation and the movement of the sap; the descriptions and figures of the parts of buds and of the course of the bundles of vessels in different parts of plants, and especially the analyses of the flower and fruit and the examination of the seed and embryo, conducted with a carefulness remarkable for that time, deserve a fuller notice, but this would detain us too long from our main subject.

If Malpighi's work reads like a masterly sketch in which the author is bent only on giving the outlines of the architecture of plants, the much more comprehensive work of NEHEMIAH GREw ${ }^{1}$, 'The anatomy of plantes' (r682), has the appearance of a text-book of the subject thoroughly worked out in all its details; the tasteful elegance of Malpighi is here replaced by a copiousness of minute detail that is often too diffuse; while in Malpighi we only occasionally encounter the philosophical prejudices of his time, which usually lead him into mistakes, Grew's treatise is everywhere interwoven with the philosophical and theological notions of the England of that day; but we are compensated for this by the more systematic way in which he pursues the train of thought, and especially by the constant

1 Nehemiah Grew, the son of a clergyman in Coventry, appears to have been born in 1628 . Having taken a Doctor's degree in a foreign University, he practised as a physician in his native town, and pursued at the same time his phytotomical researches. He became Secretary to the Royal Society in 1677 , and published his 'Cosmographia Sacra' in I 7or. He died in I III. See the 'Biographie Universelle.' 
effort to give as clear a representation as possible of what he sees. Though he too everywhere introduces physiological considerations into his anatomical investigation, yet he keeps himself free from many preconceptions which his successors imported in this way into phytotomy. To mention one point by anticipation, he avoided the erroneous notion so common at a later time, and first definitively removed by von Mohl in r 828 , that the cell-walls must have visible openings to serve for the movement of the sap.

Grew's work, as has been said, separates into two main divisions; the first, "The anatomy of plants begun, with a general account of vegetation founded thereupon,' was printed in $167 \mathrm{I}$, and contains a brief and rapid account of the general anatomy and physiology of plants in forty-nine folio pages. Then the anatomy of roots, stems, leaves, flowers, fruits and seeds appeared as separate treatises in the following years up to $\mathbf{6 8 2}$. We may pass over the chemical researches embodied in this work and the enquiries into the colours, taste and smell of plants, as well as the previously issued treatise, 'An idea of a philosophical history of plants,' which, as it was first laid before the Royal Society in 1672 , we may imagine to have been intended as a counterpart to Malpighi's 'Anatomes plantarum idea,' though it is very different in character and admits much that is foreign to vegetable anatomy and physiology.

With Grew as with Malpighi the main point of enquiry is not the individual cell, but the histology ; after distinguishing, like Malpighi, between the parenchymatous tissue and the longitudinally elongated fibrous forms, the true vessels and the sap-conducting canals, he is chiefly bent on explaining the combination of these tissues in the different organs of the plant; and in this point he is superior to Malpighi both in carefulness of description and in the beauty of his delineations. Grew's numerous figures on copper plates, more carefully executed than Malpighi's, give in fact so clear an idea especially 
of the structure of the root and stem that a beginner may still use them with advantage ; such figures as those on plates 36 and 40 and elsewhere show that he knew how to fashion his observations by aid of much reflection into a clear representation of the thing seen; there are, as might be expected, many errors in the details of the more delicate structure of the various forms of vessels and cells.

Malpighi had not said, whether he considered the cells of the parenchyma (the term parenchyma comes from Grew) to be perfectly closed or porous, nor how they cohere; Grew leaves no doubt on this point; he says distinctly on page 6I that the cells or vesicles of the parenchyma are closed, that their walls are not traversed by any visible pores, so that the parenchyma may be compared to the foam of beer. $\mathrm{He}$ quotes Malpighi's view respecting the vessels of the wood, and supplements it by saying that the spiral band is not always single, but that two or more bands entirely separate from one another may form the wall of the vessel, and also that the spiral thread is not flat but roundish like a wire, and its turns are more or less close together according to the part of the plant. He also notices that the spiral tubes are never branched, and that when they run straight, as in Arundo Donax, they can be seen throughout considerable distances. The view of the structure of spiral vessels, which began with Malpighi and was maintained through the whole of the I 8th century, Grew (p. I I 7) expresses still more distinctly than Malpighi ; but it is to be observed that neither of them clearly distinguished true spiral vessels with separable spiral threads from vessels of the kind which occurs in secondary wood, and only shows a spiral structure on being torn. From the way, says Grew, in which the threads are woven, it comes to pass that the vessels often unroll into a flat surface, as we may imagine a narrow ribbon wound in a spiral about a round staff so that edge meets edge; and if the staff is drawn out, the ribbon so wound will remain behind 
in the form of a tube, and this would answer to an air-vessel in the plant. "We should notice specially that Grew, better taught than the phytotomists of the I 8th century, considers the vessels of the wood as air-passages, though they sometimes convey water. But he goes on with his description of the wall of the vessel; the flat surface disclosed by the unwinding of a vessel is, he says, itself composed of many parallel threads, as in an artificial ribbon, and the threads that are spirally wound answer to the warp in an artificial tissue, being held together by transverse threads, which correspond to the woof. To realise to ourselves this very strange idea of the structure of a spiral vessel as it appeared to Grew, we ought to know that he thinks that all cell-walls, even those of the parenchyma, are composed of an extremely fine web; his previous comparison of cell-tissue with foam was only intended to make the more obvious circumstances clear to the reader; his real idea is, that the substance of the walls of vessels and cells consists of an artificial web of the finest threads. He hints at this on pages 76 and 77 , and on page 120 he returns once more to this conception and dwells upon it at great length. The most exact comparison, he says, which we can make of the whole body of a plant is with a piece of fine lace-tissue, such as women make upon a cushion; for the pith, the medullary rays, and the parenchyma of the rind are an extremely delicate and perfect tissue of thread. The threads of the pith run horizontally like the threads in a piece of woven stuff, and form the boundaries of the numerous vesicles of the pith and the rind, as the threads in a web bound the interstices in it. But the woody fibres and the air-vessels are perpendicular to this tissue, and therefore at right angles to the horizontal threads of the parenchyma, just as the needles in a piece of lace work that lies on the cushion are perpendicular to the threads. To complete the comparison we ought to suppose the needles to be hollow and the tissue of thread-lace in a thousand layers one above another. Grew 
himself states incidentally, that he lit upon this notion from looking at shrivelled masses of tissue, when he naturally saw wrinkles and folds, which he took for threads. Besides he seems to have used blunt knives, which might easily tear the cell-walls into threads; so we might gather from the figure in Plate 40 , where what he supposes to have been a tissue of thread from the walls of a cell is depicted quite plainly. Lastly the observation of vessels with reticulated thickening, and parenchyma-cells with crossed striation may have contributed to his view.

It will hardly be superfluous to remark here, that Grew's idea of this very delicate structure of cell-walls has evidently given rise to the common expression cell-tissue (contextus cellulosus) when speaking of plants and animals, an expression which has become naturalised in microscopy, and is still retained though we no longer think of Grew's comparison of cell-structure with artificial lace. But the word tissue has often misled later writers, as words are apt to do, and made them found their conception of vegetable structure on the resemblance to an artificial tissue of membranes and threads.

Grew, like Malpighi, derives the young layers of wood in the stem from the innermost layers of the rind. The true wood, he says on page I I 4 , is entirely composed of old lymph-vessels, that is of fibres, which lay originally in the inner circumference of the rind. But by true woody substance he understands the fibrous components of the wood, excluding the air-vessels; his lymphvessels are the bast-fibres and similar forms; for, he goes on, the air-vessels with the medullary rays and the true wood form what is commonly called the wood of a tree; he uses the term air-vessels, not because these forms never contain sap, but because they only contain a vegetable air during the proper period of vegetation, when the vessels of the rind are filled with sap.

The above is certainly a very imperfect account of Grew's services to phytotomy; for the points here made prominent 
were treated by him as accessories only to the coarser histological relations with which he chiefly occupied himself.

These two works of Malpighi and Grew, so important not only for botany but for the whole range of natural science, were not followed during the course of the next hundred and twenty years by a single production, which can claim in any respect to be of equal rank with them; that long time was a period not of progress but of steady retrogression, as we shall see in the next chapter. But before the beginning of the I 8th century ANTON von LeEUwenhoeK ${ }^{1}$ made some contributions to the knowledge of the details of vegetable anatomy, if not exactly to the settling of very important points in it; he communicated his observations on animal and vegetable anatomy in numerous letters to the Royal Society of London, and these appeared for the first time in a collected form in Delft in 1695 under the title of 'Arcana naturae.' It is not easy to gain a clear idea of Leeuwenhoek's phytotomic knowledge from his scattered statements. He too discussed the less minute anatomy of fruits, seeds and embryos, and among other things he made occasional observations on

1 Leeuwenhoek's observations in animal anatomy were perhaps more important than those which he made in botany. Carus ('Geschichte der Zoologie,' p. 399) says of him: 'While Malpighi used the microscope with system and in accordance with the requirements of a series of investigations, the instrument in the hands of the other famous microscopist of the $\mathbf{I} 7^{\text {th }}$ century was more or less a means of gratifying the curiosity excited in susceptible minds by the wonders of a world which had hitherto been invisible. Still the discoveries, which were the fruit of an assiduous use of the microscope continued during fifty years, embraced many subjects and were important and influential. Anton von Leeuwenhoek was born in Delft in $\mathbf{I}_{6} \mathbf{3}_{2}$. Being intended for trade, he had not the advantage of a learned education and is said even to have been ignorant of Latin; his favourite occupation was the preparing superior lenses, with which he incessantly examined new objects without being guided at any time by a scientific plan. The Royal Society of London, to whom he communicated his observations, made him a member of their body. He died in his native town in 1723 , being ninety years of age. 
germination, and many on the structure of different woods. But all bears the stamp of only occasional study of plants; he was led to his observations by questions of the naturephilosophy then in vogue, and especially by such as were connected with the theory of evolution, not unfrequently by mere curiosity and pleasure in things obscure and inaccessible to ordinary people, but he did not gain from them a general idea of the structure of plants. In the course of these observations he did unquestionable service in perfecting simple magnifying glasses; he made a large number with his own hands, and these possessed magnifying powers evidently not at the command either of Malpighi or Grew. By aid of such glasses he discovered the vessels of secondary wood which are. not spirally thickened but beset with pits, the true character of which however he did not investigate. $\mathrm{He}$ was the first moreover who perceived the crystals in vegetable tissue, namely in the rhizome of Iris florentina and in species of Smilax, and this could only be done with strong magnifying powers. In other matters he repeats the histological views of Malpighi and Grew, and on the whole his numerous communications seem painfully fragmentary and unscientific in presence of Malpighi's elegance and perspicuity, and Grew's systematic thoroughness. His figures too, which were not drawn by himself, are with some exceptions inferior to those of his great contemporaries. 


\section{CHAPTER II.}

\section{Phytotomy in the Eighteenth Century.}

MALPIGHI had no successor of note in Italy; in England the new light was extinguished with Hooke and Grew, and has so remained, we may almost say, till the present day; in Holland also Leeuwenhoek found none to follow him of equal rank with himself, and the work done in Germany up to the year $\mathrm{I} 770$ is more wretched than can well be imagined. There was in fact no original phytotomic research in the first fifty or sixty years of the last century; the accounts which were given of the structure of plants were taken from Malpighi, Grew, and Leeuwenhoek by persons, who, unable to observe themselves, did not understand their authors and stated things not to be found in their writings. The feebler and obscurer notions of the older writers were preserved with a particular preference, and thus it was Grew's complicated idea of the web-like structure of cell-walls that made most impression on those who reported him. This state of decline must not be ascribed to imperfect microscopes only; these certainly were not good, and still less conveniently fitted up; but no one saw and described clearly even what can be seen with the naked eye or with very small magnifying power; the worst part of the case was that no one tried fully to understand either the little he saw himself or the observations to be found in older works, but contented himself from want of reflection with most misty notions of the inner structure of plants. It is not easy to discover the causes of this decline in phytotomy in the first half of the 18th century; but one of the most important appears to lie in the circumstance, that botanists, following in 


\section{Phytotomy in the Eighteenth Century.}

this the example of Malpighi and Grew, did not make the knowledge of structure the sole aim in their anatomical investigations, but sought it chiefly for the purpose of explaining physiological processes. The food and circulation of the sap of plants were more and more the prominent questions, and Hales showed how much may be done in this direction even without the microscope; the interest therefore of the few, who like Bonnet and Du Hamel occupied themselves almost entirely with vegetable physiology, was concentrated on experiment.

Others who knew how to use the microscope, as the Baron von Gleichen-Russworm and Koelreuter, were drawn away from the examination of the structure of vegetable organs by their attention to the processes of fertilisation and especially of propagation. The real botanists, according to the ideas of the time, and specially those who belonged to the Linnaean school, considered physiological and anatomical researches generally to be of secondary importance, if not mere trifling, with which an earnest collector had no need to concern himself. That Linnaeus himself thought little of microscopical phytotomy is sufficiently shown by what has been said of him in the first book.

It is not worth while to notice each of the few small treatises on the subject which appeared towards 1760 , for they contain nothing new; a few exanples will show the truth of the opinion here expressed on the general condition of phytotomy at this time.

We first of all encounter a writer, whom few would expect to find among the phytotomists, the well-known philosopher Christian Baron von Wolff, who in his two works, 'Vernünftige Gedanken von den Wirkungen der Natur,' Magdeburg ( I 723) and 'Allerhand nützliche Versuche,' Halle ( $172 \mathrm{I}$ ) gives here and there descriptions of microscopes and discusses subjects connected with phytotomy. This he does more particularly in the latter work, where he describes a compound microscope with a focussing lens between the objective and the ocular 
but without a mirror, an instrument which must have served therefore for observing with the light from above on an opaque surface; the objective was a simple lens. But to magnify objects more strongly, he says that he used a simple instead of this compound instrument, as was more the custom at the time. Like a true amateur Wolff submitted all sorts of small and delicate objects to his glass, without examining any of them thoroughly and persistently. His phytotomic gains were small; he observed for instance that starch-flour (powder) consists of grains, but believed from the way in which they refracted light that they were small vesicles filled with a fluid; yet he satisfied himself that these grains are already in the grains of rye and therefore not produced in the grinding. He laid thin sections of portions of plants on glass which was too imperfectly polished to allow of his seeing anything distinctly. His pupil Thümmig in his 'Meletemata' ( 1736 ) addressed himself to the subject with still less skill. By the case of these two men we may see plainly that want of success was due much less to the imperfectness of the microscope than to unskilful management and unsuitable preparation. But Wolff and Thümmig at least endeavoured to see something for themselves of the structure of plants; a famous botanist of the time, Ludwig, plainly never made a similar attempt, for in his 'Institutiones regni vegetabilis' ( $\mathrm{I}_{742}$ ) he speaks of the inner structure of the plant in the following manner; 'Laminae or membranous pellicles, so connected together that they form little cavities or small cells and often reticulated by the intervention of fine threads, form the cell-tissue which we see pervading all parts of plants. These are what Malpighi and others call tubes, since they appear in different parts in the form of rows of connected vesicles!' Boehmer's 'Dissertatio

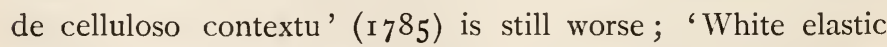
thicker or thinner fibres and threads woven together of differing shape and size form cavities or cells or caverns, and are usually known by the name of cell-tissue.' We see 
what mischief Grew did with his theory of the fibrous structure of the cell-walls, and how the expression cell-tissue literally taken led the botanists here named and others into utterly incorrect ideas. The works of Du Hamel, Comparetti, and Senebier show that such misconceptions were not confined to Germany, and Hill, a countryman of Grew, according to von Mohl's account pictured to himself cells as cups standing one above another, closed below and open above.

Baron von Gleichen-Russworm ( $17 \mathrm{I} 7-1783$ ), privy counsellor to the Margrave of Anspach, gave much attention to the perfecting of the mechanical arrangements of the microscope, but his plates themselves show how strangely unsuitable these arrangements were. With these instruments he made many observations, which are recorded in two voluminous works, 'Das Neueste aus dem Reich der Pflanzen' ( 1 764) and 'Auserlesene mikroskopische Entdeckungen' ( I 777I 78I). But these works contain little or nothing about microscopic anatomy or the structure of vegetable cells. His observations with the microscope are chiefly devoted to processes of fertilisation and to proving that spermatozoa are contained in the pollen ${ }^{1}$, and in connection with these subjects he gives magnified figures of many small flowers, some of them beautifully executed; these figures must have made his works very instructive to many in their time. He saw the stomata, which Grew had already discovered, on the leaves of ferns, but took them for the male organs of fertilisation, which at the same time showed that he was still unacquainted with the existence of stomata in phanerogams.

CASPAR FRIEDRICH WOLFF ${ }^{2}$ in his efforts in phytotomy stands

1 This subject will be noticed again in the history of the sexual theory.

${ }^{2}$ C. F. Wolff was born at Berlin in $\mathbf{1} 733$. He studied anatomy under Meckel and botany under Gleditsch, in the Collegium Medico-chirurgicum in that city. He afterwards resorted to the University of Halle, and there made acquaintance with the philosophy of Leibnitz and Wolff, which predominates too much in his dissertation, 'Theoria Generationis' (I759). 
a solitary figure among his contemporaries, not only because he was the first since Malpighi and Grew who devoted labour and perseverance to the study of the anatomy of plants, but still more because at a time, when the structure even of matured vegetable organs was almost a forgotten subject, he endeavoured to penetrate into the history of the development of this structure and the formation of cellular tissue. Unfortunately he was not directed to this by an exclusive interest in phytotomy, but by a more general question which he endeavoured to set at rest in this manner; he wished to refute the prevailing theory of evolution by demonstrating the development of the organs of plants, and to obtain an inductive basis for his doctrine of epigenesis. Though he was often diverted by these means from the pursuit of purely phytotomic questions, yet his famous work, 'Theoria Generationis' (I759) is nevertheless important in the history of phytotomy; for though it was disregarded by botanists during the succeeding forty years, or at any rate exercised no noticeable influence, yet it was Wolff's doctrine of the formation of cellular structure in plants which was in the main adopted by Mirbel at the beginning of the present century, and the opposition which it encountered contributed essentially to the further advance of phytotomy. This late but lasting influence of Caspar Friedrich Wolff's work was due not to the actual correctness but to the thoughtfulness of his observations, and to the earnest desire which inspired them to

Haller, the representative of the theory of evolution against which this work was directed, replied to it in a kindly spirit and entered into a correspondence with its youthful author. After lecturing on medicine in Breslau, he was admitted to teach physiology and other subjects in the Collegium Medico-chirurgicum in Berlin, but was twice passed over in the appointment to professorships in that institution. He received an appointment in the Academy of St. Petersburg from the Empress Catherine II in 1766 , and died in that city in $\mathbf{1 7 9 4}$. See Alf. Kirchhoff, 'Idee der Pflanzenmetamorphose,' Berlin, I867. 
search out the true nature of vegetable cell-structure and to explain it on physical and philosophical grounds. The observations themselves on this point are highly inexact, and influenced by preconceived opinions, and his account of them is rendered obscure and often quite intolerable by his eagerness to give an immediate philosophic explanation of objects which he had only imperfectly examined. His efforts to follow the course of development in the first beginnings of the formation of cell-tissue were evidently not seconded by sufficient knowledge of the structure of matured organs, and, to judge by his figures and by his theoretical reflections, his microscope was of insufficient power and its definition imperfect. Notwithstanding all these deficiencies, Wolff's treatise is doubtless the most important work on phytotomy that appeared in the period between Grew and Mirbel, not, as has been said, on account of any particular excellence of observation, but because its author was able to make some use of what he saw, and to found a theory upon it.

According to that theory all the youngest parts of plants, the punctum vegetationis in the stem, which Wolff first distinguished, the youngest leaves and parts of the flower, consist of a transparent gelatinous substance ; this is saturated with nutrient sap, which is secreted at first in very small drops (we might say vacuoles), and these, as they gradually gain in circumference, expand the intermediate substance and so present enlarged cell-spaces. The intermediate substance therefore answers to what we should now call the cell-walls, only these are at first much thicker, and are constantly becoming thinner with the growth of the cell-spaces. We may compare young vegetable tissue, formed as Wolff imagines, with the porosity of fermenting dough, except that the pores are not filled with gas but with a fluid. It is plain from the above description that the vesicles or pores, as Wolff names the cells, are connected together from the first by the intermediate substance, and that one lamina or cell-membrane 
only lies between each of two adjoining cells, a point which succeeding phytotomists were a long time in determining. As cells are formed by the secretion of drops of sap in the fundamental substance which is at first homogeneous, so vessels, according to Wolff, are produced by longitudinal extension of a drop in the mucilage and formation of a canal ; consequently adjoining vessels must be separated from one another by a single lamina of the fundamental substance. Though Wolff expressly mentions the movement of the sap within the firm mucilaginous substance between the cellular cavities and the vascular canals, a movement of diffusion as it might now be termed, he inconsistently enough thinks it necessary to assume the existence of perforations in the bounding-walls of cells and vessels to serve for the movement of sap from cell to cell and vessel to vessel; yet in the single case in which he succeeded in obtaining isolated cells, namely in ripe fruits, he was obliged to allow that the walls were closed.

The growth of the parts of plants, according to IVolff, is effected by expansion of existing cells and vessels, and by the formation of new ones between them in the same way as the first vacuoles were formed in the mucilaginous substance of very young organs; that is to say, the sap which saturates the solid substance between the passages and cavities of the tissue separates in the form of drops, which increase in size and then appear as cells and vessels introduced between the older ones. The substance between the passages and cavities, at first soft and extensible, becomes firmer and harder with increasing age, and at the same time a hardening substance may be deposited on it from the sap which is stagnant in the cellcavities and in movement in the vascular passages, and this substance in many cases appears as their proper membrane.

This is in all essential points Wolff's theory. IVe may omit his statements on the subject of the first formation of leaves at the growing point and of the development of the parts of the flower, as well as his physiological views on food and sexuality, 
which remained for a long time without influence on the growth of opinion, and mention only his doctrine of the growth of thickness of the stem. The stem is originally the prolongation 'of all the leaf-stalks united together. As many bundles of vessels are formed in the developed stem as there are leaves springing from the vegetative axis; each leaf has a single vascular bundle belonging to it in the stem, in modern phraseology an inner leaf-trace. The union of these bundles from the different leaves forms the rind of the stem; but if the leaves are very numerous, their descending bundles form a closed cylinder, and if the stem is perennial, the fresh production of leaves every year produces new zones of wood of this kind every year, which are the yearly rings. This view of Wolff's on the growth of the stem in thickness bears an unmistakable resemblance to the theory afterwards suggested by Du PetitThouars, according to which the roots which descend from the buds are supposed to effect the thickening of the stem.

The contests between Mirbel and his German antagonists at the beginning of the present century will bring us back again to the more important points in Wolff's theory of the cell. Contemporary botanists paid less attention to the 'Theoria Generationis' than they did to Hedwig's ${ }^{1}$ phytotomic views, not on the formation of cells, but on the structure of mature tissue. HEDwIG had given various figures and descriptions of phytotomic subjects in his 'Fundamentum Historiae Muscorum' ( $\mathbf{I} 782)$ and afterwards in his 'Theoria Generationis'

1 Johannes Hedwig, the founder of the scientific knowledge of the Mosses, was born at Kronstadt in Siebenbürgen in I 730 . Having completed his studies at Leipsic, he returned to his native town, but was not permitted to practice there as a physician because he had not taken a degree in Austria. He consequently went back to Saxony and settled first at Chemnitz, and in $\mathrm{I} 78 \mathrm{I}$ in Leipsic. Here he was appointed in $\mathrm{I}_{7} 84$ to the Military Hospital, and became Professor extraordinary of Medicine in 1786 and ordinary Professor of Botany in I 789. He died I 799. He commenced his botanical studies as a student at the University, and continued them in Chemnitz under trying circumstances, till as Professor he was free to devote himself entit ely to them. 
(I784); but he treats these topics at greater length in his treatise 'De fibrae vegetabilis et animalis ortu,' published in 1789 , and known to the author of this work only imperfectly from quotations in later writers. Hedwig's figures of histological objects appear to be better than those of any of his predecessors ; they show that he used strong magnifying powers, and that his glass had a clear field of sight. His defect lay in preconceived opinions and hasty interpretation of what he observed. In order to refute Gleichen's view of the stomata in ferns, he demonstrated the existence of these organs in many phanerogams, and observed the opening of the slits, which he named 'spiracula.' On the epidermis which he had removed for the purpose of these observations he saw plainly the double contour lines bounding the epidermis-cells, and therefore the cell-walls, which are at right angles to the surface. These he took for a particular form of vessel, and called them 'vasa reducentia' or 'lymphatica,' and afterwards 'vasa exhalantia,' and he thought that he had found them again in the interior of parenchymatous tissue, evidently taking the places where three wall-surfaces meet for vessels; such vessels he also saw in the milk-cells of Asclepias, described in I 779 by the elder Moldenhawer, who seems himself to have regarded even the intercellular spaces in the pith of the rose as equivalent to these milk-cells. The word vessel even in the 18 th century was used in such an indefinite manner, that the broad air-tubes of the wood and the finest fibres were called vessels. Hedwig's idea of the construction of spiral vessels was strange enough; he took the spiral band itself for the vessel, and supposed it to be hollow because it is coloured by absorption of coloured fluids; in those spiral vessels in which the turns of the spiral band are distant he saw, it is true, the delicate original membrane which lies between the turns, but he supposed that it lay inside the spiral band, which was wound round it on the outside. On the second plate of the first part of the 'Historia Muscorum' he even figures the network of ridges which the 
Cнар. II.] Phytotomy in the Eighteenth Century. 2.55

adjoining cells have left on the wall of the spiral vessel, but explains it as wrinkles caused by desiccation.

Hedwig was without doubt a very practised microscopist, and he constantly recommended the extremest care in the interpretation of all that the instrument reveals; but if an observer so careful and practised, who moreover was provided with a glass of tolerably strong magnifying power, fell into such gross mistakes, it cannot surprise us if others, as P. Schrank, Medicus, Brunn, and Senebier, accomplished still less. These highly unimportant achievements are all that mark the close of the I 8 th century. 


\section{CHAPTER III.}

Examination of the Matured Framework of Cellmembrane in Plants.

$$
\text { I } 800-1840 .
$$

THERE is no sharp line of division between the I8th and the Igth centuries; the phytotomists who appear on the scene during the first years of the new century are scarcely more successful than Hedwig and Wolff; careful and judicious interpretation of their own and others' observations is still rare, and they are often misled by preconceived opinions.

In one respect indeed a very great improvement appeared with the commencement of the rgth century; the number of phytotomists working contemporaneously, checking and criticising one another, became all at once much larger. Hitherto ten or twenty years had intervened between every two works on phytotomy; but in the course of the twelve years after 1800 nearly as many publications followed one another, and scientific discussion enlivened enquiry. Now we meet with a Frenchman for the first time in the field of phytotomy, Brisseau Mirbel, who brought out his 'Traité d'Anatomie et de Physiologie Végétale' in 1802 , and raised a series of questions in the discussion of which several German botanists, Kurt Sprengel (r802), Bernhardi (1805), Treviranus (1806), Link and Rudolphi (1807), at once took part. It was a step in advance and one affecting all botanical studies, that with the exception of Rudolphi all these men, like Hedwig before them, were botanists by profession; it was at last felt 


\section{Examination of Cell-membrane in Plants. 257}

that the examination of the internal structure of plants, as well as the describing them according to Linnaean patterns, was a part of botanical enquiry; it is at the same time true that the botanical knowledge of these observers was often of service to them in their phytotomical investigations, and directed their work decidedly and from the first towards that which was worth knowing, and towards the objects which claimed the first attention. This remark applies to the younger Moldenhawer even more than to the botanists above-named; his 'Beiträge,' published in 1812 , may be taken as closing the first section of this century, during which time he improved the methods of observation, compared his own observations and those of others with great acuteness of judgment, and did all that could be expected with the microscopes of the time.

The period of sixteen years after Moldenhawer, from I8I 2 to 1828 , has nothing of material importance to show in phytotomy. On the other hand, it produced a series of the most important improvements that the compound microscope has undergone since its invention.

As early as 1784 Aepinus had produced objectives of flint and crown glass, and in $1807 \mathrm{Van} \mathrm{Deyl}^{1}$ made similar ones with two achromatic lenses, and still the phytotomists complained of the condition of their instruments. Their figures show that they could not see clearly with them, though the magnifying powers were not high; Link says expressly in the preface to his prize-essay of 1807 , that he usually observed with a lens that magnified a hundred and eighty times. Moldenhawer in $\mathbf{r} 8 \mathbf{r} 2$ gives the preference over all the microscopes he had used to one by Wright, which was serviceable with a magnifying power of four hundred times, while the German instruments, especially those by Weickert, could not be used with higher powers than from one hundred and seventy to three hundred.

A certain interval elapsed each time between an improvement

${ }^{1}$ See P. Harting, 'Das Mikroskop,' §§ 433 and 434. 
in the instrument and the appearance of the advantages which phytotomy derived from it; thus in 1824 , Selligue exhibited to the Academy of Paris an excellent microscope with double lenses, several of which could be screwed on one over the other, and which could be used with ordinary daylight and a magnifying power of five hundred times; in 1827 Amici made the first achromatic and aplanatic objectives with three double lenses screwed on one over the other, the flat sides being turned to the object. And yet still in $18{ }_{3} 6$ a practised phytotomist like Meyen spoke with disapproval of the instruments of his time, and gave the preference to an old English microscope by James Man, though he allowed that the newest instruments by Ploessl were a little better. In his work on phytotomy, which appeared in 1830 , all the figures were magnified two hundred and twenty times, as were the very beautiful figures in his prize essay of 1836 ; but in his 'Neues System' ( 1837 ), he had already adopted powers that magnified to over five hundred times. How rapid the progress was in the years before and after 1830 is shown by comparing von Mohl's work on climbing plants of 1827 and its antiquated illustrations, with his publications of 1831 and 1833 , where the figures have a thoroughly modern appearance.

The art also of preparing anatomical objects rose by degrees with the improvement of the microscope. It was not in a very advanced state at the beginning of the century, if we judge by the language of writers and by their figures. It was a great step in advance when the younger Moldenhawer in $18 \mathrm{I} 2$ isolated cells by maceration and decay in water, and was thus enabled to view cells and vessels on every side and in a perfect condition, to see their real shape, and to survey the manner of their combination more exactly than had hitherto been done. But even Moldenhawer still made the mistake of submitting delicate microscopic objects to observation in a dry state, though Rudolphi and Link in $\mathrm{I} 807$ had urged the advisability of keeping every part of the preparations moist, especially the 
surface towards the object-glass, which shows that they did not then use covering glasses. Nor was sufficient attention shown to the use of sharp knives of suitable form, such as the razor, which is now almost exclusively employed, or to practice in making transverse and longitudinal sections of the utmost possible delicacy,-two things which, through the example of Meyen's and von Mohl's practice, were afterwards recognised as indispensable helps to phytotomy; even in their time observers were satisfied with crushing and picking their preparations to pieces.

Drawing from the microscope kept even pace on the whole with increasing skill in making preparations, and with the improvement of the instrument. If we compare together the drawings of Mirbel and Kurt Sprengel in the beginning of the century, those of Link and Treviranus in r807, Moldenhawer's in I 8 I 2, and Meyen's and von Mohl's from I 827 to 1840 , we shall obtain a rapid and instructive survey of the history of phytotomy during this period of forty years. The figures testify at once to constant increase in the magnifying powers, to the greater clearness of the field of sight, and still more to the constant improvement in the arts of preparing and observing objects. But a curious misconception crept in among the phytotomists at this time ; they believed that more correct and trustworthy figures would be obtained, if the observer and writer did not himself make them, but employed other eyes and other hands for that purpose; they imagined that in this way every kind of prejudice, of preconceived opinion would be eliminated from the drawings. Thus both Mirbel and Moldenhawer had their figures drawn by a woman, and many later phytotomists entrusted the execution of their drawings to hired draughtsmen, as Leeuwenhoek had done before them. A drawing from the microscope, like every other copy of an object in natural history, cannot pretend to take the place of the object itself, but is intended to give an exact and clear rendering of what the observer has perceived, and by so doing illustrate the 
verbal description. The drawing will be perfect in proportion to the practised skill of the eye that observes and of the mind that interprets the forms. The copy should only show to another person what has passed through the mind of the observer, for then only can it serve the purpose of a mutual understanding. There is also another point to be considered; it is exactly in the process of drawing a microscopic object that the eye is compelled to dwell on the individual lines and points and to grasp their true connection in all dimensions of space; it will often happen that in this process relations will be perceived, which previous careful observation had disregarded, and which may be decisive of the question under examination or even open up new ones. As the microscope trains the eye to scientific sight, so the careful drawing of objects makes the educated eye become the watchful adviser of the investigating mind; but this advantage is lost to the observer who has his drawings made by another hand. It is not one of the least of von Mohl's merits, that he practised microscopic drawing under the influence of the views here indicated, and sought to make his figures no mere undigested copies of the objects, but an expression of his own opinions about them.

Enough has been said to show that an important portion of the history of phytotomy lies between the beginning and the end of the period under consideration. The distance between the knowledge of the structure of vegetable tissue which existed at the beginning of the century, and that of Meyen and von Mohl on the same subject in 1840 , is wonderfully great; in the one case an uncertain groping about among obscure ideas, in the other a complete exposition of the inner architecture of the mature plant. But in spite of this great difference between beginning and end, it is better to review the efforts of this period of forty years as a connected process of historical development, and, notwithstanding the interval between the appearance of Moldenhawer's contributions in I8I 2 and Meyen's and von Mohl's labours about 1840 , to consider the latter as 
the settlement of the questions taken up at the commencement of the century. Moreover after I 840 , with the appearance of Schleiden and Nägeli on the scene, new points of view were suddenly disclosed, and new aims were proposed in phytotomic investigation; it is no objection to this view of the subject, that the most productive portion of von Mohl's labours falls in the succeeding twenty years, and that during this later period his position is one of equal authority with the new tendency and of participation in it. Up to I 845 his discoveries were the culminating point of the older phytotomy ; they put the finishing stroke to the work which Mirbel, Link, Treviranus, and Moldenhawer had begun. The object almost exclusively pursued during all this period was to frame as true a scheme as possible of the inner structure of the mature organs of the plant; it was requisite to gain a right understanding of the diversities of cells and forms of tissues, to classify them and supply them with names, and to secure well-conceived definitions of these names. Hence almost exclusive attention was paid to the configuration of the solid framework of cell-membrane, and of this chiefly in the matured state, to the form of the several elementary organs and their combination in the tissue, to the sculpture of the wall-surfaces, and to the connection of cell-spaces by pores or their separation by closed walls. There was much discussion, especially at first, on the contents of vessels and cells, and on supposed movements of sap in connection with anatomical research, but there was no careful connected investigation of the cell-contents; it was not yet recognised that the true living body of the vegetable cell is only a definite part of the contents inclosed by the cell-wall; the solid walls, the framework of the whole building, were regarded as of primary importance in the structure of the cell. It was not till the following period that in the light of historical development another view asserted itself, namely, that the solid framework of vegetable tissue with all its importance is yet in the genetic sense only a secondary product of the 
phenomena of vegetative life, that the true cell-body, the cellprotoplasm is prior in time and in conception, and can claim the higher position.

Mirbel, to whom we now return, had in I80 r laid down a theory of cell-formation which agreed in the main with that of Caspar Friedrich Wolff; he supposed with Wolff that each cell-space was separated from its neighbour by a single wall, and relying on fresh observations asserted the existence of visible pores in the dividing walls of parenchyma and of vessels, and also maintained some new views on the nature and formation of vessels. The essential points of this theory found an opponent in Germany in the person of KURT SPRENGEL, the well-known historian of botany, and one of the most variously accomplished botanists of his time, who had published in $\mathrm{r} 802$ a work written in diffuse and familiar style under the title of 'Anleitung zur Kenntniss der Gewächse.' He relied on his own observations, but these were evidently made with small magnifying powers, an obscure field of sight, and indifferent preparations. The cell-tissue, says Sprengel, consisis of cavities of very various shape communicating with one another, the dividing walls being in some places broken through and in others wanting. He took the starch-granules which he saw in the seed-leaves of beans and other plants for vesicles, which increase in size by absorption of water and so form new tissue ; but he did not explain how we are to conceive of the growth of organs with such a mode of cell-formation. His account of the vessels is extremely obscure, even more obscure than Hedwig's, though he has the merit of refuting the latter's strange theory of reconducting vessels in the epidermis; he also suggested, though only incidentally, the happy idea that spiral passages and even vessels might arise from cell-tissue, since the youngest parts of plants have only the latter ; but he did not attempt to explain how or where the process takes place. Like Malpighi 
and Grew he supposed that the spiral vessels had no wall of their own, but thought that the closely-rolled spiral threads formed a wall; the constrictions in broad short-membered vessels he regarded as real contractions in their substance, caused by the increased tightening of the spiral threads through a sort of peristaltic movement, - a mistaken notion often entertained at the beginning of the century, by Goethe among others, and connected with ideas of vital power prevalent at the time. In the stomata, to which he gave the name still in use, Sprengel like Grew, Gleichen, and Hedwig, saw a circular cushion instead of the two guard-cells; but he notices the observation first made by Comparetti, that the orifice closes and opens alternately, being wide open in the morning and closed in the evening. But he considered the stomata to be organs of absorption.

Sprengel in enunciating his own theory of cell-formation accused Mirbel of mistaking the starch-grains in the cells for the pores of the cell-walls. On this point, so important in the doctrine of the cell and in physiology, he was followed by the three candidates for the Göttingen prize, though Bernhardi had in 1805 defended Mirbel's view, and had pointed out how little likely it was, that so skilful an observer as Mirbel should fall into so gross an error. BERnHARdi's short treatise, 'Beobachtungen über Pflanzengefässe,' Erfurt $\left(\mathrm{r} 805^{1}\right)$, was in general distinguished by a variety of new and correct observations, and was the work of a simple and straightforward understanding, which takes things as they are presented to the eye without allowing itself to be led astray by preconceived opinions. His observations are certainly the best in the whole period from Malpighi and Grew to the younger Moldenhawer; his method of dealing with questions of phytotomy is much more to the purpose than that of the three rivals for the Göttingen prize.

1 Johann Jakob Bernhardi, born in 1774 , was Professor of Botany in Erfurt, and died there in $185^{\circ}$. 
In the work just mentioned Bernhardi treats of other forms of tissue as well as vessels, and endeavours to distinguish and classify them more exactly than had hitherto been done. $\mathrm{He}$ contrasts favourably with his contemporaries in the fact, that he sought to define the histological terms employed as precisely as possible,- - a great step in advance at a time when phytotomic conceptions were in a very misty condition. He distinguishes three chief forms of vegetable tissue, pith, bast, and vessels.

By pith he means the tissue which Grew had named parenchyma, and which is still so called; it remained a question with him whether the cells of the pith are pierced by visible pores. By the word bast he understood not only the fibrous elements of the rind, but those of the wood also, and in general what is now known as prosenchyma; this agrees very well with Malpighi's view, which was adopted by Bernhardi and by all his contemporaries, that the inner layers of the bast are changed into the exterior layers of wood to make the increase in thickness of the woody stem; but he did not admit the same origin in the case of the innermost portion of the wood, for this is formed from the first in the young shoots, which alone contain true spiral vessels with threads that may be wound off.

Bernhardi distinguishes vessels into two main groups, airvessels and vessels properly so called. He calls the first group air-vessels for the same reason that led Grew to give them that name, namely, that they are filled with air during a part at least of the period of vegetation; they are found in the wood, and, where there is no closed woody body, there the woody bundles are formed both of vessels and also of bast strands which enclose vascular canals. These latter he next divides into three chief kinds; annular vessels, which he was the first to discover, true spiral vessels with a band which can be unwound, and scalariform vessels, by which term he understood not only those with broad slits, such as are found in Ferns, but also the pitted vessels in secondary wood. His idea of annular and spiral vessels was perfectly correct, and he 
mentions Hedwig's notion already described, and shows that its exact opposite is true, namely, that the spiral band is surrounded by a membrane on the outside, - a fact which was afterwards denied by Link, Sprengel, and Moldenhawer. On the other hand he did not understand the sculpturing on the scalariform vessels; he took the pits in the dotted vessels for thickenings of the wall, such as are seen in the transverse ridges between the slits in true scalariform vessels, and the slits he thought were closed. If there was much that was erroneous in these views, yet Bernhardi contributed essentially to the clearing up of the subject by his effort to distinguish the different forms of air-vessels, and especially by pointing attention to the fact that neither spiral nor annular vessels are found in secondary wood. The resemblance between different forms of vessels misled many of his contemporaries into supposing that they are due to metamorphosis of true spiral vessels. Bernhardi showed that different forms of wall are found inside one vascular tube, but that this does not depend on modification with age; observation rather teaches that every kind of vessel receives its character in its young state, and especially that the youngest scalariform vessels do not present the form of spiral vessels.

Under the head of vessels proper he reckoned all tubular forms filled with a peculiar juice, milk-cells and true milk-vessels, and also resin-ducts and the like, and he made many good and still valuable observations on their distribution and sap-contents. $\mathrm{He}$ could not see the differences of structure in these various fluid-conveying vessels with the low magnifying power of his glass, and therefore attended chiefly to the structure of the large resin-ducts, which on the whole he rightly understood.

The question whether there are any other forms of vessels in the plant beside those already named gave him occasion to define a vessel better than it had yet been defined, namely as an uninterrupted tube or canal, and at the same time he found himself obliged to consider whether his bast-threads are vessels ; 
but he did not give a decided answer to the question. $\mathrm{He}$ declared however distinctly against Hedwig's reconducting vessels in the epidermis, as Sprengel had done, and it is worthy of recognition that he understood the true nature of the corners where three longitudinal walls of the parenchyma meet, while later observers found difficulties in them.

Before the appearance of Bernhardi's work the Royal scientific Society of Göttingen proposed a subject for a prize in the year 1804 , which shows very plainly what uncertainty was felt at that time on all points of phytotomy. For this reason it will be well to give it at length from the preface to Rudolphi's 'Anatomie der Pflanzen' (1807): 'Since some modern physiologists deny the peculiar construction of vessels in plants which is attributed to them by other and especially the older observers, it would be well to institute new microscopical investigations, which shall either confirm the observations of Malpighi, Grew, Du Hamel, Mustel, and Hedwig, or prove that plants have a special organisation of their own which is more simple than that of animals, whether that organisation is supposed to originate in simple peculiar fibres and threads (Medicus) or with cellular and tubular tissue (tissu tubulaire of Mirbel). Attention should also be given to the following subordinate questions: I. How many kinds of vessels may certainly be distinguished from the first period of their development? The existence of certain forms having been established; 2. Are the twisted fibres which are called spiral vessels (vasa spiralia) themselves hollow, and do they therefore form vessels, or do they serve by their convolutions for the formation of closed cavities, and how? 3. Do fluids as well as gases move in these cavities? 4. Do the scalariform ducts arise from adherence of the twisted threads (Sprengel), or do the threads owe their origin to the ducts (Mirbel)? Do alburnum and woody fibres originate in the scalariform ducts, or in true vessels, or in tubular tissue?'

We see in this case as in many similar ones, that the subject 
was proposed by persons who understood little of it, and who were unable to judge of what had been written about it; how else could they have placed the opinions of a Mustel and a Medicus side by side with those of Malpighi and Grew? Had Bernhardi or Mirbel set the question, it would certainly have been better conceived. It was in keeping that the three essays sent in, all inferior to Bernhardi's work already mentioned, though they contradicted one another on the most important points, were nevertheless all accepted; not less so that Treviranus' essay obtained only the second place, though it was decidedly better than the other two, and very much better than Rudolphi's. The best result of the whole affair was that it stirred up the phytotomists of the day, and led Mirbel to submit the three prize treatises to a searching criticism, especially that of Treviranus, which Mirbel with professional acumen recognised as the best. Link's essay appeared in 1807 under the title 'Grundlehren der Anatomie und Physiologie der Pflanzen,' that of Rudolphi as 'Anatomie der Pflanzen,' also in I 807 , each forming a handsome octavo volume. The work of Treviranus had already appeared in $\mathbf{1} 806$ with the title, 'Vom inwendigen Bau der Gewächse.'

If we compare the works of Link and Rudolphi ${ }^{1}$, which both received a prize, and which had all the appearance of text-books of general vegetable phytotomy and physiology, we miss in both any clear exposition of the conceptions connected with the words used, and the train of thought therefore is constantly obscure and vacillating. Yet it is easy to see that they are opposed to one another in all essential points, Link ${ }^{2}$

1 Karl Asmus Rudolphi, born at Stockholm in 1771, was Professor of Anatomy and Physiology in Berlin, and died there in 1832 .

${ }^{2}$ Heinrich Friedrich Link was born at Hildesheim in 1767 , and became Doctor of Medicine of Göttingen in 1788 . In $179^{2}$ he became Professor of Zoology, Botany, and Chemistry in Rostock, Professor of Botany in I8I I in Breslau, and in 1815 in Berlin, where he died in $185 \mathrm{I}$. He was a clever man of very varied accomplishment, but not a very accurate observer of 
generally hitting on the correct, or at least the correcter view. For instance, Rudolphi denies altogether the vegetable nature of Fungi and Lichens, because he finds no resemblance between their hyphae and vegetable cell-tissue, and he supposes them to arise by spontaneous generation; even of the Confervae he says that the microscope has shown him nothing that agrees with the structure of plants, - evidently a sign of bad observation or of incapacity to understand what he saw. Link on the other hand regards all Thallophytes as plants, and sees that the filaments of Lichens and Fungi consist of cells, and that cells occur at least in many Algae. Rudolphi praises in the same breath the views of IVolff and Sprengel on cell-tissue, although they are directly opposed to one another, and although he adopts Sprengel's strange theory of cell-formation without alteration. Link on the contrary declares against Sprengel's theory, and on good grounds, and shows that the vesicles which Sprengel took for young cells are starch-grains; at the same time he makes new cells be formed between the old ones. Rudolphi is of opinion that cells open into one another, as is plainly shown by the passage of coloured fluids. Link maintains that cells are closed bodies, and proves it well by the occurrence of cells with coloured juice in the middle of colourless tissue. Rudolphi represents the orifices of the stomata as encircled by a roundish rim, which he takes without hesitation for a closing muscle because the apertures enlarge and diminish.

details, and was held in estimation by many chiefly as a good teacher and philosophic author of popular works on natural science. He was one of the few German botanists in the early part of the present century who aimed at a general knowledge of plants, and combined anatomical and physiological enquiries with solid researches in systematic botany. Of his many treatises on all branches of botanical science, zoology, physics, chemistry, and other subjects, his Göttingen prize essay must be considered to have contributed most to the advancement of science. Von Martius somewhat overrates his scientific importance in his 'Denkrede auf H. F. Link' in the 'Gelehrte Anzeigen,' München (I 85 I), 58-69. 
Link is more happy in taking the part that surrounds the aperture for a cell, or a group of cells. Rudolphi considers the great cavities in hollow stems and in the tissue of water-plants as the only air-passages in plants ; Link explains these cavities as gaps caused by the irregular growth of cellular tissue. With Rudolphi the word vessel means not only vascular forms in wood, but milk-vessels and resin-ducts also, and to the former he even transfers Malpighi's view of the structure of spiral vessels. Link designates the tubes of the wood only as vessels, combining the most various forms of them under the term spiral vessels; he excludes milk-vessels, resinducts, and the like from the conception of a vessel, and in this he is somewhat inconsistent, since he assumes with Rudolphi that a vessel, in plants as in animals, is a canal for the conveyance of nutrient sap.

With all these contradictions, the two essays agree in adopting the old Malpighian view of the growth in thickness of stems, according to which the new layers of wood are formed from the inner layers of bast, while between the bast-cells, which are here taken to be identical with woody fibre, new spiral vessels arise contemporaneously, and, as Link expressly says, from juices which pour out between the bast-cells.

It is hard to understand how two treatises, so contradictory as they have been shown to be, could have both received a prize at the same time, or how the great difference could have been overlooked between Link's sensible and wellarranged account of his subject, and Rudolphi's uncritical statements, which everywhere rely more on old authority than on his own observation. It is however certain that Link's better production is inferior to Bernhardi's treatise, unless we choose to consider the greater copiousness of detail in Link, the number of his observations, and his aquaintance with the literature of the subject, as giving him the advantage. His figures, as well as Rudolphi's, are not so good as those of Bernhardi. 
The work of Treviranus ${ }^{1}$, to which the judges at Göttingen awarded the second place, is much less comprehensive than those of his competitors; the style is inferior to Link's, and may even be called clumsy. But the much better figures show at once that Treviranus was the more accurate observer, and his work, in spite of the inferiority of its style, is of far higher value on account of the attention paid in it to the history of development; Treviranus laid greater stress on this method than either Link or Rudolphi, and it led him to form views on some of the fundamental questions of phytotomy, in which we see the germs of theories afterwards perfected by von Mohl. His account of the formation of cell-tissue is mainly that of Sprengel, and therefore an unfortunate one; but nevertheless his observations on the composition of wood and the nature of vessels were as good and correct as could be expected from the condition of the microscope at the time. $\mathrm{He}$ made one discovery of considerable value, that of the intercellular spaces in parenchyma, but he lessened its merit by filling these passages with sap, and even describing its movement. Woody fibres are due, he thinks, to strong

${ }_{1}$ Ludolf Christian Treviranus, born at Bremen in I 779, became Doctor of Medicine of Jena in 1801 , and practised at first in his native town, where he became a teacher at the Lyceum in 1807 . In 1812 he accepted the professorship in Rostock vacated by Link, and was again his successor in Breslau. In 1830 he exchanged posts with C. G. Nees von Esenbeck, who was a professor in Bonn; he died in that town in 1864 . In the first part of his life he occupied himself chiefly with vegetable anatomy and physiology, afterwards with the determination and correction of species. His first works, which are noticed in the text, and the treatises on sexuality and the embryology of the Phanerogams, published between I 8 I $5_{5}$ and I 828 , are the most important in a historical point of view. His 'Physiologie der Gewächse' in two volumes $\left(1835^{-18} 83^{2}\right)$ is still of value for its accurate information on the literature of the subject ; but it can scarcely be said to have contributed to the advance of physiology, for its author adhered in it to the old views, and especially to the notion of the vital force, at a time when new ideas were already asserting themselves. The 'Botanische Zeitung' for 1864 , p. I76, contains a notice of his life. 
longitudinal extension of vesicles. He supported Bernhardi's view of the nature of vessels, that the separable spiral threads of spiral vessels are not wound round a membranous tube but are surrounded by one. He maintains against Bernhardi the distinctness of punctated vessels or porous woody tubes from false tracheae or scalariform vessels, while he gave a more correct description of the latter as they occur in Ferns. He rejected Mirbel's view that the pits in dotted vessels are depressions surrounded by a raised glandular edge, and explained them as grains or little spheres. Against this mistake we may set off the very important step which he made in advance, when he not only conjectured that the pitted vessels of the wood are formed from cells previously divided off from one another, but proved by observation that the members composing such vessels are at first actually separated by oblique cross-walls, which afterwards disappear. But this correct observation was impaired by the mistaken idea, which Treviranus shared with his predecessors, that the wood is the result of transformation of the bast, and consequently that the vessels of the wood are bast-fibres, which elongate considerably after they are arranged in a direct chain one after the other; the unevennesses caused by the oblique junctions of the tissue gradually disappear, the boundaries of each member of a vessel being still for some time indicated by oblique transverse markings. The dividing walls originally existing at these points disappear by widening of the cavities, so that the different parts come to form a continuous canal. To illustrate the disappearance of a parting wall between two adjoining cells Treviranus aptly points, somewhat to our surprise, to the formation of the conjugating tube in Spirogyra. He rejects with Bernhardi the view represented by Sprengel, Link, and Rudolphi, that the different kinds of vessels are formed from true spiral vessels; he says that he had found the scalariform ducts in Ferns so formed in their earliest stage and not as spiral vessels; he thinks it highly probable that the distinct 
transverse bands on false spiral vessels (scalariform ducts) and the pits of dotted vessels are formed on the walls of membranous fibre-tubes; in like manner he derives true spiral vessels from long thin-walled cells, on whose inner surface the spiral band is formed, and well compares the members of young spiral vessels with the elaters of the Jungermannieae. Here then we find the first more definite indications of a theory of growth in thickness of cell-walls, which, like the theory of the origin of vessels from rows of cells, was afterwards developed by von Mohl and laid on better foundations. At the close of the essay the histology of the Cryptogams, Monocotyledons and Dicotyledons is compared, and the subject is better and more perspicuously handled than in the corresponding chapters of his competitors.

Though Treviranus' account of vegetable tissues was on the whole weak as far as concerns the history of development, yet MiRBEL ${ }^{1}$ recognised in him the most dangerous opponent of his own theory, and addressed a public letter to him and not to his other German antagonists, Sprengel, Link and Rudolphi, in defence of the views he had formerly expressed. This letter is the first part of a larger work which appeared in $\mathrm{I} 808$,

${ }^{1}$ Charles François Mirbel (Brissean-Mirbel) was born at Paris in 1776 , and died in $18_{54}$. He began life as a painter, but having been introduced by Desfontaines to the study of botany, he became Member of the Institute in 1808 , and soon after Professor in the University of Paris. From 1816 to I 825 the cares of administration withdrew him from his botanical studies, but he resumed them and became in 1829 Professeur des cultures in the Museum of Natural History. Mirhel was the founder of microscopic vegetable anatomy in France. All that had been accomplished there before his time was still more unimportant than the work done in Germany. His writings involved him in many controversies, and he made enemies by refusing in his capacity of teacher to allow the importance at that time attributed to systematic botany, but directed his pupils to the study of structure and the phenomena of life in plants. We are told by Milne-Edwards that he suffered much from the fierce attacks which were made upon him; he sank at last into a weak and apathetic state, and was for some time before his death unable to continue his studies or official duties ('Botanische Zeitung' for 1855, p. 343). 
'Exposition et défense de ma théorie de l'organisation végétale,' in which Mirbel endeavours to meet the objections of his opponents with great adroitness of style and with the results of varied rather than profound observation, and to find new arguments for his theory of vegetable tissue; he admits that his former treatises were in many respects faulty, but demands that his critics should discuss his system as a whole and not take offence at single expressions. Mirbel's idea of the inner structure of plants is essentially the same as that broached by Caspar Friedrich Wolff. The first and fundamental idea is that all vegetable organisation is formed from one and the same tissue differently modified. The cell-cavities are only hollow spaces of varying form and extension in homogeneous original matter, and have no need therefore of a system of filaments, as Grew supposed, to hold them together. The tracheae only are an exception, which Mirbel, in striking opposition to the much more correct view of Treviranus, considers to be narrow spirally wound laminae, inserted into the tissue and connected with it only at the two ends. If it is asked how interchange of sap is effected in such a cellular tissue as this, it becomes necessary to assume that the membranous substance of plants is pierced by countless invisible pores, through which fluids find their way. But nature has a speedier and more powerful instrument in the larger pores, which the microscope reveals. Mirbel does not discuss the question how the fluids are set in motion, easily disregarding such mechanical difficulties, as was usual in those days, when vital power was always in reserve to be the moving agent. $\mathrm{He}$ warmly repels the imputation, which Sprengel had made against him, of having confounded pores and granules, by appealing to his figures; he says that he has depicted prominences on the outside of the walls of the dotted vessels, and an orifice in each of them, which his opponents simply never saw. The question whether these prominences lie on the inside or the outside of the walls of the vessel has no meaning, 


\section{Examination of the Matured Framework [Bоок II.}

if we suppose with Mirbel that the dividing wall is single; he is only concerned to enquire whether the perforated projections lie on the one or on the other side of the wall. He refers Treviranus, who had denied the presence of the pores, to his description of scalariform vessels, in which he had himself seen the slits which correspond to the pores.

In comparison with these fundamental questions Mirbel's further account of matters of detail does not concern us here. He gave a connected view of the whole of his doctrine of tissues in the form of aphorisms, which occupy the second part of his book. Of all that he says on the five kinds into which he distinguishes vessels the most interesting is the statement, that diaphragms pierced like a sieve separate the different members of his 'beaded' vessels. We find that the weakest part of Mirbel's phytotomy, as of that of his opponents, is his description of the true vessels (vasa propria), with which he classes the milk-cells of the Euphorbiae and the resin-ducts of Coniferae, but he saw clearly enough that the latter were canals inclosed in a layer of tissue of their own. The third part of the book is devoted to these forms of tissue, and we learn that he classes not only many kinds of sieve-cell-bundles, but also true bast-fibres, as those of nettle and hemp, with his bundles of true vessels. Like his opponents he makes the growth in thickness in woody stems to be due to transformation of the inner layer of bast; but he gives a new turn to this view, which brings it nearer to the modern theory ; during the period of vegetation a delicate tissue with large vessels is developed in Dicotyledons on the confines of the wood and the bark, and these augment the mass of the woody body, while a loose cellular tissue is formed on the other side, destined to replace the constant losses of the outer rind. To later phytotomists, who understood by the word cambium a thin layer of tissue constantly engaged in producing wood and rind, Mirbel's otherwise indistinct conception of growth in thickness must have become more indistinct from his using 
the word cambium not for the layer of tissue afterwards so called, but for a highly 'elaborated and purified sap' which is intended for the food of the plant and makes its way through all membranes; we see this cambium-sap appear at the spots where it produces new tubes and cells after the manner of the Wolffian theory. The cells appear at first as minute spheres, the tubes are very fine lines; both enlarge and gradually show pores, clefts, etc. This is essentially Wolff's doctrine, which Mirbel afterwards endeavoured to confirm against his German opponents from the germination of the date-palm with the help of a more powerful microscope.

Mirbel insisted more than the German phytotomists of his day on the idea, that all forms of vegetable tissue are developed originally from young cell-tissue, an idea suggested by Sprengel and following naturally with Mirbel from Wolff's theory. Both Mirbel and Wolff were hasty in observation and too much under the influence of theory in giving reasons for what they observed, and therefore too ready with far-reaching explanations of phenomena which only long-continued observation could decide.

Treviranus replied, though after some delay, to Mirbel's polemics by incorporating into his 'Beiträge zur Pflanzenphysiologie,' Göttingen ( I 8 I I), an essay entitled 'Beobachtungen im Betreff einiger streitigen Puncte der Pflanzenphysiologie,' in which he again took up the questions in dispute between himself, Mirbel, Link and others, and supported his own views by fresh investigations. It cannot be denied that in this short treatise Treviranus brought some important questions nearer to a decision; he added materially to the knowledge of bordered pits, on which subject his views now approximated more nearly to those of Mirbel; he drew attention to the vesicular nature of vegetable cells, which are often separable from one another, and to the occurrence of true spiral vessels in the neighbourhood of the pith in Conifers also, and among other things discovered the stomata on the capsule of Mosses. 
On the subject of the theory of cell-formation which he had borrowed from Sprengel, he endeavoured to extricate himself from his difficulty by ingeniously pointing out that though the starch-grains in the seed-leaves of the bean disappear without producing new cells in them, they are dissolved and then serve as fluid material for new cell-formation in other parts of the germinating plant, which however was giving up Sprengel's theory ; yet he cited as a direct proof of that theory the origination of gonidia in the cells of Hydrodictyon, and their development into new nets.

Mirbel and his German opponents moved for the most part in a circle of ideas which had been formed by the speculations of Malpighi, Grew, Hedwig and Wolff, though it must be allowed that the observations of Treviranus did open new points of view. But Johann Jakob Paul Moldenhawer ${ }^{1}$ travelled far beyond these older views as early as 1812 in his important work, 'Beiträge zur Anatomie der Pflanzen.' He took up from the first a more independent position as regards former opinions than either of the writers hitherto considered. He relied on very detailed, varied, and systematic observations evidently made with a better instrument, abided by what he himself saw, and chose his point of view in accordance with it, while he criticised the views of his predecessors in detail with an unmistakable superiority, and in so doing displayed minute acquaintance with the literature of the subject and varied phytotomical experience. He fixed his eye firmly on the points in question, and made each one the subject of earnest investigation and copious and perspicuous discussion. His figures prove the carefulness of his examination and the greater excellence of his instrument; they are undoubtedly the best that were produced up to I8I2. His mode of dealing with his subject and his figures, though they were not executed by

${ }^{1}$ Johann Jakob Paul Moldenhawer was Professor of Botany in Kiel; he was born at Hamburg in 1766 , and died in 1827 . 
himself, remind us in many respects of von Mohl, though it would be more correct to say that von Mohl's manner reminds us of Moldenhawer, for from the great respect which von Mohl displays for him, especially in his earlier writings, it can scarcely be doubted that he formed himself on Moldenhawer's 'Beiträge,' and first learnt from them the earnestness and carefulness demanded by phytotomic work.

It has been already mentioned that the study of vegetable physiology is indebted to Moldenhawer for one important practical improvement. He was the first who isolated cells and vessels by allowing parts of plants to decay in water and afterwards crushing and dissecting them, a process not much used in modern times, though it may still be applied with advantage in conjunction with what is known as Schulze's solution, especially if it is carried out with Moldenhawer's carefulness and circumspection. The isolation of the elementary organs of plants by maceration in water necessarily brought Moldenhawer into direct antagonism with Mirbel, who with Wolff assumed that the partition between any two cells was a single wall; whereas Moldenhawer found that the cells and vessels were closed tubes and sacs after isolation, and must necessarily, as it would seem, so lie one against another in the living plant, that the wall between every two cell-spaces is formed of two membranous laminae, and he expressly says that this is the case even in very thin-walled parenchyma. This result remained unassailable, so long as no one was in a position to conclude from the history of the development of cell-tissue that the partitions are originally single, or by aid of strong magnifying power to prove the true structure of the walls and their later separation, and the differentiation of the once single wall into two separable laminae. If the view based on the results of maceration was still not the true view, yet it was nearer the truth as regards the matured state of the cell-wall than that of Wolff and Mirbel, and the important advantage was gained of being able to study the 
278 Examination of the Matured Framework [Воок II.

form of elementary organs and the sculpture on their walls more accurately than before. It is true that Link had occasionally isolated cells by boiling in $\mathrm{r} 809$, and Treviranus had drawn attention in I 8 I I to the fact that it was possible to isolate parenchyma-cells in their natural condition; but neither of them made systematic use of these observations, and to Moldenhawer belongs the exclusive merit of having first isolated vessels and woody cells; but as usually happens, he did not himself obtain all the possible results from his method of preparation. In his work which indeed embraces the whole of phytotomy, he is continually recurring to one species, maize. This supplies the starting-point in every question to be discussed. The results obtained there are the firm supports on which he leans in the examination of a great variety of plants, which he then compares together at length. This mode of treatment was well chosen both for investigation and instruction in the existing state of the science; it was a particularly happy idea that of choosing the maize-plant for his purpose; former phytotomists had generally had recourse to dicotyledonous stems, and preferred those that had compact wood and complex rind, but the examination of these plants presents difficulties at the present day to a practised observer with a good microscope. Occasionally observers had taken the stem of the gourd, where the large cells and vessels suited small magnifying power, but where many abnormal conditions occurred to interfere with their conclusions. The Monocotyledons, like the Vascular Cryptogams, had hitherto been comparatively neglected. When then Moldenhawer made a monocotyledonous and rapidly growing plant, with very largecelled tissue and comparatively very simple structure, the chief subject of his investigations, he was sure to succeed in making out many things more clearly than his predecessors. It was an important point that he found the fibrous elementary organs in this plant united with the vessels into bundles, which are separated by a strict line of demarcation from the large- 
celled parenchyma that surrounds them. Thus the peculiar character, the idea, of the vascular bundle was brought prominently into contrast with that of other forms of tissue. This took the place of the distinction between rind, wood, and pith, which had served former phytotomists as the basis of their histological survey, but which is in itself only a secondary result of the later elaboration of certain parts of the plant. Moldenhawer, in laying the chief stress from the first on the contrast between vascular bundles and parenchyma, hit upon a histological fact of more fundamental importance, the right appreciation of which has since enabled the phytotomist to find his way through the histology of the higher plants. For while the construction of Monocotyledons and Ferns must seem abnormal and quite peculiar to any one who starts with examining the rind, wood, and pith of old dicotyledonous stems, those on the contrary who, with Moldenhawer, have recognised a special histological system in the vascular bundles of Monocotyledons, have the way opened to them to seek for a similar one in the Dicotyledons, and to refer the secondary phenomenon of wood and rind to the primary existence of vascular bundles. Moldenhawer did in fact open this way, when he showed how the growth of a dicotyledonous stem may be understood from the structure and position of the originally isolated vascular bundles (Beiträge, p. 49, etc.). But he was thus of necessity led to the rejection of Malpighi's theory of the growth in thickness of woody stems, which all vegetable anatomists from Grew to Mirbel had adopted. Though Bernhardi and Treviranus made weak attempts to discredit it, Moldenhawer was the first who distinctly rejected the origin of the external layers of wood from the inner bast, and proposed the first really practical basis for the later and correct theory of secondary growth in thickness (p. 35). The removal of this ancient error is in itself a very important result, and one which, apart from all other services, must secure him an honourable place in the history of botany. 
280 Examination of the Matured Framework [Boок II.

But the light must have its attendant shadow, and all his carefulness in observation and cautiousness in judgment did not protect him from one prejudice and its evil consequences. After Moldenhawer had isolated the elementary organs by maceration, he had to answer the question how we are to conceive of their firm coherence in the living plant. $\mathrm{He}$ came to the conclusion, as did von Mohl, Schacht, and others after him, that there must be some special connecting medium; but he did not hit upon their idea of a matrix, in which the cells are imbedded, or of a cement which holds them together, but on a much stranger theory, which reminds us at once of Grew's thread-tissue, and like that rests partly on incorrect observations. These were too hastily accepted as the basis of a theory which in its turn interfered with after observations. He thought that the cells and vessels were surrounded and held together by an extremely delicate net-work of fine fibres; in some cases he really believed that he saw these fibres, and interpreted in this way the thickened bands in the well-known cells of Sphagnum, and still more strangely he appears to have taken the thickened longitudinal and transverse edges of cells and vessels for such threads. The unfavourable impression produced by this theory is necessarily heightened by the fact that he gave the name of cell-tissue, a term long used in a different sense, to his fancy-structure of reticulated threads which were to hold the cells and vessels together, while he called the parenchyma itself cellular substance, an expression which fortunately no one copied, and which certainly contributed at a later time to discredit the great services which Moldenhawer rendered to phytotomy.

His 'Beiträge zur Anatomie der Pflanzen' are divided into two portions; the first treats of the parts surrounding the spiral vessels; the second of the spiral vessels themselves.

The position and collective form of the component parts of the vascular bundle in the stem of the maize-plant are well described in the first section of the work. It is correctly stated 
that there is a sheath to the whole bundle composed of strongly thickened fibrous cells, that each of these cells has its own membrane and is entirely closed, and that they resemble the bast and the fibrous elements of the wood of Dicotyledons. The segmented wood-cells and the parenchyma-cells of the wood arranged in rows are incidentally noticed. Under the name of fibrous tubes he included the cells of the sclerenchyma-sheath of many vascular bundles and the true bast and wood-fibres, which latter he says are wanting in the Coniferae. He explained the secondary growth in thickness of rind and bast by the example of the shoot of the vine, in which he correctly distinguished the medullary sheath and the spiral vessels. In herbaceous Dicotyledons he found the bundles of vessels to consist of a bast portion and a woody portion, and he attributed the formation of the compact wood of true woody plants to the blending together of the woody portions of these separate bundles.

In discussing the parenchymatous cell-tissue he rejects emphatically and on good grounds the origin of new cells from the granular contents of older ones, which had been the view of Sprengel and Treviranus, as also the theory of Wolff and Mirbel, while he maintains against Mirbel especially, that the separation of fibrous tubes is possible even where no dividing line can be seen between them in the cross section. He considers that both in thin-walled and thick-walled parenchyma the dividing wall is double and the cell-membrane entirely closed. 'It appears,' he continues on p. 86, 'from these observations that cellular substance consists of separate closed tubes, which may be round or oval, or more or less elongated, or almost cylindrical in shape, and these by mutual pressure assume an angular and flattened form, which is either regular like the cells of the comb of bees or more or less irregular. Such an aggregate of separate cells (and here he is certainly quite right) has nothing in common with a tissue, and the word cell-tissue seems therefore less suitable than the term cellular substance, composed of cell-like tubes.' Further on he rejects Mirbel's idea of the 
existence of visible holes in the walls of cells, and points out that they are not necessary for the movement of sap. The dispute between Mirbel and his opponents respecting the porousness of cell-walls was extended at the same time to the stomata of the epidermis ${ }^{1}$, the slits in them being supposed to be apertures in the epidermis regarded as a simple membrane. Moldenhawer took occasion to examine the anatomy of stomata more closely, and produced the first accurate descriptions and figures of these organs, showing especially that the apertures are not surrounded by a simple border, as most previous observers believed, but lie between two cells, and that therefore they are not examples of the existence of pores in cell-walls, as Mirbel imagined. It may be observed here by the way, that Mirbel afterwards considered stomata to be short broad hairs; Amici in I824, Treviranus in I 821 , demonstrated their true structure by cross sections, and von Mohl at a later period investigated it thoroughly. Moldenhawer on the present occasion also enquired into the faculty attributed to stomata of opening and closing alternately, which, first observed by Comparetti, was then much discussed by the German phytotomists, and has been made the subject of repeated investigation in modern times. The whole of this discussion was in connection with the question of the pitting of cell-walls, the true nature of which Moldenhawer however never clearly understood.

The peculiar vessels, known as 'vasa propria,' were a stone of stumbling to Moldenhawer, as they were to his predecessors and to many of his successors, because misled by the resemblance in their contents he included under this name forms of very different kinds. A very good description of the soft bast in the vascular bundle of the maize-plant is followed by a notice of the milk-tubes of Musa, the milk-cells of Asclepias which he explains incorrectly, and the milk-vessels of Chelidonium

${ }^{1}$ On the doubts which were entertained till after 1812 on the subject of stomata, see Mohl's 'Ranken und Schlingpflanzen' (1827), p. 9. 
Снар. III.] of Cell-membrane in Plants.

which he understood better. All these 'vasa propria' he took for cellular vessels, formed of tubes opening into one another ; but he clearly distinguished the turpentine-ducts from them, and has given a correct figure of such a duct from the pine, though he assumes the existence of a special membrane lying inside the cell-rows which surround it, and lining the passage. Finally he passes on to the intercellular spaces, which he considers to be gaps in the cellular substance, and illustrates by Musa and Nymphaea. He does not notice particularly the narrow interstices which Treviranus had observed traversing the parenchyma.

In the second portion of his work he includes all the vessels found in the vascular bundle of the maize-plant under the term spiral vessels, but he distinguishes the different forms of them well, and especially points out that rings and spirals appear on one and the same vascular tube in different parts of its course, as Bernhardi had already shown. The isolating of the vessels gave him a better opportunity of seeing how they are made up of portions of different lengths than his predecessors had enjoyed, and he proves at some length the existence of a thin closed membrane forming the vessel, but like Hëdwig he places the thickenings on the outside. He as little overcame the difficulties of bordered pits as did von Mohl and Schleiden after him. In this case as in others, it was the history of development which first taught the true nature of these formations (Schacht, I860).

It was mentioned in the Introduction that Moldenhawer may be said to close the first portion of the period from I 800 to 1840 , not only because the majority of the questions ventilated up to that time were to a certain extent settled by him, but also because there is no material advance in phytotomy to be recorded for several years after the publication of his work in $18 \mathrm{r} 2$. It is true that Kieser in his 'Grundzüge der Anatomie der Pflanzen' (I8I5) attempted a connected exposition of the whole subject, but his book offers nothing really new, 
being merely a playing with the unmeaning phrases of the current nature-philosophy, while it revived gross errors like Hedwig's doctrine of the presence of lymphatic vessels in the tissue of the epidermis, and made the Mosses consist of conferva-threads. Phytotomy was on the contrary really enriched by the miscellaneous works of Treviranus published in $182 \mathrm{I}$, especially in respect to questions connected with the epidermis, and by Amici's discovery in 1823 , that the intercellular spaces in plants contain not sap but air, and that the vessels too chiefly convey air. We may quietly pass over the later writings of Mirbel, Schulze, Link, Turpin and others, which appeared after 1812 and before 1830 , as our business is not so much with an account of the literature of the subject as with evidence of real advance.

Meyen and von Mohl may be said to have commenced their labours with $\mathrm{r} 830$, and in the course of the succeeding ten years they became the chief authorities on phytotomy, though a highly meritorious work of Mirbel's on Marchantia polymorpha and the formation of pollen in Cucurbita falls as late as I 835. We may even pass over so elaborate a work as the 'Physiologie der Gewächse' of Treviranus (1835-1838), which embraces also the whole of phytotomy, because though its treatment of some of the details is good, it presents its subject virtually from the points of view opened before $\mathrm{r} 8 \mathrm{r} 2$. This work, though it neglects no part of its subject and contains much useful reference to the works of other observers, was unfortunately out of date at the time of its appearance, for owing to von Mohl's labours an entirely new spirit had entered since 1828 into the treatment of phytotomy.

Though Meyen and von Mohl must be regarded as the chiet representatives of phytotomy from I 830 to I 840 , yet they are men of very different importance in the science. The essential difference between them cannot perhaps be better shown than by pointing to the fact, that Meyen's labours cannot at present claim more than a historical interest, while von Mohl's earliest 
investigations between 1828 and 1840 , so far from being obsolete, are the sources of our present knowledge, and from them every one must still draw who proposes to cultivate any portion of phytotomy. Meyen's views, in spite of the many investigations which he made himself, are entirely confined within the circle of thought represented by the Göttingen essayists, though in his observations he went beyond them, and even beyond Moldenhawer; but the phytotonical views of these men were from the first no law to von Mohl ; he took up an entirely independent position at once with respect even to Moldenhawer and Treviranus, though a longer time certainly elapsed, before he succeeded in freeing himself wholly from Mirbel's authority. For these reasons, and because Meyen's work was interrupted by his death so early as 1840 , while von Mohl aided to advance phytotomy for another thirty years, we will speak first of Meyen's labours in that department.

MEYEN $^{1}$ is remarkable for the extraordinary number of his written productions. In 1826 , at the early age of twentytwo, he wrote his treatise 'De primis vitae phenomenis in fluidis'; two years later he published researches anatomical and physiological into the contents of vegetable cells, and in I830 appeared his 'Lehrbuch der Phytotomie,' founded on his own investigations in every branch of the subject, with many figures on thirteen copper plates very beautifully executed for the time. His industry as a writer was then interrupted by a voyage round the world made in the years $1830-1832$, but was again marvellously productive during the last four years of his life $\left(183^{6-1840)}\right.$; it is difficult to conceive how he found

1 Franz Julius Ferdinand Meyen was born at Tilsit in 1804 , and died as Professor in Berlin in $184^{\circ}$. He applied himself at first to pharmacy and afterwards to medicine, and having taken a degree in 1826 he practised for some years as a physician. In 1830 he set out on a voyage round the world under instructions from $\mathrm{A}$. von Humboldt, and returned in $\mathbf{1} 83_{2}$ with large collections. He was made Professor in Berlin in 1834 . There is a notice of his life in 'Flora' of 1845, p. 618. 


\section{Examination of the Matured Framework [Воок II.}

time even for the mechanical part of his work, for in 1836 he published his treatise on the latest advances in vegetable anatomy and physiology, a quarto volume of 319 pages with twenty-two plates, which gained the prize from the Teyler society in Haarlem; the figures are well drawn, the style is that of a practised writer, but the matter of the work is somewhat superficially handled. A year later (I837) appeared the first volume of his 'Neues System der Pflanzenphysiologie,' and two more volumes by the year i $839,-\mathrm{a}$ work also rich in new observations and figures. In the course of the same years $(1836-39)$ he wrote detailed annual reports of the results of investigations in the field of physiological botany, which fill a portly volume, and published in 1837 a prize-essay on the organs of secretion, and in 1836 a sketch of the geography of plants; in 1840 appeared a treatise on fructification and polyembryony, and a posthumous work on vegetable pathology in r $84 \mathrm{I}$. The number of works thus given to the world between the years 1836 and 1840 , though partly prepared before that period, is so unprecedented, that it is impossible for the composer to have maturely meditated his facts or their inner connection, and the study of his writings shows that he was often too hasty in propounding new views, and in rejecting or accepting the statements of others. The style is perspicuous and flowing, and animated by a genuine scientific spirit; but the expressions are often inexact, the ideas not unfrequently immature, and points of fundamental importance are sometimes neglected for unimportant and secondary matters. These faults are the result of hasty production; we must set against them conspicuous merits; Meyen had an eye open to every question in phytotomy and left nothing unnoticed, while he made it his constant aim to give clear general views of his subject as a connected whole, and enable his reader to see his way in every direction, in order to make phytotomy and vegetable physiology accessible to wider circles of scientific men; the like praise is due to his drawings from 
the microscope which are beautifully executed; they present to the reader not the small fragments of earlier phytotomic works but whole masses of tissue so connected together, that it is possible to gain some insight into the disposition of the different systems of tissue and their mutual relations. The superiority of Meyen's drawings of 1836 as compared with those of 1830 is very striking, though he used the same microscope in both cases and the same magnifying power of two hundred and twenty times.

To learn what were Meyen's independent contributions to the advance of phytotomy, we must turn to his 'Phytotomie' of 1830 ; for in his later works and especially in the 'Neues System der Physiologie' of 1837 he was able to avail himself of von Mohl's earliest and searching investigations; these necessarily influenced his views, though he always assumed the character of a rival and opponent of von Mohl, and treated not only Treviranus and Link, but even Kieser and men of his stamp, as entitled to equal rank with him. And as in his later writings he was reluctant to acknowledge von Mohl's services to science and overlooked their fundamental importance, so in his earlier work in I 830 he often appears as an assailant of Moldenhawer and tries to set up Link's authority against him; we find to our astonishment in the first volume of the 'Neues System' a dedication to Link as the 'founder of German vegetable physiology.' The position of a scientific man in relation to his science as a whole is certainly most simply and clearly defined by his judgment on the merits of his contemporaries and predecessors, and we may conclude from what has now been said that Meyen moved within the circle of ideas of the Göttingen prize-essays, and did not clearly see the importance of the points of view opened by Moldenhawer and von Mohl ; though it must always be allowed that Meyen working independently far outstripped Link on his own path.

If it was our purpose to write a biography of Meyen, we should have to go through his works, and show the steps by 
which his views arrived at clearness and precision ; it is sufficient in this history to show what was peculiar and original in his general conception of the problems of phytotomy. This appears most plainly in the 'Phytotomie' of 1830 ; and we may base our historical survey on that work because its views are in the main those of the first volume of the 'Neues System' which appeared seven years later, and still more because a detailed examination of the later publication would involve us in a lengthy discussion on Meyen's scientific relation to von Mohl. It is less important in this place to give an estimate of Meyen's character as a man of science than to show, how in the year I830, when Mohl was beginning to apply himself to phytotomy but as yet exercised no important influence on opinion, views on the structure of plants were formed by one who gave himself up to its study with decided ability and great zeal; in this way we shall gain a standard by which to judge of the advance made chiefly by von Mohl and in part by Mirbel during the succeeding ten years. In judging of Meyen's book, we must not forget that it was written when he was only twentyfive or twenty-six years old, and that it is under any view of it a remarkable performance for so young a man.

Meyen adopted three fundamental forms of elementary organs in plants ; cells, spiral tubes, and sap-vessels ; systems, he says, are formed by union of similar elementary organs; hence there is a cell-system, a spiral tube-system, and a system of sap-vessels (vascular system). We see at once by this classification how closely he follows the ideas formed before Moldenhawer. The establishment of these three systems is a retrograde step, since Moldenhawer had already clearly distinguished between vascular bundles and cell-tissue. Meyen then discusses each system at length and shows how they are grouped together. He lays great stress, as he did also at a later period, on the difference in the characteristic forms of cell-tissue, for which he introduced the names merenchyma, parenchyma, prosenchyma and pleurenchyma. These he calls 
regular cell-tissue, the shapes of the cells being like geometrical bodies, in opposition to the irregular tissue of Fuci, Lichens and Fungi. It is a decided improvement on former practice, and one that marks his later works also, that in connection with the structure of the solid cell-fabric he discusses the contents of cells in a special chapter, in which first the matter in solution, then the granular bodies with organized structure are considered, though with the latter he classes not only starchgrains, chlorophyll-corpuscles and the like, but also the spermatozoa in pollen-grains and layers of thickening matter projecting on the inside of cell-walls, such as the spiral bands in the elaters of Jungermannieae and several similar formations. He describes the crystals in vegetable cells at some length, and finally discusses the movement of the cell-contents ('sap'), not omitting that of rotation in the Characeae as observed by Corti, and in other water-plants. The chapter on intercellular spaces also shows considerable advance on the views which obtained in 1812 ; Meyen calls it an account of the spaces produced in cell-tissue by the union of the cells; the true intercellular passages filled with air are here distinguished from receptacles of secretions, resin-passages, gum-passages, oilpassages, and secretion-receptacles of the nature of cavities. The large air-passages and gaps, such as occur in water-plants, are a third form of intercellular space; his air-canals in the wood of oak filled with cell-tissue are obviously vessels filled with the substance known as thylosis. The form of the cells in the tissue he thinks is not due to mutual pressure, and he rejects Kieser's view that the ideal fundamental form of cells must be a rhombododecahedron; but he thinks there is a significant resemblance between the shape of cells and that of basaltic columns.

In dealing with the spiral tube-system he first discusses the spiral fibre, which appears, he says, either detached between the cells or inside them as well,--an account of the matter decidedly inferior to those of Bernhardi and Treviranus. The spiral 
290 Examination of the Matured Framework [Воок II.

tubes are, he says on page 225 , cylindrical or conical bodies formed of spiral fibres which are afterwards surrounded by a delicate membrane. He puts annular, reticulated, and pitted vessels together as metamorphosed spiral tubes. His explanation of these forms cannot well be understood except by supposing that he assumed an actual metamorphosis in time in accordance with the view of Rudolphi and Link; but he afterwards in his 'Neues System,' i. p. I40 declares this to be a misunderstanding, though his real meaning is still doubtful ; the obscurity attending the doctrine of metamorphosis did not fail to cause misunderstandings in phytotomy, as it did in the morphology of organs. Meyen makes only the striated and pitted vessels in the wood convey air, the true spiral vessels sap. That vessels are formed from cells, as Mirbel had already maintained and Treviranus had partly observed, Meyen intimates indeed, but not with an air of entire conviction.

The different forms of laticiferous organs are examined under the head of the 'system of circulation in plants.' Meyen sees in this system the highest product of the plant, being fully persuaded with Schulz, that the latex (milk), or as he also terms it the life-sap, is in constant circulation, like the blood in the veins. He gives a more summary account than is his wont of the course of the laticiferous organs, but bestows more care on the nature of the latex, and on the structure of the receptacles that contain it. That some of these are produced by cell-fusion, that others represent intercellular spaces, while others again are long branched cells, was not known to Meyen or even to later phytotomists before i 860 .

This condensed account of the contents of Meyen's 'Phytotomie' shows a striking mixture of advance and retrogression, when compared with what had been achieved before his time; by the side of the fact established by Treviranus that the epidermis does not consist of a single membrane but of a layer of cells, to which Meyen assents, we find the gross mistake of taking the guard-cells of stomata for cuticular glands, the 
apertures in which he considers as of secondary importance. It is still more striking that Meyen expressly rejects on page $\mathbf{z} 20$ the fact established two years before by von Mohl that the pits of parenchyma are thinner spots, and treats the various pitformations of the cell-wall as raised portions of the surface.

In the first volume of his later work the 'Neues System,' Meyen gives a detailed account of phytotomy, which accords on the whole with the scheme developed in the book we have been examining, and as might be expected he corrects many errors, adduces many new observations, and introduces us to many steps in advance of former knowledge; we shall recur to some of his later views in ensuing portions of this history with which they are more in connection, remarking only here, that Meyen paid more attention to the contents of the cell than his contemporaries, and especially made a number of observations on the streaming movement, without however recognising the peculiar nature of the protoplasm which is its substratum. The cell-wall, which he had once considered to be homogeneous, he afterwards believed to be composed of fine fibres, a view resting on correct but insufficient observation and afterwards set right by von Mohl and Nägeli.

It is scarcely possible to imagine a more striking contrast between two men pursuing the same science than that between Meyen and his much more important contemporary Hugo von Mohl ; Meyen was more a writer than an investigator ; von Mohl wrote comparatively little in a long time, and only after most careful investigation; Meyen attended more to the habit, the collective impression produced by objects seen with the microscope, von Mohl troubled himself little about this, and always went back to the foundation and true inner connection of the structural relations; Meyen quickly formed his judgment, von Mohl often delayed his even after long investigation; Meyen was not critical, though always prone to opposition, in von Mohl the critical power much overweighed that of constructive thought. Meyen has not so much contributed to the definitive 
settlement of important questions, as brought to light manifold phenomena, and so to speak accumulated the raw material; von Mohl on the other hand aimed from the first at penetrating as deeply as possible into vegetable cell-structure, and employing all the anatomical facts in framing a coherent scheme.

We have already called attention to Hugo von MoHL's ${ }^{1}$ pre-eminent position in the history both of this and also of the succeeding period. Occupying himself for the most part with phytotomical questions which had been already investigated, he made the solid framework of cellulose the object of special and searching examination, and completed the work of his predecessors on this subject; he thus laid a firm foundation for the researches into the history of development afterwards undertaken by Nägeli. Von Mohl, like former phytotomists, generally connected his researches into structural relations with physiological questions; but there was one great and unmistakable difference; he never forgot that the interpreta-

1 Hugo Mohl (afterwards von Mohl) was born at Stuttgart in 1805 , and died as Professor of Botany in Tübingen in 1872 . His father held an important civil office under the Government of Wiirtemberg. Robert Mohl, also in the service of the Government, Julius Mohl, the Oriental scholar, and Moritz Mohl, the political economist, were his brothers. The instruction at the Gymnasium at Stuttgart, which he attended for twelve years, was confined to the study of the ancient languages; but Mohl early evinced a preference for natural history, physics, and mechanics, and devoted himself in private to these subjects. He became a student of medicine in Tübingen in 1823 , and took his degree in 1828 . He then spent several years in Munich in intercourse with Schrank, Martius, Zuccharini and Steinheil and obtained abundant material for his researches into Palms, Ferns, and Cycads. He became Professor of Physiology in Berne in $\mathbf{I}_{3} \mathbf{3}_{2}$, and Professor of Botany in Tübingen after Schübler's death in I83.5, and there he remained till his death, refusing various invitations to other spheres of work. He was never married, and his somewhat solitary life of devotion to his science was of the simplest and most uneventful kind. He was intimately acquainted with all parts of botanical science, and possessed a thorough knowledge of many other subjects; he was in fact a true and accomplished investigator of nature. A very pleasing sketch of his life from the pen of De Bary is to be found in the 'Botanische Zeitung' of $187^{2}$, No. 3 I. 
tion of visible structure must not be disturbed by physiological views; he used therefore his thorough physiological knowledge chiefly to give a more definite direction to his anatomical researches, and to illustrate the connection between structure and function in organs. By scarcely any other phytotomist was the true relation between physiological and anatomical research so well understood and turned to such practical account as by von Mohl, who was equally averse to the entire separation of phytotomy from physiology, and to the undue mixing up of the one with the other, which has led his predecessors, Meyen especially, into misconceptions.

His anatomical researches profited by his extraordinary technical knowledge of the microscope; he could himself polish and set lenses, which would bear comparison with the best of their time. As the majority of botanists from 1830 to I $85^{\circ}$ had little knowledge of the kind, there was no one so well qualified as von Mohl to give instruction in short treatises on the practical advantages of a particular instrument, to remove prejudices and finally as in his 'Mikrographie' (I 846) to give detailed directions for the management of the instrument.

But his mental endowments were of course of the higher importance, and it is difficult to imagine any more happily suited to the requirements of vegetable anatomy during the period from 1830 to 1850 . At a time when men were building fanciful theories on inexact observations, when Gaudichaud was once more explaining the growth in thickness of the woody portions of the plant after the manner of Wolff and Du PetitThouars, when Desfontaines' account of the endogenous and exogenous growth of stems was still accepted, when Mirbel was endeavouring to support his old theory of the formation of cells by new observations and beautiful figures, when Schulz Schulzenstein's wildest notions respecting laticiferous vessels were being rewarded with a prize by the Paris Academy, when Schleiden's hastily adopted views respecting cells and fertilisation appeared on the scene with great external success, von 
Mohl, for ever going back to exact observation, was cutting away the ground from under ill-considered theories in careful monographs, and at the same time bringing to light a mass of wellestablished facts leading to further and serious investigation. These theories have now only a certain historical interest, while von Mohl's contemporaneous works are still a rich repertory of useful observations, and true models of clear exposition.

His written productions were preceded by a careful study of all branches of botanical knowledge and the auxiliary sciences. That he not merely acquired knowledge in this way, but trained the powers of his understanding also, is shown by the striking precision and clearness of his account of his first investigations. At a time when the nature-philosophy and Goethe's doctrine of metamorphosis in a distorted form were still flourishing, von Mohl in spite of his youth approached the subjects of his investigation with a calmness and a freedom from prepossessions, which are the more remarkable when we observe that his friend Unger was at first quite carried away by the stream, and only slowly managed to reach the firm ground of genuine inductive enquiry.

Owing to the extravagances and aberrations with which he made acquaintance as a young man in the nature-philosophy, von Mohl contracted an aversion to all philosophy, evidently taking the formless outgrowths from the doctrines of Schelling and Hegel for something inseparable from it, as we may gather from his address at the opening of the faculty of natural history in Tübingen, which had been separated at his instance from that of philosophy. His dislike to the abstractions of philosophy was evidently connected with his distaste for farreaching combinations and comprehensive theories, even where they are the result of careful conclusions from exact observations. Von Mohl was usually satisfied with the establishment of separate facts, and in his speculative conclusions he kept as closely as possible to what he had actually seen, for instance, in his theory of the thickening of cell-walls; and 
where new views opened before him as a result of his exact observation, he cautiously restrained himself and was generally content to hint at matters which bolder thinkers afterwards proceeded to investigate; such a case occurred in his examination of cell-membranes by polarised light. Hence we miss to some extent the freer flight of imaginative genius in von Mohl's scientific labours; but there is more than sufficient compensation for this want in the sure and firm footing which he offers to the reader of his works ; if we pass from the study of the writings of phytotomists before I 844 to those of von Mohl, we are sensible of one predominant impression, that of security; we have the feeling that the observer must have seen correctly because the account which he gives of the matter before us seems so thoroughly natural and almost necessarily true, and all the more because he himself notices all possible doubts, and lets those which he cannot remove remain as doubts. In these points von Mohl's style resembles that of Moldenhawer, but in von Mohl it attains to a mastery which is wanting in the other.

There is an evident connection between von Mohl's dislike of far-reaching abstractions and philosophic speculation on the results of observation and the fact, that in the course of more than forty years' unintermitted application to phytotomy he never composed a connected general account of his subject. His efforts as a writer were confined to monographs usually connected with questions of the day or suggested by the state of the literature. In these he collected all that had been published on some point, examined it critically, and ended by getting at the heart of the question, which he then endeavoured to answer from his own observations.

For the purpose of these observations he looked about in every case for the most suitable objects for examination, a point to which former phytotomists, with the exception of Moldenhawer, had paid little attention; he then studied these objects thoroughly, and thus prepared the way for the examination of others, which presented greater difficulties. Every 


\section{Examination of the Matured Framework [Bоок II.}

monograph of this kind was a nucleus, round which a larger number of observations might afterwards gather. In a long series of such solid productions he treated conclusively all the more important questions of phytotomy.

Von Mohl's extraordinary carefulness was not however able to guard him, calm observer though he was, from some serious mistakes, at least in his earlier years, such as those which occur in his first theory of intercellular substance $\left(18_{3} 6\right)$, and in his earliest views on the nature of the cell-membrane of the pollengrain (1834). These and some other errors on the part of a gifted and truly inductive enquirer are instructive, since they show that observation without any ground-work of theory is psychologically impossible ; it is a delusion to suppose that an observer can take the phenomena into himself as photographic paper takes the picture ; the sense-perception encounters views already formed by the observer, preconceived opinions with which the perception involuntarily associates itself. The only means of escaping errors thus produced lies in having a distinct consciousness of these prepossessions, testing their logical applicability and distinctly defining them. When von Mohl laid down his theory of intercellular substance, there evidently floated before his mind indistinct, half-conscious ideas of the kind that Wolff and Mirbel entertained of the structure of the vegetable cell; and as he considered the cell-membrane of the pollen-grain to consist of a cell-layer, he summarised its obscure structural relations under the then very obscure conception of the cell. As a true investigator of nature, who adheres always and firmly to the results of further observation, and endeavours to clear his ideas by their aid, conceding only a relative value to every view, von Mohl soon escaped from these errors, and himself supplied proofs of the incorrectness of his former opinion. The number of really erroneous statements in his works is wonderfully small considering the very large number of investigations in which he engaged.

In examining the part which von Mohl played in the general 
development of phytotomy we can distinguish satisfactorily two periods in his scientific career, the first of which extends from i 827 to about 1845 . Before 1845 he was acknowledged to be the first of phytotomists, decidedly superior to all rivals; his authority, though often attacked by unimportant persons, grew from year to year. This period may be said to close with the publication of his 'Vermischte Schriften' in 1845 . Up to that time investigations into the form of the solid framework of cellmembrane had chiefly attracted the interest of phytotomists, and in this subject there was no one who could measure himself with von Mohl. Yet he began soon after I 830 to study the history of development in plants; in 1833 he described the development of spores in a great variety of Cryptogams, in I 835 the multiplication of cells by division in an alga, and the cell-division in the formation of stomata in 1838 ; in this period appeared Mirbel's first observations on the formation of pollencells (1833). Von Mohl too was the first, if we disregard Treviranus' somewhat imperfect notices of the origin of vessels in I 806 and I 8 I I, who explained the history of the development of those organs ; and his theory of the thickening of cell-membranes, the principles of which are to be found in his treatise on the pores in cellular tissue (I 828 ), may also be regarded as a mode of conceiving the sculpture of the cell-membrane from the point of view of the history of development.

Ever since 1838 Schleiden had raised the history of development to the first rank in botanical investigation, but he had proposed a thoroughly faulty theory of cell-formation, to which von Mohl at first at least did not withhold his assent in spite of previous and much better observations; but after 1842 Nägeli devoted himself still more thoroughly and with more lasting results to the study of the development both of vegetable cells and tissue-systems, and of the external organs. He introduced new elements into phytotomic research, and it soon became apparent that even the questions hitherto examined must be grappled with in a different fashion. Von Mohl did not hold aloof 
from the new direction, but completed a series of excellent investigations connected with the new questions in the theory of cell-formation. The most important of these was his enquiry into the nature of protoplasm, to which he gave the name still in use. In his treatise, 'Die Vegetabilische Zelle,' which came out in I85I in Wagner's Dictionary of Physiology, he even gave an excellent account of the modern theory of cell-formation; but notwithstanding all this, and the great authority which he rightly continued to enjoy, he was no longer the guide who led the way in the domain of phytotomy, as he had been before $\mathrm{I} 845$.

His zeal as an observer had at all times been chiefly attracted to the solid framework of vegetable structure in its matured condition, though a number of his most important works were devoted to the study of cell-contents.

Except in his 'Anatomie der Palmen' (I83I), where he expended much and to some extent even unnecessary labour on figures representing the general appearance of the tissue (histologic habit), von Mohl's microscopic drawings do not aim at giving the collective impression, but at facilitating the understanding of the delicate structure of single cells and their combinations by aid of the simplest possible lines. He always despised pictures from the microscope, such as were introduced at a later time by Schacht,- - a kind of artistic restoration of the originals and to some extent a playing with science; and in his later publications he was more sparing of illustrations or omitted them altogether, in proportion as he acquired the power of giving clear verbal explanations of even difficult structural conditions.

Von Mohl's scientific activity was so wonderfully productive that it is not easy to present the reader with a clear account of it ; but we must endeavour at least to furnish such a summary of its chief results as may serve to give a general idea of his importance in the history of our science. We may here pass over such of his treatises as do not bear on the main questions of phytotomy, and notice only those that relate to the structure 
of the solid framework of plants, because the historical significance of his investigations into the history of development can only be understood in connection with the questions to be treated in the following chapter. But we shall not limit ourselves to publications which appeared before I 845 , though we may be thus compelled to notice researches which in succession of time belong to the next period, and indeed almost to the present moment.

I. The view that the cell is the sole and fundamental element in vegetable structure had been already maintained by Sprengel and Mirbel, but not supported by exact observations. Treviranus too had shown that the vessels in wood are formed by the union of rows of cell-like tubes, but he had never arrived at a thoroughly clear conception of the matter. On the one side was the theory that the plant consists entirely of cells, on the other, and for long the old and strange view, that the spiral thread was an independent elementary organ of vegetable structure, - a view which Meyen still maintained in I830. Von Mohl must be regarded as the first who took up the all-important position, that not only the fibrous elements of bast and wood, which had long been considered to be elongated cells, but the vessels of the wood also are formed from cells; and we may on this point give great weight to his own assertion that he was the first who observed the formation of vessels from rows of closed cells. This discovery happened in the year $183 \mathrm{r}$, and he describes distinctly, though briefly, the decisive observations in his treatise on the structure of the palm-stem. At the points of constriction in the vessels he saw the dividing walls, the existence of which had been denied by all former phytotomists; 'these dividing walls,' he says, ' are entirely different from the rest of the membranes of the plant, being formed of a network of thick fibres with openings between them.' He studied the history of the development of these vessels both in palms and in dicotyledonous plants. 'In the young shoot,' he says, 'are found at the spots, where 
afterwards there are large vessels, perfectly closed large cylindrical tubes with a transparent and very delicate membrane.' He then shows how by degrees the sculpture peculiar to the walls of vessels is formed on the inside of these tubes, and he takes the opportunity of saying that a metamorphosis in time from one form of vessel into another is entirely out of the question, as Treviranus also and Bernhardi had maintained. 'The dividing walls (transverse septa),' he continues, ' are formed in a precisely similar manner to the side-walls of vessels ; only the original tender membrane of the septa is usually lost in the meshes of the network of fibres.' From that time no phytotomist capable of an independent judgment has had any doubt with regard to this view of the formation of the vessels in wood. It is however striking enough that von Mohl, who thought it so important to show that the cell is the sole foundation of vegetable structure, never extended the proof to milk-vessels and other secretion-canals in order to show whether and how these also are formed from the cells. In his treatise on the vegetable cell ( $185 \mathrm{I}$ ) he still expressed doubt about Unger's assertion, that the milk-vessels are also formed from rows of cells that coalesce with one another, and held rather to the view of an anonymous writer in the 'Botanische Zeitung' of 1846 , page 833 , that these vessels are membranous linings of gaps in the cell-tissue. He might well lose his taste for the examination of these and similar organs after Schultz Schultzenstein had by his various treatises, written after $\mathrm{I}_{22}$, on the so-called vital sap and the circulation which he attributed to it, made this part of phytotomy a very quagmire of error, and had not refrained from replying in an unbecoming manner to von Mohl, who repeatedly opposed his views; moreover Schultz's essay 'Ueber die Circulation des Lebenssafter' (I 833), which teems with absurdities, had received a prize from the Academy of Paris.

2. The growth in thickness of the cell-membrane, and the sculpture caused by it was a subject that is more or less connected with most of von Mohl's writings. He developed the 
chief features of his view in 1828 in his first work, 'Die Poren des Pflanzengewebes!' The way in which he represented to himself the growth in thickness of cell-membranes at a later time may be expressed as follows. All elementary organs of a plant are originally very thin-walled perfectly closed cells, which in the tissue are separated by walls formed of two laminae ${ }^{1}$; on the inside of these primary cell-membranes, after they have ceased to increase in circumference, new layers of membranous substance are formed, which lying one upon another adhere closely together, and represent the whole amount of secondary thickening layers; on the inner side of the membrane thus thickened by apposition there may usually ${ }^{2}$ be perceived a tertiary layer of a different character.

But there are certain sharply defined spots on the original cell-wall, where this thickening does not take place; in such spots the cell is still bounded only by the primary membrane; it is these thin spots which bear the name of pits, and which Mirbel, and in some cases Moldenhawer, took for holes, but von Mohl considered that it was only in very exceptional cases that they were really changed into holes by resorption of the thin primary wall. In accordance with this theory, the spiral, annular, and reticulated vessels are produced by deposition of thickening matter in the form suitable to each case on the inside of the originally smooth thin cell-wall. But like Schleiden and other phytotomists, von Mohl was not quite clear in his views either of the origin or mode of formation of matured bordered pits; it was supposed that the two laminae of the dividing wall parted from one another at certain spots in such a manner that a lenticular hollow space was formed between them, and that this space answered to the outer border of the

1 But von Mohl expressed some doubts on this point in 1844 ('Botanische Zeitung,' p. 340).

2 This tertiary layer was at first supposed by Theodor Hartig to be of general occurrence; von Mohl in 1844 considered it to be present only in certain cases. 
pit, while the inner border was the result of ordinary pitformation. This view, which could be shown to be incorrect by the history of development, arose in fact from inexact observation,- - a rare case with von Mohl ; the true course of events in the formation of bordered pits was first described by Schacht in 1860 .

It was mentioned above, that Meyen in his 'Neues System der Physiologie' of 1837 , i. p. 45, made cell-membranes consist of spirally wound fibres; von Mohl had described in $183^{6}$ the structural relations of certain long fibrous cells of Vinca and Nerium, which might be provisionally explained in this way; he was led by Meyen's ideas on the subject to a renewed and minute examination of the more delicate structure of the cellmembrane in 1837 ; he first of all cleared the ground round the question, by distinguishing the cases in which real spiral thickenings lie on the inner side of the membrane, from those in which the membrane is smooth on the outside, but shows an inner structure of fine spiral lines; in these cases he assumed a peculiar arrangement of the molecules of cellulose, and endeavoured to illustrate the possibility of such a disposition by the phenomena of cleavage in crystals ('Vermischte Schriften,' p. 329); but he did not succeed in explaining these very delicate conditions of structure, which we now call the striation of the cell-membrane, so clearly as Nägeli afterwards did in connection with his molecular theory.

3. The question of the substance and chemical nature of cellmembranes was intimately connected with von Mohl's theory of its growth in thickness; he was engaged in 1840 in minutely studying the reactions which various cell-membranes exhibit with iodine solution under different conditions,- - a question on which Schleiden and Meyen had recently disagreed; von Mohl arrived at the result, that iodine imparts very various colours to vegetable cell-membrane, according to the quantity in which it is absorbed; a small amount produces a yellow or brown, a larger a violet, a still larger a blue tint ; this depends partly on 
the extent to which the membrane is capable of distention; the blue colour especially depends on the absorption of a sufficient quantity of iodine. Greater interest, excited at first by a very important work by PAYEN ' in 1844 , was taken in the question of the chemical nature of the solid framework of the vegetable body, in which it was shown that the substance of all cellmembranes exhibits a similar chemical composition when freed from foreign elements. Payen considers that this material, cellulose, is present in a tolerably pure form in the membranes of young cells, but is rendered less pure in older ones by 'incrusting substances,' whose presence changes the physical and chemical characters of cell-membranes in various ways. These incrusting substances may be more or less removed by treating the membranes with acids, alkalies, alcohol, and ether, while other inorganic matters remain behind after combustion as an ash-skeleton. This theory, which has been more perfectly worked out in modern times, was soon afterwards met by Mulder with the assertion, that a large part of the layers composing the walls of cells consist from the first of other combinations and not of cellulose; he at the same time deduced from this view certain conclusions respecting the growth in thickness of cell-walls. $\mathrm{He}$ and Harting, relying on microscopic examination, maintained that the innermost tertiary layer in thickened membranes is the oldest, and that the other layers are deposited on the outside of this, and are not composed of cellulose. Von Mohl opposed this view decidedly and successfully in the Botanische Zeitung of r 847 ; he likewise in his work on the vegetable cell (p. I 92), refuted the view of the varying substance of cell-membrane,

1 Anselm Payen (1795-187 1 ) was born at Paris and was Professor of Industrial Chemistry in the École des Arts et Métiers in that city. His most important botanical works were his 'Mémoire sur l'amidon,' etc., Paris (1839), and his 'Mémoire sur le développement des Végétaux,' published in the Memoirs of the Academy of Paris. 


\section{Examination of the Matured Framework [Boox II.}

which Schleiden had founded on some obscure chemical grounds.

It would carry us much too far to enter into the details of this scientific dispute; Payen's view of the chemical nature of the vegetable cell-wall, which von Mohl adopted and elaborated, has maintained itself to the present day, and is generally considered to be the true one; on the other hand, the foundations of von Mohl's theory of growth in thickness were shaken in $185^{8}$ by Nägeli's observations, and we may say that on the whole it has been for ever superseded. It has been nevertheless of great service in the development of our views on cell-structure in plants; keeping closely to the facts directly observed, it served to bring almost all the conditions of the sculpture of cell-walls under one point of view, and to refer their formation to one general and very simple scheme; every such theory helps to advance science, because it facilitates mutual understanding; in this case, when Nägeli proposed his more profound theory of intussusception, the understanding of it was essentially assisted by a previous exact knowledge of von Mohl's theory in its principles and results. In conclusion it may be mentioned here that von Mohl afterwards in his investigation into the occurrence of silica in cell-membranes made a large and important addition to the knowledge of their more delicate structure, and of the way in which incrusting substances are deposited in them (Botanische Zeitung, 186I).

4. The views of phytotomists on the so-called intercellular substance during the twenty years from i 836 to 1856 were closely connected with the older theories of cell-formation, but were opposed to the modern doctrine of the cell founded by Nägeli in I 846. Von Mohl himself had introduced this idea for the first time into the science in 1836 in one of his earlier and inferior essays, 'Erläuterung meiner Ansicht von der Structur der Pflanzensubstanz,' rather in opposition to than in connection with his own theory of the growth and structure of cell-walls. Setting out from modes of formation of cell-membranes in some Algae, 
Cнат. III.] of Cell-membrane in Plants.

difficult to understand and in some respects quite peculiar, von Mohl believed that he saw in many cases in the higher plants also between the sharply-defined membranes, which bound the cell-spaces and which he regarded as the entire cellmembranes, a substance in which the cells are imbedded, for such is its appearance when it is largely developed; when it lies in small quantity only between cells in close apposition, it looks like a thin layer or cement. After Meyen in his 'Neues System,' pp. 162, I 74 had declared against this view in 1837 , von Mohl too abandoned it more and more, and afterwards limited the occurrence of intercellular substance to certain cases, being convinced that much that he had before taken for it consisted only of layers of secondary thickening, between which he still saw the primary lamina of the cell-membrane. The theory of intercellular substance was taken up and further developed by other phytotomists, by Unger especially in the Botanische Zeitung for $\mathrm{x} 847$, p. 289 , and afterwards chiefly by Schacht ; Wigand came forward as an opponent of it in 1854 in his 'Botanische Untersuchungen,' p. 65 , and logically following out von Mohl's theory of the cell-membrane declared the thin layers of intercellular substance as well as the cuticle, which had been first correctly distinguished by von Mohl, to be laminae of primary cell-membrane, the substance of which had undergone profound chemical change. These ideas also of the intercellular substance and the cuticle assumed an entirely different aspect when Nägeli introduced his theory of intussusception.

The limits imposed on this bistory render it necessary to be content with these indications of von Mohl's share in the working out of the theory of cells in its connection with the structure of the solid framework of cell-membrane; we shall return again to his observations on the formation of individual cells.

5. Forms of tissue and comparative anatomy. Phytotomy up to 1830 had been weak in its classification of tissues, in its ideas as to their arrangement, and consequently in its histological terminology; the inconvenience arising from 


\section{Examination of the Matured Framework [Bоок II.}

this state of things was most distinctly felt when it became necessary to compare the structure of different classes of plants, Cryptogams, Conifers, Monocotyledons and Dicotyledons, and to establish their true differences and actual agreements. How little phytotomy had advanced in this respect is shown plainly in the account of tissues given by Meyen in his 'Neues System' in 1837. To von Mohl belongs the merit of having perceived at an early period in his scientific career, and more clearly than his contemporaries, the value of a natural and sufficient discrimination of the various forms of tissue, and the necessity of obtaining a correct view of their relative disposition; he thus showed the way to an understanding of the general structure of the higher plants, and rendered it possible to make a scientific comparison of the structure of different classes of plants.

Von Mohl, like Moldenhawer long before, showed from the first a correct apprehension of the peculiar character of the vascular bundles as compared with other masses of tissue. $\mathrm{He}$, too, examined them first in Monocotyledons, and gave an account of them in his treatise on the structure of Palms (I83I), and also in his later essays on the stems of Tree-ferns, Cycads, and Conifers and on the peculiar form of stem in Isoëtes and Tamus elephantipes, to be found in his 'Vermischte Schriften' of 1845 . His just conception of them as special systems composed of various forms of tissue has made his account clear and intelligible, and his whole treatment of the subject appears new in comparison with that of every previous writer except Moldenhawer. If these labours of von Mohl are surpassed in value by later studies of the history of development, they served for the time as a nucleus for further investigations, especially into the nature of stems. It contributed in a high degree to a correct insight into the structure of the stem, that von Mohl, agreeing in this with Moldenhawer, distinguished the portion belonging to the wood from the portion belonging to the bast in the vascular bundles, and 
regarded both as essential constituents of a true vascular bundle. Not less important were his enquiries into the longitudinal course of the vascular bundle in the stem and leaf, which showed that in the Phanerogams the bundles in the stem are only the lower extremities of the bundles, the upper extremities of which bend outwards into the leaves, and that the Monocotyledons and Dicotyledons agree in this particular, though the course of the bundle differs considerably in the two cases. He obtained an important result in this respect in his researches on palm-stems in $18_{3} 1$, when he proved the incorrectness of the distinction between endogenous and exogenous growth in thickness, which had been laid down by Desfontaines, and even employed by De Candolle in framing his system. According to Desfontaines, the wood of Monocotyledons appears as a collection of scattered bundles, of which those that run out above into the leaves come from the centre of the stem. From this very imperfect observation he deduced the view, that the bundles of vessels in Monocotyledons originate in the centre of the stem, and that they continue to be formed there, until the older hardened bundles in the circumference form so solid a sheath that they withstand the pressure of the younger; then all further growth in thickness must cease, and hence the columnar form of the monocotyledonous stem. This doctrine found general acceptance, and was employed by De Candolle to divide vascular plants into Endogens and Exogens, in accordance with the very general inclination felt in the first half of the present century to distinguish the great groups of the vegetable kingdom by anatomical characters. It is true that Du Petit-Thouars had already shown that some monocotyledonous stems have unlimited growth in thickness; neither his nor Mirbel's later observations succeeded in shaking the theory, the adherents of which met such cases by assuming a peripherical as well as a central growth. Then von Mohl in the treatise above-mentioned demonstrated the true course of the vascular bundles in the 
stem of Monocotyledons, and at once did away with the whole theory of endogenous growth in the opinion of all who were capable of judging, though some even eminent systematists for a long time maintained the old error. The results which von Mohl obtained from his study of the comparative anatomy of the stem, rested mainly on careful observation of the mature tissue-masses, and when he studied the history of development, he was not in the habit of going back to the very earliest and most instructive stages. Hence he failed to explain fully the real points of agreement and difference of structure between Tree-ferns and other Vascular Cryptogams and Phanerogams, and in like manner he stopped half-way when engaged in explaining the secondary growth in thickness of dicotyledonous stems from the nature of their vascular bundles, and the formation of cambium. The account of growth in thickness which he still gave in I 845 ('Vermischte Schriften,' P. I53), and which rests less on observation than on an ideal scheme, is highly obscure, and even in the treatise which he published in the Botanische Zeitung in $185^{8}$ on the cambium-layer of the stem of Phanerogams, and in which he criticises the newer doctrines of Schleiden and Schacht, the subject is far from being fully cleared up, though the views there advocated are decidedly superior to his former ones. A satisfactory conclusion with respect to growth in thickness of the woody body and of the rind was not reached till the history of development in vegetable histology began to be more thoroughly studied.

As von Mohl had from the first laid special stress on the peculiar character of the vascular bundles as compared with other tissuemasses, so he perceived that the structure of the epidermis and of the different forms of exterior tissue was thoroughly characteristic, and he succeeded in arriving at a clearer understanding of the matter in this case than in the other. Very confused ideas had prevailed on the subject before he took it up, and we owe to him the best and most important knowledge which we 
at present possess. Especially important were his researches into the origination and true form of stomata ( 1838 and I 856), and into the cuticle and its relation to the epidermis (1842 and 1845). He brought entirely new facts to light by his study of the development of cork and the outer bark in 1836 ; these tissues had scarcely been examined with care till then, and their formation and relation to the epidermis and the cortical tissue were quite unknown. In the latter treatise, one of his best, the difference between the suberous periderm and the true epidermis was first shown, the various forms of the periderm were described, and the remarkable fact established that the scaling of the bark was due to the formation of fine laminae of cork, which, penetrating gradually into the substance of the cortex, withdraw more and more of it from its connection with the rest of the living tissue, and as they die off form by their accumulation a rugged crust, which is the outer bark surrounding most thick-stemmed trees. The investigation was so thorough and comprehensive, that later observers, Sanio especially in I86o, could only add to it some more delicate features in the history of the process. In the same year appeared his enquiry into the lenticels, where von Mohl however overlooked what Unger discovered at the same time ('Flora,' I836), namely, that these forms arise beneath the stomata; but he at once corrected Unger's hazardous supposition that the lenticels are similar forms to the heaps of gemmae on the leaves of the Jungermannieae. Unger, for his part, was not long in adopting von Mohl's explanation of the lenticels as local cork-formations.

Since von Mohl thus distinctly brought out the special character of the vascular bundles and of the different forms of epidermal tissues, it must excite surprise that he, like former phytotomists, did not find himself under the necessity of framing some conception of the rest of the tissue-masses in their peculiar grouping as a whole, as a special system, and of classifying and suitably naming the different forms that compose them, though his 
310 Examination of Matured Framework.

examination of Tree-ferns would seem to have offered him an occasion for doing so. Von Mohl, like his contemporaries, was satisfied with calling everything that is neither epidermis, cork or vascular bundle, parenchyma, without distinctly defining the expression.

Here we leave von Mohl and his labours for the present, to return once more in the following chapter to the share which he took in the further progress of phytotomy. We shall perhaps best realise his importance in the history of the science, if we try to think of all that we have now seen him doing for it as still undone. There would then be a huge gap in modern phytotomic literature, which must have been filled up by others before there could be any further addition to the knowledge of cells and tissues founded on the history of their development; for it can hardly be conceived that the advance to which we owe the present condition of vegetable anatomy, could have been based upon ideas such as those of Meyen, Link, and Treviranus, without von Mohl's preliminary discoveries. 


\section{CHAPTER IV.}

History of Development of the Cell, Formation of Tissues, Molecular Structure of Organised Forms.

$$
\text { I } 840-\text { I } 860 .
$$

IN the period between 1830 and 1840 it had come to be understood, that the old theories of cell-formation of Wolff, Sprengel, Mirbel, and others, resting on indistinct perceptions and not on direct and exact observation, could only give an approximate idea of the formation of cells. But in the course of that time really different cases of formation of new cells were accurately observed by Mirbel, and more especially by von Mohl, who described different modes of formation of spores, and in I 835 the first case of vegetative cell-division. Unfortunately these observations, excellent in themselves, applied to cases of cellformation which do not occur in the ordinary multiplication of cells in growing organs, and von Mohl guarded himself from founding a general theory of cell-formation on his observations on cells of reproduction and on a growing filamentous Alga. Mirbel also cautiously regarded the formation of pollen-cells and that which he supposed to be the process in the germination of spores as cases of a peculiar kind, adhering to his old theory of the origin of ordinary tissue-cells.

Schleiden's behaviour was different. Having somewhat hastily observed the free cell-formation in the embryo-sac of Phanerogams in 1838 , he proceeded at once to frame a theory upon it which was to apply to all cases of cell-formation, and especially to that in growing organs. The very positive way 
in which he announced this theory and set aside every objection that was made to it, combined with his great reputation at the time, at once procured for it the consideration of botanists generally; and the most important representatives of phytotomy, von Mohl himself at first not excepted, allowed that there was a certain amount of justification for it. It was a question in which theoretical considerations were not of primary importance; direct and varied observation of careful preparations with strong magnifying powers could alone form the basis for further investigation. Unger showed in this way that the processes at the growing point of the stem could scarcely be reconciled with Schleiden's theory, and in this view he was supported by the English botanist Henfrey; but Nägeli was the first who addressed himself with energy and sound reasoning to the important and difficult question, how cells are formed in reproductive and growing vegetative organs, and how far the processes are the same in the lower Cryptogams and in the Phanerogams. He set out by assuming that Schleiden's theory was in the main correct, but his long-continued investigations led him finally to the conviction that it must be entirely abandoned, and he proposed the outlines of the theory of cell-formation which is accepted at the present time. In this case, as before in questions of morphology, he applied himself first, and with great success, to the investigation of the lower Cryptogams, while Alexander Braun's observations on some very simple Algae contributed materially to the further development of the cell-theory, and especially to extending and correcting the idea of the cell; Hofmeister's researches also in embryology not only produced great results for morphology, but at the same time supplied a variety of facts which served to complete Nägeli's view. The further this was worked out, the more apparent it became that the external circumstances in the processes of cell-formation might be very various, and that von Mohl's earlier observations especially gave a correct representation of individual and typical cases; but more important 
than this result was the fact declared by Nägeli in 1846 , that in all these different kinds of cell-formation it was only the external and secondary matters that varied, while the essential part of the process was in all cases the same, and it was soon perceived that cell-formation in the animal kingdom, which was now being more thoroughly examined, agreed in the main with that of the vegetable kingdom, as Schwann and Kölliker had intimated in 1839 and 1845 .

It is unnecessary to give any account here of the totally different theories which Theodor Hartig and Karsten proposed about the same time. They do not rest on careful observation, and we may omit them not merely because they are rejected by the unanimous judgment of better observers, but because they had no influence upon the development of the doctrine of cell-formation, and are therefore without historical interest.

It lies in the nature of the case, that investigations into the origin and multiplication of cells should turn the attention of observers more and more to their living contents, for these are actively and immediately concerned with the formation of new cells. The various granular, crystalline, and mucilaginous portions of the contents of cells had been repeatedly observed before i 840, and Schleiden and Meyen had specially studied the 'movements of cell-sap'; but it was in the course of observations on the history of development between I 840 and I 850 that attention was first called to a substance which plays a regular part in the formation of new cells, which envelopes the cell-nucleus discovered by Robert Brown, which undergoes the most important changes as the cell grows, which forms the entire substance of swarm-spores, and the disappearance of which leaves behind it a dead framework of cell-membrane. This substance, which is much more immediately concerned with sustaining the processes of life than is the cell-wall, was seen by Schleiden in I 838 and taken for gum. It was more carefully studied by Nägeli between I 842 and $\mathrm{I} 846$, and perceived by him to be nitrogenous matter. Von Mohl described it in 1844 and 1846 
from new points of view, gave it the name of protoplasm which it still bears, and showed that it is this substance, and not the proper cell-sap, which carries out the movement of rotation and circulation in cells discovered by Corti in the previous century, and again observed by Treviranus in I8II. The Algae proved highly instructive in the study of this remarkable substance also. The swarm-spores of Algae and Fungi observed by Alexander Braun, Thuret, Nägeli, Pringsheim, and De Bary showed that protoplasm is not dependent on the cellmembrane for its vitality, that by virtue of its own internal powers it can alter its form, and even move in space. In 1855 Unger in his 'Lehrbuch' pointed out the resemblance of this substance to the matter known as sarcode in the lower forms of animals, a resemblance brought out more plainly in $\mathbf{1} 859$, when De Bary's studies of the Myxomycetes proved that the substance of these forms was protoplasm, which continues to live for a considerable time, and often in large masses, before it forms cell-membranes. Zootomists now began to take an interest in these results of botanical research; Max Schulze (I863), Brücke, and Kühne studied animal and vegetable protoplasm, and the conviction gained ground more and more in the years from 1860 to 1870 that protoplasm is the immediate principle of vegetable and animal life. This discovery is one of the most important results of research in modern natural science.

Not less important were the results obtained from the study of the rest of the organised contents of cells; von Mohl proved that chlorophyll-corpuscles, the most considerable organs of nutrition in the plant, are formed of protoplasm, and Theodor Hartig, though his cell-theory was a mistake, did good service by his discovery of aleurone-grains in seeds and of the crystalloids which sometimes occur in the grains, and which are also formed of protoplasm and renewed from protoplasm. Radikofer, Nägeli, and others added to our knowledge of the form and chemical composition of these 
aleurone-grains. To starch-grains, which had been frequently examined, by Payen especially, Nägeli devoted an investigation at once comprehensive and profound, and obtained results of extraordinary value; these were given to the world in an exhaustive work published in $\mathrm{r}_{5} 8$ under the title 'Die Stärkekörner,' and form an epoch not in phytotomy only, but in the general knowledge of organised bodies. By the application of methods of research unknown before in microscopy, Nägeli arrived at clear ideas of the molecular structure of the grains, and of their growth by the introduction of new molecules between the old ones. This theory of intussusception founded on the observation of starch-grains derives its great importance from the fact that it served directly to explain the growth of cell-membrane, could be applied generally to molecular processes in the formation and alteration of organic structures, and accounted for a long series of remarkable phenomena, especially the behaviour of organised bodies in polarised light. Nägeli's molecular theory is the first successful attempt to apply mechanico-physical considerations to the explanation of the phenomena of organic life.

While men of the highest powers of mind were devoting themselves to the solution of these difficult problems, the study of tissues was not neglected in the years after 1840 , and here too it was Nägeli who gave the chief impulse and the direction to further development. In the periodical which he published in conjunction with Schleiden he had already (1844-46) given an account of some searching enquiries which he had made into the first processes in the formation of vascular bundles from uniform fundamental tissue; in the Cryptogams he observed the production of the tissue of the whole plant from the apical cell of the growing stem, and this discovery, still further pursued by Hofmeister especially, has given rise during the last twenty years to a copious literature, which has been of service to the theory of the formation of tissues, to morphology, and consequently also to systematic botany. 
The researches of Hofmeister, Nägeli, Hanstein, Sanio, and others into the first formation of vascular bundles from the fundamental tissue of young organs led to important results for morphology, in so far as it was now for the first time possible to judge of the morphological value of anatomical and histological relations. The growth in thickness of woody plants, a question of primary importance to vegetable physiology, was first made intelligible by the discovery of the mode of formation of vascular bundles and their true relation to cambium; Hanstein and Nägeli, and afterwards Sanio especially, cleared up the questions connected with growth in thickness in their main features before and after 1860 .

When we pass on to show how the great results abovementioned were attained, we encounter some difficulties. After I 840 botanical literature multiplied to an extent before unknown; it is from elaborate monographs on single subjects in phytotomy, from some text-books, and especially from smaller essays in botanical periodicals that we must gather an account of the further development of scientific thought. Much as the founding of scientific periodicals has facilitated communication between professed botanists, yet this form of literature makes it more difficult to see the way clearly through the work of earlier periods and to discover the historical connection in the science, not to speak of the harm that usually results from it to young and inexperienced students.

Such being the nature of the sources from which we must draw our information, we shall obtain a better general view of the whole subject if we depart from the practice of former chapters, and follow out the more important questions in their historical development instead of connecting them directly with leading persons. Such a treatment of the subject is indeed suggested by the fact that we are now no longer on 
pure historic ground; for the majority of the men who have developed modern doctrines since $\mathrm{I} 840$ are still alive, and it must be uncertain whether the account here attempted may not be impugned on some ground or other. Owing to the extraordinary diversity of opinion that exists among botanists even on the most general questions in the science, it is extremely difficult to ascertain what can be considered as a common possession, - an unfortunate condition of things, from which no science perhaps suffers so much as botany.

The extent to which individual botanists have contributed to the advance of phytotomy during the period under consideration will appear of itself from the following narrative; and if we speak almost exclusively of Germans, it is for the simple reason that Englishmen from Grew's time till now can scarcely be said to have added anything to our knowledge of phytotomy; the Italians also, once so gloriously represented by Malpighi, scarcely come under consideration in the questions now to be dealt with, while French botanists, represented by Mirbel in the preceding period, though they have produced many works on phytotomy since his time, have had no important share in deciding the fundamental questions of modern science.

In the preceding period it was necessary to take into consideration the increasing improvement of the microscope, in order to understand the development of opinion on vegetable structure; but it is scarcely needful to do so after I840. Since that time good and serviceable instruments with strong magnifying powers and clear definition have been within the reach of every phytotomist; and though improvements are still being constantly made, yet the microscopes that were in the hands of skilful observers between 1840 and 1860 were fully adequate to deciding the new questions proposed to them. The chief improvement effected in the microscope during this period was the fitting it with apparatus for the polarisation of light, and for the more convenient measurement 
of objects; we shall see presently what influence the former improvement had on the perfecting of Nägeli's molecular theory. As microscopes improved and the questions to be solved grew more difficult, it became necessary to bestow increased care on the preparation of objects; it was no longer sufficient to cut or dissect neatly, and so learn the form of the solid portions of vegetable structure; measures of precaution and auxiliary measures of the most various kinds were needed to obtain a clear view of the soft contents of cells, and to observe the protoplasm as far as possible in a living state and protected from prejudicial influences; all sorts of chemical reagents were applied to make the objects more transparent, or to show their physical and chemical characters. The method invented by Franz Schulze before $185 \mathrm{I}$ deserves to be specially mentioned; it consisted in isolating the cells in a few minutes' time by boiling them in a mixture of nitric acid and potassium-chlorate, and thus shortening Moldenhawer's process of maceration or superseding it altogether. In a word, the technicalities of the microscope were perfected in a variety of ways by Schleiden, von Mohl, Nägeli, Unger, Schacht, Hofmeister, Pringsheim, De Bary, Sanio, and others, and raised to an art which must be learnt and practised like any other art. Young microscopists were able after $185^{\circ}$ to learn this art in the laboratories of their elders, and to profit by their technical experience and scientific counsels; schools of phytotomy were formed at least in the German universities; elsewhere, it is true, the old condition of things remained in which everyone had to trust to himself from the beginning.

The general dissemination of good microscopes was accompanied by a higher standard of requirement in the execution of drawings from the instrument, especially after von Mohl had shown the way; and the invention of lithography and the revival of wood-engraving ministered to the needs of science, supplying the place of the old costly copper-plate printing. Hence we find an increasing number of beautiful drawings 
in scientific monographs; the text-books also could now be supplied with an abundance of figures, and this greatly promoted the general understanding of things which could otherwise be seen only under the glass of each observer. From the close of the 16 th century wood-cuts had fallen more and more into disuse, and had been replaced by copper-plates; after 1840 wood-engraving was restored to its old rights and was found to be a more convenient method of pictorial illustration, especially for text-books ; thus Schleiden's 'Grundzüge' of $\mathrm{I} 842$, von Mohl's 'Vegetabilische Zelle' of I85 I, Unger's and Scliacht's text-books were enriched with many and sometimes very beautiful wood-cuts. Lithographs were generally preferred for periodicals and monographs; the 'Botanische Zeitung,' founded by Mohl and Schlechtendal in 1843 , and till after $\mathrm{I} 860$ the chief organ for shorter phytotomic communications, was illustrated by a large number of beautiful prints from the establishment of the Berlin lithographer, Schmidt.

\section{Development of the Theory of Cell-formation} FROM I 838 TO I 85 I.

Since we are here dealing with questions of fundamental importance not only to one branch of botanical study but to the whole science of botany, and even to the rest of the natural sciences, it seems imperative that we should follow step by step the founding and perfecting of the theory of the cell, as far as is possible in the limited space at our command; we shall deal with the sexual theory further on in a similiar manner.

As usually happens in the inductive sciences, the period of strict inductive investigation into cell-formation was preceded by a still longer time, during which botanists ventured to put forward general theories in reliance on highly imperfect observations. We have already seen how Caspar Friedrich IVolff in I759 made cells originate as vacuoles in a homogeneous 
jelly, and how this view was adopted in all essential points by Mirbel at a late period in the 18 th century; how Kurt Sprengel, and with him a number of phytotomists, among them Treviranus as late as 1830 , supposed cells to be formed from granules and vesicles in the cell-contents, an idea which Link it is true opposed in 1807 , but afterwards accepted to a great extent. Though Moldenhawer as early as I8I 2 ('Beiträge,' p. 70) distinctly rejected these theories, and published observations which if followed up would have led to the right path, yet the botanists above-named and others with them, long continued to adhere to the earlier views. Kieser, for example ('Mémoire sur l'organisation des plantes,' I 8 I 2) further developed Treviranus' theory, that the fine granules in the latex of plants are cell-germs which are afterwards hatched in the intercellular spaces. Schultz-Schultzenstein in his work 'Die Natur der lebenden Pflanze,' I823-28, i, p. 607 rejected this view and adopted that of Wolff and Mirbel. Scarcely better than the notion of cell-germs represented by Sprengel, Treviranus, and Kieser was the theory propounded by Karsten soon after 1840 ; that of the French botanists Raspail and Turpin $^{1}$ (1820-1830), though conveyed in a different terminology, corresponded in its main points with the views of Sprengel.

It had been the good fortune of Mirbel at the beginning of the century, and again thirty years later, to promote the advance of phytotomy by means of important observations, though he may have interpreted some of them incorrectly; the same thing happened again thirty years later, and it was a German enquirer, von Mohl, who corrected his observations and views on both occasions.

In his famous treatise on Marchantia polymorpha, which appeared in 1835 in the Memoirs of the French Institute, the

${ }^{1}$ On this point, see von Mohl's citation in 'Flora' of 1827, p. I3. I have not myself been able to consult the originals. 
first part having been laid before the Paris Academy in $183 \mathrm{I}-32$, Mirbel distinguished three modes of cell-formation; in the germination of the spores of Marchantia new cells are formed from the germ-tube and new cells again from these by a similar process, much in the same way therefore as that which actually occurs in the germination of Yeast-fungi; he found a second kind of cell-formation in the production of the gemmae of Marchantia, where he distinctly observed the successive appearance of the dividing walls, but formed an erroneous idea of the proceeding on the whole; in the further development of the gemmae and in other cases of growth he considered that new cells are formed between those that are already present in the manner supposed in his earlier theory.

Von Mohl's dissertation on the multiplication of vegetable cells by division, published in 1835 and reprinted in 'Flora' of I837, shows how strange these processes even then appeared ; in this work he expresses some doubts about Mirbel's statements, but he accepts them on the whole, and only makes incidental mention of his own more numerous and better observations on the development of spores ('Flora,' I833), though he had there seen several cases of cell-division and free cell-formation with tolerable distinctness. Adolph Brongniart ('Annales des sciences naturelles,' I 827) also had observed, though imperfectly, the formation of pollen-grains in their mother-cells in Cobaea scandens, and Mirbel, in the appendix to the work mentioned above, had given a correct description and good figures of the formation of pollen-cells ; and yet von Mohl neglected to compare these important observations of cases of cell-division with his own; even in 1845 , when he published the latter in a revised form in his 'Vermischte Schriften,' he overlooked the close relation between the formation of those pollen-grains and spores, and the cell-division in Cladophora. Still this treatise of von Mohl's is of great importance in the history of the theory of cellformation, because it described a case of cell-division for the first time step by step and brought all the salient points into relief. 
Dumortier had observed the division of cells as early as $183^{2}{ }^{1}$, and Morren had seen it in Closterium in $18{ }_{3} 6$, but had not given the needful details. Finally, von Mohl applied the experience which he had gained from Cladophora to other filamentous Algae, and pointed out the similarity between these processes and the division of Diatoms, which he consequently claimed as plants in opposition to Ehrenberg, who considered them to be animals ('Flora,' 1836, p. 492).

Meyen next, relying on von Mohl's observations on Cladophora, declared in the second volume of his 'Neues System' that cell-division was a very common occurrence in Algae, Filamentous Fungi and the Characeae, but he neglected any closer investigation of the processes by which the division is introduced and completed. His comparison of these cases of cellformation with the formation of spores, pollen-grains, and endosperm-cells is moreover noticeable as the first attempt to distinguish what is now known as free cell-formation from cell-division; it was obviously the want of this distinction which long prevented clearer views on the whole of this field of observation. The due separation of these two modes of cell-formation was a short step after the observations that had been already made; and if that step had been taken, Schleiden's theory would have been impossible, and the development of the cell-theory would not have been prejudiced by the mistake, introduced by Schleiden after 1838 , of applying the mode of free cell-formation, which he believed he had observed in the embryo-sac of Phanerogams, to the multiplication of vegetative cells in growing organs, and regarding it as the only mode of cell-formation. This would have been the more impossible, since von Mohl in the same year gave an excellent description of the development of stomata by division of a young epidermis-cell and the later separation of the dividing wall into two laminae. But von Mohl in the years immediately following was over-cautious in

${ }^{1}$ See Meyen, 'Neues System,' ii. 344. 
refraining from all speculative consideration of cases that lay clearly before him, and his views were still undecided in 1845, when Unger and Nägeli had already made good observations on the formation of tissue-cells in growing organs ("Vermischte Schriften,' I 845 , p. 336).

Schleiden's theory of cell-formation arose out of a curious mixing together of obscure observations and preconceived opinions, and reminds us indeed strongly of the old notions of Sprengel and Treviranus; it is true that he distinctly rejected their views, but he too made new cells arise from very minute granules, and his theory like theirs did not rest on any thorough course of observation.

Robert Brown, (see his Miscellaneous Writings, edited by T. T. Bennett, I.) had discovered the nucleus in the cells of the epidermis of Orchidaceous plants in $183 \mathbf{1}$, and had shown that it was very generally present in the tissue-cells of Phanerogams, but had obtained no results from his discovery. The cell-nucleus lay undisturbed, till Schleiden suddenly made it the soul of his theory and the starting-point of all cell-formation. He considered that the nucleus was formed from the mucilaginous content of the cell, which he assumed on insufficient grounds to be of the nature of gum; this he called the cytoblastem, and the nucleus itself the cytoblast. As he states that his cytoblastem becomes yellow and granular in solutions of iodine, we may recognise in it our own protoplasm.

We make acquaintance with Schleiden's theory of cell-formation in its original form, if we turn to his treatise, 'Beiträge zur Phytogenesis,' (in the Archiv für Anatomie, Physiologie, etc. von Johannes Müller, I838). The work begins with some remarks on the general and fundamental laws of human reason, etc., discusses the literature of cell-formation in a few lines without mentioning von Mohl's numerous observations, goes on to mention the general occurrence of the nucleus which here receives its new name, then occupies itself with gum, sugar, and starch, and at last comes to the main subject. There are 
two spots, says Schleiden, in the plant, where the formation of new organisation may be most easily and most certainly observed, the embryo-sac and the end of the pollen-tube, in the latter of which, according to his theory of fertilisation, the first cells of the embryo are supposed to be formed, but where in fact no cells are formed. At both spots small granules soon arise in the gum-mucilage, which, before homogeneous, now becomes turbid, and then single larger and more sharply defined granules, the nucleoli, appear. Soon after, the cytoblasts are seen as granular coagulations from the granular mass; they grow considerably in this free condition, but as soon as they have reached their full size, a delicate transparent vesicle is formed upon them; this is the young cell, which at first presents the appearance of a very flat segment of a sphere, whose plane side is formed by the cytoblast, the convex by the young cell (the cell-membrane), which rests upon the cytoblast as a watch-glass on a watch. Gradually the vesicle becomes larger and of firmer consistence, and now the whole of the wall, except where the cytoblast forms part of it, consists of a jelly. By-and-bye the cell grows beyond the edge of the cytoblast and rapidly becomes so large that the latter appears only as a small body inclosed in one of the side walls. The shape of the cell becomes more regular with advancing growth and under the pressure of adjoining cells, and often passes into that of a rhombododecahedron, which Kieser for reasons drawn from the nature-philosophy assumed to be the fundamental form. It is only after the resorption of the cytoblast that the formation of secondary deposits on the inner surface of the cell-wall commences, though some exceptional cases are adduced. Schleiden thinks (p. I48) that he may assume that the process here described is the general law of formation of vegetative cell-tissue in Phanerogams. He adds particularly that the cytoblast can never lie free inside the cell, but is always enclosed in a duplication of the cell-wall, and he thinks that it is an absolute law that every cell, except perhaps in 
cambium, begins as a minute vesicle, and grows to the size which it reaches in its matured state. The resemblance of this view to that of Sprengel and Treviranus is increased by what we find further on, where we read that from the cell-germs in the spores of Marchantia usually only from two to four serve to form cells, the rest becoming overlaid with chlorophyll, and being consequently withdrawn from the vital process. He who is acquainted with the modern view of the processes of free cell-formation founded on the numerous and careful investigations of later times will scarcely discover in the above account of Schleiden's theory a single correct observation.

Soon after, von Mohl published in 'Linnaea,' r839, p. 272, his observations on the division of the mother-cells of the spores of Anthoceros ; these were carefully made and were correct in all the main points ; and in opposition to Mirbel's former statements they establish the fact, that the division is effected by the mucilaginous contents of the cell, and consequently that it is not a passive division of the contents of the mother-cell produced by the growth inwards of projections of the cell-wall.

Unger $^{1}$ was the first to declare distinctly against Schleiden's

1 Franz Unger was born in 1800 on the estate of Amthof, near Leutschach in South Steiermark, and was educated up to the age of sixteen in the Benedictine Monastery of Gratz. Having gone through the three years' course of 'philosophy,' he turned his attention, by his father's wish, to jurisprudence; but he abandoned this study in 1820 , and became a student of medicine, first in Vienna, and afterwards in Prague. From the latter place he made a vacation tour in Germany, and formed the acquaintance of Oken, Carus, Rudolphi, and other men of science, and in r $_{25} 5$ of Jacquin and Endlicher, with the latter of whom he maintained an active correspondence on scientific subjects. Having taken his degree in 1827 , he practised as a physician in Vienna till the year 1830 , and after that date was medical official at Kitzbühl in the Tyrol. During these years he continued the botanical studies which he had commenced as a youth, and at Kitzbiihl directed special attention to the diseases of plants, to palaeontological researches, and to enquiries into the influence of soil on the distribution of plants. At the end of $\mathbf{r} 835$ he became Professor of Botany at the Johanneum in Gratz, and devoting himself there especially to the study of 
doctrine, and his observations on the punctum vegetationis appeared in the 'Linnaea' of r $84 \mathrm{r}$, p. 389 ; from the size and position of the cells he concluded that the tissue-cells in this case are formed by division, and not in the manner alleged by Schleiden. Soon after Nägeli also ('Linnaea,' r 842 , p. 252) observed the processes of cell-formation in the extremities of roots, but he did not conceive them to be cases of division; he saw two nuclei form in each mother-cell, and a new cell form round each nucleus, and explained the origin of the dividing wall as due to the meeting together of the two new cells; he thought that a similar process takes place in stomata and in the mother-cells of pollen; this conception was not absolutely incompatible with Schleiden's theory, but there was this difference, that in Nägeli's case essential processes were correctly observed, but were to some extent incorrectly interpreted. In the same year appeared the first edition of Schleiden's 'Grundzüge der wissenschaftlichen Botanik,' in which his theory of cell-formation was repeated in a more precise form. That he was thoroughly in earnest to maintain it is shown by the fact that he gave still another exposition of it in his 'Beiträge zur Botanik' in I844, where he insists that his method of cellformation is the general one, though it has been distinctly ascertained in the Phanerogams only. But how completely an observer may be led captive by a preconceived opinion may be learnt from Schleiden's suggestion, that the formation of zygospores in Spirogyra is in accordance with his views, though it

palaeontology, he soon became the most eminent authority on that subject. Having been made Professor of Vegetable Physiology in Vienna in I849, he applied himself more to physiology and phytotomy. He retired from this position in 1866 , and from that time forward lived as a private individual in Gratz, promoting scientific knowledge by the publication of popular treatises and the delivery of lectures. He died in I870. Information respecting his personal character and his varied and copious labours in many departments of botanical science is given by Leitgeb in the 'Botanische Zeitung' of 1870 , No. I6, and by Reyer, 'Leben und Wirken des Naturhistoriker Unger,' Gratz, I87 I. 
is impossible to conceive of a case of cell-formation more easy to observe, or less reconcilable with Schleiden's theory. It was mentioned in the first book, that Hedwig and Vaucher were acquainted with the remarkable process of the formation of zygospores in the alga-genus Spirogyra; but this as late as Schleiden's time was not regarded as an example of cell-formation, and his view was really a step in advance, since it brought a process, so highly peculiar according to existing ideas, under the general conception of cell-formation.

The systematic elaboration of the theory of cells, founded on careful observation and mature reflection, began with the year r 844. Almost at the same time in this year appeared Nägeli's detailed enquiries into the occurrence of the cell-nucleus and into cell-division, von Mohl's observations on the primordial utricle and its behaviour in the process of cell-division in young tissue, and lastly those of Unger on merismatic cell-formation (cell-division) as a general mode of proceeding in the growth of organs. As these observers were chiefly concerned to test the correctness and general applicability of Schleiden's theory, they necessarily paid special attention to the general occurrence of the cell-nucleus and to its position on the side of the cellwall, for these were the points most accessible to observation and criticism. The discussion of these observations disclosed a defect in the current phraseology, in which the word cell was commonly understood to mean only the cell-membrane, but sometimes included everything belonging to and contained in the cell ; hitherto moreover the protoplasm of the cell had not been sufficiently distinguished from the rest of the cell-contents.

Nägeli and von Mohl arrived simultaneously at a clearer understanding of these points; von Mohl recognised the primordial utricle (1844) as a component part of the cellcontents and not belonging to the cell-wall, and explained the part which it plays in cell-division; in 1846 he arrived at a clear conception of the protoplasm as a peculiar substance distinct from the other contents of the cell and gave it the name it still 
bears. Meanwhile Nägeli had also distinguished the protoplasm from everything else in the cell, and noticed its pre-eminent importance in cell-formation and its nitrogenous character.

We must not omit to mention here, that investigations into the processes of cell-formation compelled observers to search for the spots where cell-formation actually takes place, and thus the fact was ascertained, that cells in statu nascendi are not to be found in all parts, not even in all growing parts of the plant, but that we must look for them in the so-called puncta vegetationis in the stem and root, in the youngest lateral organs, and between the bark and the wood in woody plants. About this time a new idea began to be attached to the word cambium, which Mirbel had used in the sense of a nourishing juice saturating the plant; it was now applied to the tissue-masses in which the formation of new cells takes place, and specially to the very thin layer of tissue lying between the wood and the rind, from which new layers of wood and rind in woody plants are formed-a layer, which according to Mirbel's theory had been a mass of sappy matter, in which new cells arise as vacuoles.

Unger in an enquiry into the growth of internodes ('Botanische Zeitung,' I 844) again declared himself as an opponent of Schleiden's theory. He maintained first of all and erroneously that the cell-nucleus is not of general occurrence in tissue where division is taking place, but he argued rightly from the position of the cells, from the difference of thickness in their walls, and from their relative size, in favour of their multiplication by the formation of dividing walls; he noticed the part played by the cell-contents in the multiplication of cells in hairs, and asserted that merismatic cell-formation (cell-division) is the general rule in the growth of organs of vegetation, while he distinctly declared that it was not possible to bring all that is actually seen at the spots where formation of cellular tissue is taking place into agreement with Schleiden's theory. But Unger did not observe the processes that take place in cell- 
division step by step; his observations sufficed to make Schleiden's theory very improbable without offering enough foundation for a new one, and Schleiden did not fail to reply to Unger's objections in the second edition of his 'Grundzüge' in $\mathrm{r} 845$.

Earlier in the same year, von Mohl published in the 'Botanische Zeitung' the treatise on the primordial utricle which has been already mentioned; by the term primordial utricle he meant partly the very thin layer of protoplasm, which in large cells full of sap lines the inside of the cell-wall, and partly an outer layer of the protoplasm in young cells, which are still rich in that substance. It is true that the distinguishing the primordial utricle was not a very important matter; but von Mohl applied it with his usual thoroughness to obtaining a better insight into cell-formation by calling attention (p. 289) to the circumstance, that the cells of the cambium-layer between the rind and the wood fit into one another and leave no intercellular spaces; from this he concluded that there are only two possible modifications of cell-multiplication, either division of cells by formation of a dividing wall or formation of cells within cells; in each of these young cells is a primordial utricle, the origin of which must at least be contemporary with that of the cell (cell-membrane). 'Could it then be distinctly shown, that two primordial utricles exist side by side in cells, which are in the act of multiplying, before a partition-wall is formed between them, it would be evident that in the cambium layer and at the points of the stem and root the formation of the primordial utricle precedes that of the cell.' Von Mohl believed that he had seen this process, but was not perfectly satisfied as to the correctness of his observation; but he continues: 'Since every young cell contains a primordial utricle, this must either be absorbed before a multiplication of the cell commences in order to make way for two new ones formed in its stead, or the old primordial utricle must separate into two.' He considered the first supposition to be the probable one, rejecting Unger's 
statement that the nuclei are formed after the division. It is surprising that after these considerations von Mohl thought that his own observations necessarily confirmed Schleiden's theory of cell-formation, although he noticed beside that the nucleus never forms a part of the cell-wall, an essential feature in that theory ; but in fact von Mohl took the membrane which according to Schleiden separates from the nucleus for the primordial utricle. But these mistakes are soon followed by the right conjecture, that the substance of the primordial utricle may be identical with the mucilaginous mass, which commonly encloses the nucleus, and so with that which von Mohl two years later named protoplasm. In this later treatise ('Botanische Zeitung,' I846), in which he proves that the well-known movements in the interior of cells are made not by the watery cell-sap but by the protoplasm, he states (p. 75) that it is the protoplasm which produces the nucleus, that the organisation of the nucleus ushers in the formation of the new cell, and that contrary to Schleiden's theory the protoplasm completely envelopes the nucleus, which always occupies the centre of very young cells, as is the case especially in the endosperm-cells observed by Schleiden. He then shows how the protoplasm of young cells at first solid afterwards forms sap-cavities and stretches between them in walls, bands or threads, the substance of which exhibits the streaming movement. Von Mohl strangely neglected on this occasion to compare carefully his former observations on the origin of spores and the division of Alga-cells with his new results, and to seek for the essential resemblances between them ; on the contrary he said emphatically that the cell-division in Cladophora is probably a quite different process from the multiplication of tissue-cells in higher plants.

The discoveries of Unger and von Mohl up to the year I 846 were quite sufficient to refute Schleiden's theory, but not to give a clear and general view of the processes in the formation of cells; the different kinds of cell-formation were neither carefully distinguished from one another, nor could they be 
referred to a common principle. Both observers had endeavoured to conjecture the course of events from certain data, supplying by inference what they had not directly observed.

Nägeli about the same time took up a different position as an opponent of Schleiden's theory. In an exhaustive treatise on the cell-nucleus, cell-formation, and cell-growth in plants, the first part of which appeared in $\mathrm{I} 844$ in the periodical founded by himself and Schleiden, he collected together all that had hitherto been observed by himself and others from various points of view. All sections of the vegetable kingdom were once more systematically examined with reference to the occurrence of the cell-nucleus and the different kinds of cellformation; all cases of the latter were carefully compared together in their resemblances and differences, in order to deduce from the observed phenomena that which was essential and universal. The first result was, that Schleiden found himself obliged, in the second edition of his 'Grundzüge' in I 845 , to accept the cell-division established by Nägeli in Algae and the mother-cells of pollen as a second kind of cell-formation; thus began the movement in retreat which was destined to end in the following year with the overthrow of Schleiden's theory. This was effected by the continuation of Nägeli's treatise in the third volume of the periodical for 1846 . In the first part of his work Nägeli had set out by assuming the correctness of Schleiden's assertions, though he was even then compelled to modify them considerably. In the second part, however, in consequence of further observations Schleiden's theory was declared in plain terms to be utterly incorrect, and was refuted point by point. But Nägeli was not obliged to confine himself to this negative result; his comprehensive investigations supplied material at the same time for constructing a new theory of cell-formation, which not only took in all the various cases, but declared the principle which lay at the root of all. If we compare this second part of Nägeli's treatise with von Mohl's publications from 1833 to 1846 , we shall see that 
von Mohl had observed with accuracy a number of important facts, but that Nägeli added largely to them, and, which is the main point, elaborated them into a comprehensive theory embracing all kinds of cell-formation. How important the correct distinction of the protoplasm from the rest of the cell-contents was for the perfecting of the theory of cells is seen from Nägeli's declaration, that he retracts his former view which rested on the authority of Schleiden, because it sprang from a time when he was ignorant of the significance of the mucilage-layer (the protoplasm), though it is true that he indicates at the same time other points and new considerations which definitively set aside Schleiden's theory. After investigating the different modes of free cell-formation and finding the processes there quite different from Schleiden's account of them, he proceeded to search for free cell-formation where Schleiden had affirmed that it invariably occurs, namely in growing vegetative organs in the higher plants. But this investigation led him to the conclusion that all vegetative cell-formation is true cell-division, and that even the reproductive cell-formation in some Algae and Fungi is effected by division; the reproductive cells of most plants are the result of free cell-formation, but it should be observed that the term free cell-formation is here used not exactly in the modern sense, inasmuch as Nägeli included in it the formation of four-fold grains (tetrads) in spores and pollen. If the distinction between cell-division and free cell-formation had often been suggested by former observers, Nägeli was the first who distinctly defined it, though not exactly as it is now defined. 'In cell-division the contents of the mother-cell separate into two or more portions; a perfect membrane forms round each of these portions, which at the moment of its appearance rests partly on the wall of the mother-cell and partly on the adjacent walls of the sister-cells. In free cellformation a smaller or larger part of the contents of a cell, or even the whole of them becomes isolated. On its surface is formed a perfect membrane, which is everywhere free on its 
outer face. There are two processes in the formation of a cell ; the first is the isolation or individualising of a part of the contents of the mother-cell, the second the formation of a membrane round the individualised portion.' He then proceeds to show that the cell-wall is formed by the separation of nonnitrogenous molecules from the nitrogenous mucilage (protoplasm). These sentences contain all that is general and essential in vegetative cell-formation. Further on he notices the peculiarities in the various processes in cell-formation; he says that the individualising of the cell-contents assumes four forms; first, single small portions of the contents separate themselves inside the rest, as occurs in the formation of free germ-cells in Algae, Fungi, and Lichens, and of endospermcells in Phanerogams; secondly, the whole contents of one cell, or of two by conjugation of associated cells, collect into a free spherical or ellipsoidal mass, as in the formation of germcells in the Conjugatae; thirdly, the whole contents of a cell separate into two or more portions, which is now called celldivision; from this Nägeli distinguishes as his fourth form, the process known as abscision (Abschnürung), which occurs in the formation of germ-cells in many Algae and Fungi.

Schleiden had declared it to be a general law in plants, that cells are only formed inside mother-cells. Meyen however, Endlicher, and Unger, had recently assumed the formation of new cells between the older ones; Nägeli maintained that all normal cell-formation, vegetative and reproductive, takes place only within mother-cells.

In opposition to the long-cherished notion that there must be one general and fundamental form of cell, Nägeli pointed to the fact that cells have very different forms at the moment of their production. Those which arise by free cell-formation are, he says, at first always spherical or ellipsoidal; those produced by cell-division have a shape necessarily conditioned by the form of the mother-cell and the manner of division. He showed further that changes in the 
shape of cells with advancing growth depend materially on whether they enlarge equally in all parts of their circumference or not. These considerations, obvious as they are, were now for the first time pointed out and fully appreciated.

The reader who is already familiar with our subject will recognise in the passages adduced from Nägeli without further explanation the essential principles of the modern theory of cells, especially if he compares them with the views propounded at the same time and previously by Schleiden, Unger, and von Mohl. But, as might be expected, the further investigations, which were pursued with zeal during the succeeding twenty years and produced a considerable literature, did much to enlarge and perfect Nägeli's theory in many of its details and to correct it in some minor points; the theory itself facilitated this process by supplying a scheme to which the investigation of special questions could readily be referred. Whether the nucleus is a solid body or a vesicle, whether in the division of a mother-cell into compartments the wall of partition always grows from without inwards or is formed simultaneously over its whole surface, whether it is originally composed of two laminae or of one which is afterwards differentiated, - these and many other questions were decided in course of time.

Schleiden's theory was now definitively set aside, a deeper insight was obtained into the nature of the cell, and the ideas connected with the word became broader and more profound. The knowledge of the formation of cells showed that the cellwalls, which had been hitherto regarded as the important part, are only secondary products, that the true living body of the cell is represented by its contents and especially by the protoplasm. Alexander Braun, relying on numerous researches into the lower Algae, expressed himself in $185^{\circ}$ ('Verjüngung,' p. 244) to the effect that it is an inconvenience that the word cell is used at one time to designate the cell with its wall, at another time the cell without its wall, or again 
the wall without the cell. Since the contents are the essential part of the cell and form a separate and individual whole which has its own membrane-like boundary, the primordial utricle, before the secretion of the membrane of cellulose, we must either confine the term cell to the enveloping membrane or to the chamber which it forms and find another name for the body of the contents, or else call this the true and proper cell. This, which presents itself at once as the correct mode of conception to anyone who observes the formation of swarm-spores in Algae and Fungi and many other cases of cell-formation, was from this time forward a vital point in the doctrine of the cell. Braun contributed also to the clearing up of the ideas of botanists on this subject by bringing together under one systematic view and classifying all the varieties of cell-formation which were known to him up to the year 1850 , and especially by a more searching investigation into modes of conjugation. Henfrey's contributions ('Flora' of 1846 and I 847 ) rested entirely on the observations of German botanists, and brought to light nothing that was independently and essentially new. On the other hand Hofmeister's new observations on the development of pollen ( 1848 ), and his many remarks on cell-formation in his epoch-making researches into embryology in $185 \mathrm{I}$, contributed repeatedly to the deciding of doubtful points, especially in the behaviour of the nucleus in cell-formation and the production of the dividing walls. Von Mohl, who in spite of his own excellent observations maintained up to 1846 a somewhat undecided attitude of mind in respect to Schleiden's theory, which was at that time still in vogue, published in $185 \mathrm{I}$, in his treatise 'Die vegetabilische Zelle,' an excellent summary of the results which had been so far achieved. In describing cell-division he notices specially that the new nuclei occupy the centres of the future daughter-cells before the division of the contents commences; but he still clung to his old view, that in every instance of 
cell-division the parting-wall must form progressively from without inwards, as in Cladophora, contrary to Nägeli's and Hofmeister's correct statements, that cases also occur of simultaneous formation at every point of the surface of the partition-wall. As usual, however, von Mohl rested his opposition on a good observation, and showed that in the case of the formation of pollen in dicotyledonous plants it is possible to burst the membrane of a mother-cell in the act of dividing, and set free the protoplasm when it is already deeply divided into the four parts, and so to see the halfformed partition-walls; but this only proved that such was the process in the cases observed, the formation of the partitionwalls being simultaneous in others. It may be mentioned in this place, that the idea of special mother-cells in the formation of pollen introduced by Nägeli in 1842 was in entire accordance with the condition of the science at the time, since he meant by the term the laminae of membrane formed during the successive divisions of the mother-cell. To call these still special mother-cells, as some modern phytotomists do, is quite unjustifiable, because since 1846 , when Nägeli propounded his theory, the word cell, as we have seen, no longer designated the mere membrane but the whole body of the cell, while the expression special mothercell rests on the older phraseology, in which cell and cellmembrane are identical.

The additions made to the doctrine of cell-formation during the greater part of the twenty years after $185 \mathrm{I}$ were unimportant in comparison with the mighty development which it had experienced during the preceding ten years. These years had indeed been marked by the greatest possible activity and fruitfulness in results in all parts of botanical study. By the labours of Unger, von Mohl, Nägeli, Braun, and Hofmeister, not only were the foundations laid for a true theory of cells, but the details were worked out, and the conceptions connected with them finally cleared up. Text- 
books could now disseminate the new teaching through wider circles, and with these works may be classed von Mohl's treatise already mentioned on the vegetable cell, since it came much into use in a later and special edition, and was made by many teachers of botany the foundation and guide in their lectures. It was now become the fashion to compose not general text-books of botany, but compendia of anatomy and physiology, and thus morphology and systematic botany were neglected, as anatomy and physiology had been in the period immediately preceding Schleiden's time. Whoever therefore wished to consult a complete manual of general botany was for some time obliged to be content with Schleiden's 'Grundzüge'; and this had a great deal to do with keeping alive his erroneous doctrines on cells and fertilisation among general readers, while the professed botanists had long given in their adherence to more modern and more correct views. It is a misfortune in our science to be singularly poor in good text-books, which might have given a general account from time to time of the existing condition of research; this is one of the reasons why for some time past even official representatives of botanical science often differ so much from one another in their fundamental views on method, and on the question of how much has been actually established and how much still remains doubtful in the main divisions of the subject, that a mutual understanding seems often impossible. That a better state of things in this respect prevails in zoology, physics, and chemistry, is certainly not a little due to the many good compendia and text-books, which endeavour to give some account of the progress of those sciences from year to year.

However, during the period from 1850 to 1870 Schacht and Unger attempted to make the results of modern phytotomic investigation accessible to general readers by means of text-books. Such was the nature of Schacht's ${ }^{1}$ work,

${ }^{1}$ Hermann Schacht was born at Ochsenwerder in 1824 , and died in 1864 in Bonn, where he had been Professor of Botany since 1859 . 
'Die Pflanzenzelle,' published in $185^{2}$, a book which claimed to expound all parts of phytotomy by the aid of the author's own observations, with occasional reference only to the writings of others; the attempt was so far impossible, as the essential points had already been fully cleared up by the labours of other botanists. The work had however the advantage of attracting the attention of the reader by numerous good original drawings, and the style was enlivened by the constant appeal to original observation; at the same time, through insufficient use of the available literature, the author's views not unfrequently fell short of the existing standard of knowledge. Worse than this however was a certain defect of education, which led the writer into selfcontradiction and to incorrect classification of his facts ; things fundamentally important were sometimes neglected for unimportant details, and a certain unreflecting empiricism was apparent in the whole work, in marked contrast with the logical exactness of von Mohl, Nägeli, and Hofmeister. In the second edition of the work, published in 1856 under the title, 'Lehrbuch der Anatomie und Physiologie der Gewächse,' we find many improvements in the details, but still on the whole the same formal defects. It is not unimportant in a historical point of view to notice this character of Schacht's writings, because during this period most young botanists and other persons also derived their knowledge of phytotomy and of the nature of cells chiefly from him; his books did not truly represent the condition of the science; their defective reasoning had an injurious effect on the minds of younger readers, and they introduced into phytotomy and vegetable physiology a habit of accumulating a mass of undigested facts, such as has for some time marked the condition of morphology and systematic botany.

Unger's text-book 'Anatomie und Physiologie der Pflanzen' (1855) was superior in conception and execution. It introduced the beginner to the doctrine of cells with careful attention to all that was known on the subject, if sometimes 
with some hastiness of decision, while it brought the really important points everywhere into prominence and employed individual facts to explain the general propositions, as should always be done in a work intended for learners. But in addition to this Unger's book contained much that was really new and valuable, and among other things some very important remarks on the physiological characteristics of protoplasm; and it pointed out for the first time the similarity between vegetable protoplasm and the sarcode in Rhizopods, which Max Schulze had before carefully described. In this year Nägeli also published investigations into the primordial utricle and the formation of swarmspores in his 'Pflanzenphysiologische Untersuchungen,' Heft I, which gave a new insight into the physical and physiological characteristics of protoplasm. It has been mentioned above that De Bary's investigations into the Myxomycetes in I859 had thrown new light on the subject of protoplasm, and had called attention to vital phenomena connected with it, which, though analogous to what had been before observed, were rendered very striking from the circumstance that in this case the protoplasm was not in microscopically small portions enclosed by firm cell-walls, but moved about and showed changes of shape in large, sometimes in very large, masses, that were entirely free and unconfined. Here was the best opportunity for making a nearer acquaintance with protoplasm and for learning to recognise it as the immediate support of all vegetable and animal life; in succeeding years the zootomists and physiologists Max Schulze, Brücke, Kühne, and others established the fact that the substance which lies at the foundation of cell-formation in animals agrees in its most important characteristics with the protoplasm of vegetable cells. A more detailed account of modern researches on this subject, which would moreover involve the examination of Hofmeister's work of $\mathbf{1 8 6 7}$, 'Die Lehre von der Pflanzenzelle,' does not fall within the limits of our history. 
2. Further Development of Opinion on the Nature of the Solid Framework of Cell-Membrane in Plants AFter I 845 .

Between 1840 and $185^{\circ}$ the most eminent representatives of phytotomy were chiefly engaged, as we have seen, in observing the formation of vegetable cells, and in framing the true theory of the subject by process of induction. It was not to be expected that, while these labours were bringing year by year new things to light and keeping opinion on the formation of cells in a constant state of fluctuation, their results would lead to very important changes in the theory of the solid framework of cellmembrane founded by von Mohl. On the contrary, it was at this time that his views such as we have seen them on the connection of cells one with another, on the configuration of their partition-walls and on their growth in thickness, attained their greatest influence. His theory seemed to stand firm and complete when contrasted with the unsettled state of opinion respecting the origin of cells, and the question, how far it could be made to agree with the new observations on the history of cell-formation, was hardly raised. In the midst of the strife of opinion on the latter subject appeared von Mohl's 'Vermischte Schriften' in I 845, in which his views on the structure of mature vegetable tissue were produced in a series of monographs as the apparently irrefragable result of his observations. And in fact phytotomic research up to $\mathrm{I} 860$ followed the train of thought initiated by von Mohl, till at last the inadequacy of his views was rendered apparent between 1858 and 1863 by Nägeli's new theory of growth by intussusception, and by the profounder insight obtained into the nature of cell-formation.

A sufficient proof of the correctness of these remarks is to be found in the further development of the views of botanists on the intercellular substance and the cuticle, which might have adapted themselves before 1850 to the new theory of cells, but 
instead of doing so were moulded by the ideas current before I 845 . It has been shown in the preceding chapter how von Mohl gradually restricted the theory of intercellular substance which he had proposed in 1836 , and had come in $185^{\circ}$ to regard this substance as only a cement which might in many cases be perceived between the cell-walls. It should be added here, that Schleiden in connection with his theory of cells considered both the intercellular substance and the cuticle to be supplementary secretions from the cells, and made the former fill the intercellular spaces, just as laticiferous and resiniferous passages are filled with secretions from the adjacent cells (1 845). Unger too in 1855 ('Anatomie und Physiologie der Pflanzen') thought the existence of a cement between the cells necessary to prevent their falling asunder. Schacht, who in his 'Pflanzenzelle' of 1852 had followed Schleiden in explaining the intercellular substance and the cuticle as secretions or excreta from the cells of the plant, still kept on the whole to this view in 1858 , though he modified it in some important points. This theory of Schleiden and Schacht was first opposed by Wigand in a series of essays (1850-I86I), in which in strict adherence to von Mohl's theory of apposition he sought to prove, that the layers which are visible in wood-cells as intermediate laminae in the partition-walls, and which till then had been regarded as a cement between contiguous cells, an intercellular substance, were nothing else than the thin primary membranous laminae formed in the process of cell-division, and subjected to subsequent chemical change, while the secondary layers of thickening in von Mohl's sense lie on both sides of them. The cuticle on the epidermis was explained in a corresponding manner. Though Sanio in 1863 raised a variety of objections to Wigand's view, he still adhered to it in principle, and found a strong confirmation of it in the fact, that he succeeded in producing the well-known cellulose-reaction in the intercellular substance of wood-cells when freed from foreign admixtures.

The researches of Wigand and Sanio were sufficient to over- 
throw von Mohl's account of the intercellular substance and the cuticle, but they had not proved that the intermediate laminae are in fact the primary partition-walls on which von Mohl's secondary thickening-layers had been deposited, on both sides in the case of the intercellular substance, on one side in that of the cuticle. The structure of the partition-walls and the existence of the cuticle could be explained in a totally different way from the point of view now opened by Nägeli's theory of intussusception; there was no need now to see either a secretion or a primary cell-wall in the intermediate lamina of thickened cells or in the cuticle, for it was possible that this lamination might be due to subsequent chemical and physical differentiation of membranes thickened by intussusception. As phytotomists are not yet quite agreed as to the correctness of this view, we must be content with observing here that in the matter of the cuticle and the intercellular substance lies one of the points, the determination of which will involve the question of von Mohl's earlier theory of apposition. It is not the purpose of this history to give the more modern views that have asserted themselves since i 860, especially where the question is still in debate.

It was a part of von Mohl's idea of the cell-tissue and one to which he had firmly adhered since 1828 , that except in the cross walls of genuine wood-vessels and some very isolated cases the partition-walls in cellular tissue are never perforated; that both simple and bordered pits always remain closed by the very thin primary lamina of cellulose. But between $185^{\circ}$ and I 860 several cases were discovered which were at once exceptions to von Mohl's rule, and of great importance to physiology. Theodor Hartig, in his 'Naturgeschichte der forstlichen Kulturpflanzen Deutschlands' (1851), described peculiar rows of cells in the bast-system, in which the transverse and sometimes the longitudinal walls appear to be pierced like a sieve by numerous minute holes, and to these cells he gave the name of sieve-tubes. Von Mohl (1855), while in other points confirming and extending Hartig's discovery, declared against 
the perforation of the walls, believing that the appearances were due to lattice-like thickenings of the cell-walls; he proposed therefore to call Hartig's sieve-tubes latticed cells. Then Nägeli showed in I86r that in some cases at least there can be no doubt that the walls are actually perforated, and that the sieve-plates serve for the passage of mucilaginous matter in bast-tissue, and the author of this history, it may be remarked in passing in $186_{3}$, and Hanstein in 1864 , suggested means by which it may be ascertained with certainty that Hartig's sieve-plates are perforated. Meanwhile a number of laticiferous organs had been recognised as forms of vessels in von Mohl's sense, and it was found that such canals are produced by dissolution of the septa of adjacent cells. But the knowledge of the laticiferous organs continued till towards I 865 to be very unsettled and defective, and the examination of resin-passages, and the discovery that they are formed by simple parting of cells from one another, belong to modern phytotomy; Hanstein, Dippel, N. J. C. Müller, Frank, and others have since 1860 enlarged our knowledge of these forms of tissue. Schacht in 1860 established one of the most important exceptions to von Mohl's view above-mentioned, by demonstrating the formation and true form of bordered pits in the wood of Conifers and in dotted vessels in Angiosperms from the history of their development, and by showing moreover that in all cases where bordered pits are formed on both sides of a partition-wall and the adjacent cells afterwards convey air, there the original very thin partition-wall in the bordered pit disappears, and that consequently in such cases the bordered pits represent so many open holes, through which adjacent cells and vessels communicate. At the same time another hitherto inexplicable phenomenon received its explanation. Malpighi, and after him the phytotomists at the beginning of the present century had remarked, that the large vessels in the wood are not unfrequently filled with parenchymatous cell-tissue, for the origin of which no one could account. The phenomenon, 
however, could now be explained quite simply after Schacht's discovery ; the formation of thylosis in vessels only takes place when these border on closed parenchyma-cells in the wood; when this is the case, the very thin membrane which separates the bordered pits from the contiguous cells is not absorbed, but it bulges inwards into the cavity of the vessel under the pressure of the sap of the neighbouring parenchyma-cell, there swells up like a bladder, and may by the formation of partitionwalls give rise to parenchymatous tissue; this, if proceeding from a number of pits, fills up the cavity of the vessel.

\section{History of Development and Classification} of Tissues.

It has been already stated, that the first step to a real understanding of the structure as a whole of the higher plants was made by Moldenhawer, who beginning with the study of the Monocotyledons, first formed an idea of the vascular bundles as a distinct whole, a system composed of various forms of tissue, and applied this idea to explain the construction of the stems of Dicotyledons, upsetting thereby Malpighi's earlier theory of the growth in thickness of stems. It was also observed, that von Mohl, advancing further in the same direction, gave a more exact description of the epidermis and of the tissues connected with it, and classified them, that is, introduced a terminology founded on real investigation, but did not succeed in bringing the subject to an entirely satisfactory conclusion; this could in fact be reached only by the study of the history of development, the only decisive method of investigation, whether the object be to determine the true nature of cells and their subordinate forms, or the solid fabric of vegetable structure, or as in the present case to distinguish and classify forms of tissue; it is this method which supplies the morphological points of view necessary for the understanding of the inner structure of the plant by investigating tissues in 
those states of development, in which they are not yet adapted to subsequent physiological functions. The combination of morphological and physiological points of view in the determination of facts has miaintained itself longer in this part of botanical study than in any other; but here too ideas and opinions were gradually sifted and cleared up under the influence of the modern study of the history of development, though it was not till after 1850 that the determination of the chief points in the theory of cell-formation left the leading phytotomists at liberty to devote themselves to histological questions.

How little advance had been made towards the true understanding of the varieties of forms of tissue in the higher plants before $185^{\circ}$ is shown, for instance, by Schleiden's account of tissues on page 232 of his 'Grundzüge' of 1845 , where parenchyma, intercellular substance, vessels, vascular bundles, bast-tissue, bast-cells in Apocyneae and Asclepiadeae, laticiferous vessels, felted tissue, epidermal tissue, are discussed in this succession in co-ordinated sections of the text. It is obvious that no well-ordered view of the whole cellular structure of a plant of the higher order could be obtained in this way. Further on in the same work, where Schleiden attempts a classification of vascular bundles, which he distinguishes into closed and open, and assigns the latter to Dicotyledons, we find the cambium-layer named as the outer boundary of these open vascular bundles; the bast which lies outside the cambium was therefore not considered to be a part of the open vascular bundles, and this necessarily excluded any profitable comparison of the circumstances in Monocotyledons and Dicotyledons. The case is still worse in many respects in Schacht's work already mentioned, 'Die Pflanzenzelle' of 1852 , where under the heading 'Kinds of vegetable cells' the histology is discussed in the following co-ordinated sections; the swarm-filaments of Cryptogams, the spores of the same, pollen-grains, cells and tissue of Fungi and Lichens, cells and 
tissue of Algae, parenchyma and its cells, vessels of the plant, wood and its cells, bast-cells, stomata, appendicular organs of the epidermis, cork; then follows a paragraph on the thickening-ring, and then to the no small astonishment of the reader comes an account of the vascular bundles, after the vessels, the wood, and the bast-cells have been already dismissed. That such a mode of presenting the subject is due to the little insight possessed by the writer into the structure of the plant as a whole is apparent from simply reading the book, and a similar confusion of ideas is found in his text-book of I $85^{6}$.

We find a much better classification of tissues in 1855 in Unger's 'Anatomie und Physiologie der Pflanzen'; an account of cells is followed by a description of cell-complexes, as one of the chief divisions of the book, and herein of cell-families, cell-tissues, and cell-fusions. Another chief section is occupied with cell-groups, and here epidermal formations, air-spaces, sap-receptacles, glands and vascular bundles are noticed; here certainly the fact has been overlooked that vascular bundles may be co-ordinated with epidermal formations, but not air-spaces, sap-receptacles and glands. His last chief division gives an account of tissue-systems and of the way in which the vascular bundles are united together in different plants, and secondary growth in thickness and the activity of the cambium-layer are described quite in the right connection.

In this branch of the science, as in every case where it is a question of establishing fundamental conceptions, of surveying facts from extensive points of view, and of seeking the requisite principles by means of the history of development, we find that it is Nägeli who opens the way and lays the foundation. In his 'Beiträge zur wissenschaftlichen Botanik' of 1858 , he proposed a classification of tissues from purely morphological points of view. His first division was into generating and permanent tissue ; in each section he distinguished two forms, prosenchymatous and parenchymatous tissue. Parenchymatous 
generating tissue, the original component of every young organ, he named primary meristem as distinguished from prosenchymatous generating tissue, which is differentiated in the form of strands and layers, and received from him the general name of cambium; this was certainly not a happy distinction, because Nägeli's cambium by no means consists entirely of prosenchymatous tissue. By the term secondary meristem Nägeli designated the tissue-strands and tissue-layers which are formed between the permanent tissue of older parts. The cambium he regards as the first product of the primary meristem. The second chief form, permanent tissue, he divides into two classes, not according to the form of the cells or physiological relations, but according to its origin; all permanent tissue, which is derived immediately from primary meristem, is protenchyma, all that comes directly or indirectly from cambium is epenchyma. And since the tissue-strands, till then known as vascular bundles, do not contain vessels only but always fibrous elements also, as Bernhardi had shown in 1805 , Nägeli thought that they should therefore be called fibrovascular strands. If it cannot be denied that the obvious distinction between epidermal and other tissue did not find suitable expression in this classification, and though other points of view may at the present day be proposed for the genetic arrangement of tissues, yet Nägeli's classification and terminology have the merit of having for the first time exhibited the general histology of plants on comprehensive and genetic principles. It contributed materially to impart a better understanding of the collective structure of plants.

The vascular bundles or fibrovascular strands especially demanded further investigation of the genetic and morphological kind ; for a correct insight into the origin and subsequent transformation of this tissue-system is as important for phytotomy as a similar knowledge with respect to the bony system in vertebrate animals is for zootomy. But a knowledge of the vascular bundles and their course in the stem has a special im- 
portance in phytotomy, because it is the only way to the understanding of secondary growth in thickness in true woody plants.

It was noticed above, that von Mohl had proved in I83I the separate character of the bundles which begin in the stem and bend outwards into the leaves where they end, so that the entire system of bundles in a plant consists of single bundles isolated when formed and subsequently brought into connection with one another. Nägeli had already examined the corresponding circumstances in the vascular Cryptogams in 1846 , when Schacht took the retrograde step of making the vascular system in the plant originate in repeated branching, instead of in subsequent blending of isolated strands; Mohl declared unhesitatingly against this mistake in 1858 , but it was refuted at greater length and still more clearly by Johannes Hanstein in 1857 , and by Nägeli in 1858 . Hanstein in a treatise on the structure of the ring of wood in Dicotyledons confirmed Nägeli's previous statements, and proved in the case of Dicotyledons and Conifers that the first woody circle in the stem is formed from a number of vascular bundles, which are identical with those of the leaves and originate in the primary meristem of the bud. These primordial bundles pass downwards through a certain number of internodes in the stem independent and separate, and either retain their isolation to the point where they end below or unite with adjacent bundles which originated lower down. Hanstein happily termed the portions of the vascular bundles, which enter the stem from the base of the leaf and traverse a certain portion of it in a downward direction, leaf-traces, so that it may be stated briefly, that the primary wood-cylinder in Dicotyledons and Conifers consists of the sum of the leaf-traces. Nägeli's observations were of a more comprehensive character, and supplied, as we have seen, a terminology for tissues. He distinguished three kinds of vascular bundles according to their course; the common bundles, which represent Hanstein's leaf-traces in the stem, and whose upper ends bend outwards into the leaves; 
the cauline bundles, which extend above to the punctum vegetationis of the stem without bending outwards into leaves; and leaf-bundles, which belong to the leaves only. He laid it down as a general rule as regards the common bundles in Dicotyledons and Conifers that they begin to form where their ascending and descending halves meet, at the spot therefore where they bend outwards into the leaf, and continue to form as they descend into the stem and ascend into the leaf by differentiation of suitable tissue. It follows from the nature of these common bundles, that a more thorough understanding of their course and origin presupposes a more accurate knowledge of the order of formation of the leaves at the end of the stem and of the changes in the phyllotaxis during growth; these relations Nägeli took into detailed consideration, and even derived from them new points of view for the examination of the genetic arrangement of leaves, pointing out at the same time the unsatisfactory nature of the principles of the doctrine propounded by Schimper and Braun. Nägeli was also the first who compared the anatomical structure of roots with that of stems, and drew attention to the peculiar character of the fibrovascular body in these organs. As his previous discovery of the apical cell and its segmentation promoted further research, so now his treatise on fibrovascular strands called forth many others from various quarters; among them that of Carl Sanio on the composition of the wood ('Botanische Zeitung,' I863) must be mentioned as one of the first and most important, and as serving in conjunction with the works of Hanstein and Nägeli to throw light upon the processes of growth in thickness of stems. It has been already said that neither von Mohl nor Schleiden, neither Schacht nor Unger succeeded in finding the true explanation of growth in thickness. It was impossible that they should do so, for they were insufficiently acquainted with the origin, true course, and composition of the vascular bundles before growth in thickness commences; the study of the subject was greatly perplexed by 


\section{$35^{\circ}$ Nägeli's Theory of Molecular Structure [Boox II.}

the confounding together in thought and language of totally different things which came under consideration, the so-called thickening-ring, in which the first vascular bundles were supposed to originate close under the summit of the stem, being confounded with the cambium of true woody plants which is formed at a much later period, and both of them again with the very late-formed meristem-layer in arborescent Liliaceae, in which new vascular bundles are continually being produced and cause a peculiar enlargement of the stem ${ }^{1}$. Sanio's treatise first removed this confusion of ideas, which appears in von Mohl himself to some extent even in 1858 , by sharply distinguishing the thickening-ring beneath the point of the stem, in which the vascular bundles begin to be formed, from the true cambium, which is formed at a later time in and between the vascular bundles, and produces the secondary layers of wood and rind; Sanio also occupied himself with submitting the various elements of the wood to a more careful examination, and with giving them a better classification and terminology. The peculiar instance of secondary growth in thickness in the arborescent Liliaceae, which had long been known and had helped to mislead von Mohl and Schacht, was fully explained for the first time by A. Millardet in I865. The later works of Nägeli, Radlkofer, Eichler and others on abnormal woodformations contributed materially to enlarge the knowledge of normal growth also; but these coming after 1860, and Hanstein's later investigations into the differentiation of tissues at the end of the stem in Phanerogams, do not fall within the limits of our history.

\section{Nageli's theory of Molecular Structure and of}

GROWTH BY INTUSSUSCEPTION.

This theory, the importance of which to the further development of phytotomy and vegetable physiology has been already

${ }^{1}$ See Sachs, 'Lehrbuch der Botanik,' ed. 4 (1874), p. 129 (p. I28 of 2nd English edition). 
pointed out, will form the conclusion of our history of the anatomy of plants. It was a remarkable coincidence that this molecular theory of organic forms, which is not without results for zootomy also, was brought to completion at about the same time, namely, the year I860, that Darwin first published his theory of descent. At the first glance the two theories seem to have no connection with one another, and so the coincidence in time appears to be quite accidental. But if we go deeper into the matter, we find a resemblance between them which is of great historical importance ; they both of them exchange the purely formal consideration of organic bodies, which had prevailed up to that time, for a consideration of causes ; as Darwin's doctrine endeavours to account for the specific forms of animals and plants from the principles of inheritance and variability under the disturbing or favouring influence of external circumstances, so the object of Nägeli's theory is to refer the growth and inner structure of organised bodies to chemical and mechanical processes. The future will show, whether the views which we owe to Nägeli will not contribute to the laying a deeper foundation for the theory of descent, since it is not improbable that a more thorough understanding of the molecular structure of organisms may add light and certainty to the still obscure conceptions of inheritance and variation.

The first beginnings were, as is usual in similar cases, small and inappreciable, and no one could have foreseen from the first observations of the facts in question what the ultimate development would be. We have said above, that von Mohl observed as early as 1836 the striation of certain cell-walls, and that this led Meyen, on the ground of further but to some extent inaccurate observations, to conceive of vegetable cellwalls as composed of spirally twisted threads. It was also noticed that von Mohl next distinguished true striation from spiral thickenings (I837), the two having been confused together by Meyen, and advanced so far as to form some idea of the molecular structure of cell-walls, without arriving however at 
any satisfactory conclusion. Agardh, who discovered some new instances of cell-striation, was still less successful in his speculations. Von Mohl resumed the subject in 1853 in the 'Botanische Zeitung,' and insisted on the fact that it was not possible to separate the striae or apparent fibres by mechanical or chemical means, but he left it still undecided whether the lines which cross each other in the surface-view belong to the same or to different layers of membrane. The communications of Crüger and Schacht, made shortly after, did not help to advance the question; Wigand also took part in the discussion in 1856 , but wandered at once from the right path by supposing the crossstriations to belong to different layers of membrane. As long as botanists adhered to von Mohl's theory, that the concentric stratification of cell-walls was due to deposition of new layers, it was scarcely possible for them to arrive at a correct decision with respect to striation; it became possible, when Nägeli proved in his great work 'Die Stärkekörner' ( $185^{8}$ ) that the concentric stratification of starch-grains and of cell-membranes generally does not mean, that similar layers lie simply one on another, but that denser and less watery layers alternate with layers that are less dense and contain more water; and that it is not possible to explain this mode of stratification by deposition as understood by von Mohl, but that it may be explained by intercalation of new molecules between the old ones and by corresponding differentiation of the amount of water. That surface-growth in cell-walls does take place by this kind of intussusception had been incidentally suggested by Unger, and the appearance, known as the striation of the cell-wall might now be referred to the same principle as the concentric stratification, namely to the intercalation of more and less watery matter in regular alternation. But Nägeli pointed out a fact which had escaped other observers, namely, that the difference of structure which usually appears on the surfaceview as double cross-striation, passes through the whole thickness of a stratified cell-wall. Thus Nägeli arrived at a 
differentiation in three directions in space of the substance of every minute portion of cell-membrane, and made better use than von Mohl himself had made of the comparison which he had suggested, namely, that the structure of a cell-wall with cross-striation and at the same time with concentric stratification resembles that of a crystal cleaving in three directions. He first gave expression to this conception of the structure of the cell-wall in 1862 in his 'Botanische Untersuchungen,' I. p. I87, and further developed it in the second volume of the same work at p. 147 .

But the true starting-point of Nägeli's theory of molecular structure is to be found in his searching investigations in $185^{8}$, into the constitution of starch-grains. From the way in which they resist the effects of pressure, drying, distention, and withdrawal of a part of their substance, he arrived at the conclusion that the whole substance of a starch-grain is composed of molecules, whose shape must be not spherical but polyhedral, that these are separated from one another in their normal condition by envelopes of water, and that the amount of water in the stratified substance depends on the size of these molecules, the water being less when the molecules are larger; this view could at once be applied to the structure of the cellwall, the growth of which may be explained as the increase in size of the molecules already present, and the intercalation of new small molecules between the old ones. These molecules of Nägeli are themselves very compound bodies, for the smallest of them would consist of numerous atoms of carbon, hydrogen and oxygen, and ordinarily a molecule would be composed of thousands of those aggregates of atoms, which the chemists call molecules.

In examining starch-grains Nägeli came to the conclusion that molecules of different chemical character are grouped together at every visible point; the material which colours blue with iodine, the granulose, could be removed from the grains, and then there remained behind a skeleton of the 
starch-grain very poor in substance, but showing exactly the original stratification and giving no blue colour with iodine; this Nägeli named starch-cellulose. It followed from this behaviour, that two chemically different molecules lie everywhere side by side in the grain of starch, much as if red and yellow bricks had been so employed to build a house, that when all the yellow bricks were afterwards removed, the red alone would still represent the wall in its original form as a whole though in a looser condition. He arrived at similar results in the case of the crystalloid proteid bodies, which Theodor Hartig discovered, and Radlkofer had examineci crystallographically, Maschke chemically. Since it is possible in the same manner to extract the so-called incrusting matters from cell-membranes without essentially altering their form, and to obtain ash-skeletons of them which imitate all the delicacies of their structure, the comparison adopted above may also be applied in still more complex manner to the molecular structure of these membranes; and indeed many considerations lead to the belief, that the ideas which Nägeli obtained from starch-grains may be applied with some modifications to the structure of protoplasm also.

We said that the appearances in the starch-grains led Nägeli to suppose that their molecules are not spherical but polyhedral, and the question naturally arose whether they are really crystalline. The point could be settled by the use of polarised light, to which different observers had already turned their attention. Erlach in 1847 , Ehrenberg in 1849 , had employed polarised light for the determination of microscopic objects, without however arriving at any conclusions on the subject of molecular structure; Schacht indeed at a later time declared such observations to be a pretty amusement, but without scientific value. But soon we have once more one of von Mohl's careful and solid investigations ('Botanische Zeitung,' I 858), in which with the aid of technical improvements in the apparatus he arrived at conclusions respecting the nature 
and substance of cell-membranes, starch-grains, \&c., which proved that in the hands of a reflecting observer perfectly familiar with the physics of polarised light the instrument is no toy, but a means for penetrating deeply into nature's secrets. Yet on this occasion also appeared that peculiarity in von Mohl which twenty years before had prevented him from founding a conclusive theory upon his profound and extended observations on cell-formation; he was content once more to observe thoroughly and correctly, to describe what he observed carefully, and to connect it with proximate physical principles in such a manner as to supply rather a classification of phenomena, than a new and deeper insight into the essence of the matter. He wanted the creative thought, the intense mental effort, to arrive by analysis at the ultimate elements in the results of his investigations and to frame for himself a clear representation of the inner structure of the organised parts. Von Mohl in this case also stopped short at induction and did not pass on to deductive and constructive elaboration of the question before him ; this was left to Nägeli, as we shall see.

Meanwhile a more exhaustive work appeared in $\mathrm{r} 86 \mathrm{r}$ from the pen of Valentin on the investigation of vegetable and animal tissue in polarised light, in which the author, equipped with great knowledge of the subject itself and its literature, examined in detail the phenomena of polarisation, gave a good account of the instrument and the mode of using it, and explained generally the theory and practice of investigations of the kind. But he overlooked one fact noticed by von Mohl, that vegetable cell-membranes, through which rays of polarised light pass perpendicularly to their surface, show interferencecolours, and this was sure to lead him to an incorrect explanation of their inner structure.

Nägeli from 1859 onwards made the phenomena of polarisation the subject of protracted study, practical and theoretical ; the results were published in 1863 in his 'Beiträge,' Heft 3 , but he had in the previous year made known that portion 
$35^{6}$ Nägeli's theory of molecular structure.

of them which bore on the molecular structure of cell-walls and starch-grains ('Botanische Mittheilungen,' I862). The phenomena of polarisation led him once more and by a different path to the view that the organised parts of the vegetable cell consist of isolated molecules surrounded by a fluid, and his renewed investigations of these phenomena resulted in more definite conceptions of the nature of these molecules, which from the optical behaviour of the objects examined he concluded were not only polyhedral but crystalline ; in effect, the molecules of the substance of the organised parts of plants behave, according to Nägeli, as crystals with two optic axes, which therefore possess three different axes of elasticity; in starch-grains and cell-membranes these crystalline molecules are so arranged that one of these axes is always perpendicular to the stratification, while the two others lie in its plane. The effect of the organised parts of the cells on polarised light is the sum of the effects of the single molecules, whereas the fluid that lies between them is optically inactive, and only comes into consideration because according to its quantity the molecules separate more or less far from or approach one another. 


\section{THIRD BOOK}

\section{HISTORY OF VEGETABLE \\ PHYSIOLOGY

$$
\text { (1.583-1860) }
$$




\section{INTRODUCTION.}

ALL that was known in the r6th and at the beginning of the I 7 th centuries of the phenomena of life in plants was scarcely more than had been learnt in the earliest times of human civilisation from agriculture, gardening, and other practical dealing with plants. It was known, for instance, that the roots serve to fix plants in the soil and to supply them with food; that certain kinds of manure, such as ashes and, under certain conditions, salt, strengthen vegetation; that buds develope into shoots; and that the blossom precedes the production of seeds and fruits. These and a variety of minor physiological phenomena were disclosed by the art of gardening. On the other hand, the physiological importance of leaves in the nourishment of plants was quite unknown, nor can we discover more than a very indistinct perception of the connection between the stamens and the production of fruitful seeds. That the food-material taken up from the soil must move inside the plant in order to nourish the upper parts was an obvious conclusion, which it was attempted to explain by comparing it with the movement of the blood in animals. Writers on the subject up to the end of the $\mathrm{I} 7$ th century make very slight mention of the influence of light and warmth on the sustentation and growth of plants, though doubtless the operation of these agencies in the cultivation of plants, as in other matters, must have been early recognised.

So scanty was the stock of knowledge which the founders of vegetable physiology in the latter half of the $\mathrm{I}$ th century found ready to their hand. While the physiological significance of the different organs of the human body and of most 
animals were known to every one, at least in their more obvious features, the study of vegetable life had to begin with laborious enquiries, whether the different parts of plants are generally necessary to their maintenance and propagation, and what functions must be ascribed to individual parts for the good of the whole. It was no easy matter to make the first step in advance in this subject; something can be learnt of the functions of the parts of animals from direct observation, scarcely anything in the case of plants; and it is only necessary to read Cesalpino and the herbals of the 16 th century to see how helpless the botanists were in every case in presence of questions concerning the possible physiological meaning of vegetable organs, when they ventured beyond the conceptions of the root as the organ of nourishment, and of the fruit and seeds as the supposed ultimate object of vegetable life. The physiological arrangements in vegetable organs are not obvious to the eye; they must be concluded from certain incidental circumstances, or logically deduced from the result of experiments. But experiment presupposes the proposing a definite question resting on a hypothesis; and questions and hypotheses can only arise from previous knowledge. An early attempt to connect the subject with existing knowledge was made in the use of the comparison of vegetable with animal life, a comparison which Aristotle had employed with small success. Cesalpino, provided with more botanical and zoological knowledge, endeavoured to arrive at more definite ideas of the movement of the nutrient juices in plants, and when Harvey discovered the circulation of the blood in the beginning of the $\mathrm{I} 7$ th century, the idea at once arose that there might be a similar circulation of the sap in plants. Thus a first hypothesis, a definite question was framed, and attempts were made to decide it by more exact observation of the ordinary phenomena of vegetation, and still better by experiment; and though a discussion which lasted nearly a hundred years led to the opinion that there is 
no circulation of sap in plants corresponding to the circulation of blood in animals, the result was obtained by the aid of this hypothesis derived from a comparison between animals and plants. The important discovery that leaves play a considerable part in the nourishment of plants, was to some extent an incidental product of the investigation of the former question, and it preceded that of the decomposition of carbon dioxide by the green parts of plants by more than a hundred years. To give another example; it was obviously a comparison of certain phenomena in vegetable life with the propagation of animals which paved the way for the discovery of sexuality in plants; long before Rudolf Jacob Camerarius made his decisive experiments $\left(\mathrm{I}_{69} \mathrm{I}-\mathrm{I} 694\right)$ on the necessary co-operation of the pollen in the production of seeds capable of germination, the idea had been entertained that there might be an arrangement in plants corresponding to the sexual relation in animals, though that idea was highly indistinct and distorted by various prepossessions. In like manner the interest excited by the discovery of the irritability of the Mimosae in the $\mathrm{I} 7$ th century, and of similar phenomena of movement in plants at a later time, was mainly due to the striking resemblance suggested between animals and plants; and the first researches into the subject were obviously intended to answer the question whether the movements in plants are due to conditions of organisation similar to those in animals. In all cases of this kind it was matter of indifference whether the analogies presupposed were finally confirmed after prolonged investigation, as in the question of sexuality, or disproved as in that of the circulation of the sap. The result was of less importance than the obtaining points of departure for the investigation. It answered this purpose to adopt certain actual or only apparent analogies between plants and animals, and to assume, to some extent to invent, certain functions for the apparently inactive organs of plants, and to interrogate them upon the point. Scientific activity was 
set in motion, and it mattered not what the result might be. In all questions connected with the phenomena of life, our own life is not only the starting-point but also the standard of our conceptions; what animate nature is as opposed to inanimate we discern first by comparing our own being with that of other objects. From our own vital motions we argue to those of the higher animals, which we comprehend immediately and instinctively from their conduct; by aid of these the motions of the lower animals also become intelligible to us, and further conclusions from analogy lead us finally to plants, whose vitality is only in this way made known to us. While plants were thus even in ancient times regarded as living creatures and allied to animals, further reflection naturally suggested the idea that the phenomena of animal life would be reproduced in plants even in details. We learn from the botanical fragments of Aristotle that this was in fact the way in which the first questions in vegetable physiology arose; they assumed a more definite form with Cesalpino, and later physiologists repeatedly made use of similar conclusions from analogy. The historian of this branch of botanical science must seek no other beginning of it, for it had no other and could have no other from the nature of the case. And if preconceived analogies between plants and animals often proved deceptive and mischievous, yet continued investigation gradually brought to light more important and more essential points of agreement between the two kingdoms; it has become more and more evident in our own days, that the material foundations of vegetable and animal life are in the main identical,- that the processes connected with nourishment, movement of juices, sexual and asexual propagation present the most remarkable similarities in both kingdoms.

If the first founders of scientific vegetable physiology surrendered themselves thoroughly to teleological views, this was owing to the circumstances of the time, and it served indeed to promote the first advances of the science. There was no 
need in the $\mathrm{I} 7$ th and $\mathrm{I}$ 8th centuries that a man should be an Aristotelian to presuppose design and arrangements in conformity with design in all parts of physiological investigation. This is everywhere and always the original point of view which precedes all philosophy; but it is the part of advanced science to abandon this position; and as early as the $\mathrm{I} 7$ th century philosophers recognised the fact that the teleological mode of proceeding is unscientific. But the first vegetable physiologists were not philosophers in the stricter sense of the word, and in their investigations they accepted the teleological conception of organic nature without question, because they regarded it as a self-evident fact, that every organ must be purposely and exactly so made as to be in a condition to perform the functions necessary for the permanence of the whole organism. This conception was in accordance with views then prevailing, and was even useful; it was no disadvantage in the first beginnings of the science, that it should be supposed that every, even the minutest, part of a plant was expressly contrived and made for maintaining its life, for this was a strong motive for carefully examining the organs of plants, which was the first thing requisite. This is exemplified in Malpighi, Grew, and Hales, and we shall see that even towards the end of the $I 7$ th century Konrad Sprengel made splendid discoveries respecting the relations of the structure of the flower to the insect world, while strictly carrying out his teleological principles. The teleological view was injurious to the progress of morphology from the first, though the history of systematic botany shows how hard it was for botanists to free themselves from such notions. The case was different with physiology; so long as it was a question of discovering the functions of organs, and learning the connection between the phenomena of life, teleology proved highly useful if only as a principle of research. But it was another matter when it became requisite to investigate causes, and to grasp the phenomena of vegetation in their 
causal connection. To this the teleological mode of view was inadequate, and it became necessary indeed to discard it as a hindrance, in spite of the difficulty of explaining adaptation in the arrangements of organisms from any other than the teleological point of view. It is sufficient here to say that this difficulty is satisfactorily removed by the theory of selection. This theory is become as important in this respect to physiology, as the theory of descent is to systematic botany and morphology. If the theory of descent finally liberated the morphological treatment of organisms from the influence of scholasticism, it is the theory of selection which has made it possible for physiology to set herself free from teleological explanations. Only an entire misunderstanding of the Darwinian doctrine can allow anyone to reproach it with falling back into teleology; its greatest merit is to have made teleology appear superfluous, where it seemed to naturalists in former times, in spite of all philosophical objections, to be indispensable.

If the comparison of plants with animals as well as the teleological conception of organisms promoted the first attempts at the physiological investigation of plants, other influences of decisive importance came into play when the time came for endeavouring to conceive and explain the causes and conditions of the functions, which had then been ascertained at least in their most obvious features. Phytotomy was here the chief resource. In proportion as the inner structure of plants was better known and the different kinds of tissue better distinguished, it became possible to bring the functions of organs, as made known by experiment, into connection with their microscopic structure; phytotomy dissected the living machine into its component parts, and could then leave it to physiology to discover from the structure and contents of the tissues, how far they were adapted to perform definite functions. Obviously this only became possible when the phenomena of vegetation had been previously studied in the living plant. For example, the 
microscopic examination of the processes which take place in fertilisation could first be made to yield further conclusions, after sexuality itself, the necessity of the pollen to the production of fruitful seeds, had been proved by experiment; in the same way the anatomical investigation of wood could only supply material for explaining the mode in which water rises in it, when it had first been ascertained by experiment that this happens only in the wood, and so in other cases.

The relation between physiology and physics and chemistry suggests similar considerations; it is necessary to make some preliminary remarks in explanation of this relation, because we often meet with the view, especially in modern times, that vegetable physiology is virtually only applied physics and chemistry, as though the phenomena of life could be simply deduced from physical and chemical doctrines. This might perhaps be possible, if physics and chemistry had no further questions to solve in their own domains; but in fact both are still as far distant from this goal, as physiology is from hers. It is true indeed, that modern vegetable physiology would be impossible without modern physics and chemistry, as the earlier science had to rely on the aid of the physics and chemistry of the day, when she was engaged in forming a conception of ascertained vital phenomena as operations of known causes. But it is equally true, that no advance which physics and chemistry have made up to the present time would have produced any system of vegetable physiology, even with the aid of phytotomy ; history shows that a series of vital phenomena in plants had been recognised in the I 7 th and I8th century, at a time when physics and chemistry had little to offer, and were in no condition to supply explanations of any kind to the physiologist. The true foundation of all physiology is the direct observation of vital phenomena; these must be evoked or altered by experiment, and studied in their connection, before they can be referred to physical and chemical causes. It is therefore quite possible for vegetable physiology to have 
reached a certain stage of development without any explanation of the phenomena of vegetation from physics or chemistry, and even in spite of erroneous theories on those subjects. What Malpighi, Hales, and to some extent Du Hamel produced, was really vegetable physiology, and of a better kind than some moderns are inclined to believe; and their knowledge was derived from observations on living plants, and not from the chemical and physical theories of their time. The discovery even of important facts, for example, that green leaves only can form the food suitable to effect the growth and formation of new organs, was made a hundred years before that of the decomposition of carbon dioxide by the green parts of plants, at a time indeed when chemistry knew nothing of carbon dioxide and oxygen. A whole series of physiological discoveries might be mentioned, which were distinctly opposed to chemical and physical theories, and even served to correct them. We may give as examples, the establishment of the facts that roots absorb water and the materials of food without giving up anything in return, which seemed quite unintelligible on the earlier physical theory of the endosmotic equivalent ; and that the so-called chemical rays of the physicists are of subordinate importance in vegetable assimilation, while contrary to the prevailing notions of physicists and chemists the yellow portions of the spectrum and those adjacent to it actively promote the decomposition of carbon dioxide. From what doctrines of the physicists could it have been concluded, that the downward growth of roots and the upward growth of stems was due to gravitation, as Knight proved in 1806 by experiments on living plants ; or could optics have foreseen that the growth of plants is retarded by light, and that growing' parts are curved under its influence. Our best knowledge of the life of plants has been obtained by direct observation, not deduced from chemical and physical theories. After these preliminary remarks we may proceed to give a rapid survey of the progress of vegetable physiology. 
I. That the first beginnings of vegetable physiology were made about the time that chemistry and physics began to take their place among the true natural sciences, is no proof that they called vegetable physiology into existence. She, like general physiology, mineralogy, astronomy, geography, owed her origin to the outburst of the spirit of enquiry in the 16 th and $\mathrm{I}$ th centuries, which feeling the emptiness of the scholastic philosophy set itself to gather valuable knowledge by observation in every direction. It was in the second half of the $I 7$ th century that societies or academies for the study of the natural sciences were founded in Italy, England, Germany, and France under the influence of this feeling; the first works on vegetable physiology play a very prominent part in their transactions; not to speak of less important cases, it was the Royal Society of London which published between $\mathrm{I} 660$ and $\mathrm{I} 690$ the memorable works of Malpighi and Grew; the first communications of Camerarius, which form an epoch in the history of the doctrine of sexuality, appeared in the journals of the German Academia Naturae Curiosorum, and the French Academy undertook about the same time to organise methodical researches in vegetable physiology under Dodart's direction, though the results it is true did not answer to the goodness of the intention. This period of movement in all branches of science, when the greatest discoveries followed one another with marvellous rapidity, witnessed also the first important advances in vegetable physiology; such were the first investigations into the ascending and descending sap, especially those made in England, Malpighi's theory which assigned to leaves the functions of organs of nutriment, Ray's first communications on the influence of light on the colours of plants, and above all the experiments of Camerarius, which proved the fertilising power of the pollen. It was the period of first discoveries; the attempts at explanation were certainly weak; but phytotomy which was just commencing its own work lent aid from the first to physiology, while physics and chemistry could do but little for her. On 
the other hand, the predilection for mechanics and mechanical explanation of organic processes in Newton's age bore fair fruit in Hales' enquiries into the movement of sap in plants; his 'Statical Essays' of 1727 connect closely with the works before mentioned which had laid the foundations of the science, and with this important performance the first period of its history reaches a distinctly marked conclusion.

This time of vigorous advance was followed by many years, in which no notable work was done and no great discovery effected; there was active disputation on what had been already ascertained, but it did not lead to any deeper conception of the questions or to new experimental determinations.

2. About the year 1760 new life was infused into the consideration of various branches of vegetable physiology. Du Hamel's 'Physique des arbres' ( $\left.175^{8}\right)$ gave a summary of former knowledge and added a number of new observations, and from that time till the beginning of the present century a series of important discoveries was made. The doctrine of sexual propagation, which had scarcely been advanced since the time of Camerarius, and was disfigured by the theory of evolution, found an observer of the first rank in Koelreuter ( $760-1770)$, who threw new light upon the nature of sexuality by his experiments on the artificial production of hybrids; he was the first who carefully studied the arrangements for pollination, and pointed out the remarkable connection between them and insect-life. These relations were afterwards ( 1793 ) examined in greater detail by Konrad Sprengel, who arrived at such astonishing and far-reaching results, that they were not even understood by his contemporaries, nor was their significance fully appreciated till quite modern times and in connection with the theory of descent.

No less important was the advance made in the doctrine of the nourishment of plants. Between 1780 and $\mathrm{r} 790$ Ingen Houss proved, that the green parts of plants absorb carbon dioxide under the influence of light and eliminate the oxygen, 
and thus obtain the carbon which plants accumulate in organic combinations, but that all parts of plants also absorb at all times smaller quantities of oxygen, and exhale carbon dioxide, and so perform a process of respiration exactly corresponding to that of animals. He was soon followed by Theodore de Saussure with more thorough investigation of these processes, and with proofs that the ash-constituents of a plant are no chance or unimportant addition to its food, as had been hitherto commonly supposed (1804). The influence also of general physical forces on vegetation was established in some important points, though not yet submitted to searching examination. Thus Senebier showed in the period between 1780 and 1790 the great effect which light exercises on the growth and green colour of plants, and De Candolle at a later date discovered its operation in the case of leaves and flowers that show periodic movements. Still more important was Knight's discovery in 1806 that the upright growth of stems and the downward direction of the main roots are determined by gravitation.

3. This second period of important discoveries was also followed by a relapse, and again doubts were raised as to the correctness of the very facts which had been best established; attempts were made under the influence of preconceived opinions to invalidate or ignore these facts, and to substitute for them theories that wore the guise of philosophy. The socalled nature-philosophy, which had long been a great hindrance to morphology, proved in like manner injurious to vegetable physiology; the doctrine of the vital force especially stood in the way of every attempt to resolve the phenomena of life into their elementary processes, to discern them as a chain of causes and effects. The ash-constituents of plants, and even their carbon, were traced to this vital force, and misty notions connected with the word polarity were used to explain the direction of growth and much beside. In like manner the influence of the nature-philosophy was brought to bear on the established results of the sexual theory to the destruction of all sound B $b$ 
logic, and the sexuality of plants was once more openly impugned in the face of Koelreuter's investigations. This state of things continued till some time after 1820 , but then it began to improve once more. L. C. Treviranus examined and refuted the errors of Schelwer and Henschel in 1822 ; in England Herbert conducted new and very valuable investigations into the question of hybridisation; and it was in this period that Carl Friedrich Gärtner studied and experimented on normal fertilisation and the production of hybrids during more than twenty years; his conclusions, published in exhaustive works in 1844 and in 1849 , finally settled the more important questions connected with the sexual theory about the same time that Hofmeister established the microscopic embryology of Phanerogams on a firm foundation.

Other parts also of vegetable physiology had been considerably advanced before 1840 ; Theodore de Saussure observed in 1822 the production of heat in flowers and its dependence on respiration ; ten years later Goeppert proved the rise of temperature in germinating and vegetating organs. Dutrochet stimulated enquiry by his researches in various branches of the science between 1820 and 1840 ; he was the first to apply the phenomena of diosmosis to the explanation of the movement of sap in plants with a lasting influence on the further progress of physiology. Chemical investigations were less fruitful in results, though they served to collect a considerable material of single facts, which could afterwards be turned to theoretical account.

The close of this period, which began with unprofitable doubts, but in which much was set in a train for further development after $\mathrm{r} 840$, is marked by the publication of some important compilations, in which all that had as yet been done in vegetable physiology was presented in a connected form. In addition to Dutrochet's collected works ( 1837 ) three comprehensive compendia of vegetable physiology made their appearance, one by De Candolle, which was translated 
into German by Roeper and published with many improvements and additions in 1833 and 1835 ; this was followed by a work on vegetable physiology by L. C. Treviranus, I835I 838 , and lastly by Meyen's 'Neues System der Pflanzenphysiologie,' I 837-I 839. These works exhibit the characteristic features of the period chiefly in this, that physiology finds as yet no strong support in phytotomy, while the old views of vital force are brought face to face with more exact physicochemical explanations of processes of vegetation.

4. We have already pointed out the wonderful impulse given to the study of morphology and phytotomy, of embryology and cells about the year 1840 ; it was shown also that this was due in a great measure to discarding the errors of the naturephilosophy and the idea of vital force, and requiring in the place of such speculations exact observation and systematic induction, and how Schleiden's 'Grundzüge' soon after I 840 vigorously met the demands of the newer time in these respects, but without satisfying them by the positive results obtained. The rapid progress made by phytotomy and the doctrine of cells in the hands of von Mohl and Nägeli proved specially favourable to vegetable physiology, by making it possible to follow the processes of fertilisation in the interior of the ovule. The formation of the pollen-tube from the pollen-grain had been observed long before $\mathrm{r} 840$, and Schleiden in 1837 had proposed the view that the embryo of Phanerogams was formed at the end of the pollen-tube by free cell-formation after it had entered the embryo-sac. But Amici in 1846 and Hofmeister in 1849 showed that this notion was erroneous, and that the germ-primordium is in existence in the embryo-sac before the arrival of the pollen-tube and is excited by it to further development, to the forming the embryo. Similarly Hofmeister's further observations on the embryology of Vascular Cryptogams and Mosses left no doubt, that the spermatozoids of these groups of plants discovered by Unger and Nägeli serve to fertilise the germ-cell or egg-cell previously formed 
in the female organ and to excite it to further development (1849, I85r). Soon after the sexual act was observed in various Algae, and these afforded the best opportunity for solving by the aid of the microscope the questions which experiment had still left open. Thuret showed in $18_{54}$, how the large egg-cells in species of Fucus are surrounded and fertilised by spermatozoids, and he even succeeded in producing hybrids by fertilising the egg-cells of one species with the spermatozoids of another; but it was still uncertain whether simple contact of the male and female organs was sufficient, or whether fertilisation is due to the mingling of the substance of the spermatozoid and the germ-cell; the question was settled by Pringsheim in 1855 ; he saw the male organ of fertilisation of a fresh-water alga penetrate into the substance of the egg-cell and be dissolved in it, and this proceeding was afterwards observed in higher Cryptogams and is represented in its simplest form in the sexual act of the Conjugatae, which De Bary described at length in 1858 and like Vaucher regarded as a sexual process.

When we consider to what an extent the time and power of work of the most eminent botanists was devoted after 1840 to long and difficult observations on the minute anatomy of plants, on cell-formation, embryology and the history of the development of organs, we cannot wonder if other parts of vegetable physiology, which require experiments on vegetation in plants, were cultivated but little and by the way only; but these studies also gained firmer footing in the advance of phytotomy, which supplied the physiologist with a more definite idea of the organism in which the phenonema of vegetative life are produced.

The chemistry of the food of plants was one of the strictly physiological subjects, which like the sexual theory was studied without intermission and with considerable success in the period from 1840 to $\mathrm{r} 860$, but chiefly or entirely by chemists, who connected their investigations into the processes of 
nutrition in plants with Saussure's results. Agricultural chemists were chiefly engaged till nearly i 860 with the questions, whether all or certain constituents of the ash of a plant are indispensable parts of its food, and whence these constituents are derived, and with cognate considerations on the exhaustion of the soil by cultivation and its remedy by suitable manuring. In France Boussingault had undertaken experimental and analytical investigations on these subjects before 1840 , and it was he who in the course of the next twenty years made the most valuable physiological discoveries; of these the most important was the fact that plants do not make use of free atmospheric nitrogen as food, but take up compounds of nitrogen for the purpose. In Germany the interest in such questions was increased by the instrumentality of Justus Liebig, who gathered from the knowledge that had been accumulated up to I 840 all that was fundamental and of real importance, and drew attention to the great practical value of the theory of the nutrition of plants in agriculture and in the management of woods and forests ; considerable state provision was soon made for investigations of the kind, but these often wandered from the right path for the reason, that being designed to promote practical interests they lost sight of the inner connection between all vital phenomena. Still a great mass of facts was accumulated, which careful sifting might afterwards render serviceable to pure science. Some of the best agricultural chemists deserve the credit of vindicating purely scientific as well as practical points of view, and explained in comprehensive works the general subject of the nutrition of plants, so far as it was possible to do so without going deeply into their organisation; among these were Boussingault and the Germans Emil Wolff and Franz Schulze. But the questions of the nutrition of plants, which are connected with the chemical processes of assimilation and metabolism within them, remained still undecided, though some valuable preliminary work on these points dates from this time. 
In comparison with this important advance in the sexual theory and the doctrine of the nutrition of plants little was done in the branches of vegetable physiology which remain to be mentioned, and that little appeared in an unconnected and fragmentary state; different observers established the connection between the temperature of plants and oxygenrespiration; some new single facts were discovered in connection with the downward curvature of roots, Brücke published in 1848 an excellent enquiry into the movements of Mimosaleaves, and Hofmeister showed in 1857 that the phenomenon, then known as bleeding in the vine and some other trees, takes place in all woody plants, and not in spring only but in every period of the year, if the requisite conditions are present. These and many other isolated observations were very valuable for the future, but were not used at the time to frame comprehensive theories, because no one devoted himself exclusively to questions of the kind with the perseverance, which in these difficult subjects can alone lead to certain results and to a deeper insight into the inner connection of the phenomena. Surprisingly small was the addition to the knowledge of the movement of sap in plants, and still less was discovered respecting the external conditions of processes of growth and the movements connected with them. The important question of the dependence of the phenomena of vegetation on temperature, was it is true not wholly neglected; but the mistake was made of attempting a short cut by multiplying the total period of vegetation of a plant by the mean daily temperature, in the hope of finding in this product an expression for the total warmth required by a given plant; this mistake was especially misleading in the geography of plants.

The more valuable knowledge which had been gathered up to I 85 I was brought together by von Mohl in his often-mentioned work on the vegetable cell with equal perspicuity and conciseness, and current views were critically examined; vegetable physiology generally was expounded at greater length but with 
less critical sifting in Unger's text-book of 1855 ; these were the two books which did most to disseminate a knowledge of the subject up to 1860 , and they performed their task with credit ; that which appears in Schacht's books after 1852 under the head of vegetable physiology rests on such imperfect acquaintance with this branch of science, as to diminish rather than increase its reputation.

Passing from this preliminary survey to a more detailed account of the subject, it will be found necessary to keep the history of the sexual theory distinct from other questions in vegetable physiology. This mode of proceeding is required by the fact, that the establishment and further elucidation of the decisive points in the sexual theory were made independently of the rest of physiology, so that the historical continuity would be interrupted and the account rendered obscure by any attempt to connect the development of the theory chronologically with other topics. In like manner the doctrine of the nutrition of plants and of the movement of the sap was developed uninterruptedly and in independence of other physiological matters; it will be advisable therefore to devote a separate chapter to those subjects also. Earlier discoveries respecting the movements of the parts of plants and the mechanics of growth will be briefly recounted in a third chapter. 


\section{CHAPTER I.}

History of the Sexual Theory.

i. From Aristotle to R. J. Camerarius.

IT will contribute to a correct appreciation of the discoveries made towards the end of the $\mathrm{I} 7$ th century by Rudolph Jacob Camerarius and his successors in regard to the sexual relations of plants, if we first make ourselves acquainted with all that was known of the matter up to that time from Aristotle downwards; we shall learn at the same time how extremely unfruitful was the superficial observation of the older philosophy in a question in which inductive research only could lead to real results.

That Aristotle ${ }^{1}$ like many others after him reckoned sexual fertilisation among processes of nutrition, and thus failed to perceive the specific and peculiar character of the latter, is shown distinctly by his assertion, that the nutritive and propagative power of the soul is one and the same. This hasty generalisation was associated in Aristotle's mind with another error arising from very defective experience, which led him to bring sexuality in organisms into causal connection with their movement in space. He tells us in his botanical fragments, that in all animals which have the power of locomotion, the female is distinct from the male, one creature being female, another male, but both being of the same species, as in humankind. In plants on the contrary these powers are combined and the male is not distinct from the female; each

${ }^{1}$ See Ernst Meyer, 'Geschichte der Botanik,' I. p. 98, \&c. 
plant therefore reproduces itself and emits no fertilising material ; and he adds, that in animals which do not move, as those that have shells and those that live attached to some other substance, male and female are not distinguished, for their life resembles that of plants; at the same time they are called male and female by resemblance and analogy, and there is a certain slight distinction. In like manner some trees produce fruits while others do not, though they aid fruit-bearing trees in the production of fruit, as happens in the case of the fig-tree and the caprifig.

In comparison with these views of Aristotle those of his disciple Theophrastus ${ }^{1}$ appear to some extent enlightened, and to rest on a wider experience, but even his observation supplies nothing of interest on the subject; for he says that some blossoms of the 'mali medicae' produce fruit, and that some do not, and that it should be observed whether the same thing occurs in other plants, which he might easily have done for himself in his own garden. He is more concerned with putting his knowledge into logical order, than with answering the question whether there is any sexual relation in plants. It is certain, he says, that among plants of the same species some produce flowers and some do not; male palms, for instance, bear flowers, the female only fruit ${ }^{2}$; and he concludes the sentence by the remark, that in this lies the difference between these plants, and those which produce no fruit, and that it is obvious that there must be a great difference in the flowers. In his third book 'De Causis'

1 The edition here used is that of Gottlob Schneider, 'Theophrasti Eresii quæ supersunt opera,' Leipzig, I8I8. See in addition to the passages noticed in the text the 'De Causis,' l. I. c. I3. 4, and I. IV. c. 4, and the 'Historia Plantarum,' l. II. c. 8.

${ }^{2}$ It should be understood that neither Theophrastus nor the botanists of the $I 6$ th and $I 7$ th centuries considered the rudiments of the fruit to be part of the flower; this, which was pointed out in the history of systematic botany, seems to have been overlooked by Meyer, 'Geschichte,' I. p. I64. 
(c. 15,3 ) he says, that terebinths are some male and some female, and that the former are barren and are therefore called male. That Theophrastus in all these matters trusted to the relations of others is shown by a passage in the same book (c. I8, I), where he says, 'What men say, that the fruit of the female date-palm does not perfect itself unless the blossom of the male with its dust is shaken over it, is indeed wonderful, but resembles the caprification of the fig, and it might almost be concluded that the female plant is not by itself sufficient for the perfecting of the fotus; but this cannot be the case in one genus or two, but either in all or in many.' We observe the grand style in which the Greek philosopher dismisses this important question, and how far he is from condescending to make an observation for himself.

It appears that in Pliny's time the hypothesis of a sexual difference in plants had grown up and become confirmed in the minds if not of writers, yet of those who occupied themselves with nature; Pliny in his 'Historia Mundi,' describing the relation between the male and female date-palm, calls the pollen-dust the material of fertilisation, and says that naturalists tell us that all trees and even herbs have the two sexes ${ }^{1}$.

If this theme supplied little material for reflection to philosophers, it did not fail to excite the fancy of the poets. De Candolle cites the verses of Ovid and Claudian on the subject, and passing over the intervening centuries for a very sufficient reason notices the lively poetic description of two date-palms in Brindisi and Otranto by Jovianus Pontanus in 1505 . But nothing was gained in this way for natural science.

Treviranus in his 'Physiologie der Gewächse' ${ }^{1}$ ( 1838 ), II. p. $37 \mathrm{I}$, has well described the state of knowledge on this subject

1 The passage is quoted in full in De Candolle's 'Physiologie végétale,' I835, ii. p. 44 . It is said there of the pollen, 'Ipso et pulvere etiam feminas maritare.' 
among the botanists of Germany and the Netherlands in the I6th century. "The idea of a male sex in such plants as Abrotanum, Asphodelus, Filix, Polygonum mas et femina, was founded only on difference of habit, and not on the parts which are essential to it. But it should be observed that it is the less learned among the older botanists, Fuchs, Mattioli, Tabernaemontan, who make most frequent use of this mode of designating plants; the more learned, as Conrad Gesner, de l'Écluse, J. Bauhin employ it only in the case of a plant already known. De l'Écluse it is true in describing the plants which he found often notes the form, colour, and even the number of the stamens; in Carica Papaya he calls the individual with stamens the male, and the one with carpels the female, since he holds them to belong to different sexes, though of the same species; but he is satisfied with saying, that it is affirmed that the two are so far connected, that the female produces no fruit if the male is separated from it by any great distance ('Curae posteriores,' 42).

The case of the botanists above-mentioned is simply one of ignorance; in the botanical philosopher Cesalpino on the contrary we see a consequence of the Aristotelian system, which leads him distinctly to reject the hypothesis of separate sexual organs in plants as opposed to their nature. It is difficult to understand how De Candolle, at page 48 of his 'Physiologie végétale,' can say that Cesalpino recognised the presence of sexes in plants. His conception of vegetable seed-grains as analogous to the male seed in animals must have made it impossible for him to understand sexuality in plants. So too his notion that the seed is derived from the pith as the principle of life in plants, in connection with which he says at page II of the first of his sixteen books; 'Non fuit autem necesse in plantis genituram aliquam distinctam a materia secerni, ut in animalibus, quae mari et femina distinguuntur.' He regarded the parts of the flower which surround the ovary, or are separate from it, together with 
the stamens as simply envelopes of the foetus; and though he knew, as has been already shown, that in some plants, the hazel, chestnut, Ricinus, Taxus, Mercurialis, Urtica, Cannabis, Mais, the flowers are separate from the fruit, and even mentions that the barren individuals are called male, and the fruit-bearing female, he understood this only as a popular expression, without really admitting a sexual relation. Respecting the words male and female he says at page I $_{5}$ : 'Quod ideo fieri videtur quia feminae materia temperatior sit, maris autem calidior; quod enim in fructum transire debuisset, ob superfluam caliditatem evanuit in flores, in eo tamen genere feminas melius provenire et fecundiores fieri aiunt, si juxta mares serantur, ut in palma est animadversum, quasi halitus quidam ex mari efflans debilem feminae calorem expleat ad fructificandum.'

There is no mention of the pollen here, still less any attempt to extend what had been observed in dioecious plants to the ordinary cases, in which flowers and pistil, as Cesalpino would say, are united in the same individual. His view of the relation between the seed and the shoot, cited above on page 47 , shows that he conceived of the formation of seeds as only a nobler form of propagation than that by buds, but not essentially distinct from it. The idea of sexuality in plants was not in fact consonant with Cesalpino's interpretation of Aristotelian teaching.

Prosper Alpino's account ( $\mathrm{I}_{592}$ ) of the pollination of the date-palm contains nothing new, except that he had seen it in Egypt himself ${ }^{1}$.

The Bohemian botanist Adam Zaluziansky² made no observations of his own, but attempted in $\mathrm{I}_{592}$ to reduce the

1 See De Candolle, 'Physiologie végétale,' p. 47.

${ }^{2}$ His 'Methodus Herbaria' is said to have been published in $\mathbf{I} 592$. The remarks in the text are made in reliance on a long quotation from it in Roeper's translation of De Candolle's 'Physiologie,' ii. p. 49, who had before him an edition of 1604 . 
traditional knowledge on the subject to some kind of theory. The foetus, he says, is a part of the nature of plants, which they produce out of themselves, and is thus distinguished from the shoot which grows from the plant, as a part from the whole, but the other as a whole from a whole. He quotes Pliny almost word for word where he says, that observers of nature maintain that all plants are of both sexes, but in some the sexes are conjoined, in others they are separate; in many plants the male and female are united, and these have the power of propagation in themselves, like many androgynous animals; and he explains this, more explicitly than Aristotle, from defect of locomotion in plants. This is the case, he says, with the majority of plants. In some, as the palm, the male and female are separated, and the female without the male produces no fruit, and where the dust from the male does not reach the female plant by natural means, man can assist. Zaluziansky like other writers is anxious that plants of different sexes should not be taken for different species. He refers also to the popular distinction of many plants into male and female according to certain external peculiarities.

Jung again must certainly have known the facts and views that were current in his time; but there is nothing in his botanical writings to show that he entertained the idea of a real sexuality in plants, of the necessity of the co-operation of two sexes in the work of propagation. It might almost be believed that the most learned and serious men, such as Cesalpino and Jung, were just those, who regarded the hypothesis of sexuality in plants as an absurdity, and shrunk from its consideration. This impression is conveyed too by Malpighi's 'Anatomie des Plantes.' It was Malpighi who gave the first careful account of the development of the seed, and studied the earlier stages in the growth of the embryo in the embryosac; and yet even he says nothing of the co-operation of the dust contained in the anthers in the formation of the embryo, 
and does not once mention the views of former writers. Malpighi, like Cesalpino, regarded the formation of seeds as only another kind of ordinary bud-formation, and propagation as only another kind of nutrition. He mentions (p. 52) incidentally that plants with unfruitful flowers are designated as male, but treats this as a popular expression merely, and ultimately propounds the theory that the stamens and the floral envelopes remove a portion of the sap from the flower, in order to purify the sap for the production of the seeds (p. 56).

In all accounts of the theory of sexuality in plants, a botanist otherwise unknown in history, Sir Thomas Millington, is named as the person who first claimed for the stamens the character of male organs of generation. The only record of the fact, however, is contained in the following words of Grew in his 'Anatomy of Plants' (I682), ch. 5, sect. 3, p. I 7 I : 'In conversation on this matter (namely the connection of the stamens, called by Grew the attire ${ }^{1}$, with the formation of seeds) with our learned Savilian Professor Sir Thomas Millington, he told me he was of opinion that the attire served as the male organ in the production of the seed. I replied at once, that I was of the same opinion, and gave him some reasons for it, answering at the same time some objections that might be brought against it.' Grew gives on p. I 72 the following summary of his ideas on the subject ${ }^{2}$; it would appear, he says, that the attire serves to remove some superfluous parts of the sap, as a preparatory process to the production of seed. As the floral envelopes (foliature) serve to remove the volatile and saline sulphur-parts, so the attire serves to lessen

' In the 'Compositae,' however, Grew called the single flowers the florid attire, see p. 37 .

${ }^{2}$ We may compare with this, pp. $3^{S}$ and 39 of the first part of the work which appeared in $167 \mathrm{I}$, where Grew ascribed no sexual significance to the stamens. 
and adjust the gaseous, in order that the seed may become more oily and its principles be better fixed. Here we find ourselves on the ground of the chemistry of the day, in which sulphur, salt, and oil play the chief parts. Consequently, continues Grew, the flower has usually a stronger smell than the attire, because the saline sulphur is stronger than the gaseous, which is too subtle to affect the sense. Closely adhering to Malpighi's view he goes on to compare these processes in the flower with processes in the ovary of animals, inasmuch as they qualify the sap in the ovary for the approaching formation of seed, and he says that as the young and early attire before it opens contains the superfluous part of the female organ, so after it is opened it probably performs the office of the male. But how confused his ideas still were on this point may be further seen by examination of the passage which follows in his book (page I 72, section 7), where, speaking of the single flowers in the head of the Compositae, he regards the blade, that is the style and stigma, of the floral attire as a portion of a male organ, and the globulets (pollengrains) and other small particles upon the blade and in the thecae (anthers) of the seed-like attire as a vegetable sperm, which subsequently when the parts are duly matured falls down upon the seed-case and so touches it with a prolific virtue.

He meets the objection, that the same plant must consequently be both male and female, with the fact, that snails and other animals are similarly constituted. That the pollengrains communicate a prolific virtue to the ovary (uterus) or to its juices by simply falling upon it, he thinks is rendered probable by comparing this with the process of fertilisation in many animals, and here Grew has some curious remarks. The section closes with the observation that to expect complete similarity in this matter between plants and animals, is to require that the plant should not only resemble an animal, but should actually be one. 
If now we ask ourselves, what it really was that was gained from Millington and Grew, we find that it was simply the conjecture, that the anthers produce the male element in fertilisation, and that this view was closely connected in their minds with the strangest chemical theories and analogies from animal life. It is remarkable by what indirect ways science sometimes advances. If Grew had only been prepared to assume some kind of sexuality in plants, he need only have taken up Theophrastus' statement, that the anther-dust of the male palm is shaken over the female to produce fertilisation; and since both Grew and Malpighi observed the pollen in the anthers, they might at once and in reliance on this experiment of a thousand years before have come to the conclusion that the stamens are the male organs. But Grew never mentions the ancient views and experiences. Like other writers before Camerarius, he made no attempt to answer the question by experiment. It was a step in advance, when Ray in his 'Historia Plantarum' (r693), I. cap. ro, p. 17 ; II. p. I250, threw some light on the very obscure train of thought in Grew's mind, and did something to put it on the right track, by referring to the case of dioecious plants and to the old experience of the date-palm, but he too made no attempt to settle the question by experiment. The true discoverer of sexuality in plants, Camerarius, was however engaged in the experimental solution of the problem two years before the appearance of Ray's 'Historia Plantarum.' Ray's remarks on the subject in the preface to his 'Sylloge Stirpium' (I694) are only assertion founded on no experiments. But if any are prepared to attribute greater value to the utterances of Grew and Ray, the comparison of them with the way in which Camerarius addressed himself to the question will show at once, that it was he who so far advanced the theory of the subject as to make it accessible to experimental treatment, as he undoubtedly was the first who not only undertook experiments on the subject but carried them out with the skill which 
will appear in the following section. Linnaeus was right when he says in his 'Amoenitates' (I 749), I. p. 62, that it was Camerarius who first clearly demonstrated (perspicue demonstravit) the sexuality of plants and the mode of their propagation.

2. Establishment of the Doctrine of Sexuality in Plants by Rudolph Jacob Camerarius. I69I-I694.

WE have seen that all that was known with regard to sexuality in plants up to I69 I was comprised in the facts related by Theophrastus concerning the date-palm, the terebinth, and the 'malus medica,' and in the conjectures of Millington, Grew, and Ray, while Malpighi's views in opposition to these later authors were considered to be equally well founded. The sexuality of plants could only be raised to the rank of a scientific fact in one way, that namely of experiment; it had to be shown that no seed capable of germination could be formed without the co-operation of the pollen. All historic records concur in proving, that Camerarius was the first who attempted to solve the question in this way, and that he followed up this attempt by many other experiments. It is quite another question how the fertilising matter reaches the germ which is capable of being fertilised, and this could not be entertained till experiment had established the fact, that the pollen is absolutely indispensable to fertilisation.

To Johann Christian Mikan, Professor of Botany in Prague, is due the merit of having collected the scattered and therefore almost forgotten writings of RUDOLPH JACOB CAMERARIUS ${ }^{1}$, and

${ }_{1}^{1}$ Rudolph Jacob Camerarius was born at Tübingen in 1665 and died there in 1721 . Having completed the course of study in philosophy and medicine, he travelled from I 685 to 1687 in Germany, Holland, England, France, and Italy. In 1688 he became Professor Extraordinary and Director of the Botanic Garden in Tübingen; in 1689 Professor of Natural Philosophy; 
published them, together with some similar works of Koelreuter, at Prague in 1797 under the title, 'R. J. Camerarii Opuscula Botanici Argumenti.' This book, apparently little known, will be my principal authority for the following remarks. The short preliminary communications are printed without alteration from the ninth and tenth year of the second, and from the fifth and sixth year of the third decury of the Ephemerides of the Leopoldina; the letter to Valentin, which will be noticed again further on, together with an abstract of the same and an answer of Valentin, are given according to Gmelin's edition of I 749 .

Camerarius had observed, that a female mulberry-tree once bore fruit, though no male tree (amentaceis floribus) was in its neighbourhood, but that the berries contained only abortive and empty seeds, which he compared to the addled eggs of a bird. His attention was roused, and he made his first experiment on another dioecious plant, Mercurialis annua; he took in the end of May two female specimens of the wild plant (they were usually called male, but he knew them to be the female) and set them in pots apart from others. The plants throve, the fruit was abundant and filled out, but when half ripe they began to dry up, and not one produced perfect seeds; his communication on this subject is dated December 28, r69r. In the third decury of the Ephemerides, year 5, he relates that in a sowing of spinach he had found monoecious as well as dioecious plants, as Ray had observed in Urtica romana, and he himself again in three other species. The disregard of this fact was afterwards the cause of erroneous interpretation of the experiments and of doubt about sexuality.

and finally, in 1695 , First Professor of the University, in succession to his father, Elias Rudolph Camerarius. He was afterwards succeeded by his son Alexander, one of ten children. There is an article on Camerarius in the 'Biographie Universelle,' from the pen of Du Petit-Thouars. His works on other subjects, as well as those on the question of sexuality in plants, are distinguished by ingenious conception and lucid exposition. 
But Camerarius' chief composition on the subject of sexuality in plants is his letter 'De sexu Plantarum,' which is often mentioned but apparently little read, and which he addressed to Valentin, Professor in Giessen, on Aug. 25, 1694. It is the most elaborate treatise on the subject which had as yet been written, or indeed which appeared before the middle of the 18 th century, and contains more profound observations than were made by any other botanist before Koelreuter. The style contrasts favourably with the style of the writers of the time, and is thoroughly that of modern natural science; it combines perfect knowledge with careful criticism of the literature of the subject ; the construction of the flower is explained more clearly than it had ever been before, or was again for a long time after, and expressly for the purpose of making the meaning of his experiments on sexuality intelligible. The whole tone of the letter shows that Camerarius was deeply impressed with the extraordinary importance of the question, and that he was concerned to establish the existence of sexuality by every possible means.

After detailed examination of the parts of the flower, the anthers and pollen, the behaviour of the ovules before and after fertilisation, the phenomena of double flowers and similar matters, from all which he cautiously deduces the meaning of the anthers (apices), he proceeds to bring forward direct proofs. He says, 'In the second division of plants, in which the male flowers are separated from the female on the same plant, I have learnt by two examples the bad effect produced by removing the anthers. When I removed the male flowers (globulos) of Ricinus before the anthers had expanded, and prevented the growth of the younger ones but preserved the ovaries that were already formed, I never obtained perfect seeds, but observed empty vessels, which fell finally to the ground exhausted and dried up. In like manner I carefully cut off the stigmas of Mais that were already dependent, in consequence of which the two ears remained entirely without seeds, though the number of abortive husks (vesicularum) was very great.' 
He then refers to his former communications to the Ephemerides on dioecious plants, and says that the case of the spinach confirmed these results. After alluding to similar relations in animals he continues, 'In the vegetable kingdom no production of seeds, the most perfect gift of nature, the general means for the maintenance of the species, takes place, unless the anthers have prepared beforehand the young plant contained in the seed (nisi praecedanei florum apices prius ipsam plantam debite praeparaverint). It appears, therefore, justifiable to give these apices a nobler name and to ascribe to them the significance of male sexual organs, since they are the receptacles in which the seed itself, that is that powder which is the most subtle part of the plant, is secreted and collected, to be afterwards supplied from them. It is equally evident, that the ovary with its style (seminale vasculum cum sua plumula sive stilo) represents the female sexual organ in the plant.' Further on he assents to Aristotle's theory of the mixture of sexes in plants, and adduces Swammerdam's discovery of hermaphroditism in snails, which he says is the exception in animals but the rule in plants. One erroneous notion which was only seen to be erroneous a hundred years later by Konrad Sprengel, and not finally refuted till within the last few years, was his belief that hermaphrodite flowers fertilise themselves, and this by comparison with the snails he thinks is strange, though most botanists till down to our own times, in spite of Koelreuter and Sprengel, did not find it strange. That sexuality in plants was admitted by botanists, Ray excepted, at the close of the i 7 th century at most in a figurative sense, but that Camerarius conceived of it as in the animal kingdom, and sought to make this conception prevail, is apparent from the strong expressions, which he uses to show that in dioecious plants the distinction between male and female plants is not to be understood figuratively. He says that the new foetus, the young plant contained in the seed, is formed inside the coat of the seed after the plant has flowered, exactly as the new foetus is formed 
in animals. The authority of the ancients was still great at that time, for Camerarius thinks it necessary to insist that the views of Aristotle, Empedocles, and Theophrastus are not opposed to his sexual theory. Camerarius appears as the true investigator of nature, endowed with the true discerning spirit in disregarding the question which had already been raised with respect to animals, whether the ovum or the spermatozoid (vermis) produces the foetus, because the first thing to be done was to establish the fact of a sexual difference, not the mode of generation; he thinks it certainly desirable to examine and see what the pollen-grains contain, how far they penetrate into the female parts, whether they advance uninjured as far as the seed which receives them, or what they discharge if they burst before reaching it. He does full justice to Grew's services in connection with the knowledge of the pollen and its function.

It does all honour to the scientific spirit in Camerarius, that he raises a number of objections to his own theory; one was, that Lycopods and Equisetaceae produce, as he thinks, no young plants from their pollen; he suspected therefore that they have no seed. It should be remembered that the germination of Equisetaceae and Lycopods was not observed till the I 9 th century. An objection, more important at the time, was that a third ear of a castrated maize plant contained eleven fertile seeds, of whose origin he could give no account. $\mathrm{He}$ was even more disturbed by finding that three plants of hemp taken from the field and cultivated in the garden produced fertile seeds, and he tries to explain it by supposing various ways in which pollination might have taken place unobserved. This led him to make a fresh experiment; next year he placed a pot containing seedlins, of hemp in a closed room; three male and three female plants grew up; the three male were cut off (not by himself) before their flowers opened; the female produced a great number of abortive seeds, but also a good many fruitful ones. His opponents and those who sought to 
appropriate his honours fastened, as is usual, on these failures, without being able to account for the experiments which had been successful. The statement of his failures is our best proof of the exactness of his observations, for we now know the cause of failure, which Camerarius himself observed, but did not apply in explanation. IVe may assume that he would have cleared up this point in his splendid investigations in a quieter time, for at the end of his letter he laments the unjust war then raging; it was the time of the predatory campaign of Louis XIV. To his letter is appended a Latin ode of twentysix stanzas by an unknown poet, probably a pupil of his own; it is an epitome of the 'Epistola de sexu Plantarum,' as Goethe's well-known poem contains the chief points of his doctrine of metamorphosis, but it resembles Goethe's composition in no other respect ; it begins

Novi canamus regna cupidinis,

Novos amores, gaudia non prius

Audita plantarum, latentes

Igniculos, veneremque miram.

\section{Dissemination of the New Doctrine; its} AdHerents AND Opponents. I 700-I 760 .

No part of botany has so often engaged the pen of the historian, as the doctrine of sexuality in plants; but the majority of writers have not gone to the original sources for their information, and the consequence has been that the merits of the real founders and promoters of the doctrine have often been thrown into the shade for the benefit of others; even German botanists have ascribed the services of Camerarius to Frenchmen and Englishmen, because they were unacquainted with his writings, or were unable to judge of the question and its solution. We shall here endeavour to show from the records of the I8th century how far anyone before Koelreuter really contributed anything of value to the estab- 
lishment of the sexual theory. As is usually the case in great revolutions in science, some simply denied the new theory, many adopted it without understanding the question, others formed a perverse and distorted conception of it under the influence of reigning prejudices, while others again sought to appropriate to themselves the merit of the real discoverer; there were but few who with a right understanding of the question advanced it by new investigations.

The botanists who endeavoured to aid in determining the matter by their own observations may be distinguished into those, to whom the important point was the enquiry whether the pollen is absolutely necessary to the formation of seed, such as Bradley, Logan, Miller, and Gleditsch, and those who like Geoffroy and Morland assumed that sexuality was no longer an open question, and who were bent on observing in what way the pollen effects fertilisation in the ovule. But there was another class of writers altogether, who, believing that they could deal with the subject without making observations and experiments of their own, either like Leibnitz, Burckhard, and Vaillant, simply accepted the results of the observations of others on general grounds, or like Linnaeus and his disciples, endeavoured to draw fresh proofs from philosophical principles, or like Tournefort and Pontedera, simply rejected the idea of sexuality in plants. Lastly, we might mention Patrick Blair who did nothing himself, but merely appropriated the general results of Camerarius' observations, and has had his reward in being quoted even by German writers as one of the founders of the sexual theory ${ }^{1}$.

We have now to see what was really brought to light by further experiment and observation. BRADLEY appears to have been the first who experimented on hermaphrodite flowers with a view to establish the sexuality of plants ('New improve-

1 See Patrick Blair's 'Botanic Essays,' in two parts ( 1720 ), pp. 242-276. Even the Latin ode is borrowed without acknowledgment. 
ments in Gardening' (I7I7), I. p. 20). He planted twelve tulips by themselves in a secluded part of his garden, and as soon as they began to flower removed the anthers; the result was, that not one of them produced seeds, while four hundred tulips in another part of the same garden produced seeds in abundance.

Twenty years pass by before another experiment is made. JAMES LoGAN ${ }^{1}$, Governor of Pennsylvania, an Irishman by birth, set some plants of maize in each corner of a plot of ground, which was forty feet broad, and about eighty long, and experimented on them in various ways. In October he noted the following results :- the cobs of the plants, from which he had removed the male panicles when the stigmas were already dependent, presented a good appearance ; but closer examination showed that they were unfertilised, with the exception of one which was turned in the direction from which the wind might have conveyed pollen from other plants. On the cobs, from which he had removed some of the stigmas, he found exactly as many grains as he had left stigmas. One cob, which had been wrapped in muslin before the appearance of the stigmas, produced only empty husks.

Miller's experiments in I 75I, which Koelreuter has extracted from the 'Gardener's Dictionary,' part $\mathrm{II}^{2}$, are specially interesting, because the aid of insects in pollination was then observed for the first time. Miller planted twelve tulips, six or seven ells apart, and carefully removed the stamens as soon as the flowers began to open; he imagined that he should thus entirely prevent fertilisation; some days after he saw some bees

1 The account in the text is taken from Koelreuter's report in his 'Historie der Versuche über das Geschlechte der Pflanzen,' as given at p. 188 of Mikan's ' Opuscula Botanici Argumenti.' Logan's work, 'Experimenta et Meletamata de Plantarum Generatione,' unknown to me, is said by Pritzel to have been published at the Hague in 1739 . Koelreuter cites from a London edition of 1747 .

${ }^{2}$ Koelreuter's report in Mikan's collection is again the authority which is here relied on. 
load themselves with pollen in an ordinary tulip-bed and fly over to his imperfect flowers. After they were gone, he observed that they had left on the stigmas a quantity of pollen sufficient for fertilisation, and these tulips did in fact produce seed. Miller also kept some female plants of spinach apart from the male, and found that they bore large seeds without embryos.

Professor Gleditsch, Director of the Botanic Garden in Berlin, described in the same year ('Histoire de l'Académie royale des sciences et des lettres' for the year I 749, published in I 75 I at Berlin), an experiment on the artificial fertilisation of Palma dactylifera folio flabelliformi, which was no doubt our Chamaerops humilis, since he says himself in page 105 that it was Linnaeus' Chamaerops, and Koelreuter speaks of the plant in his report by that name. This treatise, in point of scientific tone and learned handling of the question, is the best that appeared between the time of Camerarius and that of Koelreuter. We learn from the introduction, that in the year I 749 there were few who doubted the existence of sexuality in plants. The author says that he has endeavoured to attain to perfect conviction on the point by many years' experiments with plants of the most various kinds. Of late years he had chiefly selected dioecious plants for investigation, Ceratonia, Terebinthus, Lentiscus, and the species of date-palm which is commonly called Chamaerops. After relating the formation of fertile seeds in Terebinth and the mastic-tree produced by artificial pollination, he turns to Chamaerops, of which species Prince Eugene had repeatedly caused specimens of considerable size to be brought over from Africa; a specimen cost as much as a hundred pistoles; but they died without flowering. 'Our palm in Berlin,' he continues, 'is a female, and may be eighty years old; the gardener asserts that it has never borne fruit, and I have myself never seen fertile seeds on it during fifteen years.' As there was no male tree of the kind in Berlin, Gleditsch procured some pollen from the garden of Caspar Bose 
in Leipsic. In the course of the nine-days' journey the greater part of the pollen escaped from the anthers, and Gleditsch feared that it was spoilt; but he was reassured by the Leipsic botanist Ludwig, who had had experience in Algiers and Tunis, and who informed him that the Africans usually employ dry pollen that has been kept for some time for the purpose of fertilisation. Though the flowering of the female tree was nearly over, he strewed the loose pollen on its flowers, and tied the withered inflorescence of the male plant to a late-blowing shoot of the female. The result was that fruit ripened in the following winter, and germinated in the spring of $175^{\circ}$. A second attempt conducted in a similar manner produced an equally favourable result ${ }^{1}$.

Koelreuter, who repeats this account in his 'Historie der Versuche,' a record of the experiments made between the years $I 69 \mathrm{I}$ and $175^{2}$ on the sexes of plants, ends his narrative with these words: 'These are, as far as I know, all the attempts which have been made and described since the year I69I to prove the existence of sexes in plants.' Koelreuter's book was written to show that experiment only can determine the question of sexuality in the vegetable kingdom, and that no one beside Camerarius, Bradley, Logan, Miller, and Gleditsch had pursued this method up to I 752 .

While these botanists occupied themselves with the question whether there was a distinction of sexes in the vegetable kingdom, we meet with two writers at the beginning of the I 8 th century who regard sexuality as proved, and who take up the question of the mode in which the pollen brings about the formation of the embryo. Both were adherents of the theory of evolution, bad observers, and not familiar with the literature of the subject. The first is Samuel Morland. In the

1 Koelreuter says that he sent pollen of Chamaerops in 1766 to St. Petersburg and to Berlin, where it w: s successfully employed by Eckleben and Gleditsch. He wished to try how long the pollen retains its efficacy. 
Снар. I.] Adlierents and Opponents of Sexuality.

'Philosophical Transactions' of I702 and I703, p. I474, he names Grew as the man who had observed that the pollen answers to the male semen, but he makes no allusion to Camerarius' experiments, the only ones which had as yet been made. He himself suggests that the young seeds may be compared to unfertilised ova, while the pollen-dust (farina) contains embryo plants, one of which must find its way into every ovule (ovum) in order to fertilise it. If so, the style must be a tube through which the embryos pass into the ova. He supposes the pollen in Fritillaria imperialis to be washed by wind and rain from the stigma through the style into the ovary, without reflecting that the movement must be an upward one in the hanging flower. If I could prove, he says, that embryos are never found in unfertilised seeds, this would be a demonstration; but I have never been so fortunate as to settle this point. He does not mention that Camerarius had shown this ten years before; he can only give as the main argument for his conjecture, that in beans the embryo lies near the orifice of the seed-coat (the micropyle), which shows that he was not aware that the two large bodies in the seed of the bean (the cotyledons) belong to the embryo, a fact which his countrymen Grew and Ray had already pointed out. It appears therefore, that Morland supplied no answer to the question how fertilisation takes place; his treatise contains nothing more than the assertion that the embryo is already contained in the pollen-grain, and that it reaches the seed through a hollow style and is there developed, an entirely erroneous and not even an original idea, for it was the offspring of the theory of evolution which was at that time in vogue.

Geoffroy's communications ('Histoire de l'Académie royale des sciences,' Paris, I7I4, p. 2 Io) contain a few more facts. He mentions neither Grew, Camerarius, nor even Morland, but connects his own observations of I 7 I I on the structure and purpose of the more important parts of the 
flower with those of Tournefort, who was a decided opponent of the doctrine of sexuality in plants. The parts of the flower are hastily described, figures are given of some forms of pollen-grains, and the notion that the style is a tube receives some apparent confirmation from the experiment of drawing water through the style of a lily. The view that the pollen is not an excrement, as Tournefort and Malpighi had maintained, is defended partly by arguments which prove nothing, for instance, by the erroneous assertion that the anthers are always so disposed that the extremity of the pistil must necessarily receive their dust. The only proof offered for the fact that seeds are infertile if deprived of the cooperation of the pollen, is a very hasty account of some experiments with maize and Mercurialis. The result of these experiments, as well as some other remarks of Geoffroy, remind us of the text of Camerarius' letter to an extent which mere accident will hardly account for. If Geoffroy really made these experiments, which is open to some doubt, yet they were made fifteen years later than those of Camerarius, who did make the same experiments among others and has described them better. Geoffroy next endeavours to show how the pollen effects the fertilisation, and offers two views on the subject; first, that the dust contains much sulphur and is decomposed on the pistil, the more subtle parts forcing their way into the ovary, where they set up a fermentation and cause the formation of the embryo; the second view is, that the pollen-grains already contain the embryos, which find their way into the seeds and are there hatched. This is Morland's notion, who however is not mentioned. Geoffroy considc.s the latter to be the more probable hypothesis, chiefly because no embryo is found in the ovule before fertilisation, and also because the seed of the bean has an orifice (the micropyle); it does not occur to him that these facts speak as much for the first as for the second view.

Enough has been produced to show that Morland and 
Geoffroy contributed nothing either to the establishment of the fact of sexuality in plants, or to the decision of the question how the pollen effects fertilisation in the ovule. Nevertheless I have mentioned these two men immediately after those who really developed the sexual theory, because they at least took their stand on experience, and endeavoured, though unsuccessfully, to demonstrate conditions of organisation which should explain the process of fertilisation. We come now to the names of men-Leibnitz, Burckhard, Vaillant, Linnaeuswho are usually supposed to have aided in establishing the sexual theory, but who may be proved to have contributed nothing whatever to the scientific demonstration of that doctrine. First as regards the philosopher Leibnitz; he says in a letter of ryor, from which Jessen has quoted the most important parts in his 'Botanik der Gegenwart und Vorzeit,' I864, p. 287 : 'Flowers are closely connected with the propagation of plants, and to discover distinctions in the mode of propagation (principiis generationis) is very useful,' etc. ; again, 'A new and extremely important point of comparison will be hereafter supplied by the new investigations into the double sex in plants,' alluding, according to Jessen, to those of Camerarius and Burckhard. We shall not expect to find that Leibnitz made experiments himself, and the words quoted merely indicate that he wished to see the parts of the flower employed for purposes of classification, because according to the observations of others they are the instruments of propagation. The remark applies in a still higher degree to Burckhard, who in his letter to Leibnitz of r 702, quoted above on p. 83, further developed the idea intimated by Leibnitz, for he too accepted the sexuality of plants as an established and self-evident truth. The address with which Sebastian Vaillant opened his lectures at the Royal Gardens in Paris in I7I 7 has often been noticed by the historians of botany. De Candolle, who assigns to him an important share in developing the sexual theory, 
says $^{1}$, that in this address he propounded the sexuality of plants most expressly and as an acknowledged fact, and that he described very graphically the way in which the anthers fertilise the pistil, into which description little that was correct probably found its way, since it required Koelreuter, Sprengel, and the botanists of quite modern times to clear up this point. Vaillant therefore can only have the credit of an eloquent description of what was then accepted. However, De Candolle goes on to say what Vaillant's discoveries were, and on the following page we read that Linnaeus confirmed these discoveries in the year 1736 in his 'Fundamenta Botanica,' and made skilful use of them in the year I 735 in laying the foundations of his sexual system. We have already in the second chapter of the first book explained the confusion of ideas which lies at the bottom of these and many similar statements, and in the same chapter have sufficiently indicated our opinion respecting Linnaeus' share in the establishment of the doctrine of sexuality. It was the character of Linnaeus' mind to attach slight value to the experimental proof of a fact, even when, like that of sexuality, it could only be proved by experiment; from the point of view of his scholastic philosophy it was more important with him to deduce the existence of this fact, in what seemed to him the philosophic way, from the idea of the plant or from reason, and in doing so to drag in a variety of analogies from the animal kingdom ; hence he acknowledged the services rendered by Camerarius, but troubled himself little about his experiments which alone could decide the question, while he undertakes himself to prove the existence of sexes in plants on grounds of reason and the like in his peculiar fashion. How he did this in the 'Fundamenta' and in the 'Philosophia Botanica' has been already shown. Here we will briefly notice the often-quoted

1 See Vol. II. p. 502, of the 'Physiologie végétale.' 
dissertation, 'Sponsalia Plantarum,' in the first volume of the 'Amoenitates Academicae' (r 749). He first gives the views of Millington, Grew, Camerarius and others; then on p. 63 he accepts the statement of Gustav Wahlboom, that he, Linnaeus, had devoted infinite labour to this question in 1735 in the 'Fundamenta Botanica,' and had there (\$\$ I $32-$ I 50) proved the sexes of plants with so great certainty that no one would hesitate to found on it a detailed classification of plants. Here then we have once more the construction of Linnaeus' so-called sexual system introduced into the question of sexuality, as if it had anything whatever to do with the establishing the existence of sexes in plants, and as to the infinite labour (infinito labore) which Linnaeus is supposed to have given to the question, the paragraphs cited from the 'Fundamenta' contain the scholastic subtleties quoted in Book I. chap. 2, but not one single really new proof. The arguments in the dissertation we are considering are of exactly the same kind, and it is itself only a lengthy paraphrase of Linnaeus' propositions in the 'Fundamenta Botanica,' illustrated by experiments made by others, and with the addition of a few unimportant observations, some of which are misinterpreted. We read, for instance, p. Ior, 'Nectar is found in almost all flowers, and Pontedera thinks that it is absorbed by the seeds that they may be the longer preserved; it might seem that bees must be hurtful to flowers, since they carry away the nectar and the pollen ;' but Linnaeus, differing from Pontedera, remarks that 'bees do more good than harm, because they scatter the pollen on the pistil, though it is not yet ascertained what is the importance of the nectar in the physiology of the flower.' This fact of the assistance rendered by insects, which was soon afterwards better described by Miller, is not further examined in this place, for Linnaeus goes on to speak of gourds, that they do not perfect their fruit under glass, because the wind is prevented from effecting the pollination. 
One experiment only is mentioned, but not the person by whom it was made. We read at p. 99 that in the year 1723 in the garden of Stenbrohuld, the male flowers of a gourd in bloom were daily removed, and that no fruit was formed. Soon after allusion is made to the artifices used by gardeners to obtain hybrid varieties of tulips and cabbage, but the matter is treated rather as agreeable trifling. In the third volume of the Amoenitates of the year I 764, in which Koelreuter's first enquiries into hybridisation had been already published, we find a dissertation on hybrids by Haartman, which was certainly written as early as $175 \mathrm{I}$. In this treatise the necessary existence of hybrid forms is concluded from philosophic principles, as Linnaeus had deduced sexuality from similar principles; no experiments are made, but certain forms are arbitrarily assumed to be hybrids ; a Veronica spuria gathered in the garden at Upsala in I $75^{\circ}$ is asserted to be the product of Veronica maritima as the mother and of Veronica officinalis as the father, but the only reason for assigning the paternity to the latter plant is that it grew close by. We find also a Delphinium hybridum stated on similar grounds to be the offspring of Delphinium elatum fertilised by Aconitum napellus, and a Saponaria hybrida to have arisen from the pollination of Saponaria officinalis by a Gentiana ; and we are told among other things that Actaea spicata alba is the offspring of Actaea spicata nigra fertilised by Rhus toxicodendron. It is obvious that in all this there was no observation of decisive facts, but simple conclusions from arbitrary premises.

We conclude therefore that neither Linnaeus nor his disciples in the interval that elapsed between the labours of Camerarius and Koelreuter contributed a single new or valid proof to the establishment of the fact, that there is a sexual difference in plants and that hybrids are formed between different species; and if many later botanists talked of the great services rendered by Linnaeus to the sexual 
Снар. I.] Adherents and Opponents of Sexuality. 401

theory, and even regarded him as its most eminent founder, this arose partly from the fact that they were unable to distinguish between his scholastic deductions and scientific proof, and partly from that confusion of the idea of sexuality with a classification of plants founded on the sexual organs, to which we have before called attention. Such a confusion of ideas gave rise to the claims which Renzi asserted on behalf of Patrizi, but which Ernst Meyer, in his 'Geschichte der Botanik,' iv. p. 420, has refuted on this very ground. Even in our own century De Candolle has been blamed by Johann Jacob Roemer for not giving Linnaeus the credit of being the actual founder of the sexual theory.

A few words in conclusion on those writers, who after Camerarius' investigations still denied sexuality in plants, because they knew nothing of what had been written on the subject or were incapable of appreciating scientific proof. Tournefort must first be mentioned on account of the great authority which he enjoyed with botanists during the first half of the I8th century. In his 'Institutiones rei herbariae' of the year I 700 (Book I. p. 69), with which we have already made acquaintance, he treats of the physiological significance of the parts of the flower, apparently in entire ignorance of Camerarius' researches, and at any rate with a leaning to Malpighi's views. He makes the petals take up nourishment from the flower-stalks, which they further digest and supply to the growing fruit, while the unappropriated parts of the sap pass through the filaments into the anthers and collect in the loculaments, to be afterwards discharged as excreta. Tournefort even doubted the necessity of the pollination of the female date-palm. The truth is that he was not well acquainted with the facts, and was led astray by his preconceptions. The same was the case with the Italian botanist Pontedera; in his 'Anthologia ' of $\mathbf{7} 720$ he reproduces Malpighi's unlucky notion, and at the same time makes the ovary absorb the nectar for 
the perfecting of the seed; he regarded the male flower in dioecious plants as a useless appendage.

Valentin, to whom Camerarius addressed his famous letter 'De sexu plantarum' in r694, did his correspondent a disservice in publishing a short abstract of it, which contained some gross misapprehensions of the facts ${ }^{1}$. Alston in $175^{6}$ relying on these incorrect statements disputed the conclusions of Camerarius, and doubted the sexual importance of the stamens on very insufficient grounds. More reasonable doubts were suggested by a German botanist, Möller, who observed that female plants of spinach and hemp produced seeds even after the removal of the male plants, and appealed to the apparently asexual propagation of Cryptogams; these objections were answered by Kästner of Göttingen, who pointed to the fact that dioecious plants, the willow for instance, sometimes bear hermaphrodite flowers. The botanists in question would never have entertained these doubts, if they had read and understood the writings of Camerarius, or had been acquainted with the literature of the subject.

\section{The theory of Evolution and Epigenesis.}

WE have already observed the influence of the theory of evolution on the doctrine of the fertilisation of plants in the case of Morland and Geoffroy. We learn more about it in the work, already quoted, of the philosopher Christian Wolff, 'Vernünftige Gedanken von den Wirkungen der Natur,' Magdeburg, 1723 ; it will be well to give his own words, for they will serve to show at the same time the amount of knowledge possessed by a cultivated and well-read man in the country of Camerarius and thirty years after the appearance of his treatise on the sexuality of plants. In the second chapter of the fourth part, which treats of the life, death, and genera-

1 See Mikan, ‘Opuscula Botanici Argumenti,' p. r8o. 
Cнар. I.] Theory of Evolution and Epigenesis.

tion of plants, Wolff says: 'Ordinarily plants are produced from seeds, for the seed not only contains the plant in embryo but also its first food.' He says that propagation by means of buds is equally natural, for each bud contains a branch in little. "We find inside in the flower a number of stalks disposed in a circle, and something at the top of each, which is full of dust and lets the dust fall on the upper part of that which holds the seed; this organ is compared by some to the genitals of the animal, and the dust to the male seed; they think also that the seed is made fruitful by the dust, and that therefore the embryo must be conveyed by the dust into the seed-case and there be formed into seeds. I have proposed to examine into the matter, but I have always let it escape me.' . . . 'Since all that has been hitherto adduced is found also in flowers which spring from bulbs, and it is also certain that the leaves of bulbs have consequently embryos in them ... it is easy to see that the embryos must come from the leaves of the bulbs. And since they could as easily be conveyed from there into the seed-grains with the sap, as into the dust which is produced in the upper part of the flower, I am inclined to think that this is the true account of the matter and that it will be confirmed by experience. But now comes the main question, whence come the embryos into the sap; since they have not an external figure only but an internal structure also, it is not plain how they can be formed either by the mere inner movement of the sap, or by separation of certain parts. ... And this is certainly more credible, that the embryos already exist in little in the sap and the plant, before they are brought by some change into the condition in which they are met with in the seed and in buds. But there is the further question where they were previously. They must either lie one in another in a minute form, as Malebranche especially maintains, or they are brought from the air and the earth with the nourishing sap into the plant, an idea which Honoratus Fabri advanced and Perrault and Sturm developed after him. According to the 
first opinion the first seed-grain must have contained everything in itself, which has grown from it to this hour.' But this demand goes beyond even Wolff's powers of belief ; for, says he, it is too great a tax on the imagination to conceive of this inclosing of germs one in another like box within box. It is well known that such notions as these were very prevalent in the I8th century, and that the spermatozoids of animals were thought to lend considerable support to them; even Albert Haller after I 760 was an adherent of the theory of evolution. However confused Wolff's general train of thought may be, we should notice his perception of the fact, that the theory of evolution does away with the sexual significance of the anthers. We shall see byand-bye, that Koelreuter was able to form a very different idea of sexual propagation. His great importance in the history of the sexual theory will be best learnt from a consideration of the speculative views of his predecessors and contemporaries. It will not be amiss therefore to disregard chronology for a while, and to notice here the views of the Baron von GleichenRussworm, and the feeble arguments of Kaspar Friedrich Wolff against the theory of evolution. The first-named writer in his work 'Das Neueste aus dem Reich der Pflanzen,' I 764, relying principally on microscopic observation of the contents of pollen-grains, supported the view that the granules in them answer to spermatozoids in animals, and that they find their way into the ovule and are there developed into embryos. Yet Gleichen was at the same time a zealous supporter of the sexual theory, and endeavoured to meet well-known objections to it by pointing to the occurrence of female flowers on male plants of spinach; he also made some experiments on maize and hemp in the interests of the theory. He did not perceive that hybrids supply convincing proof against the theory of evolution, but he rightly appealed to them as affording strong arguments in favour of sexuality. His real knowledge of hybrids is partly drawn from the statements of Linnaeus, with which we have already made acquaintance; he even describes 
a hybrid between a goat and a cow, and other similar ones, and he is angry with Koelreuter for fixing such narrow limits to the occurrence of hybrids; thus the first person who produced hybrids systematically in the vegetable kingdom must submit to be scolded for refusing to accept the imaginary hybrids of his contemporaries. Gleichen's book and the selection from his microscopic discoveries, which appeared in 1777 , abound in good detached observations; he was the first who saw and figured the pollen-tubes of Asclepias, without of course suspecting their real nature and importance.

Kaspar Friedrich Wolff is usually said to be the writer who refuted the theory of evolution. It is certainly true that in his dissertation for his doctor's degree in I 759, the well-known 'Theoria generationis,' he appeared as the decided opponent of evolution; but the weight of his arguments was not great, and the hybridisation in plants which was discovered at about the same time by Koelreuter supplied much more convincing proof against every form of evolution. Wolff conceived of the act of fertilisation as simply another form of nutrition. Relying on the observation, which is only partly true, that starved plants are the first to bloom, he regarded the formation of flowers generally as the expression of feeble nutrition (vegetatio languescens). On the other hand the formation of fruit in the flower was due to the fact, that the pistil found more perfect nourishment in the pollen. In this Wolff was going back to an idea which had received some support from Aristotle, and is the most barren that can be imagined, for it appears to be utterly incapable of giving any explanation of the phenomena connected with sexuality, and especially of accounting for the results of hybridisation. Wolff may have rejected the theory of evolution on such grounds as these, but he failed to perceive what it is which is essential and peculiar in the sexual act. 
5. Further DeVelopment of the Sexual theory by Joseph Gottlieb Koelreuter, and Konrad Sprengel.

$$
\text { I } 76 \text { I-I } 793 \text {. }
$$

Camerarius had shown by experiment that the co-operation of the pollen is indispensable to the production in plants of seeds containing an embryo, and later observers had confirmed the fact of sexuality by further and varied experiments. The next step in the strict scientific investigation of the matter was to determine by the same method of experiment the share of each principle, the male and the female, in the formation of the new plant which resulted from the sexual act. When pollen and ovule belong to the same individual plant, the offspring assumes the same form and the question remains undecided. It was necessary to bring together the pollen and ovule of different plants; this must show whether some characters are derived to the offspring from the pollen, and others from the ovule, and what the characters are which are thus distinguished, supposing of course that such a union of different forms is possible. The answer to these questions could only be obtained by experiment, that is by artificial hybridisation; for until hybrid forms had actually been produced in this manner, it must be quite unsafe to assume that certain wild plants owed their origin to cross-fertilisation.

Camerarius had already raised the question in his letter, whether cross-fertilisation in plants is possible, and had added another, whether the progeny varies from its parents (an et quam mutatus inde prodeat foetus). Bradley is our authority for the statement that a gardener in London had obtained a hybrid between Dianthus caryophyllus and Dianthus barbatus by artificial means as early as I 719 ; but KOELREUTER ${ }^{1}$ was

${ }^{1}$ Joseph Gottlieb Koelreuter was born at Sulz on the Neckar in I733, and died at Carlsruhe in 1806, where he was Professor of Natural History, and from 1768 to 1786 Director also of the Botanic and Grand-ducal Gardens. On giving up the latter position he continued his experiments in his own small garden till the year $179^{\circ}$. Karl Friedrich Gärtner in his work 
Cнат. I.] Joseph G. Koelreuter and Konrad Sprengel. 407

the first who investigated the question scientifically and thoroughly. He was the first moreover who recognised all its importance, and he applied himself to it with such admirable and unexampled perseverance and judgment, that the results which he obtained are still the best and most instructive, though a thousand similar experiments have been made since his time. He also made the first careful study of the different arrangements inside the flower in their connection with the sexual relation, discovered the purpose of the nectar and the co-operation of insects in pollination, and proposed that view of the sexual act, which with some considerable modification we must still in the main consider to be the true one, namely, that it is a mingling together of two different substances.

If we compare Koelreuter's writings, which are full of matter in a small compass, with all that was produced after Camerarius, we are astonished not only at the abundance of new thoughts, but still more at their wonderful clearness and perspicuity, and the sureness of the foundation laid for them in observation and experiment. In reading the observations of Linnaeus, Gleichen, and Wolff on the sexual theory we step into a world of thought which has long been strange and is scarcely intelligible to us, and which in the present day possesses only a historical interest. Koelreuter's works on the contrary seem to belong to our own time; they contain the best knowledge which we possess on the question of sexuality, and have not become antiquated after the lapse of more than a hundred years. We see by his example that one really gifted thinker with the requisite perseverance will effect more in a few years, than

'Ueber Bastardzeugung' of 1849 , at p. 5 says that after the latter date Koelreuter occupied himself with experiments in alchemy; but this must be a mistake. Gärtner, loco cit., and the 'Flora' of 1839 , p. 245 , supply all that seems to be known of the life of this distinguished man. The 'Biographie Universelle' contains no account of him. It would appear that he was in St. Petersburg before 1766. 
many less gifted observers in the course of many years. But the same thing happened now, which happens often in similar cases and which happened to Camerarius; a much longer time elapsed before others learnt to understand the meaning and importance of Koelreuter's labours, than he had found necessary for making his discoveries.

Koelreuter's most important and best-known work appeared in four portions in $1761,1763,1764$ and 1766 under the title, 'Vorläufige Nachricht von einigen das Geschlecht der Pflanzen betreffenden Versuchen und Beobachtungen'; we shall endeavour to give a brief summary of the more important results.

At different places in this work occur remarks and experiments on arrangements for pollination, which up to that time had been seldom and only hastily observed. As the pollentube had not yet been discovered, and Koelreuter himself set out with the view, that a fluid finds its way from the pollengrains as they lie on the stigma to the ovules, it was important first of all to determine the quantity of pollen which is required for the complete fertilisation of an ovary; with this object in view Koelreuter counted the pollen-grains formed in a particular flower and compared them with the number required to be applied to the stigma in order to effect complete fertilisation, and he found that the latter number was much the smaller. For instance, he counted four thousand eight hundred and sixty-three pollen-grains in a flower of Hibiscus venetianus, while from fifty to sixty were sufficient to produce more than thirty fertile seeds in the ovary; in Mirabilis jalapa and Mirabilis longiflora he counted about three hundred grains of pollen in the anthers, while from two to three or even one sufficed for fertilisation in the one-ovuled ovary. He also tried, whether in flowers with divided and even deeply-cleft styles fertilisation could be effected in all compartments of the ovary through one of them only, and he found that it could.

Koelreuter directed special attention to the arrangements, 
Chар. I.] Joseph G. Koelreuter and Konrad Sprengel. 409

by which in the natural course of things the pollen finds its way from the anthers to the stigmas. He ascribed perhaps too much to the agency of the wind and the oscillations of the flower from any cause; at the same time he was the first who recognised the great importance of the insect-world to pollination in flowers. 'In flowers,' he says, 'in which pollination is not produced by immediate contact in the ordinary way, insects are as a rule the agents employed to effect it,' (later observation has shown that they are generally so employed even in cases where actual contact is possible), 'and consequently to bring about fertilisation also ; and it is probable that they render this important service if not to the majority of plants at least to a very large part of them, for all the flowers of which we are speaking have something in them which is agreeable to insects, and it is not easy to find one such flower, which has not a number of these creatures busy about it.' He noticed the dichogamous construction in Epilobium, but did not further pursue his observation. $\mathrm{He}$ next examined the substance in flowers which is agreeable to insects; he collected the nectar of many flowers in considerable quantities, and found that it gave after evaporation of the water a kind of sweet-tasted honey; this honey was unpalatable only in Fritillaria imperialis, which is avoided by the humble-bees. He had no doubt therefore, that bees procure their honey from the nectar of flowers. How greatly he was interested in the relations between the existence of certain plants and that of certain animals, relations which were neglected till Darwin once more brought them into notice in quite recent times, is shown by his investigation into the propagation of the mistletoe $\left(\mathrm{I}_{7} 6_{3}\right)$; he calls special attention to the fact, that not only must the pollination of this plant be effected by insects, but that the dissemination of its seeds is also exclusively the work of birds, and that the existence of the plant therefore is dependent on two different classes of living creatures. 
Again we find observations on the movements of anthers and stigmas, especially those caused by sensitiveness. Count Giambattista dal Covolo had made the first observations in I 764 on the sensitiveness of the anthers of thistle-like plants, and had endeavoured to explain their mechanism. Koelreuter did not trouble himself about this point, so much as about the connection between the irritability of the anthers and the pollination of the stigmas. He took into consideration the sensitive stamens of Opuntia, Berberis and Cistus, which Du Hamel had already noticed, and discovered for himself the irritability of the lobes of the stigma in Martynia proboscidea and Bignonia radicans. He noticed that the lobes when touched close, but soon open again; but if pollen is placed upon them, they remain closed till fertilisation is secured.

How perfectly insects effect the pollination of flowers he showed by a comparative trial, in which he applied pollen himself to three hundred and ten flowers with a brush, while he left the same number to the operation of insects; the number of seeds formed in the latter case was very little less than in the former, though the insects had to contend with unfavourable weather.

He endeavoured also to ascertain the time required for the quantity of 'seminal matter' sufficient for fertilisation to reach the ovary after pollination; he also showed that pollination is followed by fertilisation without the aid of light; later botanists incorrectly maintained the contrary.

Koelreuter was less successful in his observations on the structure of pollen-grains; here the microscope was indispensable and microscopes were still very imperfect. Nevertheless he discovered that the outer covering of the pollen-grain consists of two distinct coats, and noticed the spines and sculpturings on the outer coat and its elasticity; he observed the lids of the orifices in the exine of Passiflora coerulea, and went so far as to see the inner coat in moistened pollen-grains protrude in the form of conical projections, which then however 
Cнар. I.] Joseph G. Koelreuter and Konrad Sprengel. 4I I

burst and allowed the contents to escape. But he explained the pollen-tube, which he had thus seen, incorrectly by supposing that these projections were intended to prevent the bursting of moistened grains. It was not till sixty or seventy years later that the matter was fully understood. Koelreuter supposed the contents of the pollen-grain to be a 'cellular tissue,' and the true fertilising substance to be the oil which adheres to the outside of the grains, but is formed inside them and finds its way out through fine passages in the coat. The bursting of the pollen-grains, which his opponent Gleichen thought must take place to allow of the escape of his supposed spermatozoids, seemed to him an unnatural proceeding.

Starting from the hypothesis, that the oil which clings to the pollen-grains is the fertilising substance, Koelreuter propounds his view of the process of fertilisation in accordance with the chemical notions of the day; he first rejects the idea that the pollen-grains themselves can reach the ovary, and then says: "Both the male seed and the female moisture on the stigmas are of an oily nature, and therefore when they come together enter into a most intimate union with one another, and form a substance which, if fertilisation is to ensue, must be absorbed by the stigma and conveyed through the style to the so-called ovules or unfertilised germs.' Koelreuter therefore made the fertilisation really take place on the stigma, the mingled male and female substance making its way into the ovary and there producing the embryos in the seed. He had expressed this view before in $\mathrm{I}_{7} 6 \mathrm{I}$; he repeated it in $\mathrm{I}_{7} 6_{3}$ with the idea that the male and female moistures unite together, as an acid and an alkali unite to form a neutral salt; a new living organism is the result at once or later of this union. In an investigation which he made in 1775 into the conditions of pollination in Asclepiadeae he reverted to this idea, and insisted that the act of fertilisation in the whole vegetable and animal kingdom is a mingling of two fluids. But at a later period he seems to have no longer considered the moisture 
of the stigma to be the female principle, for experiment had taught him, that if a stigma exchanges the moisture from another stigma for its own, and is then dusted with its own pollen, no hybrid form is produced ${ }^{1}$. In any case Koelreuter had a more correct idea of the nature of sexual fertilisation than any of his predecessors, and it was one specially adapted to enable his contemporaries to understand the results of experiments in hybridisation, while the hybrids themselves supplied most convincing arguments against the prevailing theory of evolution.

We have arrived at Koelreuter's most important performance, the production of hybrids. Here was a case for skilful experimentation, not for microscopic observation, and here he obtained results in which nothing afterwards required to be changed, but which when combined with later observations have been used for the discovery of general laws in hybridisation. The first hybrid which he obtained by placing the pollen of Nicotiana paniculata on the stigmas of N. rustica, produced pollen that was impotent; but he soon after obtained hybrids from the two species which produced seeds capable of germination, and in 1763 he described a considerable number of hybrids in the genera Nicotiana, Kedmia, Dianthus, Matthiola, Hyoscyamus, and others. In the last portion of his great work ( 1766 ) he speaks of eighteen attempts to obtain hybrids with five native species of Verbascum, and submits Linnaeus' views on hybrid plants, which we have already described, to a withering criticism. He shows at the same time from experiment, that if the stigma of a plant receives its own pollen and pollen from another plant at the same time, the former only is effectual, and that this is one reason why hybrids which can be raised artificially are not found in nature. We must not attempt to give a detailed account of his famous hybrids of the third, fourth, and fifth degrees, nor of his experiments on other points, such as the reverting of

' See Gärtner, 'Ueber Bastardzeugung ' ( 1849 ), p. 62. I have unfortunately been unable to meet with the second continuation of Koelreuter's work. 
Chap. I.] Joseph G. Koelreuter and Konrad Sprengel. 4 I3

hybrids to the original form by the repeated employment of its pollen; the value of these experiments for theoretical purposes was afterwards fully brought out by Nägeli.

It is impossible to rate too highly the general speculative value of Koelreuter's artificial hybridisation. The mingling of the characters of the two parents was the best refutation of the theory of evolution, and supplied at the same time profound views of the true nature of the sexual union. It was shown by his numerous experiments that only nearly allied plants and not always these are capable of sexual union, which at once disposed of Linnaeus' vague ideas in the judgment of every capable person, though it was long before science candidly accepted Koelreuter's results. The plant-collectors of the Linnaean school as well as the true systematists at the end of the I8th century had little understanding for such labours as Koelreuter's, and incorrect ideas on hybrids and their power of maintaining themselves prevailed in spite of them in botanical literature. Hybrids were necessarily inconvenient to the believers in the constancy of species; they disturbed the compactness of their system and would not fit in with the notion that every species represented an 'idea.'

Koelreuter's doctrines however did not always fall on unfruitful soil ; two botanists at least were found in Germany who adopted them, Joseph Gärtner the author of the famous Carpology and father of Carl Friedrich Gärtner who at a later time spent twenty-five years in experimenting on fertilisation and hybridisation, and Konrad Sprengel who took up Koelreuter's discovery of the services rendered by insects and arrived at some new and very remarkable results.

Joseph GärTNer made no fresh observations on sexuality himself, but in the Introduction to his 'De fructibus et seminibus plantarum' ( 788 ) he made use of Koelreuter's results for the purpose of distinguishing more clearly between different kinds of propagation, and strengthening his own attack on the theory of evolution. The germ-grains or spores of cryptogamic 
plants were at that time often regarded on insufficient grounds as true seeds; Gärtner distinguished them from seeds, because they are formed without fertilisation and yet are capable of germination, whereas ovules become seeds capable of germination only under the influence of the pollen. He distinctly denied the sexuality of the Cryptogams ; it was not till fifty years later that strict scientific proof was substituted in this department of botany for vague conjecture, and it was more in the interest of true science in Gärtner's day to deny sexuality in the Cryptogams altogether, than to take the stomata in Ferns with Gleichen, or the indusium with Koelreuter, or the volva in Mushrooms for the male organs of fertilisation. Gärtner rightly appealed to Koelreuter's hybrids against the defenders of the theory of evolution; and to those who saw in the seed only another form of vegetative bud, he said, that the bud can produce a new plant without fertilisation but that the seed cannot. We have already given an account in the chapters on Systematic Botany of the services rendered by Gärtner to the knowledge of the seed in its immature and in its mature condition ; as regards the process of fertilisation he adopted in the main Koelreuter's view, that it is the result of the union of a male and female fluid, from which the germ-corpuscle in the ovule is developed by a kind of crystallisation. Konrad Sprengel also fully committed himself to this view, and was thereby prevented from understanding the process of fertilisation in Asclepiadeae.

In KonRad Sprengel ${ }^{1}$ we encounter once more an observer

1 Christian Konrad Sprengel, born in $175^{\circ}$, was for some time Rector at Spandau. There he began to occupy himself with botany, and devoted so much time to it that he neglected the duties of his office, and even the Sunday's sermon, and was removed from his post. He afterward lived a solitaly life in straitened circumstances in Berlin, being shunned by men of science as a strange, eccentric person. He supported himself by giving instruction in languages and in botany, using his Sundays for excursions, which any one who chose could join on payment of two or three groschen. He met with so little support and encouragement that he never brought out 
Снар. I.] Joseph G. Koelreuter and Konrad Sprengel. 4I 5

of genius, like Camerarius and Koelreuter, who however surpassed them both in boldness of conception and was therefore even less understood by his contemporaries and successors, than they had been by theirs. The conclusions, to which his investigations led him, were so surprising, they suited so little with the dry systematism of the Linnaean school and with later views on the nature of plants, that they had become quite forgotten when Darwin brought them again before the world and showed their important bearing on the theory of descent. As Camerarius first proved that plants possess sexuality, and Koelreuter showed that plants of different species can unite sexually and produce fruitful hybrids, so now Sprengel showed that a certain form of hybridisation is common in the vegetable kingdom, namely the crossing of different flowers or different individuals of the same species. In his work, 'Das neu entdeckte Geheimniss der Natur in Bau und Befruchtung der Blumen,' Berlin, I793, he says at page 43: 'Since very many flowers are dioecious, and probably at least as many hermaphrodite flowers are dichogamous, nature appears not to have intended that any flower should be fertilised by its own pollen.' This was however only one of his surprising conclusions; still more important perhaps was the view, that the construction and all the peculiar characters of a flower can only be understood from their relation to the insects that visit them and effect their pollination; here was the first attempt to explain the origin of organic forms from definite relations to their environment. Since Darwin breathed new life into these ideas by the theory of selection, Sprengel has been recognised as one of its chief supports.

It is highly interesting to read, how this speculative mind

the second part of his famous work; his publisher did not even give him a copy of the first part. Natural disgust at the neglect with which his work was treated made him forsake botany and devote himself to languages. $\mathrm{He}$ died in 1816 . One of his pupils wrote a very hearty eulogium on him in the 'Flora' of 1819 , p. $54 \mathrm{I}$, which has supplied the above facts. 
by the study of structural relations in flowers, which were apparently trivial and open to the eyes of all men, first arrived at ideas which in the course of a few years were to lead to such far-reaching results. He says : 'In the summer of ${ }_{7} 787$ I was attentively examining the flowers of Geranium sylvaticum, and observed that the lower part of the petals was provided with slender rough hairs on the inside and on both edges. Convinced that the wise framer of nature has not produced a single hair without a definite purpose, I considered what end these hairs might be intended to serve. And it soon occurred to me, that on the supposition that the five drops of juice which are secreted by the same number of glands are intended for the food of certain insects, it is not unlikely that there is some provision for protecting this juice from being spoiled by rain, and that the hairs might have been placed where they are for this purpose. Since the flower is upright, and tolerably large, drops of rain must fall into it when it rains. But no drop of rain can reach one of the drops of juice and mix with it, because it is stopped by the hairs, which are over the juicedrops, just as a drop of sweat falling down a man's brow is stopped by the eye-brow and eye-lash, and hindered from running into the eye. An insect is not hindered by these hairs from getting at the drops of juice. I examined other flowers and found that several of them had something in their structure, which seemed exactly to serve this end. The longer I continued this investigation, the more I saw that flowers which contain this kind of juice are so contrived, that insects can easily reach it, but that the rain cannot spoil it; but I gathered from this that it is for the sake of the insects that these flowers secrete the juice, and that it is secured against rain that they may be able to enjoy it pure and unspoilt.' Next year, following out an idea suggested by the flowers of Myosotis palustris, he found that the position of spots of different colours on the corolla have some connection with the place where the juice. is secreted, and with the same ready reasoning as before he came 
Chap. I.] Joseph G. Koelreuter and Konrad Sprengel. 417

to the further conclusion: 'If the corolla has a particular colour in particular spots on account of the insects, it is for the sake of the insects that it is so coloured; and if the particular colour of a part of the corolla serves to show an insect which has lighted on the flower the direct path to the juice, the general colour of the corolla has been given to it, in order that insects flying about in search of their food may see the flowers that are provided with such a corolla from a long distance, and know them for receptacles of juice.'

$\mathrm{He}$ afterwards discovered that the stigmas of a species of Iris were absolutely unable to be fertilised in any other way than by insects, and further observation convinced him more and more, 'that many, perhaps all flowers, which have this juice, are fertilised by the insects which feed on it, and that consequently this feeding of insects is in respect of themselves an end, but in respect of the flowers only a means, but at the same time the sole means to a definite end, namely, their fertilisation; and that the whole structure of such flowers can be explained, if in examining them we keep in sight the following points, first, that flowers were intended to be fertilised by the agency of one or another kind of insects, or by several ; secondly, that insects in seeking the juice of flowers, and for this purpose either alighting upon them in an indefinite manner, or in a definite manner either creeping into them or moving round upon them, were intended to sweep off the dust from the anthers with their usually hairy bodies or with some part of them, and convey it to the stigma, which is provided either with short and delicate hairs, or with a viscid moisture, that it may retain the pollen.'

In the summer of 1790 he detected dichogamy, which he first observed in Epilobium angustifolium. He found, 'that these hermaphrodite flowers are fertilised by the humble-bee and by other bees, and that the individual flower is not fertilised by its own pollen, but the older flowers by the pollen which the insects convey to them from the younger.' Having 
observed the same thing in Nigella arvensis, he afterwards found exactly the opposite arrangement in a species of Euphorbia, in which the stigmas can receive the pollen by the aid of insects only from older flowers.

He goes on to say that he grounds his theory of flowers on these his six chief discoveries made in the course of five years; he then gives his theory at length, first of all explaining the nature of juice-secreting glands (nectaries), and organs for receiving or covering the nectar, and the contrivances for enabling insects to find their way readily to the juice. He calls attention to Koelreuter's excellent observations on the fertilisation of nectar-bearing flowers by insects, and notices that no one has hitherto shown that the whole structure of such flowers has this object in view, and can be fully explained by it. He finds the chief proof of this important proposition in dichogamy.

'After the flower,' he says, 'has opened in dichogamous plants, the filaments have or assume either all at once or one after another a definite position, in which the anthers open and offer their pollen for fertilisation. But at this time the stigma is at some distance from the anthers and is still small and closed. Hence the pollen cannot be conveyed to the stigma either by mechanical means or by insects, for there is as yet properly no stigma. This condition of things continues a certain time. When that time is elapsed, the anthers have no longer any pollen, and changes take place in the filaments the result of which is that the anthers no longer occupy their former position. Meanwhile the pistil has so changed that the stigma is now exactly in the place where the anthers were before, and as it now opens, or expands the parts of which it is composed, it often fills about the same space as the anthers filled before. Now the spot, which was at first occupied by the ripe anthers and is now occupied by the ripe stigma, is so chosen in each flower, that the insect for which the flower is intended cannot reach the juice without touching with a por- 
Cнар. I.] Joseph G. Koelventer and Konrad Sprengel. 419

tion of its body the anthers in a young flower, and the stigma in an older; it thus brushes the pollen from the anthers and conveys it to the stigma, and so the pollen of the younger flower fertilises the older.' It has been already said, that Sprengel was also acquainted with the opposite form of dichogamy; and the result of his explanation of both kinds is the conclusion, that some flowers can only be fertilised by the aid of insects, and he adds that some cases are to be found, in which the arrangements in the flower are of such a nature as to involve the injury and even the death of the insect that gives its services. Further on he tells us, that all flowers, 'which are without a proper corolla and have no calyx of any importance in its place, are destitute of nectar, and are not fertilised by insects but by some mechanical means, as by the wind, which either blows the pollen from the anthers on to the stigmas, or shakes the plant or the flower and makes the pollen fall from the anthers on to the stigmas.' He observes, that such flowers always produce a light pollen and in large quantities, whereas the pollen of nectar-bearing plants is heavy. Then he shows how his principles explain all the physiological characters of flowers, position, size, colour, smell, form, time of flowering and the like.

Sprengel set out with the idea, that the nectar and certain arrangements in flowers are expressly intended for the service of insects; but his investigations led him ultimately to the conclusion, that insects themselves serve not only to effect the fertilisation of plants generally, but also in all ordinary cases to bring about the crossing of different flowers of the same plant or of different plants of the same species. There remained a question, which from Sprengel's strictly teleological point of view especially required an answer, what was the object of this crossing of flowers or individual plants? Sprengel was content, as we have seen, with simply stating the fact, and with saying, that nature apparently did not choose that any flower should be fertilised by its own pollen. Who would 
make it a reproach to the discoverer of such remarkable and widely-prevalent phenomena in nature, that he did not answer this question and give the final touches to the body of doctrine which he created, and which could only be developed by many experiments and the labour of long years? Neither his worldly circumstances nor the reception accorded to his work with all its genius were such as to encourage him to undertake the solution of this last and most difficult problem, even if he had been inclined to do so. Botanists were just at that time and for some time after preoccupied with views, which allowed such biological and physiological facts in vegetable life to lie neglected, nor were Sprengel's results at all favourable to the doctrine of the constancy of species; from that point of view the wonderful relations between the organisation of flowers and that of insects must have seemed absurd and repulsive. In such cases it is the character of less-gifted natures, rather to deny the facts or to disregard them, than to sacrifice their own favourite views to them; this is one explanation of the neglect which Sprengel's book met with everywhere. Then notwithstanding the labours of a Camerarius and a Koelreuter there were many even at the beginning of our own century who still doubted the sexuality of plants. Even after Knight and IVilliam Herbert, with a right understanding of the question left open by Sprengel, had obtained experimental results which helped to answer it, the new doctrine did not make its way. The earlier simple-minded but consistent teleology had been succeeded by a rejection of all teleological explanations in the treatment of physiological questions, and this spirit conduced to make Sprengel's results seem inconvenient in proportion as they appeared to admit only of such explanation. With regard to phenomena of this kind botanists before 1860 were in a position, in which they were without the means of forming a judgment; they shrank from the teleological point of view and from believing with Konrad Sprengel, that every, even the least-obvious, arrangement in an organism was the 
Снар. I.] Joseph G. Koelreuter and Konrad Sprengel. 421

direct work of a Creator; but they had nothing better to put in the place of this idea, and hence Sprengel's discoveries not being understood were neglected till Darwin recognised all their importance, and by opposing the theory of descent and selection to the principle of design was in a position not only to show that they had a scientific meaning, but also to employ them as powerful supports of the theory of selection. Then, too, it became possible rightly to appreciate the contributions of Knight, Herbert, and K. F. Gärtner to the further completion of Sprengel's doctrine, for their discoveries also were for a while neglected. A few years after the appearance of Sprengel's book, Andrew Knight ${ }^{1}$ relying on the results of experiments made for the purpose of comparing self-fertilisation and crossing in the genus Pisum, laid down the principle, that no plant fertilises itself through an unlimited number of generations; in 1837 Herbert summed up the results of his numerous experiments in fertilisation in the statement, that he was inclined to believe that he attained a better result, when he fertilised the flowers from which he wished to obtain seeds with pollen from another individual of the same variety or at least from another flower, than when he fertilised it with its own pollen; K. F. Gärtner came to the same conclusion after experiments in fertilising Passiflora, Lobelia, and species of Fuchsia in 1844 . In these observations lay the first germ of the answer to the question left undecided by Sprengel, why most flowers are so constructed that fertilisation can only be fully effected by the crossing of different flowers or of different plants of the same species ; the artificial crossings of this kind, which Knight, Herbert, and Gärtner compared with the selffertilisation of single flowers, showed that crossing procures a more complete and vigorous impregnation than self-fertilisation. It was but a short step from this fact to the idea, that

${ }^{1}$ See Hermann Müller, 'Befruchtung der Blumen durch Insecten,' Leipzig (I873), p. 5 . 
the arrangements in the flower discovered by Sprengel together with the aid of insects serve to secure the strongest and most numerous progeny possible. Darwin was the first who fixed his eye distinctly on this idea also, in order to employ it in his theory of selection, and sought support for it in a number of experiments made after 1857 .

\section{New opponents of Sexuality and their Refutation}

\section{BY EXPERIMENTS. I $785-1849$.}

Those who have read the writings of Camerarius and Koelreuter carefully find it difficult to believe, that after their time doubts were still entertained not about the manner in which the processes of fertilisation are accomplished but about the actual existence of difference of sex in plants. And yet such doubts were expressed repeatedly during the succeeding sixty years in various quarters and with the greatest confidence, and this not in consequence of increased accuracy in experimental research or of contradictions that could be proved in the views of the founders of the sexual theory, but because a number of observers made unskilful experiments and obtained con- tradictory results, or made inaccurate observations on the plants on which they experimented, and generally had not the requisite experience and circumspection. Such were Spallanzani and later Bernhardi, Giron de Bouzareingue and Ramisch. Schelver, his pupil Henschel, and their adherents erred still more grossly and from a different cause; they thought themselves justified by preconceived opinions and conclusions from the nature-philosophy in denying facts established by experiment. The destructive effects of the nature-philosophy on the powers of the understanding at the beginning of the rgth century was shown in the case of many botanists, who were no longer able to estimate the result of simple experiments, and to trace back the phenomena of nature to the scheme of causes and effects. As Linnaeus once imagined that he could 
prove sexuality in plants on philosophical grounds and paid comparatively slight attention to their behaviour as shown by experiment, so we have in Schelver a nature-philosopher who conversely endeavoured to prove the impossibility of sexuality in plants on philosophical grounds. As Linnaeus deduced sexuality from the nature or idea of the plant, Schelver denied it from the same nature or idea; as a matter of logic one was as much in the right as the other, but the question could not be decided in this way but only by experiment. However our nature-philosophers thought it advisable to get some empirical support for their theories, and they found it in SPALLANZANI ${ }^{1}$. He published his enquiries into fertilisation in animals and plants under the title 'Expériences pour servir à l'histoire de la génération des animaux et des plantes,' Geneva, I 786 ; his account of those relating to plants, with which only we are concerned, betrays a very defective acquaintance with botanical literature, for he reckons Cesalpino among those who had admitted sexuality in plants. His experiments themselves testify to very slight knowledge of the biological considerations by which the cultivation of plants for experiment must be guided, and generally little botanical acumen, as is often the case with amateurs who without sufficient preparation suddenly turn their attention to questions of vegetable physiology; his treatment of his topics is superficial, his criticism of others is dogmatic and bitter without exciting confidence in the author's own skill and judgment. His experiments were often undertaken in haste and with little consideration, and some of them were made on plants the least suitable for such investigations, as

${ }^{1}$ Lazaro Spallanzani was born at Scandiano in Modena, and died at Pavia in 1799 , where he was for a long time Professor of Natural History. $\mathrm{He}$ made researches in very various questions of natural science, and especially in animal physiology; but they seem to have been conducted with the same want of care and deliberation which appears in his experiments on sexuality in plants. A long article in the "Biographie Universelle' gives a detailed account of his scientific labours. 
for instance on Genista, beans, peas, radishes, Basilicum, Delphinium. It is no matter of surprise therefore that in the case of some plants, as Mercurialis and Basilicum, he arrived at the conclusion that the pollen is necessary to the production of fertile seeds, while he makes others, as the gourd, the water-melon, hemp, and spinach produce such seeds without fertilisation. His countryman Volta, a greater man, repeated his experiments and impugned the results which he had obtained from them.

Such was the character of the experiments to which Franz Joseph Schelver, Professor of Medicine in Heidelberg appealed in his 'Kritik der Lehre von dem Geschlecht der Pflanzen,' I8I2. It is unnecessary to give a detailed account of this strange production of a mind misled, even though a considerable number of German botanists as late as 1820 took its nonsense for profound wisdom. Schelver dismissed the experiments of Camerarius in four lines, and while he treated Koelreuter with contempt, he praised Spallanzani as the weightiest author on the subject. The statements of Camerarius and Koelreuter are true, he said, but they do not prove the fertilisation. He is more concerned to decide the question from the nature of vegetative life, and from this nature constructed by himself he concludes that the organs of plants are of no use at all, that they cannot even tend to be of use to one another and to propagate life together, because this one end of their action can be a living one only where all the parts are present at the same time, which of course disposes of the fertilising effect of the pollen; accordingly he does not refer the effect of a male plant on a neighbouring female plant, which results in the formation of seeds, to pollination by the former, but it is the proximity itself which has the fertilising effect. But these are very insufficient specimens of his reasoning.

The writings of his pupil Henschel ${ }^{1}$ are even worse than

${ }^{1}$ August Henschel was a practising physician and a University teacher in Breslau. 
Снар. I.] Opponents of Sexuality, I785-1849.

those of his master, and the worst of these is his large work 'Von der Sexualität der Pflanzen' of $\mathbf{8} 820$. He thought himself obliged to prove the doctrines of the nature-philosophy by countless experiments; but the way in which these are devised, managed and described displays the extreme of dulness and incapacity to form a sound judgment. The doubt which must occasionally rise in the mind of the reader as to the accuracy of his reports, and the remarks which have been made on this point by Treviranus and Gärtner, are not needed to disgust him with the scientific efforts of this writer.

It would be superfluous to give an account of the contents of Henschel's book, which is interesting from the pathological rather than from the historical point of view. To what an extent better men than Henschel even later than 1820 lost under the influence of the nature-philosophy their capacity for judging such questions as we are discussing, how even investigators of merit thought it worth while to treat the productions of Schelver and Henschel with a certain respect, is shown among other works, by a collection of letters, which were published by Nees von Esenbeck as a second supplement to the 'Regensberg Flora' of $182 \mathrm{I}$, and by the later remarks of Goethe on the metamorphosis of plants, to be found in Cotta's edition of his works in forty volumes (vol. xxxvi. p. 134) under the title 'Verstäubung, Verdunstung, Vertropfung.' But there were some who set themselves distinctly against these pernicious ideas, such as Paula Schrank ('Flora,' I 822, p. 49) and C. L. Treviranus, who published in I822 a full refutation of Henschel in his 'Lehre von dem Geschlecht der Pflanzen in Bezug auf die neuesten Angriffe erwogen.' A few stray supporters of the dying nature-philosophy were still to be found at a later time; among them Wilbrand, Professor in Giessen, who ('Flora,' r830, p. 585) adopted the very subtle distinction that there is in plants something analogous to sexuality in animals, but no real sexuality. We see in the whole literature of the nature- 
philosophy an incapability of judging of experiments simply with the sound human understanding; an imaginary something was constantly introduced into the results of experiments which had not the remotest connection with their conditions and results.

The doubts expressed by Bernhardi in $\mathrm{I} 8 \mathrm{I} \mathbf{I}$, by Girou in I 828-30, and by Ramisch in 1837 were of a different kind; these men made experiments and judged of them in a scientific manner; but they were insufficiently acquainted with what had been done before them, and their experiments were not devised with the requisite knowledge of the conditions of the problem, or carried out with sufficient precautions. Camerarius and Ray had noticed in the previous century the occasional occurrence of male flowers on female plants of spinach, hemp and mercury; and yet the observers above mentioned chose these plants for their experiments without being on their guard against the possible appearance of these exceptional circumstances, or of other means of pollination.

We see then that doubts were entertained till as late as after 1830 with regard either to sexuality in plants altogether, or to its general prevalence in Phanerogams; the Cryptogams were not mentioned, for they were assumed to be devoid of sex in spite of many valuable observations of earlier times. The great majority of botanists however admitted the sexual significance of the organs of the flower; most of them rested in entire faith on Linnaeus' authority, while some were able to appreciate the experimental proofs of Camerarius, Bradley, Logan, Gleditsch and Koelreuter. But all who took up the subject in earnest between 1820 and 1840 were naturally led to desire that the question should once more be thoroughly examined. The Berlin Academy of science had offered in I 8 I 9 at Link's suggestion a prize for an essay on the question, whether there is such a thing as hybrid fertilisation in the vegetable kingdom, in the hope of stimulating botanists to new investigations into the decisive points in the sexual 
theory. The only reply to this offer, an essay by Wiegmann which was not sent in till ${ }_{1} 828$, did not come up to the requirements of the Academy, and was rewarded with only half the prize. The Dutch Academy at Haarlem was more successful when induced by Reinwardt in ${ }_{1} 8_{3} \circ$ to propose the question in a somewhat altered form and in connection with practical horticulture. This prize was contended for by KARL FRIEDRICH GäRTNER ${ }^{1}$, whose essay delayed by circumstances till I 837 received the prize of honour and an extraordinary reward. But the whole body of his results, derived from the experimental researches of five-and-twenty years, were not published till 1849 and then in a large volume, 'Versuche und Beobachtungen über die Bastardzeugung,' Stuttgart, x 849, having been preceded by an introductory work of equal extent, 'Versuche und Beobachtungen über die Befruchtungsorgane der vollkommeneren Gewächse und über die natürliche und künstliche Befruchtung durch den eigenen Pollen.' The two works together are the most thorough and complete account of experimental investigation into sexual relations in plants which had yet been written. They are a brilliant termination of the period of doubt with respect to sexuality in plants which succeeded to the age of Koelreuter-a termination which coincides in time with the lively discussion which was being maintained on the strength of microscopical investigations by

1 Karl Friedrich Gärtner, son of Joseph Gärtner, was born at Calw in $\mathbf{I 7 7 2}$, and died there in 1850 . He attended lectures on natural science at the Carlsacademie at Stuttgart, and then went first to Jena for medical instruction, and in I 795 to Göttingen, where he was a pupil of Lichtenberg. He took a degree in 1796 and settled as a physician in his native town. Here he occupied himself at first with questions of human physiology, and afterwards worked at the supplement to his father's 'Carpologia.' $\mathrm{He}$ collected notices and extracts for a complete work on vegetable physiology. This design was never fulfilled, but it led to his taking up the question of sexuality in plants, to which he devoted twenty-five years ('Jahresheft des Vereins für vaterl. Naturkunde in Würtemberg,' 1852 , vol. viii, p. I6). 
Schleiden and Schacht on the one side and by Hofmeister on the other respecting the processes in the formation of the embryo.

Gärtner's writings derive their importance not so much from new and surprising discoveries or brilliant ideas and unexpected combinations, as from their very searching examination into all the circumstances and relations which can come under consideration in the sexual propagation of Phanerogams. His experiments in hybridisation, of which he kept most exact accounts, exceeded the number of nine thousand; in these and in normal cases of pollination he studied all the sources of error which could in any way affect his experiments, and took into careful consideration all the conditions of fertilisation connected with the development of the plant itself and with its external circumstances; at the same time he examined critically all that had been written on the subject, and submitted every experiment reported by former observers to the test of his own wide experience. The volume on self-fertilisation is a complete account of the biology and physiology of flowers. The phenomena connected with the unfolding and fertilisation of the flower are described from the writer's own observations, some of which are quite new ; it specially investigates the relations between the calyx, the corolla, the secretion of nectar and the opening of the anthers, also the temperature of flowers and the physiological processes in the ovary, the style and the stigma; all that was then known of irritability and the phenomena of movement in the flower and in the organs of fructification was collected together and elucidated by fresh observations, and thus a picture was drawn complete to the smallest detail of the life of a flower, such as we do not yet possess of any other organ. It would be idle to think of giving in a small compass a clear idea of the wealth of these observations. But all this was only preliminary to the main point, the proof that Camerarius was right, that notwithstanding the objections of a hundred years 
the co-operation of the pollen is indispensable to the formation of the embryo in the growing seed, and that plants therefore have sexuality exactly as animals have it. Gärtner did not content himself with simply making new experiments in fertilisation; he refuted the objections of Spallanzani, Schelver, Henschel, Girou and others in detail from fresh experiments and from other sources of information, paying particular regard to all the circumstances which could come under consideration in each case; he exposed the inaccuracy of the observations of the opponents of sexuality point by point, and finally called attention to a number of remarkable phenomena observable in the ovary even before fertilisation, and to the circumstances under which the pollen may find its way to it in cases where ordinary pollination has been apparently prevented. These observations once more confirmed the existence of sexuality in plants, and in such a manner that it could never be again disputed. When facts were observed in 1860 , which led to the presumption that under certain circumstances in certain individuals of some species of plants the female organs might produce embryos capable of development without the help of the male, there was no thought of using these cases of parthenogenesis to disprove the existence of sexuality as the general rule; men were concerned only to verify first of all the occurrence of the phenomena, and then to see how they were to be reasonably understood side by side with the existing sexuality, as had to be done also in the corresponding cases in the animal kingdom.

Gärtner's work on hybridisation had been preceded by other enquiries into the same subject, those namely of Knight mentioned above at the beginning of the century, and Herbert's more ample investigations published in his work on Amaryllideae in 1837. Gärtner did not neglect to compare his observations at all points with the results of his predecessors, especially those of Koelreuter, and he deduced from the astonishing mass of material a number of general propositions 
respecting the conditions under which the production of hybrids is possible, the results of crossing, and the causes of failure. A special interest attaches to his mixed and compound hybrids, to his experiments on the various degrees of influence which foreign pollen exercises on the behaviour of the female organ, and the connection of this point with the formation of varieties. It is impossible to give a more distinct account of Gärtner's results without entering into discussions which would exceed the limits of a historical survey. It is the less necessary to do so, since Nägeli undertook in 1865 to give a summary view of all the important results to be found in the wealth of material supplied by Koelreuter, Herbert and Gärtner ${ }^{1}$. Gärtner's experiments in hybridisation were conducted at Calw in Würtemberg, the place where Koelreuter had made his in 1762 and 1763 . And thus it was in two small cities of Würtemberg that the foundations of the sexual theory were laid and the theory itself perfected, as far as it could be by experiment only, by three of the most eminent among observers. Camerarius in Tübingen, Koelreuter and K. F. Gärtner in Calw contributed so largely to the empirical establishment of the theory, that all that was done by others would seem of small importance, if artificial pollination only were in question. But Koelreuter was imperfectly acquainted with the methods by which pollination is usually effected in nature; Sprengel was the first who saw into all their more important relations, and the fact must not be concealed, that Gärtner in regarding Konrad Sprengel's observations as unworthy of serious consideration, neglected the most fruitful source of new and magnificent results. His careful study of the secreting of nectar and of the sensitiveness of the organs of fertilisation, and his many observations on other biological relations in flowers, would have found their natural termination, if he had connected them at all points with Sprengel's general

${ }^{1}$ See also Sachs, 'Lehrbuch der Botanik,' Leipzig, I874. 
conclusions respecting the relation of the structure of the flower to the insect world. This Gärtner entirely failed to do, and hence in this case also it was reserved for Darwin's wonderful talent for combination to sum up the product of the investigations of a hundred years, and to blend Koelreuter's, Knight's, Herbert's, and Gärtner's results with Sprengel's theory of flowers into a living whole in such a manner, that now all the physiological arrangements in the flower have become intelligible both in their relations to fertilisation, and in their dependence on the natural conditions under which pollination takes place without the aid of man. Here, as in morphology and systematic botany, Darwin found the premisses given and drew the conclusion from them; here too the certainty of his theory rests on the results of the best observers, on investigations which find in that theory their necessary logical and historical consummation.

\section{Microscopic investigation into the processes of}

FERTILISATION IN THE PHANEROGAMS; POLLEN-TUBE AND EGG-CELLS ${ }^{1}$. I 830-I850.

THOSE who were convinced of the sexuality of plants had endeavoured as early as the previous century to form some idea with the help of the microscope of the way in which the pollen effects the formation of the embryo in the ovule. We may pass over Morland's and Geoffroy's very rude attempts in this direction; Needham ( 1750 ), Jussieu, Linnaeus, Gleichen, and Hedwig imagined that the pollen-grain bursts upon the stigma, and that the granules it contains make their way down-

1 The more important works referred to in this section are Robert Brown's 'Miscellaneous Writings,' edited by Bennett, I866-67; von Mohl on G. Amici, in the 'Botanische Zeitung,' I863, Beilage, p. 7 ; Schleiden, 'Ueber die Bildung des Eichens und Entstchung des Embryos,' in 'Nova Acta Academiae Leopoldinensis,' 1839, vol. xi, Abtheilung, I ; Hofmeister, ' Zur Uebersicht der Geschichte von der Lehre der Pflanzenbefruchtung,' in 'Flora' of 1867 , p. II 9 . 
wards through the style to the ovules, and are there either hatched into embryos or assist in their production. This way of conceiving the matter was closely connected with the theory of evolution which then prevailed, and seemed to find some countenance in the seed-corpuscles of animals; it was also supported by the observation that pollen-grains placed under the microscope in water often burst and discharge their contents in the form of a granular mucilage. It has been already mentioned that Koelreuter rejected this view; he declared the bursting of the pollen-grains to be contrary to nature, and considered the oil which exudes from the grains to be the fertilising substance. This view was adopted by Joseph Gärtner and Sprengel, but it fell into disesteem, while that of Needham and Gleichen commanded some assent some years longer. The next question was, how the granular contents of the pollengrain reach the ovules. Accident supplied a starting-point for further consideration. Amici, who was examining the hairs on the stigma of Portulaca for another purpose, saw on that occasion ( 1823 ) the pollen-tube emerge from the pollen-grain, and the granular contents of the latter, commonly known as the fovilla, execute streaming movements like the well-known movement in Chara. The desire to verify this remarkable fact, and to discover how the fertilising substance is absorbed by the stigma, led Brongniart in 1826 to examine a great number of pollinated stigmas. He succeeded in establishing the fact that the formation of pollen-tubes is a very frequent occurrence. The want of perseverance in following out his observation and a prepossession in favour of Needham's old theory prevented him from discovering the course of the pollen-tubes all the way to the ovules; he supposed, indeed, that after penetrating into the stigma they open and discharge their granular contents, and he maintained distinctly that these are analogous to the spermatozoids in animals, and are the active part of the pollen. But now Amici addressed himself more earnestly to the question, and in 1830 he not only 
Снар. I.] Investigation of the fertilization-process.

followed the pollen-tubes into the ovary, but also observed that one finds its way into the micropyle of each ovule.

Thus the question was suddenly brought near to its solution, when observers began to wander from the right path in different directions. Robert Brown showed in I 83 I and I 833 that the grains in the pollen-masses of Orchids and Asclepiads put forth pollen-tubes as in other plants, and that fine tubes are found in the ovary of Orchids in which pollination has taken place; but he was in doubt about the connection of these tubes with the pollen-grains, and rather inclined to think that they were formed in the ovary, though possibly in consequence of the pollination of the stigma. Schleiden went wrong in a very different way, and by so doing made the question as prominent in botanical research, as was that of the origin of cells at this time. He published in 1837 some excellent investigations into the origin and development of the ovule before fertilisation, certainly the best and most thorough of the day. He at the same time showed that Brongniart's and Brown's doubts were unfounded, and confirmed the statement of Amici, that the pollen-tubes make their way from the stigma to the ovule, which they enter through the micropyle. But he made them push forward a little too far, for he asserted positively that 'the pollen-tube pushes the membrane of the embryo-sac before it, making an indentation, and its extremity then appears to lie in the embryo-sac. The extremity of the tube now swells out into a round or oval shape, and cell-tissue forms from its contents; the lateral organs, one or two cotyledons, are then produced, the original apical point remaining more or less free and forming the plumule. The portion of the tube underneath the embryo and the fold of the embryosac which envelopes it are divided off sooner or later and disappear, so that the embryo now really lies in the embryo-sac.' This view, which appears to rest on direct observation and is illustrated by figures which answer to the description, corresponds with the old theory of evolution and has a striking 
approximation to the ideas of Morland and Geoffroy; and if it were correct, it would like these imply the necessity of pollination to the formation of seeds that should contain embryos, but at the same time it would do away with that which is the essential point in the sexuality of plants, for the ovule would merely be the spot adapted to the hatching of the embryo formed from the pollen. Schleiden's idea was at once adopted by Wydler, Gelesnow and various other botanists, and especially by Schacht, but the most eminent microscopists withheld their assent. Amici was the first who openly opposed the new doctrine; before the Italian congress of savants at Padua in 1842 he endeavoured to prove that the embryo is not formed at the end of the pollen-tube, but from a portion of the ovule which was already in existence before fertilisation, and that this part is fertilised by the fluid contained in the pollen-tube. But the choice of a gourd, a plant eminently unsuitable for his purpose, prevented his discovering the exact details of the process, and Schleiden did not hesitate to denounce his assertions in I 845 in the plainest terms. But in the next year (I846) Amici produced decisive proof for the views which he had maintained; he showed from the Orchidaceae, which were peculiarly well adapted for such investigations, not only that Robert Brown's doubts above mentioned were without foundation, but, which is the main point, that a body, the egg-cell, is present in the embryo-sac of the ovule before the arrival of the pollen-tube, and that this body is excited by the presence of the pollen-tube to further development, the formation of the embryo. $\mathrm{He}$ gave a connected account on this occasion for the first time of the whole course of these processes from the pollination of the stigma to the perfecting of the embryo.

The correctness of the account given by Amici was confirmed in the following year by von Mohl and Hofmeister, the latter of whom described in detail the points which were decisive of the question from a variety of plants, and illustrated them by very beautiful figures in a more copious work, 'Die 
Enstehung des Embryo der Phanerogamen,' Leipzig, I849. Tulasne also came forward in opposition to Schleiden's theory, being thoroughly convinced that there was no actual contact of the pollen-tube with the egg-cell, denying indeed the existence of the egg-cell before fertilisation. Thus a vehement controversy arose on the subject; a prize offered by the Institute of the Netherlands at Amsterdam was awarded to an essay of Schacht's in $185^{\circ}$, which defended Schleiden's theory, and illustrated it by a great number of drawings giving incorrect and indeed inconceivable representations of the decisive points. Von Mohl says very admirably on this occasion ('Botanische Zeitung,' r $86_{3}$, Beilage, p. 7) : 'Now that we know that Schleiden's doctrine was an illusion, it is instructive, but at the same time sad, to see how ready men were to accept the false for the true; some renouncing all observation of their own dressed up the phantom in theoretical principles; others with the microscope in hand, but led astray by their preconceptions, believed that they saw what they could not have seen, and endeavoured to exhibit the correctness of Schleiden's notions as raised above all doubt by the aid of hundreds of figures, which had every thing but truth to recommend them; and how an academy by rewarding such a work gave fresh confirmation to an experience which has been repeatedly made good especially in our own subject during many years past, namely that prize-essays are little adapted to contribute to the solution of a doubtful question in science.' In this case the prize-essay had been refuted before it appeared by von Mohl, Hofmeister and Tulasne. Schacht adhered all the more firmly to Schleiden's theory; after further controversy, in which other writers of less authority took part, Radlkofer published in 1856 a complete review of the question, which fully confirmed Hofmeister's observations, and gave incidentally an account of Schleiden's views in the altered form which they had by that time assumed; this account showed in fact that Schleiden had completely retracted his former opinions, and in this retracta- 
tion Schacht was soon after compelled to follow him, having become acquainted with facts observed in the ovule of Gladiolus, which were obviously irreconcilable with Schleiden's theory.

Hofmeister had from the first directed special attention to the questions, whether any bodies are found in the pollen-tube which answer in any way to spermatozoids, and whether any opening can be perceived at the end of the tube. He found indeed forms in Coniferae in $185 \mathrm{I}$, which reminded him of the male organs of fertilisation in the higher Cryptogams ; but the pollen-tube was closed both in them and in the rest of the Phanerogams, in which moreover its outer coat attains to a considerable thickness. There remained therefore only the hypothesis, that a fluid substance passes through the walls of the pollen-tube and of the embryo-sac and effects the fertilisation of the egg-cell ; thus it was not the theory of preformation of the last century, to which Brongniart still adhered, but the view represented by Koelreuter, which ultimately proved to be nearer the truth, though it may be said that all that remained of that view was, that the fertilising substance in the Phanerogams is a fluid. The granular contents of the pollen-grains, which were supposed to be spermatozoids, have since been partly found to be only innocent starch-grains and drops of oil.

\section{Discovery of Sexuality in the Cryptogams. I $837-1860$.}

By the year I 845 no one capable of forming a judgment on the question any longer doubted the existence of different sexes in Phanerogams. But it was not so with the Cryptogams, though a number of facts were acknowledged at this time which seemed to point to the conclusion, that a moment arrives sooner or later in the course of their development also, when a sexual act is accomplished. But the question had not as yet been systematically studied; no experimental investigations had been made, or observations of such a kind as to demonstrate the necessity of sexual union. 
The great majority of botanists in the second half of the I 8 th century had no longer any doubt that the stamens were organs of reproduction, and they were anxious to prove the existence of similar organs in the Cryptogams ; they rested in this matter on external resemblances and analogies, which they interpreted in a more or less arbitrary manner. The obvious external resemblance between the antheridia and archegonia in Mosses and the sexual organs in the Phanerogams led Schmidel and Hedwig to consider them to be stamens and ovaries, and the conjecture was correct, though the true nature of the mossfruit had to be learnt in another way. Micheli, Linnaeus and Dillen, trusting still more to external appearance and with slight knowledge of these plants, had before this taken the fruit for a male flower, and in the case of the rest of the Cryptogams the best botanists were only feeling their way in the daik with no certain experience to guide them. It is not necessary to give a particular account of the views which originated in this way; one or two may be mentioned by way of example. Koelreuter regarded the volva of Mushrooms, Gleditsch and Hedwig certain tube-like cells in their lamellae, as the male organs of fertilisation. Gleichen took the stomata, Koelreuter the indusium, Hedwig even the glandular hairs of Ferns for anthers. It was not yet suspected that the course of development and the whole morphology of the Cryptogams could not be so compared with that of the Phanerogams; correct and incorrect assumptions with regard to the sexual organs of the Cryptogams were alike devoid of scientific value, being mere guesses and vague conjectures. Nor was the state of things much better even in the first years of the rith century; and if by that time a number of occasional observations had been made which could afterwards be turned to scientific account, these were as yet only isolated facts without scientific connection, and every one was at liberty to concede or to refuse sexual organs to the Cryptogams generally at his own discretion. Meanwhile observations gradually accumu- 
lated, and towards $\mathrm{r} 845$ it began to be possible by critical examination of them to arrive at something like a clearer understanding of this part of botany. The majority of botanists readily accepted Schmidel's and Hedwig's opinion with respect to the Mosses; Vaucher had as early as 1803 maintained that the long-known conjugation of Spirogyra was a sexual act; Ehrenberg observed in 1820 the conjugation of a Mould, Syzygites; Bischoff and Mirbel explained the organisation of the antheridia of the Liverworts in 1845 , while Nees von Esenbeck saw the spermatozoids of Sphagnum in 1822 and Bischoff those of Chara in 1828 , though they were at first taken for Infusoria, an opinion maintained by Unger as late as 1834. But it was Unger ${ }^{1}$, who in 1837 , after careful study of the spermatozoids of the Mosses in 1837 , declared them to be the male organs of fertilisation; in 1844 Nägeli discovered corresponding forms on the prothallium of Ferns, which had till then been called a cotyledon, and in 1846 the spermatozoids of Pilularia, the products of the small spores which Schleiden had explained to be the pollen-grains of that plant.

These facts were of the highest importance, but little was to be made of them as long as the female organ in the plants in question, the Mosses excepted, was unknown, and meanwhile it was only the resemblance between vegetable and animal spermatozoids which led to the conjecture, that the one had the same sexual significance as the other.

Light was suddenly thrown upon the subject, when Count Lesczyc-Suminsky discovered in 1848 on the supposed cotyledon (prothallium) of Ferns both the antheridia and the peculiar organs, inside which the embryo or young fern is formed. Though the statements respecting the structure and development of these female organs and of the embryo were inaccurate in some important points, yet the place was now indicated

1 The authorities for these statements are collected by Hofmeister in 'Flora,' I857, p. I 20, etc. 
where it might be presumed that the fertilisation by the spermatozoids takes place; and as the history of the germination of the rest of the vascular Cryptogams was to some extent known through the earlier labours of Vaucher and Bischoff, the organs of fructification of these plants might now be sought, where they are really to be found. But an erroneous idea respecting the meaning of the small spores of the Rhizocarps propounded by Schleiden had first to be put out of the way, and this was done by an appeal to the discovery of Nägeli mentioned above and by the investigations of Mettenius. Then in 1849 Hofmeister supplied a connected description of the germination of Pilularia and Salvinia, in which the decisive points as regards the sexual act were clearly set forth, and the connection of the spermatozoids with the fertilisation of the eggcells in the archegonium was established. He did the same for Selaginella, which is very unlike the Rhizocarps and Ferns, and in which the spermatozoids are developed from smaller spores, and fertilise the egg-cells in archegonia formed in the prothallium of the large spores. By comparing the processes of germination in these plants with those of Ferns and Mosses, he succeeded in throwing entirely new light on the whole of the morphology of these classes of plants, and thus made it possible for the first time to compare them with one another and with the Phanerogams, and to form a right estimate of the sexual act in the Muscineae and Vascular Cryptogams in its relation to the history of the development of these plants. Hofmeister arrived at the following conclusion from his observations in 1849: "The prothallium in the vascular Cryptogams is the morphological equivalent of the leaf-bearing Moss-plant, while the leafy plant of a Fern, of a Lycopodium and a Rhizocarp answers to the capsule of the Moss. In Mosses as in Ferns there is an interruption of the vegetative development by sexual procreation, an alternation of generations; this takes place in the Vascular Cryptogams very soon after germination, in the Mosses much later.' The vast importance of this dis- 
covery to systematic botany has been already noticed. The conception of these relations developed by Hofmeister was not less important to the doctrine of the sexuality of plants; it swept away at one stroke all the old false analogies between Phanerogams and Cryptogams and brought to light the real agreement; Hofmeister had detected in the archegonium of the Cryptogams the body which is developed there, as in the ovule of the Phanerogams, into an embryo after fertilisation, namely the germinal vesicle or egg-cell. Here was the point of departure for all further systematic comparison in the sexual propagation of Cryptogams and Phanerogams. All beside was of secondary importance, even the fact, that the fertilisation of the egg-cell in the Cryptogams is not effected by a pollentube, but by spermatozoids. It was now easy to show the corresponding relations of generation in the other cases which Hofmeister had not yet observed.

Hofmeister's statements and conclusions respecting Selaginella and Isoetes were confirmed and some additions made to them by Mettenius in 1850 , and in $185^{1}$ appeared Hofmeister's exhaustive work 'Vergleichende Untersuchungen,' in which the mode of production of the embryo in Coniferae was represented as an intermediate form between those of Phanerogams and Cryptogams. Further contributions were made to the knowledge of the subject; Henfrey confirmed Hofmeister's results in the case of Ferns; Hofmeister himself and Milde observed in 1852 the history of fertilisation in Equisetaceae, and the former supplied at the same time a more complete account of the development of Isoetes; in 1855 he described the decisive points in Botrychium and Mettenius in 1856 those in Ophioglossum.

The processes of development before and after fertilisation were now cleared up by all these discoveries, but the direct observation of the act of fertilisation was still wanting. Hofmeister ('Flora,' 1857 , p. 122) describes the state of affairs in the following terms: "While numerous investigations had 
thrown a clear light on the character of the male and female organs, and on the way in which the embryo is formed by repeated division of the egg-cell present before fertilisation, we continued quite in the dark respecting the particular nature of the fertilisation. Observation and experiment had established the fact, that the influence of the spermatozoids on the archegonia was required to produce an embryo in the latter. Female moss-plants ${ }^{1}$ separated from the male, macrospores in the Vascular Cryptogams separated from the microspores, had in all cases proved unproductive; but it was not even certainly known to what point in the female organ the spermatozoids force their way. It is true that Lesczyc and after him Mercklin had seen the entry of moving spermatozoids into the mouth of archegonia in Ferns; but Lesczyc's account of the part which he supposed them to play there afterwards, was proved to be an illusion. I had myself observed motionless spermatozoids halfway down the neck of archegonia of an Equisetum; but nothing was to be learnt of the manner in which the spermatozoid affects the egg-cell. Then it happened that in the spring of $185 \mathrm{I}$, being engaged in observing the development of the organs of vegetation of Ferns, I repeatedly saw spermatozoids moving about in the basilar cells which enclose the egg-cell in the archegonia of Ferns, and the majority of them even playing about the egg-cell. Their movements were put an end to during the observation by the commencement of changes, which the contents of young vegetable cells which have been cut open usually experience under the prolonged influence of water.' Later observations leave no doubt now that in the Muscineae and Ferns single spermatozoids force their way into the naked egg-cell of the archegonium.

1 W. P. Schimper, in his 'Recherches anatomiques et morphologiques sur les Mousses' of 1850 , had made some important statements respecting the sterility of female moss-plants growing at a distance from male specimens, and proved that the presence of male plants among females that are otherwise barren renders them fruitful. 
The question was first set at rest in the Algae, where the process of fertilisation could be seen directly and without exposing the objects to destructive influences. That sexual propagation occurs in the Algae also had seemed probable, since Decaisne and Thuret in 1845 discovered organs in species of Fucus, and Nägeli in 1846 in Florideae, which scarcely admitted of any other explanation. Alexander Braun also had called attention to the formation of two kinds of spores in a large number of freshwater Algae. But as yet there was only conjecture. Then Thuret proved by experiment in 1854 , that in the genus Fucus the large egg-cells must be fertilised by very small swarming spermatozoids, in order to set up germination ; both organs can be collected separately and in numbers in this genus, and be brought together at pleasure; Thuret even succeeded in obtaining hybrids. Pringsheim first observed in I 855 the formation of spermatozoids in the little horns of Vaucheria and established the fact that spores capable of germination are not formed unless the spermatozoids approach the egg-cell. To Thuret's statements he added the very important one, that the remains of spermatozoids may be recognised on the surface of the contents of the fertilised egg-cell of Fucus, which is already surrounded by a membrane. About the same time Cohn published his observations on Sphaeroplea annulina, which confirmed the fact of the approach of the spermatozoids to the egg-cells, which consequently, as in Fucus and Vaucheria, form a cell-wall and are rendered capable of further development.

Still the decisive observation had not yet been made; no one had yet seen how the two fertilising elements behaved at the moment of fertilisation. Pringsheim had the good fortune to make this observation in one of the commonest of fresh water Algae, Oedogonium. There he saw the moving spermatozoid first come into contact with the protoplasmatic substance of the egg-cell, and then force its way into it, blend with it and dissolve. And thus the first observation was made, which 
proved decisively that a real intermixture takes place of the male and female elements of fertilisation; this important fact was confirmed by De Bary in the same year.

Now that it was once established, that fertilisation in Cryptogams consists in the blending together of two naked bodies of protoplasm, the spermatozoid and the egg-cell, it was reasonable to conclude that conjugation in Spirogyra and generally in Conjugatae, was an act of fertilisation, only in this case the two fertilisation-elements are not of different size and shape, but similar in appearance. To this conclusion De Bary arrived in 1858 in his monograph of the Conjugatae. This extension of the idea of fertilisation to cases in which the uniting cells are to outward appearance alike, was of special value to the theory of sexuality, as was seen in the sequel, when other forms of fertilisation were observed which made it necessary still further to extend the idea of sexuality. In 1858 Pringsheim discovered arrangements for fertilisation in another group of Algae, the Saprolegnieae, which to outward appearance at least departed widely from those hitherto known in the lower plants.

Thus between the years i 850 and i 860 a number of fundamental facts were discovered, and were afterwards confirmed and extended by fresh observations in the course of the following years. It does not fall within the limits of this work to notice the many discoveries that were made in this part of botanical science after 1860 ; we will only remark, that between I 860 and I 870 the processes of fructification were observed by Thuret and Bornet in Florideae, and especially by De Bary and his pupils in Fungi, in some of which very peculiar forms were brought to light. No doubt any longer exists that difference of sex prevails generally in the Thallophytes also, though it is still an open question, whether it may not be wanting in some of the very simplest and smallest kinds.

One of the most important results of these investigations is obviously the striking resemblance between many of 
the processes of fertilisation in Cryptogams and in the lower animals; here is another confirmation of the fact, often brought out in other ways by modern zoological and botanical research, that the points of resemblance in the vegetable and animal kingdoms appear most plainly, if we compare together the simplest forms to be found in both; we have in this fact a plain proof also, that both kingdoms have been developed from like common elements, as the theory of descent implies. With respect to the true nature of fertilisation itself, which is evidently a similar process in the main in animals and plants, we can only say at present, that it amounts in all cases to a material blending together of the contents of two cells, neither of which is capable of further development by itself, while the product of the combination is not only capable of such development, but unites in itself the characteristics of the two parent forms and transmits them to its descendants. That fertilisation is not the intimate union of two bodies possessing a definite form, but that the male fertilising substance at least may be a simple fluid, appears to be distinctly shown by the process in Phanerogams; and we may assume, that in Cryptogams also, the sexual act is not affected by the form of the fertilisationelements, though a certain shape and power of movement is necessary for the conveyance of the fertilising substance to that which is to be fertilised. 


\section{CHAPTER II.}

History of the Theory of the Nutrition of Plants.

$1583-1860$.

THAT plants take up certain substances from their environment for the purpose of building up their own structures could not be a matter of doubt even in the earliest times; it was also obvious, that movements of the nutrient material must be connected with this proceeding. But it was not so easy to say, what was the nature of this food of plants, in what manner it finds its way into and is distributed in them, and what are the forces employed; it was even for a long time undecided, whether the food taken up from without suffers any change inside the plant, before it is applied to purposes of growth. Such were the questions which had engaged the attention of Aristotle, and which formed the chief subject of Cesalpino's physiological meditations.

But the questions respecting the nutrition of plants acquired a much more definite shape in the latter half of the 17 th century, when the various phenomena of vegetation began to be more closely observed, and some attempt was made to understand their relations to the outer world. Malpighi, the founder of phytotomy, was the first who undertook to explain the share which belongs to the different organs of the plant in the whole work of nutrition; guided by analogy, he perceived that the green leaves are the organs which prepare the food, and that the material so prepared by them passes into all parts of the plant, there to be stored up or employed for purposes 
of growth. But this gave no insight into the nature of the substances from which plants prepare their food. On this point Mariotte endeavoured to give such information as could be obtained from the chemistry of his day; and he has the merit of having shown, in opposition to the old Aristotelian notion, that plants convert the food-material which they derive from the ground into new chemical combinations, while the earth and the water supply the same elements of nutrition to the most different kinds of plants. It could not escape the notice of physiologists even of that time, that the water which plants take up from the ground introduces into them but very small quantities of matter in solution. Van Helmont in the first half of the 17 th century had shown this by an experiment, the results of which, however, led him to think that plants were able to produce both the combustible and incombustible parts of their substance from water. Hales at the beginning of the I 8 th century formed a different opinion, being led by the evolution of the gases in the dry distillation of plants to conclude, that a considerable part of their substance was absorbed in a gaseous form from the atmosphere.

The views propounded by Malpighi, Mariotte, and Hales contained the most important elements of a theory of the nutrition of plants; fully understood they would have taught that one part of the food of plants comes from the earth and the water, and another part from the air; that the leaves change the materials thus obtained in such a manner as to produce from them the substance of plants and to apply this to the purposes of growth; but the ideas were not combined in this way, for during some years after their time botanists were chiefly engaged in observations on the movement of the sap in plants, and they arrived even on this point at very obscure and even contradictory results, because they overlooked the function of the leaves which had already been recognised by Malpighi. All insight not only into the chemical processes in the nutrition of plants, but also into the mechanical laws of 
the movement of the sap, and generally into the whole internal economy of plants, depends on a knowledge of the fact, that it is only the cells which contain chlorophyll, and therefore in the higher plants the leaves chiefly as consisting largely of such cells, which have the power of converting the gaseous food supplied by the atmosphere into the substance of the plant with the aid of the materials taken up from the soil. This fact is of fundamental importance to the whole theory of the nutrition of plants ; it is only by a knowledge of it that we can explain the movement of material connected with nutrition and growth, the dependence of vegetation on light, and to a great extent also the function of the roots.

But this principle could not be discovered till the new chemical system founded by Lavoisier took the place of the old phlogistic chemistry, and it is remarkable that the discoveries, which laid the foundation of modern chemistry in the period between 1760 and $I_{7} 80$, contributed essentially to the establishment at the same time of the modern doctrine of the nutrition of plants. Ingen-Houss, in reliance on Lavoisier's antiphlogistic views on the composition of air, water, and the mineral acids, succeeded in proving that all parts of plants are continually absorbing oxygen and forming carbon dioxide, but that the green organs at the same time under the influence of light absorb carbon dioxide and exhale oxygen; and as early as 1796 he considered it probable that plants obtain the whole mass of their carbon from the carbon dioxide of the atmosphere. Soon after (I804) de Saussure proved, that plants, while they decompose carbon dioxide, increase in weight by a greater amount than that of the carbon which they retain, and that this is to be explained by the fact that they at the same time fix the elements of water. He likewise showed that the small quantities of saline compounds, which plants take up from the soil, are a necessary part of their food, and that it was at least probable, that the nitrogen of the atmosphere does not contribute to the formation of nitrogenous substances in plants. Senebier 
had before insisted on the fact, that the decomposition of carbon dioxide under the influence of light only takes place in green organs.

Thus the most important points in the nutrition of plants were discovered by Ingen-Houss, Senebier and de Saussure. But, as often happens in the case of discoveries of such magnitude, their ideas were for a long time exposed to great misunderstanding. They were better appreciated in France than in any other country; Dutrochet and De Candolle were able to see the importance of the interchange of gases in the green organs to the general nutrition and respiration; but others, and especially German botanists, were not content with these simple chemical processes as the foundation of the whole system of nutrition and consequently of the whole life of the plant; the theory of the vital force, which was elaborated in connection with the nature-philosophy during the first years of the I 9 th century, and was generally accepted by philosophers and physiologists, chemists and physicists, preferred to supply the plant with a mysterious substance for its food, which had its source in the life itself and which it called humus. The most obvious considerations, which must at once have shown that this humus-theory was absurd, were entirely overlooked; and thus in the face of de Saussure's results the food of plants was once more referred entirely to the soil and the roots, as it was in the earliest times; one of the consequences of this humustheory in combination with the vital force was that the ashconstituents of plants were supposed to be merely accidental admixtures or stimulants, or to be directly produced in the plant by the vital force.

In the period between 1820 and 1840 the reaction set in from different quarters against the theory of vital force; chemists succeeded in producing by artificial means certain organic compounds, which had hitherto been regarded as products of that force; Dutrochet discovered in endosmose a process, which served to refer various vital phenomena in 
plants to physico-mechanical principles ; de Saussure and others showed that the heat of plants is a product of respiration, and by 1840 the earlier theory of a vital force might be looked upon as antiquated and obsolete. It remained to restore to their rights the observations of Ingen-Houss and de Saussure, which under the influence of that theory and of the notions respecting the humus had been so utterly misconstrued. Liebig set aside the humus-theory in 1840 , and referred the carbon of plants entirely to the carbon dioxide of the atmosphere, and their nitrogenous contents to ammonia and its derivatives ; he claimed the components of the ash as essential factors in the nutrition, and taking his stand on the general laws of chemistry endeavoured to obtain chiefly by the method of deduction an insight into the chemical processes of assimilation and metabolism. The whole theoretical value of the facts discovered by Ingen-Houss, Senebier and de Saussure was first made apparent by the connection which Liebig succeeded in establishing between the phenomena of nutrition. The doctrine of nutrition burst suddenly into new life; firm ground was gained, and the botanist, no longer distracted by the difficulties raised by the vital force but resting on physical and chemical principles, might now resume the task of investigation. Oxygen-respiration denied by Liebig was first of all re-established by von Mohl and others. Liebig's views on the source of nitrogen in plants and on the importance of the ash-constituents rested chiefly on general considerations and observations and on calculation, and had now to be tested by systematic investigation and especially by experiments on vegetation in individual plants. And here the place of honour must be assigned to Boussingault, who pursued the path of pure induction as contrasted with Liebig's deductive mode of proceeding, gradually improved the methods for experimenting on vegetation, and soon succeeded in so producing plants in a purely mineral soil free from all humus, that he finally settled the question of the derivation of the carbon from the atmosphere 
and of the source of the nitrogen also. He showed from the plants thus artificially nourished, and with due consideration of the many sources of error which beset the question, that the uncombined nitrogen of the atmosphere does not contribute to the nutrition of plants, but that a normal increase in the nitrogenous substances in a plant takes place when the roots take up nitrates as well as the necessary constituents of the ash.

With the exception of some doubts which still remained respecting the necessity of certain constituents of the ash, such as sodium, chlorine and silicic acid, the source of the materials which take a part in the chemistry of the nutrition of plants was known before 1860 ; but the knowledge obtained with regard to processes in the interior of the plant, the origination of organic substances in the processes of assimilation, and the further changes which they undergo was still fragmentary and uncertain, and led to no general and conclusive results.

\section{Cesalpino.}

Aristotle had sought to determine the nature of the materials which plants take up as food, and had laid down the proposition, that the food of all organisms is not simple but composed of various substances. This view was correct, but he united with it the erroneous notion, that the food of plants is elaborated beforehand in the earth, as in a stomach, and is made applicable to purposes of growth, so as to exclude the necessity of any separation of excrements in the plant; this error was refuted by Jung, as we shall see, but nevertheless it continued to live as late as into the $\mathrm{I} 8$ th century, and ultimately quite spoilt Du Hamel's theory of nutrition.

Cesalpino, whom we have learnt to regard as a faithful and gifted disciple of Aristotle, directed his speculations to the mechanical rather than to the chemical side of the question, and chiefly tried to explain the movement of the nutrient sap in plants. He had a larger stock of material drawn from 
experience at his disposition than his master, and it is instructive therefore to make a nearer acquaintance with his views, because they show how far the old philosophy was in a condition to turn better empirical knowledge than Aristotle possessed to a satisfactory use; they will also show that Cesalpino's first essays led him to views which can no longer be said to be strictly Aristotelian.

In the second chapter of the first book of the work from which we have already quoted, 'De plantis libri XVI,' ${ }^{5} 8_{3}$, he raises the question, in what way the food of plants is taken in and their nutrition accomplished. In animals we see the food conveyed from the veins to the heart, which is the laboratory of the warmth of the body, and after it has been finally perfected there, spread abroad through the arteries into all parts of the body; and this is effected by the operation of the force (spiritus) which is generated in the heart from the food. In plants on the contrary we see no veins, or other channels, nor do we feel any warmth in them, so that it is difficult to understand how trees grow to so great a size, since they seem to have much less natural heat than animals. Cesalpino explains this enigma by saying, that animals require much food for maintaining the activity of the senses and the movements of their organs. The larger quantity of animal food also requires larger receptacles, namely the veins. Plants on the other hand need less food, because this is only used for purposes of nutrition, or to a very small extent for the production of internal heat as well, and therefore they grow more vigorously and bear more fruit than animals. At the same time plants are not without internal heat, though it cannot be perceived by the touch because all objects seem cold to us, which are less warm than our organ of feeling. That plants moreover have veins, though only narrow ones in accordance with the small mass of their food, is shown by those which yield a milky juice, such as Euphorbia and Ficus, which when cut bleed like the flesh of animals; Cesalpino adds 'and this is 
very frequent also in the vine,' which shows that he made no distinction between milky juice and the exuding water of the weeping vine-stock. These narrow veins cannot be seen on account of their fineness; but in every stem and in every root things may be discerned which like nerves in animals can be split longitudinally and are called the nerves of the plant, or also certain thicker things, such as those which branch in most leaves and are there called veins. These should be considered as food-passages and as answering to the veins in animals; but plants have no main vein like the vena cava in animals, but many fine veins pass from the root to the heart of the plant (cor, root-neck, see above, Book I. chap. 2), and ascend from it into the stem; for it was not necessary that the food should be collected in a common receptacle in plants, as it is in the heart in animals, where this is necessary for the production of the spiritus, but it was sufficient that the fluid in plants should be changed by contact with the medulla cordis (in the root-neck), as it is changed in animals in the marrow of the brain or in the liver; and in these organs the veins are very narrow, as they are in plants.

Since plants have no sense-perception, they cannot seek their food like animals, but they draw up the moisture from the ground into themselves in a way of their own; but it is not easy to see how this takes place. Cesalpino, in trying to explain this, gives us a glimpse into the physics of the day, and we observe also to our surprise an attempt made to explain phenomena in living creatures by physical laws, a step beyond the limits of Aristotelian modes of thought and in the right direction. It is not the ratio similitudinis, which draws iron to the magnet, that can cause the attraction of the juice by the roots, for then the smaller would be drawn to the larger; and if the attraction of the fluid of the earth by the roots were the same thing as the attraction of the iron by the magnet, the moisture of the earth would draw out the juice from the plant, which is just what does not happen. Nor can 
it be the ratio vacui ; for since not moisture only but air also is contained in the earth, the plant would be filled not with juice but with air. But Cesalpino hits upon a third kind of cause by which juices may be drawn into the plant. Do not many dry things, he says, in accordance with their nature attract moisture, as linen, sponge and powder, while others repel it, as the feathers of many birds and the herb Adiantum, which are not wetted even when dipped in water; but the former absorb much water, because they have more in common with it than with air ; of this kind Cesalpino thinks those parts of plants must be, which the nourishing soul employs to take in food. Therefore these organs are not traversed by a continuous canal such as the veins in animals, but formed like the nerves of a fibrous substance; and thus the power of suction (bibula natura) conveys the moisture continually to the place, where the principle of internal heat is placed, just as may be seen in the flame of a lantern, to which the wick continually conducts the oil. The absorption of the moisture is also increased by the outer warmth, for which reason plants grow more vigorously in spring and summer.

That Cesalpino had no suspicion of the use of the leaves in the nutrition of plants appears incontestably from his repeating the Aristotelian idea, that the leaves are only for the protection of young shoots and fruits from air and sun-light; this idea is no result of speculation, but came simply from observing a vineyard in a hot country.

2. First INDUCTIVE EXPERIMENTS AND OPENING OF NEW POINTS OF VIEW IN THE History OF THE TheORY OF the Nutrition of Plants.

All that Aristotle and his school, Cesalpino not excepted, are able to tell us about the phenomena of vegetable life, was the result of the most every-day observations, none of which were critically and exactly tested to ascertain their actual correctness, 
while the larger part of their physiological axioms were not derived from observations on plants at all, but from philosophical principles, and especially from analogies taken from the animal world.

The first step towards a scientific treatment of the doctrine of nutrition was an enlargement and critical examination of the materials to be gained from experience; nor were any difficult observations or experiments needed to discover contradictions between the truths of nature and the old philosophy; all that was necessary was to look into things more closely and to judge of them with less prejudice.

In this way Jung was led to oppose one important point of the Aristotelian account of nutrition. In the second fragment of his work 'De plantis doxoscopiae physicae minores' is to be found a remark, which is evidently directed against the notion that plants receive their food already elaborated from the earth, and therefore give off no excrements ${ }^{1}$. Plants, says Jung in accord with Aristotle, appear not to need a thinking soul (anima intelligente), which would be able to distinguish wholesome from unwholesome food, and Aristotle therefore provided them with food which had already been perfectly prepared in the earth. But Jung takes another view founded on actual observation. It is very possible, he says, that the openings in the roots which take in liquid matter are so organised, that they do not allow every kind of juice to enter, and who can say that plants have the peculiarity of only absorbing what is useful to them, for like all other living creatures they have their excreta, which are exhaled through the leaves, flowers, and fruits. But among these he reckons the resins and other exuding liquids, and says that it is possible after all that a large part of the juices of plants escapes by imperceptible evaporation, as happens in animals.

${ }^{1}$ See the Fragments of Aristotelian phytology in Meyer's ' Geschichte der Botanik,' i. p. I20. 
ChAP. II.]

According to Aristotle's view the plant itself was quite passive in the work of nutrition; since food was offered to it which had been already prepared for it in the earth, growth was to some extent merely a process of crystallisation unaccompanied by chemical change. In pointing to the formation of excreta Jung on the contrary ascribed a chemical activity to the plant, and by supposing that the organisation of the root was such as to prevent the entrance of certain matters and to favour that of others, he made the plant co-operate in its own nourishment, though he did not assume that it needed a thinking soul for this purpose.

Johann Baptist van Helmont', physician and chemist, and a contemporary of Jung, took up a position still more decidedly opposed to Aristotelian doctrines. He rejected the four elements of that philosophy, and regarding water as a chief constituent of all things he considered that the whole substance of plants, the mineral parts (the ash) as well as the combustible, was formed from water. 'Thus while Aristotle made the component parts of plants be introduced into them by water in a state ready for use, Van Helmont, on the contrary, ascribed to the plant the power of producing all kinds of material from water. It would scarcely have been necessary to mention this resistance to old dogmas, originating as it did in the notions of the alchemists, if Van Helmont had not made an attempt to establish his views by experiment; this was the first experiment in vegetation undertaken for a scientific purpose of which we have any information, and it was repeatedly quoted by many later physiologists, and employed in support of their theories. He placed in a pot a certain quantity of earth, which when highly dried weighed two hundred pounds; a willow-branch

$1 \mathrm{~J}$. B. van Helmont was born at Brussels in 1577 , and died at Villvorde near Brussels in $16_{44}$. He was a leading representative of the chemistry of his day. Kopp, in his 'Geschichte der Chemie,' $1_{43}$, i. p. I I 7 , has given a full account of his life and labours. 
weighing five pounds was set in this pot, which was protected by a cover from dust, and daily watered with rain-water. In five years' time the willow had grown to be large and strong, and had increased in weight by a hundred and sixty-four pounds, though the earth in the pot, when once more dried, only showed a loss of two ounces. Van Helmont concluded from this experiment that the considerable increase of weight in the plant had been gained entirely at the cost of the water, and consequently that all the materials in the plant, though distinct from water, nevertheless come from it.

These objections to Aristotelian teaching on the part of Jung and Van Helmont remained isolated and unproductive. But an incentive to new investigations in vegetable physiology was supplied from a different quarter, and its influence lasted till far into the I8th century. This was the suggestion, that not only does a nutrient sap taken up by the roots ascend to the leaves and fruits of plants, but that there is also a movement of the same sap in the opposite direction in the rind. But this idea assumed from the first two different forms. Some botanists, evidently resting on the analogy of the circulation of the blood in animals, supposed that there was also an actual circulation of the sap in plants; others on the contrary were content with supposing that while the watery sap absorbed by the roots rises in the wood, an elaborated sap capable of ministering to growth moves in the rind, the laticiferous vessels, and the resin-ducts. The two views were at a later time repeatedly confounded together, and those who refuted the first believed that they had refuted the other also. It appears that a physician from Breslau, Johann Daniel Major ${ }^{1}$, Pro-

1 J. D. Major, who was born at Breslatu in 1639 , and died at Stockholm in I693, is quoted by Christian Wolff, as well as by Reichel ('De vasis plantarum,' I $75^{8}, \mathrm{p} .4$ ) and others, as the founder of the theory of circulation, which he propounded in $166_{5}$ in his 'Dissertatio Botanica de planta monstrosa Gottorpiensi,' etc. Kurt Sprengel ("Geschichte der Botanik, ii. p. 7) classes him also among the defenders of the doctrine of palingenesia, a 
fessor in Kiel, first gave expression to the opinion, that there is a circulation of the nourishing substance in plants as in animals; and from this time to the end of the $\mathrm{r} 8$ th century the circulation of the juices of plants was a favourite subject of discussion, but more often chosen by the impugners of the doctrine than by its defenders.

The better form of the idea, namely, that there is a returnmovement of material towards the root, combined with the view, that the leaves are the organs which produce the substances required for growth from the crude material supplied to them, was expressed by Malpighi as early as I77 I in the shape of a wellconsidered theory. In his 'Anatomes plantarum idea' of that year he devotes the last pages to a short account of the theory of nutrition, as he understood it. He regarded the fibrous constituents of the wood as the organs for conducting the sap taken up by the roots, and the vessels as air-passages, which he named tracheae on account of their resemblance to the tracheae of insects. He was in doubt whether the air came from the earth through the roots, or from the atmosphere through the leaves, for he had never succeeded in finding openings for the entrance of air in the roots or the leaves; but he thought it more probable that the air is absorbed by the roots, because they are well supplied with tracheae, and air has besides a tendency to ascend. Beside these fluid-conducting fibres and air-conducting tracheae in the wood he called attention to the existence of special vessels, which conduct peculiar juices in many plants, as the laticiferous vessels, gum-passages, and turpentine-canals.

Respecting the movement of the juices, he notices that the direction may be reversed, because shoots planted upside down send out roots into the earth from what is organically their upper end, and grow into trees; and though they do not grow vigorously, yet the experiment proves that the movement of the sap in them is in the reverse direction.

superstitious belief in the reproduction of plants and animals from their ashes, which was used to prove the resurrection of the dead. 
After these preliminary remarks he proceeds to prove, that it is in the leaves that the crude juices of nutrition undergo the change which fits them for the maintenance of growth. The way in which Malpighi arrives at this view is as simple as it is original. He considers the cotyledons of young plants to be genuine leaves (in leguminibus seminalis caro, quae folium est conglobatum), as is shown in the gourd, where the cotyledons grow into large green leaves. Liquid is conveyed to them through the radicle, and a portion of the substances which they contain passes from them into the plumule to make it grow, which it will not do if the cotyledons are removed; hence he concludes that all other leaves also are intended to elaborate (excoquere) the nutritive juice contained in their cells, which the woody fibres have conveyed to them. The liquids mingled together in their long passage through the network of fibres are changed in the leaves by the power of the sun's rays, and blended with the sap before contained in their cells, and thus a new combination of the constituent parts is effected, transpiration proceeding at the same time; he compares the whole process with that which goes on in the blood of animals.

We see that Malpighi's view of the function of the leaves in nutrition approaches very closely to the truth, as closely indeed as was at all possible in the existing condition of chemical knowledge. He was induced by the results of anatomical investigation to carry this view farther and indeed correctly; he supposed that the parenchymatous tissue of the rind acts in the same way as the leaves; but he went a step too far in assigning the function of the leaves to the colourless parenchyma also, which only serves for the storing up of assimilated matter. He says we must ascribe a character similar to that of the leaf-cells to the corresponding cells in the rind and to those also which lie transversely in the wood (the medullary and cortical rays), and that it is not unreasonable to conclude that the food of the plant is elaborated and stored up in these cells. As he makes no sharp distinction between elaboration and 
mere storing up, he ascribes the function of the leaves to the parenchyma of fleshy fruits also and to the scales of bulbs; he concludes from the exudations from stumps of trees and from the cut surfaces of other parts of plants, that they are filled with reserve-matter (asservato humore turgent).

Thus the essential points in Malpighi's theory of nutrition in the year 1671 were, that the vessels of the wood are primarily air-conducting organs, that the leaves elaborate the crude sap for purposes of growth, that the sap so elaborated is stored up in different parts of the plant, and that the fibrous elements of the wood convey upwards to the leaves the crude materials of nutrition which are absorbed by the roots. No mention is made of a circulation of juices, comparable to the circulation of the blood, though this idea was in later times often imputed to him ; and we find by his later remarks, that while he was in no doubt as to the elementary organs which convey the ascending sap, he confined himself to conjecture with respect to the way by which the sap elaborated in the cell-tissue of the leaves, rind and parenchyma generally is carried on its further course. But he was in no doubt about the direction of that course ; he believed that this sap forces itself downwards through the stem into the roots, and upwards in the branches above the leaves and so into the fruit. Thus Malpighi had formed a more correct idea of the movement of assimilated matter than the majority of his successors who introduced the very unsuitable expression, 'descending sap.' He further thought it probable that the elaborated sap passes through the bast-bundles ${ }^{1}$, but without a continuous flux and reflux (absque perenni et considerabili fluxu et refluxu); that it rests to some extent in the laticiferous vessels, but that it is also driven sometimes, when occasion requires, by transpiration and external causes into the higher

${ }^{1}$ He says, 'in mediis vasculis reticularibus,' which when taken in connection with his general histology, must be understood to mean the bastbundles. 
parts of the plant, where it is the means of maintaining growth and nutrition. These later remarks also are better than much that was said about the movement of the sap in the $\mathrm{r} 8$ th and even in the Igth century, and at all events they prove that to speak of Malpighi as a defender of the circulation of the sap in Major's sense, as was often done in later times, was an entire misunderstanding of his views.

Malpighi published his theory in a brief and connected form in $\mathrm{r}_{7} \mathrm{I}$; it appeared again further worked out in detail in the fuller edition of the Phytotomy in 1674 ; he attributed a special value to his discovery, that plants require air to breathe as much as animals, and that the vessels of the wood answer in function to the tracheae in insects and to the lungs in other animals; he recurs also several times to the importance of leaves as organs for the elaboration of the food.

If we compare Malpighi's theory of the nutrition of plants with the views of his predecessors, we cannot help seeing, that it was an entirely new creation, in which Aristotelian doctrines had no share. If his successors had apprehended the important and essential points in his doctrine and had striven by experimenting on living plants to support and illustrate them by new facts, we should have been spared many erroneous notions which established themselves in the theory, and made it a perfect chaos of misconceptions. That particular misconception, which we have already mentioned more than once, namely, that Malpighi, like Major and Perrault after him, assumed a continuous circulation of the juices of the plant, necessarily involved an incorrect idea of the function of the leaves; that function was by many later writers either quite neglected, or sought for chiefly in transpiration, the chemical activity of the leaves being quite overlooked.

Malpighi's theory can hardly be said to take into consideration the chemical nature of the food of plants; it is chiefly occupied with the relation of the organs to the main points in the nutritive process; its foundations are for the most part 
laid in the anatomy of the plant. Grew, who in all essential points adopted Malpighi's views, but without doing much to advance them by his lengthy discussions on particular questions, made some attempt to extend the knowledge of the chemistry of the subject; but his notions were entirely borrowed from the corpuscular theory of Descartes, and he may be said to have constructed his own chemical processes; the consequence was that he usually overlooked the points that were of fundamental importance, and brought nothing to light that could assist the further development of the theory of nutrition. But there is another writer, whose name is in the present day known to few in the history of vegetable physiology, but whose ideas on the chemistry of plants are of great interest. This writer is MARIOTTE ${ }^{1}$, the discoverer of the well-known law of gases, one of the greatest physicists of the latter half of the 17 th century, who also enriched the physiology of the human body with some valuable discoveries. We have a tolerably copious treatise of Mariotte's in the form of a letter to a M. Lantin in the year 1679 , to be found in the 'CEuvres de Mariotte,' Leyden, I 7 I 7, under the title, 'Sur le sujet des plantes.' It is highly instructive to gather from this letter the ideas of one of the most famous and ablest of the natural philosophers of that day on chemical processes and conditions in the nutrition of plants, a few years after the appearance of Malpighi's great work and about the time that Grew's Phytotomy was being published. It is to be expected that Mariotte should give but an incidental and superficial attention to the more delicate structure of

1 The date of the birth of Edme Mariotte is not known. He was a native of Burgundy, and lived in Dijon at the time of his earliest scientific labours. He was an ecclesiastic and became Prior of St. Martin sous Beaune near Dijon; he was a Member of the Academy of Sciences in Paris from its foundation in 1666, and was one of the first Frenchmen who experimented in physics and applied mathematics to them. He died in Paris in 1684 ('Biographie Universelle'). 
plants; but we are compensated for this by his making us acquainted with everything fundamentally important and new which could at that time be said on the chemistry of the food of plants. Speaking of the 'elements' or 'principles' of plants, Mariotte propounds three hypotheses. The first is, that there are many immediate principles (principes grossiers et visibles, evidently what we should call proximate constituents) in plants, such as water, sulphur or oil, common salt, nitre, volatile salt or ammonia, certain earths, etc. ; and that each of these immediate constituents is a compound of three or four more simple principles, which have united together into one body ; nitre for instance has its 'phlegma' or tasteless water, its 'spiritus,' its fixed salt, and other things ; common salt in the same way has the like constituents, and it may be assumed with much probability, that these more simple principles also are compounds of parts that differ among themselves, but are too small to be distinguished by any artificial means as to figure or any other characters. Having shown how certain principles unite together, he goes on to say, that he is unwilling to ascribe to them any sort of consciousness (connaissance) by which they seek to unite together; but he thinks that they are endowed with a natural disposition to move towards one another, and to unite closely as soon as they touch one another; though it is very difficult to define the nature of this disposition, it is enough to know that there are many instances of such movements to be found in nature; thus heavy bodies move towards the centre of the earth, and iron to the magnet; nor are these movements more difficult to conceive, than that of the planets in their courses or of the sun round its axis, or that of the heart in a living animal. With this first hypothesis Mariotte places himself, in opposition to the Aristotelian doctrine with its entelechies and final causes which prevailed at that time among botanists and physiologists, upon the firm ground of modern science with its atoms, and its assumption of necessarily active forces of attraction. 
Mariotte's second hypothesis more specially concerns the chemical nature of plants; he supposes that several of his principes grossiers are contained in every plant, and he endeavours first to explain their source; the motes in the air, he says, which when burnt by lightning smell of sulphur, are carried by rain into the earth, and parts of them are taken up into the plant. Moreover distillation in all plants produces a water, which the chemists call phlegma, and also acids and ammonia, and if the residuum is burnt there remains an ash, from which we obtain an earth which is without taste and insoluble in water, and fixed salts ; these salts differ from one another according as they are mixed with more or less acid and ammoniacal spirit or other unknown principles, which the fire could not volatilise. It is not to be wondered at that these principles are found in plants, since they derive their food from the earth which contains them. We see how great has been the advance since the time when Van Helmont believed that he had proved by his experiment, that all the materials in plants come from pure water.

It remained to confront one view of the source of the substances in plants, which was also drawn from the treasurehouse of Aristotelian conceptions, and was still in vogue. It was supposed that the very materials of which the plant is composed were contained in their own form in the earth, and had only to be taken up by the roots. Aristotle had himself said: 'Everything feeds on that of which it consists, and everything feeds on more than one thing; whatever appears to feed only on one thing, as the plant on water, feeds on more than one thing, for earth in the case of the plant is mixed with the water; therefore the country-people water plants with mixtures of things.' This passage might leave some doubt about Aristotle's view, if we did not find the following: 'As many savours as there are in the rinds of fruits, so many it is plain prevail also in the earth. Therefore also many of the old philosophers said, that the water is of as many kinds as the ground through 
which it runs ${ }^{1}$.' These passages taken with those quoted above show that Aristotle made the substances required for the growth of plants reach them from the earth ready elaborated, as has been before observed; and this view, still maintained in Mariotte's time, may yet be met with among those who are ignorant of physiology. It is interesting then to see, how vigorously Mariotte exposes the incorrectness and absurdity of this idea, though he has no new discovery to help him. In his third hypothesis he maintains, that the salts, earths, oils, and other things, which different species of plants yield by distillation, are always the same, and that the differences are due entirely to the way in which these principes grossiers and their simplest parts are united together or separated, and he proves it thus: If a bonchretien pear is grafted on a wild one, the same sap, which in the wild plant produces indifferent pears, produces good and well-flavoured pears on the graft; and if this graft has a scion from the wild pear again grafted on it, the latter will bear indifferent fruit. This shows that the same sap in the stem assumes different qualities in each graft. But still more forcible is his proof of the fact, that plants do not take their substance direct from the earth, but produce it themselves by chemical processes. Take a pot, he says, with seven to eight pounds of earth and grow in it any plant you like; the plant will find in this earth and in the rain-water which has fallen on it all the principles of which it is composed in its mature state. You may put three or four thousand different kinds of plants in this earth; if the salts, oils, earths were different in each species of plant, all these principles must be contained in the small quantity of earth and rain-water which falls upon it in the course of three or four months, which is impossible; for each of these plants would yield in the mature state a dram of fixed salt at least and two drams of

1 See the Fragments of Aristotelian phytology in Meyer's 'Geschichte der Botanik,' i. pp. I I9, I2 j. 
earth, and all these principles together with those which are mixed with the water would weigh at least from two to three ounces, and this multiplied by four thousand, the number of the species of plants, would give a weight of five hundred pounds.

These arguments like those of Jung, and in the main also those of Malpighi, rested on facts which were on the whole as well known in ancient times as in the $\mathrm{r} 7$ th century; but no one had before given heed to considerations, which were in themselves quite sufficient to do away with the Aristotelian teaching on the subject of the nutrition of plants.

In the second part of his letter Mariotte discusses the phenomena of vegetation which depend on nutrition; he compares the endosperm in the seed with the yolk of the egg in animals, and the entrance of the water into the roots with its rising in capillary tubes; he takes the milky juice to be the nutrient sap and compares it with arterial blood, the other watery juices answering to venous blood. He says something quite new about the pressure of the sap; he notices the high pressure at which the sap stands in plants, and concludes from it that there must be contrivances in them, which allow of the ingress of the water but not of its egress. The existence of the pressure is well demonstrated by the outflow from plants which contain milky juice when they are wounded, and is compared with the pressure on the blood in the veins. Equally striking is his further conclusion, that the pressure of the sap expands the roots, branches, and leaves, and so contributes to their growth. The sap, he adds, would not be able to remain at this pressure, if it did not enter by pores, which forbid its return. In these remarks lay the first germs of speculation on the growth of plants, such as we shall meet with in Hales also in a somewhat different form, but in the backward state in which phytotomy then was they could not at present be further developed; we shall recur to them further on, though in a different connection. 
Mariotte concluded that the primary sap finds its way into the plant through the leaves as well as through the roots from the fact, that if a branch is taken from a tree, and one of its smaller branches kept in water, another will remain fresh for some days; the conclusion was not quite justified, as the future showed. His remarks on the necessity of sunlight to nutrition, on the ripening of fruit, and other matters, rests on very imperfect experience and need not be noticed.

The characteristic and the important point in Mariotte's theory of nutrition is the marked contrast between his point of view in natural science and the Aristotelian and scholastic doctrines still widely diffused, and thus he is led to declare war also against Aristotle's vegetable soul. He connects his remarks on this point with a fact which excites his astonishment, namely that every species of plant reproduces its properties so exactly; no explanation of this fact, he says, is gained by the assumption of a vegetable soul, of which no one knows what it is. He declares as decidedly against the theory of evolution, also much in vogue in his day. In opposition to the notion that all future generations are shut up one inside another in the seeds of a plant, he thinks it much more probable that the seeds only contain the essential substances, and that their influence on the crude sap brings about the successive formation of the rest of the constituents of the plant, a view which we may still allow to be correct. He regards the whole process of nutrition and life in plants as a play of physical forces, as the combination and separation of simple substances, but he believes at the same time that he can prove the commonly received doctrine of spontaneous generation to be a necessary conclusion from this view. On this point he went wrong from want of sufficient and well-sifted experience, for he regarded it as a proof of generatio spontanea that numerous plants spring up from the soil thrown out from ditches and swamps that have been laid dry. 'We may therefore suppose,' he says, 'that there are in the air, in the water, 
and in the earth an infinite number of minute bodies so fashioned that two or three uniting together may make the beginning of a plant, and represent the seed of such a plant, if they find a soil favourable to their growth. - But it is not probable that this little complex body contains already all the branches, leaves, fruits, and seeds of this plant, and still less that this seed contains all the branches, leaves, flowers, etc., which proceed ad infinitum from the first germination.' The contrary he thinks is proved by the fact, that a rose-bush which has lost its leaves in the winter may produce in the next year nothing but leafy shoots from its flower buds, which shows that the blossoms were not previously formed in those buds, and that a similar conclusion is to be drawn from another fact, that the seeds of one and the same fruit-tree or of a melon produce descendants that differ from one another by variation; here we have an argument against the theory of evolution much more to the purpose than the greater part of those which were alleged against it before Koelreuter obtained his hybrids.

Other prejudices also of his day were opposed by Mariotte, and on good grounds; the medicinal effects, commonly known as the 'virtutes' of plants, played an important part in the botany, and still more in the medicine and chemistry of that time. $\mathrm{He}$ rejects the old theory of heat and cold, moisture and dryness, things supposed to be essentially immanent qualities of the substance of plants and used to explain their medicinal effects, and pointing to the fact, that poisonous plants grow in the same soil as harmless ones and side by side with them, he concludes, as he had before concluded, that different plants do not derive their peculiar constituents immediately from the soil, but that they form them themselves by separation and combination of the common principles. Finally he declared against one of the grossest errors which had come down from the previous century, the 'signatura plantarum,' which supposed that the medicinal properties of plants could be deduced from their external features, and especially from resemblances between 
their organs and the organs of the human body. Mariotte insists that the medicinal properties of plants are to be ascertained by trying them on sick people.

Mariotte's letter, the most important parts of which have here been given, presents us with a lively picture of the views which prevailed in the second half of the 17 th century respecting the life of plants; it shows at the same time how an eminent investigator of nature, adopting the principles of a more modern philosophy and knowing how to make a skilful use of the facts that were known to him, was led to oppose antiquated error, the result of prepossessions and want of reflection. If we combine the views of Malpighi on the internal economy of the plant, derived chiefly from its anatomy, with the chemical and physical disquisitions of Mariotte, we have an entirely new theory of the nutrition of plants, not only antagonistic to the Aristotelian doctrine, but distinguished from it by a much greater wealth of ideas and by more sagacious combinations.

These two men had in truth discovered all the principles of vegetable life and nutrition, which could have been discovered in the existing condition of phytotomy and chemistry; Mariotte especially had succeeded in applying the very best that was to be obtained from the uncertain chemical knowledge of his day to the explanation of the phenomena of vegetation. Chemistry was at that time beginning to set herself free from the notions of the medical science, the iatro-chemistry of a former age, only to throw herself into the arms of the theory of the phlogiston; and how little she could contribute to the explanation of the processes of nutrition in plants, how little the methods then in use were adapted to the examination of organised bodies, may be learnt from a little book published in 1676 and again in 1679 , 'Mémoires pour servir à l'histoire des plantes,' which appeared indeed in Dodart's name, but which was compiled and approved by the body of members of the Academy of Paris. It contains no results of investigation, 
but a detailed scheme for researches into botanical science, and more particularly into the chemical part of it. There we read, that plants must be burnt slowly, in order that the destroying and transmuting power of the fire may have less effect ; the 'virtutes plantarum' play an important part in the chemical examination of plants, and blood was mixed with their juices, in order to discover their properties. A writer named Dedu in a treatise, 'De l'âme des plantes' (1685) derived the generation and growth of plants from the fermentation and effervescence of the acids in combination with the alkalies, as Kurt Sprengel informs us. It is by comparison with these and similar notions that we recognise the full superiority of the utterances of Malpighi and Mariotte respecting the nutrition of plants, and their sagacity is still further shown by the fact, that there are some things which they forebore to say, evidently because they thought that they were not clearly proved.

The views of Malpighi and Mariotte on the nutrition of plants were respected and often quoted by their contemporaries and immediate successors; but as has happened in other cases unfortunately up to recent times, much that was fundamentally important and significant in them was neglected from the first for comparatively unimportant matters, and the views of these clear thinkers were so mixed up with indistinct ideas and actual misconceptions, that no real advance was made, though a variety of new facts were from time to time brought to light. It has been already noticed that Malpighi's correct idea of the connection of the leaves with the nutrition of the plant was at a later time commonly supposed to be equivalent to Major's theory of circulation, and since the latter was for various reasons considered to be incorrect, it was thought that Malpighi's view was dismissed with it. Yet even Major's theory deserved the preference over the views of those who assumed only an ascent of the sap in the wood, because it at least attempted to account for certain phenomena 
of growth. It found a new supporter in 1680 in the person of Claude Perrault, who does not however appear ${ }^{1}$ to have added anything essentially new to Malpighi's conclusive arguments for a returning sap. Nor did his opponent Magnol in his very weak treatise published in 1709 succeed in saying anything that will bear examination against the theory of circulation, which he too ascribed to Malpighi.

Among the phenomena of vegetation in woody plants, there is scarcely one so striking as the outflow of watery sap from wounded vines and from some tree-stems in the spring. This phenomenon, like the outflow of milky juice, gum, resin and the like, could not fail to be regarded with lively interest by those who occupied themselves with vegetable physiology in the I 7 th century. Even supposing the movements of water in the wood and of the milky and other juices in their passages not to be necessary accompaniments of the nutrition of plants, yet it was natural that the physiologists of the $\mathrm{r} 7$ th century should see in them striking proofs of that movement of the sap which is connected with nutrition, and should therefore make them a subject of study. It might also seem to them that the problem in question was easy to solve, for it was not till long after that it came to be understood that these movements are in reality one of the most difficult questions of vegetable physiology. We discover the interest taken in these matters from a series of communications in the form of letters from Dr. Tonge, Francis Willoughby, and especially from Dr. Martin Lister, to be found in the Philosophical Transactions for $1670^{2}$. The phenomenon to which these men chiefly directed their attention was just the one best calculated to

1 His views are known to me only from Magnol's paper in the 'Histoire de l'Académie Royale des Sciences,' I 7o9, and Sprengel's 'Geschichte der Botanik,' ii. 20. Perrault's treatise is according to Pritzel's 'Thesaurus ' of the date of 1680 , but is published in the 'CEuvres divers de Perrault' of I 721 .

${ }^{2}$ Especially in pages $116_{5}, 1201,2067,2119$. 
lead to misconceptions respecting the movements of water in woody plants, namely that which is known as the bleeding of the wood in winter, and which depends on entirely different causes from those which produce the weeping of the vine and other woody plants in spring; but the two things were supposed to be identical, and hence arose an unfortunate confusion of ideas. Lister indeed showed that it is possible to force water out of the wood of a portion of a branch cut from a tree in winter time by warming it artificially, and then to cause the water to be sucked in again by cooling it; but it was reserved for a modern physiologist to prove that this phenomenon has nothing to do with the bleeding of cut stems from root-pressure, and cannot be used to explain it.

John Ray, who gave a clear and intelligent summary of all that was known respecting the nutrition of plants in the first volume of his 'Historia plantarum' (I693), also communicated some experiments made by himself on the movements of water in the wood. He follows Grew's nomenclature, who called the ascending sap in the wood lymph and the woody fibres therefore lymph-vessels, and notices particularly that the lymph especially in spring cannot be distinguished in taste or in consistence from common water. He agrees with Grew that in spring the lymph fills the true vascular tubes of the wood and oozes from them in cross sections, while in summer these are filled with air, and the lymph at that time, when there is strong transpiration in woody plants, ascends only in the lymph-vessels, that is in the fibrous elements of the wood and the bast. By suitable incisions Ray proved that the lymph can also move laterally in the wood; and by causing water to filter in opposite directions through pieces of a branch cut off at both ends, he refuted those who thought that the cavities of the wood and especially the vessels were furnished with valves to hinder the return of the lymph. But his knowledge of the mechanical causes of the movement of water in the wood was not very great. 
Some years elapsed before Hales' labours added materially to the progress which had been already made in the study of these processes in vegetation. His important services to vegetable physiology close our present period, but before we pass on to them, we must first notice a few less important writers. The pages of Woodward and Beale on transpiration and the absorption of water are not very valuable contributions to the theory of nutrition. The fact stated by Woodward, that a Mentha growing in water took up and discharged by evaporation through the leaves forty-six times as much water as it retained in itself, was perhaps the most important of all that he discovered, but his own conclusions from it were of no value.

None of Malpighi's doctrines had from the first excited so much attention as the one which makes the air which is necessary for the respiration of the plant circulate in the spiral vessels of the wood, as it does in the tracheae in insects; while Grew and Ray after him agreed with Malpighi in the main, his countryman Sbaraglia in 1704 ventured even to deny the existence of such vessels, and before long phytotomy was fallen into such a state of decadence that the question, whether there were any vessels, or as they were then called spiral vessels, at all, was repeatedly affirmed and as often denied again, and ultimately it was thought better in the interest of physiological questions to take counsel of experiment rather than of the microscope. Thus in I 7 I 5 Nieuwentyt endeavoured with the help of the air-pump to make the air contained in the vessels issue in a visible form under a fluid. Here we again encounter the philosopher Christian Wolff as a zealous representative of vegetable physiology in Germany; in the third part of his work, 'Allerhand nützliche Versuche,' I 72 I, among other experiments he mentions some which confirmed the presence of air in plants; the question was more interesting, in the state in which physics and chemistry then were, than that of the anatomical character of the air-conducting crgans. 
Снар. II.]

Wolff submitted leaves lying in water containing no air to the vacuum of the air-pump, and saw air-bubbles issue, especially on the under side; but when he allowed the atmospheric pressure to come into play again the leaves became filled with water, and a piece of fir-wood treated in a similar manner sank after the infiltration. In similar experiments with apricots air issued from the rind and especially from the stalk. Wolff's pupil Thümmig described similar experiments in his 'Gründliche Erläuterung der merkwürdigsten Begebenheiten in der Natur,' I 723, and both continued in this question, as in all their physiological and phytotomical views, faithful adherents of Malpighi, as it was wisest then to be. We must linger a moment longer over Christian Wolff, because he published a few years later a general view of the nutrition of plants in a popular form. Wolff's services in the dissemination of natural science in Germany seem not to have been as highly appreciated up to the present time as they deserve to be; his various works on natural science, some of which took a wide range and were partly founded on his own observations, were full of matter and for his time very instructive; they contributed moreover to introduce more liberal habits of thought at a time when gross superstitions, such as that of palingenesia, reigned even among men who published scientific treatises in the German Academy of Sciences (the 'Acta of the Leopoldina).' If Wolff's own scientific researches show more good will than skill, yet he had an advantage over many others in a really philosophical training, a habit of abstract thought which enabled him to fix with certainty on what was fundamentally important in the observations of others, and thus to expound the scientific knowledge of his day from higher points of view. For this reason his work which appeared in 1723 , 'Vernünftige Gedanken von den Wirkungen der Natur,' deserves recognition. It is a work of the kind which would now be called a 'Kosmos,' and treats of the physical qualities of bodies generally, of the heavenly bodies and specially of our own planet, of meteor- 
ology, physical geography, and lastly of minerals, plants, animals and men. In accordance with his chief object, general instruction, it is written in German and in a good homely style, and contains the best information that was at that time to be obtained on scientific subjects; among these he gives an account of the processes of nutrition in plants, in which he made careful and intelligent use of all that had been written on the subject, bringing together all the serviceable material which he could gather from Malpighi, Grew, Leeuwenhoek, Van Helmont, Mariotte and others into a connected system, and occasionally introducing pertinent critical remarks. If we consider the state of scientific literature in Germany in the first years of the I 8 th century, we shall be inclined to assign as great merit to comprehensive text-books of this popular character as to new investigations and minor discoveries. Wolff's chapter on nutrition has however a special interest for us, because it contains several observations of value which were lost sight of after his time. These refer chiefly to the chemistry of nutrition and touch many problems which were not solved before our time; for instance, the statement that it is a well-known fact that the earth loses its fruitfulness, if much is grown on it; that it requires much to feed it, and must be manured with dung or ashes; in these few words we have the questions of the exhaustion of the soil, and the restitution of the substances taken from it by the crop, brought into notice by Wolff at this early period. 'It should be particularly noted,' continues Wolff, 'how fruitful nitre makes the soil; Vallemont has praised the usefulness of nitre, and has mentioned other things which have a like operation by reason of their saline and oily particles, such as horn from the horns and hoofs of animals; dung likewise contains saline and oily particles, which are present in the ash also, and we see therefore that such particles should not be wanting, if a plant is to be fed from water. The seed also, which supplies the first food of the plant, shows the same thing, for there are none which do 
not contain oil and salt, and there are many from which the oil may be squeezed out; and oil and salt are found in all plants if they are examined chemically.' He insists on the correctness of the view taken by Malpighi and Mariotte, that the constituents of the food must be chemically altered in the plant. Since every plant, he says, has its own particular salt and its own particular oil, we must readily allow that these are produced in the plant and not introduced into it. But at the same time since plants cannot grow where the soil does not supply them with saline and especially with nitrous particles, it is from these that the salts and oils in the plant must be produced, and the water also changed into a nutritious juice. Further on he alludes to the saline, nitrous and oily particles which float in the air, and says that daily experience shows that most of the substance of putrefying bodies passes into the air, and that if we admit light through a narrow opening into a dark place, we can see a great number of little particles of dust floating about; water also readily takes up salt and earth, and mineral springs show that metallic particles are mixed with it. Therefore there is no reason to doubt that rain-water also contains a variety of matters which it conveys to the plant. Alluding once more to the chemical changes in the constituents of the food which must be supposed to take place in the plant, he connects the subject with some remarks on the organs of plants, in which he closely follows Malpighi ; he says that these changes cannot take place in tubes, because the sap merely rises or falls in them; we can only therefore suppose that it is in the spongy substance (the cellular tissue) that the nutrient sap is elaborated, and accordingly the vesicles or utriculi are a kind of stomach; but the change in the water can only be this, that the particles of various substances which are in rain-water are separated from it and united together in some special manner, and this cannot be effected without special movements. But his ideas on these movements in the sap are somewhat obscure. He employs the expansion of the 
air and the capillarity of the woody tubes as his moving forces. He agrees decidedly with those who postulated a returning sap as well as an ascending crude sap, but he appeals in this matter to Major, Perrault, and Mariotte, and not to Malpighi ; yet like Malpighi he notices the growth of trees set upside down as a proof that the juices can move in opposite directions in the conducting organs, and with Mariotte he ascribes the enlargement of growing organs to the expanding power of the juices which force their way into them.

But these well-meant efforts on the part of Christian IVolff, and indeed all that was done from Malpighi and Mariotte to Ingen-Houss to advance the knowledge of the nutrition of plants, was thrown into the shade by the brilliant investigations of STEPHEN HALES ${ }^{1}$, in whom we see once more the genius of discovery and the sound original reasoning powers of the great explorers of nature in Newton's age. His 'Statical Essays,' first published in 1727 , reappeared in two new editions in English, and afterwards in French, Italian and German translations; in the last with a preface by Christian Wolff. This was the first work devoted to a more complete account of the nutrition of plants and of the movements of the sap in them, and while it noticed what had been already written on the subject, it was chiefly composed of the author's own investigations. An abundance of new experiments and observations,

1 Stephen Hales was born in the county of Kent in 1677 and was educated at home without showing any special ability. At the age of nineteen he became a member of Christ's College in Cambridge, and there showed his taste for physics, mathematics, chemistry, and natural history. Nevertheless he took orders and held Church preferment in different counties. $\mathrm{He}$ became a Member of the Royal Society in 1718 , and read before it his 'Statical Essays.' His 'Hæmostatics' appeared in 1733. He made and published other investigations and discoveries of very various kinds before his death in 1761 . He was buried in his church at Riddington, which he had rebuilt at his own cost, and the Princess of Wales caused an inscription to his memory to be placed in Westminster Abbey. See his Éloge in 'Histoire de l'Académie Royale des Sciences,' I 762. 
measurements and calculations combine to form a living picture of the whole subject. Malpighi endeavoured to discover the physiological functions of organs by the aid of analogies and a reference to their structure; Mariotte discerned the main features of the connection between plants and their environment by combining together physical and chemical facts ; Hales may be said to have made his plants themselves speak; by means of cleverly contrived and skilfully managed experiments he compelled them to disclose the forces that were at work in them by effects made apparent to the eye, and thus to show that forces of a very peculiar kind are in constant activity in the quiet and apparently passive organs of vegetation. Penetrated with the spirit of Newton's age, which notwithstanding its strictly teleological and even theological conception of nature did endeavour to explain all the phenomena of life mechanically by the attraction and repulsion of material particles, Hales was not content with giving a clear idea of the phenomena of vegetation, but sought to trace them back to mechanico-physical laws as then understood. He infused life into the empirical materials which he collected by means of ingenious reflections, which brought individual facts into connection with more general considerations. Such a book necessarily attracted great attention, and for us it is a source of much valuable instruction on matters of detail, though we now gather up the phenomena of vegetation into a somewhat differently connected whole.

His investigations into transpiration and the movement of water in the wood were greeted with the warmest approbation. He measured the quantity of water sucked in by the roots and given off by the leaves, compared this with the supply of moisture contained in the earth, and endeavoured to calculate the rapidity with which the water rises in the stem, and to compare it with the rapidity of its entrance into the roots and its exit by the leaves. The experiments, by which he showed the force of suction in wood and roots, and that of the root- 
pressure in the case of the bleeding vine, were particularly striking and instructive. His measurements and the figures, on which he founded his calculations, were not so exact as they were often at a later time supposed to be, but he was himself satisfied with obtaining round, approximative numbers; these under given circumstances supplied a sufficient basis for propositions which were new and afforded a certain amount of insight into the economy of the plant. This mode of proceeding showed his understanding ; for the case of living bodies is different from that of metals and gases; in these we seek for constants which can then be inserted in general formulae, and to which therefore the nicest accuracy is applied; but in plants we have to deal with individual cases, and it is from a right interpretation of the measurements taken from them that we can arrive at general laws of vegetation.

To show that the forces of suction and pressure which operate in plants are not something sui generis, but prevail also in dead matter, in other words that they are an example of the general attraction of matter, a subject of particular interest at that time, Hales observed the absorption of water by substances with fine pores; and measured the force employed. These processes he compared with the force which swelling peas exert on the obstacles which they encounter, and thus obtained a more correct idea of the forces concerned in the movement of water in the plant than that given by the capillarity of glasstubes, which Mariotte and Ray had employed to illustrate them.

Hales failed to appreciate the value of Malpighi's observations on the function of leaves, and was induced by the copiousness of the evaporation of water from their surfaces to overrate the physiological importance of that process; hence he saw in leaves chiefly organs of transpiration, which raise the sap by suction from the roots through the stem. In accordance with this view he denied the existence of a descending sap in the bark, and only admitted that the ascending sap 
in the wood might possibly sink in the night in consequence of the lowering of the temperature, like the quicksilver in a thermometer, and that so far there might be a return-movement. This was the weak point in Hales' system.

One of his most important discoveries has generally been overlooked even in modern times, probably because it was entirely neglected by his successors in the I 8 th century; he was the first who proved, that air co-operates in the building up the body of the plant, in the formation of its solid substance, and that gaseous constituents contribute largely to the nourishment of the plant; consequently that neither water, nor the substances which it carries with it from the earth, alone supply the material of which plants are composed, as had been generally imagined. He showed also with the aid of the air-pump, and better than Nieuwentyt and Wolff, that air enters the plant not only through the leaves but also through apertures in the rind, and circulates in the cavities of the wood. He then connected this with the fact which he had confirmed by numerous experiments, that large quantities of 'air' are obtained from vegetable substance by fermentation and dry distillation; the air thus set free by fermentation and heat must in his opinion be condensed and changed to a solid condition during the period of vegetation. He says in chap. 7 , that we find by chemical analysis (dry distillation) of vegetables, that their substance is composed of sulphur, volatile salt, water and earth; these principles are all endowed with mutual power of attraction (of their parts). But air also enters into the composition of the plant, and this in its solid state is powerfully attractive, but in an elastic condition has the highest powers of repulsion. It is on infinitely various combinations, actions, and reactions of these principles that all activity in animal and vegetable bodies depends. In nutrition the sum of the forces of attraction is greater than that of the forces of repulsion, and thus the viscid ductile parts are first produced, and then by evaporation of the water 
the harder parts. But if the latter again absorb water, and the forces of repulsion consequently gain the preponderance, then the consistence of the vegetable parts is dissolved, and this decomposition restores to them the power of forming new vegetable products; therefore the stock of nutritive substance in nature can never be exhausted; this stock is the same in animals and plants, and is fitted by a small change of texture to feed the one or the other.

He goes on to say, that it results from his experiments, that leaves are very useful for the nourishing of the plant, inasmuch as they draw up the food from the earth; but they seem also to be adapted to other noble and important services; they remove the superfluous water by evaporation, retaining the parts of it that are nutritious, while they also absorb salt, nitre, and the like substances, and dew, and rain ; and since, like Newton, he regarded light as a substance, he concludes by asking: 'may not light, which makes its way into the outer surfaces of leaves and flowers, contribute much to the refining of the substances in the plant?'

It might be gathered from these expressions that Hales attributed importance for purposes of nutrition only to the substances suspended in the air; but this was not the case; for we read in the 6th chapter, that he had proved by experiment that a quantity of true permanently elastic air is obtained from vegetable and animal bodies by fermentation and dissolution (dry distillation); the air is to a great extent immediately and firmly incorporated with the substance of these bodies, and it follows therefore that a large quantity of elastic air must be constantly used in forming them.

But Hales not only regards the air as a nourishing substance, but he sees also in its elasticity, which counteracts the attraction of other substances, the origin of the force which maintains the internal movements in the plant. $\mathrm{He}$ says that if all matter were endowed only with forces of attraction, all nature would at once contract into an inactive 
mass; it was therefore absolutely necessary in order to set in movement and animate this huge mass of attracting matter, that a sufficient quantity of strongly repellent and elastic matter should be mixed with it; and since a large portion of these elastic particles are constantly changing to a solid condition through the attraction of the other parts, they must be endowed with the power of again assuming their elastic condition, when they are set free from the attracting mass. Thus the formation and dissolution of animal and vegetable bodies go on in constant succession. Air is therefore very important to the production and growth of animals and plants in two ways; it invigorates their juices while it is in the elastic state, and contributes much to the firm union of the constituent parts, when it has become fixed.

IVe see what good use Hales could make of the small stock of ideas in physics and chemistry at his disposal, and that he succeeded with their help in rising to a point of view, from which he was able to form some idea of the phenomena of vegetation in their most important relations to the rest of nature, and in their inner course and connection. But his successors did not comprehend the fundamental importance of these considerations, and made no use of the pregnant idea, that a much larger part of the substance of plants comes from the air and not from the water or the soil; they were for ever wondering that so little is furnished by the soil to the plant, as Van Helmont had shown, though they did not confess to supposing that the water was changed into the substance of the plant, as he had imagined. Thus physiologists lost sight of the principle, which might long before the time of Ingen-Houss have sufficiently explained the most important of all the relations of the plant to the outer world, namely that it derives its food from the constituents of the atmosphere, and so neglected further experimental enquiry into the matter; they quoted and repeated Hales' experiments and observations again and again, but forgot that which in his mind bound all the separate facts together. 
Hales is the last of the great naturalists who laid the foundations of vegetable physiology. Strange as some of their ideas may seem to us, yet these observers were the first who gained any deep insight into the hidden machinery of vegetable life, and handed down to us a knowledge both of individual facts and of their most important relations. If we compare what was known before Malpighi's time with the contents of Hales' book, we shall be astonished at the rapid advance made in less than sixty years, while scarcely anything had been contributed to the subject in the period between Aristotle and Malpighi.

3. Fruitless attempts to explain the movement of THE SAP IN PLANTS. I730-I780.

IF those, who studied the nutrition of plants and especially the movement of their sap in the period between Hales and Ingen-Houss, had kept a firm hold on Malpighi's view, that the nutritive substances are elaborated in the leaves, and had combined it with Hales' idea, that plants derive a large portion of their substance from the air, they would have had a principle to guide them in their investigations into the movement of the sap; and by experimenting on living plants they might have succeeded in giving a more definite expression to these ideas, even though chemistry and physics supplied during that time no new aids. We have said already that such was not the course of events ; physiologists confined their attention to the obvious phenomena of vegetation, and trusted in so doing to gain a firmer footing, but in this they never got beyond a commonplace and unreflecting empiricism, because their observation was without an object, and their conclusions without a principle. They wandered from the right direction, as always happens when observation is not guided by a wellconsidered hypothesis; and their conceptions were rendered more obscure by their imperfect acquaintance with one of the most important aids to understanding the movement of the 
sap, namely the structure of the more delicate parts of the plant, the knowledge of which had not advanced since the days of Malpighi and Grew. Since most of them made no phytotomical investigations of their own, and only partially understood the descriptions of those writers, they had to be content with misty and often quite inaccurate ideas of the inner structure of wood and bark, and yet expected to obtain an insight into the movement of the sap in them. In reading the writings of Malpighi, Grew, Mariotte, Hales and even Wolff, notwithstanding many mistakes in details we find a pleasure in the connected reasoning, and in the sagacity which knew how to distinguish between what was important and what was not; whereas the observers, whom we have now to mention, give us only isolated statements, nor have we the satisfaction of feeling that we are conversing with men of superior understanding.

We may pass over the unimportant writings of Friedrich Walther (I740), Anton Wilhelm Platz ( $175 \mathrm{I}$ ) and Rudolph Böhmer (I 753), as merely barren exercises; but some notice should be taken of those of De la Baisse and Reichel, since these authors at least endeavoured to bring to light something new. But the method which they employed of making living plants suck up coloured fluids was calculated to give rise to serious errors both at the time and afterwards. Magnol had mentioned experiments of the kind in 1709 , and the Jesuit father Sarrabat, known by the name of DE LA BAISSE, occupied himself with them and described them in a treatise, 'Sur la circulation de la sêve des plantes,' I 733, which received a prize from the academy of Bordeaux ${ }^{1}$. He set the roots of different plants in the red juice of the fruit of Phytolacca, and found that in two or three days the whole of the bark of the roots and especially the tips of the root-fibres were coloured

${ }^{1}$ See Sprengel, 'Geschichte der Botanik,' i. 229, and Reichel's and Bonnet's works mentioned below. 
red inside. It was a natural conclusion at that time, that it was these parts which chiefly absorbed the red colouring matter, and in fact this opinion was maintained till quite recent times, and it was on such results that Pyrame de Candolle founded his theory of the spongioles of the root, which is still accepted in France. At present it is known, that the bark and especially the youngest tips of the fibres of the root are not coloured under these circumstances, until they have been first poisoned and killed by the colouring matter; these experiments therefore, which have been frequently repeated since De la Baisse's time, prove nothing respecting the action of living roots, but they were from the first the cause of a pernicious error in vegetable physiology, which as we shall see gave rise to others also. One result however of De la Baisse's experiments was less misleading; he placed the cut ends of branches of woody plants in the coloured fluid, and found that not only the general body of the wood, but the woody bundles which pass from it into the leaves and parts of the flowers, were coloured red, while the succulent tissue of the bark and leaves remained uncoloured. It appeared therefore that the red juice passed only through the wood, and a somewhat bold analogy might lead to the further conclusion that this is true also of the nutrient substances dissolved in the watery sap; but the view so stated is not at present considered to be correct, and that the sap which ascends from the roots to the leaves, the water especially, is conveyed through the wood only, and not through the rind, had been already sufficiently proved by the experiments of Hales and others. The uncritical treatment of experiments of this kind by Georg Christian Reichel ${ }^{1}$ afterwards led to new errors, though his dissertation, 'De vasis plantarum spiralibus,' shows to advantage by the side of similar productions of the day

1 Georg Christian Reichel was born in 1727 and died in $177 \mathrm{I}$. He was Professor in the University of Leipsic. 
owing to its careful notices of the literature, and the author's original researches in phytotomy. Reichel was not satisfied with the arguments of Malpighi, Nieuwentyt, Wolff, Thümmig and Hales for the view that the vessels of the wood contain air. He observed quite correctly, that if branches are cut off from woody and herbaceous plants and the cut surfaces are placed in red decoction of brazil-wood, the red colouring matter spreads through all the vascular bundles, even those of the flowers and fruit; but on examination with the microscope he found the red fluid to some extent in the cavities of the vessels, and hastily concluded that they too in the natural condition convey sap and not air. His description and his drawing show however, that only some vessels had received any of the red fluid and that none of these were filled with it. Reichel and the many who repeated his statements forgot to ask whether the vessels had contained air or fluid before the experiment, or whether the result would have been the same, if plants with uninjured and living roots had absorbed the coloured fluid, and no divided vessels had therefore come in contact with it. There was no reason why observers of that day should not have been alive to the simple consideration, that the vessels of a branch parted from the stem and placed in a fluid must necessarily show the capillary action of narrow glass tubes if they are filled with air in their natural condition, and that in the experiment the transpiration of the leaves must favour the ascent of the red juice in the cavities of the vessels, as was to be gathered from other and better experiments made by Hales. But these obvious reflections were not made; the supposed results of the experiment were heedlessly accepted, and the unfounded notion, that vessels are natural sap-conducting organs, was set up in opposition to the trustworthy decision of Malpighi and Grew, that they convey air. Thus on the strength of badly interpreted experiments one of the most important of physiological discoveries was called in question, and a hundred years later there were persons, 
who, relying on the same experiments as Reichel, supposed that the vessels of the wood convey the ascending sap, a view which made it impossible from the first to arrive at any real understanding of the movement of the sap in plants provided with organs of transpiration. But even the other great discovery which we owe to Malpighi, that leaves are organs for elaborating the food, was denied by Bonnet, who substituted for it the utterly false view, that they chiefly serve to absorb rain-water and dew. BonNET ${ }^{1}$, who had previously done good service to insect-biology, and had discovered the asexual propagation of aphides, having injured his eyes in these studies, found an agreeable pastime in a variety of experiments on plants. Much that he did was unimportant, yet he obtained some results, which could afterwards be turned to account by more competent persons, for the weakness of his own judgment is shown even in his more serviceable observations, such as those on the curvature of growing plants. We notice the same defect in his observations on the part played by leaves in the nutrition of the plant. It shows the character of the time that a book like Bonnet's 'Recherches sur l'usage des feuilles des plantes,' a mere accumulation of undigested facts, should have been generally considered an important production. He tells us, that his attention was called by Calandrini to the fact, that the structure of the under side of leaves seems to show that they were intended to absorb 'the dew that rises from the ground' and introduce it into the plant. Starting from this sensible suggestion, as he calls it, he proceeded to make a variety of senseless experiments

${ }^{1}$ Charles Bonnet, born at Geneva in I 720 , sprang from a wealthy family, and was intended for the profession of the law, but gave himself up from an early age to scientific pursuits, and especially to zoology. He was afterwards a member of the great council of Geneva, and wrote various treatises on scientific subjects, psychology, and theology. He died on his property at Genthod near Geneva in I793. See the 'Biographie Universelle' and Carus, ' Geschichte der Zoologie,' p. $5_{226}$ 
with leaves, which were cut off from their plants, and having been smeared over with oil or other hurtful substances were laid on water, some on their upper some on their under side, the object being to note the time which they took to perish. It is impossible to imagine worse-devised experiments on vegetation ; for if Bonnet wished to test Calandrini's 'sensible' conjecture, he ought certainly to have left the leaves on the living plants and have observed the effect of the supposed absorption of dew on the vegetation. It is to be observed, that by rising dew he evidently meant aqueous vapour, for the real dew descends chiefly on the upper side of the leaf; and what could he have expected to learn by laying cut leaves on water? how could this prove that leaves absorb dew? Nevertheless Bonnet came to the conclusion that the most important function of leaves was to absorb dew, and in order to make this result agree with Hales' investigations on transpiration, he propounded the theory ${ }^{1}$, that the sap which rises by day from the roots into the stem is carried by the woody fibres assisted by the air-tubes into the under side of the leaves, where there are many stomata to facilitate its exit (evaporation). At the approach of night, when the leaves and the air in the air-tubes are no longer under the influence of heat, the sap returns to the roots; then the under side of the leaves commences its other function; the dew slowly rising from the earth strikes against it, condenses upon it, and is detained there by the fine hairs and by other contrivances (this really takes place to a much greater extent on the upper side). The fine tubes of the leaves absorb it at once, (this is evidently not so, since the dew increases in quantity till sunrise), and conduct it to the branches, whence it passes into the stem. He thought so highly of this strange theory, that he believed he found in it a teleological explanation of the heliotropic and geotropic curvature of leaves and stems, two things which

${ }^{1}$ See p. 35 of the German translation by Arnold, 1762 . 
he did not distinguish, and of the position of leaves on the stem. Bonnet's view of the functions of leaves, foolish as it is, is historically important and therefore required to be noticed, because it was really accepted during many years in preference to the older and better ideas, and because it shows how the power of judging of such matters had fallen off since Malpighi's time. It appears to have been the praise lavished on Bonnet by his contemporaries that made later physiologists, who might have known better, take him for an authority on the nutrition of plants. His experiments on the growth of plants in another material than earth are if possible more worthless than those with cut leaves. Here too the idea was not his own; for hearing that land-plants had been grown in Berlin in moss instead of earth, he made numerous experiments of the kind, and found that many plants grow vigorously in this way, and bloom and bear seed. But the theory of nutrition gained nothing by these experiments, which were only a childish amusement. The few pages which Malpighi wrote on the nutrition of plants are worth more than all Bonnet's book on the use of leaves; the former by the help of some simple considerations and conclusions from analogy really discovered the use of leaves; Bonnet on the faith of many unmeaning experiments ascribed to them another function than the true one.

We are unable to pass a much more favourable judgment on the views respecting the nutrition of plants of another writer, who otherwise did good service to vegetable physiology, and to whom we shall return in our last chapter. It is true that DU HAMEL ${ }^{1}$, of whom we speak, was not an investigator of

1 Henri Louis du Hamel du Monceau was born at Paris in 1700 and died in $178 \mathrm{r}$. He had an estate in the Gatinais, and turned his studies in physics, chemistry, zoology, and botany to account in the composition of a number of treatises on agriculture, the management of woods and forests, naval affairs, and fisheries. He was made Member of the Academy in 1728 
nature, as were Malpighi, Mariotte or Hales; compared with those great thinkers he was only a compiler, and a somewhat uncritical one. But he was not a dilettante in science, like Bonnet; he made the vegetable world the subject of serious and diligent study, and he endeavoured to turn the results of that study to practical account. Long familiarity with plants gave him a kind of instinct for the truth in dealing with them, as is shown in his observations and experiments, many of which are still instructive; but he had neither that faculty of combination which can alone bring a meaning out of experiments and observations in physiological investigations, nor the power to distinguish between matters of fundamental and secondary importance. So thinks also his biographer Du Petit-Thonars.

The merits and the faults here mentioned are combined in an especial degree in Du Hamel's most famous work, 'Physique des arbres,' which appeared in two volumes in $175^{8}$ and is a text-book of vegetable anatomy and physiology with numerous plates. His remarks on the nutrition of plants and the movement of the sap are a lengthy compilation chiefly from Malpighi, Mariotte and Hales, though he has not succeeded in appropriating exactly that which is theoretically important or adopting the most commanding points of view. He introduces the results of his own experiments into his account, and these are often instructive in themselves, but are never made use of to establish a definite view with respect to the connection between the processes of nutrition. $\mathrm{He}$ hits upon the right view only when he is dealing with plain and obvious matters; for instance, he restores the vessels of the wood to their old rights, and concludes from experiments, as had been already done in the 17 th century, that an elaborated sap moves in the reverse direction in the rind;

on presenting to it an essay on a disease then raging in the saffron-plantations, and caused by the growth of a fungus ('Biographie Universelle'). 
so too he perceives that if bulbs, tubers, and roots, with or without the help of water which they have absorbed, produce shoots and even flowers, this must be done at the expense of material laid up in reserve, but he does not turn this fact to any further account. But he utterly spoilt the best part of his subject; he made the leaves nothing but pumps that suck up the sap from the roots; he quotes Malpighi's better view as a curiosity, and never mentions it again; but he accepts Bonnet's unfortunate theory, though he himself adduces many facts, which make for Malpighi's interpretation of the leaves. $\mathrm{He}$ is almost more unsuccessful with chemical points in nutrition; he repeats Mariotte's statements with regard to the necessity of a chemical change in the nutrient substances in the plant, and even supplies further proof of it; but he cannot shake off the Aristotelian dogma, that the earth like an animal stomach elaborates the food of plants, and that the roots absorb the elaborated matter like chyle-vessels (II. pp. I89, 230). He concludes from his own attempts to grow land-plants without earth and in ordinary water that the latter supplies the plant with very little matter in solution, but he makes no use of Hales' statements with regard to the co-operation of the air in the building up of the plant, and ends by saying (II. p. 204) that he only wished to prove that the purest and simplest water can supply plants with their food, which his experiments do not prove. Thus almost all that Du Hamel says on the nutrition of plants is a mixture of right observations in detail with wrong conclusions, and reflections which never rise above the individual facts and give no account of the connection of the whole. These faults appear in a still higher degree in a later and almost more comprehensive work, the 'Traité théorique et pratique de la végétation' of Mustel ( 78 I). The further the distance from the founders of vegetable physiology, the larger were the books that were written on the subject; but the thread that held the single facts together became thinner and thinner, till at last it broke. 
Cнар. II.] of Plants. Ingen-Houss and de Saussure. 491

The theory of nutrition, like a forced plant, needed light that it might recover strength. This light came with the discoveries of Ingen-Houss, and with the mighty strides made by chemistry after 1760 in the hands of Lavoisier.

4. The Modern theory of NUtrition founded by IngenHouss and Theodore de Saussure. I 779-1804.

THE two cardinal points in the doctrine of the nutrition of plants, namely that the leaves are the organs which elaborate the food, and that a large part of the substance of the plant is derived from the atmosphere, were established, as we have seen, by Malpighi and Hales, and employed by them in framing their theory; it remained to supply a direct and tangible proof of the fact that the green leaves take up a constituent of the atmosphere and apply it to purposes of nutrition. It was evidently the want of such direct proof which caused the successors of the first great physiologists to overlook the importance of the propositions thus obtained by deduction, and so to grope their way in the dark with no principle to guide them.

The discoveries of Priestley, Ingen-Houss and Senebier, and the quantitative determinations of de Saussure in the years between I 774 and I 804 , supplied the proof that the green parts of plants, and the leaves therefore especially, take up and decompose a constituent of the air, while they at the same time assimilate the constituents of water and increase in weight in a corresponding degree; but that this process only goes on copiously and in the normal way, when small quantities of mineral matter are introduced at the same time into the plant through the roots. The discoveries and facts, from which this doctrine proceeded, were those which overthrew the theory of the phlogiston, and from which Lavoisier deduced the principles of modern chemistry; the new theory of the nutrition of plants was indeed directly due to Lavoisier's doctrines, and it is necessary therefore to take at least a hasty glance at the 
revolution which was effected in chemistry between $\mathrm{I} 770$ and I 790. It is a well-known fact $^{1}$ that this revolution dates from the discovery of oxygen-gas by Priestley in I774. Priestley himself was and continued to be a stubborn adherent of the phlogiston; but his discovery was made by Lavoisier the basis of an entirely new view of chemical processes. By the combustion of charcoal and the diamond, Lavoisier proved as early as 1776 that 'fixed air' was a compound of carbon and 'vital air.' In like manner phosphoric acid, sulphuric acid and, after a preliminary discovery by Cavendish, nitric acid also were found to be compounds of phosphorus, sulphur and nitrogen with vital air; in 1777 Lavoisier showed that fixed air and water are produced by the combustion of organic substances, and after establishing within certain limits the quantitative composition of fixed air, he named it carbonic acid, and the gas which had up to that time been known as vital air he called oxygen. Cavendish in $\mathrm{I}_{7} 83$ obtained water by the combustion of hydrogen-gas, and then Lavoisier proved that water is a compound of hydrogen and oxygen. These discoveries not only did away step by step with the old theory of the phlogiston, and supplied the principles of modern chemistry, but they also affected exactly those substances which play the most important part in the nutrition of plants; every one of these discoveries in chemistry could at once be turned to account in physiology. In I 779 Priestley discovered that the green parts of plants occasionally exhale oxygen, and in the same year Ingen-Houss described some fuller investigations, which showed that this only takes place under the influence of light, and that the green parts of plants give off carbon dioxide in the dark, as those parts which are not green do both in the light and the dark. A correct interpretation of these facts was not however possible in 1779 ; it was not till $\mathrm{I}_{7} 85$ that Lavoisier

1 See Kopp, 'Geschichte der Chemie' (1843), i. p. 306, and 'Entwicklung der Chemie in der neuerenzeit' (1873), p. $13^{8}$. 
succeeded in setting himself quite free from the old notions, and developed his antiphlogistic system into a connected whole. It should be mentioned that he had discovered in I 777 that the respiration of animals is a process of oxidation which produces their internal heat, heat being the product of every form of combustion. This fact was equally important for vegetable physiology, but it was some time before it was used to explain the life of plants.

The establishment of the fact, that parts of plants give off oxygen under certain circumstances, did little or nothing to further the theory of their nutrition ${ }^{1}$; and that was all that vegetable physiology owes to Priestley. Ingen-Houss on the other hand determined the conditions under which oxygen is given off, and further showed that all parts of plants are constantly giving rise to carbon dioxide; on these facts rests the modern theory of the nutrition and respiration of plants, and we must therefore consider that Ingen-Houss was the founder of that theory. But since we are dealing here with a discovery of more than ordinary importance, it seems necessary to go more closely into the details.

A work of Priestley's appeared in I 779, which was translated into German in the following year under the title, 'Versuche und Beobachtungen über verschiedene Theile der Naturlehre,' and contained among other things the writer's experiments on plants. His way of managing them was eminently unsuitable, nor did he arrive at any definite and important result, though he expressed the idea which had led him to make them clearly enough, where he says, 'If the air exhaled by the plant is of better character (richer in oxygen) than atmospheric air, it follows that the phlogiston of the air is retained in the plant

1 Still less was gained from an observation made by Bonnet, that leaves exposed to sunlight in water containing air show bubbles of gas on their upper surface. Bonnet expressly denied the active participation of the leaves in the phenomenon, since the same thing happens with dead leaves in water containing air. 
and used there for its nourishment, whlle the part which escapes, being deprived of its phlogiston, necessarily attains a higher degree of purity.' After he had ceased his experiments with plants in 1778 , he observed that there was a deposit of matter in the water in some vessels which he had used for them, and that it gave off a very 'pure air'; a number of further observations taught him that this air was given off only under the influence of sun-light ; Priestley himself did not suspect that the deposit in question, afterwards known as Priestley's matter and found to consist of Algae, was a vegetable substance.

In the same year (I779) appeared the first book by INGENHouss $^{1}$, in which the subject was treated at length; it was called, 'Experiments on Vegetables, discovering their great power of purifying the common air in the sunshine and of injuring it in the shade and at night,' and was at once translated into German, Dutch and French. The title itself shows that the author had observed more and more correctly than Priestley. But he did not come to an understanding of the inner connection of the facts, till Lavoisier completed his new antiphlogistic theory. He says himself in his essay, 'On the nutrition of plants and the fruitfulness of the earth,' which appeared in $179^{6}$, and was translated into German with an introduction by A. v. Humboldt in 1798 , that when he published his discoveries in 1779 , the new system of chemistry was not yet fully declared, and that without its aid he had been unable to deduce the true theory from the facts; but that since the composition of water and air had been discovered, it had become much easier to explain the phenomena of vegetation. But in order to establish his priority he says on p. 56 , that he had been fortunate enough to find out the real

${ }^{1}$ Jan Ingen-Houss, physician to the Emperor of Austria, practised first in Breda, and afterwards in London. He was born at Breda in Holland in I730, and died near London in 1799. 
cause why plants at certain times vitiate the surrounding air, a cause which neither Priestley nor Scheele had suspected. He had discovered, he says, in the summer of 1779 , that all vegetables incessantly give out carbonic acid gas, but that the green leaves and shoots only exhale oxygen in sun-light or clear day-light. It appears therefore that Ingen-Houss not only discovered the assimilation of carbon and the true respiration of plants, but also kept the conditions and the meaning of the two phenomena distinct from one another. Accordingly he had a clear idea of the great distinction between the nutrition of germinating plants and of older green ones, the independence of the one, the dependence of the other, on light ; and that he considered the carbon dioxide of the atmosphere to be the main if not the only source of the carbon in the plant, is shown by his remark on a foolish assertion of Hassenfratz that the carbon is taken from the earth by the roots; he replied that it was scarcely conceivable that a large tree should in that case find its food for hundreds of years in the same spot. There was a certain boldness in these utterances of Ingen-Houss, and a considerable confidence in his own convictions, for at that time the absolute amount of carbon dioxide in the air had not been ascertained, and the small quantity of it in proportion to the other constituents of air would certainly have deterred some persons from seeing in it the supply of the huge masses of carbon which plants accumulate in their structures.

Before Ingen-Houss in the work last mentioned explained the results of his observations of 1779 in accordance with the new chemical views, and laid the foundations of the doctrine of nutrition in plants, JEAN SENEBIER ${ }^{1}$, of Geneva, made pro-

1 Jean Senebier, born at Geneva in $\mathrm{I}_{74^{2}}$, was the son of a tradesman, and after $I_{7} 6_{5}$ pastor of the Evangelical Church. On his return from a visit to Paris he published his 'Moral Tales,' and at the suggestion of his friend Bonnet competed for a prize offered at Haarlem for an essay on the Art of Observation. He was awarded the second place in this competition. In 1769 he became 
tracted researches into the influence of light on vegetation (I782-I 788), and founded on their results a theory of nutrition, which he published in $\mathbf{I} 800$ in a tediously prolix work in five volumes entitled, 'Physiologie végétale.' In this work some valuable matter was concealed in a host of unimportant details and tiresome displays of rhetoric, which for the most part are beside the question. But it must be acknowledged that Senebier was better provided with chemical knowledge than Ingen-Houss, and that he brought together all the scattered facts that the chemical literature of the day offered, in order to obtain a more complete representation of the processes of nutrition. It was of especial importance at that time to insist on the principle that the processes of nutrition within the plant must be judged by the general laws of chemistry; organised beings, said Senebier, are the stage, on which the affinities of the constituents of earth, water, and air mutually influence each other; the decompositions however are generally the result of the influence of light, which separates the oxygen of the carbon dioxide in the green parts of plants. $\mathrm{He}$ insists (II. p. 304) upon this among other facts, that the simple constituents of all plants are the same, and the differences are only quantitative. He then brings before us the simple and compound constituents of plants one after the other, and among them light and heat figure as material substances, in accordance with the view of the time. He treats at great length the old question of the meaning of the salts in the plant, and it is

pastor at Chancy, and in I773 librarian of Geneva. At this time, among other literary labours, he translated Spallanzani's more important writings; he also studied chemistry under Tingry, and carried out his rescarches into the influence of light. In I79I he wrote an article for the 'Encyclopaedie méthodique' on vegetable physiology. The revolution in Geneva drove him into the Canton Vaud, and there he composed his 'Physiologie végétale,' in five volumes. He returned to Geneva in 1799 and took part in a new translation of the Bible. He died in that city in 1809 ('Biographie Universelle'). 
Cinap. II.] of Plants. De Saussure.

instructive to observe how he tries to decide whether the nitrates, sulphates and ammonia, which are found in the sap of plants, are introduced from without, or are formed in them from their constituent elements; he concludes finally that the former is the more probable opinion. That the greater part at least of the carbon of plants comes from the atmosphere could scarcely be a matter of doubt with those who knew the writings of Ingen-Houss ; but Senebier devotes special attention to this question; he endeavours to take all the co-operating factors into the calculation, and especially to prove once more that the oxygen given off from the plant in light comes from the carbon dioxide which has been absorbed, that the green parts only and no others are able to effect this decomposition, and that there is a sufficiency of carbon dioxide in nature to supply the food of plants. But although he convinced himself that green leaves decompose the carbon dioxide which surrounds them in a gaseous form, he supposed that it is chiefly through the roots that this substance finds its way with the ascending sap into the leaves, and this view often gave occasion to further error in later writers.

The tedious prolixity of Senebier's book was one reason why it never enjoyed the measure of appreciation and influence which it deserved; but it was also thrown into the shade by the appearance of a work of superior excellence, distinguished at once by the importance of its contents, by condensation of style, and by perspicuity of thought. This work was the 'Recherches chimiques sur la végétation' of THÉODORE DE SAUSSURE ${ }^{1}$ ( 1804 ), which contained new observations and new

1 Nicolas Théodore de Saussure was born at Geneva in 1767 , and died there in 1845 . He was the son of the famous explorer of the Alps, and assisted his father in his observations on Mont Blanc and the Col du Géant. In $\mathrm{x} 797$ he wrote his treatise on carbonic acid in its relation to vegetation, a prelude to his 'Recherches chimiques'; the latter work received great attention from the scientific world, and he was made a corresponding member of the French Institute. He was a man of literary tastes, and took

$\mathrm{K} \mathrm{k}$ 
results, and what was still more important, a new method. Saussure adopted for the most part the quantitative mode of dealing with questions of nutrition; and as the questions which he put were thus rendered more definite, and his experiments were conducted in a most masterly manner, he succeeded in obtaining definite answers. He knew how to manage his experiments in such a manner that the results were sure to speak plainly for themselves; they had not to be brought out by laborious calculation from those small and, as they are called, exact data, which less skilful experimenters use to hide their own uncertainty. The directness and brevity with which precise quantitative results are expressed, the close reasoning and transparent clearness of thought, impart to the reader of de Saussure's works a feeling of confidence and security such as he receives from scarcely any other writer on these subjects from the time of Hales to our own. The 'Recherches chimiques' have this in common with Hales' 'Statical Essays,' that the statements of facts which they contain have been made use of again and again by later writers for theoretical purposes, while the theoretical connexion between them was constantly overlooked, as we shall have reason to learn in the following section. It is not every one who can follow a work like this, which is no connected didactic exposition of the theory of nutrition, but a series of experimental results which group themselves round the great questions of the subject, while the theoretical connection is indicated in short introductions and recapitulations, and it is left to the reader to form his own convictions by careful study of all the details. It was not de Saussure's intention to teach the science, but to lay its foundations ; not to communicate facts, but to establish them ;

part also in public affairs, being repeatedly elected to the Council of Geneva. His preference for a secluded life is said to have been the reason why he never undertook the duties of a professorship. See the supplement to the 'Biographie Universelle' and Poggendorf's 'Biographisch-litterarisches Handwörterbuch.' 
the style therefore, as might be expected, is dry and unattractive; the writer seems to confine himself too anxiously within the limits of what is given in experience, and there is no doubt that many errors in later times might have been avoided if the inductive proof of de Saussure's doctrines had been accompanied with a deductive exposition of them of a more didactic character.

The processes of vegetation examined by de Saussure were, for the most part, the same as those which Ingen-Houss and Senebier had studied at length and correctly described in their general outlines. But de Saussure went beyond this, and by means of quantitative determinations struck a balance between the amount of matter taken up and given off by the plant, thereby showing what it retains. In this way he made two great discoveries: that the elements of water are fixed in the plant at the same time as the carbon, and that there is no normal nutrition of the plant without the introduction of nitrates and mineral matter. But we cannot form a due idea of de Saussure's services to physiology without going further into the detail of his work.

We will first consider his investigations respecting the assimilation of carbon in plants. Here we have the important result, that larger quantities of carbon dioxide in the atmosphere surrounding the plants are only favourable to vegetation if the latter are in a condition to decompose them, that is, if they are in sufficiently strong light; that every increase in the amount of carbon dioxide in the air in shade or in darkness is unfavourable to vegetation, and that if that increase is greater than eight times in the hundred it is absolutely injurious. On the other hand he found, that the decomposition of carbon dioxide by the green parts in light is an occupation that is necessary to them, that plants die when they are deprived of it. The first clear insight into the chemical processes which accompany the decomposition of carbon dioxide in the interior of the plant was obtained by perceiving, that plants by appro- 
priating a definite quantity of carbon make a much more than proportionate addition to their dry substance, and that this is due to the simultaneous fixation of the component parts of water. The full significance of this fact could only be apprehended at a later time, when the theory of the combinations of carbon, organic chemistry, had been further developed. As regards the importance of the decomposition of carbon dioxide by the green organs under the influence of light to the whole nourishment of the plant, de Saussure arrived by more definite proofs than Ingen-Houss had given at the result, that only a small portion of the substance of plants is derived from the constituents of the soil in solution in water, but that the great mass of the vegetable body is built up from the carbon dioxide of the atmosphere and the constituents of water; he convinced himself of this partly by considering the small quantities of matter which the water is able to dissolve from a soil capable of sustaining vegetation, partly by experiments in vegetation and considerations of a more general character.

Not less important were de Saussure's investigations into oxygen-respiration by plants, which taken simply as a fact, had been previously discovered by Ingen-Houss. But de Saussure showed that growth is impossible without this process of respiration, even in germinating plants, though these are rich in assimilated matter. He further showed that green leaves and opening flowers, and generally the parts of plants which are distinguished by greater activity of vital processes, require more oxygen for respiration than those in a less active and resting state. He determined the loss of weight which the organic substance of germinating plants suffers from respiration, and found it to be greater than was proportionate to the weight of carbon exhaled; but the chemical science of his day did not supply him with a certain explanation of this fact. Lastly, de Saussure at a later time (I822) discovered the chief relations between the internal heat of flowers and their consumption of oxygen, and thus we see that he supplied the most important 
elements in the modern theory of the respiration of plants, though he did not fully explain their mutual connection.

It evidently was the received opinion before the time of Ingen-Houss, and in spite of Hales' views, that plants derive the larger part of their food from the constituents of earth and water. But when it became known that the carbon, which is the chief constituent of vegetable substance, comes from the atmosphere, and it was considered that much the larger part of that substance is combustible, it naturally became a question whether the incombustible ingredients which form the ash take any part in the nutrition of plants. This question was by many physiologists answered in the negative ; but de Saussure maintained the contrary view. He insisted that certain ingredients, which are found in the ash of all plants, must not be regarded as accidental admixtures, and that the small quantities in which they occur are no proof that they are not indispensable; and he showed from a large number of analyses of vegetable ash, which for a long time were unsurpassed in excellence, that there are certain relations between the presence of certain substances in the ash and the condition of development of the organs of the plant; for instance, he found that young parts of plants capable of development were rich in alkalies and phosphoric acid, while older and inactive portions were richest in lime and silicic acid. Still more important were the experiments in vegetation, by which he showed that plants, whose roots grow not in earth but in distilled water, only take up as much ash-constituents as corresponds with the particles of dust which fall into the water; and further, that the increase in the organic combustible substance of a plant so grown is very insignificant, and consequently that there is no normal vege tation where the plant does not take up ash-constituents in sufficient quantity, - $\mathrm{a}$ result of the highest importance to the main question. Unfortunately de Saussure neglected to state these results with due emphasis and to point out their fundamental importance, and consequently doubts were enter- 
tained even till after 1830 respecting the necessity of the constituents of the ash to vegetation.

It was known in de Saussure's time that nitrogen entered into the substance of living plants ; the question was, whence it was obtained. As it was known that four-fifths of the atmosphere consists of nitrogen, it was natural to suppose that it is this which the plant makes use of for forming its nitrogenous substance. De Saussure endeavoured to settle the question by the volumetric method, which, as was afterwards discovered, was not in this case to be trusted. Nevertheless he arrived at the right conclusion, that plants do not assimilate the nitrogen of the atmosphere; this gas must therefore be taken up by the roots in some form of chemical combination. He made no experiments on growing plants to decide what that form was, but contented himself with the conjecture that vegetable and animal matter in the soil and ammoniacal exhalations from it supply the nitrogen in plants. This question, first ventilated certainly by de Saussure, and afterwards the subject of protracted discussion, was finally settled fifty years later by the experiments of Boussingault.

In connection with his researches into the importance of the constituents of the ash, de Saussure proposed the question whether roots take up the solutions of salts and other substances exactly in the form in which they offer themselves. He found first of all that very various and even poisonous matters are absorbed by them, and that there is therefore no such power of choice, as Jung had once supposed; on the other hand, it appeared that the solutions do not enter unchanged into the roots, for in his experiments in every case the proportion of water to the salt absorbed was greater than the proportion between them in the solution, and that some salts enter the plant in larger, some in smaller quantities, under circumstances in other respects the same. But at this time, and for a long time after, it was not possible to understand and rightly explain these facts ; the theory of diffusions was not yet known, 
and fifty or sixty years were to elapse before light was thrown on the questions thus raised by de Saussure.

Such were the most important contents of de Saussure's pub)lication in ISo4. His later contributions to the knowledge of some important questions in vegetable physiology will be mentioned further on. A comparison of the contents of the 'Recherches chimiques' with what was known of the chemistry of the food of plants before $\mathrm{I} 780$ excites the liveliest astonishment at the enormous advance made in these twentyfour years. The latter years of the $\mathrm{i} 8$ th century had proved still more fruitful, if possible, as regards the theory of nutrition than the latter years of the $\mathrm{I} 7$ th ; both periods have this in common, that they developed an extraordinary abundance of new points of view in every branch of botanical science. They resemble each other also in the circumstance that they were both followed by a longer period of inactivity; the time from Hales to Ingen-Houss was highly unproductive, and so also were the thirty years that followed the appearance of de Saussure's great work, though it must be admitted that some good work was done during that period in France, while in Germany the new theory was grossly misunderstood by the chief representatives of botany, as we shall see in the following section. It should be mentioned however that one of these misconceptions, which was not removed till after i 860 , was caused by de Saussure himself. He had observed that the red leaves of a variety of the garden Orache disengage oxygen from carbon dioxide, as much as the green leaves of the common kind. In this case he was hasty, and concluded from this single observation that the green colour is not an essential character of the parts which decompose carbonic acid; if he had only removed the epidermis of the red leaves he would have found that the inner tissue is coloured as dark green as the ordinary green leaves. He who was usually so extremely careful as an observer was for once negligent, and later writers, as is apt to happen, fixed exactly on this one weak point, and repeatedly 
called in question one of the most weighty facts of vegetable physiology, namely, that only cells which contain chlorophyll eliminate oxygen.

5. Vital force. Respiration and heat of plants. Endosmose. I $804-1840$.

DURING the twenty years that followed the appearance of de Saussure's chemical researches the theory of the nutrition of plants can scarcely be said to have been advanced in any one direction, while much that had already been accomplished was not even understood. Various circumstances worked together to introduce misconceptions in this province of botany ; above all others the inclination, more strongly pronounced than ever at this period, to attribute to organisms a special vital principle or force, which was supposed to possess a variety of wonderful powers, so that it could even produce elementary substances, heat, and other things out of nothing. Whenever any process in such organisms was difficult to explain by physical or chemical laws, the vital force was simply called in to bring about the phenomena in question in some inexplicable manner. It was not that the question was now raised, which at a later time engaged the attention of profounder thinkers, whether there was a special agent operating in organic bodies beside the general forces which govern inorganic nature; for a careful examination of this question would certainly have led to the most earnest efforts to explain all the phenomena of life by physical or chemical laws. On the contrary, it was found convenient to assume this vital force as proved, and to assign it as the cause of a variety of phenomena, thus escaping the necessity of explaining the way in which the effects were produced; in a word, the assumption of a vital force was not a hypothesis to stimulate investigation, but a phantom that made all intellectual efforts superfluous.

Another hindrance to the progress of physiology, especially 
where questions of nutrition turned on the movement of the sap, was the backward condition of the study of the inner structure of plants, as described in the second book. For instance, the question of the descending sap was complicated in the strangest way by Du Petit-Thouars's theory of bud-roots that descend between the bark and the wood; Reichel's unfounded idea of the rising of the sap in the tubes of the wood was generally accepted, and a still worse error was maintained by some, that the intercellular spaces of the parenchyma are true sap-conveying organs. In I 8 I 2 Moldenhawer had to insist, but without producing any general conviction, that the vessels of the wood contain air, and Treviranus in $182 \mathrm{I}$ that the stomata serve for the entrance and exit of air. We need not notice here what nature-philosophers like Kieser said about nutrition and the movement of the sap; but even those who were far from adopting the extravagancies of this school were incapable of either making use of or carrying on the labours of Ingen-Houss, Senebier, and de Saussure. We may adduce in proof of this statement the remarks of Link on the function of leaves in his 'Grundlehren der Anatomie und Physiologie,' I 807. He says at p. 202 that their function is according to Hales transpiration, according to Bonnet absorption, according to Bjerkander the exudation and secretion of a variety of fluids, according to Hedwig the storing up of juices, and inasmuch as leaves increase the green surfaces of plants, bear stomata and hairs, and hold a quantity of juices in their abundant parenchyma, we may ascribe all these functions, but none of them exclusively, to leaves; the only thing peculiar to them is that they convey elaborated juices to the young parts. Their great work, the decomposition of carbon dioxide, he does not mention. But this neglect of the doctrines of Ingen-Houss, Senebier, and de Saussure was common, especially in Germany; it is seen in the efforts made to prove once more the existence of a descending sap in the rind, just as it had been proved in the two previous centuries, by the result of removing a ring of bark 
from the stem, and by similar experiments; whereas the simple consideration that it is only in the green leaves that carbonaceous vegetable substance is formed, would have made the existence of what was known as a descending sap appear to be a matter of course, and must have led to a much clearer conception of the matter. But this consideration was either quite overlooked or only mentioned incidentally by those who occupied themselves with experiments on the movement of the descending sap. This is the case in Heinrich Cotta's 'Naturbeobachtungen über die Bewegung und Function des Saftes in den Gewächsen,' I 806, in many respects an instructive work, and in Knight's otherwise serviceable experiments on the growth in thickness of trees. It was not till after 1830 that De Candolle and Dutrochet perceived that the fact that the green leaves are assimilating organs must be decisive of the question of the movement of the sap in the stem.

No progress was made with the general doctrine of nutrition between 1820 and 1840 except in one point, the absorption of oxygen by all parts of plants; here something was done to consolidate the theory and to enrich it with new facts; it was indeed a subject more adapted to the views of the day, because it at once suggested a variety of analogies with the respiration of animals. Grischow showed in I8I9 that Fungi never decompose carbon dioxide, but absorb oxygen and give off carbon dioxide. Marcet carried the subject further in $\mathbf{8} 834$, after de Saussure had published in 1822 an excellent investigation into the absorption of oxygen by flowers; in this work we have the basis laid for the theory of vegetable heat, to which we shall return. But Dutrochet was the first who made an elaborate comparison of the respiration of plants and animals (I837), and showed that not only growth, as de Saussure had already perceived, but also the sensitiveness of plants depends on the presence of oxygen, that is on their respiration. The recognition of the fact, that the inhalation of oxygen plays the same part in plants that it does in animals, prepared the way 
for the view that heat in plants is simply a result of their respiration, as it is in animals. It is not necessary to describe at length the experiments which were made on heat in plants before $\mathrm{x} 822$; they were one and all vitiated by a want of clearness in the statement of the question, which made success impossible; it was assumed that this heat by raising the temperature of the plant would make itself felt by surrounding objects, and it was sought for exactly where it is least to be found, in the wood, in fruits and tubers, and generally in resting, inactive parts. Moreover the previous experiments, collected in Goeppert's book 'Ueber die Wärmeentwicklung der Pflanzen,' ı 83 , were so unskilfully managed that they could not possibly lead to any result. Nor could the question whether plants really develope internal heat, as animals do, be determined by a few cases of active development of heat in flowers, because an idea was prevalent at the time in connection with the theory of a vital force, that flowers as the organs of reproduction alone possessed the power of generating heat.

Lavoisier had clearly perceived in 1777 that the combustion of substances containing carbon by inhaled oxygen was the source of animal heat, and had proved it by experiments. Senebier, who first observed the rise of temperature in the inflorescence of Arum by the thermometer, had at least suggested in his work on physiology of 1800 (iii. p. 315) that a vigorous absorption of oxygen might be the cause of the phenomenon. Bory de St. Vincent reported in $\mathbf{I} 804$ that Hubert, the owner of a plantation in Madagascar, had observed among other things that the air in which the flowering spike of one of the Aroideae had developed its heat could support neither animal respiration nor combustion. These indications were however disregarded, until de Saussure in 1822 proved directly the connection between the absorption of oxygen and the rise of temperature in flowers. It was however a long time before heat in plants was conceived of as a general fact necessarily connected with their respiration. This conception would have swept away the 
whole mass of facts accumulated by Goeppert in his book of 1830 , from which he tried to prove (p. 228) that plants at no period of their life possess the power of generating heat-a view which he retracted however in 1832 , when he had observed a rise of temperature in germinating plants, bulbs, tubers, and in green plants, when collected into heaps. How difficult it was for physiologists under the dominion of the 'vital force' to hold firmly to the simple principle of natural heat, and not to be led away by isolated observations, is shown by the expressions of De Candolle in 1835 , and still more by those of Treviranus in 1838 . It is therefore refreshing to see Meyen in his 'Neues System' (1838), vol. ii, warmly asserting this principle, and making the development of heat in plants a necessary consequence of their respiration and of other chemical processes. Meyen himself produced no new observations; but Vrolik and De Vriese showed by laborious experiments in $183^{6} 6$ and 1839 the dependence of the generation of heat in the flowers of Aroideae on the absorption of oxygen. A higher importance as regards the general principle attaches to the attempt of Dutrochet in 1840 to prove that even growing shoots generate small quantities of heat, as shown by a thermo-electric apparatus. Some of the details in these observations are open to objection; but it cannot be denied that they are based on a clear recognition of the general principle, though they ignore the consideration that the generation of heat in plants is not necessarily accompanied with a rise in temperature, since cooling causes may be acting at the same time with greater effect. However the doctrine of the natural heat of plants was in the main established by the observations of de Saussure, Vrolik, De Vriese, and Dutrochet, and by Meyen's and Dutrochet's assertion of the principle laid down by Lavoisier, though thirty years elapsed before it became an accepted truth in vegetable physiology.

The crude idea of a vital force was deprived of one of its chief supports when it was recognised that the natural heat of 
organisms was a product of chemical processes induced by respiration, for this had been regarded since the time of Aristotle as more peculiarly an effect of the principle of life. And now another discovery was made, equally calculated to promote the reference to mechanical principles of those general and important phenomena of life which had hitherto been indolently ascribed to the operation of the vital force. It appears to be a matter of indifference whether Professor Fischer of Breslau is or is not to be considered as the true discoverer of endosmose in 1822 , for it is certain that it was DutrocheT ${ }^{1}$ who first studied the subject with exactness, and above all perceived its extraordinary value for the explanation of certain phenomena in living organisms. He repeatedly called attention to this value in the years between 1826 and 1837 , and endeavoured to refer a variety of phenomena in vegetation to this agency. He had first observed the operation of endosmose in its mechanical effects in living bodies; the escape of the zoospores of an aquatic Fungus and the ejection of the sperm from the spermathecae of snails first led him to the hypothesis, that the more concentrated solutions inclosed in organic membranes exercise an attraction on surrounding water, which, forcing its way into the inclosed space, is there able to exert considerable powers of pressure. To Dutrochet

${ }^{1}$ Henri Joachim Dutrochet, born in 1776 , was a member of a noble family which belonged to the department of the Indre and lost its property during the revolution; he therefore adopted medicine as a profession, and took his degree at the Faculty of Paris in ISo6. He was attached to the armics in Spain as military surgeon in I808 and I809; but he retired as soon as possible from practice and devoted himself in great seclusion to his physiological pursuits, living for some years in Touraine. He was made corresponding member of the Academy in 1819 , and communicated his discoveries to that body. Becoming an ordinary member in 1831 , he spent the winter months from that time forward in Paris. He died in 1847 after two years' suffering from an injury to the head. Dutrochet was one of the most successful champions, in animal as well as vegetable physiology, of the modern ideas which displaced the old vitalistic school of thought after 1820. See the 'Allgemeine Zeitung' for 1847 , p. 780 . 
must always belong the merit of having brought into notice this mechanical effect of endosmose and of employing it to explain a number of vital phenomena. Many things in which a mechanical explanation had not been hitherto thought of could now be traced to a mechanical principle, the effects of which could be exhibited and more accurately studied by means of artificial apparatus. Dutrochet rightly attached a special value to the fact, that all states of tension in vegetable tissue could be at once explained by endosmose and exosmose, though, as so often happens in such matters, he may have extended his new principle to cases where it was not applicable, as we shall see below. His account of the nature of endosmose itself must now be considered to be obsolete, nor did the mathematician Poisson or the physicist Magnus about I 830 succeed in framing a satisfactory theory on the subject. It was discovered in the course of the succeeding twenty or thirty years, that the phenomena observed by Dutrochet, and which he called endosmose and exosmose, were only complicated cases of hydro-diffusion, which with the diffusion of gas forms an important part of molecular physics. Dutrochet, like his immediate successors, conducted his investigations into osmose with animal and vegetable membranes, the latter being of a complex structure; with these he always observed in addition to the endosmotic flow of water into the more concentrated solution, an escape of the solution itself, and from this he concluded that there must always be two currents in opposite directions through the membrane which separates the two fluids, that, as he expresses it, the endosmose is always accompanied with exosmose. This error, which was even developed later into a theory of the endosmotic equivalent, has had much to do till recently with making it impossible or difficult to refer certain phenomena of vegetation to the processes of hydro-diffusion. To mention only one case, Schleiden rightly observed that if endosmose, as Dutrochet understood it, is the sole cause why water is absorbed by the roots, 
there must also be a corresponding exosmose at the roots; and this, which was called root-discharge, Macaire Prinsep thought he had actually discovered, and even Liebig firmly believed in its existence till a recent period, although the researches of Wiegman and Polstorff (r842) and later more careful investigations showed, that there was no noticeable discharge by exosmose to answer to the great quantity of water with substances in solution in it which is taken up by the roots. Again, Dutrochet's theory of endosmose did not fully explain the way in which the several substances which feed the plant find their way into and are disseminated in it. But notwithstanding these and other defects it deserved the greatest consideration, because it gave the first impulse to the further development of the theory of diffusion, and contained a mechanical principle which might serve to explain very various phenomena in vegetation as yet unexplained. Dutrochet hastened to apply it to this purpose, where it was at all possible to do so, and chiefly in his treatise on the ascending and descending sap ('Mémoires,' 1837 , i. p. 365), which was superior to anything which had been written on the movement of the sap in plants in its clear conception of the question and in perspicuity of treatment. It should be especially mentioned that Dutrochet formed a true estimate of the functions of the leaves as regards both the ascending and descending sap, and to some extent pointed out the fault which lies at the bottom of the earlier experiments with coloured fluids. After communicating a number of good observations on the paths of the ascending and descending sap, and noticing particularly that in the vine the vessels of the wood serve for the movement of the sap only in spring, when vines bleed, but that they are air-passages in summer, when transpiration cruses the most copious flow of water in the wood, he proceeds to consider the forces which effect the movement of the ascending sap in the wood both in spring and summer. He first of all judiciously distinguishes two things which had been before always mixed 
up together, the weeping of severed root-stocks and the rise of the sap in the wood in transpiring plants. The first is caused, he thinks, by impulsion, the other by attraction; we should now say, that in weeping root-stocks the water is pressed upwards, in transpiring plants drawn up. He then refers the phenomenon of impulsion to endosmose in the roots, and without going much into detail as regards the anatomical conditions, he compares a weeping root-stock to his own endosmometer, in the tube of which the fluid that has been sucked in rises by endosmose and even flows over; it is true that no very thorough understanding of the matter was gained in this way, but at any rate the principle which was to explain it was indicated. He then endeavours to explain the movement of the water which ascends in the wood of transpiring plants by the action of endosmose from cell to cell. In this he failed entirely, as was afterwards perceived; but he succeeded in showing that all the mechanical explanations that had been previously attempted were incorrect, and the whole treatise, though unsatisfactory in its main result, contains a great number of ingenious experiments and acute remarks.

With the exception of Théodore de Saussure, who occupied himself exclusively with chemical questions in physiology, Dutrochet was the only vegetable physiologist in the period between I 820 and I 840 who studied all its more important questions thoroughly and experimentally; his treatise on the respiration of plants, which has been already mentioned, is excellent in itself, and was of the greatest importance at the time it appeared, because it brought the chemical processes in respiration, the entrance and exit of the gases, for the first time into correct connection with the air-passages in the plant, with the stomata, the vessels, and the intercellular spaces, and submitted the composition of the air contained in the cavities of plants to careful examination. It was the best work on the respiration of plants in the year 1837 and for a long time after ; and if Dutrochet made the mistake of regarding the oxygen 
which is disengaged from the plant itself in the light as the chief agent in respiration, and the oxygen directly absorbed from the atmosphere as only subsidiary to this, he compensated for it by recognising the importance of the fact, that only cells which contain chlorophyll decompose carbon dioxide, and still more by correctly distinguishing between respiration by the absorption of oxygen and the decomposition of carbonic dioxide in light; these two processes were at that time and afterwards very inappropriately distinguished as the diurnal and nocturnal respiration of plants, and this misleading expression maintained itself in spite of Garreau's protest in $185 \mathrm{I}$ till after I860, when a modern German physiologist succeeded in establishing the true distinction between respiration and assimilation in plants. Another mischievous complication arose about 1830 connected with the expression, circulation of the sap ; it was thought that an argument for such a circulation even in the higher plants was to be found in the 'circulation of the sap' (protoplasm) in the cells of the Characeae, which had been detected by Corti and more exactly described by Amici ; Dutrochet (Mémoires, I. p. 43I) exposed this confusion of ideas, and has the merit of refuting at the same time the absurd theory of the 'circulation of the vital sap,' for which Schultz-Schultzenstein had received a prize from the Academy of Paris.

We shall recur in the next chapter to Dutrochet's minute investigations into the movements connected with irritability in plants, which he also endeavoured to refer to endosmotic changes in the turgidity of the tissues, but he did not do justice to the anatomical conditions of the problem. And here we may take occasion to remark, that Dutrochet's works were often undervalued, especially in Germany, greatly to the detriment of vegetable physiology. His younger German contemporaries, von Mohl and Schleiden, and at a later time Hofmeister, were right in pointing out what was erroneous and sometimes arbitrary in his mechanical explanations of 
various movements in plants, and it cannot be denied that he was sometimes led into obscure and doubtful views, as for instance when without any apparent connection he regarded the inhalation of oxygen as a mechanical condition of the rising of the sap and also of heliotropic curvatures, and that his attempts at explanation were not seldom forced and improbable; but all this does not prevent it from being true, that an attentive reader will still gain much instruction from his physiological writings and be excited by them to examine for himself. Dutrochet was a decidedly able man and an independent thinker, who it is true was often led astray by his prejudices, but at the same time manfully protested against the old traditional way of dealing with physiological ideas, and substituted careful examination both of his own and others' inyestigations for the accumulation and comfortable retailing of isolated observations which was then the fashion. After de Saussure's 'Recherches chimiques' Dutrochet's 'Mémoires pour servir à l'histoire anatomique et physiologique des végétaux et des animaux,' I837, are without doubt the best production, which physiological literature has to show in the long period from I 804 to 1840 . If later botanists, instead of dwelling on his faults, had developed with care and judgment all that was really good in his general view of vegetable physiology, this branch of botanical science would not have declined as it did in the interval between $\mathrm{I} 840$ and $\mathrm{r} 860$. We shall discover the greatness of Dutrochet as a vegetable physiologist by comparing his work above-mentioned with the best text-books of the subject of the same time, those of De Candolle, Treviranus, and Meyen; not one of them comes up to Dutrochet's Mémoires in acuteness or depth.

The three text-books just mentioned contained little or nothing new either in facts or ideas on the subject of the nutrition of plants; all three were rather compilations of what was already known, and differed from each other only in their selection of material and in the form which each sought to give 
to the general theory; but this is a reason why we should take a nearer look at them, that we may learn how the spirit and tendencies of the time were reflected in vegetable physiology, and made themselves felt particularly in the theory of nutrition.

De Candolle's work appeared in French in ${ }^{2} 832$ in two volumes, the first only being devoted to the subject of the nutrition of plants, and in German in 1833 with many valuable annotations by the translator Roeper, under the title, 'Pflanzen-physiologie oder Darstellung der Lebenskräfte und Lebensverrichtungen der Gewächse.' It suffers, in common with the other two books we have mentioned on the same subject, and with the earlier works of Du Hamel, Mustel, and other writers, from a too discursive mode of treatment, which has the effect of burying the points of fundamental importance under a huge mass of facts and statements from other writers. It contains much that might have been omitted as obsolete, and much empirical material of a purely chemical nature, which could not at that time be applied to the purposes of physiology. Nevertheless, it deserved the great consideration which it enjoyed for a long time, especially in Germany, for its author had undertaken to treat vegetable physiology as a separate and peculiar branch of knowledge, not ignoring at the same time its connection with and dependence on physics, chemistry, phytotomy, and biology proper, and thus to give a full and complete delineation of vegetable life; whereas the best works that had been written since Du Hamel's time, especially on the nutrition of plants, had proceeded from chemists and physicists or from plantgrowers like Knight and Cotta, who treated the subject in a one-sided manner, each from his own point of view, and made no attempt to give a connected account of all the phenomena of vegetation. For this reason De Candolle's 'Physiologie végétale' is the most important performance that appeared after Du Hamel's ' Physique des Arbres'; and if we wish to know what progress was made in vegetable physiology gener- 
rally, and in the doctrine of nutrition particularly, in the period from $175^{8}$ to 1832 , we have only to compare the contents of these two books. That this progress was a considerable one, appears plainly from a short summary at the end of the first volume of the general theory of nutrition, as De Candolle himself conceived it ; this summary will show us at the same time that he aimed rather at giving a clear account of the whole of the internal economy of the plant, than at searching into the moving forces, the causes and effects. From this he was necessarily withheld by his assumption of a vital force. $\mathrm{He}$ distinguished four kinds of forces ; the force of attraction which produces the physical, and that of elective affinity which causes the chemical phenomena; then the vital force, the original source of all physiological, and the soul-force, the cause of all psychical phenomena. Only the first three of these forces operate in the plant, and though it is necessary to find out what phenomena in vegetation are due to physical or chemical causes, yet the main task of the vegetable physiologist is to discern those which proceed from the vital force, and the chief mark of such phenomena is that they cease with the death of the plant (p. 6). Of course therefore all the peculiar phenomena of nutrition, which are manifested only in the living plant, come within the domain of the vital force. It must be allowed, however, that De Candolle has made a very moderate use of the vital force, and confines himself wherever he can to physical and chemical explanations ; and when he has recourse to the vital force, it is owing less to the influence of his philosophical point of view than to the fact that his account is based rather on tradition and information at second hand than on actual research. It is true that De Candolle was perhaps better acquainted than any contemporary botanist with the physics and chemistry of his day, and it is part of his great merit that he should have acquired so much knowledge on these subjects while engrossed in his splendid labours as a systematist and morphologist ; but he betrays, at least in his later years, a want of practice in the study 
of physics and a want also of the habit of mind which this imparts, and which is more important to the physiologist than a knowledge merely of many facts. But this defect is still more apparent in Treviranus and Meyen, whose works on physiology were published soon after that of the great systematist.

De Candolle first brings together all the facts in physiology which have been discovered from the beginning, not omitting the chemical researches of more modern times into the substance of plants, and then gives a general delineation of the processes of nutrition in the plant: 'The spongioles (an unfortunate invention of his own which has not yet disappeared from French books, and plays a great part in Liebig's latest work)the spongioles of the roots, being actively contractile and aided by the capillarity and hygroscopic qualities of their tissue, suck in the water that surrounds them together with the saline organic or gaseous substances with which it is laden. By the operation of an activity which is manifested principally in the contractility of the cells and perhaps also of the vessels, and is maintained by the hygroscopic character and capillarity of the tissue of the plant and also by the interspaces produced by exspiration of the air and by other causes, the water sucked in by the roots is conducted through the wood and especially in the intercellular passages to the leaf-like parts, being attracted in a vertical direction by the leaves and in a lateral direction by the cellular envelope (cortical parenchyma) at every period of the year, but chiefly in the spring; a considerable part of it is exhaled all day long through the stomata into the outer air in the form of pure water, leaving in the organs in which the evaporation takes place all the saline, and especially all the mineral particles which it contained. The crude sap which reaches the leaf-like parts of the plant there encounters the sun-light, and by it the carbonic acid gas held in solution by the sap, whether derived from the water sucked in by the roots or from the atmospheric air, or being part of that which the oxygen of the air produced with the surplus carbon of the plant 
is decomposed in the day-time; the carbon is fixed in the plant and the oxygen discharged as gas into the air. 'The immediate result of this operation appears to be the formation of a substance which in its simplest and most ordinary state is a kind of gum consisting of one atom of water and one of carbon, and which may be changed with very little alteration into starch, sugar, and lignine, the composition of which is almost the same. The nutrient sap thus produced descends during the night from the leaves to the roots, by way of the rind and the alburnum in Exogens, by way of the wood in Endogens. On its way it falls in with glands or glandular cells, especially in the rind and near the place where it was first formed; these fill themselves with the sap and generate special substances in their interior, most of which are of no use in the nutrition of the plant, but are destined either to be discharged into the outer air or to be conducted to other parts of the tissue. The sap deposits in its course the food-material, which becoming more or less mixed up with the ascending crude sap in the wood, or sucked in with the water which the parenchyma of the rind draws to itself through the medullary rays, is absorbed by the cells and chiefly by the roundish or only slightly elongated cells, and is there further elaborated. This storing up of food-material, which consists chiefly of gum, starch, sugar, perhaps also lignine, and sometimes fatty oil, takes place copiously in organs appointed for the purpose, from which this material is again removed to serve for the nourishment of other organs. The water, which rises from the roots to the leaf-like parts of the plant, reaches them in an almost pure state, if it passes quickly through the woody parts, the molecules of which are but slightly soluble. If, on the other hand, the water flows through parts in which there is much roundish cell-tissue filled with food-material, it moves more slowly and mixes with this material and dissolves it ; when it is drawn away from these places by the vital activity of the growing parts, it reaches them not as pure water but charged with nutrient substances. The juices of plants appear 
to be conveyed chiefly through the intercellular passages. The vessels probably share in certain cases in these functions, but serve generally as air-canals. The cells appear to be the really active organs in nutrition, since decomposition and assimilation of the juices take place in them. Cyclosis (of Schultze's vital $\operatorname{sap}^{1}$ ) is a phenomenon which appears to be closely connected only with the preparation of the milky juices, and to be caused by the actively contractile nature of the cell-walls or of the tubes. Woody and other substances are deposited in every cell in different quantities according to their kinds and the accompanying circumstances, and clothe their walls; the unequal thickness of the layer so deposited appears according to Hugo von Mohl to have given rise to the supposition of perforated cells ; that is, the parts of the cell-wall that remain transparent appear under the microscope as pores. Every cell may be regarded as a body which prepares juices in its interior; but in vascular plants their activity stands in such a connection with a complex of organs, that a single cell does not represent the whole organism, as may be said of the cells of certain cellular plants, which are all like one another. There is no circulation in plants like the circulation in animals, but there is an alternating ascent and descent of the crude sap and of the formative sap which is often mixed with it. Both these phenomena depend perhaps on the contractile power in cells that are still young, and if so, this power would be the true vital energy in plants.'

What is strange to us in De Candolle's theory of nutrition is due chiefly to the predominance of the vital force; yet at the same time it gives the facts in their general connection, and its best feature is, that the true function of the leaves, the decomposition of carbon dioxide in light and the production of organisable substance, is made the central point of the whole circle of the processes of nutrition. Very different in this respect were the views of the two most eminent German

1 See above on page $5^{1} 3$. 
vegetable physiologists at the close of the period before us, Treviranus and Meyen, though they are not in accord with one another in their general conception of the subject. It may be said that all the prejudices and errors, built up on the foundation of the hypothesis of a vital force during the first thirty years of the rith century, culminated in Treviranus; while others were already setting up the mechanical explanation of the phenomena of vegetation as the one object to be attained, Treviranus produced once more the whole machinery of the obsolete doctrine of the vital force, and with such effect, that his 'Physiologie der Gewächse' was already obsolete when it appeared in 1835 . The second volume of Meyen's 'Neues System der Pflanzenphysiologie' was a striking contrast to the work of Treviranus; Meyen endeavours as far as possible to trace back the phenomena of vegetation to mechanical and chemical causes, though he does not often succeed in bringing anything to light that is new or of lasting service. He, like Treviranus, was deficient in sound training in chemistry and physics; they did not stand in this respect, as Hales and Malpighi once did, at the highest point of knowledge of their time. At the same time there was a great difference in the way in which each dealt with the writings of his predecessors; Treviranus, who had done good service in former years in phytotomy, was not equal to the task which he had now undertaken; his physiological expositions are marked by feebleness of thought and by an inability to survey as from a higher ground the connection between the facts; he distrusts all that had been done during the previous thirty years, and almost everywhere appeals to the publications of the I8th century; he lives indeed in the ideas of the past, without gaining vigour from the forcible reasoning and freshness of thought of a Malpighi, a Mariotte, or a Hales. Meyen's treatment of his subject is on the contrary fresh and vigorous; he does not disregard the old, but he holds chiefly to the modern conquests of science; while Treviranus with singular 
ill-luck constantly overlooks what is valuable in itself and important in its results, Meyen generally picks out the best things from the books before him; Treviranus timidly avoids expressing any view decidedly and maintaining it ; Meyen, amid the multiplicity of the labours which we have already described, finds no time to arrange his thoughts, is hasty in judgment and often contradicts himself. But with all these defects, he is still the champion of the new tendencies that were being developed, while Treviranus lives entirely in the past, and shows no trace of the actively creative spirit which was soon to burst forth so mightily in every branch of natural science.

If we examine what both these writers have said on the subject of the nutrition of plants, we shall find that the difference in their general views in physiology as described above appears at once in their treatment of the work of suction in the roots, and of the means by which the sap ascends; here in Treviranus the vital force is everything; it makes the vessels of the wood conduct the juices from the roots into the leaves, with other antiquated notions of the kind; Meyen on the contrary adopts Dutrochet's position, and even rejects De Candolle's spongioles. Treviranus knows not what to make of respiration; Meyen explains it without hesitation as a function that answers to respiration in animals, and finds in it the main cause of the natural heat which Treviranus derives in the old mystical fashion from the vital force. In one point however they agree, namely, in a complete misconception of the connection between the decomposition of carbon dioxide in the leaves and the general nutrition of the plant. It is necessary to the understanding of the confusion of ideas which had crept at this time into the doctrine of nutrition, and to a right estimate of the services of Liebig and Boussingault on this point, that we should look a little more closely into the chemical part of the theory of nutrition in Treviranus and Meyen.

Treviranus in the introduction to his book repudiated the idea of a vital force separable from matter, but he was in fact 
a prisoner within that circle of ideas, and he made a much freer use of the vital force than De Candolle; he went even farther than this, and in his want of chemical experience he hit upon the grossly materialistic notion of a vital matter (I. p. 6). This vital matter is a half-fluid substance, which may be obtained from all bodies that were once alive by boiling and by decay; it is formed from other elements, but it is itself the true elementary matter with which alone physiology has to do; it is common to the animal and vegetable kingdom, and is purest when in the form of mucilage, albumen, and gelatine; that animals and plants alike consist of this vital matter explains the circumstance, that plants serve as food for animals and animals as food for plants. He goes on to show that a similar unctuous substance, called by chemists extract of the soil, and considered by many of them to be an important ingredient in the nutrition of plants, is their true and proper food. This extract of the soil was therefore the vital matter which plants take up; it was natural that Treviranus should no longer attribute any importance to the decomposition of carbon dioxide in the leaves, especially as he was unable to understand the chemical connection of all that Ingen-Houss, Senebier, and de Saussure had written. He explained the cooperation of light in the nutrition of plants to be a merely 'formal condition,' and the salts in solution in the water of the soil were in his opinion stimulants for the use of the extremities of the roots, which were thus put into a condition of 'vital turgescence'; and as the functions of the leaves, such as Malpighi and Hales had conjectured, and Ingen-Houss, Senebier, and de Saussure had proved it to be, had no existence for Treviranus, he made the assimilation of the soil-sap take place on its way, as it flowed upwards and downwards through the plant. We see that nothing can be conceived more deplorable than this theory of nutrition; it would have been bad at the end of the $I 7$ th century, it is difficult to believe that it could have been published thirty years after de Saussure's work. 
Chap. II.]

There is much in the details of Meyen's views on the chemical processes in the nutrition of plants that is better than what we find in Treviranus; it is a great point that he concluded from earlier experiments, that the salts which find their way with the water into the roots are not merely 'stimulants' but food-material, and, as was before said, he explained the respiration of oxygen by plants correctly in accordance with de Saussure's observation. But he too stumbled over the assimilation of carbon; he, like so many before and after hin, was confused by the simple fact, that gaseous matter takes part both in the nutrition and the respiration of the plant; and taking the processes in both cases for processes of respiration, he considered the absorption of oxygen to be the only important and intelligible function, and the decomposition of carbon dioxide in light to be a matter of indifference as regards the internal economy of the plant. Instead of ascertaining by a simple calculation, whether the apparently small quantity of carbon dioxide in the atmosphere was perhaps sufficient to supply vegetation with carbon, he simply declared it to be insufficient, and because plants will not flourish in barren soil merely by being supplied with water containing carbon dioxide, he gave up the importance of that gas altogether. He too found the humus-theory, which had been constructed by the chemists, more convenient for his purpose, and like Treviranus derived the whole of the carbon in plants from 'extract' of the soil, without any close attention to the facts of the case; he refused to believe that the soil is rendered not poorer but richer in humus by the plants that grow on it. It is obvious then that the account given by Treviranus and Meyen of the chemical processes that take place in the nutrition of plants, though correct in some of the details, could afford no true general view of the processes of nutrition, because it entirely misconceived the cardinal points in the whole theory, namely the source of the carbon, and the co-operation of light and of the atmosphere; and 
thus the best results of the observations of Ingen-Houss, Senebier, and de Saussure were lost upon the German vegetable physiologists.

6. Settlement of THE QUeStion of THE FOOD-MATERial OF PLANTS. I 840-I860.

WE have noticed in the previous section the rise of views during the period between I 830 and I 840 which were calculated to make the hypothesis of a vital force appear superfluous, at least as an explanation of certain important phenomena in vegetation; such were the referring the natural heat of plants to chemical processes, and the movement of the sap to osmose ; in the domain of chemistry also, in which Berzelius had in the year 1827 made the distinction between organic and inorganic matter to consist in the fact, that the former is produced under the influence of the vital force, the opinion was openly expressed that such an intrusion of the vital principle could not be allowed, since organic compounds had been repeatedly produced from inorganic substances by artificial means, and therefore without its aid. The general tendency of scientific thought was now in fact unfavourable to the nature-philosophy of former days; it inclined to free itself from the obscurity that attended the idea of a vital force, and to assert the belief, that chemical and physical laws prevail alike outside and inside all organisms; this idea became an axiom with the more eminent representatives of natural science after 1840 , and if not always expressed in words, was made the basis of all their attempts to explain physiological phenomena.

Thus a freer course began to open for the intellectual movement of the time even before the year 1840 , and strict inductive research, and above all the establishment of facts and closer reasoning were now demanded in the question of the nutrition of plants, as they were also in the domain of morphology and phytotomy. But in dealing with the theory 
of nutrition, the first thing required was not the discovery of new facts so much as the forming a correct appreciation of the discoveries of Ingen-Houss, Senebier, and de Saussure, and clearing away the misconceptions that had gathered round them. The chief modern representatives of vegetable physiology, De Candolle, Treviranus, and Meyen, had increased the difficulty of the task by neglecting to keep the several questions of their science, the chemical especially and the mechanical, sufficiently distinct from one another. The question, what are the materials which as a rule compose the food of plants, though one of the first and most immediate importance, had been very imperfectly investigated, while attention had been diverted to a confused mass of comparatively unimportant matters, and the solution of that question had been rendered impossible for the time by the humus-theory, an invention of chemists and agriculturists, which Treviranus and others had fitted so readily into the doctrine of a vital force. To Liebig belongs the merit of removing these difficulties and all the superfluous matter which had gradually gathered round the subject, and of setting forth distinctly the points which had to be considered ; this was all that was required to ensure a satisfactory solution of the problem, for former observations had supplied an abundance of empirical material. But some points of minuter detail were brought out in the course of his investigations which required new and comprehensive experiments, and for these a most capable and successful observer was found between $\mathrm{r} 840$ and $\mathrm{r} 85^{\circ}$ in the person of Boussingault.

But before we go on to give a fuller account of the work of Liebig and Boussingault, we may mention a circumstance which serves to indicate the character of the revolution in scientific opinion before and after I840. An anonymous 'Friend of science' had put a prize at the disposal of the Academy of Göttingen for an answer to the questions, ' whether the inorganic elements, which are found in the ashes of plants, are found in the plants themselves, in cases where they are not 
supplied to them from without; and whether these elements are such essential constituents of the vegetable organism, as to be required for its full development.' The first question appears in the present day absurd, since it implies the possibility of elementary matter coming into being, and of certain special elements coming into being in the plants themselves, an idea however not unfamiliar to the nature-philosophy and the vital force school. It was easy for Wiegman and Polstorff, the authors of the essay that gained the prize (1842), men of the new school, to answer the first question in the negative, and indeed their answer to the second question involved a negative answer to the first. The investigations made by Wiegman and Polstorff in connection with the subject of the second question were conducted in a thoroughly intelligent manner, though they set out from the hypothesis that a certain quantity of compounds of humic acid, as it was called, must be present in the food-mixtures. Their experiments, better adapted to the purpose than any previous ones, showed convincingly that it is necessary to the normal nutrition of the plant that it should take up the constituents of the ash; the observers also took into consideration a number of other questions connected with nutrition, in which however we may already see the influence of Liebig's book which had come out during their investigations.

This work was the one entitled 'Die organische chemie in ihrer Anwendung auf Agricultur und Physiologie,' which appeared first in 1840 and was afterwards repeatedly reprinted and enlarged. The name of the author, the first chemist of Germany, raised an expectation that the questions respecting nutrition would be dealt with otherwise than they had hitherto been, and this expectation was more than fulfilled by the novelty and boldness with which Liebig cleared up the most important points of the theory, seized upon all that was essential and fundamental, and disregarded the unimportant matter which had before only served to confuse the question. 
Moreover, he was able to rest on long-accepted facts in just those points which were the most important, and on these he had only to throw the light of his chemical knowledge to dispel the previous darkness. In accordance with his main purpose, which was to apply organic chemistry and vegetable physiology to the service of agriculture, Liebig directed the severity of his criticism first of all against the humus-theory constructed by chemists and agriculturists and thoughtlessly adopted by various physiologists; this was the first thing that must be got rid of, if the question was to be answered, of what substances does the food of plants consist, for the humustheory was at once incorrect, and the product of a want of reflection which overlooked facts which lay before men's eyes. Liebig showed that what was known as humus is not diminished but constantly increased by vegetation, that the quantity in existence would not suffice for any length of time for the support of a vigorous vegetation, and that it is not taken up by plants. This once established, and Liebig's calculations left no doubt on the point, there remained one source only for the carbon of the plant, namely, the carbon dioxide of the atmosphere, with regard to which it was shown by a very simple calculation resting on eudiometric results that its quantity is sufficient to supply the vegetation of the whole earth for countless generations. It is true that Liebig in his zeal went much too far, when he found something contradictory in the true respiration of plants, because it is connected with the elimination of carbon dioxide, and simply denied its reality. On the other hand the theoretical significance of the fact established by de Saussure, that the elements of water are assimilated at the same time as the carbon, was now for the first time clearly explained. Liebig was better able to realise the importance of this fact for the theory of nutrition than de Saussure had been. But these weighty points were not the ones which attracted most attention with the adherents and opponents of Liebig; the practical tendency of his book made 
the discussion, to which it gave rise especially among chemists and agriculturists, turn rather on the question of the source of the nitrogen in the substance of plants. The humus-theory had made the nitrogen like the carbon enter the plant in the form of organic compounds. De Saussure in his great work of I 804 had named ammonia as a compound of nitrogen which might be taken into consideration with others, but he arrived at no definite conclusion. Liebig, from different points of view and in reliance on his own investigations into the nature of nitrogen and its compounds, arrived at the result, that ammonia must ultimately be the sole source of the nitrogen in the plant, and that the ammonia in the atmosphere and in the soil is quite sufficient to supply vegetation with the requisite amount of nitrogen just as the carbon dioxide of the atmosphere is the sole source of the carbon of the plant; and so he concluded that 'carbon dioxide, ammonia, and water contain in their elements the requisites for the production of all the substances that are in animals and plants during their life-time. Carbon dioxide, ammonia, and water are the ultimate products of the chemical process of their putrefaction and decay.'

Liebig was less happy, at least as regards his mode of treating the subject, in his remarks on the necessity and specific importance of the constituents of the ash to the nutrition of plants. Instead of insisting on an experimental answer to the question, what constituents of the ash are absolutely indispensable to the health of one or all plants, he lost himself in ingenious chemical theories, intended to show the operation of inorganic bases in fixing vegetable acids, the extent to which different bases can replace each other, and similar matters.

It is not requisite for our purpose to follow Liebig in his applications of his theoretical remarks to agriculture, still less to occupy ourselves with the sensation and the discussions which his work excited among practical and theoretical farmers and agricultural chemists. The scientific value of Liebig's considerations on the nutrition of plants stood out in 
a purer and more definite form for the vegetable physiologists, who turned their attention chiefly to the points mentioned above. It is true that Liebig's work encountered lively opposition from these men also, and the two foremost representatives of vegetable physiology at that time, Schleiden and von Mohl, criticised it unsparingly; this was due partly to the deductive method adopted by Liebig, to which botanists were unaccustomed in physiological questions, and partly to the derogatory expressions in which he indulged against the vegetable physiologists, whom he held responsible with the botanists generally for all the absurdities connected with the humus-theory. Von Mohl asked, and justly, whether deSaussure, Davy, Carl Sprengel, Berzelius and Mulder, the real founders of the theory, were botanists. But it was unnecessary for von Mohl, Schleiden and others to feel touched by Liebig's reproach, at least so far as it was addressed to professed physiologists, for they were no more physiologists than Davy, Berzelius or Mulder. Professed vegetable physioligists, official public representatives of vegetable physiology there were none, and then as now every one who occupied himself occasionally with questions of the kind was called a vegetable physiologist. In this way the contest became a dispute about words, and Liebig, von Mohl and Schleiden lost an excellent opportunity for influencing public opinion in favour of the idea, that it was high time to establish public official representatives of so important a branch of science, who should devote themselves entirely to it; how could it be expected that Professors of botany, who were required by the government and the public to work for the advancement of systematic botany, phytotomy, and medical botany, to give instruction in these subjects, and to devote a large portion of their time to the management of botanic gardens, should do much to promote the study of vegetable physiology, which demands very considerable acquaintance also with physics and chemistry? and where were the laboratories and the instruments for the serious 
prosecution of this branch of science? But these questions were not raised, and the old state of things remained for the time unchanged.

As regards the scientific questions at issue between Liebig and von Mohl, Schleiden, and various agricultural chemists, the contest was chiefly about matters of secondary importance, and among these might be included the objection that Liebig knew scarcely anything of the anatomy of the plant. The main point was, that he had corrected mistaken views as to the way in which plants are fed, had refuted gross errors, had shown what was fundamental and essential and what was unimportant. Everything that was written on the subject after $\mathrm{i} 840$ shows that he did all this completely; the publications called forth by the controversy on his book occupied in the main the ground which Liebig had cleared. Now every body knew all at once what was meant by the decompositon of carbon dioxide in the green parts of plants, that the constituents of the ash are not mere seasoning to the vegetation, and the like; firm ground had been won for all, a number of scientific truths had become common property for ever; this did not of course make it less meritorious in others, to test the rest of Liebig's theories, or even to correct his great mistake about the respiration of plants, as was done emphatically by von Mohl.

It would not be consistent with the design of this work to go into all the details of the discussion excited by the appearance of Liebig's book, into questions for instance respecting the first products of assimilation in plants, and their further transformations by metabolism. Whether the primary use of the basic mineral constituents is merely to fix the vegetable acids, whether these acids are the first products of assimilation, or whether carbo-hydrates are the immediate result of that process, and similar questions, were for some time only matter of conjecture, deduction and combination, unsupported by certain observation obtained by suitable methods; it was not till after 
r 860 that new paths were struck out on these subjects, and important results achieved. More important at the time for the advance of the science was the further examination of the question respecting the source of the nitrogen which plants assimilate; it was the more necessary that this point should be finally settled, because Liebig's deductions still gave room for many doubts, and the first of vegetable physiologists, de Saussure, in his later days made the mistake of coming forward in opposition to Liebig as a defender of the humus-theory, maintaining $\left(\mathrm{I}_{42}\right)$ that ammonia or the nitrates are not themselves the food-material of plants, but only serve to dissolve the humus. Others also found it difficult to give up entirely the old and favourite doctrine of the humus; though von Mohl and others acknowledged that the carbon of plants is mainly derived from the atmosphere, yet they thought themselves obliged to assign to the humus, on account of the nitrogen which it contains, a very important share in promoting vegetation. Under these circumstances it was extremely fortunate for physiology that Boussingault took up the question. He had occupied himself before the appearance of Liebig's book with experimental and analytical investigations into germination and vegetation, and specially into the source of nitrogen in plants. His experiments in vegetation in 1837 and $\mathrm{r} 838$ produced no very decisive results; but he continued them for some time longer, improving his methods of observation from year to year; and between the years $\mathrm{I} 85 \mathrm{I}$ and $\mathrm{I} 855$ he succeeded in establishing with all certainty as the result of many repeated trials, that plants are not capable of assimilating the free nitrogen of the atmosphere, but that a normal and vigorous vegetation is produced, when they are supplied with nitrogen from the nitrates in the soil. It appeared also that plants will flourish in a soil from which all trace of organic substance has been removed by heat, if a nitrate is added to the constituents of the ash ; this proves at the same time that the whole of the carbon in such plants is derived from the 
carbon dioxide of the atmosphere without the co-operation of the humus, and that consequently the favourable effect of a soil rich in humus on vegetation must be due to other causes than those which were assumed by the humus-theory. We cannot describe the further services rendered by Boussingault to the theory of nutrition, for this would take us too much into technical details, and the best and most important of his results were first given to the world after I860, and do not fall therefore within the limits of this history. But it should be mentioned that Boussingault must be considered the founder of modern methods of conducting experiments in vegetation. Liebig had before spoken in terms of sufficient severity of the miserable way in which experiments on the subject of the nutrition of plants were managed after de Saussure's time till later than 1830 , but he did not himself introduce better methods; this was reserved for Boussingault. One instance may be given; those who desired to decide the question of the humus by experiment, such as Hartig in conjunction with Liebig and others, generally adopted the plan of supplying plants with compounds of humus-acid, and seeing what would be the result. Boussingault did as Columbus with the egg; he simply made plants supply themselves with food in a soil artificially deprived of all trace of humus and containing a mixture of food-material, in order to prove beyond question that they do not need humus.

In Germany also Prince Salm-Horstmar made similar experiments to those of Boussingault; he occupied himself chiefly in determining the relative importance of the acids and bases of the ash in the nutrition of plants, whether any and which of them are indispensable; these are questions which approached their solution only after I860, and some are not yet decided.

The establishment of the facts, that plants containing chlorophyll derive the whole of their carbon from the carbon dioxide of the atmosphere, and that the latter is also the original source of the carbon in plants and animals which do not contain 
chlorophyll; further that the nitrogen which plants assimilate is derived from ammoniacal salts or nitrates, and that the alkalies, alkaline earths in the form of sulphates and phosphates, are indispensable ingredients in the food of plants, must be considered to be the great results of the labour bestowed on the theory of nutrition in the period from 1840 to 1860 , while the way was also prepared for many points, which were afterwards of the first importance in the enquiry.

On the other hand the advance made in the theory of the movement of the sap from the time of Dutrochet till nearly I 860 was so small as to be scarcely worth mentioning; yet it was an advance, that the physiological value of the doctrine of endosmose was more and more highly estimated, and that more solid proofs of the theory itself and a more exact acquaintance with osmotic processes were making it possible to explain more of the details of the movement of material in the plant, though the whole question was far from being finally settled. One discovery must be specially mentioned, the establishment by Hofmeister in 1857 of the fact, that the phenomenon observed for centuries in the grape-vine and other trees, and more recently in Agave and in many tropical climbing plants, known by the name of bleeding or weeping and supposed to be confined to certain periods of vegetation, not only occurs in all plants with true woody cells, but may be produced in them at all times by suitable means. The knowledge of this fact was an aid to the investigation of the cause of the weeping.

The theory of the descending sap was in the least advanced condition during this period; appeal was still made to experiments of the kind which Malpighi, Du Hamel, and Cotta had made, and which in reality show nothing more than that in dicotyledonous woody plants a food elaborated in the leaves is carried downwards through the cortex. As soon as it was understood, that all organic substance originates in the leaves, a fact which no one could doubt after 1840 , no experiment was required to prove that the formative matter necessary for 
the growth of the roots, buds, and fruit, must be conducted to those parts from the leaves. It could no longer be a question whether such a movement of assimilated material takes place; it remained only to consider what are the conducting tissues, and what is the nature of the substances which are produced in the leaves and conducted to the rest of the organs. Both questions in accordance with the organisation of the plant could be properly answered only by microchemical methods, and these were not adopted and further developed till after 1857 . We have already said that nothing certain was known even as late as 1860 about the chemical combinations formed by assimilation in the leaves; De Candolle supposed that the primary formative sap was a gum-like substance, from which the rest of the various vegetable substances were secreted in the different tissues. Theodor Hartig, who had done good service between $185^{\circ}$ and $r 860$ by his investigations into the starch in the wood of trees and into proteid in seeds, by the discovery of sieve-tubes, by observations on the amount of water in woods at different times of the year, and by other contributions to botanical science, also occupied himself with the subject of the descending sap, which he conceived of as a formless primary mucilage, from which, as from De Candolle's gum, the various substances in the plant were deposited as it travelled through the plant. He says ('Botanische Zeitung' for I 858, p. 34r), "The crude sap is changed in the leaves into primitive formative sap,' and 'the formation of solid reservematerial (from this) involves the elimination of large quantities of watery fluid.' The occasional remarks of vegetable physiologists of all sorts between 1840 and 1860 prove, that similar ideas respecting the formation of a primary mucilage of this kind in the leaves were generally entertained. 


\section{CHAPTER III.}

\section{History of the Doctrine of the Movements of Plants (Phytodynamics).}

IT will scarcely be doubted at the present day, that the mechanical laws of growth, of geotropic and heliotropic curvatures, of the various kinds of periodic movements, of the twining of tendrils and climbing plants, and of movements dependent on irritation, may be referred to a common principle, and that in all these movements besides the elasticity of the cell-walls the still unknown qualities of the protoplasm play the most important part, and that consequently the 'streamings' of the protoplasm, the movements of swarm-spores and similar occurrences must be ranked with these phytodynamical phenomena. From this point of view phytodynamics would appear to be one of the most important foundations of vegetable physiology. The recognition of this fact is however of very recent date, and to imagine that such a conception of the movements of plants was present to the minds of the early physiologists would be to attribute to the past ideas to which it was entirely a stranger. These movements were scarcely noticed even as curiosities in former ages, and it was not till the end of the $I 7$ th century that some attention began to be paid to them; and very slow progress was made at a later time in disentangling the relations which come under consideration and which are some of them very complicated, in determining the dependence of the phenomena on external influences, and explaining to some extent their mechanical conditions.

Single movements of parts of plants are noticed in a cursory manner by some early writers. Varro was the first who men- 
tioned the heliotropic movements of the stalks of many flowers, which he says were for that reason called heliotropic flowers; in the following century Pliny says that the leaves of clover close when bad weather is approaching; Albertus Magnus in the I 3 th century, Valerius Cordus and Garcias del Huerto in the I6th, thought the daily periodical movements of the pinnate leaves of some Leguminosae worth recording; Cesalpino noticed the movements of tendrils and climbing plants, and was surprised to see that the latter to some extent seek for their supports. These were every-day phenomena, but the striking sensitiveness of the leaves of Mimosa pudica introduced from America could not fail to attract attention, and so we find an essay on the causes of it in Robert Hooke's 'Micrographia' of 1667 . The irritability of the stamens of Centaurea had been already mentioned by Borelli in 1653 .

I. We meet with the first speculations on the subject at the end of the I 7 th century. Ray in his 'Historia Plantarum' (r693) commences his general considerations on the nature of the plant with a succinct account of phytodynamical phenomena, and introduces the whole by a sentence of Jung: 'Planta est corpus vivens non sentiens,' etc. Though Ray, like Cesalpino, seems to believe in the Aristotelian soul of plants, yet he does on the whole endeavour to explain the movements which he describes by physical and mechanical laws; he thinks that the irritability of Mimosa in particular is not due to sensation, but to known physical causes; the movement of the leaf when it is touched is caused by a contraction, which again is due to a withering or relaxation of its parts. He endeavours to apply the knowledge of his time to the explanation of the mechanical process : leaves, he says, remain tense only because the loss by evaporation is kept constantly supplied by the water that flows to them from the stem; if then in consequence of a touch the sap-passages of the leaves are pressed together, the supply of water is not sufficient to prevent their becoming relaxed. Ray mixes up together 
the movements from irritability and the daily periodical movements, as was done till recent times; the latter, he says, occur not only in the leaves of Leguminosae, but in almost all similar pinnate leaves, and with these periodical movements of leaves he places also the periodical opening and closing of the flowers of Calendula, Cichorium, Convolvulus, and others. That these last movements are due to changes of temperature appeared to him to be proved by an experiment of Jacob Cornutus on flowers of Anemone, which, when cut off and placed in a wellclosed box in a warm place, opened at an unusual time if the flower stalk only was dipped in warm water. This fact, afterwards forgotten and discovered again a few years ago, of the dependence of the movements of flowers on changes of temperature, was applied by Ray to explain the periodical movements of leaves, which, to use his own expression, fold themselves together as the cold of night draws on, and open again with the day, and as he thought that these movements are of the same kind as the movements of irritability in Mimoseae, he tries to explain how cooling has the same effect as a touch. It was natural in the existing state of science to assume that changes of temperature were the first causes of various movements, for a thrust was at that time almost the only recognised cause of motion. Hence Ray explained the movements of growing stems which are now called heliotropic by a difference of temperature on the opposite sides. A certain Dr. Sharroc had observed the stem of a plant on which he was experimenting grow towards that part of a window, where the air found free entrance through an opening; from this circumstance, and from the rapid elongation of the stems of plants growing under cover, which he ascribed to the higher temperature, Ray concluded that cold air hinders the growth of the side of a stem on which it falls, and that this side must become concave. Thus Ray used the etiolation of plants grown under cover to explain their heliotropic curvatures, as De Candolle did one hundred and forty years later, only with this difference, that he 
described the rapidity with which forced plants shoot up to the higher temperature, De Candolle to want of light. On the other hand Ray knew perfectly well that the green colour of leaves is not produced by the access of air but by the light, for, as he says, plants become green under glass, and not under an opaque cover ; and if they become less green under glass than in the open air, this is because the glass absorbs certain rays of light and reflects others. Ray however, like almost all later observers till quite recent times, did not keep the elongation and bleaching of etiolated plants sufficiently distinct; his account of this phenomenon is spoilt by the presence of much that is obscure.

It has been justly observed by other writers on botanical subjects that no notice is usually taken of one of the most remarkable of the phenomena of which we are here speaking, because, being a matter of every-day occurrence, it is simply accepted as something obviously in accordance with the nature of things ; this is the fact, that the main stems of plants grow vertically upwards and their main roots downwards. To the French academician Dodart, whom we have already encountered in the history of the theory of nutrition, is due the great merit of being the first to find this apparently simple phenomenon really very remarkable; he convinced himself by experiments on germinating plants, that these vertical positions are caused by. curvatures, and endeavoured to discover the physical reason why the main roots if placed in an abnormal position escape from it by curving in the downward direction, and the main stems in the upward direction, till they both reach the vertical line. It was a matter of minor importance that his mechanical explanation, which supposed that the fibres of the roots contract on the moister side and those of the stem on the same side lengthen, was quite unsatisfactory; it was much more important that these remarkable phenomena were made the subject of scientific enquiry, and we find that various observers soon after directed their attention to them, and exercised their 
acuteness in attempts at explaining them ; to these attempts we shall return in a future page.

A still more universal phenomenon than the vertical growth of stems and roots is the growth of plants generally, and it required as much or even more of the spirit of enquiry to propose the question, whether this growth can be explained by mechanical laws, and what that explanation is. Mariotte touched on this question in 1679 , but only incidentally, and supposed that the stretching of the pith, which meant at that time the whole of the parenchymatous tissue, was the cause of the growth of the parts of plants. This idea might have had its origin in the Aristotelian notion that the pith is the seat of the vegetable soul, but Mariotte endeavoured to give physical reasons for it. Hales in his 'Statical Essays' of 1727 went much more minutely into the question of the growth of plants. Following the train of thought in his doctrine of the nutrition of plants, he introduces his observations on their growth with the remark, that plants consist of sulphur, volatile salts, earth, water, and air, the first four of which attract one another, and therefore form the solid, inert part of the substance of plants; the air behaves in a similar manner as long as it is kept by the other substances in a solid condition; but as soon as it is set at liberty it is capable of expansion. On this power of expansion in the air, by which the juices of plants are quickened and strengthened, he builds his mechanical theory of growth, according to which the plastic parts of the plant assume a state of tension, and as the air enters into combination with other substances and so becomes fixed, warmth and movement are excited, and these make the particles of sap assume by degrees a form and shape. These principles supplied his starting-point. To get a clearer idea of the way in which the growth of the parts of plants proceeds, he made equi-distant punctures in young stalks and leaves, and found that the intervals between them increased by growth more in the younger intervening parts than in the older. In the course of these observations he is 
particularly struck by the great longitudinal extension which accompanies growth, because, as he says, the vessels still continue hollow, as a glass tube when drawn out to its utmost extent retains its canal. He finds Borelli's idea confirmed, that the young shoot grows by the extension in length of the moisture in the spongy pith; and he endeavours to explain the fact that the growing shoot does not extend equally in the transverse direction, and so become spherically rounded off like an apple, from the nature of the structure of the cell-tissue. That the air enclosed in the tissue and the sap with it presses into the shoot with sufficient force to produce so great an extension, he thinks is proved by his experiments, which show him the great force with which the water rises in the bleeding vine, and forces itself into swelling peas; it is known, he says, that water acts with great force when it is heated in a vessel, for water can be driven into the air by heat; the sap in plants is composed of water, air, and other active ingredients, and makes its way with great force into the tubes and cells, when it is heated by the sun.

2. The course of the I8th century gradually increased the number of the phytodynamical phenomena, to which physiologists paid more or less attention, and repeated attempts were made to explain them on mechanical principles. These attempts were for the most part unsatisfactory, because movements distinct in kind from one another were mixed up together, their dependence on external influences was not distinctly perceived, and the knowledge of the anatomical structure of the parts which exhibited the movements was, owing to the decline of phytotomy, extremely imperfect. Moisture and warmth played the chief part in these explanations, but their mode of operation was expressed in the most general terms; the mechanical processes in plants were described much in the way in which a person with very indefinite ideas as to the nature of steam and the construction of the inside of a steam-engine might speak of its movements. The 
majority of writers, in accordance with the tendencies of the age, professed their desire to refer the phenomena of life in plants not to an unknown principle called the soul, but to mechanical and physical causes; but they did not apply their minds to the examination of these phenomena with that strenuous effort, which in this subject especially could alone lead to a complete and satisfactory explanation of them.

Linnaeus studied the periodical movements of flowers in I $75 \mathrm{I}$ and those of leaves in $\mathrm{r} 755$, but a mechanical explanation of them was not to be expected from him; he contented himself with pointing out the external conditions of these phenomena in many species, with classifying them, and giving the periodical movements a new name by calling the positions assumed by night the sleep of plants; nor did he use the word at all in a metaphorical sense, for he saw in this sleep of plants a phenomenon entirely analogous to sleep in animals. That the sleep-movements were not capricious but due to external influences was with him a necessary consequence from the nature and idea of the plant, which was that of a living and growing being, only without sensation. But it should be mentioned that he stated correctly that the movements connected with the sleep of plants are not caused by changes of temperature, or not by these only, but by change of light, since they take place in the uniform temperature of a conservatory.

Linnaeus' account of these kinds of movement was only formal, it is true, but still it was well-arranged and clear; the treatment of the same and other movements by his contemporary Bonnet was quite the reverse. It is scarcely possible to imagine anything more shapeless, such an utter confusion of things entirely different from one another, as is to be found in Bonnet's experiments and reflections on the various movements of leaves and stems in his work on the function of leaves, published in 1754 ; geotropic and heliotropic curvatures, nutations and periodic movements, are all run one into another; a person who understands something of the subject may find 
here and there single things in his experiments that may be turned to account, but he was himself unable to make any use of them. He set out with a preconception which prevented him from the first from understanding what his experiments showed him ; it was his object to prove from a multitude of instances, that stalks and leaves so curve, twist and turn in all cases, that the under sides of the leaves are directed towards the ground, in order that they may be able to suck up the dew, which according to his theory is the chief nutriment of plants and rises from the ground. It is no great merit in him, that amid all this confusion a correct observation here and there forced itself upon him, as for instance that organs, chiefly such as are young and ductile, if they are put out of their natural position, endeavour to recover it by bending and twisting. On the other hand his conclusions with regard to the mechanical causes of these movements are utterly inane; the least skill in judging of the results of his experiments must have led him to very different ideas; warmth and moisture, he says, appear to be the natural causes of movement, but warmth is more effective than moisture, and the warmth of the sun more effective than that of the air. This explanation is unsuitable to just those cases which he chiefly studied, the geotropic and heliotropic curvatures. In one point only he arrived ultimately at a right judgment, namely that the great lengthening of the stem, the small size attained by the leaves and the want of colour in plants grown under cover, are caused by partial or entire absence of light ; Ray however had shown this before as regards the colour.

Though Du Hamel, like many later writers, treated Bonnet's investigations, uncritical as they were and without plan, with great respect, he gave himself a much better account of the various movements of plants. In the sixth chapter of the fourth book of his 'Physique des arbres,' I 758, he discussed all the phenomena of the kind that were known to him under the title: 'On the direction of stem and roots, and on the 
nutation of the parts of plants.' Under the head of upright or oblique direction of the stem and roots, he speaks of geotropic, heliotropic, and some other curvatures; then follows a chapter on etiolation, and under the title, 'Movements of plants, which approximate to some extent to the voluntary movements of animals,' he enquires into the periodical and sensitive movements of the leaves of Mimosa; he winds up with a short account of Linnaeus' flower-clock, and of the hygroscopic movements of the valves of fruits. The movements of tendrils and climbing stems, of which Du Hamel seems to have known little, are not mentioned in this connection; but they are noticed in a former chapter with hairs, thorns and similar things, - a plan which Cesalpino also adopted. If this way of dealing with the different movements of plants is to be taken as a classification of them, it was a very unsatisfactory one; for it separates like things, and brings together things unlike; still it is an improvement on Bonnet's arrangement, while the author gives us also some new and valuable observations. He may claim to be the first who made heliotropic curvature depend on light, and it is a significant fact that he got this conclusion from Bonnet's experiments. After examining, like Hales, into the distribution of growth in shoots, and discovering that this ceases with the commencement of lignification, he proposed to himself the question: at what spots does the lengthening of the roots take place, and he found from suitable experiments that every root-fibre grows only at its terminal portion, which is a few lines in length, and that no other part of it increases in length. In the chapter on the direction of the parts of plants he examines the explanations which had been given of heliotropic curvatures. Astruc and De la Hire had supposed the weight of the descending sap to be the cause of the downward curvature of the roots, and the lighter vapours which ascend in the tissue to be the cause of the upward curvature of the stem; Bazin on the contrary attributed the geotropism of the roots to the moisture in the earth. Du Hamel 
undertook to determine whether the moisture, the low temperature, or the absence of light in the earth made the roots curve downwards, and he was obliged by the result of his experiments to deny that they do. But he was unfortunate in his own explanation of the movements which we should now call geotropic, heliotropic and periodic, for he came to the conclusion that the 'direction of the vapours' inside the vessels of the plant and round about the plant has more to do with producing these movements than any other causes, and that if warmth and light appear to influence them, it is perhaps only because they produce vapours or communicate a definite movement to them. As regards the movements of the leaves of Mimosa, Du Hamel repeated the experiment made by Mairan in 1729 , in which the periodic movement continued even in constant darkness; he found that this was so, and concluded that the periodic movements of Mimosa do not essentially depend on temperature and changes of light; Hill had determined in 1757 that the alternation of day and night was the cause of the movements connected with the sleep of plants, because he found that darkness artificially produced in the daytime made the plants assume the nocturnal position ; but Zinn in I759 came to the same conclusion as Mairan and Du Hamel. It was not till long after that the question was to some extent cleared up by Dutrochet. Du Hamel thought it necessary to give a formal refutation of the opinion expressed by Tournefort, that the movements of plants are produced by muscles, and to show that Tournefort's vegetable muscles are hygroscopic fibres.

We have to mention in conclusion, that Du Hamel was the first who observed that the two branches of a vine-tendril twine in opposite directions round a support that happens to be between them; he also appears to have been the first who compared the irritability of the stamens of Opuntia and Berberis with that of Mimosa-leaves; the stamens of Berberis were afterwards examined by Covolo in 1764 , by Koelreuter 
I 788 , by Smith in I 790 , and by others, but without leading to any discoveries respecting the nature of the irritability. Dal Covolo's famous essay on the stamens of the Cynareae (I 764) produced no absolutely final result, but it contained some particulars which threw light on the mechanical laws of these movements of irritability. Koelreuter, who studied these objects in 1766 , thought less of discovering a mechanical explanation of them, than of finding arguments in the irritability of the stamens for the necessity of insects to pollination. An entirely new kind of movement was discovered by Corti in 1772 in the cells of Chara, which is now known as the circulation of the protoplasm; this form of movement in plants appeared at first to bear no resemblance whatever to the phytodynamic processes then known, and it was not brought into connection with them till a long time after; on the contrary an erroneous idea soon began to prevail, that it was a real rotation of the sap, as understood by the early physiologists ; this idea held its ground till far into the I $9^{\text {th }}$ century, and being combined with mistaken notions respecting the movements of latex, was developed by Schultz-Schultzenstein into the doctrine of the circulation of the vital sap. For a time indeed Corti's discovery was forgotten, and had to be reproduced by Treviranus in I8Ir. A somewhat similar fortune attended the discovery of the movement of the Oscillatorieae by Adanson in 1767 , which misled Vaucher into pronouncing them to be animals.

3. Imperfect as were the theoretical efforts of the 18 th century in this branch of botanical study, yet they aimed at tracing the various movements back to the play of physical forces. But in the closing years of the century another order of ideas, injurious to the healthy progress of science, made its appearance in this, as in other parts of botany and zoology. Even the majority of those who had no sympathy with the nature-philosophy and its phraseology, believed that there was in organised bodies something of a special and peculiar nature; because the attempts made to explain the phenomena of life by mechanical 
laws were on the whole unsatisfactory, all such explanations were looked upon as impossible and even absurd, while it was forgotten that the vital force, which was to explain everything, was a mere word for everything that could not be explained in the life of organisms. This vital force was personified, and seemed to assume a really tangible form in the movements of plants. But the moment that a phenomenon was handed over to this force, all further investigation was abandoned; the idea with regard to phytodynamical phenomena especially was that of the peasant, who could only explain the movement of the locomotive by supposing that there was a horse shut up in it. Moreover the knowledge of the inner structure of plants was at its lowest point at the end of the ISth century; the spiral threads which could be unwound were the only structural element whose form was to some extent understood, and their hygroscopic movements were supposed to be due to a combination of the pulsations of the vital force with the spiral tendency of the plant. At the same time whole bundles of vessels were taken for spiral fibres, or were supposed to consist of them, and these were thought to be vegetable muscles, which contract under the influence of various kinds of irritation, and so cause the movements in the organs of plants; but it was forgotten that in the organs which exhibit the most striking movements, such as sensitive leaves and leaves that suffer periodical changes of position, these 'muscles' occupy a central position which unfits them for the function ascribed to them. It would be unprofitable and wearisome to give many examples of what is here stated, though many might easily be collected; it will suffice to quote some sentences only from Link's 'Grundlehren der Anatomie und Physiologie' of 1807 ; they are particularly instructive, because Link declared against the nature-philosophy and professed to be on the side of inductive science. Under the head of movements of plants, he discussed geotropic curvatures and other movements in the superficial manner of the time and only to come to the conclusion, that the direction of 
growth of stems and roots is caused by a polarity of a definite kind in every plant, from which we may argue, he says, 'to higher connections of our planet in the world of space.' He says again, 'that it is natural to conjecture that light is the cause of the sleep of plants,' and then gives the contradictory statements of Hill, Zinn, and De Candolle, all jumbled together into an inextricable tangle in a fashion which sets all maxims of reasonable discussion at defiance. He then puts aside all attempts at mechanical explanation with the remark, that plants observe their regular times of sleep even when kept in the dark and at a low temperature, for this evident habituation is one of the most important marks of vitality. He is led to similar results by Desfontaine's observation, that a Mimosa, exposed to the shaking of a wheeled vehicle, closes at first but then opens again. Speaking of the rapid oscillations of the leaves of Hedysarum gyrans and similar movements, he rejects Percival's idea of a will in plants, but says that the attempts to derive them from mechanical or chemical causes has only led to solemn trifling.

It is plain that men who could print such remarks as these and still worse than these, could not possibly effect anything in the province of botany which we are considering. The broad and shallow stream of such opinions as these flowed on till later even than 1830 , but it ran dry at last when its supplies were cut off by the effect of new discoveries, and scientific investigation again gained the upper hand. Some calmer thinkers, who could not rest content with empty words, had meanwhile been pursuing the path trodden by Ray, Dodart, Hales; and Du Hamel, and by experiment and earnest reflection had brought new facts to light, which were at least calculated to pave the way for the mechanical explanation of phytodynamical phenomena. Senebier in his 'Physiologie végétale' ( 1700 ) had described some minute researches which he had made into the subject of etiolation; and though he made the great mistake of attributing the want of colour in the leaves and the excessive elongation of the stems to the decom- 
position of carbon dioxide which does not take place in the dark, yet he gave an example of genuine scientific investigation and again expressed its true spirit, when he said that the Linnaean phrase, 'the sleep of plants,' was unsuitable, because the sleeping leaves are not relaxed, but continue as stiff as in the day-time. De Candolle also, like Senebier, experimented in 1806 on the influence of light on vegetation, and succeeded in proving that the daily period of leaves may be reversed by artificial illumination; he was, as we have said above, an adherent of the theory of a vital force, but only made use of it when physical explanations failed him. The same year, ( 1806 ) is the date of a brilliant discovery, which was extremely inconvenient to the thorough-going adherents of the naturephilosophy and the vital force, and did much to bring the scientific study of the movements of plants back to the right path. ANDREw KNIGHT ${ }^{1}$ showed by experiment that the vertical growth of stems and primary roots is due to gravitation ; he attached germinating plants to a rapidly revolving wheel, and thus exposed them to the centrifugal force, either alone or combined with gravitation; the radicles, which normally follow gravitation, here took the direction of the centrifugal force, while the stems assumed the opposite direction. The next question was, why gravitation makes the roots and stems take exactly opposite directions, why, that is, in a plant placed in a horizontal direction, the root-end curves downwards and the stem upwards. Knight supposed that the root, being of a semifluid consistence, is bent downwards by its own weight, while the nutrient sap in the stem moves to the underside and causes stronger growth there, until by means of the curvature so produced the stem assumes the upright position. Here too, as in Dodart's case, it was no great misfortune that the explanation proved afterwards to be insufficient; it served at the time to

1 Thomas Andrew Knight, President of the Horticultural Society, was born at Wormsley Grange, near Hereford, in $175^{8}$, and died in London in 1838 . 
explain as much as was then known of the matter. The spirit of true scientific research displayed in Knight's explanation of geotropism was expressed in many other contributions which he made to vegetable physiology; two only must be mentioned here. He showed in I 8 r I that under suitable conditions roots are diverted from the vertical direction by moist earth, an observation which was confirmed by Johnson in ${ }_{1} \delta_{2} 8$ and afterwards forgotten. More attention was excited by his discovery in I 8 I 2, that the tendrils of Vitis and Ampelopsis are negatively heliotropical, that is, that they turn away from the source of light. A few other cases of this kind of heliotropism have since been discovered, and they are highly interesting, because they teach that there is the same opposition in the relations of plants to light as in their relations to gravitation. Knight possessed some of the direct and bold reasoning power of his countryman Hales; he defied the vital force, and was always ready with a mechanical explanation, if it was at all possible to find one. Thus he explained the twining of tendrils by supposing that the pressure of the support drives the juices to the opposite side, which consequently grows more vigorously and causes the curvature, which makes the tendril wind round the support. This theory was at all events better than the one which von Mohl sought to put in its place in 1827 , and no better one was suggested till very recently. Much the same may be said of Knight's explanation of geotropic curvatures ; it is true that Johnson showed in 1828 that the ends of roots as they curve downwards set in motion a heavier weight than themselves, and therefore do not simply sink down, and Pinot in I 829 , that they force their way even into quicksilver, and that consequently Knight's theory, at least as regards the roots, is unsatisfactory; but no better theory has yet been found, and his view also of the progress in the upward curvature of the stem has not given place to any one that can be said to be more generally accepted.

It was the commonly received opinion till after 1820 that the 
movements of the parts of plants are produced by the spiral vessels, or, which meant the same thing in those days, by the vascular bundles. It was an important event therefore when Dutrochet proved in 1822 , that the movements of the leaves of Mimosa were due to the alternate expansion of the antagonistic masses of parenchyma in the pulvinus or cushion of succulent tissue found at the articulation, and that the central vascular bundle follows passively their curvatures. Lindsay had indeed arrived at the same conclusion from similar experiments as early as 1790 , but his unprinted essay on the subject was first produced by Burnett and Mayo in I827. Meanwhile Dutrochet had also found that light influences the movements of the leaves in different ways; alternation of light and darkness excites them to motion, while leaves which have become rigid in continued darkness are restored by light to their normal condition of sensitiveness.

Much attention was bestowed in the period between 1820 and 1830 on various questions connected with the movements of the organs of plants. In 1826 the faculty of medicine in Tübingen offered a prize for an essay on the peculiar nature of tendrils and climbing plants, which was intended to bring into discussion all the points which required to be cleared up before a more thorough understanding of the whole subject could be obtained. The two essays which gained the prize were published in 1827 . One was by Palm, the other by von Mohl, both of very different value. Palm's essay is a good and careful college-exercise ; but there is nothing of this character in von Mohl's. The skill of the composition, the exact knowledge of the literature of the subject, the wealth of personal experience, the searching criticism, the prominence given to all that is fundamental and important, the feeling of certainty and superiority which the book inspires, all unite to make the reader forget that it is not the work of a mature and professed naturalist, but of a student of two-and-twenty years of age. This academical prize-essay on the structure and twining 
of tendrils and climbing-plants was one of von Mohl's best works, and altogether the best that appeared on the subject before Darwin wrote upon it in 1865 ; at the same time it must be said that von Mohl did not explain the exact mechanical processes in the tissues, for he assumed a sensitiveness in both cases which causes the winding round the support, and thought that this sensitiveness must be conceived of 'dynamically' and not 'mechanically.' Nevertheless von Mohl conducted his investigation up to this point according to strict rules of inductive science, and studied the facts which were capable of being established by observation and experiment with an exactness such as had not yet been applied to any case of movement in plants. It was a genuine production of its author, strictly inductive up to the point at which deduction became necessary. Von Mohl pointed out in it essential differences in the behaviour of tendrils and climbing plants, and the corresponding distinction between the organs which have to be considered in each case, and he made the important discovery that contact with the support acts as a stimulus on the tendril, though he was wrong in supposing that the climbing stem also is similarly affected. He at once assented to Dutrochet's new view, that it is not the vascular bundles but the layers of parenchyma which produce the movements. He distinctly rejected the notion constantly repeated, though with some hesitation, since the time of Cesalpino, that tendrils and climbing-plants 'seem to seek for' their supports, as also the idea which many had adopted without reflection from Grew, that the varying direction of a climbing-stem is due to the varying influence of the course of the sun and moon, and showed that the movements of nutation in the stem are sufficient to explain the apparent seeking for the support ; it is true that he did not fully explain the corresponding phenomena in tendrils, but he saw enough to set aside the old ideas. We must not here go further into his many, and for the most part excellent, observations ; some of course had afterwards to be corrected, but the important 
point was, that his full investigation of the subject showed how such phenomena must be studied, if we are to arrive at a strictly mechanical explanation of them.

If von Mohl had attempted to give a mechanical explanation of the processes in the tissue of twining organs he must necessarily have failed from ignorance of the agency of diffusion, which must certainly be taken into consideration. This agency was not discovered by Dutrochet till the year (1826) in which von Mohl undertook his investigation, and some time elapsed before it was sufficiently understood to be successfully applied to the explanation of phenomena in vegetation. Dutrochet did indeed attempt so to apply his theory in 1828 , and showed that changes in the turgidity of tissue are produced by endosmose and exosmose, and consequently that a new mechanical method of explanation had been discovered for processes which had been usually referred to a supposed vital principle; but in his later and more detailed researches into geotropism, heliotropism, periodical movements and movements of irritability, which he collected together in his 'Mémoires' of 1837 , he fell into two different mistakes: he assumed conditions of size and stratification in cells which do not actually exist, for the purpose of explaining very various kinds of curvature by endosmose, and he was not satisfied with endosmose in the parenchyma; he postulated changes in the vascular bundles also, which were supposed to be produced by the influence of the oxygen in a way which he did not explain. Thus there were blots in his explanation of separate processes, and his mechanical theories remained unsatisfactory; but it is worthy of recognition and was most important for the development of phytodynamics, that he was thoroughly in earnest in his purpose of explaining every movement in plants by mechanical laws. Even the opponents of such explanations were obliged to go deeply into mechanical relations in order to refute him, and no one could any longer be imposed upon by the simple assertion that all depends on the vital force; so devoted 
a partisan of vital force as Treviranus had to deal with endosmose as an established principle. Moreover Dutrochet's copious investigations presented such an abundance of interesting observations, delicate combinations, and suggestive considerations, that the study of them is still instructive and indeed indispensable to any one who is occupied with such researches. Comparison of his papers in the 'Mémoires' of I 837 with what was before known on the mechanical laws of the movements of plants leaves us in no doubt that energetic mental effort had taken the place of the old complacent absence of thought.

Still no single movement had as yet been fully explained on mechanical principles; but by the year 1840 clearer views had been attained on the whole subject; the co-operation of external agencies was in substance recognised, and the different forms of movement were better distinguished, though much still remained to be done in this direction; and as regards the mechanical changes in the tissue of the parts capable of movement, a factor had been given in endosmose which must be taken into account, though it might be necessary to seek a different mode of applying it.

4. Before proceeding to give some account of the theoretical efforts that were made in this subject between 1840 and 1860 , it should be mentioned that new cases of movement in plants had been discovered. Dutrochet observed that the stem in the embryo of Viscum is negatively heliotropic, and had carefully studied its behaviour; he opposed the old notion that the geotropic downward curvature is peculiar to main roots, and that that is the reason why they are in 'polar' opposition to the stem, by pointing to the shoots of the rhizomes of Sagittaria, Sparganium, Typha, and other plants, which at least when young curve downwards with some force; and on extending Knight's experiment with a rotating wheel he found that the leaves also exhibit a peculiar geotropism. These observations and some new examples of periodical movement 
and movements of irritability were connected without difficulty with the forms of movement that had been long known in the vegetable kingdom, and contributed to correct the views that had been entertained respecting them. But this was not the case for a time with two phenomena which also fall within the province of phytodynamics, namely normal growth and the movements of the protoplasm, which exhibit the two opposite extremes, so to speak, of the facts connected with movement. Various measurements had been made of the growth of plants since the beginning of the century, and attempts had been made to establish its dependence on light and heat, but without any great success. Treviranus had rediscovered the movements of the protoplasm in I8I I in Nitella. Similar movements were repeatedly pointed out by Amici, Meyen, and Schleiden in the cells of higher plants, but they were taken for streamings of the cell-sap; it was still unknown that all these were movements of the same organised substance, which moves independently in water in the form of swarmspores. These phenomena, especially the movements of swarmspores, were noticed and studied separately between I 830 and I 840 , but no one thought of bringing both these movements and the mechanical laws of normal growth into connection with the phenomena which had usually been treated together under the head of movements in the vegetable kingdom. De Candolle and Meyen did not mention them in this connection in their 'Compendia' of 1835 and I839; Meyen on the contrary discussed the 'circulation of the cell-juice' with nutrition, and the movement of swarmspores with the propagation of Algae. The two writers just named, like Du Hamel before them, divided into two main groups the movements in the vegetable kingdom which had been long known and were usually put together, and treated of geotropic and heliotropic curvatures and the movements of tendrils and climbing plants under the head of direction of plants, and the periodical movements and movements connected with irritability under that of move- 
ments, though they gave no reasons for this classification; it rested evidently on an indistinct feeling outrunning clear perception-that in the one they were dealing with growing parts of plants, in the other with parts which had ceased to grow. Dutrochet made no such distinction, but he was the only one among the chief representatives of vegetable physiology between ${ }_{3} \delta_{3}$ and $\mathrm{I} \delta_{40}$ who had thoroughly adopted the mechanical view of phytodynamical phenomena. We have said that Treviranus was a warm adherent of the theory of vital force. De Candolle and Meyen, it is true, endeavoured to explain each separate movement if possible by mechanical laws, but in their more general speculations they readily lapsed into antiquated views; thus De Candolle speaks of the sensitiveness of Mimosa as a case of extreme 'excitability,' and Roeper, in accordance with his other views, translated De Candolle's expression, autonomous movements, by the term 'voluntary' movements. 'The movements he is speaking of are those of Hedysarum gyrans, and Meyen also terms them 'voluntary' movements, and ranks them with those of Oscillatoria. That he was influenced in this by a dim reminiscence of the old vegetable soul is shown by the heading, 'Of movements and sensation in plants,' placed over the section of his work in which the expression occurs; and in the last chapter of this section, he attributes some kind of sensation to plants on account of the evident marks of design in their movements, though he veils his meaning in obscure and tortuous phrases.

5. The mists of the nature-philosophy and the vital force disappeared from the phytodynamical province of botanical science after the year 1840 . The methodical research of inductive science, which had still to contend with them up to that time, was once more acknowledged as the supreme guide and ruler. A few stray dissentients were still to be found, but the general voice was against them. There was an eager desire for exact investigation of the facts, in order to lay a 
firmer foundation for future theory. But no conclusive results, no such entirely new points of view were gained before $\mathbf{1} 860$, as were established during the same time in phytotomy, morphology, and systematic botany. To these subjects the most eminent enquirers applied their best powers almost exclusively, while phytodynamics vanished from the field of view of the generality of botanists, and no one made them the object of the comprehensive, intense, and effectual study, which Dutrochet had previously devoted to them. At the same time his example was not without a powerful effect. The working of endosmose was further investigated and treated as a part of molecular physics. Greater freedom was thus gained in the mechanical treatment of phytodynamical questions, and a firmer basis secured by aid of the advances which were being at the same time made in phytotomy. But with the exception of Brücke's essay on Mimosa (1848), the works produced during this period were chiefly devoted to the critical examination of the writings of previous observers, and whatever appeared that was new and positive remained incomplete till after the date at which this history ends. Under these circumstances we must be content to indicate briefly the more important of the new discoveries and of the efforts made at this time to advance the theory of the subject.

Several observers occupied themselves soon after 1840 with the influence of light on the growing parts of plants. Payer maintained in 1843 that the radicles of various Phanerogams turn from the light, and a controversy arose between him and Dutrochet on the point, in which Durand took part in 1845 , but no definite conclusion was arrived at even as regards the certainty of the fact. The beautiful discovery of Schmitz in 1843 , that the Rhizomorphs grow more slowly in the light than in the dark, and are at the same time negatively heliotropic, might have proved much more important; but the theoretical value of this fact has till quite recently been entirely misconstrued. Sebastian Poggioli had discovered in I 8 I 7 that highly refringent 
rays of light were more heliotropically active, and the fact was confirmed by Payer in 1842 ; but Dutrochet in 1843 maintained, and incorrectly, that it is the brightness of the light, and not its refrangibility, which is the determining factor. Zantedeschi found in. $\delta_{43}$ that red, orange, and yellow light are heliotropically inactive. Gardner on the contrary in $\mathrm{I} 844$, and Guillemain in 1857 , came with the help of the spectrum to the conclusion that all its rays are heliotropically active, and the question long remained hampered by these contradictory statements, till it was taken up again in 1864 . This was a similar case to that of the question of the effect of variegated light on the elimination of oxygen and the formation of chlorophyll. Daubeny had given attention to the subject in I 836 and inclined to the view, that it was the brightness of the light rather than its refrangibility which was the important point; and Draper's observation, made with the spectrum in I 844 , that the elimination of oxygen reaches its maximum in yellow light and decreases on each side of it, was generally understood as though it was a question only of the brightness of the light. It is only within recent times that this view has been abandoned, and in the same way all the investigations which have just been mentioned were not settled till after I 860, and were scarcely turned to any theoretical account.

The bright point in the history of phytodynamics at this time is Brücke's treatise in 1848 on the movements of the leaves in Mimosa, not only on account of the very important results which it records, but still more for the exactness of its method which has made it a model of research in these subjects. He first established the essential difference between the periodical nocturnal position of the leaves of Mimosa and the position which they assume when irritated, and showed that the former is connected with an increase in turgidity, the latter with relaxation; he showed further that if the upper half of the organ is removed, the periodical movements and the irritability both continue. Of great importance to the theory was 
the clear account given of the tension which is produced between the vascular bundle and the turgescent layer of parenchyma, and the reference of the periodic movements and of those of irritation to the movements of water in the antagonistic masses of parenchyma. The details were still imperfect, but one great advantage was secured, namely, the doing away with the mysticism associated with the idea of irritability, from which even von Mohl was not entirely free.

A full enquiry into the downward curvature of roots, published by Wigand in 1854 , deserves mention, because it threw some light on the theory of the strictly mechanical questions connected with a subject which had been for some time neglected, and because, while containing other instructive matter, it refuted the theory, founded on endosmose and on the structure of tissue, which had been suggested by Dutrochet and adopted by von Mohl, since it showed that one-celled organs also exhibit geotropic curvatures. The great theoretical importance of the fact that all the various phytodynamical phenomena, with the exception of movements of irritability, are manifested in one-celled organs, was not fully understood till after 1860.

It has been already observed, that no theoretical result was obtained from the discovery of circulation in cells made by Corti in $\mathrm{I} 77_{2}$, and repeated by Treviranus in $\mathrm{I} 8 \mathrm{II}$. The same may also be really said of the later observations of Amici, Meyen, and Schleiden, which went to show that such movements occur very generally in vegetable cells. In like manner the movements of swarm-spores, of which a considerable number of instances had been observed before 1840 , were rather the subject of astonishment than of scientific consideration. They could not in fact find their place in the general system until Nägeli and von Mohl discovered in I 846 , that it is in the protoplasm that the so-called movement of the cell-sap takes place, and Alexander Braun made it known in 1848 that the swarmspores are naked masses of protoplasm, and indeed true 
vegetable cells. A new substratum for the movements in plants, and one of the simplest kind, was thus obtained; and Nägeli attempted in 1849 a mechanical explanation of the movements of swarm-spores, while in 1859 De Bary exhibited in the Myxomycetes most instructive examples of such movements. If Nägeli failed in his attempt, yet it seemed possible that the protoplasm had an important share in the production of all phytodynamic phenomena, and the idea appeared capable of a very wide application when Unger pointed out in ${ }_{1} 85$ the resemblance between vegetable and animal protoplasm. It is true that not one of these later observations led to any conclusive results till after i 860 ; but that the whole subject of phytodynamics had made considerable advance as early as $185^{\circ}$ is apparent from the account given of it by von Mohl in his 'Vegetabilische Zelle' of I $_{5}$ I, and by Unger in his 'Lehrbuch der Anatomie und Physiologie der. Pflanzen' of 1855 . Von Mohl chiefly exposes the unsatisfactory nature of the attempts that had been made to explain the phenomena; Unger, on the other hand, shows how much that is fundamentally important had been already established.

The mechanics of growth had not been included by former writers among the phenomena of phytodynamics, nor was it so included by either Unger or von Mohl. It seemed to be supposed that there was a fundamental difference between growth and other movements in the vegetable kingdom, and this idea was entertained even in the most recent times. From the time of Mariotte and Hales no one had made the mechanical laws of growth the subject of special investigation or theoretical consideration; yet some observations had been made on the formal relations of growth and its dependence on external influences. Ohlert (1837) was the first after Du Hamel who studied the distribution of growth in the root; Cotta in 1806 , Chr. F. Meyer in 1808 , Cassini in 1821 , Steinheil and others made measurements in connection with the same question in the stem, but only with the result of showing that the distribu- 
tion of growth at the internodes may vary very greatly, and even Münter's measurements in growing internodes in I84I and 1843 , and Grisebach's in 1843 led to no appreciable result, because the observers neglected to apply the figures obtained to the theory of the subject. It seemed to be generally supposed that it was enough simply to write down the measurements in figures, and that a theoretical result would spring into being of itself; on the contrary the real scientific work begins after the figures are obtained. The same cause prevented the observations which have yet to be mentioned from producing real fruit. The influence of the variability of the temperature of the air ${ }^{1}$, and of the alternation of daylight and darkness on the longitudinal growth of internodes and leaves after they have emerged from the bud-condition, had often been investigated; Christian Jacob Trew published in 1727 longcontinued daily measurements on the flowering stem of Agave Americana in conjunction with observations on temperature and weather; a hundred years later similar observations were made by Ernst Meyer in 1827 , by Mulder in 1829 , and by Van der Hopp and De Vriese in 1847 and $\mathrm{r} 848$; but Harting in I 842 and Caspary in 1856 were the first who went at all deeply into the questions involved. These observations, some of which were carefully made, led to no further result than the discovery of the fact, which Münter indicated and Harting applied to theoretical purposes but which no one else thought worthy of attention, namely that the rate of growth increases at first and independently of external causes, till it reaches a maximum, and then decreases till at length it comes to an end ; they did not even establish a really practical method of observation. Scarcely two observers arrived at the same result, because the questions respecting the relations of growth in length to temperature and light had not been clearly and distinctly put. Communications were published in the periodicals, which simply

1 See 'Arbeiten des botanischen Institutes in Würzburg,' vol. i. p. 99. 
tabled long-continued measurements of the longitudinal growth of parts of plants, and gave an idea of constant irregularity of growth, without suggesting any explanation of the causes which produced it ; so indistinct were the ideas of observers on these subjects even after $185^{\circ}$, that the majority of them proposed to themselves the question, what difference there is between growth by day and by night; it did not occur to them that day and night are not simple forces of nature, but different and very variable complications of external conditions of growth, such as temperature, light and moisture, and that such a mode of putting the question could not possibly lead to the discovery of the relations established by law, so long as the several factors were unknown which are included in the conceptions of day and night. Harting's essay of $\mathrm{I} 842$ is superior to those above mentioned, inasmuch as he distinctly endeavoured to obtain from his measurements some definite propositions that might be applied to the theory of the subject, and especially to give a mathematical expression to the dependence of growth on temperature, but his success in this particular point was not great. The idea, that there must be a simple arithmetical relation to be discovered between growth and temperature, had been suggested by Adanson in the previous century, and it found many supporters in the period between 1840 and 1860: but it should be observed that the term growth was used in a loose and popular sense to sum up all the phenomena of vegetation in one expression. Adanson had supposed that the time occupied in the unfolding of the bud was determined by the sum of the degrees of the mean daily temperature, reckoned from the beginning of the year; Senebier, and at a later time De Candolle, declared against the existence of any such relation, but a similar idea was not only very generally entertained after $\mathrm{I} 840$, but it even came to be treated as a probable natural law. Boussingault had pointed out that in the case of cultivated plants in Europe and America, if the whole period of vegetation expressed in days is multiplied by 
the mean temperature of the same period, the products do not deviate widely from one another in the same species. It was thereupon assumed that these deviations are due to incorrect observation, and that such a constant product of the period of vegetation and the mean temperature will be found in every species. This product then received the unmeaning appellation of the sum of the temperature. If such a relation between vegetation and temperature really exists, it would necessarily follow that other things, such as light, moisture, the soil, \&c., have no influence at all on the period of vegetation, not to speak of those internal causes which help to complicate the simplest processes of growth. It is unnecessary to expose in this place the absurdities involved in this idea of the sum of the temperature; the needful remarks will be found in the 'Jahrbücher für wissenschaftliche Botanik' of r860, i. p. 370. It is a remarkable fact however that such monstrous reasoning should have been able to prejudice science in various ways even later than the year i860. A new science was actually invented and called Phaenology, which accumulated thousands and thousands of figures, in order to discover the sum of the temperature for every plant, and as this crude empiricism showed that the simple multiplication of the period of vegetation by the temperature gave no constant result, the square of the temperature was tried and other tricks of arithmetic adopted. Though Alphonse de Candolle as early as I $85^{\circ}$ expressed well-founded objections to the whole of this method of treating the subject, in which the mean temperature played much too important a part, yet he was so far unable to keep clear of the prevailing ideas, that he thought he could express the effect of light by an equivalent number of degrees of temperature, and so save the supposed law of temperature in vegetation. To this idea may be traced his work on the geography of plants, published in two volumes in 1855 , which however contains a rich treasure of personal experience and knowledge of the works of other writers. 
CHAP. III.]

It appears then that scarcely any point of fundamental importance in phytodynamics was cleared up before the period at which this history closes; it was not till after that date that these questions began to be studied from new points of view, and they are at the present time still under discussion. 



\section{N D E X.}

Adanson, 66, I16, 545, 561.

Aepinus, 257.

Agardh, I 43, I60, 205, 352.

Albertus Magnus, $1_{4}$.

Aldrovandi, 18 .

Alpino, 380.

Alston, 402.

Amici, 223, 284, 371, 432, 434, $55^{8}$.

Ammann, 39.

Aristotle, 4, 6, I3, 16, 43, 51, 219 , 376,450 .

Astruc, 543.

Bachmann, $7,39,63,74-76,8_{3}$, I о I .

Baisse (de la Baisse), $4^{8} 3$.

Banks, I 39.

Bartling, I 44, I 45 .

Batsch, I 25, I 37, I 43 .

Bauhin, Kaspar, 5, 6, 8, I 2, I 3, I 7, I $9,24-26,33,39,64,80$, 100, I I 5 .

Bazin, 543 .

Beale, 472.

Berkeley, 205.

Bernhardi, I09, 225, 256, 263-266, 347 .

Bischoff, I61, I98, 207, 438, 439 .

Blair, Patrick, $39^{1}$.

Bock, Hieronymus, 3, I3, If, I9, $24,2 \pi, 28$.

Boehmer, $248,4^{8} 3$.

Boerhaave, 78 .

Bonnet, I63, 247, 4 S6-488, 54I.

Borelli, 536 .

Bornet, 2 I $0,443$.

Boussingault, $373,449,531,561$.

Bradley, 39I, 406.

Braun, A., I 62, I 65, I 69, I 70-I $S_{1}$, I 84 , 208, 3I 2, 3I $4,334,33^{6}, 44^{2}, 55^{8}$.

Bravais, 169 .

Brisseau-Mirbel, 198, $224,226,250$, $256,259,261,262,272-275,284$, $307,31 \mathrm{I}, 32 \mathrm{I}$.

Brongniart, Adolph, I 47, 321, 432, 436.

Brown, Robert, I Ic, I I 2, I 2 2, I 39I 44, I 55, I 6I, $227,323,433$.
Briicke, 339, 556, 557 .

Brunfels, 3, 5, I 3,14 .

Brunn, 255.

Buffon, 89 .

Burckhard, 83, 391, 397.

Burnett, $55^{\circ}$.

Calandrini, 486 .

Camerarius, Rud. Jak., 60, 77, 81, $87,361,376,385-390,406$.

Candolle (see De Candolle).

Caspary, 560.

Cassini, 559 .

Cesalpino, Andrea, 5, 7, 9, I 2, I 7 , I $8,23,37,40,42-57,61,63,80$, 8 I, I03, I 25, I63, $219,220,450$.

Cessati, 213 .

Choulant, I 9

Clusius (see de l'Écluse :

Cohn, 209, 2 I 3, 442.

Comparetti, $249,26_{3}, 282$.

Corda, $\mathrm{IS}_{4}, 205$.

Cordus, Valerius, 29, 536 .

Cornutus, Jakob, 537.

Corti, 31 4,5 I3, 545,558 .

Cotta, 506, 559 .

Covolo, dal, +1 0,545 .

Cramer, Karl, 203.

Dalechamps, 29, 30.

Darwin, Chas., I I , I 2, 49, 53, I 52 , I $69,180,183,351,431$.

Daubeny, 557 .

De Bary, 210, 213-215, 292, 314, 3I $8,339,372,443,559$.

Decaisne, $44^{2}$.

De Candolle, Alphonse, 562 .

De Candolle, Pyrame, 9, 71, 92, I I O, I I 2, I 22, I 26-I 39, 307, 484 , $5^{1} 5,537,554,555,561$.

De la Baisse, 483 .

De Lamarck, 127 .

De l'Écluse, I 3, 18, 19, 29-31, 55 .

De la Hire, 543 .

De l'Obel, 3, 6, 13, I 7, 18, 23, 26, $32,35,58,64,6$. 
Desfontaines, I $36,293,307$.

De Vriese, 508, 560 .

Dillenius (Dillen), 76, 2 I I, 437 .

Dioscorides, 3, 4, I 3, I 5, 28, 34 .

Dippel, 343 .

Dodart, 538,547 .

Dodoens (Dodonaeus), I3, I 8,22 , 29, 30.

Draper, 557 .

Du Hamel du Monceau, 89, 247, $368,488-49$ I $, 542-545,559$.

Du Petit-Thouars, I 37,489 .

Durand, $55^{6}$.

Dutrochet, 2I 2, 370, 509-5I 4, 550, $55^{2}, 553$.

Ehrenberg, 208, 21 I, 32 2, 354, 438.

Eichler, 350 .

Endlicher, 9, I го, 146, 333 .

Erlach, 354.

Fabri, 403 .

Fischer, 509 .

Fogel, 59.

Frank, 39, 343.

Fries, Elias, IO, 111 , I $53,205$.

Fuchs, 3, I3. I4, I 5, I8, I9, 20, 24.

Fürnrohr, I92.

Gärtner, Karl Friedrich, 370, 421, 427-430.

Gärtner, Joseph, 23, I10, I 22-I 25, $207,4 \mathrm{I} 3$.

Galen, 3, I 5 .

Garcias del Huerto, 536 .

Gardner, 557 .

Gaudichand, 293.

Geoffroy, 39I, 395.

Gesner, Konrad, I 8, 20, 29, 379.

Ghini, Luca, I 8.

Girou de Bouzareingue, 422, 426 .

Giseke, I 37 .

Gleditsch, 21 1, 21 2, 391, 393 .

Gleichen-Russworm, 247, 249, 263, 404,43 .

Goeppert, I84, 370, 507.

Goethe, 62, I 44, I 56-160, 263, 390.

Grew, Nehemiah, 69, 89, 93, 97, $22 \mathrm{I}, 222,223,225,23 \mathrm{I}, 232,234$, $239-244,263,3^{82-38} 5,55^{1}$.

Grischow, 506.

Grisebach, $5^{60}$.
Guillemain, 557.

Haartman, 400.

Hales, 89, 224, 363, 476-482, 539 .

Haller, 66, 89, 404 .

Hanstein, Johannes, 203, 343, 348, 350.

Hartig, Theodor, 3 OI, 3I 4, 342, 354 , $53^{2}, 534$.

Harting, 303, 560, 56r.

Harvey, 205.

Hassenfratz, 495 .

Hebenstreit, 76 .

Hedwig, I $23,198,207,224,253^{-}$ $255,263,283,43 \mathrm{I}, 437,438$.

Henfrey, 3I 2, 335, 440 .

Henschel, August, 422, 424, 425 .

Herbert, William, 370, 420, $42 \mathrm{I}, 43^{\mathrm{I}}$.

Hermann, 68.

Heucher, 76 .

Hill, 76,544 .

Hofmeister, Wilhelm, II, II8, I67, I $70,184,199-203,208,209,210$, 228, 31 2, 31 $8,335,336,37$ I , 439, 440.

Hooke, Robert, 221, 223, 229-232, 536.

Hornschuch, 206.

Ingen-Houss， 224，368，49I，493, 494-497.

Irmisch, 165 .

Jessen, 397 .

Johnson, 549 .

Jungermann, 39 .

Jung (Jungius', 40, 43, 58-63, 64, 73,80 , I I 5 , I 55, 22 I , 38 I , 454-456. Jussieu, Antoine Laurent de, 9, 23, 77, 92, Iо9, I Iо, II6-I 22, I 25 , $\mathrm{I} 55,43 \mathrm{I}$.

Jussieu, Bernard de, 9, 4I, I 09, I I 5.

Karsten, 3I 3, 320.

Kessler, I 9.

Kieser, I60, 283, 320.

Knaut, Christopher, 74,76 .

Knight, Andrew, 42 I, 43I, 506, 548 . Kölliker, 3I 3.

Koelreuter, 89, I 2 2, I 23, 247, 406$4^{\mathrm{I}} 4,43 \mathrm{I}, 437,544,545$.

Kuitzing, $205,206$. 
Lantzius-Beninga, I9S.

Lavoisier, 491, 492, 50\%.

Leeuwenhoek, 223, 244, 245, 259 .

Leibnitz, 83, 391, 397.

Leitgeb, 203.

Lesczyc-Suminsky, $43^{8}, 44^{1}$.

L'Heritier, 137.

Léveillé, 205.

Liebig, 373, 449, 525-531.

Lindley, $9,147, \mathrm{I} 48$.

Lindsay, 550.

Link, I 6I , 2 I I , 225, 255-259, 26 I, $267-270,310,505,546$.

Linnaeus, 8-10, $37,4^{\circ}, 4^{1}, 49,5^{6}$, $65,71,79^{-108,113}, 118,397^{-}$ 402,431 .

Lister, $47^{\circ}$.

Lobelius (see de l'Obel).

Logan, James, 391, $39^{2}$.

Ludwig, 76,248 .

Macaire, Prinsep, 5 I I.

Magnol, 8, 470.

Mairan, 544 .

Major, Johann Daniel, $456,460,4^{6} 9$. Malpighi, 44, 48, 63, 69, 89, 155 , $22 \mathrm{I}, 223,23 \mathrm{I}-239,24 \mathrm{I}, 262,3^{6} 3$, $366,3^{67}, 3^{81}, 457-46 \mathrm{I}$.

Man, James, $25^{8}$.

Marcet, 506 .

Mariotte, $461-470,539$.

Mattioli, 3, I 8, 29.

Mayo, 550.

Medicus, 255, 267 .

Menzel, 39 .

Mercklin, 44I.

Mettenius, I98, 202, 439 .

Meyen, 208, 225, 226, 259, 260, $284-292,305,310,322,333,35$ I, $508,5^{14}, 5^{2} 3,554,555,55^{8}$.

Meyer, Chr., 559 .

Meyer, Ernst, I8, I60, 161, 401, 560.

Micheli, 2 I I, 437 .

Mikan, 385 .

Milde, 202, 440 .

Millardet, 350 .

Miller, 391, 392.

Millington, $382,384,385,399$.

Mirbel (see Brisseau-Mirbel).

Mohl, Hugo von, 105, 161, 183, I $9^{2}, 223,226,227,259,260,284$, 29I-3II, 318, 32I, 325, 329, 336,
$340,349,350,35 \mathrm{I}, 354,355,374$, $529-532,550,551,558$.

Moldenhawer, J. J. P., $225,25 \%$ $261,276-284$.

Morison, 7, 8, 63, 66-68, го .

Morland, Samuel, 391, 394.

Morren, 20S, 322 .

Mulder, $303,529,560$.

Miiller, 343 .

Minter, 560 .

Mustel, 266, 267, 490 .

Nägeli, I I , 63, I 8, I 6 r, I 66, I 83 , $1<5,193^{-1} 97,208,226,227,297$, 302,3 I $2-316,3$ I $8,326-334,336$, $340,34^{6}-356,43^{8}, 55^{8}, 559$.

Naumann, I 69 .

Needham, 43I.

Nees von Essenbeck, I 60, 205, 2 I 2 , $43^{8}$.

Nieuwentyt, $4 \tau^{2}$.

Oelhagfn, 39 .

Ohlert, 559.

Oken, I6I.

Palm, 550 .

Payen, 303.

Payer, I 9I, 556, 557.

Percival, 547.

Perrault, 403, 460, 470 .

Persoon, 2 I I.

Plato, I I .

Platz, Wilhelm, 4\$3.

Pliny, 3, I 3, I 5, 34, $37^{8}$.

Ploessl, 258.

Poggioli, $55^{6}$.

Polstorff, 526 .

Pontedera, 391, 399, 401.

Priestley, 491-494.

Pringsheim, 203, 209, 210, 213,318 , $372,44^{2}, 443$.

Radlkofer, 3I 4, 350, 354, 435 .

Ramisch, 422, 426 .

Raspail, 320.

Ratzenberger, I 9.

Ray, 7, 8, 39, 40, 59, 60, 63, 67, 6874 , IO I, I I $5,384,47$ I, 536-538.

Reichel, Christian, 484 .

Rivinus (see Bachmann).

Roemer, 401. 
Roeper, 144, 371, 555 .

Rudbeck, 76, 79 .

Rudolphi, 21 I, 256, 258, 267-270.

Ruppius, $7^{6}$.

Saint-Hilaire, Auguste de, I49.

Saint-Pierre, 137 .

Salm-Horstmar, 532 .

Sanio, Karl, 309, 316, 318, 341, 349, 350.

Sarrabat (see de la Baisse).

Saussure, Theodore de, I 26, 369, $370,497-504,506,53 \mathrm{I}$.

Sbaraglia, 472 .

Schacht, Hermann, 280, 283, 302, $305,318,337,338,34 \mathrm{I}, 343,345$, $34^{8}, 434,435$.

Schaeffer, J. C., 21 I.

Scheffer, 39 .

Schellhammer, 74.

Schelver, F. J., 422, 424.

Schimper, C. Friedr., I62-I 70.

Schimper, W. B., I98.

Schlechtendal, I 92.

Schleiden, 63, I61, I79, I 83, I88I 93, $226,297,302,3$ I I , 322, 323 , 326, 34I, 345, 433-436, 529, $55^{8}$.

Schmidel, 20, I $23,197,438$.

Schmitz, $212,556$.

Schrank, Paula, 255, 425 .

Schulz-Schulzenstein, 293, 300, 320 , 545 .

Schulze, Franz, 284, 318, 373 .

Schulze, Max, 3I 4, 339.

Schwann, 3I3.

Schwendener, 215.

Selligue, 258.

Senebier, I 26, 224, 249, 369, 495$497,547,56$ I.

Sharroc, 537 .

Smith, 545 .

Spallanzani, Lazaro, 422-424.

Sprengel, Konrad, $363,368,4{ }^{1} 4-422$.

Sprengel, Kurt, 66, 125, 224, 256 , $259,262,263,268,320,469$.

Steinheil, 559 .

Sternberg, I 84.

Suminsky (see Lesczye-Suminsky).

Thal (Thalius), I 8.
Theophrastus, 3, 4, I3, I 5-I7, 34, 219, 377.

Thiimmig, 248,473 .

Thuret, 209, 210, 3I 4, 37 2, 442, 443 .

Tonge, 470 .

Tournefort, Pitton de, $7,8,39,63$, $76-79,83$, IOI, I I 5, 391 , 4 OI , 544 . Tragus (see Bock).

Trentepohl, 206, 207.

Treviranus, 19, 161, 256, 261, 267, $270-272,275,290,310,320,425$, $5^{20}-5^{24}, 545$.

Trew, 560 .

Trog, 2 I 2.

Tulasne, 2 I 3,435 .

Turpin, 320.

Unger, г61 , I 84, I 98, 206, 227,300 , $305,312,3$ I $4,318,325-329,333$, $33^{6-340}, 346,375,43^{8}, 559$.

Vagetius, 59 .

Vaillant, Sebastian, 39I, 397, 398.

Valentin, 355, 386, 387, 402 .

Van der Hopp, 560.

Van Deyl, 257.

Van Helmont, 455 .

Varro, 535 .

Vaucher, I 26, 207, 372, 438, 545 .

Voight, I6o.

Volkamer, 39 .

Vrolik, 508.

Wallroth, 2I 5 .

Walther, Friedrich, 483 .

Weickert, 257.

Wiegman, 526 .

Wigand, I0 5, 34I, $55^{8}$.

Wilbrand, 425 .

Willoughby, 470.

Wolff, Christian, 221, 247, 402, 403, $472-476$.

Wolff, Kaspar Friedr., 44, I 55, I 90 , $249^{-2} 53,273,275,276,3^{19}, 405$.

Woodward, 472 .

Wright, 257 .

Wydler, I 65 .

Zaluziansky, 380,38 I.

Zantedeschi, 557 .

Zinn, 544 . 


\section{SELECT LIST OF STANDARD WORKS}

PRINTED AT

\section{Ebe Elarendon (Prewab, Oxford.}

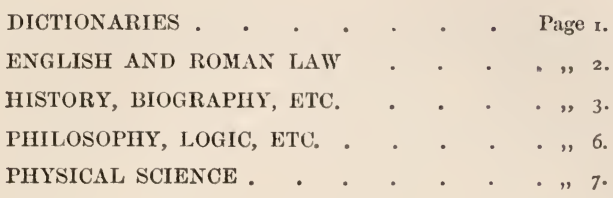

\section{DICTIONARIES.}

A New English Dictionary on Historical Principles, founded mainly on the materials collected by the Philological Society. Imperial 4to. In Parts, price I $2 s .6 d$. each.

Vol. I (A and B), half moroceo, 2l. I2s. $6 d$.

Part IV, Section 2, C-CAss, beginning Vol. II, price $5^{s}$.

Part V, CASS-CLIVY, price I 2s. 6d. Just Published.

Edited by James A. H. Murray, LL.D.

Vol. III (E, F, and G), Part I, edited by Henry Bradley. In the Press.

An Etymological Dictionary of the English Language, arranged on an Historical Basis. By W. W. Skeat, Litt.D. Second Edition. 4to. 2l. $4^{s}$.

An Anglo-Saxon Dictionary, based on the MS. collections of the late Joseph Bosworth, D.D. Edited and enlarged by Prof. T. N. Toller, M.A., Owens College, Manchester. Parts I-III. A-SAR. 4to. stiff covers. I5s. each. Part IV (completing the Work) in the Press.

An Icelandic-English Dictionary, based on the MS. collections of the late Richard Cleasby. Enlarged and completed by G. Vigfússon, M.A. With an Introduction, and Life of Richard Cleasby, by G. Webbe Dasent, D.C.L. 4to. $3 l .7 s$.

A Greek-English Lexicon, by H. G. Liddell, D.D., and Robert Scott, D.D. Seventh Edition, Revised and Augmented throughout. 4 ts. Il. I6s.

An Intermediate Greek-English Lexicon, abridged from the above. Small 4 to. I2s. $6 d$. 
A Latin Dictionary, founded on Andrews' edition of Freund's Latin Dictionary, revised, enlarged, and in great part rewritten by Charlton T. Lewis, Ph.D., and Charles Short, LL.D. 4to. I $l .5^{s .}$

\section{A School Latin Dictionary. By Charlton T. Lewis,} Ph.D. Small 4 to. I 8 s.

\section{A Sanskrit-English Dictionary. Etymologically and} Philologically arranged, with special reference to Greek, Latin, German, Anglo-Saxon, English, and other cognate Indo-European Languages. By Sir M. Monier-Williams, D.C.L. 4to. $4 l .14 s, 6 d$.

Thesaurus Syriacus : collegerunt Quatremère, Bernstein, Lorsbach, Arnoldi, Agrell, Field, Raediger: edidit R. Payne Smitl, S.T.P. Vol. I, containing Fase. I-V, sm. fol. 5l. 5 s.

Fase. VI. Il. Is. Fasc. VII. Il. IIs. $6 d$. Fase. VIII. Il. I6s.

\section{ENGLISH AND ROMAN LAW.}

Anson. Principles of the English Law of Contract, and of Agency in its Relation to Contract. By Sir W. R. Anson, D.C.L. Fifth Edition. 8vo. IOs. $6 d$.

\section{Law and Custom of the} Constitution. Part I. Parliament. 8vo. Ios. 6 d.

Bentham. An Introduction to the Principles of Morals and Legislation. By Jeremy Bentham. Crown 8vo. $6 s .6 d$.

Digby. An Introduction to the History of the Law of Real Property. By Kenelm E. Digby, M.A. Third Edition. 8vo. Ios. 6 .

Gaii Institutionum Juris Civilis Commentarii Quattuor; or, Elements of Roman Law by Gaius. With a Translation and Commentary by Edward Poste, M.A. A New Edition. Nearly Ready.
Gentilis, Alberici, I.C.D., I.C., De Iure Belli Libri Tres. Edidit T. E. Holland, I.C.D. Small $4^{\text {to. half }}$ moroceo, 2 Is.

Hall. International Law. By W. E. Hall, M.A. Second Edition. 8vo. 21 s.

Holland. Elements of Jurisprudence. By T. E. Holland, D.C.L. Fourth Edition. 8vo. Ios. $6 d$. The European Concert in the Eastern Question; a Collection of Treaties and other Public Acts. Edited, with Introductions and Notes, by T. E. Holland, D.C.L. 8vo. I $2 s, 6 d$.

Justinian. Imperatoris Iustiniani Institutionum Libri Quattuor; with Introductions, Commentary, Excursus and Translation. By J. B. Moyle, D.C.L., M.A. SecondEdition. 2 vols. 8vo. Vol. I. I6s. Vol. II. $6 s$. 
Justinian. The Institutes of Justinian, edited as a recension of the Institutes of Gaius, by T. E. Holland, D.C.L. Second Edition. Extra feap. Svo. $5^{s}$.

\section{Select Titles from the} Digest of Justinian. By T. E. Holland, D.C.L., and C. L. Shadwell, B.C.L. 8vo. I 4 s.

Also sold in Parts, in paper covers, as follows :-

Part I. Introductory Titles. 2s.6d.

Part II. Family Law. Is.

Part III. Property Law. 2s. $6 d$.

Part IV. Law of Obligations (No. I). 3s. 6d.

Part IV. Law of Obligations (No. 2). $4 s .6 d$.

Lex Aquilia. The Roman Law of Damage to Property: being a Commentary on the Title of the Digest 'Ad Legem Aquiliam' (ix. 2). With an Introduction to the Study of the Corpus Iuris Civilis. By Erwin Grueber, Dr. Jur., M.A. 8vo. Ios. $6 d$.
Markby. Elements of Law considered with reference to Principles of General Jurisprudence. By Sir William Markby, D.C.L. Fourth Edition. 8vo. I 2s. $6 c_{\text {. }}$

Pollock and Wright. $A n$ Essay on Possession in the Common Lau. By Sir F. Pollock, M.A., and R.S. Wright, B.C.L. 8vo. $8 s .6 d$.

Raleigh. The English Law of Property. By Thos. Raleigh, M.A. In the Press.

Stokes. The Anglo-Indian Codes. By Whitley Stokes, LL.D.

Vol. I. Substantive Law. 8vo. 30.s. Vol. II. Adjective Law. $8 \mathrm{vo} .35^{\mathrm{s}}$. A Supplement to the above, $1887^{-}$ I 888. Stiff covers, $2 s .6 d$.

Twiss. The Law of Nations considered as Independent Political Communities. By Sir Travers Twiss, D.C.L.

Part I. On the Rights and Duties of Nations in time of Peace. New Edition. 8vo. $15 s$.

Part II. On the Rights and Duties of Nations in time of War. Second Edition. 8vo. 2 Is.

\section{HISTORY, BIOGRAPHY, ETC.}

Baker's Chronicle. Chronicon Galfridi le Bater de Swynebroke. Edited with Notes by Edward Maunde Thompson, Hon. LL.D. St. Andrews ; Hon. D.C.L. Durham ; F.S.A. ; Principal Librarian of the British Museum. Small 4to., stiff covers, I8s.; cloth, gilt top, 2 Is.

Bluntschli. The Theory of the State. By J. K. Bluntschli. Translated from the Sixth German Edition. Svo. half bound, I $2 s .6 c$.
Boswell's Life of Samuel Johnson, LL.D. Edited by G. Birkbeck Hill, D.C.L. In six volumes, medium 8vo. With Portraits and Facsimiles. Half bound, $3 l .3^{s}$.

Calendar of the Clarendon State Papers, preserved in the Bodleian Library. In three volumes. I $869-76$.

Vol. I. From 1523 to January I649. Sro. I 8 s.

Vol. II. From 1649 to 1654 . $16 \mathrm{~s}$. Vol. III. From 1655 to 1657 . 14 s. 
Calendar of Charters and Rolls preserved in the Bodleian Library. 8vo. Il. IIs. $6 d$.

Carte's Life of James Duke of ormond. 6 vols. 8 vo. Il. 5 s.

Clarendon's History of the Rebellion and Civil Wars in England. Re-edited from a fresh collation of the original MS. in the Bodleian Library, with marginal dates and occasional notes, by W. Dunn Macray, M.A., F.S.A. 6 vols. Crown 8vo. 2l. $5^{s}$.

History of the Rebellion and Civil Wars in England. To which are subjoined the Notes of Bishop Warburton. 7 vols. medium 8vo. 21. IOS.

- History of the Rebellion and Civil Wars in England. Also his Life, written by himself, in which is included a Continuation of his History of the Grand Rebellion. Royal 8vo. Il. $2 s$.

Life, including a Continuation of his History. 2 vols. medium 8vo. Il. $2 s$.

\section{Clinton's Fasti Hellenici.}

The Civil and Literary Chronology of Greece, from the LVIth to the CXXIIIrd Olympiad. Third Edition. 4to. $\mathrm{i} l .14 s .6 d$.

Fasti Hellenici. The Civil and Literary Chronology of Greece, from the CXXIVth Olympiad to the Death of Augustus. Second Edition. 4to. Il. I $2 s$.

Epitome of the Fasti Hellenici. 8vo. 6s. $6 d$.

Fasti Romani. The Civil and Literary Chronology of Rome and Constantinople, from the Death of Augustus to the Death of Heraclius. 2 vols. 4 to. $2 l .2 s$.
Clinton's Epitome of the Fasti Romani. 8vo. 7 s.

Earle. Handbook to the LandCharters, and other Saxonic Documents. By John Earle, M.A., Professor of Anglo-Saxon in the University of Oxford. Crown 8vo. I6s.

Finlay. A History of Greece from its Conquest by the Romans to the present time, B. c. 146 to A. D. 1864 . By George Finlay; LE.D. A new Edition, revised throughout, and in partre-written, with considerable additions, by the Author, and edited by H. F. Tozer, M.A. 7 vols. 8 vo. $3 l .10 s$.

Fortescue. The Governance of England: otherwise called The Difference between an Absolute and a Limited Monarchy. By Sir John Fortescue, Kt. A Revised Text. Edited, with Introduction, Notes, etc., by Charles Plummer, M.A. 8 vo. half bound, I2s. $6 d$.

Freeman. History of the Norman Conquest of England; its Causes and Results. By E. A. Freeman, D.C.L. In Six Volumes. 8vo. 5l. 9 s. $6 d$.

\section{The Reign of William} Rufus and the Accession of Henry the First. 2 vols. 8vo. 1 l. $16 s$.

\section{$A$ Short History of the} Norman Conquest of England. Second Edition. Extra feap. 8vo. 2s. $6 d$.

Gardiner. The Constitutional Documents of the Puritan Revolution, 1628-1660. Selected and Edited by Samuel Rawson Gardiner, M.A. Crown 8vo. 9s. Just Published.

Gascoigne's Theological Dictionary ('Liber Veritatum'): Selected 
Passages, illustrating the Condition of Cliureh and State, I403-1 $45^{8}$. With an Introduction by James E. Thorold Rogers, M.A. Small $4^{\text {to. }}$ Ios. 6 d.

George. Genealogical Tables illustrative of Modern History. By H. B. George, M.A. Third Edition. Small 4 to. I $2 s$.

Hodgkin. Italy and her Invaders. With Plates and Maps. By T. Hodgkin, D.C.L. Vols. I IV, A.D. 376-553. Svo. 3l. $8 s$.

The Dynasty of Theodosius ; or, Seventy Years' Struggle with the Barbarians. By the same Author. Crown Svo. $6 s$.

Hume. Letters of David Hume to William Strahan. Edited with Notes, Index, etc., by G. Birkbeck Hill, D.C.L. Svo. I2s. $6 d$.

Kitchin. A History of France. With Numerous Maps, Plans, and Tables. By G. W. Kitchin, D.D. In three Volumes. Second Edition. Crown 8vo. each Ios. 6 $d$.

Vol. I. to I453. Vol. II. I4531624. Vol. III. 1624-I793.

Lucas. Introduction to a Historical Geography of the British Colonies. By C. P. Lucas, B.A. With Eight Maps. Crown 8vo. 4 s. $6 d$.

Historical Geography of the Colonies. Vol. I. By the same Author. With Eleven Maps. Crown 8vo. $5^{\text {s. }}$

Luttrell's (Narcissus) Diary. A Brief Historical Relation of State Affairs, I678-I7I4. 6 vols. $8 v o$. Il. 4 s.

Magna Carta, a careful Reprint. Edited by W. Stubbs, D.D., Bishop of Oxford. 4to. stiched, Is.
Metcalfo. Pussio et Miracula Beati Olaui. Edited from a 'TwelfthCentury MS. by F. Metcalfe, M.A. Small 4 to. $6 s$.

Oxford. Manuscript Muterials relating to the History of Oxford; contained in the Printed Catalogues of the Bodleian and College Libraries. By F. Madan, M.A. 8vo. $7 s .6 d$.

Ranke. A History of Enyland, principally in the Seventeenth Century. By L. von Ranke. Translated under the superintendence of G. W. Kitchin, D.D., and C. W.

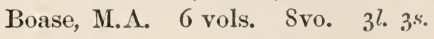

Rawlinson. A Manual of Ancient History. By George Rawlinson, M.A. Second Edition. Demy 8vo. I 4 s.

Ricardo. Letters of David Ricardo to T. R. Malthus (1810-1823). Edited by James Bonar, M.A. 8vo. Ios. $6 d$.

Rogers. History of Agriculture and Prices in Englard, A.D. I259I 793. By James E. Thorold Rogers, M.A.

Vols. I and II (1 259-1400). 8vo. 2l. $2 s$.

Vols. III and IV (I4OI-I $\left.5 \mathrm{~S}^{2}\right)$. Svo. 2l. Ios.

Vols. V and VI. (1583-1;02). 8vo. 2l. IOS.

First Nine Years of the Bank of England. Svo. 8s. 6d.

Protests of the Lords, including those which have been expunged. from $\mathrm{I}_{624}$ to 1874 ; with Historical Introductions. In three volumes. 8vo. 2l. $2 s$.

Smith's Wealth of Nutions. A New Edition, with Notes, by J. E. Thorold Rogers, M.A. 2 vols. Svo. 2 Is. 
Sprigg's England's Recovery; being the History of the Army under Sir Thomas Fairfax. 8vo. $6 s$.

Stubbs. Select Charters and other Illustrations of English Constitutional History, from the Earliest Times to the Reign of Edward $I$. Arranged and edited by W. Stubbs, D.D., Lord Bishop of Oxford. Fifth Edition. Crown 8vo. Ss. $6 d$.

The Constitutional History of England, in its Origin and Development. Library Edition. 3 vols. Demy 8vo. 2l. $8 s$.

Also in 3 vols. crown 8 vo. price I $2 s$. each.

\section{Seventeen Lectures on} the Study of Medieval and Modern History, delivered at Oxford I867-I884. Crown 8vo. 8s. $6 d$.
Stubbs. Registrum Sacrum Anglicanum. An attempt to exhibit the course of Episcopal Succession in England. By W. Stubbs, D.D. Small 4 to. $8 s .6 d$.

Wellesley. A Selection from the Despatches, Treaties, and other Papers of the Marquess Wellesley, K.G., during his Government of India. Edited by S. J. Owen, M.A. 8vo. Il. $4 s$.

Wellington. A Selection from the Despatches, Treaties, and other Papers relating to India of Field-Marshal the Duke of Wellington, K.G. Edited by S. J. Owen, M.A. Svo. Il. $4 s$.

Whitelock's Memorials of English Affairs from $\mathbf{1 6 2 5}$ to 1660 . 4 vols. Svo. Il. IOs.

\section{PHILOSOPHY, LOGIC, ETC.}

Bacon. Novum Organum. Edited, with Introduction, Notes, \&c., by T. Fowler, D.D. Second Edition. 8vo. I5s.

\section{Novum Organum.} Edited, with English Notes, by G. W. Kitchin, D.D. 8vo. $9 s .6 d$.

\section{Novum Organum.}

Translated by G. W. Kitchin, D.D. 8vo. 9s. $6 d$.

\section{Berkeley. The Works of} George Berkeley, D.D., formerly Bishop of Cloyne ; including many of his writings hitherto unpublished. With Prefaces, Annotations, and an Account of his Life and Philosophy, by Alexander Campbell Fraser, LL.D. 4 vols. 8vo. 2l. I8s.

The Life, Letters, \&.c., separately, I6s.
Bosanquet. Logic; or, the Morphology of Knowledge. By B. Bosanquet, M.A. 8vo. $2 \mathrm{Is}$.

Butler's Works, with Index to the Analogy. 2 vols. 8vo. IIs.

Fowler. The Elements of Deductive Logic, designed mainly for the use of Junior Students in the Universities. By T. Fowler, D.D. Ninth Edition, with a Collection of Examples. Extra feap. 8vo. 3s. $6 d$.

$$
\text { The Elemients of Induc- }
$$

tive Logic, designed mainly for the use of Students in the Universities. By the same Author. Fifth Edition. Extra feap. 8 vo. $6 s$.

The Principles of Morals (Introductory Chapters). By T. Fowler, D.D., and J. M. Wilson, B.D. 8 vo. boards, $3 s .6 d$. 
Fowler. The Principles of Morals. Part II. By'T. Fowler, D.D. Svo. Ios. 6d.

Green. Prolegomenato Ethics. By T. H. Green, M. A. Edited by A. C. Bradley, M.A. Svo. I2s. 6il.

Hegel. The Logic of Hegel; translated from the Encyclopaedia of the Philosophical Sciences. With Prolegomena by William Wallace, M.A. Svo. I $4^{\text {s. }}$.

Hume's Treatise of Human Nature. Reprinted from the Original Edition in Three Volumes, and edited, with Analytical Index, by L. A. Selby-Bigge, M.A. Crown Svo. 9 s.

Locke's Conduct of the Understanding. Edited by T. Fowler, D.D. Second Edition. Extra feap. 8vo. 2s.
Lotze's Logic, in Three Books ; of 'Thought, of Investigation, and of Knowledge. English Translation; Edited by B. Bosanquet, M.A. Second Edition. 2 vols. Crown 8 vo. $12 s$.

Metapliysic, in Three Books; Ontology, Cosmology, and Psychology. English Translation ; Edited by B. Bosanquet, M.A. Second Edition. 2 vols. Crown 8vo. I 2 s.

Martineau. Types of Ethical Theory. By James Martineau, D.D. Third Edition. 2 vols. Crown 8vo. I5s. its Sources and Contents. Second Edition. 2 vols. Crown 8 vo. I 5 s.

\section{PHYSICAL SCIENCE.}

De Bary. Comparative Anatomy of the Vegetative Organs of the Phanerogams and Ferns. By Dr. A De Bary. Translated and Annotated by F. O. Bower, M.A., F.L.S., and D. H. Scott, M.A., Ph.D., F.L.S. Royal 8vo., half moroceo, Il. $2 s, 6 d$.

\section{Comparative Mor-} phology and Biology of Fungi, Mycetozoa and Bacteria. By Dr. A. De Bary. Translated by H. E. F. Garnsey, M.A. Revised by Isaac Bayley Balfour, M.A., M.D., F.R.S. Royal $8 \mathrm{vo}$., half morocco, $\mathrm{Il}$. 2s. $6 d$.

\section{Lectures on Bacteria.}

By Dr. A. De Bary. Second Improved Edition. Translated by $\mathrm{H}$. E. F. Garnsey, M.A. Revised by Isaac Bayley Balfour, M.A., M.D., F.R.S. Crown 8vo. 6 s.
Goebel. Outlines of Classification and Special Morphology of Plants. A new Edition of Sachs' Text-Book of Botany, Book II. By Dr. K. Goebel. Translated by H. E. F. Garnsey, M.A. Revised by Isaac Bayley Balfour, M.A., M.D., F.R.S. Royal 8vo., half moroceo, Il. $1 s$.

Sachs. Lectures on the Pliysiology of Plants. By Julius von Såchs. Translated by H. Marshall Ward, M.A., F.L.S. Royal 8vo., half moroceo, il. i Is. $6 d$.

\section{A Histomy of Botany.} Translated by H. F. F. Garnsey, M.A. Edited by I. Bayley Balfour, M.A., M.D., F.R.S. Crown 8vo. IOS. 
Solms-Laubach. Introduction to Fossil Botany. By Count H. von Solms-Laubach. Authorised English Translation, by H. E. F. Garnsey, M.A. Edited by Isaac Bayley Balfour, M.A., M.D., F.R.S. In the Press.

Annals of Botany. Edited by Isaac Bayley Balfour, M.A., M.D., F.R.S., Sydney H. Vines, D.Sc., F.R.S., and W. G. Farlow, M.D.

Vol. I. Parts I-IV. Royal 8vo., half morocco, gilt top, Il. I6s.

Vol. II. Parts V-VIII. 2l. $2 s$. Part IX. IIs. 6. Part X. 13s, $6 d_{\text {. }}$

Biological Series. (Translations of Foreign Biological Memoirs.)

I. The Physiology of Nerve, of Muscle, and of the Electrical Organ. Edited by J.Burdon-Sanderson. M.D., F.R.SS. L. \& E. Medium 8vo. Il. Is.

II. The Anatomy of the Frog. By Dr. Alexander Ecker, Professor in the University of Freiburg. Translated, with numerous Annotations and Additions, by G. Haslam, M.D., Scientific Assistant in the Medical Department in the University of Zürich. Demy 8vo. Nearly ready.
III. Contributions to the History of the Physiology of the Nervous System. By Professor Conrad Eckhard. Translated by Miss Edith Prance. In Preparation.

IV. Essays upon Heredity and Kindred Biological Problems. By Dr. August Weismann, Translated and Edited by E. B. Poulton, M.A., Selmar Schönland, Ph.D., and Arthur E. Shipley, M.A. Medium 8vo. I6s.

Prestwich. Geology, Chemical, Physical, and Stratigraphical. By Joseph Prestwich, M.A., F.R.S. In two Volumes.

Vol. I. Chemical and Physical. Royal 8vo. I $l .5$ s.

Vo1. II. Stratigraphical and Physical. With a new Geological Map of Europe. Royal 8vo. $\mathrm{rl}$. $16 \mathrm{~s}$.

New Geological Map of Europe. In case or on roller. $5 s$.

Rolleston and Jackson. Forms of Animal Life. A Manual of Comparative Anatomy, with descriptions of selected types. By George Rolleston, M.D., F.R.S. Second Edition. Revised and Enlarged by W. Hatehett Jackson, M.A. Medium 8vo. Il. I6s.

\section{Oxford}

\section{AT THE CLARENDON PRESS}

LONDON : HENRY FROWDE 


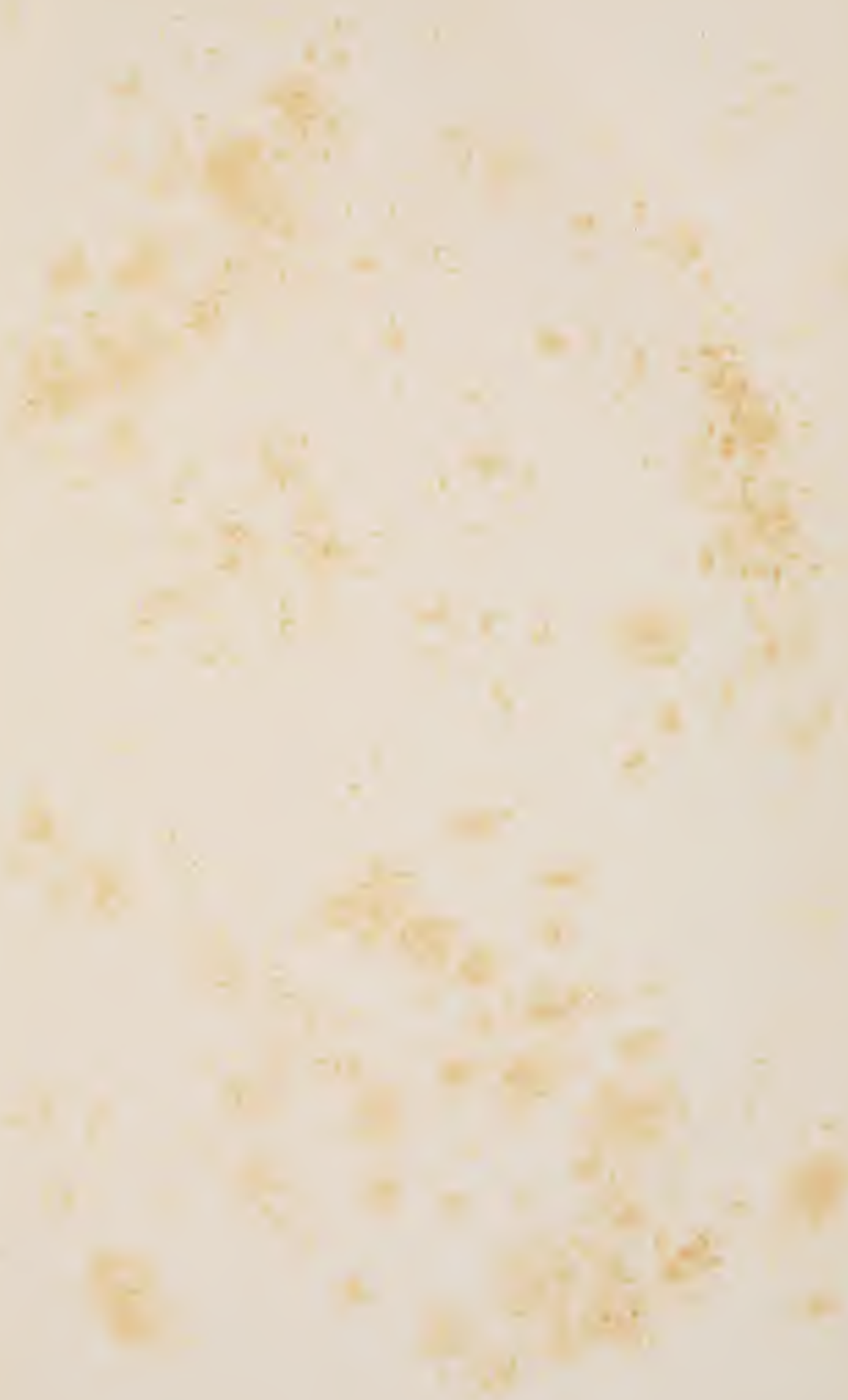




(1)

10.7.

ingugring

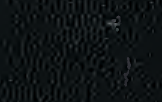

onosinges

6.

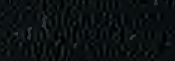

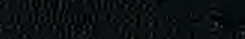

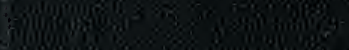

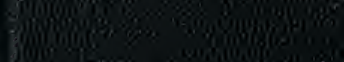

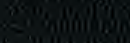

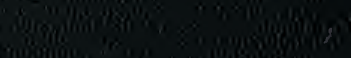

soming
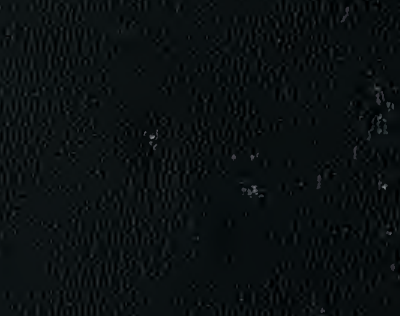

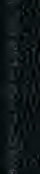

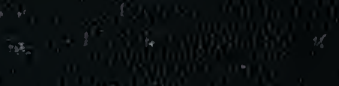

s.

\section{sis}

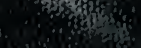

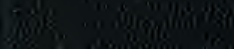

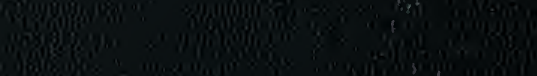

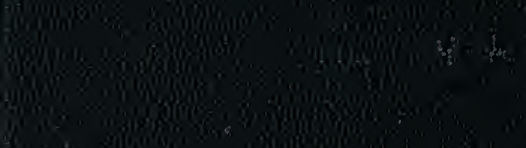

